Técnicas moleculares aplicadas a la caracterización y estudio de la supervivencia de bacterias lácticas del yogurt

Jorge García Hernández 
UNIVERSIDAD POLITÉCNICA DE VALENCIA DEPARTAMENTO DE BIOTECNOLOGÍA

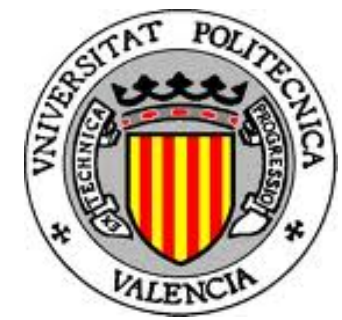

\title{
TÉCNICAS MOLECULARES APLICADAS A LA CARACTERIZACIÓN Y ESTUDIO DE LA SUPERVIVENCIA DE BACTERIAS LÁCTICAS DEL YOGUR
}

\author{
Tesis doctoral \\ Jorge García Hernández \\ Noviembre 2010 \\ Directores \\ Manuel Hernández Pérez \\ Yolanda Moreno Trigos
}




\section{Esta editorial es miembro de la UNE, lo que garantiza la difusión y comercialización de sus publicaciones a nivel

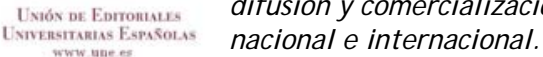

(C) Jorge García Hernández, 2012

Primera edición, 2012

(C) de la presente edición:

Editorial Universitat Politècnica de València

www.editorial.upv.es

ISBN: 978-84-8363-804-0 (versión impresa)

Ref. editorial: 5516

Queda prohibida la reproducción, distribución, comercialización, transformación, y en general, cualquier otra forma de explotación, por cualquier procedimiento, de todo o parte de los contenidos de esta obra sin autorización expresa y por escrito de sus autores. 


\section{UNIVERSIDAD POLITÉCNICA DE VALENCIA ESCUELA TÉCNICA SUPERIOR DE INGENIERÍA AGRONÓMICA Y DEL MEDIO NATURAL DEPARTAMENTO DE BIOTECNOLOGÍA ÁREA DE MICROBIOLOGÍA}

D. Manuel Hernández Pérez, profesor titular y Dña. Yolanda Moreno Trigos, técnico de laboratorio, pertenecientes al Departamento de Biotecnología (Área de Microbiología) de la Universidad Politécnica de Valencia,

\section{CERTIFICAN:}

Que la tesis doctoral titulada "TÉCNICAS MOLECULARES APLICADAS A LA CARACTERIZACIÓN Y ESTUDIO DE LA SUPERVIVENCIA DE BACTERIAS LÁCTICAS DEL YOGUR", que presenta D. Jorge García Hernández para optar al grado de Doctor por la Universidad Politécnica de Valencia, ha sido realizada bajo su dirección y reúne los requisitos adecuados para ser presentada como tesis doctoral ante el tribunal correspondiente para su lectura y defensa.

Y para que conste a los efectos oportunos, firman el presente certificado,

Valencia, 26 de noviembre de 2010

Fdo.: D. Manuel Hernández Pérez

Fdo.: Dña. Yolanda Moreno Trigos 
A Cris y a mis padres 
Una vez finalizada la redacción de mi Tesis Doctoral, tengo que enfrentarme a la complicada tarea de agradecer a muchas personas el apoyo y cariño proporcionado. Intentaré no olvidarme de nadie y pido disculpas por anticipado si ésto ocurriera.

No me cabe duda que, en primer lugar, debo expresar mis agradecimientos a Cris. Sin tus ánimos, tu paciencia y sobre todo, tu ayuda, ambos sabemos que jamás habría podido acabar este trabajo.

Gracias a mis directores. A Yoli por enseñarme todo lo que sé en cuanto a técnicas de laboratorio. A Manolo por haberme dado la oportunidad de realizar este trabajo en el Departamento. Ambos habéis estado siempre ahí y me habéis dado vuestro apoyo en los momentos en los que lo necesité. Pero sobre todo gracias por vuestra amistad. Tenéis en mí un amigo para siempre.

Quiero agradecer a D. Enrique la confianza que un día me dio para poder formar parte del área de Microbiología.

Gracias a Javier por haberse portado siempre tan bien conmigo y por sus buenos consejos en todo momento.

Quiero mandar un fuerte abrazo a todas las personas con las que felizmente trabajo todos los días: $M^{a}$ Antonia, Salut, Rosa, $M^{a}$ Angeles (gracias por tu ayuda con la estadística), Ana J., Rafa, Gonzalo y Ana G.

Me acuerdo especialmente de los amigos que pasaron un día por el C.A.M.A. y de los cuales guardo muchos recuerdos por los buenos momentos vividos: Patri, Irene, Lore, Gerard. Espero de corazón que a todos os vaya muy bien.

Mi cariño también para los que han pasado por el laboratorio de Microbiología de la Escuela de Agrónomos: Paula, Albert, Claudia y tantos otros.

A todos mis amigos, en especial a los del Liceo, los de la Facultad, los de Denia los del Barrio y los de Campo Arcís. 
Y como no a toda mi familia que siempre me ha apoyado en todas las decisiones tomadas. Muchas gracias a mis padres. $Y$ un recuerdo especial a mis dos abuelas, Librada y Maruja, que están viviendo un momento de salud delicado.

Gracias a todos 
"La ignorancia afirma o niega rotundamente; la Ciencia, duda"

François-Marie Arouet (Voltaire) (1694-1778) 
INTRODUCCIÓN

1. ALIMENTOS FUNCIONALES 3

2. LOS MICROORGANISMOS PROBIÓTICOS COMO COMPONENTES ALIMENTARIOS FUNCIONALES

3. EL CONCEPTO DE MICROBIOTA INTESTINAL EQUILIBRADA 11

4. PROBIÓTICOS Y PRODUCTOS LÁCTEOS 18

5. EL YOGUR Y EL YOGUR PASTEURIZADO DESPUÉS DE LA 20 FERMENTACIÓN. LA GUERRA DEL YOGUR

3

6 1 8

6. ANTECEDENTES HISTÓRICOS DE LAS BACTERIAS ACIDOLÁCTICAS

7. FILOGENIA DE LAS BACTERIAS ACIDOLÁCTICAS 30

8. GÉNERO Lactobacillus 31

8.1. Antecedentes históricos 31

8.2. Taxonomía 32

8.3. Hábitats 33

8.4. Características morfológicas $\quad 34$

8.5. Características fisiológicas y culturales $\quad 34$

8.6. Características bioquímicas $\quad 35$

8.7. Lactobacillus delbrueckii $\quad 35$

9. GÉNERO Streptococcus 38

9.1. Antecedentes históricos 38

9.2. Taxonomía 38

9.3. Hábitats $\quad 39$

9.4. Características morfológicas $\quad 39$

9.5. Características fisiológicas y culturales $\quad 40$

9.6. Características bioquímicas $\quad 40$

9.7. Streptococcus thermophilus $\quad 40$ 
10.1. Detección por cultivo 43

10.2. Detección por PCR tradicional 46

10.3. Caracterización mediante iniciadores aleatorios, RAPDs (Random Amplified Polymorphic DNA)

10.4. Detección mediante hibridación in situ con sondas fluorescentes (FISH)

MATERIALES Y MÉTODOS

1. AISLAMIENTO, IDENTIFICACIÓN, RECUENTO Y CARACTERIZACIÓN MOLECULAR DE LAS BACTERIAS LÁCTICAS (Lactobacillus delbrueckii subsp bulgaricus y Streptococcus thermophilus) PRESENTES EN YOGURES DE ONCE MARCAS COMERCIALES

1.1. Yogures analizados y cepas de referencia utilizadas

1.2. Muestreo, recuento y aislamiento de microorganismos

1.3. Identificación de los microorganismos mediante pruebas bioquímicas

1.4 Recuento e identificación de BAL mediante la utilización de sondas específicas (FISH)

1.4.1. Sondas

1.4.2. Hibridación in situ (FISH)

1.5 Caracterización genotípica 
Índice

("Random Amplified Polymorphic DNA" o RAPDs)

1.6. Análisis de los perfiles de bandas generados por RAPDs

2. DETECCIÓN DE Lactobacillus delbrueckii subsp. bulgaricus y Streptococcus thermophilus MEDIANTE PCR TRADICIONAL Y PCR SEMINESTED

2.1. Cepas bacterianas utilizadas, condiciones de cultivo y conservación

2.2. Aislamiento del ADN genómico bacteriano

2.3. Detección de L. delbrueckii mediante PCR simple

2.4. Detección de L. delbrueckii subsp. bulgaricus mediante PCR seminested

2.5. Detección de S. thermophilus mediante PCR

2.6. Análisis de los productos de PCR

3. PUESTA A PUNTO DE UN MÉTODO DE DETECCIÓN Y RECUENTO DE Lactobacillus delbrueckii subsp. bulgaricus y Streptococcus thermophilus MEDIANTE HIBRIDACIÓN IN SITU CON SONDAS FLUORESCENTES (FISH)

\section{PUESTA A PUNTO DE MÉTODO COMBINADO DVC-FISH PARA} LA DETECCIÓN DE CÉLULAS VIABLES DE Lactobacillus 95 delbrueckii subsp bulgaricus y Streptococcus thermophilus

4.1. Puesta a punto de la técnica DVC-FISH para la detección de células viables de $L$. delbrueckii subsp. bulgaricus

4.2. Puesta a punto de la técnica DVC-FISH para la detección de células viables de Streptococcus thermophilus 
5. ESTUDIO IN VITRO DE LA RESISTENCIA DE Lactobacillus delbrueckii subsp. bulgaricus Y Streptococcus thermophilus A LAS CONDICIONES DE TRNSITO GASTROINTESTINAL MEDIANTE LA APLICACIÓN DE LA TÉCNICA DVC-FISH

5.1. Estudio de la resistencia a la pepsina

5.2. Estudio de la resistencia a la pancreatina

6. ESTUDIO IN VIVO PARA DETERMINAR LA SUPERVIVENCIA AL TRACTO GASTROINTESTINAL DE LAS CEPAS DE BAL DE UN PRODUCTO FERMENTADO (YOGUR)

6.1. Determinación del límite de detección de las diferentes técnicas empleadas para la detección de las BAL en heces

6.1.1. Detección de Lactobacillus delbrueckii subsp. bulgaricus en heces inoculadas artificialmente para determinar el límite de detección de las técnicas de cultivo en placa, PCR y DVC$\mathrm{FISH}$

6.1.2. Detección de Streptococcus thermophilus en heces inoculadas artificialmente para determinar el límite de detección de las técnicas de cultivo en placa, PCR y DVC$\mathrm{FISH}$

6.1.3. Aplicación del DVC-FISH para la detección de células viables en heces y determinación del límite de detección del método

6.2. Estudio in vivo para determinar la supervivencia al tracto gastrointestinal de las cepas de BAL de un producto fermentado (yogur)

6.2.1. Diseño del estudio

6.2.2. Análisis de las muestras fecales

6.2.3 Estudio de la viabilidad por DVC-FISH y detección por PCR seminested de Lactobacillus delbrueckii subsp. bulgaricus en muestras de heces 
Índice

PCR de Streptococcus thermophilus en muestras de heces

6.3. Estudio de la evolución de la microbiota de las heces de las personas sometidas al ensayo in vivo

6.3.1. Recuentos de la población bacteriana presente en las heces a lo largo del ensayo

6.3.2. Análisis estadísticos

RESULTADOS

1. AISLAMIENTO, IDENTIFICACIÓN Y CARACTERIZACIÓN MOLECULAR DE LAS BACTERIAS LÁCTICAS (Lactobacillus delbrueckii subsp bulgaricus $Y$ Streptococcus thermophilus) PRESENTES EN 11 YOGURES COMERCIALES

1.1. Aislamiento y recuento en placa de BAL de las muestras de yogur analizadas

1.2. Identificación de los microorganismos mediante pruebas bioquímicas (sistema comercial $\mathrm{API}-50 \mathrm{CHL}$ )

1.3. Identificación y recuento de Lactobacillus delbrueckii subsp. bulgaricus y Streptococcus thermophilus mediante hibridación in situ con sondas fluorescentes (FISH)

1.3.1. Identificación de L. delbrueckii subsp. bulgaricus mediante sondas fluorescentes. Especificidad de las sondas y recuento en productos comerciales

1.3.2. Identificación de $S$. thermophilus mediante sondas fluorescentes. Especificidad de la sonda y recuento en productos comerciales

1.4. Análisis de los perfiles de bandas generados por RAPDs

1.4.1. Caracterización molecular mediante RAPDs de las cepas de $L$. delbrueckii subsp. bulgaricus aisladas de productos comerciales

1.4.2 Caracterización molecular mediante RAPDs de las cepas de $S$. thermophilus aisladas de productos comerciales 
Índice

2. DETECCIÓN DE Lactobacillus delbrueckii subsp. bulgaricus $Y$ Streptococcus thermophilus MEDIANTE PCR TRADICIONAL y PCR SEMINESTED

2.1. Detección de L. delbrueckii mediante PCR

2.2. Detección de L. delbrueckii subsp. bulgaricus mediante PCR seminested

2.3. Detección de S. thermophilus mediante PCR

155

3. PUESTA A PUNTO DEL MÉTODO COMBINADO DVC-FISH PARA LA DETECCIÓN DE CÉLULAS VIABLES DE Lactobacillus 158 delbrueckii subsp. bulgaricus $Y$ Streptococcus thermophilus

3.1. Detección de células viables de Lactobacillus delbrueckii subsp bulgaricus

3.2. Detección de células viables de S. thermophilus

4. ESTUDIO IN VITRO DE LA RESISTENCIA DE Lactobacillus delbrueckii subsp. bulgaricus $\mathrm{Y}$ Streptococcus thermophilus A LOS JUGOS GASTROINTESTINALES MEDIANTE LA APLICACIÓN DEL MÉTODO DVC-FISH

4.1. Acción de los jugos gástricos

4.2. Acción de los jugos intestinales

5. ESTUDIO IN VIVO CON PARA DETERMINAR LA SUPERVIVENCIA AL TRACTO GASTROINTESTINAL DE LAS CEPAS DE Lactobacillus delbrueckii subsp. bulgaricus $Y$ Streptococcus thermophilus 
Índice

5.1. Estudio de sensibilidad de métodos ensayados en heces humanas inoculadas artificialmente

5.1.1 Sensibilidad de los métodos de cultivo en placa, PCR, FISH y DVC-FISH para la detección de Lactobacillus delbrueckii subsp. bulgaricus en heces inoculadas artificialmente

5.1.2. Sensibilidad de los métodos de cultivo en placa, PCR, FISH y DVC-FISH para la detección de Streptococcus thermophilus en heces inoculadas artificialmente

5.2. Estudio in vivo para determinar la supervivencia al tracto gastrointestinal de las cepas de L. delbrueckii subsp. bulgaricus y S. thermophilus de un producto fermentado

5.2.1 Detección y recuento de L. delbrueckii subsp. bulgaricus en heces

5.2.2. Análisis de las muestras de heces mediante PCR y DVC-FISH para la detección de $S$. thermophilus en heces

6. ESTUDIO DE LA EVOLUCIÓN DE LA MICROBIOTA DE LAS HECES DE LAS PERSONAS SOMETIDAS AL ENSAYO IN VIVO

6.1. Recuentos de la población bacteriana presente en las heces a lo largo del ensayo

6.1.1. Recuentos de lactobacilos

6.1.2. Recuentos de microorganismos anaerobios estrictos y facultativos

6.1.3. Recuentos de microorganismos aerobios

6.1.4. Recuentos de bifidobacterias

6.1.5. Recuentos de enterobacterias 
$\begin{array}{ll}\text { ANEXOS } & 263\end{array}$

ANEXO I. Abreviaturas empleadas 265

ANEXO II. Lista actual de especies incluidas en el género Lactobacillus (datos obtenidos de List of Prokaryotic names with Sanding in Nomenclatura, agosto 2008, www.bacterio.cict.fr)

ANEXO III. Lista actual de especies incluidas en el género Streptococcus (datos obtenidos de List of Prokaryotic names with Sanding in Nomenclatura, agosto 2008, www.bacterio.cict.fr)

ANEXO IV.

Medios de cultivo

Soluciones, reactivos y material para identificación con PCR y FISH

Soluciones y reactivos para FISH 286

$\begin{array}{ll}\text { ANEXO V. Otros reactivos } & 289\end{array}$

ANEXO VI. Secuenciación parcial de los genes 16S y 23S de 290 Lactobacillus delbrueckii subsp bulgaricus Y7

ANEXO VII. Recuentos de la microbiota en las heces de los individuos sometidos al ensayo in vivo 
Índice de tablas

\section{INTRODUCCIÓN}

Tabla 1. Ejemplos de alimentos funcionales $\quad 5$

Tabla 2. Propiedades deseables en los microorganismos probióticos 9

Tabla 3. Microorganismos utilizados como probióticos y efectos 10 beneficiosos comprobados por ensayos clínicos

Tabla 4. Patologías relacionadas con disfunción de la flora intestinal $\quad 15$

Tabla 5. Distribución y consumo de productos lácteos 20

Tabla 6. Características diferenciales de las bacterias acidolácticas $\quad 27$

Tabla 7. Características de los lactobacilos homofermentativos obligados (grupo I), heterofermentativos facultativos (grupo II), 31 heterofermentativos obligados (grupo III)

Tabla 8. Características fisiológicas y bioquímicas de las cuatro subespecies del L. delbrueckii

Tabla 9. Patrón de carbohidratos fermentados por las cuatro subespecies de $L$. delbrueckii

Tabla 10. Características bioquímicas más importantes de Streptococcus thermophilus

Tabla 11. Iniciadores específicos de especies normalmente disponibles

Tabla 12. Iniciadores múltiples empleados para la identificación de lactobacilos

Tabla 13. Algunos iniciadores de RAPDs empleados por distintos autores

Tabla 14. Sondas oligonucleótidas para la identificación de lactobacilos 
Índice de tablas

\section{MATERIALES Y MÉTODOS}

Tabla 15. Condiciones de reacción de amplificación por RAPDs para lactobacilos y estreptococos

Tabla 16. Cepas de referencia utilizadas

Tabla 17. Condiciones de PCR para Lactobacillus delbrueckii

Tabla 18. Condiciones de PCR para Lactobacillus delbrueckii subsp bulgaricus

Tabla 19. Medios de cultivo, condiciones y tiempos de incubación para cada grupo de microorganismos estudiado

\section{RESULTADOS}

Tabla 20. Recuentos de la microbiota de los productos lácteos analizados.

Tabla 21. Alineamiento de secuencias de la sonda LDE16S

Tabla 22. Especificidad de la sonda LDE16S

Tabla 23. Alineamiento de secuencias de la sonda LDE23S

Tabla 24. Especificidad de la sonda LDE23S

Tabla 25. Recuentos de Lactobacillus delbrueckii subsp bulgaricus en los diferentes yogures naturales mediante FISH.

Tabla 26. Alineamiento de secuencias de la sonda STH23S

Tabla 27. Hibridación de cepas de LAB con la sonda STH23S

Tabla 28. Recuentos de células de Streptococcus thermophilus hibridadas en los diferentes yogures

Tabla 29. Porcentajes de homología genética entre la cepa de Lactobacillus delbrueckii subsp. bulgaricus $\mathrm{Y} 7$ y el resto de lactobacilos de otras marcas comerciales obtenido por RAPD mediante el uso del iniciador RAPD1 
Índice de tablas

Tabla 30. Porcentajes de homología genética entre la cepa de Lactobacillus delbrueckii subsp. bulgaricus $\mathrm{Y} 7$ y el resto de lactobacilos de otras marcas comerciales obtenido por RAPD mediante el uso del iniciador RAPD2

Tabla 31. Porcentajes de homología genética entre la cepa del $S$. thermophilus $\mathrm{Y} 7 \mathrm{y}$ el resto de estreptococos aislados de otras marcas comerciales obtenido por RAPD mediante el uso del iniciador RAPD1

Tabla 32. Porcentajes de homología genética entre la cepa de $S$. thermophilus que $\mathrm{Y} 7$ y el resto de estreptococos aislados de otras marcas comerciales, obtenido por RAPD mediante el uso del iniciador RAPD1

Tabla 33. Alineamiento de las secuencias de los iniciadores Ldelb1 y Ldelb2

Tabla 34. Alineamiento de las secuencias de los iniciadores Ldelb1 $y$ Ldelb2 con L. delbrueckii subsp. delbrueckii

Tabla 35. Alineamiento de las secuencias de los iniciadores Ldelb1 y Ldelb2 con L. delbrueckii subsp. lactis

Tabla 36. Alineamiento de las secuencias de los iniciadores LdelbF, LdelbR1 y LdelbR2

Tabla 37. Alineamiento de las secuencias de los iniciadores TH1 y $\mathrm{TH} 2$

Tabla 38. Antibióticos, concentraciones y tiempos de incubación evaluados en la puesta a punto de la técnica DVC-FISH para la detección de células viables de $L$. delbrueckii subsp bulgaricus LDY7 según longitud celular

Tabla 39. Antibióticos, concentraciones y tiempos de incubación evaluados en la puesta a punto de la técnica DVC-FISH para la detección de células viables de Streptococcus thermophilus STY7 según diámetro celular

Tabla 40. Media de los recuentos del producto $Y 7$ realizados en placa y por DVC-FISH previos a la realización de las pruebas de resistencia a los jugos gastronintestinales

Tabla 41. Efecto in vitro del tránsito gástrico (pepsina) sobre la viabilidad de las cepas de Lactobacillus delbrueckii subsp bulgaricus y de Streptococcus thermophilus de un yogur natural comercial 
Índice de tablas

Tabla 42. Efecto in vitro del tránsito intestinal (pancreatina) sobre la viabilidad de las cepas de Lactobacillus delbrueckii subsp bulgaricus y de Streptococcus thermophilus de un yogur natural comercial empleando la técnica del DVC-FISH para realizar los recuentos

Tabla 43. Viabilidad acumulada de Lactobacillus delbrueckii subsp bulgaricus y de Streptococcus thermophilus tras superar tránsito gastrointestinal por recuento mediante DVC-FISH

Tabla 44. Comparación de los límites de detección de las distintas técnicas para la detección de $L$. delbrueckii subsp. bulgaricus en muestras de heces inoculadas en u.f.c./g de heces

Tabla 45. Comparación de los límites de detección de las distintas técnicas para la detección de Streptococcus thermophilus en muestras de heces inoculadas en u.f.c./g de heces

Tabla 46. Análisis de muestras fecales de las tomas T1 y T2 para la detección de Streptococcus thermophilus mediante PCR seminested y DVC-FISH

Tabla 47. Análisis de muestras fecales de las tomas T3 y T4 para la detección de Streptococcus thermophilus mediante PCR seminested y DVC-FISH

Tabla 48. Análisis de muestras fecales de las tomas T5 y T6 para la detección de Streptococcus thermophilus mediante PCR seminested y DVC-FISH

Tabla 49. Recuentos de células viables de Streptococcus thermophilus mediante DVC-FISH en diferentes individuos durante la toma de muestras

Tabla 50: análisis de varianza simple (ANOVA) para lactobacilos según Tiempo (días)

Tabla 51. ANOVA para Anaerobios según Tiempo (días)

Tabla 52. ANOVA para Aerobios según Tiempo (días)

Tabla 53. ANOVA para Bifidobacterias según Tiempo (días)

Tabla 54. ANOVA para Enterobacterias según Tiempo (días) 


\section{INTRODUCCIÓN}

Figura 1. Géneros que dominan en número en el tracto gastrointestinal de un humano adulto

Figura 2. Colonización bacteriana del intestino

Figura 3. Los grupos de microbios más importantes, sus cantidades y división aproximada según su potencial de efectos dañinos y beneficiosos (Saxelin, 2002)

Figura 4. Lactobacillus delbrueckii subsp. bulgaricus (bacilo) y Streptococcus thermophilus (coco) en yogur

Figura 5. Fabricantes de yogur tradicional

Figura 6. Morfología de algunas especies del género Lactobacillus

Figura 7. Morfología de Lactobacillus delbrueckii subsp. bulgaricus

Figura 8. Morfología de algunas especies del género Streptococcus

Figura 9. Representación esquemática de un ciclo de la PCR

Figura 10. Esquema de la técnica de hibridación in situ

\section{MATERIALES Y MÉTODOS}

Figura 11. Puesta a punto del método DVC-FISH para $L$. delbrueckii subsp. bulgaricus

Figura 12. Puesta a punto del método DVC-FISH para Streptococcus thermophilus

Figura 13. Estudios de resistencia a la pepsina de L. delbrueckii subsp. bulgaricus y Streptococcus thermophilus

Figura 14. Estudios de resistencia a la pancreatina de L. delbrueckii subsp. bulgaricus y Streptococcus thermophilus 
Índice de fiquras

Figura 16. Detección de Streptococcus thermophilus en heces inoculadas con concentraciones crecientes de la bacteria

Figura 17. Estudio de la sensibilidad del método DVC-FISH para Lactobacillus delbrueckii subsp. bulgaricus en heces inoculadas con concentraciones crecientes de la bacteria

Figura 18. Estudio de la sensibilidad del método DVC-FISH para Streptococcus thermophilus en heces inoculadas con concentraciones crecientes de la bacteria

Figura 19. Esquema de las tomas de muestras durante el estudio in vivo

\section{RESULTADOS}

Figura 20. Medio de Cultivo LS Diferencial. Colonia A: lactobacilos y Colonia B: estreptococo.

Figura 21. Estreptococos en agar M17

Figura 22. Lactobacilos en agar MRS

Figura 23. Perfil de Lactobacillus delbrueckii subsp. bulgaricus en tira API-50 CHL

Figura 24. Cultivo puro de Lactobacillus delbrueckii subsp. bulgaricus hibridado con LDE16S marcada CY3 (rojo)

Figura 25. Acceso a la estructura secundaria del ARNr 16S

Figura 26. Cultivo puro de Lactobacillus delbrueckii subsp. bulgaricus hibridado con LDE23S marcada CY3 (rojo)

Figura 27. Lactobacillus delbrueckii subsp. bulgaricus en yogur natural hibridado con LDE23S marcada CY3 (rojo)

Figura 28. Lactobacillus delbrueckii subsp. bulgaricus (Y7) hibridado con LDE23R marcada con CY3 (rojo)

Figura 29. Cultivo puro de Streptococcus thermophilus hibridado con STH23S marcada CY3 (rojo)

Figura 30. Streptococcus thermophilus en yogur $Y 7$ hibridado con 
STH23S marcada CY3 (rojo)

Figura 31. Perfiles obtenidos mediante RAPDs de las diferentes cepas de Lactobacillus delbrueckii subsp. bulgaricus con el iniciador RAPD1

Figura 32. Dendrograma de las cepas de L. delbrueckii subsp. bulgaricus, empleando el iniciador RAPD1 y el coeficiente de similitud de DICE

Figura 33. Perfiles obtenidos mediante RAPDs de bacterias del género Lactobacillus spp. con el iniciador RAPD2

Figura 34. Dendrograma de las cepas de L. delbrueckii subsp. bulgaricus, empleando el iniciador RAPD2 y el coeficiente de similitud de DICE

Figura 35. Perfiles obtenidos mediante RAPDs de bacterias del género Streptococcus con el iniciador RAPD1

Figura 36. Dendrograma de las cepas de Streptococcus thermophilus empleando el iniciador RAPD1 y el coeficiente de similitud de DICE.

Figura 37. Perfiles obtenidos mediante RAPDs de bacterias del género Streptococcus con el iniciador RAPD2

Figura 38. Dendrograma de las cepas de Streptococcus thermophilus empleando el iniciador RAPD2 y el coeficiente de similitud de DICE.

Figura 39. Detección de Lactobacillus delbrueckii subsp bulgaricus aisladas de productos comerciales

Figura 40. 1) Detección de Lactobacillus delbrueckii subsp bulgaricus, 2) Detección de Lactobacillus delbrueckii subsp lactis, 3) Detección de Lactobacillus delbrueckii subsp delbrueckii

Figura 41. Detección de L. delbrueckii subsp. bulgaricus por PCR seminested 1) marcador pesos moleculares (100pb), 2) L. delbrueckii subsp. bulgaricus, 3-6) otros lactobacilos

Figura 42. Detección de Streptococcus thermophilus por PCR 1) Streptococcus thermophilus aislado del producto $Y 7,2)$ marcador pesos moleculares (100pb)

Figura 43. Control negativo del DVC-FISH para Lactobacillus delbrueckii subsp bulgaricus LDY7 mostrando el tamaño normal de la 
Índice de fiquras

célula (barra: $10 \mu \mathrm{m}$ )

Figura 44. Lactobacillus delbrueckii subsp bulgaricus LDY7 incubado con una concentración de $10 \mu \mathrm{g} / \mathrm{ml}$ de novobiocina durante $7 \mathrm{~h}$ detectado mediante microscopía de fluorescencia con la sonda LDE marcada con CY3 (barra: $10 \mu \mathrm{m}$ )

Figura 45. Lactobacillus delbrueckii subsp bulgaricus LDY7 incubado con una concentración de $10 \mu \mathrm{g} / \mathrm{ml}$ de novobiocina durante $24 \mathrm{~h}$ detectado mediante microscopía de fluorescencia con la sonda LDE marcada con CY3 (barra: $10 \mu \mathrm{m}$ )

Figura 46. Lactobacillus delbrueckii subsp bulgaricus LDY7 incubado con una concentración de $100 \mu \mathrm{g} / \mathrm{ml}$ de novobiocina durante $7 \mathrm{~h}$ detectado mediante microscopía de fluorescencia con la sonda LDE marcada con CY3 (barra: $10 \mu \mathrm{m})$

Figura 47. Lactobacillus delbrueckii subsp bulgaricus LDY7 incubado con una concentración de $100 \mu \mathrm{g} / \mathrm{ml}$ de novobiocina durante $24 \mathrm{~h}$ detectado mediante microscopía de fluorescencia con la sonda LDE marcada con CY3 (barra: $10 \mu \mathrm{m}$ )

Figura 48. Lactobacillus delbrueckii subsp bulgaricus LDY7 incubado con una concentración de $100 \mu \mathrm{g} / \mathrm{ml}$ de ciprofloxacino durante $7 \mathrm{~h}$ detectado mediante microscopía de fluorescencia con la sonda LDE marcada con CY3 (barra: $10 \mu \mathrm{m}$ )

Figura 49. Control de Lactobacillus delbrueckii subsp bulgaricus LDY7 incubado en MRS ( $\sin$ antibiótico)durante $24 \mathrm{~h}$ detectado mediante microscopía de barrido

Figura 50. Lactobacillus delbrueckii subsp bulgaricus LDY7 incubado con una concentración de $10 \mu \mathrm{g} / \mathrm{ml}$ de novobiocina durante $7 \mathrm{~h}$ detectado mediante microscopía de barrido.

Figura 51. Lactobacillus delbrueckii subsp bulgaricus LDY7 incubado con una concentración de $10 \mu \mathrm{g} / \mathrm{ml}$ de novobiocina durante $24 \mathrm{~h}$ detectado mediante microscopía de barrido

Figura 52. Lactobacillus delbrueckii subsp bulgaricus i LDY7 ncubado con una concentración de $100 \mu \mathrm{g} / \mathrm{ml}$ de ácido nalidíxico durante $7 \mathrm{~h}$ detectado mediante microscopía de barrido

Figura 53. Lactobacillus delbrueckii subsp bulgaricus LDY7 incubado con una concentración de $100 \mu \mathrm{g} / \mathrm{ml}$ de ácido nalidíxico durante $24 \mathrm{~h}$ detectado mediante microscopía de barrido 
Figura 54. Lactobacillus delbrueckii subsp bulgaricus LDY7 incubado con una concentración de $10 \mu \mathrm{g} / \mathrm{ml}$ de ciprofloxacino durante $7 \mathrm{~h}$ detectado mediante microscopía de barrid

Figura 55. Lactobacillus delbrueckii subsp bulgaricus LDY7 incubado con una concentración de $100 \mu \mathrm{g} / \mathrm{ml}$ de ciprofloxacino durante $7 \mathrm{~h}$ detectado mediante microscopía de barrido

Figura 56. Lactobacillus delbrueckii subsp bulgaricus LDY7 incubado con una concentración de $100 \mu \mathrm{g} / \mathrm{ml}$ de ciprofloxacino durante $24 \mathrm{~h}$ detectado mediante microscopía de barrido

Figura 57. Streptococcus thermophilus STY7 incubado con una concentración de $10 \mu \mathrm{g} / \mathrm{ml}$ de novobiocina durante $7 \mathrm{~h}$ detectado mediante microscopía de fluorescencia con la sonda STH23S marcada con FLUOS (barra: $10 \mu \mathrm{m}$ )

Figura 58. Streptococcus thermophilus STY7 incubado con una concentración de $10 \mu \mathrm{g} / \mathrm{ml}$ de novobiocina durante $7 \mathrm{~h}$ detectado mediante microscopía de fluorescencia con la sonda STH23S marcada con CY3 (barra: $10 \mu \mathrm{m}$ )

Figura 59. Streptococcus thermophilus STY7 viables y no viables tras su incubación con una concentración de $10 \mu \mathrm{g} / \mathrm{ml}$ de novobiocina durante $7 \mathrm{~h}$ detectado mediante microscopía de barrido (SEM)

Figura 60. Células viables y no viables de L. delbrueckii subsp bulgaricus LDY7 tras la acción de la pepsina (10 min) y tras el DVCFISH con la sonda LDE marcada con CY3 (barra: $10 \mu \mathrm{m}$ )

Figura 61. Células viables y no viables de Lactobacillus delbrueckii subsp bulgaricus LDY7 tras la acción de la pepsina $(60 \mathrm{~min})$ y tras el DVC-FISH con la sonda LDE marcada con CY3 (barra: $10 \mu \mathrm{m}$ )

Figura 62. Células viables y no viables de Streptococcus thermophilus STY7 tras la acción de la pepsina (60 min) y tras el DVC-FISH con la sonda STH23 marcada con CY3

Figura 63. Células viables y no viables de Lactobacillus delbrueckii subsp bulgaricus LDY7 tras la acción de la pancreatina (10 min) y tras el DVC-FISH con la sonda STH23 marcada con CY3

Figura 64. Células viables de Lactobacillus delbrueckii subsp bulgaricus LDY7 tras la acción de la pancreatina (240 min) y tras el DVC-FISH con la sonda STH23 marcada con CY3 
Índice de fiquras

Figura 65. Células viables y no viables de Streptococcus thermophilus STY7 tras la acción de la pancreatina (10 min) y tras el DVC-FISH con la sonda STH23 marcada con CY3

Figura 66. Células viables y no viables de Streptococcus thermophilus STY7 tras la acción de la pancreatina (240 min) y tras el DVC-FISH con la sonda STH23 marcada con CY3

Figura 67. Lactobacilos y estreptococos del producto $Y 7$ tras la acción de la pepsina y tras el DVC-FISH detectado mediante microscopía electrónica de barrido

Figura 68. Resistencia a la pepsina (evolución de su viabilidad) de las cepas de lactobacilos y de estreptococos aisladas del producto Y7

Figura 69. Resistencia a la pancreatina (evolución de su viabilidad) de las cepas de lactobacilos y de estreptococos aisladas del producto $\mathrm{Y} 7$

Figura 70. Viabilidad acumulada de las cepas de lactobacilos y de estreptococos aisladas del producto $\mathrm{Y} 7$ tras el tránsito gastrointestinal

Figura 71. Detección de Lactobacillus delbrueckii subsp bulgaricus LDY7 mediante PCR en heces inoculadas artificialmente en cantidad de $10^{4}$ células/g de heces

Figura 72. Detección de Lactobacillus delbrueckii subsp. bulgaricus LDY7 mediante FISH en heces inoculadas artificialmente en cantidad de $10^{6}$ células/g de heces empleando la sonda LDE23S (CY3)

Figura 73. Detección de Lactobacillus delbrueckii subsp. bulgaricus LDY7 mediante FISH en heces inoculadas artificialmente en cantidad de $10^{5}$ células/g de heces empleando la sonda LDE23S (CY3)

Figura 75. Límite de detección de la PCR de $S$. thermophilus en heces inoculadas artificialmente (1: $10^{6}$ u.f.c/g; 2: $10^{5}$ u.f.c./g; 3: $10^{4}$ u.f.c./g; $4: 10^{3}$ u.f.c./ M: marcador de pesos moleculares)

Figura 76. Detección de Streptococcus thermophilus STY7 mediante FISH en la dilución $10^{4}$ empleando la sonda LDE23S (CY3)

Figura 77. Detección y determinación de viabilidad de Streptococcus thermophilus STY7 mediante DVC-FISH en heces inoculadas artificialmente en cantidad de $10^{5}$ células $/ g$ de heces, empleando la 
sonda LDE23S (FLUOS)

Figura 78. Detección de $S$. thermophilus STY7 en muestras de heces en T4 mediante PCR (1: N5T4; 2: N6T4; 3: N7T4; 4: N8T4; 5: N9T4; M: marcador de pesos moleculares)

Figura 79. DVC-FISH mostrando células viables de $S$. thermophilus STY7 en muestras N5T4

Figura 80. DVC-FISH mostrando células viables (derecha) y no viables (izquierda) de S. thermophilus STY7 en muestras N13T4 
Un alimento puede ser considerado como funcional si se demuestra que afecta beneficiosamente a una o más funciones del organismo, más allá de los efectos nutricionales esperados, de manera que sea relevante para mejorar el estado de salud y de bienestar y/o para reducir el riesgo de enfermedad.

Los probióticos se incluyen dentro de los alimentos funcionales y la FAO los define como "microorganismos vivos que, administrados en cantidades adecuadas, ejercen un efecto beneficioso sobre el huésped".

Aunque es difícil precisar cuáles son las características más deseables que un microorganismo debe presentar para ser buen probiótico, los requisitos mínimos son: estar definido a nivel de género, especie y cepa; la cepa debe depositarse en una colección de cultivos internacional; deben realizarse evaluaciones in vitro y en animales para lograr un mejor entendimiento de los atributos fisiológicos de la cepa; antes de su uso, la seguridad de la cepa debe haber sido totalmente considerada; deben realizarse estudios controlados para documentar un beneficio para la salud; debe evaluarse su aptitud para mantener al probiótico vivo en los niveles requeridos hasta el final de la vida útil.

El empleo de productos lácteos funcionales permite combinar alimentos de amplio uso, aceptabilidad y tolerancia, con moléculas biológicamente activas. Varias especies de lactobacilos y bifidobacterias combinadas (o no) con Streptococcus thermophilus son las principales bacterias usadas como probióticos en yogures y otros productos lácteos fermentados.

Sin embargo, para que los microorganismos probióticos ejerzan su efecto beneficioso sobre el huésped, han de encontrarse en proporciones elevadas en el producto y ser capaces de sobrevivir en suficiente cantidad al tránsito gastrointestinal.

A mediados de los años 90, una importante marca comercial, se planteó entrar en el mercado de los yogures mediante el lanzamiento de un producto lácteo tratado térmicamente tras la fermentación que podía conservarse sin frío durante tres meses. Además, esta empresa defendía que su postre tenía el mismo efecto que el yogur tradicional puesto que los microorganismos vivos de éste no lograban llegar al intestino. Inició una larga ofensiva denominada en su día como la "guerra del yogur" con el objetivo de que la Administración española permitiera calificar su producto como yogur. 
En este contexto, se ha producido una cierta discrepancia entre diferentes líneas de investigación a la hora de afirmar los efectos beneficiosos del yogur tradicional. Algunas de ellas aseguran que sus bacterias no son capaces de sobrevivir al tracto gastrointestinal mientras que otras afirman lo contrario.

En base a lo anteriormente expuesto, en este trabajo se planteó desarrollar métodos rápidos alternativos a los tradicionales de cultivo para estudiar las posibles propiedades como probióticos de las bacterias contenidas en diferentes productos lácteos. Se procedió, en primer lugar, al aislamiento, identificación y caracterización molecular de las bacterias lácticas (Lactobacillus delbrueckii subsp bulgaricus y Streptococcus thermophilus) presentes en yogures de 11 marcas comerciales. A continuación, se realizó la puesta a punto de las técnicas de PCR y FISH para la detección de ambos microorganismos. Se desarrolló la técnica DVC-FISH para la detección de células viables de Lactobacillus delbrueckii subsp bulgaricus y Streptococcus thermophilus que permitió determinar la resistencia de las cepas in vitro a los jugos gastrointestinales, demostrando la variabilidad de la misma a nivel de cepa. Finalmente, se hizo un estudio in vivo de la supervivencia al tracto gastrointestinal de las cepas de BAL de uno de los yogures comenrciales mediante la aplicación de los protocolos desarrollados en muestras de heces, estudiando la evolución de la microbiota intestinal a lo largo del ensayo. Este ensayo permitió demostrar la presencia Streptococcus thermophilus viables en las heces tras la ingesta de producto.

La técnica DVC-FISH se mostró como el método más rápido y eficaz para la determinación de la viabilidad de LAB en matrices complejas como las heces humanas. Asimismo, se observó mediante cultivo que el consumo de yogur durante un periodo determinado produce un aumento de la microbiota endógena de lactobacilos así como una disminución de la población de enterobacterias. 
Un aliment pot ser considerat com funcional si es demostra que afecta beneficiosament una o més funcions de l'organisme, més enllà dels efectes nutricionals esperats, de manera que siga rellevant per a millorar l'estat de salut i de benestar i/o per a reduir el risc de malaltia.

Els probiòtics s'inclouen dins dels aliments funcionals i la FAO els definix com "microorganismes vius que, administrats en quantitats adequades, exercixen un efecte beneficiós sobre l'hoste".

Encara que és difícil precisar quines són les característiques més desitjables que un microorganisme ha de presentar per a ser bon probiòtic, els requisits mínims són: estar definit a nivell de gènere, espècie i cep; la cep ha de depositar-se en una collecció de cultius internacional; han de realitzar-se avaluacions in vitro i en animals per a aconseguir un millor enteniment dels atributs fisiològics del cep; abans del seu ús, la seguretat del cep ha d'haver sigut totalment considerada; han de realitzar-se estudis controlats per a documentar un benefici per a la salut; ha d'avaluar-se la seua aptitud per a mantindre al probiòtic viu en els nivells requerits fins al final de la vida útil.

L'ocupació de productes lactis funcionals permet combinar aliments d'ampli ús, acceptabilitat i tolerància, amb molècules biològicament actives. Diverses espècies de lactobacils i bifidobacteris combinades (o no) amb Streptococcus thermophilus són els principals bacteris usats com probiòtics en iogurts i altres productes lactis fermentats.

No obstant, perquè els microorganismes probiòtics exercisquen el seu efecte beneficiós sobre l'hoste, han de trobar-se en proporcions elevades en el producte i ser capaços de sobreviure en suficient quantitat al trànsit gastrointestinal.

A mitjan dels anys 90, una important marca comercial, es va plantejar entrar en el mercat dels iogurts per mitjà del llançament d'un producte lacti tractat tèrmicament després de la fermentació que podia conservar-se sense fred durant tres mesos. A més, esta empresa defenia que el seu postres tenia el mateix efecte que el iogurt tradicional ja que els microorganismes vius d'este no aconseguien arribar a l'intestí. Va iniciar una llarga ofensiva denominada en el seu dia com la "guerra del iogurt" amb l'objectiu que l'Administració espanyola permetera qualificar el seu producte com a iogurt. 
En este context, s'ha produït una certa discrepància entre diferents línies d'investigació a l'hora d'afirmar els efectes beneficiosos del iogurt tradicional. Algunes d'elles asseguren que els seus bacteris no són capaços de sobreviure al tracte gastrointestinal mentres que altres afirmen el contrari.

Basant-se en l'anteriorment exposat, en este treball es va plantejar desenvolupar mètodes ràpids alternatius als tradicionals de cultiu per a estudiar les possibles propietats com probiòtics dels bacteris continguts en diferents productes lactis. Es va procedir, en primer lloc, a l'aïllament, identificació i caracterització molecular dels bacteris làctics (Lactobacillus delbrueckii subsp bulgaricus i Streptococcus thermophilus) presents en iogurts d'11 marques comercials. A continuació, es va realitzar la posada al punt de les tècniques de PCR i FISH per a la detecció d'ambdós microorganismes. Es va desenvolupar la tècnica DVC-FISH per a la detecció de cèllules viables de Lactobacillus delbrueckii subsp bulgaricus i Streptococcus thermophilus que va permetre determinar la resistència dels ceps in vitro als sucs gastrointestinals, demostrant la variabilitat de la mateixa a nivell de cep. Finalment, es va fer un estudi in vivo de la supervivència al tracte gastrointestinal dels ceps de BAL del iogurt per mitjà de l'aplicació dels protocols desenvolupats en mostres d'excrements, estudiant l'evolució de la microbiota intestinal al llarg de l'assaig. Este assaig va permetre demostrar la presència de Streptococcus thermophilus viables en les excrements després de la ingesta de producte.

La tècnica DVC-FISH es va mostrar com el mètode més ràpid i eficaç per a la determinació de la viabilitat de LAB en matrius complexes com les excrements humanes. Així mateix, es va observar per mitjà de cultiu que el consum de iogurt durant un període determinat produïx un augment de la microbiota endògena de lactobacils així com una disminució de la població d'enterobacteris. 
Food can be considered as functional if it can be demonstrated that it is benefitial for one or more functions of the human body, over and above the expected nutritional effects, being essential for improving health and well-being and/or for reducing the risk of illness.

Probiotics belong to the group of functional foods and FAO defines them as "Live microorganisms which when administered in adequate amounts confer a health benefit on the host".

Although it is difficult to specify which are the most desirable features that a microorganism must show for being a good probiotic, the minimum requirements are: genus, species and strain designation; strains should be deposited in an internationally recognized cultura collection; in vitro and animal assessment must be carried out in order to get a better understanding of the phisiological properties of the strain; safety of the strain must be completely considered before its use; controlled studies must be undertaken for reporting some health benefit; its capability for keeping the minimum required numbers of viable bacteria by the end of shelf-life must be assessed.

The use of functional dairy products makes possible to combine widely used foods, successful and tolerance, with biologically active molecules. Some species of lactobacilli and bifidobacteria in combination (or not) with Streptococcus thermophilus are the main bacteria used as probiotics in yoghurt and other fermented milks.

However, microorganisms must be in high numbers in the final product and survive to the gastrointestinal passage for confering a health benefit on the host.

In the mid-nineties, an important commercial brand, considered the idea of getting into the yoghurt market with the launching of a pasteurised after fermentation dairy product that could be preserved for three months without any refrigeration. In addition to this, the company defended that its product had the same effect as the traditional yoghurt since its live cultures could not reach the intestine. It started a fight called the yogurt war with the aim of getting the consent of the Spanish government for qualifying the product as yoghurt.

In this context, there is a discrepancy among the different research groups when confirming the beneficial effects of traditional yoghurt. Some of them maintain 
that its bacteria are not capable of surviving the passage through the gastrointestinal tract while others confirme the opposite.

Based on the previous arguments, this work considered the development of quick methods other than the traditional culture ones for studying the possible properties as probiotics of bacteria contained on different dairy products. Firstly, lactic bacteria present on 11 commercial yoghurts (Lactobacillus delbrueckii subsp bulgaricus and Streptococcus thermophilus) were isolated, identificated and molecularly characterized. Then, PCR and FISH techniques were developed for the detection of both microorganisms. DVC-FISH technique was developed for the detection of viable cells of Lactobacillus delbrueckii subsp. bulgaricus and Streptococcus thermophilus that allowed to determine in vitro resistance to the gastrointestinal juice of the strains, demonstrating its variability on a strain level. Finally, an in vivo study of the survival to the gastrointestinal tract of BAL strains from yoghurt was undertaken with the application of the developed protocols on fecal samples, studying the evolution of intestinal microbiota all along the test. This test allowed to demonstrate the presence of viable Streptococcus thermophilus on feces after the intake of the product.

DVC-FISH technique showed to be the most quick and effective method for determining $L A B$ viability on complex matrices such as human feces. Also, it was observed with cultura media that yoghurt consumption for a determined period produces an increase on lactobacilli endogenous microbiota and a decrease on the enterobacteria population. 
INTRODUCCIÓN 
Introducción

\section{ALIMENTOS FUNCIONALES}

Hoy en día, la ciencia de la nutrición ha evolucionado a partir de conceptos clásicos, como evitar las deficiencias de nutrientes y la suficiencia nutricional básica, a los conceptos de nutrición positiva u óptima. De esta forma, las investigaciones se han centrado más en la identificación de componentes biológicamente activos en los alimentos, que ofrezcan la posibilidad de mejorar las condiciones físicas y mentales y/o de reducir el riesgo a contraer enfermedades. Se ha descubierto que muchos productos alimenticios tradicionales contienen componentes que pueden resultar beneficiosos para la salud pero, además, se están desarrollando nuevos alimentos que añaden o amplían estos componentes beneficiosos (página web del Consejo Europeo de Información sobre la Alimentación (EUFIC); Farjas, 2003).

Los desarrollos tecnológicos en este campo han sido espectaculares y estos productos, que están irrumpiendo con fuerza en los mercados internacionales, serán probablemente la herramienta más importante de la Ciencia de la Nutrición en el futuro (Juárez, 2007).

El término alimento funcional nació en Japón. Así, a comienzos del decenio de 1980 se iniciaron tres programas de investigación a gran escala financiados por el gobierno de Japón sobre "análisis sistemático y desarrollo de los alimentos funcionales", "análisis de la regulación fisiológica de la función de los alimentos" y "análisis de los alimentos funcionales y diseño molecular". En un esfuerzo nacional por reducir el costo creciente de la atención de salud, se estableció en 1991 una categoría de alimentos potencialmente beneficiosos, denominados alimentos de uso especifico para la salud (Foods for Specific Health Use, FOSHU en adelante) (Ashwell, 2004).

En Europa, no fue hasta mediados de los 90 cuando tuvo lugar la creación de un proyecto relativo a los alimentos funcionales, denominado Acción Concertada sobre Ciencia de los Alimentos Funcionales en Europa (FUFOSE). Éste fue coordinado por el International Life Sciences Institute - European Branch (Instituto Internacional de Ciencias de la Vida, ILSI en adelante), y en él participaron de forma activa muchos de los expertos europeos más destacados de la ciencia de la nutrición y afines (www.consumer.es; Bañares, 2006). 
La primera reunión plenaria del grupo de expertos, se celebró en Francia en 1996 y en ella se discutió el estado de la ciencia de los alimentos funcionales. A ella le siguió otra, celebrada en Helsinki en 1997 (www.consumer.es; Bañares, 2006).

Fruto de esas reuniones y de los documentos de trabajo elaborados en las mismas fue el Documento de consenso sobre los conceptos científicos de los alimentos funcionales en Europa, el cual se sometió a revisión en una tercera reunión plenaria celebrada en Madrid en 1998, que fue finalmente publicado en 1999 (Bañares, 2006).

De acuerdo con el Documento de Consenso del proyecto FUFOSE, un alimento puede ser considerado como funcional si se demuestra de forma satisfactoria que afecta beneficiosamente a una o más funciones objetivo del organismo, más allá de los efectos nutricionales esperados, de manera que es relevante para mejorar el estado de salud y de bienestar y/o para reducir el riesgo de enfermedad. Además, estos productos deben presentarse en forma de alimentos ordinarios (no como comprimidos o cápsulas) y deben ser consumidos como parte de una dieta corriente y no como productos muy ocasionales asociados a síntomas específicos. La mayoría de los productos FOSHU actualmente aprobados contienen bien oligosacáridos, bien bacterias ácido lácticas para promover la salud intestinal (Diplock et al., 1999; Ashwell, 2001; Ashwell, 2004).

Desde un punto de vista práctico, un alimento funcional puede ser (Diplock et al., 1999; www.eufic.org):

- Un alimento natural en el que uno de sus componentes ha sido mejorado mediante condiciones especiales de cultivo.

- Un alimento al que se ha añadido un componente para que produzca beneficios (por ejemplo, bacterias probióticas seleccionadas, de probados efectos beneficiosos sobre la salud intestinal).

- Un alimento del cual se ha eliminado un componente para que produzca menos efectos adversos sobre la salud por medios tecnológicos o biotecnológicos (por ejemplo, la disminución de ácidos grasos saturados).

- Un alimento en el que la naturaleza de uno o más de sus componentes ha sido modificada químicamente para mejorar la salud (por ejemplo, los 
Introducción

hidrolizados proteicos adicionados en los preparados para lactantes para reducir el riesgo de alergenicidad).

- Un alimento en el que la biodisponibilidad de uno o más de sus componentes ha sido aumentada para mejorar la asimilación de un componente beneficioso.

- Cualquier combinación de las posibilidades anteriores.

Además, y de acuerdo también con lo establecido en el documento de consenso, un alimento funcional debe ser funcional para todos los miembros de la población o para grupos particulares de la misma que deben ser previamente definidos.

La tabla 1 muestra algunos ejemplos de alimentos funcionales.

Tabla 1. Ejemplos de alimentos funcionales.

ALIMENTO FUNCIONAL Yogures,
azúcar

\section{$\begin{array}{ll}\text { Margarinas } & \text { Ésteres de esteroles y estanoles de origen } \\ \text { vegetal añadidos }\end{array}$}

Probióticos: Alimentos con cultivos vivos beneficiosos, como resultado de la fermentación, o que se han añadido para mejorar el equilibrio microbiano intestinal, como el Lactobacillus sp. Bifidobacteria sp. Prebióticos: Componente no digerible que tiene efectos beneficiosos, debido a que estimula el crecimiento de la microbiota intestinal, como la inulina y la oligofructosa

\begin{tabular}{|c|c|c|}
\hline Margarinas & $\begin{array}{l}\text { Ésteres de esteroles y estanoles de origen } \\
\text { vegetal añadidos }\end{array}$ & $\begin{array}{l}\text { Reducen niveles de } \\
\text { colesterol LDL (malo) } \\
\text { Disminuyen el riesgo de } \\
\text { padecer afecciones } \\
\text { cardiacas }\end{array}$ \\
\hline $\begin{array}{l}\text { Huevos ricos } \\
\text { en ácidos } \\
\text { grasos } \\
\text { esenciales } \\
\text { omega-3 }\end{array}$ & Ácidos grasos omega-3 & $\begin{array}{l}\text { Control de hipertensión, } \\
\text { metabolismo de lípidos }\end{array}$ \\
\hline
\end{tabular}

Fuente: página web de Consejo Europeo de Información sobre la Alimentación (EUFIC)
Mejora de funcionamiento intestinal y equilibrio microbiano intestinal
Reducen niveles de colesterol LDL (malo) padecer afecciones cardiacas

Control de hipertensión, metabolismo de lípidos 


\section{LOS MICROORGANISMOS PROBIÓTICOS COMO COMPONENTES ALIMENTARIOS FUNCIONALES}

Hace casi un siglo, Ellie Metchnikoff observó que en Bulgaria un número muy elevado de personas vivía más de 100 años. Este hecho lo relacionó con el gran consumo de bacterias en las leches fermentadas como una forma de modular la microbiota intestinal y así evitar enfermedades y alargar la vida de la gente. En 1907 afirmó que "la dependencia de los microbios intestinales con respecto a los alimentos hace posible adoptar medidas para modificar la microbiota de nuestro organismo y sustituir los microbios nocivos por microbios útiles". Sus investigaciones le valieron el premio Nobel de Medicina en 1908 (FAO/OMS, 2006; Figueroa et al., 2006).

Por aquella época, el pediatra francés Henry Tissier observó que los niños con diarrea tenían en sus heces un escaso número de bacterias caracterizadas por una morfología peculiar en forma de Y. Estas bacterias "bífidas" eran, por el contrario, abundantes en los niños sanos. Sugirió la posibilidad de administrar estas bacterias a pacientes con diarrea para facilitar el restablecimiento de una microbiota intestinal sana.

Desde entonces, la ciencia ha trabajado para conocer más a dichos microorganimos llamados probióticos a las que Fuller definió en 1989 como "aquellos microorganismos vivos, principalmente bacterias y levaduras, que son agregados como suplemento en la dieta y que benefician al huésped mejorando el balance microbiano de su microbiota intestinal". En 1930, Minoru Shirota aisló de heces humanas una cepa de Lactobacillus casei, que posteriormente cultivó en leche, originando una bebida con características probióticas.

Las obras de Metchnikoff y Tissier fueron las primeras en las que se hicieron propuestas científicas con respecto al uso probiótico de bacterias, aun cuando la palabra probiótico no se acuñó hasta 1960, para designar las sustancias producidas por microorganismos que promovían el crecimiento de otros microorganismos (Lilly y Stillwell, 1965). Fuller (1989), con objeto de recalcar el carácter microbiano de los probióticos, definió de nuevo el término como "un suplemento dietético a base de

microbios vivos que afecta beneficiosamente al animal huésped mejorando su equilibrio intestinal". 
Introducción

Havenaar y Huis in't Veld en 1992 propusieron una definición similar: "un monocultivo o cultivo mixto viable de bacterias que, al aplicarse a animales o seres humanos, afecta beneficiosamente al huésped mejorando las propiedades de la microbiota autóctona". Otra más reciente, es: "microorganismos vivos que, cuando se consumen en cantidades apropiadas, confieren al huésped efectos saludables" (Guarner y Schaafsma, 1998).

Ya en 2001, los probióticos son definidos por la FAO (Food and Agriculture Organization, 2001) como "microorganismos vivos que, administrados en cantidades adecuadas, ejercen un efecto beneficioso sobre el huésped".

Cada día se conoce más acerca del papel de los microorganismos sobre la salud y sobre la multitud de efectos beneficiosos asociados al consumo del tipo adecuado de microorganismos probióticos. De hecho, en los 20 últimos años la investigación sobre los probióticos ha progresado considerablemente y se han realizado avances notables en la selección y caracterización de cultivos de probióticos concretos y la justificación de las declaraciones de propiedades saludables en relación con su consumo.

Las investigaciones sugieren que los microorganimos probióticos pueden:

- Ayudar a reducir el riesgo de ciertos tipos de diarreas (Thomas et al., 2001; Cremonini et al., 2002; de Vrese and Marteau, 2007; Van Niel et al., 2007).

- Ayudar a las personas con intolerancia a la lactosa en la digestión de la misma (Roberfroid, 2000; de Vrese et al., 2001).

- Reforzar la función inmune (Roberfroid, 2000; Rolfe, 2000; Nova et al., 2006; Corthésy et al., 2007).

Algunos estudios preliminares también ponen de manifiesto que ciertos probióticos pueden jugar un importante papel en la reducción del desarrollo de alergias en niños (Kalliomäki et al., 2001; Furrie, 2005), en la disminución de la colonización del estómago por Helicobacter pylori (Lionetti et al., 2006; LesbrosPantoflickova et al., 2007), en ayudar a los pacientes a sobreponerse de los efectos secundarios de la terapia con antibióticos, en la recuperación de procesos inflamatorios del intestino (Sheil et al., 2007), en reducir el riesgo de algunos tipos de 
cáncer (Rolfe, 2000; Aso et al., 2005; Ishikawa et al., 2005; Roller et al., 2007), en disminuir el crecimiento de los microorganismos causantes de las caries en la boca (Näse et al., 2001), en reducir los niveles elevados de colesterol en sangre (Roberfroid, 2000; Pereira y Gibson, 2002), en las vaginosis (Reid et al., 2001; Anukam et al., 2006) y en mantener saludable a la gente sana (Saran et al., 2002; Turchet et al., 2003; Tubelius et al., 2005; Weizman et al., 2005).

La mayoría de los productos probióticos contienen bacterias de los géneros Lactobacillus o Bifidobacterium, aunque otros géneros como Escherichia, Enterococcus y Bacillus se han comercializado como probióticos.

Es difícil de precisar cuáles son las características más deseables que un microorganismo debe presentar para ser buen probiótico (Mayo y Delgado, 2003). Pese a ésto, un informe de la FAO acerca de las "Directrices para la evaluación de probióticos en alimentos", considera en profundidad cuáles son los requisitos mínimos que un probiótico debe cumplir:

- Un probiótico debe estar definido a nivel de género, especie y cepa, usando las técnicas fisiológicas y moleculares más adecuadas.

- La cepa debe depositarse en una colección de cultivos internacional, para que los científicos puedan replicar las investigaciones publicadas sobre la cepa.

- Deben llevarse a cabo evaluaciones in vitro y en animales para lograr un mejor entendimiento de los atributos fisiológicos de la cepa.

- Antes de su uso, la seguridad de la cepa debe haber sido totalmente considerada.

- Deben realizarse estudios controlados para documentar un beneficio para la salud.

- Aptitud para mantener al probiótico vivo en los niveles requeridos hasta el final de la vida útil.

Durante los últimos años las ventas de probióticos han aumentado notoriamente en muchos países. Su producción industrial exige la búsqueda del 
Introducción

microorganismo y su validación científica, la optimización de su producción industrial, la formulación del alimento adicionado del probiótico y su validación clínica (Vidal, 2006).

En la tabla 2 se relacionan algunas de las características que a priori se consideran más interesantes, así como su posible función.

Tabla 2. Propiedades deseables en los microorganismos probióticos

\begin{tabular}{ll}
\hline \multicolumn{1}{c}{ Características } & \multicolumn{1}{c}{ Razón } \\
\hline Origen humano & Interacción especie-específica con el huésped \\
\hline Seguridad & $\begin{array}{l}\text { Sin riesgos de salud para el consumidor, no } \\
\text { patógeno ni inflamatorio, sin resistencias a } \\
\text { antibióticos }\end{array}$ \\
\hline $\begin{array}{l}\text { Resistencia al pH del estómago, } \\
\text { gastrointestinal a los enzimas } \\
\text { pancreáticos y a los ácidos biliares }\end{array}$ & Supervivencia al tránsito \\
\hline Adhesión a la mucosa intestinal & $\begin{array}{l}\text { Inmunomodulación, exclusión de patógenos, } \\
\text { incremento del sellado de la mucosa, } \\
\text { colonización prolongada }\end{array}$ \\
\hline Actividades enzimáticas deseables & $\begin{array}{l}\text { Inmunoestimulación, actividad antimutagénica y } \\
\text { anticarcinogénica }\end{array}$ \\
\hline $\begin{array}{l}\text { Producción de sustancias } \\
\text { antimicrobianas }\end{array}$ & $\begin{array}{l}\text { Inactivación de patógenos, normalización de la } \\
\text { microbiota intestinal }\end{array}$ \\
\hline Efectos beneficiosos documentados & $\begin{array}{l}\text { Validación clínica de los efectos "reales", dosis } \\
\text { mínima, relación dosis/efecto, aplicaciones } \\
\text { específicas }\end{array}$ \\
\hline Buenas propiedades tecnológicas & $\begin{array}{l}\text { Buena estabilidad, producción a gran } \\
\text { escala, tolerancia al oxígeno }\end{array}$ \\
\hline
\end{tabular}

Fuente: B. MAYO Y S. DELGADO, 2003 (Compilado de Collins y cols., 1998; Salminen et al., 1998a; Svenson, 1999; Vaughan y Mollet, 1999; Ouwehand et al., 2002).

En la actualidad, se utilizan bacterias con distintas propiedades en la prevención o el tratamiento de enfermedades (tabla 3), de modo que no es necesario que un único microorganismo presente todas las características deseables. Las actividades positivas podrían, por tanto, ser aportadas no por una bacteria aislada sino por una mezcla microbiana (Mayo y Delgado, 2003). 
Tabla 3. Microorganismos utilizados como probióticos y efectos beneficiosos comprobados por ensayos clínicos

\begin{tabular}{|c|c|c|}
\hline Género y especie & Cepa & Efecto saludable \\
\hline Bacillus cereus & Tojoy & - \\
\hline Bacillus subtilis & Varias & - \\
\hline $\begin{array}{l}\text { Bifidobacterium } \\
\text { bifidum }\end{array}$ & - & $\begin{array}{l}\text { Mejora la diarrea por rotavirus, mejora el equilibrio } \\
\text { intestinal }\end{array}$ \\
\hline $\begin{array}{l}\text { Bifidobacterium } \\
\text { breve }\end{array}$ & Varias & $\begin{array}{l}\text { Reduce los síntomas de las enfermedades } \\
\text { inflamatorias crónicas }\end{array}$ \\
\hline $\begin{array}{l}\text { Bifidobacterium } \\
\text { lactis }\end{array}$ & $\mathrm{Bb} 12$ & $\begin{array}{l}\text { Mejora el tratamiento de alergias, acorta la infección } \\
\text { por rotavirus, reduce la incidencia de diarrea del } \\
\text { viajero, mejora el efecto de vacunación oral }\end{array}$ \\
\hline $\begin{array}{l}\text { Bifidobacterium } \\
\text { longum }\end{array}$ & BB536 & - \\
\hline $\begin{array}{l}\text { Enterococcus } \\
\text { faecium }\end{array}$ & SF68 & - \\
\hline Escherichia coli & Nissle 1917 & $\begin{array}{l}\text { Reduce las recaídas en las enfermedades } \\
\text { inflamatorias crónicas }\end{array}$ \\
\hline $\begin{array}{l}\text { Lactobacillus } \\
\text { acidophilus }\end{array}$ & La5 & $\begin{array}{l}\text { Reduce la diarrea asociada al tratamiento con } \\
\text { antibióticos, mejora el equilibrio intestinal }\end{array}$ \\
\hline $\begin{array}{l}\text { Lactobacillus } \\
\text { acidophilus }\end{array}$ & NCFO 1748 & $\begin{array}{l}\text { Reduce actividades enzimáticas fecales dañinas, } \\
\text { previene la diarrea por radiación, alivia el } \\
\text { estreñimiento }\end{array}$ \\
\hline $\begin{array}{l}\text { Lactobacillus } \\
\text { casei }\end{array}$ & Shirota & $\begin{array}{l}\text { Acorta la diarrea por rotavirus, estimula la respuesta } \\
\text { inmune, reduce la recurrencia de cáncer de vejiga }\end{array}$ \\
\hline $\begin{array}{l}\text { Lactobacillus } \\
\text { delbrueckii } \\
\text { subsp. } \\
\text { bulgaricus } \\
\end{array}$ & Numerosas & $\begin{array}{l}\text { Mejora el equilibrio intestinal, reduce la diarrea } \\
\text { asociada a los tratamientos antibióticos, alivia la } \\
\text { intolerancia a la lactosa }\end{array}$ \\
\hline $\begin{array}{l}\text { Lactobacillus } \\
\text { johnsonii }\end{array}$ & La1 & $\begin{array}{l}\text { Mejora la respuesta a la vacunación oral, reduce la } \\
\text { colonización por H. pylori, alivia la inflamación }\end{array}$ \\
\hline $\begin{array}{l}\text { Lactobacillus } \\
\text { plantarum }\end{array}$ & $299 v$ & $\begin{array}{l}\text { Alivia el síndrome de intestino irritable, reduce los } \\
\text { niveles del colesterol LDL }\end{array}$ \\
\hline $\begin{array}{l}\text { Lactobacillus } \\
\text { reuteri }\end{array}$ & SD2112 & Acorta la diarrea por rotavirus \\
\hline $\begin{array}{l}\text { Lactobacillus } \\
\text { rhamnosus }\end{array}$ & GG & $\begin{array}{l}\text { Acorta la diarrea por rotavirus, estimula la respuesta } \\
\text { inmune, alivia la inflamación crónica del intestino, } \\
\text { ayuda en el tratamiento y la prevención de alergias }\end{array}$ \\
\hline $\begin{array}{l}\text { Lactobacillus } \\
\text { salivarius }\end{array}$ & UCC118 & $\begin{array}{l}\text { Reduce los síntomas de las enfermedades } \\
\text { inflamatorias crónicas }\end{array}$ \\
\hline $\begin{array}{l}\text { Propionibacterium } \\
\text { freudenreichii }\end{array}$ & JS & - \\
\hline $\begin{array}{l}\text { Saccharomyces } \\
\text { cerevisiae }\end{array}$ & Boulardii & $\begin{array}{l}\text { Reduce las recaídas en las enfermedades } \\
\text { inflamatorias crónicas, inhibe la proliferación de } \\
\text { Clostridium difficile }\end{array}$ \\
\hline $\begin{array}{l}\text { Streptococcus } \\
\text { thermophilus }\end{array}$ & Numerosas & $\begin{array}{l}\text { Mejora el equilibrio intestinal, reduce la diarrea } \\
\text { asociada a los tratamientos antibióticos, alivia la } \\
\text { intolerancia a la lactosa }\end{array}$ \\
\hline
\end{tabular}

Fuente: B. MAYO Y S. DELGADO, 2003 (Compilado de Salminen y cols., 1998a, Dunne y cols., 2001; Ouwehand y cols., 2002). 
Introducción

\section{EL CONCEPTO DE MICROBIOTA INTESTINAL EQUILIBRADA}

Para entender las bases del desarrollo de probióticos como componentes alimentarios funcionales es necesario familiarizarse un poco con las características del intestino y su microbiota (ILSI, 2002).

El primer investigador que señaló que la especie humana tiene aliados dentro del intestino que ayudan a combatir las infecciones fue Metchnikoff, quien dijo que la composición de la microbiota es esencial para el bienestar del huésped.

La microbiota intestinal es el término que define al ecosistema microbiano del intestino, que incluye especies nativas que colonizan permanentemente el tracto gastrointestinal y una serie variable de microorganismos vivos que transitan temporalmente por el tubo digestivo. Las bacterias nativas se adquieren al nacer y durante el primer año de vida, mientras que las bacterias en tránsito se ingieren continuamente a través de alimentos, bebidas, etcétera (Guarner, 2006).

Las bacterias viven normalmente en el cuerpo humano (así como en el de los animales superiores e insectos), incluido el aparato digestivo, donde existen más de 400 especies bacterianas. Más de la mitad del peso de la materia que se encuentra en el colon corresponde a células bacterianas cuyo número es diez veces superior al de las células de los tejidos que constituyen el cuerpo humano. El estómago contiene normalmente pocas bacterias $\left(10^{3}\right.$ u.f.c/ml jugo gástrico), mientras que la concentración bacteriana aumenta a lo largo del intestino hasta llegar a una concentración final en el colon de $10^{12}$ bacterias/g (Berg, 1996; Salminen et al., 1998a; Tannock, 1999; Guarner y Malagelada, 2003). La figura 1, recoge algunos de los géneros que predominan en número en el tracto gastrointestinal de un humano adulto. 


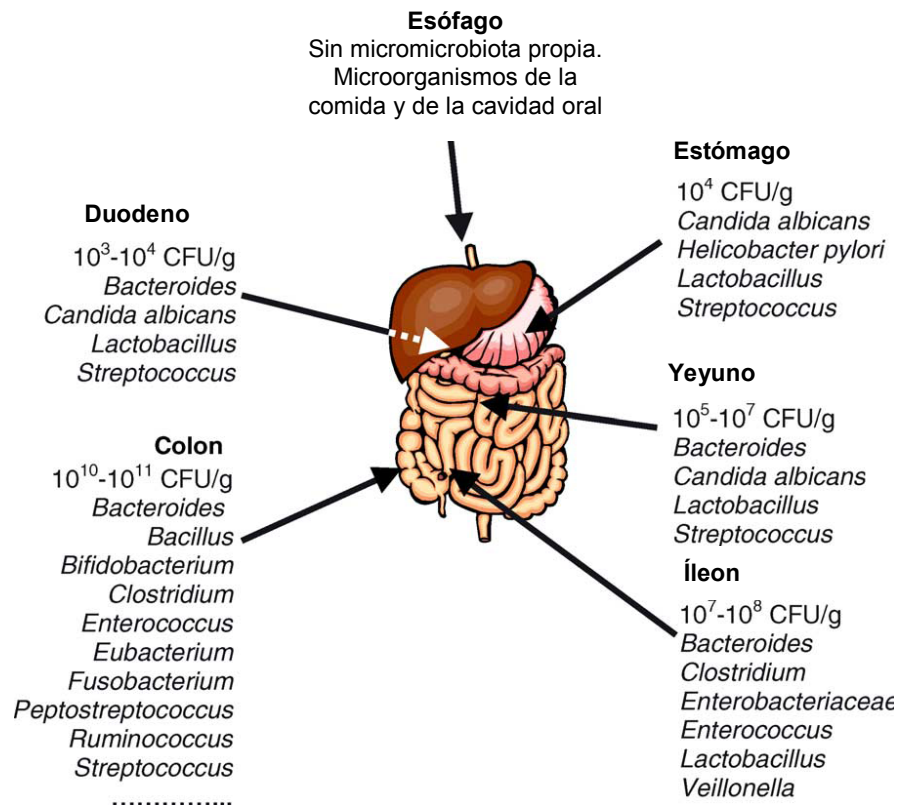

Figura 1. Géneros que predominan en número en el tracto gastrointestinal de un humano adulto (Fuente: Isolauri et al., 2004)

En términos cuantitativos, los géneros de bacterias intestinales más importantes en los humanos son los bacteroides y las bifidobacterias, que representan alrededor de $35 \%$ y $25 \%$, respectivamente, de las especies conocidas (ILSI , 2002).

La colonización es la presencia de un microorganismo en un huésped, de acuerdo con ciertas condiciones: tiene que haber crecimiento y multiplicación; debe pasar desapercibido desde el punto de vista clínico y no debe provocar ninguna respuesta inmune al ser aislado (Moreno, 2001).

La colonización bacteriana del intestino comienza con el nacimiento $y$ continúa durante toda la vida (Mitsuoka,

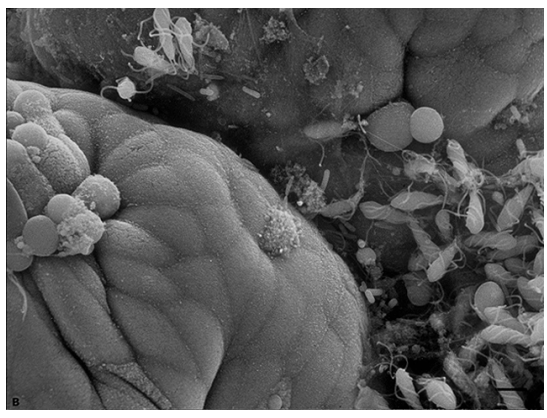

Figura 2. Colonización bacteriana del intestino

Fuente: web de la universidad de Wichita, EEUU. 
Introducción

1992).

Durante el embarazo, el lumen intestinal es estéril y tiene una baja tensión de oxígeno, porque recibe oxígeno a través de la placenta. El recién nacido empieza a adquirir una microbiota, que al final es propia de cada ser humano, a partir de la microbiota fecal materna e, incluso, de probióticos que la madre haya recibido (Collins y Gibson, 1999; Isolauri et al. 2004).

Las primeras bacterias que llegan al colon en el momento de nacer son enterobacterias microaerófilas, que consumen el escaso oxígeno restante en el lumen intestinal y producen un ambiente favorable para el desarrollo de los anaerobios. Este proceso es muy especial, porque varía si la vía del parto es vaginal o por cesárea, siendo el porcentaje de individuos colonizados mayor en el parto por vía vaginal (www.pediatraldia.cl; Grönlund et al., 1999; Larsen y Monif, 2001). Las bacterias pioneras en esta colonización tienen la capacidad de modular la expresión de los genes de las células del epitelio intestinal para mejorar las condiciones ambientales y, así, incrementar la proliferación bacteriana (www.saludlandia.com; Isolauri et al., 2004).

Después viene el efecto de la dieta, que determina un predominio de lactobacilos y bifidobacterias en los lactantes alimentados al pecho y microbiota diversa en los que reciben fórmula (Harmsen et al., 2000). Esta microbiota cumple importantes funciones, entre las que destaca, por su importancia, la protección del lactante contra una serie de enfermedades como la diarrea aguda (www.pediatraldia.cl; Salminen et al., 1998a; Sanders, 2003).

Por último, con el destete se produce una microbiota de transición y un paso paulatino hacia la microbiota del adulto, influenciada por factores intrínsecos (secreciones dentro del intestino) y extrínsecos (envejecimiento, dieta, estrés, ambiente étnico,...) (www.pediatraldia.cl; Benno et al., 1986).

Las concentraciones de bacterias en diferentes partes del tracto intestinal varían en gran manera (Saxelin, 2002).

El intestino grueso tiene un extenso metabolismo bacteriano. Las bacterias descomponen los nutrientes que aún permanecen en la comida, como las proteínas parcialmente digeridas y los componentes fibrosos. Alrededor de la mitad de la mayoría de excrementos consiste en masa bacteriana. Se han reconocido entre 400 
y 500 especies de bacterias en el intestino grueso y en los excrementos. Además, están presentes entre 100 y 1000 veces más bacterias anaeróbicas que aeróbicas. La figura 3 presenta los géneros o grupos de bacterias más comunes y su principal influencia en el metabolismo bacteriano del intestino (Saxelin, 2002).

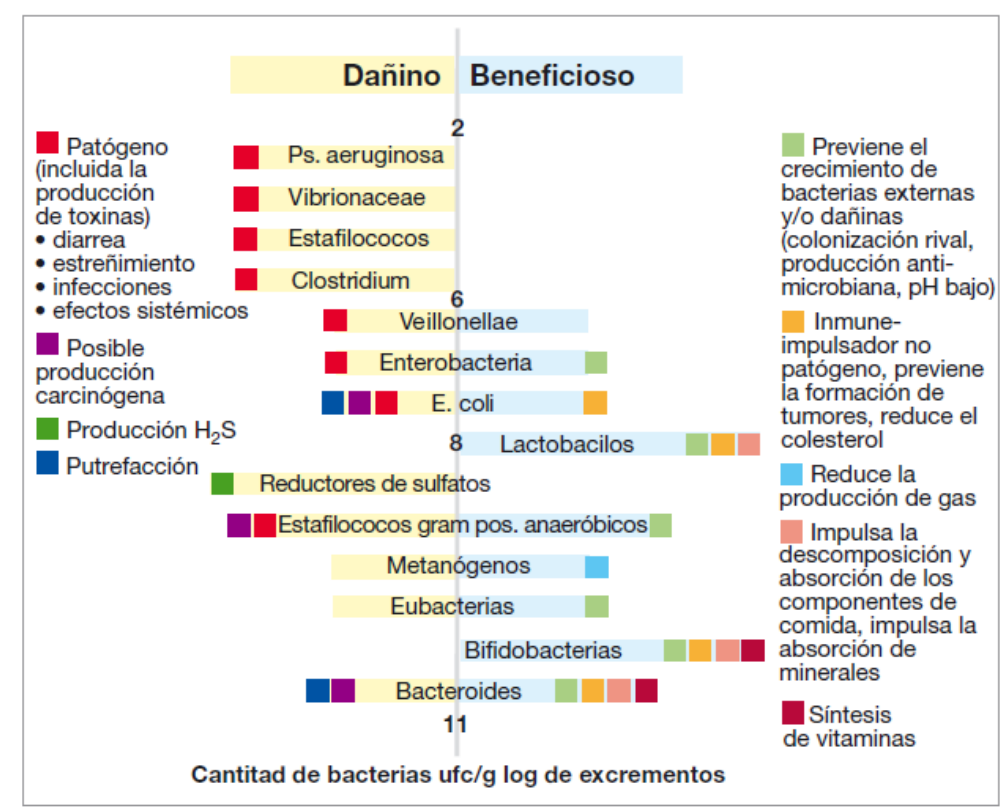

Figura 3. Los grupos de microbios más importantes, sus cantidades y división aproximada según su potencial de efectos dañinos y beneficiosos (Saxelin, 2002).

Se ha demostrado que la composición de la microbiota bacteriana varía mucho de un individuo a otro, pero en cambio sus funciones metabólicas son casi iguales (Guarner, 2002; Tejeda et al., 2003; AFSSA, 2005). Además, cada individuo mantiene una microbiota relativamente estable (McCartney et al., 1996; Wang et al., 1996; Wilson y Blitchington, 1996; Kimura et al., 1997; Zoetendal et al., 1998; Guarner, 2002; Tejeda et al., 2003), si bien el uso indiscriminado de antibióticos (Sullivan et al., 2001) y los cambios dietéticos pueden producir modificaciones transitorias a lo largo de la vida, que suelen ser reversibles.

Las bacterias, que forman la denominada microbiota intestinal residente, no suelen tener efectos nocivos agudos, y se ha demostrado que algunas de ellas son necesarias para mantener el bienestar de su huésped (Mitsuoka, 1992). De hecho, 
Introducción

tal y como recoge Guarner (2002), son varias las patologías que están relacionadas con la disfunción de la microbiota.

Tabla 4. Patologías relacionadas con disfunción de la microbiota intestinal

\begin{tabular}{l}
\hline Encefalopatía hepática \\
Diarrea inducida por antibióticos \\
\hline Diabetes tipo 2 \\
Cáncer de colon \\
Atopia \\
\hline Enfermedades inflamatorias intestinales \\
\hline
\end{tabular}

Fuente: Guarner, 2002.

Cabe citar como ejemplo de la función beneficiosa de la microbiota intestinal lo que se ha denominado "resistencia a la colonización" o "efecto barrera" (Falk et al., 1998; Adlerberth et al., 2000; Hooper et al., 2001; Guarner, 2006), en referencia al mecanismo que utilizan las bacterias ya presentes en el intestino para establecerse en ese medio y evitar la colonización de esas mismas zonas intestinales por microorganismos ingeridos recientemente, incluidos patógenos. Además, la microbiota ejerce una influencia muy importante en el desarrollo y maduración del sistema inmune asociado al tubo digestivo (Guarner, 2002) estimulando la generación de anticuerpos y células de defensa (Cebra, 1999; Grönlund et al., 2000; Isolauri et al., 2002). De hecho, existen estudios que demuestran que los mamíferos criados en condiciones experimentales de asepsia total no adquieren su microbiota natural $y$, por tanto, no se desarrollan normalmente (Tannock, 2001).

Además de su función de barrera contra la infección, la microbiota intestinal aporta energía mediante la fermentación de los hidratos de carbono no digeridos en el tracto gastrointestinal superior. Ésta también produce ácidos grasos de cadena corta (AGCC), que cumplen varias funciones metabólicas importantes (Brouns et al., 2002; ILSI, 2002; Guarner, 2006). Además, algunas especies sintetizan vitamina K, y varias de las vitaminas del grupo $\mathrm{B}$, que son absorbidas en el colón (Hooper et al., 2002). 
Otra función importante de la microbiota intestinal es su capacidad para metabolizar y detoxificar componentes potencialmente nocivos tales como los carcinógenos (ILSI, 2002).

La microbiota intestinal es una comunidad interactiva compleja de organismos, cuyas funciones son consecuencia de las actividades combinadas de todos los componentes microbianos. Suele aceptarse que desempeña un importante papel en infecciones gastrointestinales, estreñimiento, síndrome de colon irritable, enfermedades inflamatorias intestinales y, quizás, cáncer colorrectal (ILSI, 2002).

Las especies bacterianas más frecuentes en el intestino humano se clasifican en tres grupos de bacterias: ácido-lácticas, anaerobias y aeróbicas (Moreno, 2001). El primer grupo (ácido-lácticas) es el más importante y está constituido por los géneros Bifidobacterium, Lactobacillus, Streptococcus y Enterococcus. Las bacterias anaerobias son inocuas, pero cuando se rompe la continuidad de la superficie mucosa intestinal pueden causar problemas. El grupo de las bacterias aerobias está compuesto fundamentalmente por las enterobacterias Escherichia coli, Klebsiella pneumoniae, Proteus, Pseudomonas, bacilos, Staphylococcus, hongos y levaduras diversas.

La modulación de la microbiota intestinal puede ser de gran beneficio para la salud. Así, en años recientes, el concepto de alimento funcional ha desplazado a los suplementos con vitaminas y minerales, pues mejora la funcionalidad de la microbiota intestinal (Tejeda et al., 2003).

El actual ritmo de vida, la disminución de la actividad física, el estrés y malos hábitos en la dieta, deterioran el balance microbiano en nuestro organismo, situación que se asocia a enfermedades tales como la obesidad, diarrea, estreñimiento, enfermedad inflamatoria del colón, diabetes tipo II y cáncer de colon. Por todo esto, favorecer este equilibrio con el consumo de alimentos que contienen probióticos y prebióticos contribuye a una vida saludable (Fooks and Gibson, 2002; Isolauri et al., 2004).

Actualmente, la mayor parte de trabajos de investigación sobre probióticos, se centra en la caracterización de la microbiota intestinal de cada individuo, evaluando las especies en cada parte del intestino. El objetivo es llegar a entender las interacciones de los microorganismos con el intestino, las interacciones entre microorganismos y microbiota intestinal y los efectos combinados para la salud de 
estas interacciones. La meta es definir y caracterizar la microbiota como herramienta para el control nutricional en enfermedades específicas relacionadas con el intestino y como fuente de nuevos microorganismos para futuras aplicaciones en bacterioterapias con probióticos (Isolauri et al. 2004). 


\section{PROBIÓTICOS Y PRODUCTOS LÁCTEOS}

Algunas de las bacterias que habitualmente se utilizan en productos lácteos fermentados, encuentran también su hábitat en diferentes partes del cuerpo humano, incluyendo la boca, el tracto intestinal o la vagina. Algunos de estos microorganismos, por tanto, pueden jugar un doble papel transformando la leche en diversos tipos de productos lácteos (yogur, queso, kéfir,...) y contribuyendo al importante papel de bacterias colonizadoras (www.usprobiotics.org; Salminen et al., 1998b; Crittenden et al., 2001).

El empleo de productos lácteos funcionales proporciona la oportunidad de combinar alimentos de amplio uso, aceptabilidad y tolerancia, con microorganismos probióticos, como estrategia para corregir pequeñas disfunciones metabólicas que pueden conducir a enfermedades crónicas (Recio y López-Fandiño, 2005).

Los productos lácteos pueden ser un buen vehículo de transmisión de bacterias probióticas por varias razones (www.usprobiotics.org):

1. Pueden proteger a las bacterias probióticas al atravesar el tracto digestivo humano, donde el ácido gástrico y las secreciones pancreáticas (tales como enzimas digestivos y bilis) pueden producir daños e, incluso, la muerte de las bacterias probióticas ingeridas. Aunque algunas bacterias son más resistentes que otras a este estrés, el consumo de probióticos con los alimentos incluidos la leche, el yogur y otros derivados lácteos, neutraliza el ácido del estómago y puede aumentar las probabilidades de que las bacterias sobrevivan en el intestino.

2. Aunque el contenido de ácido láctico de un yogur puede suponer una barrera para la estabilidad del cultivo, el almacenamiento en refrigeración de los productos lácteos contribuye a promover la estabilidad de los probióticos.

3. Un producto lácteo con probióticos se convierte en un alimento saludable y funcional: además de las vitaminas, calcio, otros minerales y las proteínas obtenidas de los lácteos, las investigaciones recientes han sugerido la existencia de determinadas propiedades 
Introducción

saludables de los péptidos derivados de la fermentación y del ácido butírico encontrado en algunos lácteos. 


\section{EL YOGUR $Y$ EL YOGUR PASTEURIZADO DESPUÉS DE LA FERMENTACIÓN. LA GUERRA DEL YOGUR}

La leche y los productos lácteos representan un grupo de alimentos de primera necesidad. El valor nutritivo y gastronómico de quesos, yogures y leches fermentadas responde a los gustos de cada cliente, aportando además una parte importante de la cantidad diaria recomendada (CDR) de proteínas, vitaminas A y B2, zinc y calcio (Castro, 2007).

La distribución y el consumo de productos lácteos en España, quedan recogidos en la tabla que sigue.

Tabla 5. Distribución y consumo de productos lácteos

\begin{tabular}{lcc}
\hline & $\begin{array}{c}\text { Consumo total } \\
\text { (millones de litros) }\end{array}$ & $\begin{array}{c}\text { Per cápita } \\
\text { (kilo y año) }\end{array}$ \\
\hline Total derivados lácteos & 1693,61 & 39,58 \\
Leches fermentadas & 666,81 & 15,56 \\
Yogures & 484,81 & 11,33 \\
Quesos & 320,78 & 7,50 \\
Otros & 1026,80 & 24,02 \\
\hline
\end{tabular}

Fuente: MAPA, 2005

La existencia del yogur se remonta a tiempos muy antiguos. Se desconoce exactamente dónde se originó, aunque algunos historiadores atribuyen su descubrimiento a la civilización sumeria, que vivía en el Suroeste de Asia por los años 4000 o 5000 aC. En Europa, comenzó a elaborarse en Bulgaria y Turquía por pueblos cuya riqueza pricipal eran sus rebaños.

En el momento actual, el yogur no es un alimento más, sino que es casi un alimento mítico, lo que se debe, además de a su valor nutritivo, a derivarse de otro alimento de gran prestigio como es la leche y al hecho de evocar etnias lejanas con una envidiable salud y longevidad (Albalat et al., 1998).

Según la Norma de Calidad Española para el yogur, aprobada por el Real Decreto 179/2003, se entiende por "yogur» o "yoghourt» el producto de leche coagulada obtenida por fermentación láctica mediante la acción de Lactobacillus 
bulgaricus y Streptococcus thermophilus a partir de leche pasterizada, leche concentrada pasterizada, leche total o parcialmente desnatada pasterizada, leche concentrada pasterizada total o parcialmente desnatada, con o sin adición de nata pasterizada, leche en polvo entera, semidesnatada o desnatada, suero en polvo, proteínas de

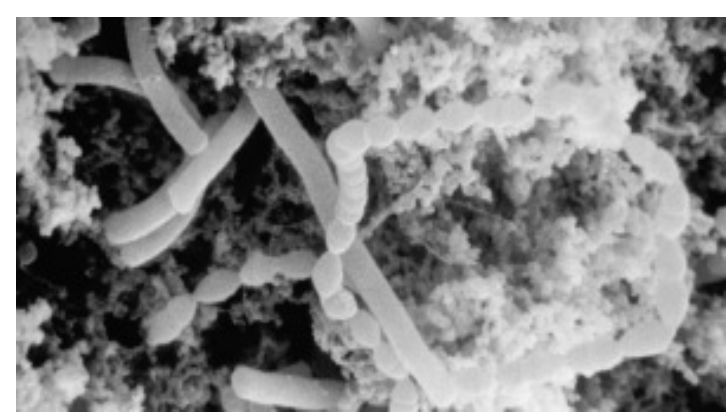

Figura 4: Lactobacillus delbrueckii subsp. bulgaricus (bacilo) y Streptococcus thermophilus (coco) en yogur

Fuente: INRA/M. Rousseau - PCD0668-IMG0017.PCD. leche $y / u$ otros productos procedentes del fraccionamiento de la leche. Los microorganismos productores de la fermentación láctica deben ser viables y estar presentes en el producto terminado en cantidad mínima de 1 por $10^{7}$ u.f.c./ml.

La FAO y la OMS dan una definición similar, si bien no precisan el número de microorganismos viables mínimo en el producto final, indicando tan sólo que deben ser abundantes.

De ellos, Lactobacillus bulgaricus se desarrolla bien entre 45 y $50^{\circ} \mathrm{C}$, acidificando fuertemente el medio, mientras que Streptococcus thermophilus sobrevive a temperaturas de $65^{\circ} \mathrm{C}$ durante 30 minutos, aunque es mucho menos acidificante. Sin embargo, ambos soportan bien los medios ácidos ( $\mathrm{pH}$ de 4 a 4,5$)$ y en el yogur viven en estrecha simbiosis (Aleixandre y García, 1999).

Al comienzo de la elaboración, el pH de la leche es favorable al desarrollo de Streptococcus thermophilus que predomina y pone en marcha la fermentación láctica. Al aumentar la acidificación, el $\mathrm{pH}$ se vuelve desfavorable para este microorganismo que, progresivamente, irá siendo reemplazado por Lactobacillus bulgaricus. La leche cuaja cuando su acidez alcanza los 70 u 80 grados Dornic (Aleixandre y García, 1999). A partir de entonces, el producto se debe enfriar para detener el proceso fermentativo.

A lo largo de la elaboración del yogur se producen diversos cambios. El primero de ellos es la transformación de la lactosa en ácido láctico, aumentando su concentración y disminuyendo el pH de la leche, lo que provocará su coagulación. 
En segundo lugar, destaca la acción de las bacterias sobre las proteínas de la leche, con la consiguiente liberación de ciertos aminoácidos y péptidos con actividad biológica importante. En tercer lugar, estas bacterias actúan sobre los lípidos, originando un aumento de ciertos ácidos grasos volátiles y no volátiles, proceso responsable del aroma y el sabor final característico del yogur. Finalmente, las vitaminas también se ven modificadas, como es el caso de las vitaminas del grupo B y en particular la B12, aumentando en concentración (www.institutotomas pascual.es).

Como se ha indicado, uno de los campos de estudio más prometedores para el desarrollo de componentes alimentarios funcionales es el uso de probióticos capaces de modificar la composición y las actividades metabólicas y enzimáticas de la microbiota intestinal (ILSI, 2002).

Varias especies de lactobacilos y bifidobacterias combinadas (o no) con Streptococcus thermophilus son las principales bacterias usadas como probióticos en yogures y otros productos lácteos fermentados. Sus principales beneficios para la salud, demostrados en los seres humanos, son la disminución de la intolerancia a la lactosa y la estimulación del sistema inmunitario para reducir la incidencia o gravedad de infecciones gastrointestinales. También se ha demostrado que disminuyen la incidencia de lesiones precancerosas en animales tratados con carcinógenos, pero hacen falta estudios clínicos que confirmen la importancia de esta observación para los humanos (ILSI, 2002).

Otro mecanismo por el que las bacterias probióticas pueden favorecer la salud del tracto digestivo es la alteración de la respuesta inmunitaria local. La supervivencia de las bacterias durante el tránsito intestinal y la adhesión a las células intestinales parecen ser importantes para que las bacterias ejerzan su efecto sobre el huésped. En estudios animales y humanos se ha observado una modificación favorable de las respuestas inmunitarias después de la ingestión de probióticos o sus extractos.

En lo que se refiere al mercado español de los yogures, está indiscutiblemente dominado por la multinacional Danone, que acapara más del $50 \%$ de cuota de mercado. La inversión en promoción y en investigación es el elemento estratégico que permite mantener su posición de liderazgo en ese sector (Euromarket 2005). 
Introducción

Los restantes competidores se pueden agrupar en tres grupos estratégicos claramente diferenciados. Por un lado, existe un número reducido de importantes empresas que siguen unas estrategias similares a Danone en cuanto a inversión publicitaria y a investigación y desarrollo (formado principalmente por Nestlé y Central Lechera Asturiana). Por otro lado, existe un conjunto de empresas de pequeño y mediano tamaño que centran su estrategia en la imitación de los lanzamientos de las grandes empresas y que en la mayoría de los casos tienen una gama de productos más reducida e, incluso, una presencia geográfica limitada a algunas regiones. Y, finalmente, están los fabricantes de marcas blancas, que acaparan en torno al 30\% del mercado principalmente dentro de la gama de yogures tradicionales (natural y de sabores), cuyos precios prácticamente no han subido desde mediados de los 90 (Euromarket 2005; Anónimo, 2006).

Danone es la marca más vendida, con una cuota de mercado del $49,1 \%$ en volumen de ventas $(325.211 \mathrm{~T}$ ) y el $63,7 \%$ en valor (1.018, 3 millones de euros). A continuación, figuran las marcas blancas, con el 39,6\% del volumen (262.083 T) y el 24,5\% del valor (391,2 millones). Destaca aquí lbérica, filial de la matriz francesa, fundamentalmente como marca de la distribución para el grupo Mercadona. Nestlé, Central Lechera Asturiana (3,4\% del volumen y 3,3\% de las ventas) ocupan los siguientes lugares de la lista de marcas de yogures más adquiridas (Anónimo, 2006; www.elpais.com, Vidal Maté 18/02/2007).

La figura 5 recoge de forma esquemática las cifras anteriores.

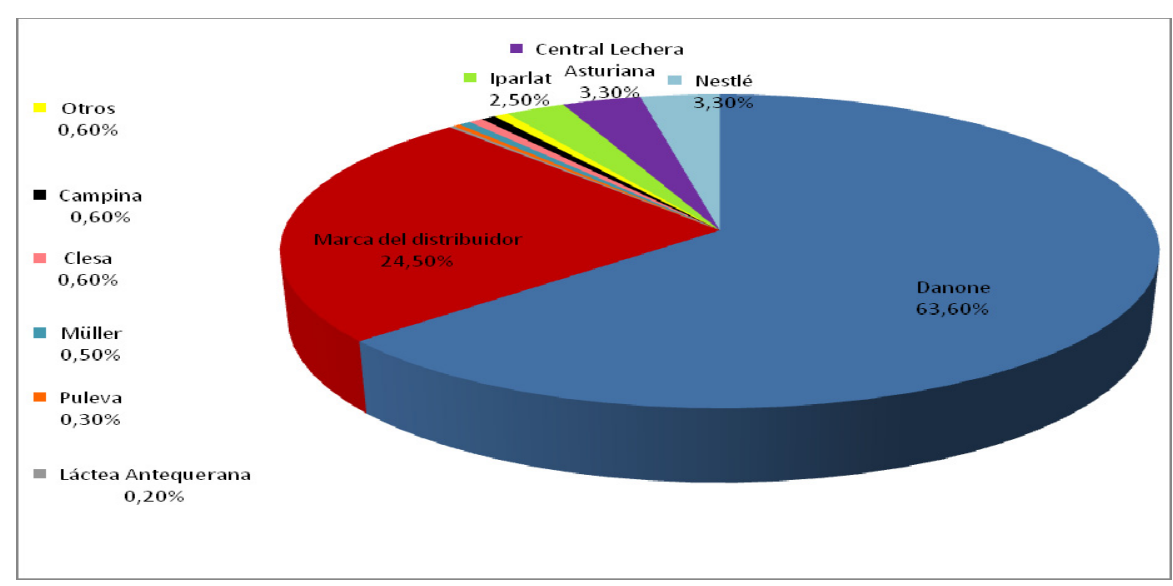

Figura 5. Fabricantes de yogur tradicional 
La venta de leche líquida supone una actividad escasamente rentable para las industrias ante la fuerte presión de precios a la baja de la gran distribución. Por este motivo, la elaboración de productos de mayor valor añadido (funcionales, desnatados, enriquecidos, líquidos, cremosos, etc.), ha significado la principal alternativa de la industria para aumentar su facturación y, sobre todo, sus beneficios (Euromarket 2005; www.elpais.com, Vidal Maté 18/02/2007).

En su política de diversificación hacia los alimentos lácteos, el Grupo Leche Pascual, se planteó introducirse en el mercado de los yogures a mitad de los años 90 , mediante el lanzamiento de una innovación radical que le permitiese acaparar una significativa cuota de mercado y poder luchar en condiciones adecuadas con Danone por el liderazgo del mercado. Se trataba de yogur al que, tras la fermentación, se le aplica un tratamiento térmico de pasteurización, de forma que, sin perder sus cualidades nutricionales, puede conservarse sin frío durante tres meses. Se trataba de un yogur de "larga vida" (Euromarket 2005).

Así, de acuerdo con el Real Decreto 179/2003, al que anteriormente se ha hecho alusión, se entiende por "yogur pasteurizado después de la fermentación» o «yoghourt pasteurizado después de la fermentación» el producto obtenido a partir del «yogur» o «yoghourt» que, como consecuencia de la aplicación de un tratamiento por calor posterior a la fermentación equivalente a una pasteurización, ha perdido la viabilidad de las bacterias lácticas específicas y cumple todos los requisitos establecidos para el yogur en esta norma, salvo las excepciones indicadas en ésta.

A partir de la obtención del yogur, el tradicional se envasa y tiene un periodo de duración de 28 días a una temperatura entre 1 y $8^{\circ} \mathrm{C}$. En el caso de Pascual, el producto se pasteuriza y se puede conservar sin frío tres meses (www.instituotomaspascual.es).

El lanzamiento de esta nueva gama de producto no fue fácil y ha generado una dura y larga "guerra" de casi una década entre Pascual y el resto de fabricantes de yogures que, incluso, ha sobrepasado los límites del enfrentamiento puramente comercial (Euromarket 2005). Así, en 2000, el grupo Pascual inició una larga ofensiva denominada en su día como la "guerra del yogur" con el objetivo de que la Administración española permitiera calificar con esa denominación al producto pasteurizado después de la fermentación (www.elpais.com, Vidal Maté 18/02/2007). 
Introducción

La primera batalla se centró en el cambio en la normativa legal. Por la parte de las multinacionales (con Danone y Nestlé a la cabeza), se alegaba que el yogur tradicional es un producto históricamente implantado en la población. Sobre la base de estudios científicos, se defendía que el yogur sólo se puede llamar así si es un producto con fermentos vivos, algo además indispensable para que tenga un efecto beneficioso sobre el intestino y para la salud en general. Desde una perspectiva económica, se alegaba que si se cambiaba la normativa, se produciría una invasión de esos postres desde el exterior, atentando contra la industria láctea española.

Desde Leche Pascual se defendía, por el contrario, la necesidad de modificar una normativa que databa de los años 1987 y 1994 para adecuar la misma a las nuevas posibilidades tecnológicas. Pascual alegaba que su producto se hace con el mismo método que el yogur tradicional, pero sólo con leche de calidad, mientras para el yogur tradicional se admite hasta un 5\% de leche en polvo. También con el soporte de científicos cualificados, Pascual defendía que su postre tiene el mismo efecto que el yogur tradicional y argumentaba que los microorganismos vivos del yogur no logran llegar al intestino, con escasos efectos sobre la salud (www.elpais.com).

En la disputa para lograr la denominación "yogur" se enfrentaron científicos, empresas y políticos para acabar finalmente con una disposición de Agricultura (el Real Decreto 179/2003) por la que se daba luz verde al producto con la nueva denominación de "yogur pasteurizado después de la fermentación".

En el conjunto del sector de la industria láctea, Pascual fue prácticamente el único grupo que optó por la producción de este tipo de alimento, mientras el resto de las industrias se posicionaron en contra o al margen de la medida (www.elpais.com, Vidal Maté 18/02/2007).

Esta denominación es también reconocida por las legislaciones de varios países, entre ellos Estados Unidos, Reino Unido, Holanda, Alemania, Canadá y Australia (Tecnifood, 2006).

Por el contrario, el Codex Alimentarius, que depende de Naciones Unidas y de la Organización Mundial de la Salud (OMS), adoptó una norma que impide que los postres lácteos pasteurizados después de la fermentación puedan denominarse yogures, al menos en los países que no tienen legislación alguna sobre la materia (www.elpais.com, 2003; CODEX STAN 243-2003; Tecnifood, 2006). 
La polémica norma de calidad para el yogur tuvo en 2006 dos nuevos capítulos, en forma de sentencias del Tribunal Supremo que, en dos decisiones adoptadas a finales de 2005, determinó que pueden recibir la denominación de "yogur pasteurizado después de la fermentación» los productos que, una vez fermentados con bacterias, se someten a un proceso de tratamiento térmico con la consiguiente muerte de estas bacterias. Un concepto, según ellos, que constituía una evolución propia del mercado en la comercialización de estos productos (Tecnifood, 2006).

El Tribunal Supremo llegó a esta decisión tras desestimar en noviembre un recurso contencioso-administrativo interpuesto por la Asociación Española de Yogur y Postres Lácteos Frescos (AEFY) integrada por empresas como (Danone, Corporación Alimentaria Peñasanta (Capsa), Nestlé o Puleva Food) contra la Norma de Calidad del Yogur, que admite la denominación de yogur para productos pasteurizado después de la fermentación (Tecnifood, 2006). 


\section{ANTECEDENTES HISTÓRICOS DE LAS BACTERIAS ACIDOLÁCTICAS}

Las bacterias ácido lácticas (BAL) son un grupo de bacterias Gram-positivas unidas por una serie de características morfológicas, metabólicas y fisiológicas. Entre sus rasgos comunes se encuentra el que son Gram-positivas, normalmente catalasa negativas y que crecen en condiciones de microaerofilia y de anaerobiosis estricta, con producción de acido láctico como producto de la fermentación de carbohidratos (Couret et al., 2003).

La tabla 6 recoge las principales características diferenciales de las bacterias acidolácticas.

Tabla 6. Características diferenciales de las bacterias acidolácticas ${ }^{a}$

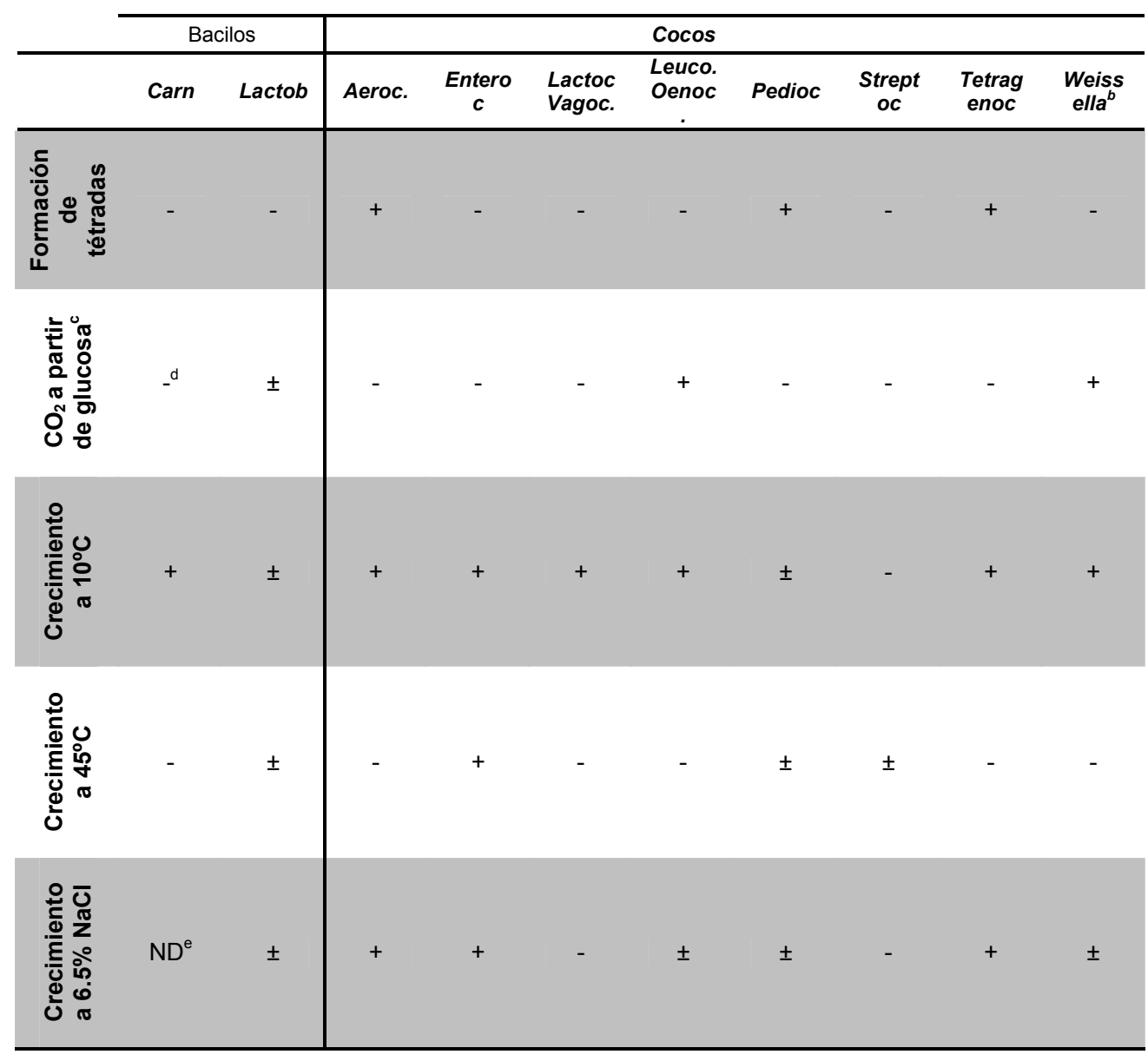




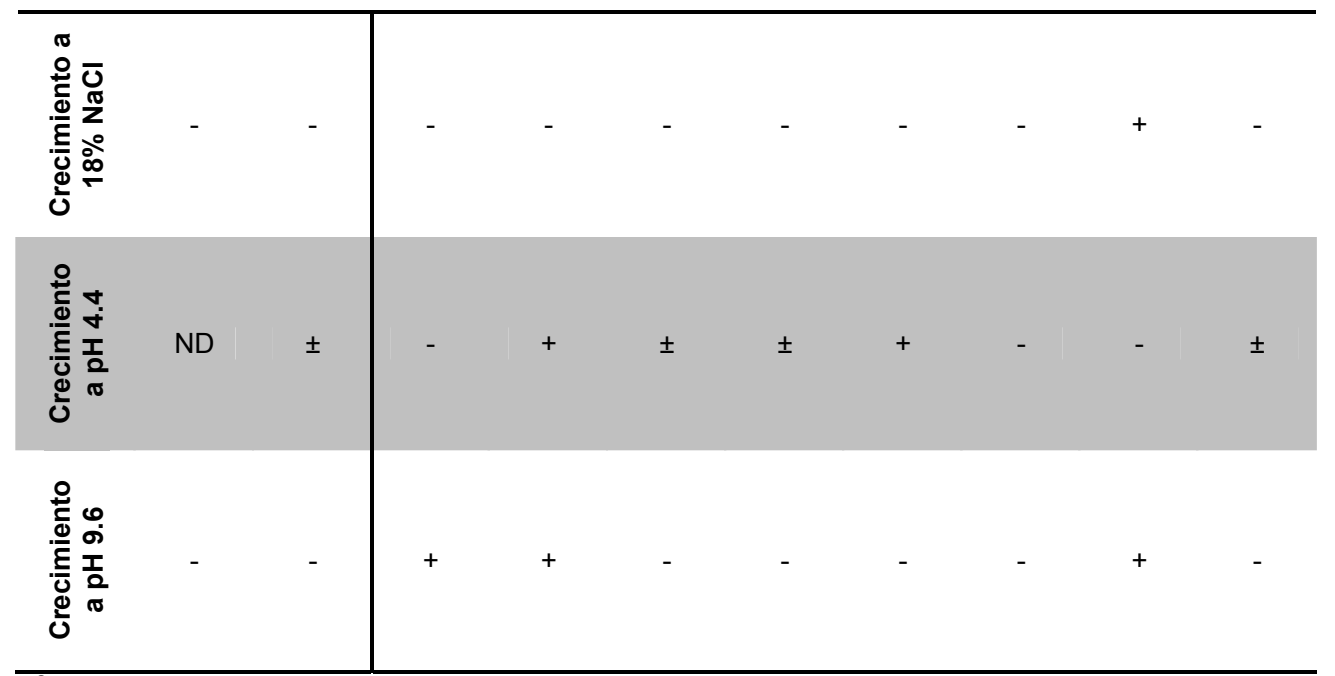

a +: positivo; -: negativo; \pm : respuesta en varias especies; ND: no determinado.

${ }^{b}$ Algunos tipos de Weissella también poseen forma bacilar.

c Test para homo- o heterofermentadores de glucosa. Negativo y positivo denotan homofermentativo y heterofermentativo, respectivamente.

${ }^{\mathrm{d}}$ Pequeñas cantidades de $\mathrm{CO}_{2}$ pueden ser producidas, dependiendo del medio.

${ }^{\text {e }}$ Crecimiento nulo en $8 \%$ de $\mathrm{NaCl}$

La clasificación de las bacterias acidolácticas, de Orla-Jensen aún se acepta como método estándar de identificación de estos microorganismos. Los de forma esférica (cocoidea) se conocen como Streptococcus y los bacilos se clasifican como Thermobacterium, Streptobacterium y Betabacterium. Según la séptima edición del Bergey (1957), todas las bacterias acidolácticas se incluyen en la familia Lactobacillaceae, que a su vez se subdivide en Streptococcaceae (de forma esférica u ovoide) y Lactobacillaceae (de forma bacilar). Esta clasificación ha sido reorganizada en la octava edición del manual de Bergey (1994), que las considera dos familias separadas: Streptococcaceae y Lactobacillaceae.

Los límites de este grupo han sido objeto de controversia, pero históricamente los géneros Lactobacillus, Leuconostoc, Pediococcus y Streptococcus son los más importantes. Las revisiones taxonómicas de este género y la descripción de nuevos géneros sugieren que las bacterias acidolácticas comprendan los siguientes géneros: Aerococcus, Alloiococcus, Carnobacterium, Dolosigranulum, Enterococcus, Globicatella, Lactobacillus, Lactococcus, Lactosphaera, Leuconostoc, Oenococcus, Pediococcus, Streptococcus, Tetragenococcus, Vagococcus y Weissella. El género Bifidobacterium, 
Introducción

frecuentemente está considerado en el mismo contexto que las bacterias acidolácticas y posee algunas características comunes.

La clasificación de las bacterias acidolácticas en diferentes géneros está basada en la morfología, modo de fermentar la glucosa, el crecimiento a diferentes temperaturas, la configuración del ácido láctico producido, la habilidad para crecer a elevadas concentraciones de sales y la tolerancia ácido base. Las bacterias acidolácticas obtienen energía metabólica esencialmente mediante la fosforilación a nivel de sustrato, durante la oxidación de carbohidratos, formando ácido láctico como principal metabolito. Además, poseen actividad proteolítica, lo que les permite la obtención de aminoácidos a partir de proteínas, en medios ricos en dichos constituyentes, si bien ésta es reconocidamente inferior a otros grupos bacterianos como Bacillus, Proteus o Pseudomonas, entre otros.

Uno de los primeros estudios bacteriológicos del yogur fue realizado por Grigoroff en 1905, quien observó la presencia de tres tipos distintos de microorganismos, unos denominados "diplostreptococcus", otros microorganismos de forma cocobacilar y otros de forma bacilar. Esta misma observación fue realizada por Lüerssen y Kühn (1908). No obstante, la popularidad alcanzada por el yogur se atribuye a Metchnikoff (1910), quien postuló la teoría de que la ingestión de una bacteria acidoláctica, denominada Bulgarian bacillus, prolongaba la vida. La presencia de este microorganismo en el yogur parecía inhibir el crecimiento en el intestino de los microorganismos responsables de la putrefacción. Bulgarian bacillus pasó a denomiarse "Thermobacterium bulgaricum" (orla-Jensen, 1931) y finalmente Lactobacillus bulgaricus (normalmente conocido como Lactobacillus delbrueckii subsp. bulgaricus). 


\section{FILOGENIA DE LAS BACTERIAS ACIDOLÁCTICAS}

Las verdaderas relaciones filogenéticas entre las bacterias se establecen mediante las comparaciones de las secuencias de ARNr (Woese, 1987). Inicialmente, estas comparaciones fueron realizadas mediante hibridaciones de ADN-ARNr. Los avances en las técnicas moleculares han encabezado los métodos de secuenciación de fragmentos largos de rARN, primero mediante el uso de la transcriptasa inversa (Lane et al., 1988) y por la secuenciación directa por PCR (reacción en cadena de la polimerasa) de los genes de rARN. Los bancos de datos genéticos disponibles para agrupar las grandes cantidades de secuencias hacen posible construir árboles filogenéticos (Woese, 1987). Los datos obtenidos, demuestran que la pared celular Gram positiva también posee una fuerte relevancia filogenética. Así, todas las bacterias Gram-positivas se agrupan en uno de los once principales taxones (Woese, 1987).

La composición global del ADN, entendida como el porcentaje de cada una de las bases presentes en la secuencia y expresada normalmente en porcentaje de moles $\mathrm{G}+\mathrm{C}$, es uno de los parámetros que caracterizan el genoma. Sin embargo, su valor taxonómico es limitado, ya que aunque diferencias importantes en dicho porcentaje son indicativas de la existencia de divergencia filogenética, la determinación de valores similares no lleva implícita una relación de proximidad. Pese a ello, el contenido en $\mathrm{G}+\mathrm{C}$, expresado como porcentaje molar en $\mathrm{G}+\mathrm{C}$ en el ADN es una de las características requerida para la delimitación de especies y géneros (Stackebrandt et al., 1992). El "Punto de Fusión" está frecuentemente fijado en un $50 \%$, pero más bien se encuentra dentro del intervalo $53-55 \%$.

Los detalles de las relaciones filogenéticas entre el género de las bacterias acidolácticas y entre ellas y otros géneros con bajo contenido en $\mathrm{G}+\mathrm{C}$ se han conocido gracias al extenso estudio Collins, empleando la transcriptasa y las técnicas de secuenciación por PCR (Collins et al., 1989, 1991, 1999; MartínezMurcia y Collins, 1990; Martínez-Murcia, 1993). Se han definido límites máximos de variación en el contenido de $\mathrm{G}+\mathrm{C}$, entre cepas de la misma especie, del 3-5\%, según autores, y entre cepas del mismo género el $10-12 \%$. Dentro de las $B A L$, el contenido en $\mathrm{G}+\mathrm{C}$ del género Lactobacillus varía entre 32 y $53 \%$. 
Introducción

\section{GÉNERO Lactobacillus}

\subsection{Antecedentes históricos}

En 1901, Beijerinck propone el género Lactobacillus y Orla-Jensen, en 1919 hace una primera clasificación de este grupo basado en características morfológicas, de crecimiento y utilización de algunos azúcares. Con glucosa como fuente de carbono, los lactobacilos pueden ser homofermentativos, cuando el producto final de su metabolismo es casi exclusivamente ácido láctico, o heterofermentativos, cuando producen una mezcla de ácido láctico, dióxido de carbono, etanol y/o ácido acético. Esta característica, permitió a Kandler y Weiss en 1986 clasificar Lactobacillus en tres grupos. El grupo A son los lactobacilos homofermentativos obligados que sólo pueden fermentar los azúcares por la vía de la glucólisis, poseen el enzima fructosa-1,6-difosfato aldolasa pero carecen de fosfocetolasa, por lo que no fermentan pentosas ni gluconato. El grupo B son heterofermentativos facultativos, poseen tanto fructosa-1,6-difosfato aldolasa como fosfocetolasa. El grupo C son heterofermentativos estrictos, sólo pueden fermentar las hexosas por la vía de las pentosas fosfato, también denominada vía del fosfogluconato, debido a que carecen de fructosa-1,6-difosfato aldolasa (Wood and Holzapfel, 1995).

Tabla 7. Características de los lactobacilos homofermentativos obligados (grupo I), heterofermentativos facultativos (grupo II), heterofermentativos obligados (grupo III).

\begin{tabular}{|c|c|c|c|}
\hline Características & $\begin{array}{c}\text { GRUPO I } \\
\text { Homofermentativos } \\
\text { obligados }\end{array}$ & $\begin{array}{c}\text { GRUPO II } \\
\begin{array}{c}\text { Heterofermentativos } \\
\text { facultativos }\end{array} \\
\end{array}$ & $\begin{array}{c}\text { GRUPO III } \\
\text { Heterofermentativos } \\
\text { obligados }\end{array}$ \\
\hline $\begin{array}{c}\text { Fermentación } \\
\text { de pentosas }\end{array}$ & - & + & + \\
\hline $\begin{array}{c}\mathrm{CO}_{2} \text { a partir de } \\
\text { glucosa }\end{array}$ & - & - & + \\
\hline $\begin{array}{c}\mathrm{CO}_{2} \text { a partir de } \\
\text { gluconato }\end{array}$ & - & + & + \\
\hline $\begin{array}{l}\text { Presencia de } \\
\text { aldolasa }\end{array}$ & + & + & - \\
\hline \multirow[t]{5}{*}{$\begin{array}{l}\text { Presencia de } \\
\text { fosfocetolasa }\end{array}$} & - & + & + \\
\hline & Lb. acidophilus & Lb. casei & Lb. brevis \\
\hline & Lb. delbrueckii & Lb. curvatus & Lb. buchneri \\
\hline & Lb. helveticus & Lb. plantarum & Lb. fermentum \\
\hline & Lb. salivarus & Lb. sake & Lb. reuteri \\
\hline
\end{tabular}


En 1991 Collins et al., basándose en el análisis de las relaciones filogenéticas de acuerdo a la secuencia del gen que codifica para el 16S rARN, forman tres subgrupos que no difieren mucho de la primera clasificación: grupo a de Lactobacillus delbrueckii; grupo b de Lactobacillus casei- Pediococcus; y grupo c de Leuconostoc (Vandamme et al., 1996).

La utilización de letras mayúsculas para asignar los grupos según las características fenotípicas y las letras minúsculas para los grupos filogenéticos se debe a Hammes y Vogel, que en 1995 propusieron una nomenclatura basada en la combinación de ambas propiedades. Así, por ejemplo, Aa sería un Lactobacillus homofermentativo obligado del grupo filogenético del L. delbrueckii (Vandamme et al., 1996).

Actualmente, el género Lactobacillus, cuenta con más de 100 especies reconocidas, caracterizadas por una alta diversidad, que se refleja en la dificultad para su clasificación taxonómica.

\subsection{Taxonomía}

La clasificación taxonómica en procariotas ha evolucionado continuamente de forma paralela a los avances en las técnicas de laboratorio, permitiendo cada día el uso de mayor información para la adecuada diferenciación entre especies. El desarrollo de la taxonomía numérica por Sokal y Sneath en 1962 y los avances en informática hacen posible en la actualidad el manejo de grandes cantidades de datos que reúnen las características de un gran número de cepas bacterianas. Ésto, sumado al desarrollo de la biología molecular durante los años 60 que permitió el conocimiento de las propiedades del ADN, ha hecho de la taxonomía una ciencia en continua evolución, que permite la adecuada clasificación de las especies. Para la clasificación de los organismos en grupos o taxones en función de sus semejanzas, es necesaria la aplicación de un variado número de técnicas que permitan conocer sus características fenotípicas y su información genética, la integración de estos parámetros y la medición de las relaciones existentes entre ellos se conoce como taxonomía polifásica (Vandamme et al., 1996).

Entre las características fenotípicas que tienen valor discriminativo entre cepas o especies bacterianas están la composición química de la pared celular, requerimientos nutricionales, capacidad de usar diferentes fuentes de carbono, productos de fermentación, tolerancia a diferentes temperaturas, crecimiento a 
Introducción

diferentes concentraciones de sal o diferentes $\mathrm{pH}$, características inmunológicas, etcétera. La información genética es la que puede ser obtenida desde los ácidos nucleicos y ésta puede ser directa, como en el caso de la secuenciación, o indirecta a través de parámetros como la hibridación ADN-ADN o el porcentaje de guanina más citosina $(G+C)$ (Sarmiento, 2008).

La unidad taxonómica en microbiología es la especie, que corresponde a una población de células genéticamente idénticas derivadas de la división sucesiva de una sola célula. Un grupo de cepas que muestran un alto grado de similitud entre ellas y difieren considerablemente de otro grupo de cepas con respecto a unas determinadas características, se denomina especie. El parámetro numérico más aceptado para establecer los límites entre especies de procariotas, es la similitud de su ADN expresado como porcentaje, el cual debe ser mayor al $70 \%$ entre cepas de la misma especie sometidas a un análisis de hibridación ADN-ADN (Roselló-Mora y Amann, 2001). Otro parámetro aceptado en la clasificación de especies consiste en la temperatura de fusión Tm, a la cual el $50 \%$ de la cadena de ADN está disociada, pues es característica de cada especie, ya que depende exclusivamente de la proporción de guanina más citosina presentes. Entre cepas de la misma especie la diferencia en la $\mathrm{Tm}$ no debe ser superior a $5^{\circ} \mathrm{C}$ (Grimont, 1988).

En el Anexo II puede encontrarse una tabla con las diferentes especies actualmente incluidas en el género Lactobacillus.

\subsection{Hábitats}

Los lactobacilos se encuentran ampliamente distribuidos en los vegetales, carnes y pescados. Forman parte de la microbiota normal de la boca, tracto intestinal y aparato reproductor femenino humano y de muchos animales. No son considerados patógenos, excepto algunas especies que parecen intervenir en la caries dental. Tienen una gran importancia industrial, pues se utilizan en diversos procesos de fermentación láctica (yogur, quesos,...) e intervienen también en la fabricación de productos derivados de los vegetales como pepinillos o aceitunas (Bergey's Manual-9a edición; Sanders and Klaenhammer, 2001). 


\subsection{Características morfológicas}

El género Lactobacillus, está conformado por bacilos o cocobacilos de dimensiones $0,5-1,2 \times 1,0-10,0 \mu \mathrm{m}$. Aunque normalmente se trata de largos bacilos, algunas veces son casi cocos, habitualmente formando cortas cadenas.

Son Gram positivos, no formadores de esporas, y pocas veces móviles por flagelos peritricos.
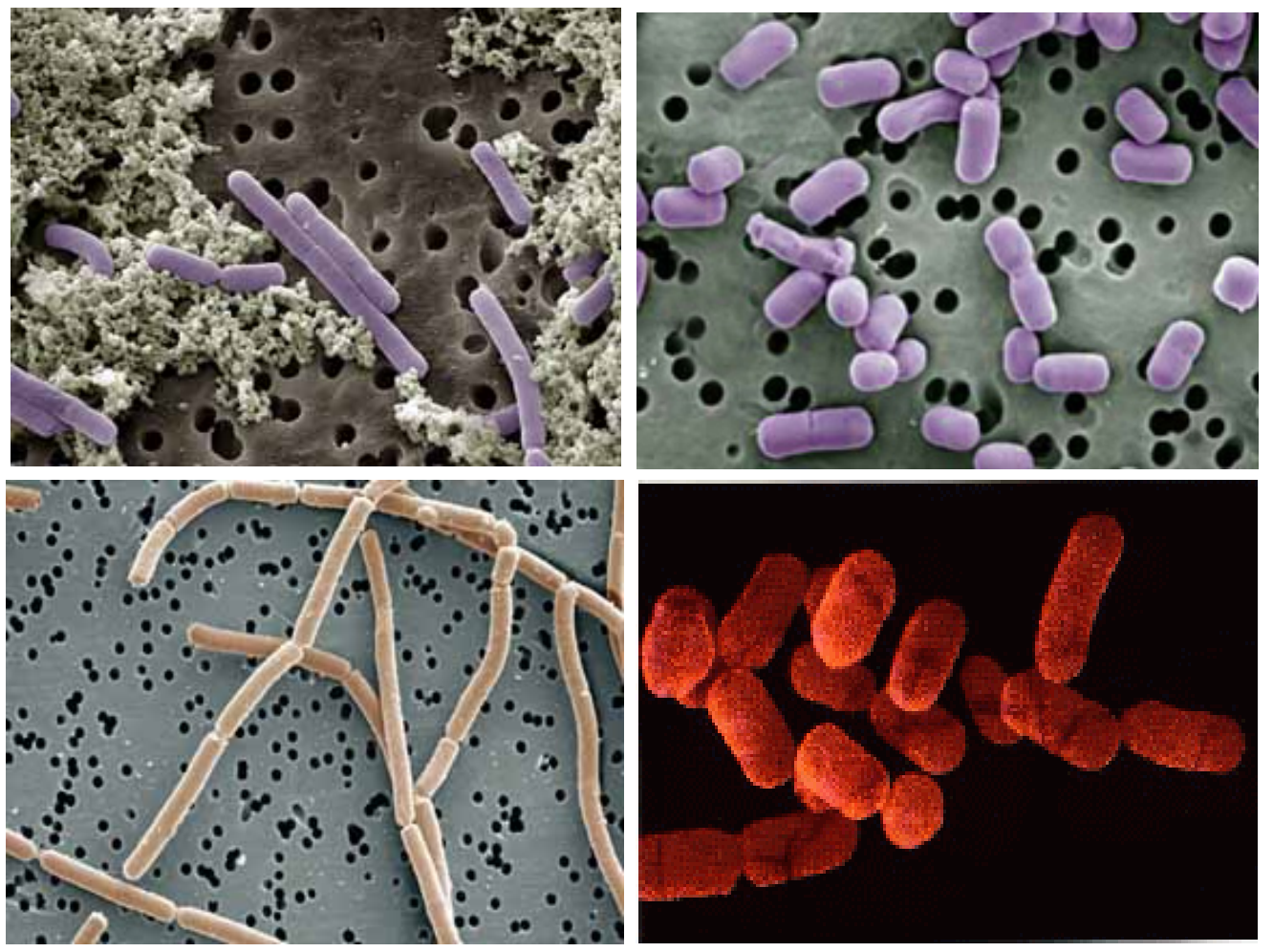

Figura 6. Morfología de algunas especies del género Lactobacillus. De arriba abajo y de izquierda a derecha: Lactobacillus casei; Lactobacillus brevis; Lactobacillus delbrueckii subsp. bulgaricus; Lactobacillus plantarum.

\subsection{Características fisiológicas y culturales}

Son anaerobios facultativos, algunas veces microaerófilos, creciendo muy poco en presencia de aire, si bien lo hace mejor con baja tensión de oxígeno. Su crecimiento se ve generalmente favorecido con un $5 \%$ de dióxido de carbono. 
Introducción

Tienen importantes requerimientos nutricionales, en cuanto a aminoácidos, péptidos, derivados de ácidos nucleicos, vitaminas, sales, ácidos grasos o sus ésteres y carbohidratos fermentables. Las colonias en el agar tienen un tamaño variable entre 2 y $5 \mathrm{~mm}$, convexas, opacas y sin pigmentos.

Crecen entre $2^{\circ} \mathrm{C}$ y $53^{\circ} \mathrm{C}$, aunque su temperatura óptima es de $30-40^{\circ} \mathrm{C}$.

En cuanto al $\mathrm{pH}$, son acidúricos creciendo óptimamente entre 5,5-6,2. El crecimiento suele ocurrir a pH 5,0 o incluso menos.

\subsection{Características bioquímicas}

Su metabolismo es estrictamente fermentativo. Al menos la mitad de los productos carbonosos finales es lactato. El lactato normalmente no es fermentado. Otros productos adicionales pueden ser acetato, etanol, $\mathrm{CO}_{2}$, formato o succinato. No se producen ácidos volátiles con más de dos átomos de carbono.

No suelen reducir los nitratos y, si lo hacen, es sólo cuando el pH final está en torno a 6,0 .

No licuan la gelatina y la caseína no la digieren, aunque la mayoría de las cepas producen pequeñas cantidades de nitrógeno soluble. Tampoco producen indol ni $\mathrm{H}_{2} \mathrm{~S}$.

Son catalasa y citocromo negativas. Sin embargo, algunas cepas descomponen el peróxido por medio de una pseudocatalasa. La reacción de la bencidina es negativa.

Es rara la producción de pigmentos.

\subsection{Lactobacillus delbrueckii}

Lactobacillus delbrueckii es una especie perteneciente al género Lactobacillus y son bacilos con extremos redondeados, con unas dimensiones de 0,5-0,8 por aproximadamente $2-9 \mu \mathrm{m}$, que se presentan tanto aislados como en cortas cadenas.

En cuanto a los requerimientos nutricionales para su crecimiento, generalmente el ácido pantoténico y la niosina son esenciales; la riboflavina, el ácido 
fólico, la vitamina B12 y la timidina son necesarios para determinadas cepas; la tiamina, la piridoxina, la biotina y el ácido p-aminobenzoico no se precisan. Crecen bien a $45^{\circ} \mathrm{C}$ e incluso entre 48 y $52^{\circ} \mathrm{C}$. El porcentaje $\mathrm{G}+\mathrm{C}$ del $A D N$ es de $49-51 \%$

Actualmente, hay cuatro subespecies reconocidas del Lactobacillus delbrueckii. La primera de ellas es $L$. delbrueckii subsp. delbrueckii, aislado de material vegetal fermentado a elevadas temperaturas $\left(40-53^{\circ} \mathrm{C}\right)$ y cuya cepa tipo es ATCC

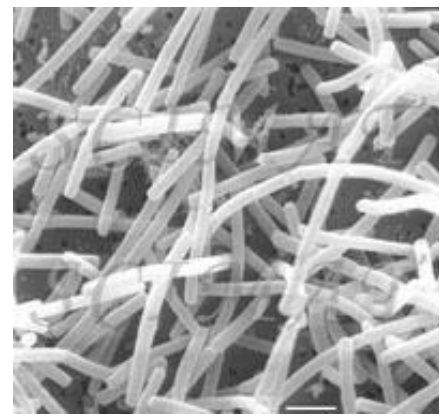

Figura 7. Morfología de Lactobacillus delbrueckii subsp. bulgaricus 9649. La segunda, es L. delbrueckii subsp. bulgaricus, aislado de yogur y queso y con cepa tipo ATCC 11842. L. delbrueckii subsp. lactis ha sido aislado de leche, queso, levadura comprimida y cereales molidos y su cepa tipo es ATCC 12315.

Finalmente, $L$. delbrueckii subsp. indicus ha sido aislada de productos lácteos indios siendo su cepa tipo NCC 725.

Las tablas 8 y 9 recogen algunas de las características fisiológicas y bioquímicas que permiten distinguir entre las cuatro subespecies.

Tabla 8. Características fisiológicas y bioquímicas de las cuatro subespecies del $L$. delbrueckii

\begin{tabular}{|c|c|c|c|c|c|}
\hline Especie & & $\begin{array}{c}\text { L. delbrueckii } \\
\text { subsp. } \\
\text { delbrueckif }\end{array}$ & $\begin{array}{c}\text { L. delbrueckif } \\
\text { subsp. } \\
\text { bulgaricus }\end{array}$ & $\begin{array}{c}\text { L. } \\
\text { delbrueckii } \\
\text { subsp. } \\
\text { lactis }\end{array}$ & $\begin{array}{c}\text { L. delbrueckif } \\
\text { subsp. } \\
\text { indicus }\end{array}$ \\
\hline $\begin{array}{l}\text { Tipo de } \\
\text { peptidoglicano }\end{array}$ & & Lys-DAsp & Lys-DAsp & Lys-DAsp & Lys-DAsp \\
\hline Ácido teitoico & & Glicerol & Glicerol & Glicerol & Glicerol \\
\hline \multirow{2}{*}{$\begin{array}{l}\text { Motilidad } \\
\text { electroforética }^{c}\end{array}$} & $\begin{array}{l}\mathrm{D}- \\
\mathrm{LDH}\end{array}$ & 1,50 & 1,50 & 1,70 & 1,50 \\
\hline & $\begin{array}{l}\mathrm{L}- \\
\mathrm{LDH}\end{array}$ & - & - & - & - \\
\hline $\begin{array}{l}\text { L-LDH } \\
\text { alostérico }\end{array}$ & & - & - & - & - \\
\hline Mol \% G+C & & $49-51$ & $49-51$ & $49-51$ & $49-51$ \\
\hline $\begin{array}{l}\text { Isómero de } \\
\text { ácido láctico }\end{array}$ & & $\mathrm{D}$ & $\mathrm{D}$ & $\mathrm{D}$ & $\mathrm{D}$ \\
\hline $\begin{array}{l}\text { Crecimiento a } \\
15^{\circ} \mathrm{C}\end{array}$ & & - & - & - & - \\
\hline
\end{tabular}


Introducción

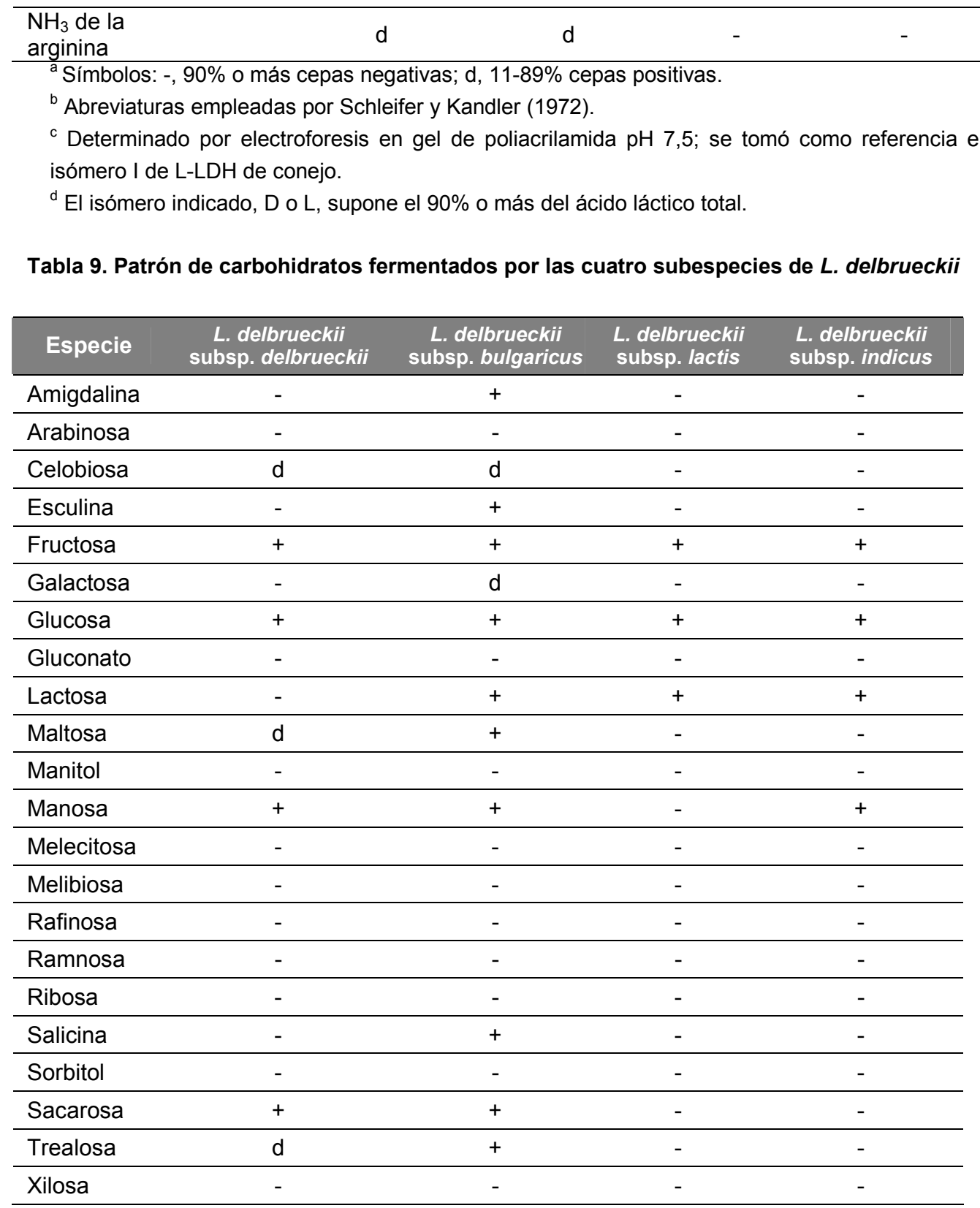

Símbolos:,$+ \mathbf{9 0} \%$ o más cepas positivas; -, $90 \%$ o más cepas negativas; $\mathrm{d}, \mathbf{1 1 - 8 9} \%$ cepas positivas. 


\section{GÉNERO Streptococcus}

\subsection{Antecedentes históricos}

Los estreptococos son un género de bacterias Gram positivas, esféricas pertenecientes al filo Firmicutes. Crecen en cadenas o pares, donde cada división celular ocurre a lo largo de un eje. De allí que su nombre, del Griego streptos, significa que se dobla y retuerce con facilidad, como una cadena. Son oxidasa y catalasa negativos.

Existen más de 66 especies y la especie tipo es Streptococcus pyogenes. A pesar de la formación de nuevos géneros, el género Streptococcus sensu stricto es todavía muy amplio y su clasificación compleja. El género está ampliamente dividido en tres grupos: piogénicos, orales y otros estreptococos (Hardie y Whiley, 1995).

Sin embargo, la única especie de Streptococcus que está asociada a la tecnología de los alimentos es $S$. thermophilus, que se emplea en la fabricación de yogur (en cocultivo con Lactobacillus delbrueckii sbsp. bulgaricus).

S. thermophilus, es una bacteria termorresistente homofermentativa que produce ácido láctico como principal producto de la fermentación, se desarrolla a 37 $40^{\circ} \mathrm{C}$ pero puede resistir $50^{\circ} \mathrm{C}$ e incluso $65^{\circ} \mathrm{C}$ durante media hora. Tiene menor poder de acidificación que el lactobacillus. En el yogur viven en perfecta simbiosis (Spreer, E y Sutherland, 1991). S. thermophilus, está actualmente incluido dentro de los estreptococos orales, que son comúnmente encontrados en la cavidad oral y el tracto respiratorio superior del hombre y otros animales.

\subsection{Taxonomía}

Los estreptococos son un género de bacterias gram-positivas y catalasa negativos, esféricas pertenecientes al filo firmicutes. Observadas bajo el microscopio, se ve que Streptococcus thermophilus crece formando pares (diplococos) o cadenas medianamente largas de células esféricas o elipsoides de un diámetro aproximado de 0,7-0,9 $\mu \mathrm{m}$. Dentro de esta familia también se encuentran otras especies que son causantes de enfermedades como estreptococos del grupo A (Streptococcus pyogenes produce amigdalitis e impétigo) y estreptococos del grupo B (Streptococcus agalactiae produce meningitis en neonatos y trastornos del

embarazo en la mujer; Streptococcus pneumoniae es la principal causa de 
neumonía adquirida en la comunidad; Streptococcus viridans es una causa importante de endocarditis y de abscesos dentales).

En el Anexo III puede encontrarse una tabla con las diferentes especies actualmente incluidas en el género.

\subsection{Hábitats}

Son parásitos de vertebrados, siendo habituales en la boca y la parte superior del tracto respiratorio. Además, algunas especies son patógenas para el hombre y los animales.

\subsection{Características morfológicas}

Son células esféricas u ovoides de 0,5-2,0 $\mu \mathrm{m}$ de diámetro, distribuidas en parejas o formando cadenas cuando crecen en medios de cultivo líquidos. En ocasiones, se elongan en el eje de la cadena, apareciendo formas lanceoladas.

Su motilidad es nula, son no esporulados y Gram positivos. Algunas especies presentan cápsulas.
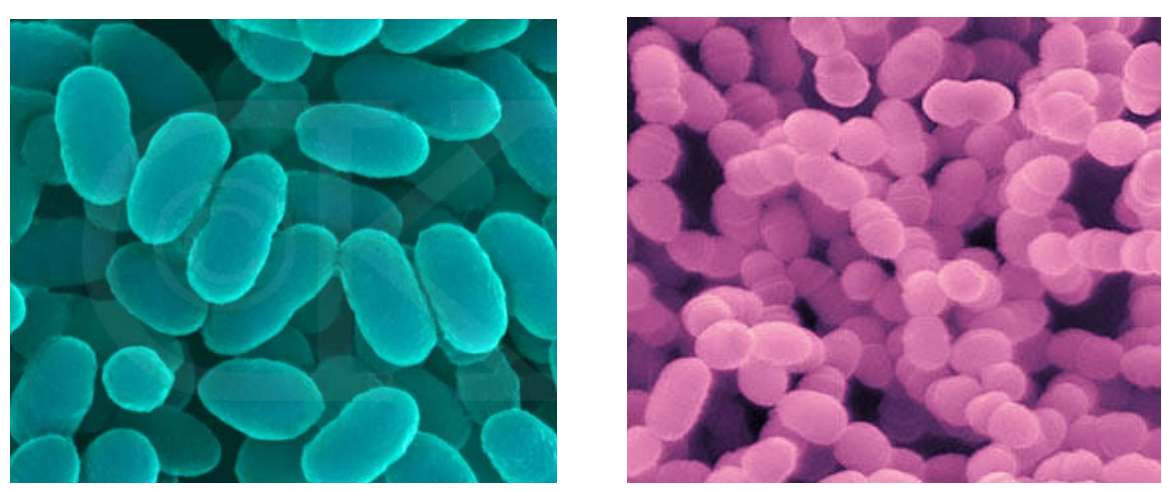

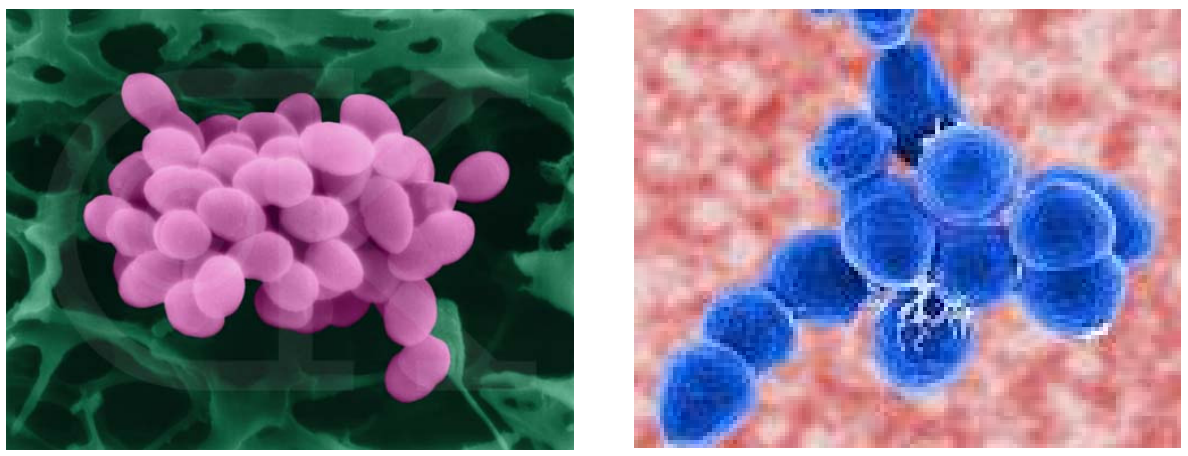

Figura 8. Morfología de algunas especies del género Streptococcus. De arriba abajo y de izquierda a derecha: Streptococcus sanguis; Streptococcus mutans; Streptococcus faecalis; Streptococcus pneumoniae.

\subsection{Características fisiológicas y culturales}

Son anaerobios facultativos y quimioorganotrofos, requiriendo medios de cultivo muy ricos desde el punto de vista nutricional y, en ocasiones, el $5 \%$ de dióxido de carbono. La temperatura de crecimiento suele restringirse a $25-45^{\circ} \mathrm{C}$, siendo la óptima de $37^{\circ} \mathrm{C}$.

\subsection{Características bioquímicas}

Su metabolismo es fermentativo, produciendo principalmente ácido láctico aunque no gas. Son oxidasa y catalasa negativos.

Normalmente, atacan a los glóbulos rojos sanguíneos, produciendo bien una decoloración verdosa ( $\alpha$-hemólisis) bien un aclaramiento total ( $\beta$-hemólisis).

\subsection{Streptococcus thermophilus}

Streptococcus thermophilus, fue descrito por primera vez por Orla-Jensen en 1919. Su nombre procede del término griego "therme" que significa calor y de "philus" que significa afinidad (Collado, 2004).

Son células esféricas u ovoides de 0,8-1,0 $\mu \mathrm{m}$ de diámetro. La longitud de la cadena puede variar desde corta hasta muy larga. 
Introducción

Crece con facilidad en medios de cultivo adecuados en presencia de oxígeno.

La mayoría de las cepas son no hemolíticas en agar sangre, aunque en ocasiones se han encontrado cepas $\alpha$ - y $\beta$-hemolíticas.

Los requerimientos nutricionales mínimos fueron determinados por Smiley et al. (1943), quienes indicaron que son necesarios para su crecimiento nueve aminoácidos, cinco vitaminas y uracilo.

Produce ácido a partir de la glucosa, sacarosa, maltosa, rafinosa, inulina, salicina y, normalmente, trealosa y lactosa. No hay producción de ácido, en cambio, con glicerol, manitol, sorbitol, xilosa y arabinosa. Algunas cepas fermentan únicamente la fracción fructofuranósica terminal de la rafinosa (formando polisacáridos) y los acumulados de melibiosa.

La mayoría de las cepas hidroliza la escualina y la urea (Colman, 1976), pero no así la arginina, y la mayoría produce también acetoína a partir de la glucosa.

Crece con un $2,5 \%$ de cloruro sódico pero no con un $4 \%$. No crece a pH superiores a 9,6 ni en leche que posea un $0,1 \%$ de azul de metileno. La temperatura mínima de crecimiento es de $19-21^{\circ} \mathrm{C}$. La habilidad para crecer a $52^{\circ} \mathrm{C}$, la resistencia al calor y el conjunto de carbohidratos que puede fermentar, distingue a Streptococcus thermophilus de otros muchos estreptococos.

Streptococcus thermophilus se encuentra en la boca del hombre y de otros animales, estando particularmente asociado con la lengua y la saliva, y también en heces. Se aísla ocasionalmente de la sangre en casos de endocarditis infecciosa.

El porcentaje G+C del ADN es de 39-42\%. La cepa tipo es la ATCC 7073. 
Tabla 10. Características bioquímicas más importantes de Streptococcus thermophilus ${ }^{a}$.

\begin{tabular}{|c|c|c|c|}
\hline Característica & Resultados & Característica & Resultados \\
\hline Fermentación de & & Producción de & \\
\hline Manitol & - & Acetoína & $\mathrm{d}$ \\
\hline Sorbitol & - & $\mathrm{H} 2 \mathrm{O} 2$ & - \\
\hline Inulina & $d^{b}$ & Glucano & - \\
\hline Rafinosa & $\mathrm{d}$ & Fructano & + \\
\hline Lactosa & + & Crecimiento en/a & \\
\hline Trealosa & $d^{b}$ & $4 \% \mathrm{NaCl}$ & $d$ \\
\hline Hidrólisis de & & $6,5 \% \mathrm{NaCl}$ & - \\
\hline Arginina & - & $10 \%$ Bilis & + \\
\hline Esculina & + & $40 \%$ bilis & $\mathrm{d}$ \\
\hline Almidón & $\mathrm{d}$ & $45^{\circ} \mathrm{C}$ & $\mathrm{d}$ \\
\hline Urea & $\mathrm{d}$ & $\mathrm{Mol} \% \mathrm{G}+\mathrm{C}$ & $39-42$ \\
\hline
\end{tabular}

á́mbolos: +, $90 \%$ o más cepas positivas; -, $90 \%$ o más cepas negativas; $\mathrm{d}, 11-89 \%$ cepas positivas.

${ }^{b}$ Los resultados registrados varían entre distintos laboratorios.

Fuente: Bergey's 
Introducción

\section{TÉCNICAS DE DETECCIÓN Y CARACTERIZACIÓN}

\subsection{Detección por cultivo}

El método tradicional por excelencia para la detección e identificación de microorganismos es la observación de su crecimiento en sustancias nutritivas preparadas en el laboratorio.

Los lactobacilos requieren medios nutricionales complejos, con aminoácidos, péptidos, derivados de ácidos nucleicos, vitaminas, sales, ácidos grasos y carbohidratos fermentables.

El medio de cultivo más empleado es el MRS descrito por Man, Rogosa y Sharpe en 1960. Este medio, contiene además, magnesio, manganeso, acetato y polisorbato 80 (Tween 80 ) que facilitan de gran forma el crecimiento de los bacilos lácticos, incluso de las especies más exigentes, como Lactobacillus brevis y Lactobacillus fermenti. El medio MRS está especialmente recomendado para la enumeración y mantenimiento de bacilos lácticos, ya sea por la técnica del número más probable (NMP) en caldo o por siembra en masa. El problema de este medio es que con frecuencia se suelen presentar contaminantes, con lo cual se precisa una mayor selectividad. Por ello, se desarrolló el medio MRS modificado ( $\mathrm{mLSM}$ ) al que se le adiciona ácido acético como agente selectivo.

Por su parte, el medio más empleado para el aislamiento, mantenimiento o cultivo e identificación de estreptococos relacionados con productos lácteos es el agar M-17, que fue desarrollado por Teragazhi y Sandine en 1975, pero posteriormente Shankar y Davies (1977) demostraron la eficacia del medio para el aislamiento selectivo de Streptococcus thermophilus del yogur, que se debe a la combinación de un fuerte efecto tampón, que facilita el desarrollo de los estreptococos y una elevada concentración de glicerofosfato, que inhibe el desarrollo de los lactobacilos. Shankar y Davies (1977) observaron que se suprime el crecimiento de Lactobacillus si el pH del medio M-17 es de 6,8. El CeNAN (Centro Nacional de Alimentación y Nutrición) ha adoptado este medio de forma paralela con MRS para el examen rutinario del yogur.

También se emplea para el aislamiento de los microorganismos del yogur el medio LS-agar diferencial, formulado por el CeNAN (1982). Este medio está concebido para la enumeración simultánea de Lactobacillus bulgaricus y 
Streptococcus thermophilus. A la mezcla base que contiene triptona, peptonas, extractos de carne y levadura, cisteína y cloruro sódico, se le adiciona leche descremada y la solución estéril de cloruro de trifeniltetrazolio (TTC) al 1\%. En este medio, Lactobacillus delbrueckii crece en forma de colonias lobuladas rojas de 1-1,5 $\mathrm{mm}$ de diámetro rodeadas de una zona blanca opaca y Streptococcus thermophilus crece en este medio formando colonias ovales o redondas rojas de aproximadamente $0,5 \mathrm{~mm}$ de diámetro con un pequeño halo claro a su alrededor. El CeNAN ha adoptado este medio de forma alternativa al recuento con dos medios, el MRS y el M-17.

El método tradicional de crecimiento en medios de cultivo ha sido empleado por diversos autores.

Autores como Davis et al. (1971), Lee et al. (1974) y Bracquart (1981) han descrito medios de cultivo que permiten la determinación simultánea de $\mathrm{S}$. thermophilus y de L. delbrueckii subsp. bulgaricus.

Chagnaud et al. (2000) desarrollaron químicamente un medio de cultivo que denominaron BMP (milieu proche du lait) para el cultivo de lactobacilos y de Streptococcus thermophilus. Este medio resultó útil para llevar a cabo ensayos fisiológicos en estos microorganismos bajo condiciones nutricionales bien controladas.

García de los Ríos et al. (2003) en un estudio para analizar la composición de la microbiota y la supervivencia de los microorganismos en animales alimentados con yogur fresco y termizado, usaron el medio MRS para el cultivo de Lactobacillus y el M17, para la enumeración selectiva de $S$. thermophilus a partir del yogur.

Para el recuento de Lactobacillus procedentes del yogur no necesitó ningún suplemento para hacerlo más selectivo, aunque para emplearlo en el recuento de microorganismos procedentes de las muestras del tubo digestivo se empleó suplementado con $16 \mathrm{mg} / \mathrm{l}$ de metronidazol y $4 \mathrm{mg} / \mathrm{l}$ de colistina. El primero, por ser un antibiótico que actúa sobre la microbiota anaerobia del tubo digestivo y por haber resultado resistente la cepa de Lactobacillus del yogur empleado. El segundo, por ser un antibiótico que actúa sobre los microorganismos gram negativos en general. 
Introducción

Para el recuento de los estreptococos procedentes del yogur, se usó sin suplemento y para el recuento de los microorganismos del tubo digestivo, suplementado, como el MRS, con 4 mg/l de colimicina.

Por su parte, del Campo et al. (2003) buscaron la presencia de las bacterias en heces de 114 voluntarios por dos métodos, siendo uno de ellos un cultivo microbiológico en MRS y M17 seguido de una PCR específica para buscar segmentos de ADN exclusivos del L. delbrueckii y $S$. thermophilus.

Tal y como describen Coueret et al. 2003 en su revisión acerca del aislamiento, caracterización e identificación de lactobacilos, centrándose fundamentalmente en quesos y otros productos lácteos, autores como Lankaputhra et al. (1995), Hartemink et al. (1997) y Shah (2000) emplearon también en sus investigaciones MRS pero con la adición al mismo de un $0.05 \%$ de cisteína al constatar una mejora de la especifidad del medio para el aislamiento de lactobacilos.

Tharmaraj y Shah (2003) evaluaron 19 medios de cultivo para evaluar su eficacia para enumerar de forma selectiva Lactobacillus delbrueckii ssp. bulgaricus, Streptococcus thermophilus, Lactobacillus acidophilus, Bifidobacteria, Lactobacillus casei, Lactobacillus rhamnosus y Propionibacteria. De sus trabajos concluyeron que el agar MRS y el agar M17 eran los más adecuados para los recuentos de $L$. delbrueckii ssp. bulgaricus y $S$. thermophilus, respectivamente.

Elli et al. 2006, llevaron a cabo un estudio para investigar la recuperación de L. delbrueckii subsp. bulgaricus y $S$. thermophilus viables de muestras fecales de 20 individuos sanos alimentados con yogur comercial durante una semana.

Para el crecimiento de microorganismos de heces emplearon en un primer ensayo el medio de leche desnatada (RSMA), mientras que en un ensayo posterior lo suplementaron con $0.05 \%$ de tinte rojo de rutenio, para así obtener el RSMA modificado (m-RSMA), que permitió la clara distinción entre colonias de Enterococcus, Lactobacillus y Streptococcus.

En cualquier caso, incluso cuando la enumeración vaya a realizarse a partir de técnicas moleculares, el uso de medios de cultivo es fundamental para el crecimiento inicial de los microorganismos (Hertel et al., 1991; Beimfohr et al., 1993). 


\subsection{Detección por PCR tradicional}

La PCR es un método enzimático que permite copiar de forma exponencial una zona concreta de un genoma, pudiéndose obtener millones de copias de ella. Este proceso se lleva a cabo cíclicamente.

En la primera etapa (desnaturalización) la doble hélice de ADN se separa en dos hebras. Para ello, se realiza una incubación de la muestra a altas temperaturas $\left(93-97^{\circ} \mathrm{C}\right)$. La renaturalización se producirá cuando la temperatura disminuya. En el segundo paso (hibridación) los cebadores se unen a las zonas $3^{\prime}$ complementarias que flanquean el fragmento que se desea amplificar. En la tercera etapa (elongación) se produce la síntesis de una cadena sencilla (produciéndose un fragmento de doble cadena por complementariedad) en la dirección $5^{\prime} \rightarrow 3^{\prime}$ mediante la enzima ADN polimerasa, la cual incorpora los desoxinucleótidos fosfato presentes en el medio, siguiendo la cadena molde. Una vez completado el primer ciclo, se dispone de 2 copias de la muestra original, al final del segundo ciclo se tienen 4 , al final del tercero 8 y así sucesivamente. Si los ciclos se producen un número " $n$ " de veces y suponiendo que el número de copias de ADN se duplica en cada ciclo, se obtiene una cantidad de $A D N$ de $2^{n}$, por lo que la amplificación se realiza en forma de progresión geométrica.

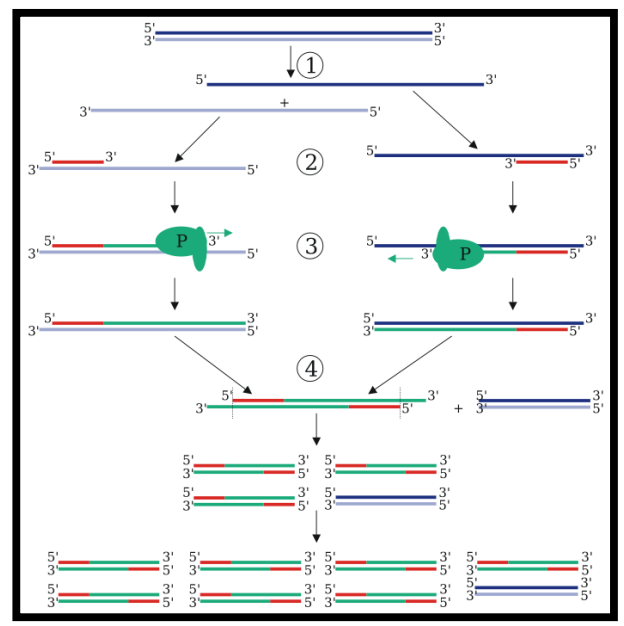

Figura 9. Representación esquemática de un ciclo de la PCR. (1) Desnaturalización a 94$96^{\circ} \mathrm{C}$. (2) Hibridación. (3) Elongación a $72^{\circ} \mathrm{C}(\mathrm{P}=$ Polimerasa). (4) El primer ciclo queda completado. Las dos hebras resultantes de ADN se convierten en la plantilla de ADN para el 
Introducción

siguiente ciclo, doblándose de esta manera la cantidad de ADN duplicado en cada nuevo ciclo. Fuente: www.juliantrubin.com/encyclopedia/biochemistry/pcr.html

La PCR se ha empleado en una gran cantidad de estudios para detectar Lactobacillus delbrueckii subsp. bulgaricus y Streptococcus thermophilus en un variado tipo de muestras.

Así, del Campo et al. 2005 identificaron cepas de yogur en heces mediante la técnica de PCR con los iniciadores específicos descritos por Lick et al. (2001). Los iniciadores para L. delbrueckii, basados en la secuencia del gen fueron DEL-F (5'AATTCCGTCAACTCCTCATC 3') y DEL-R (5' TGATCCGCTGCTTCATTTCA 3'). En cuanto a los iniciadores usados para la identificación de $S$. thermophilus, basados en el gen lacZ, fueron THER -F (5' CACTATGCTCAGAATACA 3') y THER$\mathrm{R}$ (5' CGAACAGCATTGATGTTA 3'). Las condiciones de la PCR fueron diferentes en cada caso.

La misma metodología aplicaron Yuste et al. en 2003 para la detección de bacterias vivas del yogur en heces.

Bentley y Leigh (1995) en su trabajo desarrollaron un protocolo de hibridación basado en la PCR para la identificación de especies de estreptococos. Así, describieron el uso de una técnica para hibridar oligonucleótidos de los genes16S rARN o rARN amplificado por PCR (rADN) de S. agalactiae, S. uberis y S. parauberis en solución.

Tilsala-Timisjärvi y Alatossava (1997) utilizaron la técnica de la PCR para amplificar y determinar la secuencia de la región intergénica 16S-23S del rARN de diferentes bacterias lácticas presentes en productos lácteos y en probióticos, entre ellas, de Lactobacillus delbrueckii y Streptococcus thermophilus para lo que diseñaron una serie de iniciadores que dieron resultados satisfactorios.

Berthier y Ehrlich (1998) estudiaron las secuencias 16S/23S del ADN de 6 especies de lactobacilos ( $L b$. curvatus, $L b$. graminis, $L b$. sake, $L b$. plantarum, $L b$. paraplantarum y $L b$. pentosus) mediante $\mathrm{PCR}$, definiendo iniciadores para cada una de ellas (Coeuret et al. 2003). 
Tannock et al. (1999) utilizaron la amplificación por PCR para secuenciar la región 16S-23S de aislados de Lactobacillus demostrando la adecuación de esta técnica para la identificación de especies.

En 1997, Kaufmann et al. dedicaron su trabajo a la identificación y cuantificación de Bifidobacterium spp. aislados de alimentos con sondas específicas de género (con blanco la región $16 S$ del rARN) mediante la técnica de PCR, sin el aislamiento previo de $A D N$, por rotura de las células con proteinasa $\mathrm{K}$.

Tannock et al., en 1999, identificaron aislados de Lactobacillus a partir del tracto intestinal, de ensilados y de yogur mediante comparaciones de la secuencia de la región intergénica 16S-23S del gen rARN, por amplificación de la misma mediante PCR.

Mannu et al. (2000) utilizaron la PCR para identificar lactobacilos mesofílicos en queso Fiore Sardo, un queso curado tradicional de Sardinia. Para ello, usaron siete iniciadores específicos de los diseñados por Berthier y Ehrlich (1998), Drake et al. (1996) y Ward y Timmins (1999).

Heilig et al., en 2002, emplearon la PCR junto a la electroforesis en gel con gradiente de desnaturalización (DGGE) para determinar la diversidad molecular de Lactobacillus spp. y otras bacterias lácticas en el intestino humano, concluyendo que esta combinación permite detectar bajos números de bacterias en ecosistemas específicos y caracterizarlas, tales como los lactobacilos en el tracto gastrointestinal humano.

En 2003, De Champs et al. estudiaron la colonización por Lactobacillus casei subsp. rhamnosus Lcr 35 del tracto intestinal de ratones y humanos. Para ello, diseñaron una sonda específica para hibridar la región 16S del rARN y aplicaron la técnica de la PCR, demostrando la capacidad de la cepa de sobrevivir en el tracto digestivo.

En 2004, Savadogo et al., emplearon algunos de los iniciadores diseñados por Tilsala-Timisjärvi y Alatossava (1997) para identificar algunas de las bacterias presentes en muestras de leche fermentada Burkina Faso, amplificando las secuencias de la región intergénica 16S-23S por medio de la PCR, resultando el grupo de lactobacilos el más dominante. 
Introducción

Vlková et al., (2004), emplearon la PCR para identificar a nivel de género varias cepas de Bifidobacterias derivadas de seis productos lácteos, obteniendo buenos resultados.

Dickson et al (2005) diseñaron en su trabajo iniciadores de PCR específicos de especie que permiten la identificación directa de $L$. fermentum en muestras clínicas y los usaron en PCR para la detección del mismo en muestras de saliva y de pus.

Elli et al., en un estudio llevado a cabo en 2006, aplicaron la PCR para estudiar la supervivencia de las bacterias del yogur en el intestino humano.

Se han descrito numerosos iniciadores específicos de especies, estando los normalmente disponibles recogidos en la tabla 11.

Tabla 11. Iniciadores específicos de especies normalmente disponibles

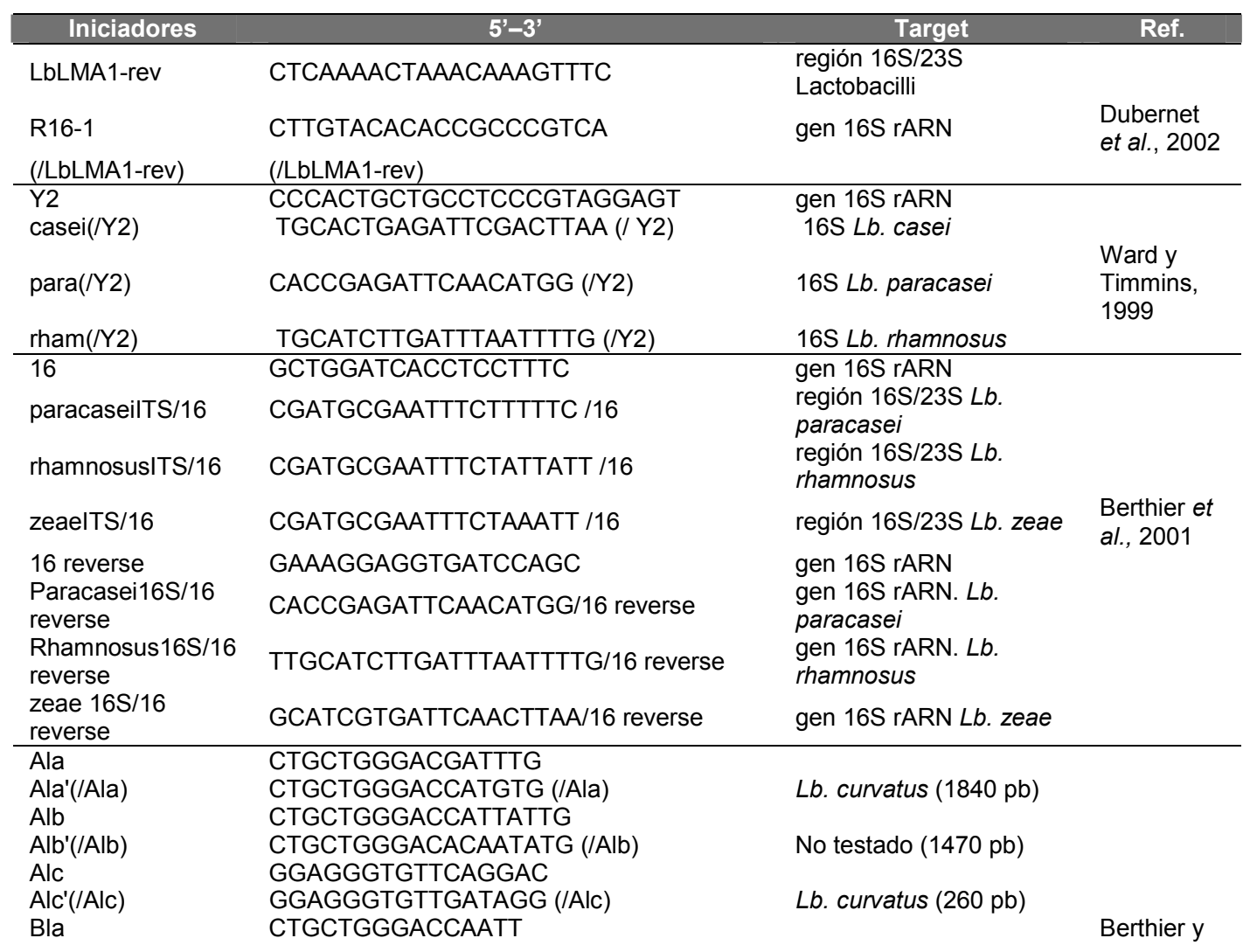




\begin{tabular}{|c|c|c|c|}
\hline & & & $\begin{array}{l}\text { Ehrlich, } \\
1999\end{array}$ \\
\hline Bla'(/Bla) & CTGCTGGGACGAAAAG (/Bla) & Lb. sake B1 (750 pb) & \\
\hline $\mathrm{B} 2 \mathrm{a}$ & CTGCTGGGACCTTAA & & \\
\hline B2a'(/B2a) & CTGCTGGGACTGAAG (/B2a) & Lb. sake B2 (1700 pb) & \\
\hline & GCTGGATCACCTCCTTTC & & \\
\hline $\operatorname{Lc}(/ 16)$ & TTGGTACTATTTAATTCTTAG (/16) & Lb. curvatus (220 pb) & \\
\hline $\operatorname{Ls}(/ 16)$ & ATGAAACTATTAAATTGGTAC (/16) & Lb. sake $(220 \mathrm{pb})$ & \\
\hline & GCTGGATCACCTCCTTTC & \multirow{3}{*}{$\begin{array}{l}\text { gen16S rARN } \\
\text { Gen } 23 S \text { rARN }(/ 16 S) \\
\text { región } 16 S / 23 S L b \text {. } \\
\text { curvatus }\end{array}$} & \multirow{8}{*}{$\begin{array}{l}\text { Berthier y } \\
\text { Ehrlich, } \\
1998\end{array}$} \\
\hline $23(/ 16)$ & AGTGCCAAGGCATCCACC (/16) & & \\
\hline $\operatorname{Lc}(/ 16)$ & TTGGTACTATTTAATTCTTAG (/16) & & \\
\hline $\operatorname{Lg}(/ 16)$ & GTTGGTACATTTAATTCTTGA (/16) & $\begin{array}{l}\text { región } 16 \mathrm{~S} / 23 S L b . \\
\text { graminis }\end{array}$ & \\
\hline Lpapl(/16) & ATGAGGTATTCAACTTATT (/16) & $\begin{array}{l}\text { región } 16 S / 23 S \text { Lb. } \\
\text { paraplantarum/plantarum }\end{array}$ & \\
\hline $\operatorname{Lpe}(/ 16)$ & GTATTCAACTTATTAGAACG (/16) & $\begin{array}{l}16 S / 23 S \text { región } L b . \\
\text { pentosus }\end{array}$ & \\
\hline $\operatorname{Lpl}(/ 16)$ & ATGAGGTATTCAACTTATG (/16) & $\begin{array}{l}\text { región } 16 S / 23 S \text { Lb. } \\
\text { plantarum }\end{array}$ & \\
\hline $\operatorname{Ls}(/ 16)$ & ATGAAACTATTAAATTGGTAC (/16) & región $16 S / 23 S$ Lb. sake & \\
\hline LB1 & AAAAATGAAGTTGTTTAAAGTAGGTA & $\begin{array}{l}\text { Lb. delbrueckii } \\
\text { bulgaricus (1065 pb) }\end{array}$ & \multirow[t]{2}{*}{$\begin{array}{l}\text { Torriani et } \\
\text { al., } 1999\end{array}$} \\
\hline LLB1 (/LB1) & AAGTCTGTCCTCTGGCTGG (/LB1) & $\begin{array}{l}\text { Lb. delbrueckii lactis } \\
(1600 \mathrm{pb})\end{array}$ & \\
\hline $20 \mathrm{~A}$ & AATTCCGTCAACTCCTCATC & \multirow{3}{*}{$\begin{array}{l}\text { Lb. delbrueckii ssp. (715 } \\
\text { pb) }\end{array}$} & \multirow{6}{*}{$\begin{array}{l}\text { Lick et al., } \\
2000\end{array}$} \\
\hline $23 B(/ 20 A)$ & TGATCCGCTGCTTCATTTCA(/20A) & & \\
\hline $34 / 2$ & CGTCAACTCCTCATCAACCGGGGCT & & \\
\hline $37 / 1(/ 34 / 2)$ & CGCCGCCCGGGTGAAGGTG(/34/2) & $\begin{array}{l}\text { Lb. delbrueckii ssp. } \\
\text { bulgaricus ( } 678 \mathrm{pb})\end{array}$ & \\
\hline 33 & ССТСATCAACTGGCGCC & \multirow[b]{2}{*}{$\begin{array}{l}\text { Lb. delbrueckii ssp. lactis } \\
(670 \mathrm{pb})\end{array}$} & \\
\hline $37(/ 33)$ & CGCCCGGGTAAAGGTA(/33) & & \\
\hline LbP11 & AATTGAGGCAGCTGGCCA & & \multirow{4}{*}{$\begin{array}{l}\text { Quere et } \\
\text { al., } 1997\end{array}$} \\
\hline LbP12 (/LbP11) & GATTACGGGAGTCCAAGC (/LbP11) & $\begin{array}{l}\text { Iniciador derivado de } \\
\text { RAPD. Lb. plantarum }\end{array}$ & \\
\hline Lb1 & AGAGTTTGATCATGGCTCAG & & \\
\hline Lb2 (/Lb1) & CGGTATTAGCATCTGTTTCC (/Lb1) & $\begin{array}{l}\text { Iniciador semi-universal. } \\
\text { 16S rARN }\end{array}$ & \\
\hline Aci I & TCTAAGGAAGCGAAGGAT & \multirow{3}{*}{$\begin{array}{l}\text { región } 16 \mathrm{~S}-23 S . L b . \\
\text { acidophilus }\end{array}$} & \multirow{9}{*}{$\begin{array}{l}\text { Tilsala- } \\
\text { Timisjarvi y } \\
\text { Alatossava, } \\
1998\end{array}$} \\
\hline Aci II (/Aci I) & СTCTTCTCGGTCGCTCTA (/Aci I) & & \\
\hline PrI & CAGACTGAAAGTCTGACGG & & \\
\hline Prll 5/Prl) & GTACTGACTTGCGTCAGCGG (/Prl) & $\begin{array}{l}\text { región } 16 S-23 S \text { Lb. } \\
\text { paracasei/rhamnosus }\end{array}$ & \\
\hline Pcas I (/Prl) & GCGATGCGAATTTCTTTTTC (/Prl) & $\begin{array}{l}\text { región } 16 S-23 S \text { Lb. } \\
\text { paracasei }\end{array}$ & \\
\hline Rha II(/Prl) & GCGATGCGAATTTCTATTATT (/Prl) & $\begin{array}{l}\text { región } 16 S-23 S L b . \\
\text { rhamnosus }\end{array}$ & \\
\hline Del I & ACGGATGGATGGAGAGCAG & \multirow{3}{*}{$\begin{array}{l}\text { región 16S-23S Lb. } \\
\text { delbrueckii }\end{array}$} & \\
\hline Del II (/Del I) & GCAAGTTTGTTCTTTCGAACTC (/Del I) & & \\
\hline $\begin{array}{l}\text { Hel I } \\
\text { Hel II (/Hel I) }\end{array}$ & $\begin{array}{l}\text { GAAGTGATGGAGAGTAGAGATA } \\
\text { CTCTTCTCGGTCGCCTTG (/Hel I) }\end{array}$ & & \\
\hline
\end{tabular}


Introducción

helveticus

\begin{tabular}{|c|c|c|c|}
\hline & & & \\
\hline DB1 & ACCTATCTCTAGGTGTAGCGCA & & \\
\hline SS1 (/DB1) & $\begin{array}{l}\text { GTGCTGCAGAGAGTTTGATCCTGGCTCAG } \\
\text { (/DB1) }\end{array}$ & $\begin{array}{l}\text { 16S Lb. delbrueckii } \\
(1100 \mathrm{pb})\end{array}$ & \\
\hline HE1 & AGCAGATCGCATGATCAGCT & & $\begin{array}{l}\text { Drake et } \\
\text { al., } 1996\end{array}$ \\
\hline SS2 (/HE1) & $\begin{array}{l}\text { CACGGATCCTACGGGTACCTTGTTAC- } \\
\text { GACTT(/HE1) }\end{array}$ & $\begin{array}{l}16 S \text { Lb. helveticus/Lb. } \\
\text { acidophilus }(1400 \mathrm{pb})\end{array}$ & $\begin{array}{l}\text { Andrighetto } \\
\text { et al., } 1998\end{array}$ \\
\hline CA1 (/SS1) & TGATCTCTCAGGTGATCAAAA (/SS1) & $\begin{array}{l}16 S \text { Lb. casei, } L b . \\
\text { rhamnosus }\end{array}$ & \\
\hline $\begin{array}{l}16 \text { SII } \\
\text { Aci 16SI (/16SII) } \\
\text { Cri 16SI(/16SII) } \\
\text { Gasl }\end{array}$ & $\begin{array}{l}\text { ACTACCAGGGTATCTAATCC } \\
\text { AGCTAACCAACAGATTCAC (/16 SII) } \\
\text { GTAATGACGTTAGGAAAGCG (/16 SII) } \\
\text { GAGTGCGAGAGCATAAAG }\end{array}$ & $\begin{array}{l}16 S \text { Lb. acidophilus } \\
16 S \text { Lb. crispatus }\end{array}$ & \\
\hline Gasll (/Gasl) & СTATTTCAAGTTGAGTTTCTCT (/Gasl) & $\begin{array}{l}\text { región 16S-23S Lb. } \\
\text { gasseri }\end{array}$ & \\
\hline Joh 16SI(/16SII) & GAGCTTGCCTAGATGATTTTA (/16 SII) & $\begin{array}{l}\text { región } 16 S-23 S \text { Lb. } \\
\text { johnsonii }\end{array}$ & \\
\hline Lpfr & GCCGCCTAAGGTGGGACAGAT & & \\
\hline Planll (/Lpfr) & TTACCTAACGGTAAATGCGA (Lpfr) & $\begin{array}{l}\text { región } 16 S-23 S \text { Lb. } \\
\text { plantarum }\end{array}$ & $\begin{array}{l}\text { Walter et } \\
\text { al., } 2000\end{array}$ \\
\hline Prl & CAGACTGAAAGTCTGACGG & & $\begin{array}{l}\text { Tynkkynen } \\
\text { et al., } 1999\end{array}$ \\
\hline Casll (/Prl) & GCGATGCGAATTTCTTTTTC (/Prl) & $\begin{array}{l}\text { región 16S-23S Lb. } \\
\text { casei }\end{array}$ & \\
\hline $\begin{array}{l}\text { Zeael } \\
\text { Zeaell (/Zeael) }\end{array}$ & $\begin{array}{l}\text { TGTTTTGAGGGGACG } \\
\text { ATGCGATGCGAATTTCTAAATT (/Zeael) }\end{array}$ & región $16 S-23 S$ Lb. zeae & \\
\hline Rhall(/Prl) & GCGATGCGAATTTCTATTATT (/Prl) & $\begin{array}{l}\text { región } 16 S-23 S \text { Lb. } \\
\text { rhamnosus }\end{array}$ & \\
\hline $\operatorname{Reu}(/ / p f r)$ & AACACTCAAGGATTGTCTGA (/lpfr) & $\begin{array}{l}\text { región } 16 \mathrm{~S}-23 S \text { Lb. } \\
\text { reuteri }\end{array}$ & \\
\hline Fermll(/lpfr) & CTGATCGTAGATCAGTCAAG (/lpfr) & $\begin{array}{l}\text { región } 16 \mathrm{~S}-23 S \mathrm{Lb} \text {. } \\
\text { fermentum }\end{array}$ & \\
\hline Shal & GATAATCATGTAAGAAACCGC & & \\
\hline Shall(/Shall) & ATATTGTTGGTCGCGATTCG (/Shall) & $\begin{array}{l}\text { región } 16 \mathrm{~S}-23 \mathrm{~S} \text { S Lb. } \\
\text { sharpae }\end{array}$ & \\
\hline SAL1 & ATTCACTCGTAAGAAGT & $16 \mathrm{~S}$ & \\
\hline $\begin{array}{l}\text { LOWLAC(/SAL1) } \\
\text { (/SAL1) }\end{array}$ & CGACGACCATGAACCACCTGT & 16S Lb. salivarius & $\begin{array}{l}\text { Chagnaud } \\
\text { et al., } 2001\end{array}$ \\
\hline CbsA2F & GTACCAAGCCAAAGCAAGAC & $\begin{array}{l}\text { CbsA (S-Layer protein } \\
\text { gene) }\end{array}$ & $\begin{array}{l}\text { Horie et al., } \\
2002\end{array}$ \\
\hline CbsA2R(/CbsA2F) & GTTTGAAGCCTTTACGTAAGTC (/CbsA2F) & Lb. perolens & \\
\hline $97 \mathrm{~K}$ & GCCTCCCGTA & $16 S U$ & $\begin{array}{l}\text { Bunte et } \\
\text { al., } 2000\end{array}$ \\
\hline Lpacaf(/97K) & CCGAGATTCAACATGG(/97K) & 16S Lb. paracasei & \\
\hline
\end{tabular}

Fuente: Coeuret et al., 2003

Se han realizado multitud de modificaciones sobre la técnica básica que pretenden aumentar el potencial de la PCR, como es el caso de la PCR múltiple, que permite detectar varias especies o varios genes de una misma especie en una misma muestra y reacción (Winter y Slavic, 2000), con el consiguiente ahorro de tiempo, reactivos y volumen de muestra. 
Sin embargo, la combinación de más de un par de iniciadores en la reacción presenta algunos inconvenientes: la especificidad puede verse reducida debido a la formación de dímeros por complementariedad interna de las secuencias de los iniciadores. Ésto puede reducir la disponibilidad de los reactivos y, por tanto, hacer que la sensibilidad de la amplificación también disminuya. La PCR múltiple ha permitido la identificación y la detección simultánea de factores de virulencia tales como cagA y vacA (Chisholm et al., 2002).

Muchos estudios recientes se han llevado a cabo empleando esta PCR múltiple (Coeuret et al., 2003). Así, la técnica se ha aplicado para detectar Lb. pontis y Lb. panis en fermentaciones en productos de panadería (Muller et al., 2000) y Lactobacillus en muestras fecales (Lucchini et al., 1998) y en carne deteriorada (Yost y Nattress, 2000).

Song et al. (2000) usaron la PCR múltiple como método rápido, simple, y fiable para la identificación de Lactobacillus aislados de heces humanas.

También en este mismo año, Dong et al., sobre la base de secuencias del $16 S$ rARN, diseñaron iniciadores específicos para la identificación simultánea de cinco especies de Bifidobacterium aisladas del intestino humano.

Ventura et al. (2001), desarrollaron un nuevo set de iniciadores de PCR para una identificación específica de especies de una mezcla de bifidobacterias o como cultivo puro de $B$. lactis. El objetivo de su estudio era el desarrollo de un método rápido y fiable para la detección e identificación de este microorganismo detectable con frecuencia en heces de niños y en determinados productos comerciales. Para ello, se aplicó la técnica de PCR múltiple.

Germond et al., en 2002, diseñaron unos iniciadores específicos, basados en las secuencias $16 S$ del rARN para la rápida identificación por amplificación del ADN de nueve especies de Bifidobacterium humanas.

Tal y como recogen Ward et al. (2005) en su revisión, se han diseñado diferentes sondas múltiples para la detección simultanea de $B$. bifidum, $B$. breve, $B$. infantis, B. longum, $B$. adolescentes de origen humano (Dong et al., 2000). También Mullié et al. 2003, aplicaron la técnica para detectar a) B. bifidum, B. breve, $B$. infantis, b) $B$. angulatum, B. catenulatum/ B. pseudocatenulatum continuum, $B$. 
Introducción

dentium, B. longum y c) B. adolescentis, B. scardovii, B. gallicum, en todos los casos de origen humano.

Settani et al. 2005 diseñaron un método basado en la PCR múltiple, con dos pasos para la rápida detección de 16 especies de lactobacilos comúnmente presentes en masa panaria. El primer paso consistió en desarrollar una mezcla de iniciadores específicos de grupo, mientras que el segundo incluyó tres ensayos de PCR múltiple con una mezcla de iniciadores específicos de especie. El resultado fue una rápida diferenciación y la detección in situ de los lactobacilos seleccionados.

En un trabajo posterior, Settani et al. (2006) emplearon esta PCR múltiple en combinación con la electroforesis en gel con gradiente de desnaturalización (DGGE) para detectar lactobacilos en masas panarias fermentadas, demostrando la alta especificidad del nuevo método en este producto concreto.

En la tabla 12, se detallan algunos Iniciadores múltiples empleados para la identificación de lactobacilos.

Tabla 12. Iniciadores múltiples empleados para la identificación de lactobacilos

\begin{tabular}{|c|c|c|c|}
\hline Iniciadores & $5^{\prime}-3^{\prime}$ & Blanco & Referencias \\
\hline Lac-2 & CCTCTTCGCTCGCCGCTACT & & \\
\hline $\begin{array}{l}\text { Ldel-7 (/lac- } \\
\text { 2) }\end{array}$ & ACAGATGGATGGAGAGCAGA (/lac-2) & $\begin{array}{l}\text { ISR/23S PCR-G } \\
\text { lactobacilos Grupo I } \\
(450 \mathrm{pb})\end{array}$ & \\
\hline $\begin{array}{l}\text { LU-1'(/lac- } \\
\text { 2) }\end{array}$ & ATTGTAGAGCGACCGAGAAG (/lac-2) & $\begin{array}{l}\text { ISR/23S PCR-G } \\
\text { lactobacilos Grupo II } \\
(300 \mathrm{pb})\end{array}$ & \\
\hline $\begin{array}{l}\text { LU-3'(/lac- } \\
\text { 2) }\end{array}$ & AAACCGAGAACACCGCGTT (/lac-2) & $\begin{array}{l}\text { ISR/23S PCR-G } \\
\text { lactobacilos Grupo } \\
\text { IV ( } 350 \text { pb) }\end{array}$ & \\
\hline LU-5(/lac-2) & CTAGCGGGTGCGACTTTGTT (/lac-2) & $\begin{array}{l}\text { ISR/23S PCR-G } \\
\text { lactobacilos Grupo III } \\
(400 \mathrm{pb})\end{array}$ & \\
\hline $23-10 \mathrm{C}$ & CCTTTCCCTCACGGTACTG & & \\
\hline $\begin{array}{l}\text { Laci-1 (23- } \\
\text { 10C) }\end{array}$ & TGCAAAGTGGTAGCGTAAGC (/23-10C) & $\begin{array}{l}\text { ISR/23S PCR-II-1 } \\
\text { Grupo II, Lb. } \\
\text { acidophilus (210 pb) }\end{array}$ & \\
\hline $\begin{array}{l}\text { Ljen-3 (23- } \\
\text { 10C) }\end{array}$ & AAGAAGGCACTGAGTACGGA (/23-10C) & $\begin{array}{l}\text { ISR/23S PCR-II-1 } \\
\text { Grupo II, Lb. jensenii } \\
\text { (700 pb) }\end{array}$ & \\
\hline Lcri-1 & AGGATATGGAGAGCAGGAAT & & \\
\hline $\begin{array}{l}\text { Lcri-2(/Lcri- } \\
\text { 1) }\end{array}$ & СААСТАТСТСТTАСАСТGCC (Lcri-1) & $\begin{array}{l}\text { ISR/23S PCR-II-2 } \\
\text { Grupo II, Lb. }\end{array}$ & \\
\hline
\end{tabular}




\begin{tabular}{|c|c|c|c|}
\hline & & crispatus (522 pb) & \\
\hline jas-1 & AGCGACCGAGAAGAGAGAGA & & \\
\hline $\begin{array}{l}\text { Lgas-2 } \\
(/ \text { Lgas-1) }\end{array}$ & TGCTATCGCTTCAAGTGCTT (/Lgas-1) & $\begin{array}{l}\text { GRR/23S PCR-II-2 } \\
\text { Grupo II, Lb. gasseri } \\
(360 \text { pb) }\end{array}$ & $\begin{array}{l}\text { Song et al., } \\
2000\end{array}$ \\
\hline Lfer-3 & ACTAACTTGACTGATCTACGA & & \\
\hline $\begin{array}{l}\text { Lfer-4 } \\
\text { (/Lfer-3) }\end{array}$ & TTCACTGCTCAAGTAATCATC (/Lfer-3) & $\begin{array}{l}\text { ISR/23S PCR-IV } \\
\text { Grupo IV, Lb. } \\
\text { fermentum (192 pb) }\end{array}$ & \\
\hline Lpla-3 & ATTCATAGTCTAGTTGGAGGT & & \\
\hline $\begin{array}{l}\text { Lpla-2 } \\
\text { (Lpla-3) }\end{array}$ & CCTGAACTGAGAGAATTTGA (/Lpla-3) & $\begin{array}{l}\text { ISR/23S PCR-IV } \\
\text { Grupo IV, Lb. } \\
\text { plantarum (248 pb) }\end{array}$ & \\
\hline Lreu-1 & CAGACAATCTTTGATTGTTTAG & & \\
\hline $\begin{array}{l}\text { Lreu-4 } \\
\text { (/Lreu-1) }\end{array}$ & GCTTGTTGGTTTGGGCTCTTC (/Lreu-1) & $\begin{array}{l}\text { ISR/23S PCR-IV } \\
\text { Grupo IV, Lb. reuteri } \\
(303 \text { pb) }\end{array}$ & \\
\hline Lsal-1 & AATCGCTAAACTCATAACCT & & \\
\hline $\begin{array}{l}\text { Lsal-2 (/lsa- } \\
2)\end{array}$ & CACTCTCTTTGGCTAATCTT (/lsa-2) & $\begin{array}{l}\text { ISR/23S PCR-IV } \\
\text { Grupo IV, Lb. } \\
\text { salivarius ( } 411 \mathrm{pb})\end{array}$ & \\
\hline $\begin{array}{l}\text { Lpar-4 (/LU- } \\
\text { 5) }\end{array}$ & GGCCAGCTATGTATTCACTGA (/LU-5) & $\begin{array}{l}\text { ISR/23S PCR-III } \\
\text { Grupo III, } L b . \\
\text { paracasei (312 pb) }\end{array}$ & \\
\hline $\begin{array}{l}\text { Rhall (/LU- } \\
5)\end{array}$ & GCGATGCGAATTTCTATTATT (/LU-5) & $\begin{array}{l}\text { ISR/23S PCR-III } \\
\text { Grupo III, Lb. } \\
\text { rhamnosus (113 pb) }\end{array}$ & \\
\hline $\mathrm{Y} 1$ & TGGCTCAGAACGAACGCTAGGCCCG & $16 \mathrm{~S}$ rARN & \\
\hline Y2 (/Y1) & $\begin{array}{l}\text { CCCACTGCTGCCTCCCGTAGGAGT } \\
(/ \mathrm{Y} 1)\end{array}$ & $\begin{array}{l}\text { 16S rARN PCR A } \\
(350 \mathrm{pb})\end{array}$ & \\
\hline 16 & GCTGGATCACCTCCTTTC & gen $16 S$ rARN & \\
\hline Ls (/16) & ATGAAACTATTAAATTGGTAC (/16) & $\begin{array}{l}\text { 16S/23S SR Lb. sake } \\
\text { PCR A ( } 220 \mathrm{pb}) \\
\text { 16S/23S SR Lb. }\end{array}$ & Yost y \\
\hline Lc $(/ 16)$ & TTGGTACTATTTAATTCTTAG (/16) & $\begin{array}{l}\text { curvatus PCR B (220 } \\
\mathrm{pb})\end{array}$ & $\begin{array}{l}\text { Nattress, } \\
2000\end{array}$ \\
\hline Lu1r & CCACAGCGAAAGGTGCTTGCAC & $\begin{array}{l}\text { Leuconostoc gen } 16 \mathrm{~S} \\
\text { rARN }\end{array}$ & \\
\hline Lu2 (/lu1r) & GATCCATCTCTAGGTGACGCCG (/lulr) & $\begin{array}{l}\text { Leuconostoc PCR B } \\
(175 \mathrm{pb})\end{array}$ & \\
\hline Lw5 (/Y1) & ACTAGAATCATTCCCTATTCTAGC (/Y1) & $\begin{array}{l}\text { Leuconostoc PCR C } \\
(470 \mathrm{pb})\end{array}$ & \\
\hline $\mathrm{Cb} 1$ & CCGTCAGGGGATGAGCAGTTAC & $\begin{array}{l}\text { Carnobacterium gen } \\
16 S \text { rARN }\end{array}$ & \\
\hline $\mathrm{Cb} 2 \mathrm{r}(/ \mathrm{Cb} 1)$ & ACATTCGGAAACGGATGCTAAT (/CbI) & $\begin{array}{l}\text { Carnobacterium PCR } \\
\text { D ( } 340 \mathrm{pb})\end{array}$ & \\
\hline $616 \mathrm{~V}$ & AGAGTTTGATYMTGGCTCAG & universal & \\
\hline $\begin{array}{l}\text { 609R } \\
(/ 616 \mathrm{~V})\end{array}$ & ACTACYNGGGTATCTAAKCC (/616V) & universal $(800 \mathrm{pb})$ & \\
\hline $\begin{array}{l}\text { LaponR } \\
\text { (/616V) }\end{array}$ & AGCCATCTTTGAAAT (/616V) & Lb. pontis (236 pb) & $\begin{array}{l}\text { Muller et al., } \\
2000\end{array}$ \\
\hline LapanR & AАCCATCTTTTATAC (/616V) & Lb. panis(236 pb) & \\
\hline
\end{tabular}


Introducción

(/616V)

LaspecR

(/616V)

AGCCTTCTTTTATAC (/616V)

Lb. $s p .(236 \mathrm{pb})$

Fuente: Coeuret et al., 2003

Otra modificación de la técnica se conoce como PCR anidada (nested PCR) (Waage et al., 1999): en ella, se realiza una doble amplificación con dos parejas de iniciadores, en donde la segunda pareja reconoce y amplifica una región interna del primer amplificado. Esta modificación aumenta la sensibilidad y la especificidad de la $\mathrm{PCR}$, siendo muy útil en la detección de muestras en la que los microorganismos se encuentren en muy poca cantidad, como las muestras ambientales (Cellini et al., 2005). Sin embargo, su utilización presenta un elevado riesgo de contaminación, al ser necesario pasar muestra del producto de la primera amplificación a nuevos viales con la mezcla de reacción para la segunda amplificación. En este caso, es necesario la realización de múltiples controles para desechar la posibilidad de aparición de falsos positivos debido a la contaminación con ADN.

En ocasiones se emplea una variante de esta técnica conocida como PCR semi-anidada, cuya diferencia básica con la anterior es que sólo emplea tres iniciadores diferentes, utilizándose uno de ellos en las dos amplificaciones (Fujimura et al., 2002).

En esta tecnología se están produciendo continuos avances. El objetivo es conseguir una automatización completa del proceso en todas sus fases, extracción, amplificación y detección, pasando esta última, incluso, por un análisis de la secuencia del producto obtenido.

Ha sido empleada, por ejemplo, por Ventura et al. 2001, en el estudio descrito en líneas anteriores para una identificación específica de especies de una mezcla de bifidobacterias o como cultivo puro de $B$. lactis en heces de niños y en determinados productos comerciales.

\subsection{Caracterización mediante iniciadores aleatorios, RAPDs (Random Amplified Polymorphic DNA)}

Descrita por Williams et al. (1990), es el más simple de los métodos de tipado basados en los ácidos nucleicos. Esta técnica, se basa en la detección de diferencias en la secuencia del ADN genómico total de distintas cepas, amplificando 
al azar regiones del ADN encabezadas por secuencias a las que son capaces de unirse iniciadores de secuencia única aleatoria. La secuencia del iniciador no guarda homología conocida con el ADN diana, por lo que la amplificación se realiza con una temperatura baja de unión del iniciador. Así se generan fragmentos de distintos tamaños, que mediante separación en gel de agarosa proporcionan patrones de bandas distintos para aquellas cepas que presentan diferencias en sus secuencias genéticas (Welsh y McClelland, 1990), que son específicas para cada par iniciadorpatrón empleados, obteniéndose una huella genómica o "fingerprinting" característica de cada cepa (Tilsala-Timisjarvi y Alatossava, 1998).

Las ventajas de esta técnica son que no es necesario conocer con anterioridad información sobre la secuencia a amplificar y que se puede emplear con gran variedad de especies, requiriéndose poca cantidad de cultivo (Swaminathan y Matar, 1993). Es más rápido que otros métodos (PCR-RFLP's), ya que no se realiza la digestión del producto amplificado. Por el contrario, esta técnica posee una reducida reproducibilidad inter laboratorios debido a que diferentes aparatos puedan dar lugar a diferentes patrones de bandas (McPherson et al. 1993; Swaminathan y Barrett, 1995). Además, el patrón de bandas que se obtiene en unas determinadas condiciones, no siempre es constante, sobre todo cualitativamente. Los análisis densitométricos por ordenador de cada amplificación, permiten estudios más precisos.

Los RAPDs han mostrado ser discriminatorios a nivel de especie, se ha aplicado al grupo de $L$. acidophilus que tiene seis especies con similares fenotipos (Du Plessis y Dicks, 1995). En un estudio sobre los diferentes tipos de L. plantarum, esta técnica presentó una discriminación mayor entre subespecies que mediante ribotipado (Johansson et al., 1995). La técnica RAPDs se ha empleado con éxito para diferenciar las subespecies de Lactobacillus delbrueckii (Lactobacillus delbrueckii subsp. bulgaricus y Lactobacillus delbrueckii subsp. lactis) (Torriani et al. 1999) y otros lactobacilos (Ward y Timmins, 1999; Tynkkynen et al., 1999; Roy y Sirois, 2000 y Cusick et al., 2000).

Las variedades de Streptococcus thermophilus han sido diferenciadas por RAPDs (Moschetti et al., 1998). Esta técnica ha sido aplicada para caracterizar la variabilidad genética de bifidobacterias aisladas de ratas alimentadas con dietas específicas (Fanedl et al., 1998). 
Introducción

El género Bifidobacterium ha sido diferenciado por la técnica de RAPDs (Vincent et al., 1998; Kullen et al., 1997), usando cinco iniciadores que distinguen tres especies diferentes ( $B$. breve, $B$. bifidum y $B$. adolescentes) en base a la similitud de los perfiles RAPDs obtenidos con cepas de referencia (Vincent et al. 1998). Esta técnica también es útil para monitorizar cepas industriales dentro de clusters específicos (B. longum/infantis o B. animalis/lactis).

Numerosos grupos de investigación han demostrado la fiabilidad del tipado con RAPDs para la diferenciación inter e intra específica de la mayoría de las especies de Lactobacillus. Además, es considerada, junto con la secuenciación del gen $16 S$ rARN, la técnica más ampliamente utilizada para caracterizar lactobacilos asociados a alimentos, y se ha demostrado que distingue de forma precisa entre cepas de Lactobacilus pentosus y Lactobacillus plantarum (Charteris et al. 1997).

Además, el RAPD múltiple (RAPD con múltiples iniciadores arbitrarios) se ha empleado con éxito para la diferenciación de bacterias aacidolácticas aisladas del tracto gastrointestinal (Lucchinin et al. 1998).

Más recientemente, los estudios incluyen el uso de RAPD para la identificación de sondas específicas para especies y cepas o iniciadores de PCR para algunos lactobacilos incluyendo Lactobacillus gasseri y Lactobacillus rhamnosus (Lucchini et al. 1998; Tilsala- Timisjarvi y Alatossava, 1998; McCartney (2002).

La tabla 13 recoge algunos iniciadores de RAPDs.

Tabla 13. Algunos iniciadores de RAPDs empleados por distintos autores

\begin{tabular}{|c|c|c|}
\hline $\begin{array}{c}\text { Iniciadores de RAPD }\left(5^{\prime}-\right. \\
\left.3^{\prime}\right)\end{array}$ & Empleado para & Referencias \\
\hline 1254 & Lb. delb. bulgaricus, Lb. acidophilus, & \\
\hline CCGCAGCCAA & Lb. kéfiranofasciens, Lb. helveticus, & Torriani et al., 1999 \\
\hline M13 & $\begin{array}{l}\text { Lb. delb. lactis, Lb. casei, Lb. } \\
\text { rhamnosus, }\end{array}$ & \\
\hline GAGGGTGGCGGTTCT & $\begin{array}{l}\text { Lb. maltoromicus, Lb. buchneri, Lb. } \\
\text { kéfir }\end{array}$ & \\
\hline 9898 & Lb. brevis, Lb. hilgardi & \\
\hline GCAGCCGG & & Sohier et al., 1999 \\
\hline AGTCAGCCAC & Lb. casei, Lb. rhamnosus, Lb. zeae & Tynkkynen et al., 1999 \\
\hline \multicolumn{3}{|l|}{ P1 } \\
\hline $\begin{array}{l}\text { GCGGCGTCGCTAATACAT } \\
\text { GC }\end{array}$ & & $\begin{array}{l}\text { Cocconcelli et al., } 1996 \\
\text { Rebechi et al., } 1998\end{array}$ \\
\hline
\end{tabular}




\begin{tabular}{|c|c|c|}
\hline P4 & Lactobacillus & \\
\hline & & \\
\hline GGAGGGTGTT & Lb. curvatus, Lb. graminis, Lb. sakei & \\
\hline OPL-01 & & \\
\hline GGCATGACCT & $\begin{array}{l}\text { Lb. acidophilus, Lb. crispatus, } L b \text {. } \\
\text { amylovorus, }\end{array}$ & Du Plessis y Dicks, 1995 \\
\hline OPL-04 & $\begin{array}{l}\text { Lb. gallinarum, Lb. gasseri, Lb. } \\
\text { johnsonii }\end{array}$ & \\
\hline GACTGCACAC & & \\
\hline UNAMED & Lb. plantarum & Johansson et al., 1995 \\
\hline ACGCGCCCT Lactobacillus & Lactobacillus & Antonsson et al., 2001 \\
\hline UNAMED & $\begin{array}{l}\text { Lb. acidophilus, } L b \text {. helveticus, } L b \text {. } \\
\text { casei, } L b \text {. reuteri, }\end{array}$ & Cocconcelli et al., 1995 \\
\hline AGCAGCGTGG & Lb. plantarum. & Baruzzi et al., 2000 \\
\hline OPL-01 & & \\
\hline GGCATGACCT & & \\
\hline OPL-04 & & \\
\hline GACTGCACAC & $\begin{array}{l}\text { Lb. pentosus, Lb. casei, Lb. sake, Lb. } \\
\text { curvatus, }\end{array}$ & Van Reenen y Dicks, 1996 \\
\hline OPL-02 & Lb. plantarum & \\
\hline TGGGCGTCAA & & \\
\hline OPL-05 & & \\
\hline ACGCAGGCAC & & \\
\hline OPB-06 & & \\
\hline TGCTCTGCCC & & Giraffa et al., 1998 \\
\hline OPB-10 & Lb. helveticus & Bouton et al., 2002 \\
\hline CTGCTGGGAC & & \\
\hline P1 & & \\
\hline TGCTCTGCCC & & Quiberoni et al., 1998 \\
\hline P2 & Lb. helveticus & \\
\hline CTGCTGGGAC & & \\
\hline RP & & \\
\hline CAGCACCCAC & Lb. paracasei, Lb. rhamnosus & Ward y Timmins, 1999 \\
\hline CRA 23 & & \\
\hline GCGATCCCCA & & \\
\hline CRA25 & Lactobacillus sp. & Daud Khaled et al., 1997 \\
\hline AACGCGCAAC & & \\
\hline OPA-02 & & \\
\hline TGCCGAGCTG & & \\
\hline OPM-05 & & \\
\hline GGGAACGTGT & Lb. acidophilus group & Gancheva et al., 1999 \\
\hline OPL-07 & & \\
\hline AGGCGGGAAC & & \\
\hline OPL-16 & & \\
\hline AGGTTGCAGG & & \\
\hline
\end{tabular}

Fuente: Coeuret et al., 2003 


\subsection{Detección mediante hibridación in situ con sondas fluorescentes (FISH)}

La hibridación in situ con sondas fluorescentes fue desarrollada independientemente por dos grupos de investigación. El ADN o ARN 28S marcado radiactivamente fue hibridado con preparaciones citológicas realizadas con oocitos de Xenopus y detectado por microautoradiografía. Esta técnica permitió examinar las secuencias de ácidos nucleicos dentro de las células, sin alterar su morfología o la integridad de sus compartimentos. Desde entonces, la técnica ha sido modificada para el estudio de evolución cromosómica y estudios citogenéticos de una gran variedad de especies. Finalmente, fue introducido en la bacteriología por Giovannoni, quien fue el primero en usar sondas de oligonucleótidos marcadas radiactivamente para la detección microscópica de bacterias. Posteriormente, los marcadores radiactivos fueron sustituidos por colorantes fluorescentes (Pinkel et al., 1998).

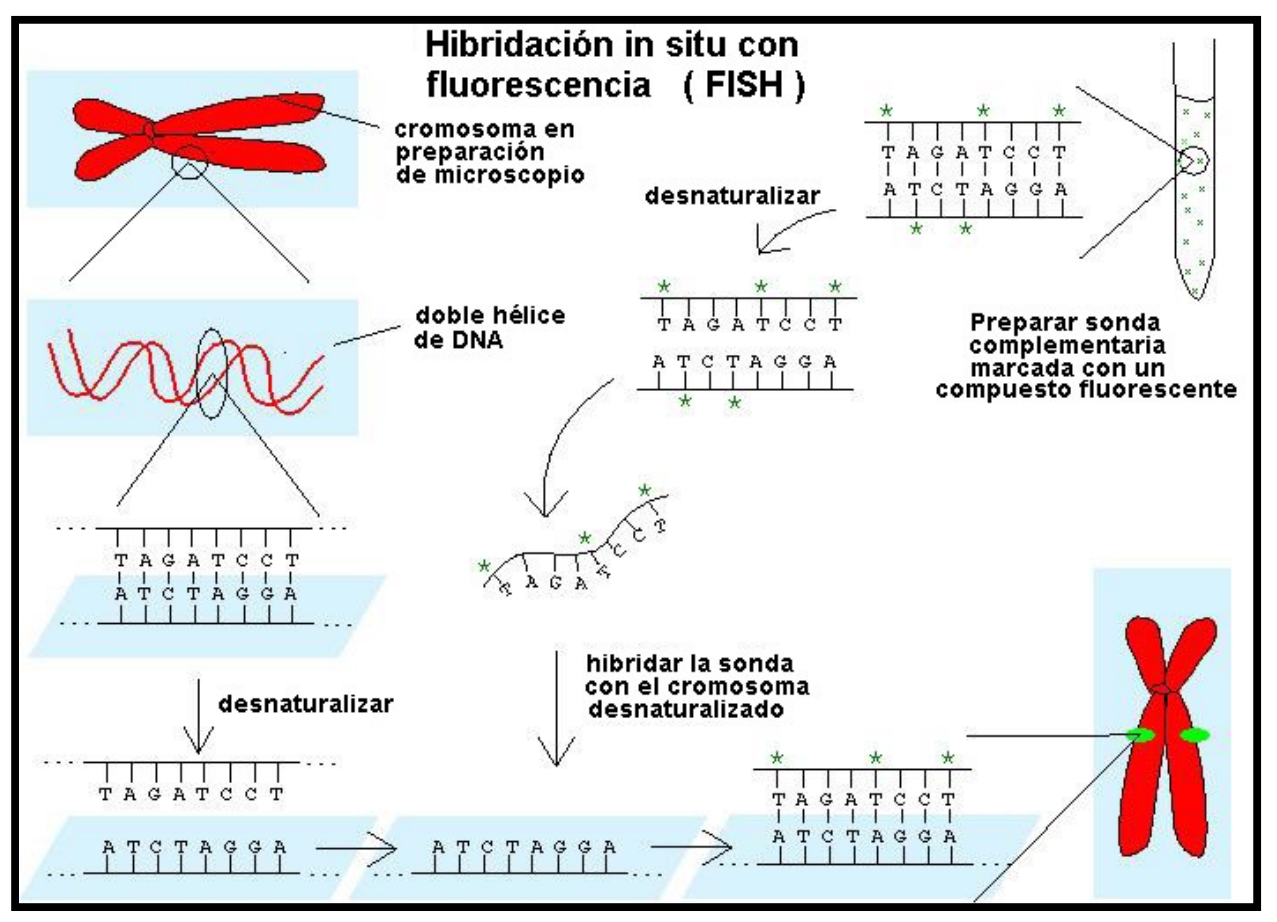

Figura 10: Esquema de la técnica de hibridación in situ

Fuente: biomodel.uah.es/citogene/horwitz/cytogen1.htm 
Comparadas con las radioactivas, las sondas fluorescentes son más seguras, ofrecen una mejor resolución y no necesitan pasos adicionales. Además, las sondas fluorescentes pueden marcarse con colorantes de distinta longitud de onda de emisión, permitiendo la detección de varias secuencias con un paso simple de hibridación.

La técnica FISH detecta secuencias de ácidos nucleicos mediante una sonda marcada por fluorescencia que hibrida específicamente con la secuencia complementaria sin dañar la célula. Se emplea como blanco una región del ARN ribosómico $16 S$ o $23 S$ por su estabilidad genética, su estructura, en la que coexisten regiones conservadas con regiones variables y su alto número de copias (Woese, 1987), lo que permite una amplificación de la señal fácilmente detectable.

Esta técnica se ha convertido en una herramienta potente, rápida y sensible para la detección e identificación de microorganismos en diferentes ambientes microbianos (Amman et al., 1995). Presenta ventajas sobre otros métodos, como la PCR o la detección con anticuerpos, ya que no requiere un cultivo previo ni extracción de ácidos nucleicos, ni surgen problemas de uniones inespecíficas ni sustancias inhibidoras que dificulten la hibridación. Además, FISH combina la precisión de la genética molecular con la información visual de la microscopía, permitiendo la visualización e identificación de células microbianas individuales dentro de su microambiente natural o del tejido enfermo.

La mayor limitación del método es la sensibilidad, en función de la propia sonda y de la matriz donde se esté hibridando. El método utilizado para el crecimiento bacteriano, los métodos de fijación de la bacteria y los agentes utilizados para embeber la muestra antes de visualizarla parece que ejercen una importante influencia en la intensidad de la señal (Fuchs et al., 2001).

La parte más crítica de esta técnica es el diseño de las sondas, que deben ser suficientemente específicas para unirse únicamente a la bacteria que queremos detectar en presencia de otras, en muchos casos con moléculas de ARNr muy homólogas. La accesibilidad de la sonda al ARNr es diferente según la molécula de ARNr de la que se trate (23S o 16S) y la zona del mismo de la que sea complementaria, lo que hay que tener en cuenta en el diseño de la sonda. El tamaño de las sondas oscila entre 15 y 30 pares de bases y las más cortas son las que presentan una mayor accesibilidad, pero pueden llevar menos marcadores 
Introducción

(Charteris et al., 1997; Fuchs et al., 2001). Muchas de estas sondas específicas para rARN se han usado de forma extensiva en el análisis de productos lácteos (Hertel et al., 1993; Andrighetto et al., 1998).

Hertel et al. (1991), identificaron secuencias específicas del 23S rARN para Lactobacillus curvatus, L. sake y L. plantarum/pentosus, desarrollando sondas complementarias para la identificación rápida de lactobacilos en productos cárnicos.

La misma técnica (hibridación por sondas específicas para la región 23S) emplearon Pot et al. (1993) para la identificación y clasificación de cepas de Lactobacillus acidophilus, L. gasseri y L. johnsonii.

Por su parte, Hensiek et al. (1992), desarrollaron sondas para el diagnóstico de oligonucleótidos para cuatro especies de Lactobacillus presentes en el tracto intestinal.

Para investigar la estructura de la población de los grupos filogenéticos predominantes en la microbiota típica de heces de adultos, Sghir et al. (2000) diseñaron, validaron y usaron una sonda para la región $16 \mathrm{~S}$ del rARN.

Del mismo modo, Ehrmann et al. (1992), diseñaron una sonda específica para hibridar la región $23 \mathrm{~S}$ del rARN de las cepas tipo de Streptococcus thermophilus y de Streptococcus salivarius.

VIková et al., (2004), emplearon el método FISH para identificar a nivel de género varias cepas de Bifidobacterias derivadas de seis productos lácteos, obteniendo buenos resultados. Para ello, usaron un kit específico para Bifidobacterium spp., siendo el componente de este kit una sonda de ADN específica de género marcada con isotiocianato de fluoresceína, que se une al rARN de la bifidobacteria. Finalmente, las muestras se analizaron con un microscopio de epifluorescencia. 
Tabla 14. Sondas oligonucleótidas para la identificación de lactobacilos

\begin{tabular}{|c|c|c|c|c|}
\hline $\begin{array}{c}\text { Sond } \\
\text { a }\end{array}$ & Secuencia $5^{\prime} 3^{\prime}$ & Blanco & Especificidad & Referencia \\
\hline Lba & TCTTTCGATGCATCCACA & $23 S$ & Lb. acidophilus & Vogel et al., 1994 \\
\hline Lba & $\begin{array}{c}\text { AGCGAGCUGAACCAACAGAUU } \\
\text { C }\end{array}$ & $16 S$ & Lb. acidophilus & Hensiek et al., 1992 \\
\hline Lbam & GTAAATCTGTTGGTTCCGC & $16 S$ & Lb. amylovorus & Ehrmann et al., 1994 \\
\hline Lbb & TGTTGAAATCAAGTGCAAG & $16 S$ & Lb. brevis & Vogel et al., 1994 \\
\hline Lbc & ATGATAATACCCGACTAA & $23 S$ & Lb. curvatus & Hertel et al., 1991 \\
\hline Lbco & AGCACTTCATTTAACGGG & $16 \mathrm{~S}$ & Lb. collinoides & Ehrmann et al., 1994 \\
\hline Lbcp & CAATCTCTTGGCTAGCAC & $23 S$ & Lb. crispatus & Ehrmann et al., 1992 \\
\hline Lbcr & GCAGGCAATACACTGATG & $23 S$ & $\begin{array}{l}\text { Lb. casei /Lb. } \\
\text { rhamnosus }\end{array}$ & Hertel et al., 1993 \\
\hline Lbcrp & CTGATGTGTACTGGGTTC & $23 S$ & $\begin{array}{l}\text { Lb. casei / Lb. } \\
\text { paracasei / } \\
\text { Lb.Rhamnosus }\end{array}$ & Hertel et al., 1993 \\
\hline Lbd & AAGGATAGCATGTCTGCA & $23 S$ & Lb. delbrueckii & Hertel et al., 1993 \\
\hline Lbdb & ATCCGAAAACCTTCT & $16 S$ & $\begin{array}{l}\text { Lb. delbrueckii } \\
\text { ssp. Bulgaricus }\end{array}$ & Lick et al., 2000 \\
\hline Lbdl & ATCCGAAGACCTTCT & $16 S$ & $\begin{array}{c}\text { Lb delbrueckii } \\
\text { ssp. } \\
\text { lactis/delbrueckii }\end{array}$ & Lick et al., 2000 \\
\hline $33 / 2$ & CATCAACTGGCGCCTT & $\begin{array}{c}\text { fragmento } \\
\text { ADN 730pb } \\
\text { EcoRl/Pstl }\end{array}$ & $\begin{array}{l}\text { Lb. delbrueckii } \\
\text { ssp. Lactis }\end{array}$ & Lick et al., 2000 \\
\hline 34B & CATCAACCGGGGCTTT & $\begin{array}{c}\text { fragmento } \\
\text { ADN 730pb } \\
\text { EcoRI/Pstl }\end{array}$ & $\begin{array}{l}\text { Lb. delbrueckii } \\
\text { ssp. bulgaricus }\end{array}$ & Lick et al., 2000 \\
\hline Lbfe & GCGACCAAAATCAATCAGG & $16 \mathrm{~S}$ & Lb. fermentum & Vogel et al., 1994 \\
\hline Lbfr & CTCGCTGCTAACTTAAGTC & $16 S$ & $\begin{array}{l}\text { Lb. fructivorans } \\
\text { /Lb. homohiochii }\end{array}$ & Vogel et al., 1994 \\
\hline Lbg & TCCTTTGATATGCATCCA & $23 S$ & Lb. gasseri & Pot et al., 1993 \\
\hline Lbh & ACTTACGTACATCCACAG & $23 S$ & Lb. helveticus & Hertel et al., 1993 \\
\hline Lbhi & CTCAACTTCATTGACCAAG & $16 S$ & Lb. hilgardii & Ehrmann et al., 1994 \\
\hline Lbj & ATAATATATGCATCCACAG & $23 S$ & Lb. johnsonii & Pot et al., 1993 \\
\hline Lbk & GTTTCATGTTAAATCATTCA & $16 S$ & Lb. kefir & Ehrmann et al., 1994 \\
\hline Lbkf & TGCGGCTAGCCCTTCCGG & $23 S$ & $\begin{array}{c}L b . \\
\text { kefiranofaciens }\end{array}$ & Ehrmann et al., 1994 \\
\hline Lbl & TCGGTCAGATCTATCGTC & $16 \mathrm{~S}$ & Lb. lindneri & Ehrmann et al., 1994 \\
\hline Lbma & CAAAAGCGACAGCTCGAAAG & $16 S$ & $\begin{array}{c}b b . \\
\text { manihotivorans }\end{array}$ & Ampe, 1993 \\
\hline Lbp & ATCTAGTGGTAACAGTTG & $23 S$ & $\begin{array}{l}\text { Lb pentosus / } L b \\
\text { plantarum }\end{array}$ & Hertel et al., 1991 \\
\hline Lbpa & CACTGACAAGCAATACAC & $23 S$ & Lb paracasei & Hertel et al., 1993 \\
\hline Lbpa & TAACTCATTGACTGACTCG & $23 S$ & Lb parabuchneri & Ehrmann et al., 1994 \\
\hline Lbpe & TCAAATGTAAATCATGATG & $16 S$ & $\begin{array}{l}\text { Lb pentosus / } \\
\text { plantarum }\end{array}$ & Ehrmann et al., 1994 \\
\hline Unamed & GGTATTGGTGATGCAAG & $16 S$ & Lb. perolens & Back et al., 1999 \\
\hline Lbpp & ATCTAGTCGTAACAGTTG & $23 S$ & Lb plantarum / & Hertel et al., 1991 \\
\hline
\end{tabular}


Introducción

\begin{tabular}{ccccc}
\hline \multicolumn{4}{c}{ pentosus } \\
\hline Lbpo & GGTAATCCATCGTCAAATC & $16 \mathrm{~S}$ & Lb pontis & Vogel et al., 1994 \\
\hline Lbru & GATCCATCGTCAATCAGG & $16 \mathrm{~S}$ & Lb reuteri & Ehrmann et al., 1994 \\
\hline Lbs & TTCGGTGAAAGAAAGCTTG & $16 \mathrm{~S}$ & Lb ruminis & Hensiek et al., 1992 \\
\hline \multirow{2}{*}{ Lbsa } & TAAGAATCAATTGGGCGAC & \multirow{2}{*}{$16 \mathrm{~S}$} & $\begin{array}{c}\text { Lb sake } \\
\text { sanfransiscensis }\end{array}$ & Vortel et al., 1991 \\
\hline
\end{tabular}

Fuente: Coeuret et al., 2003

Hay diferentes métodos de marcaje de las sondas. El marcaje fluorescente directo es el más utilizado, rápido, barato y fácil, ya que no requiere ningún paso posterior de detección tras la hibridación. Una o más moléculas de colorante fluorescente se unen al oligonucleótido, bien químicamente durante la síntesis a través de un aminoenlace en el extremo 5' terminal de la sonda, o enzimáticamente, utilizando una transferasa terminal que une los nucleótidos marcados fluorescentemente al extremo 3' terminal. Los fluorocromos de última generación emiten una señal fluorescente más intensa y son mucho más estables frente a la luz (Ammann et al., 1990).

Para asegurar la especificidad de las sondas, los dos parámetros determinantes van a ser la temperatura y la concentración de formamida en el tampón de hibridación. En la mayoría de los protocolos, la temperatura de hibridación se mantiene constante y es la concentración de formamida lo que va a dar lugar a unas condiciones más o menos astringentes. La formamida hace que disminuya la temperatura de unión de las sondas mediante el debilitamiento de los puentes de hidrógeno, permitiendo temperaturas más bajas con condiciones astringentes (Moter y Göbel, 2000).

Beimfohr et al. (1993) emplearon esta técnica para la identificación in situ de lactococos, enterococos y estreptococos.

También Langendijk et al. (1995) y Harmsen et al. (1999 y 2000) han utilizado esta técnica para detectar bifidobacterias en muestras fecales, obteniendo datos cuantitativos en la microbiota intestinal.

Welling et al. (1997), usaron sondas fluorescentes específicas para la región $16 \mathrm{~S}$ del rARN para la hibridación in situ con sondas fluorescentes de bacterias en muestras de heces humanas. 
Franks et al. 1998, aplicaron FISH para estudiar las variaciones de las poblaciones bacterianas en heces humanas empleando sondas específicas para el 16S rARN, contribuyendo así al conocimiento de la composición y dinámica de la microbiota.

En 2002, Harmsen et al., diseñaron siete sondas basadas en el 16S rARN para la detección de seis grupos de bacterias anaerobias presentes en heces humanas. Las condiciones de hibridación fueron optimizadas para aplicar FISH, siendo entonces las sondas validadas para una mezcla de organismos de referencia. Las sondas se aplicaron también en heces de 11 voluntarios.

Así lo hicieron también Ouwehand et al. (2004), quienes emplearon una cepa probiótica de Bifidobacterium en una matriz alimentaria seca, para llevar a cabo un estudio de viabilidad. Los recuentos de la cepa en heces de los diez individuos participantes en el estudio se determinaron aplicando la hibridación in situ con sondas fluorescentes.

Sakai et al. 2004 aplicaron la hibridación in situ con sondas fluorescentes para cuantificar las bacterias lácticas presentes en residuos de cocina fermentados, para lo cual diseñaron dos sondas específicas de grupos de bacterias. La técnica permitió conocer la evolución de este grupo de bacterias a lo largo del proceso de fermentación.

\subsection{Detección de formas viables por DVC-FISH}

Las primeras definiciones de viabilidad de una población celular se referían a la proporción de células capaces de multiplicarse tras la incubación en condiciones microbiológicas estándar. Se consideraría que una bacteria está muerta cuando no muestra crecimiento visible en un medio bacteriológico en un tiempo determinado. EI método clásico para determinar la viabilidad es, por tanto, el recuento en placa (Villarino et al., 2000).

Sin embargo, esta definición de viabilidad celular cuenta con muchas limitaciones. En primer lugar, no todas las especies bacterianas de muestras ambientales pueden ser cultivadas en condiciones de laboratorio. $Y$ en segundo lugar, se ha descrito un nuevo estadio fisiológico llamado viable pero no cultivable (VBNC) (Haq et al., 1996). Estas células serían viables, pero habrían perdido su 
Introducción

capacidad de formar colonias bajo condiciones de análisis, por lo que no serían detectadas.

Por lo tanto, ha sido necesario desarrollar varios métodos alternativos para determinar la viabilidad celular. Algunos métodos se basan en la demostración de actividad metabólica, como la reducción de sales de tetrazolio como indicador de un transporte activo de electrones (Rodríguez et al., 1992), la detección de actividad esterasa mediante el uso de un sustrato fluorogénico (Reynolds y Fricker, 1999), o la detección de consumo de sustratos (Rahman et al., 1994). Otros métodos ensayan la viabilidad por la demostración de la integridad de la membrana celular (Virta et al., 1998) o la presencia de ácidos nucleicos (ADN o ARN) mediante PCR (Islam et al., 1993) o FISH (Karner et al., 1997).

\section{Direct Viable Count (DVC)}

La atención se ha dirigido hacia otros nuevos marcadores de viabilidad como la elongación celular en respuesta a nutrientes en presencia de un inhibidor de la división celular, la técnica Direct Viable Count (DVC) o la detección del ARN mensajero (ARNm), una molécula con una vida corta, que podría establecer una correlación más estrecha con el estado viable que los métodos basados en el ADN.

El método original de DVC fue propuesto por el grupo de Kogure en 1979 para la enumeración de bacterias viables en un ambiente marino natural (Kogure et al., 1979). Se basa en la incubación de las muestras con un agente antimicrobiano y nutrientes. Este agente antimicrobiano actúa como un inhibidor específico de la síntesis de ADN, con lo que se previene la división celular sin afectar a otras actividades metabólicas. Las células pueden por lo tanto continuar metabolizando nutrientes y aparecen elongadas y/o más gruesas tras la incubación.

Este método original presenta dos dificultades para la aplicación en comunidades complejas. En primer lugar, en un microambiente real hay bacterias que son resistentes al agente antimicrobiano empleado y, en consecuencia, serían capaces de crecer sin la formación de células elongadas. En segundo lugar, es difícil discriminar entre células elongadas y células que no lo están. Las células elongadas pueden ser más pequeñas que la media de la población y enmascarar las células que se están buscando (Coullier et al., 1994; Joux and LeBaron, 1997). 
Singh et al. (1989) en una trabajo inicial modificaron el método tradicional de DVC para hacerlo compatible con el análisis de imagen. Realizaron una comparación entre los recuentos de células viables por el método de siembra en placa y por los recuentos directos de viables (DVC) obtenidos empleando microscopía epifluorescente por análisis de imagen manual o automático, a partir de cultivos de Escherichia coli, Salmonella typhimurium, Vibrio cholerae, Yersinia enterocolitica y Pseudomonas aeruginosa en un medio de cultivo con ácido nalidíxico. Las muestras filtradas se tiñeron para la microscopía eifluorescente y se analizaron manualmente y por análisis de imagen, considerando viables las células elongadas. En todos los casos, los recuentos de viables obtenidos con el análisis de imagen fueron superiores a los obtenidos por los otros dos métodos (siembra en placa o recuento manual de viables), variando eso sí la concentración óptima de ácido nalidíxico y el periodo de incubación con el cultivo. Como conclusión de su estudio, los investigadores indicaron que, bajo condiciones óptimas, la combinación del DVC con el análisis al microscopio, proporcionó una técnica de recuento de bacterias viables eficaz y cuantitativa a corto plazo.

En un trabajo posterior (Singh et al. (1990)), los autores emplearon esta combinación de DVC y análisis de imagen para la enumeración rápida de células dañadas por cloro en un cultivo de Escherichia coli. También emplearon el método para determinar los daños causados por el cloro en aislados de coliformes y bacterias patógenas entéricas. Con sus resultados demostraron que el análisis de imagen, bajo condiciones óptimas, proporcionó recuentos significativamente superiores de $E$. coli sometidas a estrés que el método tradicional de recuento en placa y permitió detectar daños en varios cultivos en 4 a 6 horas.

Buchrieser y Kaspar (1993) modificaron el método propuesto por Kogure et al. (1979), reemplazando el ácido nalidíxico por ciprofloxacina para la enumeración de bacterias de la leche. Esta modificación hizo posible que el método fuese también aplicable a una gran variedad de bacterias Gram positivas y Gram negativas. Para ello, probaron cuatro antibióticos diferentes (ácido nalidíxico, novobiocina, ciprofloxacino y mitomicina $\mathrm{C}$ ), siendo estos dos últimos los únicos que resultaron eficaces para aplicar el DVC con todas las bacterias probadas. Además, la cipofloxacina fue la única que podía usarse en una sola concentración $(1 \mu \mathrm{g} / \mathrm{ml})$, mientras que para el resto fueron necesarios ajustes según géneros e, incluso, especies. El uso del cirofloxacino en el DVC resultó en células viables elongadas hasta 5-11 veces con respecto a su longitud original, concluyendo de su estudio que 
Introducción

este DVC modificado es una técnica muy útil para estudios de crecimiento y supervivencia de patógenos y no patógenos en leche y otros alimentos.

Barcina et al. (1995), siguiendo también el método descrito por Kogure et al. (1979), emplearon ciprofloxacina, una quinolona que inhibe la división celular de bacterias tanto Gram-positivas como Gram-negativas, para cuantificar el número de bacterias viable en una serie de cultivos. Así, como bacterias emplearon tres cepas de Escherichia coli, dos de ellas sensible al ácido nalidíxico y la tercera resistente a este inhibidor y tres bacterias Gram positivas: un bacilo (Lactobacillus plantarum) y dos cocos (Enterococcus faecalis y Micrococcus varians). Pese a que la ciprofloxacina resultó ser un inhibidor de la división celular para las seis cepas, se detectaron diferencias en la morfología de bacilos y de cocos. De hecho, el porcentaje de bacterias viables fue determinado en el caso de los bacilos por el aumento bien de longitud bien de biovolumen, mientras que para los cocos se hizo por el aumento de biovolumen. Para detectar las variaciones en biovolumen, se necesitó aplicar el análisis de imagen. Se detectaron porcentajes similares de bacterias viables con el uso de ambos inhibidores.

Servis et al. (1995), desarrollaron un procedimiento de DVC para algunas bacterias Gram positivas. Para facilitar el DVC diferencial para bacterias Gram positivas, la ciprofloxacina, enoxacina, norfloxacina e isopropil cinodina reemplazaron al ácido nalidíxico. Se eligieron estos antibióticos puesto que, al igual que el ácido nalidíxico, son inhibidores de la ADN girasa. Se emplearon diferentes concentraciones $(1000 \mathrm{pg} / \mathrm{ml}, 100 \mathrm{pg} / \mathrm{ml}$ y $10 \mathrm{mg} / \mathrm{ml})$ para los antibióticos y los microorganismos que se seleccionaron para el estudio fueron Staphylococcus aureus, Enterococcus faecalts, Streptococcus agalactiae, Listeria monocytogenes y Bacillus subtilis, así como un estreptococo fecal aislado de una planta de tratamiento de aguas residuales. En todos los casos excepto para el estreptoco fecal se encontró el antibiótico así como su concentración más adecuadas para optimizar el porcentaje de células elongadas.

Joux y LeBaron, 1997 emplearon también el DVC descrito por Kogure et al. 1997 para estudiar las implicaciones ecológicas de la aplicación del mismo para bacterias acuáticas, pero en este caso, mejorado mediante el uso de una mezcla de antibióticos en vez de ácido nalidíxico exclusivamente. De su estudio concluyeron la mejora en la eficacia del método, concluyendo que el DVC debe ser adaptado a cada ecosistema, puesto que las concentraciones de antibiótico son dependientes 
de la cepa. Hicieron asimismo hincapié en la gran utilidad del DVC combinado con la hibridación in situ con sondas fluorescentes (FISH).

Kalmbach et al. 1997 resaltaron también la importancia y efectividad de esta combinación de técnicas, aplicándolas para estudiar la dinámica de la formación de una biopelícula en agua potable.

Guyard et al. (1999), realizaron un estudio para determinar qué antibióticos eran más potentes y a qué concentraciones para la enumeración directa y la caracterización de células viables de poblaciones bacterianas de agua mineral. Para ello, se aislaron quince cepas de dos aguas minerales emergentes y se estudiaron sus sensibilidades a siete antibióticos del grupo de las fluoro quinolonas inhibidores de la replicación (ácidos nalidíxico y pipemídico, flumequina, norfloxacina, ofloxacina, perfloxacina y ciprofloxacina). Se demostró con ello que el procedimiento de DVC puede ser mejorado empleando ciertos cócteles de antibióticos. Las características morfológicas de las bacterias se determinaron con éxito empleando el análisis de imagen y un software adaptado. De su estudio concluyeron la adecuación del método para su aplicación a otras comunidades bacterianas tales como los cultivos mixtos en biofermentadores o en alimentos con una microbiota conocida.

Regnault et al. (2000), en su trabajo trataron de poner de manifiesto los problemas asociados con la aplicación del procedimiento de recuento directo de viables (DVC) a las bacterias Gram positivas. Así, según los autores, el procedimiento de DVC original, está limitado a bacterias Gram negativas que son sensibles al ácido nalidíxico y, por ello, el objetivo de su estudio consistió en desarrollar un procedimiento para estimar el número de células Gram positivas metabólicamente activas de Staphylococcus aureus y Enterococcus faecalis, empleando un método que combinaba el número de células dependientes del sustrato y su identificación por FISH.

Para ello, para cada especie, evaluaron diferentes medios bajos en nutrientes y medios de cultivo complejos, diferentes fluoroquinolonas y antibióticos beta-lactama, concentraciones de antibióticos, combinaciones de antibióticos, temperatura y tiempo empleando bacterias en diferentes estados fisiológicos y en muestras naturales. 
Introducción

Por su parte, Yokomaku et al. 2000, desarrollaron un procedimiento de DVC cuantitativo para discriminar clara y fácilmente la viabilidad de las células bacterianas. En él, las células viables fueron lisadas selectivamente por la formación de esferoplastos causada por la incubación con antibióticos y glicina. Este efecto de la glicina provoca la formación de células hinchadas con una pared celular muy débil siendo entonces cuando las células viables son lisadas fácilmente con un tratamiento sencillo de congelación-descongelación.

\section{$\underline{\text { DVC FISH }}$}

Para solucionar este problema se puede llevar a cabo la combinación de los ensayos de DVC, que incrementan los niveles intracelulares de ARNr, con el análisis mediante FISH, basado en secuencias diana específicas de la bacteria que se desea detectar. Villarino et al. (2000) han empleado el método DVC-FISH para la detección de células viables de $E$. coli. demostrando que células inactivadas con bajas dosis de radiación UV, que habían perdido la cultivabilidad, eran capaces de elongarse, mostrando un estado viable.

Baudart et al. (2002), llevaron a cabo su trabajo al objeto de evaluar la especificidad y sensibilidad de un nuevo método que combinaba el FISH con el DVC para la enumeración directa, a nivel de célula individual, de células viables altamente diluidas de miembros de la familia Enterobacteriaceae en agua dulce y agua potable tras una filtración por membrana. Los resultados de su investigación demostraron la presencia de células viables pero no cultivables de algunos miembros de Enterobacteriaceae en agua potable tratada.

Lepeuple et al. (2003), se plantearon un estudio cuyo objetivo se centraba en desarrollar un método de detección con citometría de fase sólida para células de Escherichia coli marcadas para DVC-FISH. Para lograr la detección automática con un escáner se combinó la epifluoresceína-tiramida con una sonda oligonucleótida directamente marcada con peroxidasa para aumentar la intensidad de la fluorescencia. El método desarrollado se probó para la enumeración de cultivos puros, y para muestras de agua potable y filtrada con carbón activo granulado. El método que resultó ser equivalente al método de cultivo, fue menos sensible que el DVC-FISH seguido de análisis microscópico.

Piqueres et al., 2006, utilizaron una combinación de DVC y de FISH para estimar la viabilidad de las células de Helicobacter pylori. Para ello, en su estudio, el 
DVC fue modificado y adaptado para el análisis de este microorganismo probando diferentes tiempos de incubación y concentraciones de inhibidores de ADN girasa. El procedimiento de DVC se combinó con el FISH para la detección específica de las células viables de $H$. pylori (DVC-FISH), concluyendo que la combinación de ambas técnicas puede proporcionar un método rápido y especifico para detectar e identificar células viables de $H$. pylori en muestras ambientales, tras haberla aplicado en muestras de agua dulce y de agua marina. 


\section{OBJETIVOS}


Un probiótico es un suplemento dietético microbiano (principalmente localizado en leches fermentadas y productos lácteos) que, consumido en ciertas cantidades, es capaz de ejercer beneficios sobre la salud.

Para que estos microorganismos probióticos ejerzan su efecto beneficioso sobre el huésped, han de encontrarse en proporciones elevadas en el producto $\left(>10^{7}\right.$ microorganismos $\left./ \mathrm{ml}\right)$ y ser capaces de sobrevivir en suficiente cantidad al tránsito gastrointestinal.

En la actualidad, se ha producido una cierta discrepancia entre diferentes líneas de investigación a la hora de afirmar los efectos beneficiosos del yogur tradicional. Algunas de ellas aseguran que sus bacterias no son capaces de sobrevivir al tracto gastrointestinal mientras que otras afirman lo contrario.

Todo ello nos llevó a establecer cuatro objetivos globales:

1. Aislamiento, identificación y caracterización molecular de las bacterias lácticas (Lactobacillus delbrueckii subsp bulgaricus y Streptococcus thermophilus) presentes en yogures de 11 marcas comerciales.

A. Realizar recuentos totales de la población microbiana de los yogures para comprobar que cumplen con la normativa legal.

B. Muestreo y aislamiento de las diferentes cepas presentes en cada uno de los yogures.

C. Caracterización fenotípica: identificación bioquímica de las cepas por el sistema comercial API-50CHL.

D. Caracterización genotípica de las diferentes cepas mediante RAPDs y análisis de los perfiles generados.

2. Puesta a punto de técnicas de detección de Lactobacillus delbrueckii subsp bulgaricus y Streptococcus thermophilus basadas en el análisis de los ácidos nucleicos, ADN y ARN: PCR y FISH. 
A. Puesta a punto de técnicas de detección de Lactobacillus delbrueckii subsp bulgaricus mediante PCR y PCR seminested y Streptococcus thermophilus mediante PCR.

B. Diseño de sondas específicas y puesta a punto de técnicas de detección y recuento de Lactobacillus delbrueckii subsp bulgaricus y Streptococcus thermophilus mediante FISH.

3. Desarrollo de la técnica DVC-FISH para la detección de células viables, de Lactobacillus delbrueckii subsp bulgaricus y Streptococcus thermophilus.

A. Puesta a punto (in vitro) de la técnica DVC-FISH.

B. Aplicación (in vitro) de la técnica DVC-FISH: simulación de jugos gastrointestinales para determinar la resistencia de las cepas.

4. Estudio in vivo de la supervivencia al tracto gastrointestinal de las cepas de BAL de un producto fermentado (yogur).

A. Estudio de la viabilidad de Lactobacillus delbrueckii subsp. bulgaricus mediante la aplicación de las técnicas de PCR y DVC-FISH en muestras de heces.

B. Estudio de la viabilidad de Streptococcus thermophilus mediante la aplicación de las técnicas de PCR y DVC-FISH en muestras de heces.

C. Estudio de la evolución de la microbiota intestinal a lo largo del ensayo. 


\section{MATERIALES Y MÉTODOS}


Materiales y métodos

1. AISLAMIENTO, IDENTIFICACIÓN, RECUENTO Y CARACTERIZACIÓN MOLECULAR DE LAS BACTERIAS LÁCTICAS (Lactobacillus delbrueckii subsp bulgaricus $Y$ Streptococcus thermophilus) PRESENTES EN YOGURES DE ONCE MARCAS COMERCIALES

\subsection{Yogures analizados y cepas de referencia utilizadas}

Se analizaron un total de once yogures naturales tradicionales y tres pasteurizados después de la fermentación de diferentes marcas comerciales. Los yogures naturales se denominaron como $\mathrm{Y} 1, \mathrm{Y} 2$, sucesivamente hasta $\mathrm{Y} 11$ y los pasteurizados como YP1, YP2 e YP3.

Se utilizaron cepas de referencia de Lactobacillus delbrueckii subsp bulgaricus (CECT 4005T) y Streptococcus thermophilus (CECT 801) para la puesta a punto de los diferentes métodos de aislamiento, identificación, recuento y caracterización molecular. Estas cepas se sembraron en agar MRS y M17, respectivamente, y se incubaron en anaerobiosis a dos temperaturas distintas $\left(37^{\circ} \mathrm{C}\right.$ y $42^{\circ} \mathrm{C}$ ) para comprobar sus condiciones óptimas de crecimiento.

Todas las cepas utilizadas en la investigación se conservaron a $-20^{\circ} \mathrm{C}$ y $-80^{\circ} \mathrm{C}$ en caldo nutritivo adicionado con un $20 \%$ de glicerol.

\subsection{Muestreo, recuento y aislamiento de microorganismos}

Como paso previo a la toma de muestra, los yogures anteriormente descritos fueron homogeneizados y atemperados a temperatura ambiente. Se pesaron en condiciones de esterilidad 10 gramos de cada yogur que fueron introducidos en una bolsa estéril de plástico conteniendo $90 \mathrm{ml}$ de agua de peptona tamponada. La mezcla se llevó al homogeneizador de muestras Stomacher MIX1 (Aes Laboratoire) para su emulsión durante 3-4 minutos, aproximadamente.

Después se realizaron diluciones decimales seriadas en agua con Tween 80 al $4 \%$ que se sembraron por duplicado en los medios de cultivo apropiados para realizar los recuentos.

Los medios de cultivo utilizados fueron los siguientes: 
- Medio agar LS Differential (Scharlau Schemie) para el recuento diferencial de las bacterias lácticas presentes en el yogur y para su aislamiento. En este medio, Lactobacillus delbrueckii subsp. bulgaricus crece en forma de colonias lobuladas rojas de 1-1,5 mm de diámetro rodeadas de una zona blanca opaca y Streptococcus thermophilus crece en este medio formando colonias ovales o redondas rojas de aproximadamente $0,5 \mathrm{~mm}$ de diámetro con un pequeño halo claro a su alrededor.

- Medio agar MRS (Merck) para el aislamiento de lactobacilos y su crecimiento mediante siembra en masa. En este medio, las colonias que aparecen son grandes, blancas y con los bordes bien definidos. Éstas se corresponden con el género Lactobacillus.

- Medio agar M-17 (Merck) para el aislamiento de estreptococos y su crecimiento en masa. Las colonias que aparecen son color crema y se corresponden con el género Streptotococcus.

Las placas se incubaron a $37^{\circ} \mathrm{C}$ durante $72 \mathrm{~h}$ en condiciones de anaerobiosis (generada mediante sobres de anaerobiosis AnaeroGen (Oxoid)).

Se realizaron recuentos específicos en agar LS Diferencial por duplicado, en base a la morfología de las colonias. Los aislammientos iniciales de las cepas de lactobacilos y estreptococos de cada yogur también se realizaron en este medio de cultivo. A los lacotobacilos se les otorgó la nomenclatura LDY1 a LDY11 y a los estreptococos STY1 a STY11, según el producto del cual fueron aislados.

\subsection{Identificación de los microorganismos mediante pruebas bioquímicas}

Del análisis de cada yogur natural (Y1, Y2..., Y11) realizado se seleccionaron colonias características de Lactobacillus delbrueckii subsp. bulgaricus y Streptococcus thermophilus crecidas en el medio de cultivo selectivo LS Differencial agar y se procedió a su identificación fenotípica mediante tinción Gram, prueba de la catalasa y perfiles de fermentación de carbohidratos (tira API $50 \mathrm{CHL}$ ).

El sistema de identificación API $50 \mathrm{CHL}$ (Biomerieux, France) fue empleado para comprobar la acción de estas cepas seleccionadas (aisladas de cada una de las 11 muestras de yogur) sobre 50 sustratos. Este sistema se basa en el estudio de 
Materiales y métodos

fermentación de los 49 azúcares que posee la galería (compuesta por 50 microtubos, el primer tubo, sin principio activo, sirve como control negativo).

Antes de iniciar la prueba, las colonias aisladas seleccionadas se sembraron mediante triple estría en agar Plate Count (Merck) para obtener un cultivo puro (cultivo a $37^{\circ} \mathrm{C}$ durante 24 horas y en condiciones de anaerobiosis). Se picó una colonia que se resuspendió en el medio incluido en el test (color violeta) hasta una turbidez equivalente al tubo de McFarland número 2 y después se inoculó en cada microtubo de la galería. Se realizó todo el procedimiento según instrucciones del fabricante, incubando la galería en condiciones anaerobias a $37^{\circ} \mathrm{C}$ durante 48 horas, siendo la primera lectura una vez transcurridas 24 horas y la segunda a las 48 horas.

Durante la incubación, el catabolismo de los glúcidos produce ácidos orgánicos que hacen virar el indicador del $\mathrm{pH}$, pasando el medio de color violeta a color amarillo (prueba positiva). Los resultados obtenidos constituyeron los perfiles bioquímicos de cada una de las cepas y sirvieron para su identificación.

\subsection{Recuento e identificación de BAL mediante la utilización de sondas específicas (FISH)}

La hibridación in situ por fluorescencia (FISH) detecta las células de interés mediante la hibridación de la muestra con sondas sintéticas marcadas con fluorocromos. La molécula empleada como blanco para FISH es una región del ARN ribosómico 16S o $23 \mathrm{~S}$ por su estabilidad genética, su dominio estructural con regiones conservadas y regiones variables y su alto número de copias que permite la unión de la sonda produciendo una amplificación de la señal.

Se propuso diseñar un protocolo para la detección de las BAL Lactobacillus delbrueckii subsp. bulgaricus y Streptococcus thermophilus mediante la hibridación con sondas específicas sin necesidad de cultivo previo (FISH). Mediante esta técnica (FISH) se analizaron los productos descritos en el apartado 1.1, identificando y cuantificando las bacterias aisladas en los mismos.

Para realizar los recuentos de lactobacilos y estreptococos en cada uno de los productos comerciales estudiados anteriormente, se tomaron $2 \mathrm{ml}(1 \mathrm{ml}$ para la hibridación con la sonda correspondiente de Lactobacillus delbrueckii subsp. bulgaricus y $1 \mathrm{ml}$ para la de Streptococcus thermophilus en dos eppendorfs 
diferentes) de las muestras de yogur utilizadas para el recuento en placa (descrito en el apartado 1.2) para poder comparar los resultados obtenidos por ambos métodos. La hibridación in situ se realiza según la técnica descrita a continuación.

\subsubsection{Sondas}

\section{L. delbrueckii subsp. bulgaricus}

Se diseñaron sondas complementarias y específicas de las secuencias parciales de los genes $16 \mathrm{~S}$ y $23 \mathrm{~S}$ del ARN ribosómico, para la detección a nivel de subespecie de $L$. delbrueckii subsp. bulgaricus así como para la realización de recuentos mediante FISH en diferentes matrices.

Para la detección de Lactobacillus delbrueckii subsp. bulgaricus se utilizaron varias sondas.

En primer lugar, se diseñó la sonda LDE16S complementaria a una región del gen $16 S$ del ARNr cuya secuencia es:

LDE16S: 5'- GAC TCT TCG GGG TGA TTT -3'

Por otro lado, se diseñó una sonda específica, complementaria a una región del ARNr 23S. La secuencia de la sonda es la siguiente:

LDE23S: 5'- GCG TGT TCC CTC CTT AAG C -3'

Se comprobó la especificidad teórica de ambas. Para ello, se llevó a cabo un análisis comparativo de ambas con las secuencias del ARN ribosómico $16 \mathrm{~S}$ y $23 \mathrm{~S}$ de Lactobacillus delbrueckii subsp. bulgaricus contenidas en las bases de datos RDP (Ribosomal Data Proyect II) y mediante el programa BLAST del GenBank.

Así mismo, se valoró la especificidad de las sondas mediante la hibridación de una batería de cepas pertenecientes a distintas especies de BAL (de referencia y aisladas de producto y de heces). Se realizaron recuentos de Lactobacillus 
delbrueckii subsp. bulgaricus de los productos comerciales estudiados mediante hibridación in situ con esta sonda.

Por otro lado, se diseñó otra sonda basada en la secuencia específica de la cepa aislada de Lactobacillus delbrueckii subsp. bulgaricus del producto Y7. Para ello, se secuenciaron parcialmente los genes $16 \mathrm{~S}$ y $23 \mathrm{~S}$ de la cepa de este yogur natural. En la región complementaria a la sonda LDE23S se observó que había un cambio de base precisamente en esa zona. Se diseñó otra sonda LDE23R con ese cambio de base para los posteriores experimentos (in vitro e in vivo) que se realizaron con ese producto cuya secuencia fue:

$$
\text { LDE23R: 5'- GCG TGT TCC (T/C)TC CTT AAG C -3' }
$$

La secuenciación parcial de los genes $16 \mathrm{~S}$ y $23 \mathrm{~S}$ de la cepa de Lactobacillus delbrueckii subsp. bulgaricus aislada del producto comercial que se empleó para realizar todos los productos posteriores aparece en el anexo VI.

\section{Streptococcus thermophilus}

Se diseñó una sonda complementaria y específica de las secuencias parciales del gen 23S del ARN ribosómico, para la detección a nivel de especie de Streptococcus thermophilus así como para la realización de recuentos mediante FISH en diferentes matrices. Se compararon las secuencias del gen que codifica el ARNr $23 S$ de Streptococcus thermophilus con las del resto de microorganismos almacenadas en los distintos bancos de datos. La especificidad de las sondas se comprobó de forma teórica mediante el programa BLAST. Las secuencias de las sondas fueron las siguientes:

STH23S: 5'-CAT GCC TTC GCT TAC GCT-3'

A nivel práctico, la especificidad de la misma se comprobó mediante la hibridación con una batería de cepas de BAL y otros estreptococos y enterococos endógenos que pudieran estar presentes en heces humanas y pudieran dar falsos positivos en un futuro ensayo in vivo. 


\section{Sondas EUB}

Se empleó una combinación de tres sondas EUB338, complementarias de una región del ARNr $16 S$ del dominio Eubacteria como control positivo, ya que hibridan con todas las bacterias que pueden estar presentes en la muestra (Amann et al.,1995).

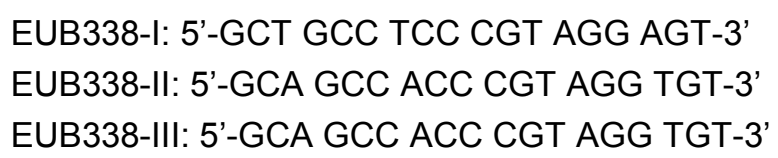

Todas las sondas empleadas fueron sintetizadas y marcadas por TIB MOLBIOL (Berlin, Germany) con 5 (6)-carboxifluoresceina-N-hidroxisuccinimida éster (FLUOS), que emite en el espectro del verde y con $\mathrm{CY} 3$, que emite en el espectro del rojo.

\subsubsection{Hibridación in situ (FISH)}

Para llevar a cabo la fijación de las células se tomaron las alícuotas de $1 \mathrm{ml}$ descritas anteriormente (apartado 1.4.) de cada uno de los yogures a analizar (Y1 hasta Y11) y se procedió a su centrifugación. El precipitado se resuspendió en PBS y paraformaldehído en proporción $1: 3$, manteniéndose durante 3 horas a $4^{\circ} \mathrm{C}$. A continuación, se procedió a dos lavados de las muestras con PBS y, tras los mismos, se resuspendió el precipitado con etanol y PBS en una proporción 1:1 y se almacenó a $-20^{\circ} \mathrm{C}$. Una vez fijadas, las muestras se depositaron sobre los pocillos de los portaobjetos de hibridación, tratados previamente con gelatina. Se dejaron secar al aire y se añadió $10 \mu \mathrm{l}$ de lisozima a una concentración de $10 \mathrm{mg} / \mathrm{ml}$. Se incubó durante 10 minutos a temperatura ambiente. Se procedió a la deshidratación, sumergiendo el portaobjetos en volúmenes de 50,80 y $100 \%$ de etanol, durante 3 minutos en cada uno.

Posteriormente, cada uno de los pocillos se cubrió con $10 \mu \mathrm{l}$ de tampón de hibridación (0,9 M/l NaCl, 0,01\% SDS, $20 \mathrm{mM} / \mathrm{l}$ Tris- $\mathrm{HCl}$ y X\% formamida, $\mathrm{pH} 7,6)$ conteniendo $50 \mathrm{ng}$ de sonda marcada con el correspondiente fluorocromo. Para la puesta a punto de la técnica se probaron varias concentraciones de formamida. La función de la formamida es aumentar la astringencia de unión, de forma que cuanto 
mayor sea la concentración, más específica debe ser la unión de la sonda con la secuencia diana.

El portaobjetos se introdujo en posición horizontal en un tubo tipo Sarsted de $50 \mathrm{ml}$, en el que se había introducido previamente una base de papel de celulosa humedecida con el mismo tampón de hibridación. La reacción se llevó a cabo a $46^{\circ} \mathrm{C}$, en oscuridad y en condiciones de humedad según Moreno et al. (2001). El tiempo de hibridación fue de aproximadamente 2 horas.

A continuación, se procedió al lavado del portaobjetos con una solución de lavado (20 mM/l Tris- $\mathrm{HCl}, 0,01 \%$ SDS, $5 \mathrm{mM} / /$ EDTA) atemperada a $48^{\circ} \mathrm{C}$, primero vertiendo una pequeña cantidad sobre el mismo para arrastrar el tampón de hibridación y, después, sumergiéndolo en $50 \mathrm{ml}$ de la misma para eliminar el resto de sonda que no se hubiera unido al ARNr. El tiempo de lavado fue de 15 minutos, manteniéndose a $48^{\circ} \mathrm{C}$ en oscuridad. Al tampón de lavado se le añadió una concentración de $\mathrm{NaCl}$ condicionada por el porcentaje de formamida utilizado en la hibridación.

\begin{tabular}{cc}
\hline $\begin{array}{c}\text { \%Formamida } \\
\text { (Tampón de hibridación) }\end{array}$ & $\begin{array}{c}\mu \mathrm{l} \text { de } \mathrm{NaCl} \mathrm{0.5M} \\
\text { (Tampón de lavado) }\end{array}$ \\
\hline 0 & 9000 \\
\hline 10 & 4500 \\
\hline 20 & 2150 \\
\hline 30 & 1020 \\
\hline 40 & 460 \\
\hline
\end{tabular}

Tras los 15 minutos de lavado, los portaobjetos se lavaron con agua y se secaron al aire en oscuridad. Posteriormente, se montaron con FluoroGuard Antifade Reagent (Bio-Rad) entre cubre y portaobjetos y se visualizó mediante un microscopio de fluorescencia Olimpus BX 50 con los filtros U-MWB, U-MWIB y UMWIG. Las fotografías se realizaron con la cámara DP-10 de Olympus.

Se contaron un total de 20 campos por muestra. Todos los recuentos se hicieron por duplicado. 


\subsection{Caracterización genotípica}

\subsubsection{Aislamiento de ADN genómico}

El aislamiento del ADN genómico de las cepas de Lactobacillus delbrueckii subsp. bulgaricus (LDY1 a LDY11) y Streptococcus thermophilus (STY1 a STY11), asi como de las cepas de referencia de estas bacterias utilizadas se realizó con el método de extracción del CTAB modificado descrito por Wilson (1987).

Se partió de un cultivo puro que se resuspendió en $500 \mu \mathrm{l}$ de tampón TE. El tampón contiene EDTA, capaz de acomplejar tanto los cationes divalentes como los iones $\mathrm{Mg}^{+2}$, que mantienen la estructura de la pared celular. La eliminación de estos iones produce un debilitamiento de la misma. EI EDTA también inhibe los enzimas que pueden degradar el ADN, ya que éstos necesitan la presencia de cationes divalentes para poder actuar.

A continuación, se añadieron $30 \mu \mathrm{l}$ de SDS al 10\%, cuya función es disociar las proteínas unidas a los ácidos nucleicos y eliminar los lípidos que actuarían formando micelas con lipoproteínas y $3 \mu \mathrm{l}$ de proteinasa $\mathrm{K}(20 \mathrm{mg} / \mathrm{ml})$ para facilitar la eliminación de los restos proteicos. Toda la mezcla se agitó e incubó a $37^{\circ} \mathrm{C}$ durante 1 hora.

Transcurrida la incubación, se añadieron $100 \mu \mathrm{l}$ de $\mathrm{NaCl} 5 \mathrm{M}$, que proporciona la concentración salina necesaria para que el CTAB no acompleje con el ADN. A continuación, se adicionaron $80 \mu \mathrm{l}$ de solución $\mathrm{CTAB} / \mathrm{NaCl}$ para separar las proteínas del $A D N$, manteniéndolas en solución. De nuevo se agitó y se incubó la mezcla a $65^{\circ} \mathrm{C}$ durante 10 minutos. Tras la incubación se añadieron $700 \mu \mathrm{l}$ de cloroformo/alcohol isoamílico (24:1). El detergente y los lípidos se extraen con el cloroformo, el alcohol isoamílico facilita la separación de las fases y evita la formación de espuma durante las mezclas.

Se agitó y, después, se centrifugó la mezcla a 12000 rpm durante 10 minutos, con el fin de separar la fase acuosa, que contiene el $A D N$, de la fase CTAB-restos celulares. El sobrenadante obtenido $(400-600 \mu \mathrm{l})$ se transfirió a un nuevo tubo y se añadió el mismo volumen de fenol/cloroformo/alcohol isoamílico (25:24:1). El fenol desnaturaliza las proteínas, que precipitan, separándolas del 
Materiales y métodos

ADN, que permanece soluble. Tras agitar, la mezcla se centrifugó a 12000 rpm durante 5 minutos para eliminar cualquier resto de CTAB precipitado.

El sobrenadante $(300-400 \mu \mathrm{l})$ se transfirió a un tubo nuevo y se añadió isopropanol frío (200-250 $\mu$ l). La mezcla se agitó suavemente durante unos minutos y se centrifugó a $12000 \mathrm{rpm}$ durante 5 minutos para precipitar el ADN. Al finalizar la centrifugación, se eliminó todo el isopropanol y el precipitado se lavó con $500 \mu \mathrm{l}$ de etanol frío al $70 \%$ y se secó al vacío. Por último, se resuspendió en $25 \mu$ de tampón TE y se le añadió $1 \mu \mathrm{l}$ de solución ARNsa, conservándolo a $-20^{\circ} \mathrm{C}$.

Se comprobó la extracción de ADN mediante un gel de agarosa al $1 \%$ en tampón TAE (1x). Se realizó la electroforesis de este gel y, tras finalizar, se tiñó con bromuro de etidio $(0,5 \mu \mathrm{g} / \mathrm{ml})$ durante 15 minutos. La presencia de ADN se comprobó tras su visualización con luz ultravioleta.

\subsubsection{Amplificación del ADN mediante iniciadores aleatorios ("Random Amplified Polymorphic DNA" o RAPDs)}

La técnica RAPDs (Random Amplified Polymorphic DNA) se emplea como técnica de caracterización molecular que abarca todo el ADN bacteriano, obteniéndose de este modo una diferenciación intraespecífica. Diferencia, por tanto, entre cepas pertenecientes a una misma especie. La técnica se basa en la detección de diferencias en la secuencia del ADN genómico total de distintas cepas, amplificando al azar regiones del ADN encabezadas por secuencias a las que son capaces de unirse iniciadores de secuencia única aleatoria. Se generan fragmentos de distintos tamaños, que mediante separación en gel de agarosa proporcionan patrones de bandas distintos para aquellas cepas que presentan diferencias en sus secuencias genéticas, obteniéndose una huella genómica característica de cada cepa.

Se utilizaron dos iniciadores distintos de nueve pares de bases para la caracterización de lactobacilos y estreptococos.

El primero de ellos, fue el inciador que se denominó RAPD1, descrito por Tynkkynen et al. (1999). 
RAPD1 : 5' - AGT CAG CCA C - 3'

El segundo fue el inciador que se denominó RAPD2 (Torriani et al., 1999)

RAPD2: 5' - CCG CAG CCA A - 3'

Las reacciones de amplificación se llevaron a cabo en un volumen total de $50 \mu \mathrm{l}$, conteniendo:

\begin{tabular}{|ll}
\hline Taq- ADN polimerasa & $2,5 \mathrm{U}$ \\
Tampón Buffer $(10 \mathrm{x})$ & $5 \mu \mathrm{l}$ \\
Desoxirribonucleótido trifosfato (dNTP) & $200 \mu \mathrm{M}$ \\
Cloruro de Magnesio $\left(\mathrm{Cl}_{2} \mathrm{Mg}\right)$ & $4 \mu \mathrm{M}$ \\
Iniciador & $0,4 \mu \mathrm{M}$ \\
ADN muestra & $5 \mu \mathrm{l}$ \\
Agua & $32 \mu \mathrm{l}$
\end{tabular}

Tabla 15. Condiciones de reacción de amplificación por RAPD’s para lactobacilos y estreptococos

\begin{tabular}{ccc}
\hline $\mathrm{N}^{\circ}$ ciclos & Temperaturas y tiempos & Proceso \\
\hline 1 ciclo & $94^{\circ} \mathrm{C}$ durante $5 \mathrm{~min}$ & Desnaturalización \\
\hline 35 ciclos & $94^{\circ} \mathrm{C}$ durante $1 \mathrm{~min}$ & Desnaturalización \\
& $32^{\circ} \mathrm{C}$ durante $2 \mathrm{~min}$ & Unión al iniciador \\
& $72^{\circ} \mathrm{C}$ durante $2 \mathrm{~min}$ & Extensión del producto \\
\hline 1 ciclo & $72^{\circ} \mathrm{C}$ durante 2 min & Extensión del producto \\
\hline
\end{tabular}

Para comprobar la amplificación se realizó una electroforesis en gel de agarosa al 1\% (agarosa MS-12, HispanLab). 
Materiales y métodos

\subsection{Análisis de los perfiles de bandas generados por RAPDs}

Los perfiles de bandas fueron visualizados bajo luz ultravioleta y se registraron en un soporte informático. A continuación, las bandas se analizaron con el programa informático TDI Lane Manager (TDI España).

El primer paso del análisis consistió en determinar el tamaño de cada banda, mediante extrapolación de la distancia de migración de los fragmentos del marcador (100 pb ADN Ladder, Fermentas). Para ello, se empleó el programa 1D-Manager (TDI), mediante el cual se definen los perfiles de bandas y el perfil de referencia correspondiente al marcador de pesos moleculares, de modo que el programa estima el tamaño de las diferentes bandas de cada microorganismo.

Posteriormente, se construye una matriz de distribución de los fragmentos. En la matriz, las filas representan las diversas bandas generadas por amplificación del ADN y las columnas se corresponden con los distintos microorganismos analizados. La comparación entre microorganismos se realiza mediante el coeficiente de similitud de Dice $\left(S_{D}\right)$, definido como:

$$
S_{D}=\frac{2 a}{2 a+b+c}
$$

siendo a: número de bandas comunes para ambas cepas.

b y c: número de bandas no comunes en cada cepa.

La comparación entre microorganismos, también, se realiza mediante el coeficiente de similitud de Jacard $\left(\mathrm{S}_{\mathrm{D}}\right)$, definido como:

$$
S_{D}=\frac{a}{a+b+c}
$$

siendo a : número de bandas comunes para ambas cepas.

b y c: número de bandas no comunes en cada cepa. 
Los coeficientes de similitud de Dice y de Jacard se utilizan en la construcción de una representación gráfica de las relaciones entre los microorganismos analizados, denominada "Dendrograma". Con ayuda del programa informático Lane Manager (TDI) se determinan los coeficientes de similitud de Dice y de Jacard para cada combinación de parejas de microorganismos.

El programa construye una matriz de similitud cuyas filas y columnas se corresponden con los microorganismos y que está compuesta por los valores del coeficiente de Dice y de Jacard. Aplicando el algoritmo matemático UPGMA (Unweighted-Pair Group Meted with Average linkage) los microorganismos son agrupados basándose en la similitud de sus perfiles de bandas y se construye el dendrograma. 
Materiales y métodos

2. DETECCIÓN DE Lactobacillus delbrueckii subsp. bulgaricus Y Streptococcus thermophilus MEDIANTE PCR TRADICIONAL y PCR SEMINESTED

\subsection{Cepas bacterianas utilizadas, condiciones de cultivo y conservación}

Para el ensayo de especificidad, se emplearon las cepas que aparecen en Tabla 16. Se incluyeron cepas de referencia de los géneros Lactobacillus, Streptococcus y Enterococcus, procedentes de la Colección Española de Cultivos Tipo (CECT). El resto fueron las cepas de Streptococcus thermophilus y Lactobacillus delbrueckii subsp. bulgaricus aisladas de los productos comerciales utilizados (STY1 a STY11 y LDY1 a LDY11, respectivamente).

Tabla 16. Cepas de referencia utilizadas

\begin{tabular}{lc}
\hline \multicolumn{1}{c}{ Especies o subespecies } & Cepa \\
\hline $\begin{array}{l}\text { Streptococcus thermophilus } \\
\text { (aislados de los yogures comerciales Y1 a Y11) }\end{array}$ & STY1 a STY11 \\
\hline Streptococcus thermophilus & CECT 801 \\
\hline Streptococcus intermedius & CECT 803T \\
\hline Enterococcus faecalis & CECT 407 \\
\hline Enterococcus faecium & CECT 4102 \\
\hline Lactobacillus delbrueckii subsp bulgaricus & LDY1 a LDY11 \\
\hline (aislados de los yogures comerciales Y1 a Y11) & CECT 4005T \\
\hline Lactobacillus delbrueckii subsp bulgaricus & CECT 286T \\
\hline Lactobacillus delbrueckii subsp. delbrueckii & CECT 282 \\
\hline Lactobacillus delbrueckii subsp. lactis & CECT 4022 \\
\hline Lactobacillus paracasei & CECT 4121 \\
\hline Lactobacillus brevis & CECT 903 \\
\hline Lactobacillus acidophilus & CECT 475 \\
\hline Lactobacillus casei & CECT 278 \\
\hline Lactobacillus rhamnosus & CECT 4063 \\
\hline Lactobacillus salivarius & CECT 225T \\
\hline Lactobacillus reuteri & CECT 562 \\
\hline Lactobacillus fermentum & CE \\
\hline
\end{tabular}


El cultivo de las cepas de L. delbrueckii subsp. bulgaricus y $S$. thermophilus se llevó a cabo en MRS y M17, respectivamente, según las condiciones descritas anteriormente.

El resto de especies incluidas en el estudio se incubaron en un agar nutritivo en condiciones adecuadas para su crecimiento, según el manual de la Colección Española de Cultivos Tipo (www.cect.org).

Todas las cepas utilizadas en la investigación se conservaron a $-20^{\circ} \mathrm{C}$ y $-80^{\circ} \mathrm{C}$ en caldo nutritivo adicionado con un $20 \%$ de glicerol.

\subsection{Aislamiento del ADN genómico bacteriano}

Para el aislamiento del ADN bacteriano se utilizó el protocolo de Wilson et al. (1987), del mismo modo que se ha descrito anteriormente en el apartado 1.5.1. de material y métodos.

\subsection{Detección de $L$. delbrueckii mediante PCR simple}

Para la detección de la especie $L$. delbrueckii se emplearon los iniciadores descritos por Lick et al. (2000):

$$
\begin{aligned}
& \text { 1: AAT TCC GTC AAC TCC TCA TC } \\
& \text { 2: TGA TCC GCT GCT TCA TTT CA }
\end{aligned}
$$

Estos iniciadores amplifican una región de 717 pares de bases del gen ARNr $16 S$.

La reacción de amplificación se llevó a cabo, según las condiciones descritas por dicho autor, en un volumen de $50 \mu$ conteniendo: tampón $10 \mathrm{X}, 15 \mathrm{mM}$ de $\mathrm{MgCl}_{2}$, 0,1 mM de cada nucleótido, $1 \mathrm{mM}$ de los iniciadores Ldelb1 y Ldelb2, $1 \mathrm{U}$ del enzima Taq ADN polimerasa y $5 \mu \mathrm{l}$ de ADN molde de cada muestra.

Las condiciones de PCR aparecen en la tabla 17. 
Materiales y métodos

Tabla 17. Condiciones de PCR para Lactobacillus delbrueckii

\begin{tabular}{ccc}
\hline $\mathbf{N}^{\circ}$ ciclos & Temperaturas y tiempos & Proceso \\
\hline \multirow{3}{*}{10 ciclos } & $92^{\circ} \mathrm{C}$ durante $20 \mathrm{~s}$ & Desnaturalización \\
& $65^{\circ} \mathrm{C}$ durante $75 \mathrm{~s}$ & Unión al iniciador \\
& $72^{\circ} \mathrm{C}$ durante $40 \mathrm{~s}$ & Extensión del producto \\
\hline \multirow{3}{*}{35 ciclos } & $90^{\circ} \mathrm{C}$ durante $20 \mathrm{~s}$ & Desnaturalización \\
& $55^{\circ} \mathrm{C}$ durante $50 \mathrm{~s}$ & Unión al iniciador \\
& $72^{\circ} \mathrm{C}$ durante $30 \mathrm{~s}$ & Extensión del producto \\
\hline 1 ciclo & $72^{\circ} \mathrm{C}$ durante $3 \mathrm{~min}$ & Extensión del producto \\
\hline
\end{tabular}

Se trataron de identificar mediante PCR todas las cepas aisladas como $L$. delbrueckii subsp. bulgaricus de los 11 productos comerciales denominadas como LDY1 a LDY11 y la cepa de referencia de esta bacteria indicada anteriormente. Se realizaron también reacciones con el resto de cepas de referencia (tabla 16) para comprobar que no fueran amplificadas.

\subsection{Detección de $L$. delbrueckii subsp. bulgaricus mediante PCR seminested}

Para poder detectar L. delbrueckii subsp. bulgaricus en muestras más complejas, se puso a punto un protocolo de PCR seminested para intentar mejorar la especificidad y la sensibilidad de la PCR vista anteriormente.

Se emplearon los iniciadores descritos por Lick et al. (2000) LdelbF, LdelR1 y LdebR2. Estos primers amplifican una región de 678 pares de bases del gen ARNr $16 S$ de esta bacteria.

La reacción de amplificación se llevó a cabo, según indicaciones de los autores, en un volumen de $50 \mu \mathrm{l}$ conteniendo: Tampón $10 \mathrm{X}, 15 \mathrm{mM}$ de $\mathrm{MgCl}_{2}, 0,1$ $\mathrm{mM}$ de cada nucleótido, $1 \mathrm{mM}$ del iniciador LdelbF, 0,5 mM de los iniciadores LdelbR1 y LdelbR2, $1 \mathrm{U}$ del enzima Taq ADN polimerasa y $5 \mu \mathrm{l}$ de ADN molde de cada muestra.

LdelbF: CCT CAT CAA CCG GGG CT
LdelbR1 (2PCR simple): TGA TCC GCT GCT TCA TTT CA
LdelbR2: CGC CCG GGT GAA GGT G


Las condiciones de esta PCR seminested aparecen en la siguiente tabla.

Tabla 18. Condiciones de PCR seminested para Lactobacillus delbrueckii subsp. bulgaricus.

\begin{tabular}{ccc}
\hline$N^{\circ}$ ciclos & Temperaturas y tiempos & Proceso \\
\hline 1 ciclo & $94^{\circ} \mathrm{C}$ durante $20 \mathrm{~s}$ & Desnaturalización \\
\hline \multirow{3}{*}{35 ciclos } & $90^{\circ} \mathrm{C}$ durante $20 \mathrm{~s}$ & Desnaturalización \\
& $55^{\circ} \mathrm{C}$ durante $75 \mathrm{~s}$ & Unión al iniciador \\
& $72^{\circ} \mathrm{C}$ durante $40 \mathrm{~s}$ & Extensión del producto \\
\hline 1 ciclo & $72^{\circ} \mathrm{C}$ durante $2 \mathrm{~min}$ & Extensión del producto \\
\hline
\end{tabular}

Se estudió la especificidad de esta reacción con todas las cepas mostradas en la tabla 16.

\subsection{Detección de S. thermophilus mediante PCR}

Se utilizaron los iniciadores $\mathrm{TH} 1$ y $\mathrm{TH} 2$, cuyas secuencias describieron Timisjärvi y Alatossawa en 1996. Estos dos iniciadores amplifican un fragmento de 259 pares de bases de la región intermedia ("spacer region") comprendida entre los genes 16 s y $23 \mathrm{~s}$ del ARNr de $S$. thermophilus.

\section{TH1: 5'-ACG GAA TGT ACT TGA GTT TC-3' \\ TH2: 5'-TTT GGC CTT TCG ACC TAA C-3'}

Se ensayaron diferentes temperaturas de unión de los iniciadores y tiempos de extensión del producto. Los primeros ensayos se realizaron a una temperatura de $51^{\circ} \mathrm{C}$, que fue aumentándose de $1^{\circ} \mathrm{C}$ en $1^{\circ} \mathrm{C}$ hasta $55^{\circ} \mathrm{C}$. Los tiempos de extensión evaluados fueron 20 segundos, 30 segundos, 40 segundos y 1 minuto.

La especificidad de esta reacción de PCR se comprobó con las cepas de referencia (tabla 16). Se trataron de identificar mediante PCR las cepas de $S$. thermophilus aisladas de productos comerciales denominadas de STY1 a STY11. 
Materiales y métodos

\subsection{Análisis de los productos de PCR}

En todos los casos, $10 \mu \mathrm{l}$ del producto generado por la PCR se analizaron por electroforesis en gel de agarosa al $1 \%$ en tampón TAE $1 \mathrm{X}$ sometido a $100 \mathrm{~V}$ durante 60 minutos. Los fragmentos se visualizaron bajo luz UV tras teñirlos con bromuro de etidio con una concentración del $1 \%$. 


\section{PUESTA A PUNTO DE UN MÉTOdO DE DETECCIÓN Y RECUENTO DE} Lactobacillus delbrueckii subsp. bulgaricus $\mathrm{Y}$ Streptococcus thermophilus MEDIANTE HIBRIDACIÓN IN SITU CON SONDAS FLUORESCENTES (FISH)

El método FISH utilizado para la detección y recuento de Lactobacillus delbrueckii subsp. bulgaricus y Streptococcus thermophilus, así como las sondas empleadas para ello (diseño, especificidad), han sido descritos en el apartado 1.4 de material y métodos. 
Materiales y métodos

\section{PUESTA A PUNTO DEL MÉTODO COMBINADO DVC-FISH PARA LA DETECCIÓN DE CÉLULAS VIABLES DE Lactobacillus delbrueckii subsp. bulgaricus y Streptococcus thermophilus}

Con la finalidad de poder diferenciar entre células viables y no viables de $L$. delbrueckii subsp. bulgaricus y $S$. thermophilus se puso a punto una técnica molecular (DVC-FISH) que permitiera detectar e identificar, de forma específica, las células vivas.

El método del DVC (Direct Viable Count method) discrimina por microscopía las células viables y no viables. Se basa en la incubación de las muestras en la presencia de nutrientes y un inhibidor de la ADN girasa y, por tanto, de la síntesis de ADN, impidiendo la división de las células sin afectar a otras actividades metabólicas celulares. Las células pueden continuar metabolizando nutrientes y se elongan o aumentan su tamaño tras la incubación.

Este método se combinó con la detección específica con sondas sintéticas marcadas con fluorocromos (FISH) descrito en el apartado 1.4.

\subsection{Puesta a punto de la técnica DVC-FISH para la detección de células viables de $L$. delbrueckii subsp. bulgaricus}

Para llevar a cabo el ensayo se empleó la cepa de Lactobacillus delbrueckii subsp. bulgaricus (LDY7), aislada del producto Y7. Se sembró en agar MRS durante 48 horas en anaerobiosis. Esta cepa se utilizó para establecer las condiciones óptimas del método DVC, ya que es la misma que se utilizaría para el ensayo in vivo (descrito en apartados posteriores).

Se inoculó una cantidad equivalente a un asa en varios matraces que contenían $25 \mathrm{ml}$ de caldo MRS con distintos antibióticos a diferentes concentraciones. También se inoculó un matraz del mismo medio que no contenía ningún antibiótico como control negativo. Se realizaron controles negativos, consistentes en inocular diferentes matraces (con los distintos antibióticos y concentraciones), con la bacteria que previamente se había mantenido durante 10 minutos a $100^{\circ} \mathrm{C}$, tratamiento que producía la muerte celular.

Los antibióticos (posibles inhibidores de la ADN girasa) ensayados fueron ácido nalidíxico, ciprofloxacino, novobiocina y ácido pipemídico y las 
concentraciones evaluadas de cada uno de ellos fueron 0,5, 1, 10, 100 y 1000 $\mu \mathrm{g} / \mathrm{ml}$.

Todos los matraces se incubaron a $37^{\circ} \mathrm{C}$ en condiciones de anaerobiosis $\mathrm{y}$, tras $0,3,7$ y 24 horas de haber introducido la bacteria en el medio de cultivo se procedió a la extracción de dos alícuotas de $1 \mathrm{ml}$ de cada matraz, para el análisis mediante FISH y mediante Microscopía Electrónica de Barrido (SEM) (figura 11). 
Materiales y métodos

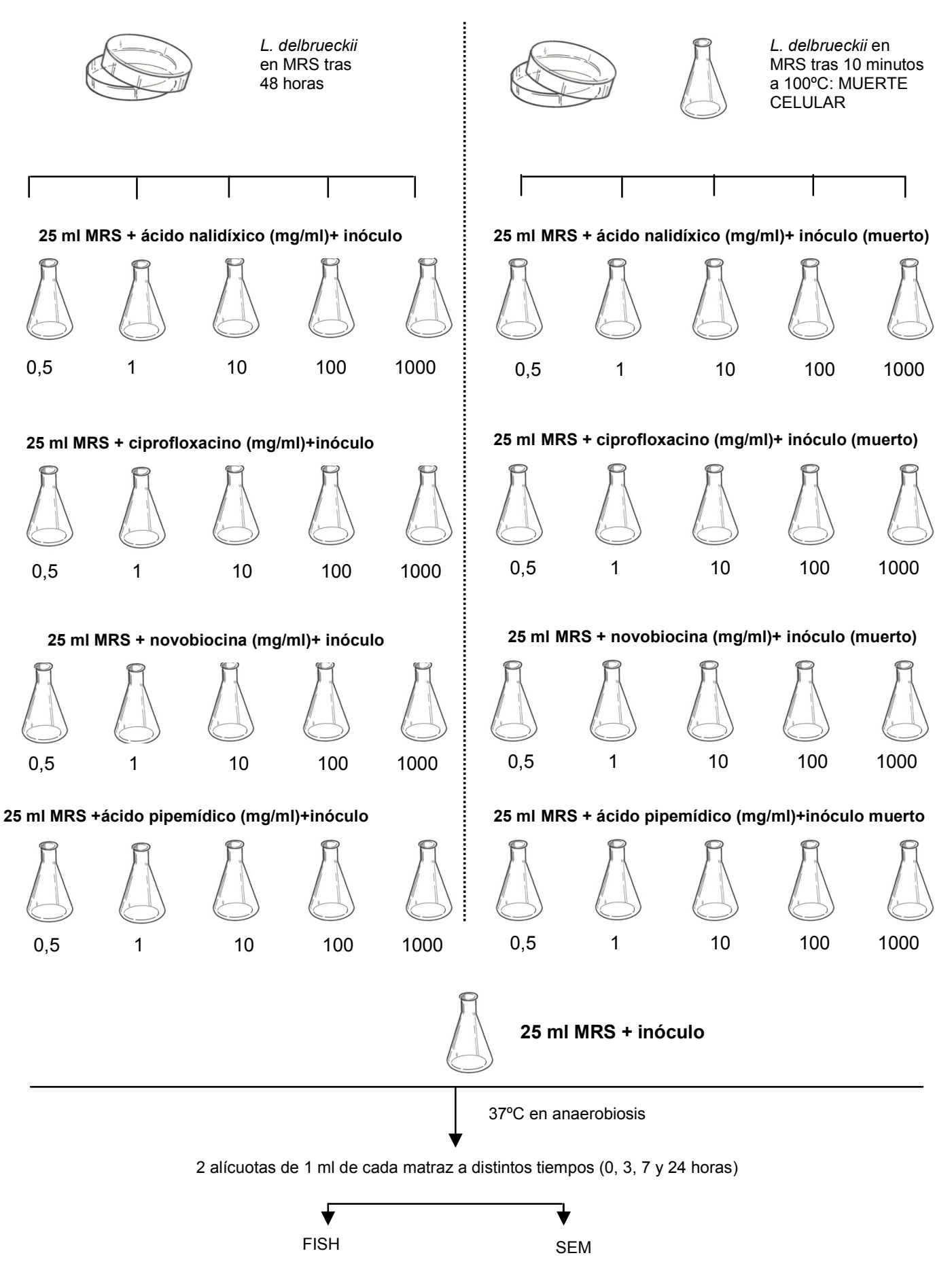

Figura 11. Puesta a punto del método DVC-FISH para $L$. delbrueckii subsp. bulgaricus 
Para el análisis mediante $\mathrm{FISH}$, se tomó $1 \mathrm{ml}$ de cada matraz y se centrifugó. Se fijó la muestra y se llevó a cabo la hibridación in situ tal y como se describió anteriormente en el apartado 1.4.1 de Material y Métodos.

Para el análisis mediante SEM, las células se fijaron con PBS $0,1 \mathrm{M}(\mathrm{pH}$ 7,2 ), que contenía un $2.5 \%$ de glutaraldehído y un $2 \%$ de tetraóxido de osmio a $4^{\circ} \mathrm{C}$ durante 8 horas. Las células fijadas se lavaron con PBS $0,1 \mathrm{M}$ tres veces $y$, finalmente, se resuspendieron en un volumen de $100 \mu \mathrm{l}$. Se depositaron $10 \mu \mathrm{l}$ de la suspensión en la superficie de membranas de policarbonato de $25 \mathrm{~mm}$ con un tamaño de poro de 0,2 $\mu \mathrm{m}$ y se procedió a su inmersión en un baño de nitrógeno líquido. Las membranas se cubrieron con oro y las muestras se visualizaron con un Microscopio Electrónico de Scanning, JEOL JSM-5410, que operaba a 20 kv (JEOL, Ldt., Tokyo, Japan).

De acuerdo con trabajos previos (Besnard et al., 2000; Buchrieser, 1993), se consideraron como células viables aquéllas que se elongaron al menos dos veces respecto al tamaño original.

\subsection{Puesta a punto de la técnica DVC-FISH para la detección de células viables de Streptococcus thermophilus}

Para llevar a cabo el ensayo se empleó un cultivo de 48 horas de la cepa de Streptococcus thermophilus STY7 crecida en MRS. Esta cepa fue aislada previamente del producto $\mathrm{Y} 7$ (mismo producto que para la cepa aislada de Lactobacillus delbrueckii subsp. bulgaricus). Se decidió utilizar el medio MRS en lugar del M17 para optimizar el procedimiento futuro en el estudio de resistencia de las cepas al tracto intestinal tanto in vitro como in vivo ya que, como se apunta en la introducción, tanto el M17 como el MRS son válidos según el CeNAN para el examen rutinario del yogur. De esta forma, en los siguientes estudios se realizó el enriquecimiento de la muestra para ambas cepas del yogur en un único medio de cultivo.

Se inoculó una cantidad equivalente a un asa en varios matraces que contenían $25 \mathrm{ml}$ de Caldo MRS con distintos antibióticos a diferentes concentraciones. Se utilizaron los mismos antibióticos y las mismas concentraciones descritos en el apartado anterior. Igualmente, se prepararon los mismos controles negativos descritos para $L$. delbrueckii subsp. bulgaricus. 
Todos los matraces se incubaron a $37^{\circ} \mathrm{C}$ en condiciones de anaerobiosis $\mathrm{y}$, tras $0,3,7$ y 24 horas de haber introducido la bacteria en el medio de cultivo con los antibióticos, se procedió a la extracción de una alícuota de la muestra para el análisis mediante FISH y mediante Microscopía Electrónica de Barrido (SEM). La preparación de la muestra para FISH y para SEM se realizó del mismo modo que se ha descrito en el apartado anterior.

Según los trabajos previos de Besnard et al. 2000 y Buchrieser, 1993 se consideraron como células viables de $S$. thermophilus aquellas que alcanzaron un diámetro de coco de, al menos, dos veces el tamaño original. 


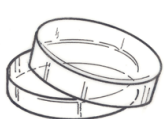

Streptococcus

thermophilus

en MRS tras

48 horas

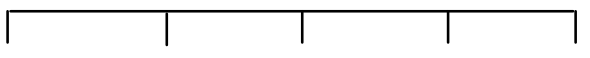

$25 \mathrm{ml}$ MRS + ácido nalidíxico $(\mathrm{mg} / \mathrm{ml})+$ inóculo
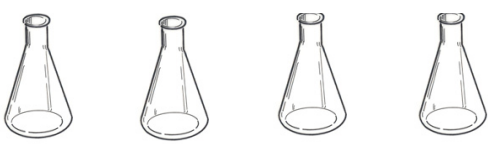

0,5

1

10

100

$25 \mathrm{ml}$ MRS + ciprofloxacino $(\mathrm{mg} / \mathrm{ml})+$ inóculo
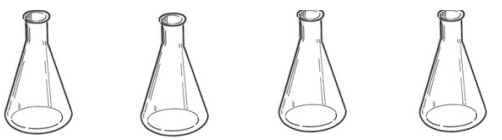

0,5

1

10

100

$25 \mathrm{ml} \mathrm{MRS} \mathrm{+} \mathrm{novobiocina}(\mathrm{mg} / \mathrm{ml})+$ inóculo
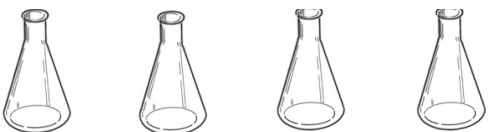

0,5

1

10

100

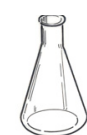

1000

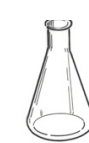

1000

$25 \mathrm{ml}$ MRS +ácido pipemídico $(\mathrm{mg} / \mathrm{ml})+$ +inóculo
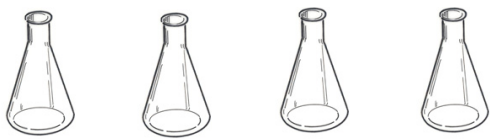

10

1000

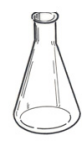

0,5

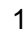

100
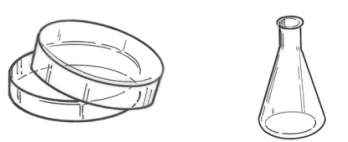

Streptococcus

thermophilus en

MRS tras 10 minutos a $100^{\circ} \mathrm{C}$ : MUERTE

CELULAR

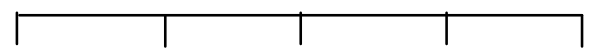

$25 \mathrm{ml}$ MRS + ácido nalidíxico $(\mathrm{mg} / \mathrm{ml})+$ inóculo (muerto)
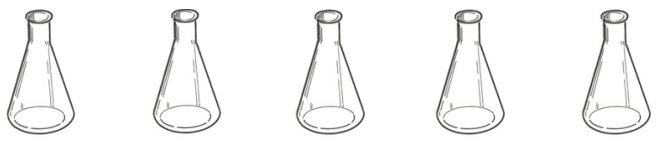

0,5

1

10

100

1000

$25 \mathrm{ml}$ MRS + ciprofloxacino $(\mathrm{mg} / \mathrm{ml})+$ inóculo (muerto)
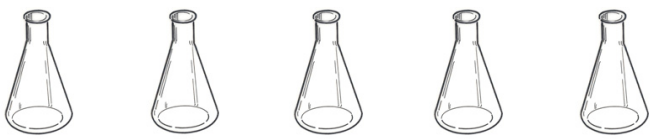

0,5

1

10

100

1000

$25 \mathrm{ml}$ MRS + novobiocina ( $\mathrm{mg} / \mathrm{ml})+$ inóculo (muerto)
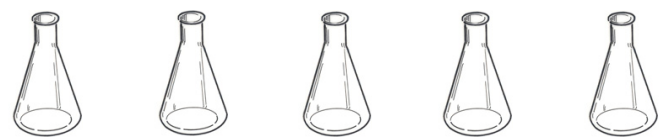

0,5

1

10

100

1000

$25 \mathrm{ml}$ MRS + ácido pipemídico $(\mathrm{mg} / \mathrm{ml})+$ +inóculo muerto
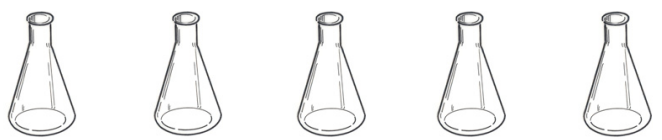

0,5

10

100

1000

25 ml MRS + inóculo

\section{$37^{\circ} \mathrm{C}$ en anaerobiosis}

2 alícuotas de $1 \mathrm{ml}$ de cada matraz a distintos tiempos (0, 3, 7 y 24 horas)

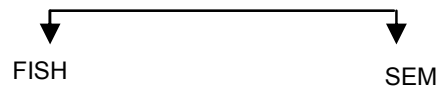

Figura 12. Puesta a punto del método DVC-FISH para Streptococcus thermophilus 
Materiales y métodos

\section{ESTUDIO IN VITRO DE LA RESISTENCIA DE Lactobacillus delbrueckii subsp. bulgaricus $Y$ Streptococcus thermophilus A LAS CONDICIONES DE TRÁNSITO GASTROINTESTINAL MEDIANTE LA APLICACIÓN DE LA TÉCNICA DVC-FISH}

Una vez puesta a punto en apartados anteriores la combinación DVC-FISH para la detección de células viables de las BAL contenidas en el yogur natural Y7 (lactobacilo y estreptococo LDY7 y STY7 respectivamente), se procedió a comprobar la utilidad de la misma en ensayos de supervivencia de estas BAL a los jugos gástricos. Para ello, se simuló in vitro el paso de las BAL del yogur a través de los jugos gastrointestinales.

En los dos estudios descritos en los apartados 4.1 y 4.2, varios antibióticos, a diferentes concentraciones y tiempo de exposición resultaron efectivos para diferenciar de forma rápida y sencilla células vivas y muertas tanto de $L$. delbrueckii subsp. bulgaricus como de S. thermophilus mediante DVC-FISH. Sin embargo, tras optimizar el método se decidió seleccionar el antibiótico novobiocina, a una concentración de $10 \mu \mathrm{g} / \mathrm{ml}$ y una incubación de 7 horas puesto que esta combinación resultó efectiva para ambas bacterias, al permitir discriminar entre células vivas y muertas además de no reducir el número de células totales pudiendo ser considerado el recuento como real (ver apartado 3 de resultados).

En primer lugar, se simularon los jugos gástricos y pancreáticos en condiciones de esterilidad y por separado, resuspendiendo pepsina (Sigma) (3 g/l) y pancreatina $(1 \mathrm{~g} / \mathrm{l})$ en suero salino estéril $(0,5 \% \mathrm{~m} / \mathrm{vol})$ de acuerdo con los procedimientos descritos por Charteris et al. (1998). El pH de estas soluciones fue ajustado a $\mathrm{pH} 2,0$ y 8,0 , usando $\mathrm{HCl}$ concentrado y $\mathrm{NaOH} 0,1 \mathrm{M}$ respectivamente, mediante el uso del pH-metro MicropH 2001 (Crison).

Para todo el estudio se utilizó un yogur natural de una marca comercial conocida. El yogur utilizado fue el denominado anteriormente como Y7. Sus recuentos de Lactobacillus delbrueckii subsp. bulgaricus y Streptococcus thermophilus así como la caracterización fenotípica y otros datos de interés aparecen en el apartado 1 resultados.

Antes de iniciar el experimento, se volvieron a realizar recuentos en placa de las dos bacterias del yogur en estudio para comprobar que, el recuento era el 
habitual. Para ello, se tomó $1 \mathrm{ml}$ de yogur, se realizaron diluciones decimales y se sembraron en agar LS-diferencial.

Los estudios de resistencia a la pepsina y a la pancreatina se realizaron por separado, simulando así el paso del producto por el tracto gastrointestinal. Se tomaron diversas muestras del yogur a distintos tiempos de contacto con dichos jugos, de acuerdo a los tiempos de exposición a los jugos gástricos e intestinales que tienen lugar en un proceso de digestión humana. Así, el tránsito por el estómago tiene una duración, normalmente, de aproximadamente de tres horas, mientras que el tránsito intestinal tiene una duración habitual de seis horas desde que el alimento entra en el sistema digestivo. Según algunos autores estos tiempos se reducen de forma importante si la ingesta se produce en ayuno, lo que no se correspondería con el presente estudio.

Así pues, las tomas de muestra se realizaron para los jugos gástricos a los 0 minutos, 10 minutos, 60 minutos y 180 minutos (tres horas), mientras que para los jugos intestinales a los 0 minutos, 10 minutos, 4 horas y 6 horas.

\subsection{Estudio de la resistencia a la pepsina}

Lo primero que se hizo fue realizar un recuento inicial del producto $Y 7$ a ensayar para comprobar que, el recuento era el habitual. Para ello, se tomó $1 \mathrm{ml}$ de yogur, se realizaron diluciones decimales y se sembraron en agar LS-diferencial.

Antes de comenzar el ensayo, se homogenizó el yogur Y7 durante 1 minuto. Se realizó una dilución 1:5 del yogur en la disolución de pepsina. Para ello, se tomaron $3 \mathrm{ml}$ del yogur en condiciones estériles y se diluyeron en $15 \mathrm{ml}$ de dicha disolución antes descrita. Posteriormente, se tomaron alícuotas de $1 \mathrm{ml}$ de esta dilución a los 0, 10, 60 y 180 minutos para aplicar el DVC-FISH tanto a los lactobacilos como a los estreptococos, que se centrifugaron inmediatamente a 7000 rpm durante 5 minutos, recuperando de esta forma las células. El sedimento de cada muestra se resuspendió en una pequeña cantidad de caldo MRS, se introdujo en un matraz con $100 \mathrm{ml}$ de caldo MRS conteniendo $10 \mu \mathrm{g} / \mathrm{ml}$ de novobiocina y se incubó a $37^{\circ} \mathrm{C}$ en anaerobiosis durante 7 horas.

Se tomaron $2 \mathrm{ml}$ de cada matraz para fijar las células de L. delbrueckii subsp. bulgaricus y de $S$. thermophilus tal y como se ha descrito anteriormente en el apartado 1.4. 
También se procedió a la extracción de una alícuota de $1 \mathrm{ml}$ de cada muestra para el análisis mediante Microscopía Electrónica de Barrido (SEM) según el método descrito anteriormente.

Tras la hibridación de las muestras con las sondas específicas, se procedió al recuento de las células viables y no viables de $L$. delbrueckii subsp. bulgaricus por un lado y de $S$. thermophilus por el otro. Se contaron un mínimo de veinte campos en cada hibridación. Los experimentos se realizaron por duplicado.

Para la diferenciación en ambos casos entre células vivas y muertas se siguieron los criterios descritos en los apartados 4.1 y 4.2 de material y métodos. Mediante una sencilla fórmula matemática (factor de multiplicación en función del objetivo utilizado en el microscopio), se calculó el número real de microorganismos de la muestra, así como el porcentaje de bacterias viables y no viables y su variación en función del tiempo de exposición a la pepsina. De esta forma se obtuvieron los resultados de la resistencia de ambas cepas a la pepsina a diferentes tiempos. 


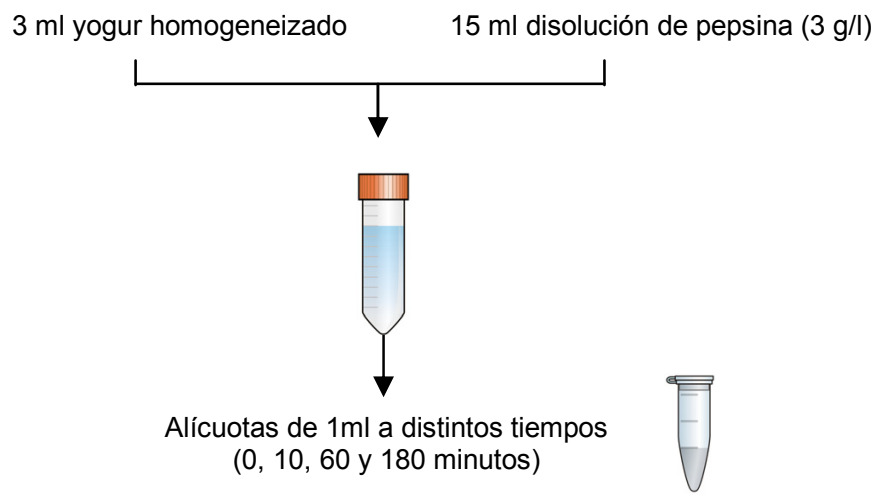

PROCEDIMIENTO PARA CADA UNO DE LOS TIEMPOS:

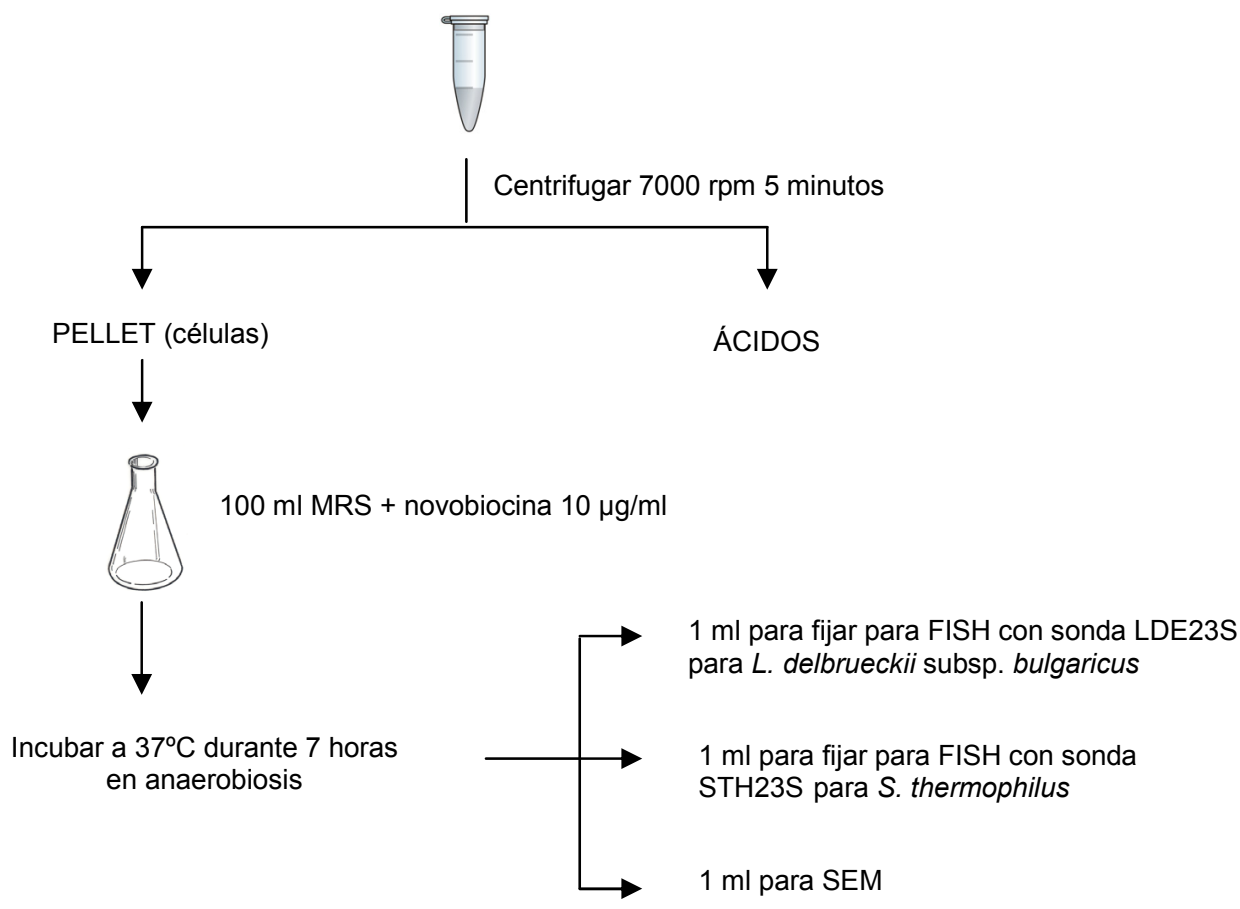

Figura 13. Estudios de resistencia a la pepsina de Lactobacillus delbrueckii subsp. bulgaricus y Streptococcus thermophilus 
A su vez, se comprobó la viabilidad mediante un recuento en placa de lactobacilos y de estreptococos. Para ello, se tomó una alícuota de $1 \mathrm{ml}$ a cada tiempo de exposición a la pepsina, realizando la misma operación de separación de los ácidos descrita en líneas anteriores. Tras ello, se resuspendió el pellet en agua estéril, se realizaron diluciones decimales seriadas y recuentos en placa en agar LS diferencial. Las placas se incubaron a $37^{\circ} \mathrm{C}$ durante tres días en condiciones de anaerobiosis.

Los resultados para los recuentos en placa se expresaron como la media de dos determinaciones (recuento por duplicado), mientras que para los recuentos con epifluorescencia, se expresaron como la media de los recuentos en veinte campos diferentes multiplicada por el factor de microscopio.

\subsection{Estudio de la resistencia a la pancreatina}

Como en el estudio anterior, se homogenizó el yogur Y7 durante 1 minuto. Se tomaron $3 \mathrm{ml}$ de éste en condiciones estériles y se diluyeron en $15 \mathrm{ml}$ de la disolución de pancreatina descrita anteriormente. Se tomó una alícuota de $1 \mathrm{ml}$ de esta dilución a los 0,10, 240 y 360 minutos. El procedimiento a partir de este punto fue exactamente el mismo al aplicado para el estudio de la resistencia a la pepsina y puede verse de forma completa en la figura 14. 


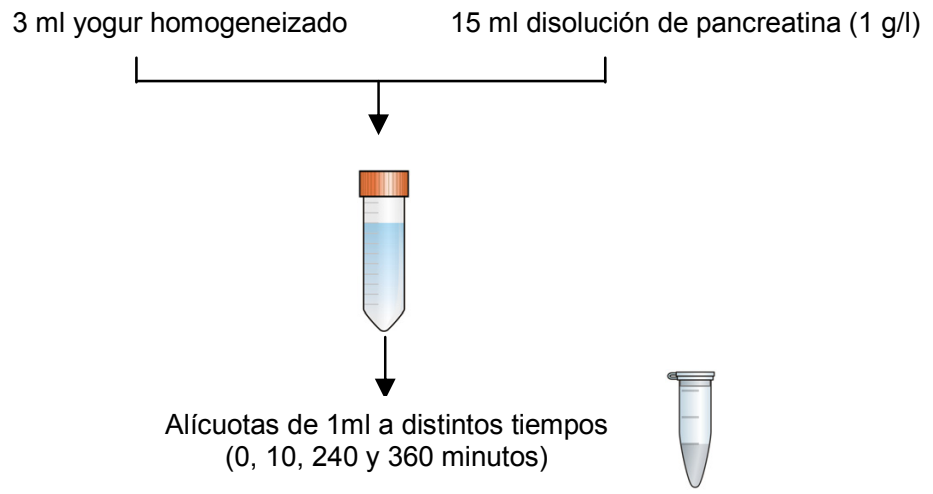

PROCEDIMIENTO PARA CADA UNO DE LOS TIEMPOS:

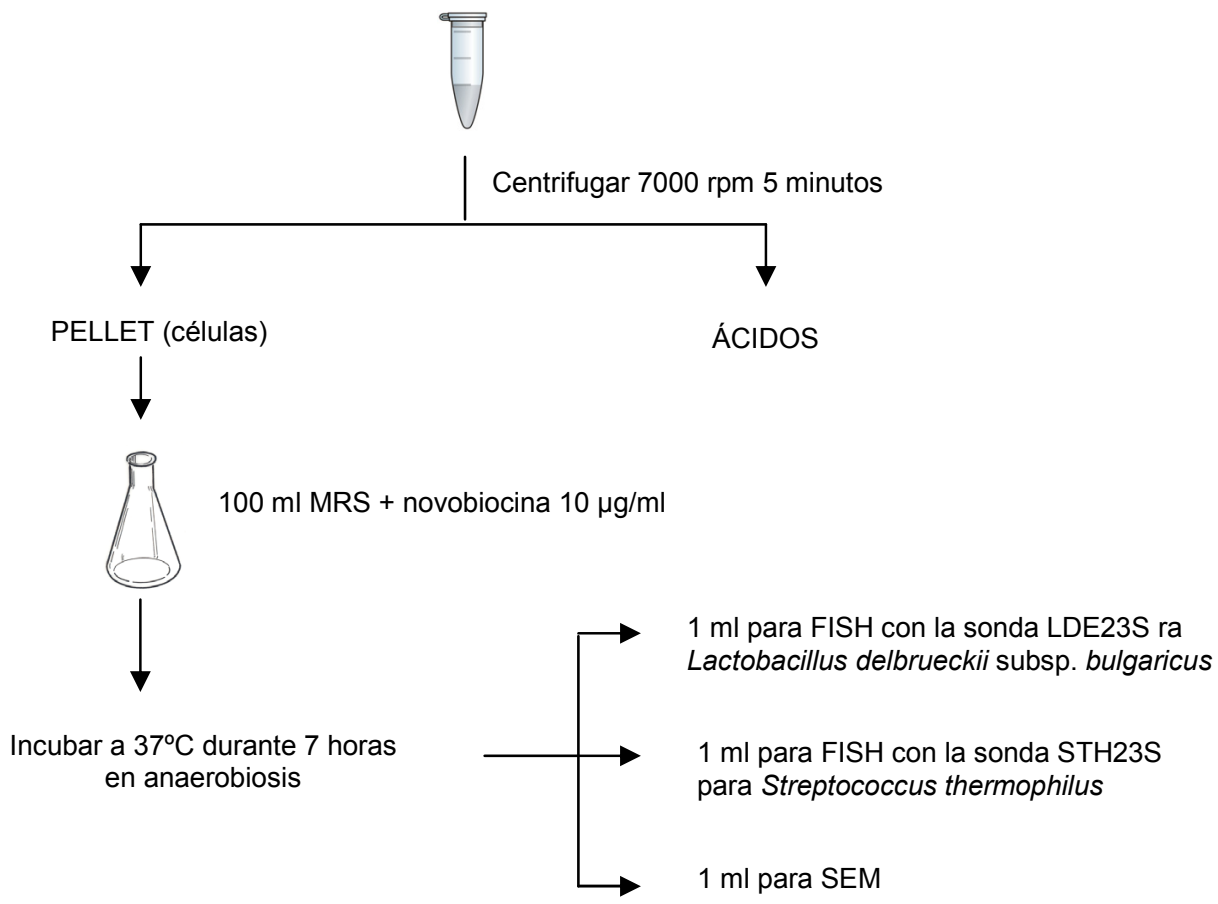

Figura 14. Estudios de resistencia a la pancreatina de Lactobacillus delbrueckii subsp. bulgaricus y Streptococcus thermophilus 
Materiales y métodos

\section{ESTUDIO IN VIVO PARA DETERMINAR LA SUPERVIVENCIA AL TRACTO GASTROINTESTINAL DE LAS CEPAS DE BAL DE UN PRODUCTO FERMENTADO (YOGUR)}

Una vez puestas a punto todas las técnicas de detección e identificación molecular de las BAL, se pasó a comprobar la eficacia de las mismas en un estudio in vivo en personas mediante la ingesta de un producto comercial.

\subsection{Determinación del límite de detección de las diferentes técnicas empleadas para la detección de las BAL en heces}

\subsubsection{Lactobacillus delbrueckii subsp. bulgaricus en heces inoculadas artificialmente para determinar el límite de detección de las técnicas de cultivo en placa, PCR y DVC-FISH}

Antes de aplicar las técnicas desarrolladas al estudio in vivo con heces humanas, se determinó el límite de detección de cada una de ellas mediante inoculación de heces con un número conocido de BAL. Se llevaron a cabo ensayos, por duplicado, con muestras de heces inoculadas artificialmente con distintas concentraciones de la cepa L. delbrueckii subsp. bulgaricus LDY7. Todas las muestras fueron de personas que no habían ingerido ningún producto lácteo fermentado durante las dos semanas anteriores a la recogida.

Para ello, se homogeneizó $1 \mathrm{~g}$ de cada una de estas heces en diferentes tubos conteniendo $9 \mathrm{ml}$ de PBS estéril. Cada uno de los tubos de PBS había sido previamente inoculado con diluciones decimales seriadas de un cultivo de 48 horas de $L$. delbrueckii subsp. bulgaricus, desde $10^{7}$ hasta $10^{2}$ u.f.c./ml. La cantidad de células de cada dilución se ajustó mediante recuento en placa en MRS de una dilución inicial, incubando las placas a $37^{\circ} \mathrm{C}$ en condiciones de anaerobiosis durante 48 horas.

Tras su homogeneización durante 2 minutos, se tomaron alícuotas de $1 \mathrm{ml}$ para la extracción de ADN para la detección por PCR. También se sembraron 100 $\mu l$ en diferentes medios de cultivo como Agar MRS y Agar LS diferencial para la detección mediante cultivo. Finalmente, se tomó $1 \mathrm{ml}$ para realizar el DVC-FISH, cuyo estudio del límite de detección en heces se describe posteriormente en el apartado 6.1.3. 


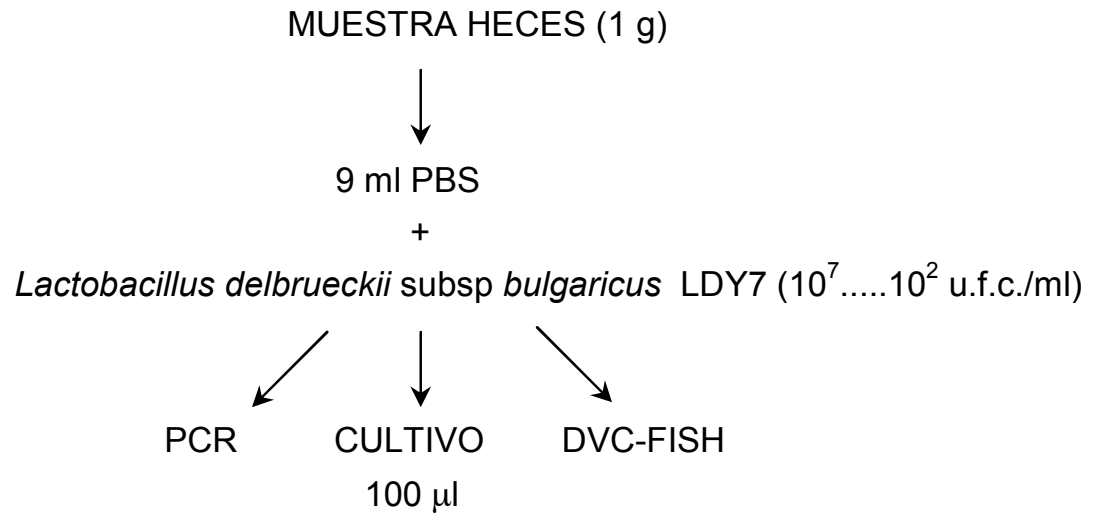

Figura 15. Detección de Lactobacillus delbrueckii subsp. bulgaricus en heces inoculadas con concentraciones crecientes de la bacteria

\subsubsection{Streptococcus thermophilus en heces inoculadas artificialmente para determinar el límite de detección de las técnicas de cultivo en placa, PCR y DVC-FISH}

Para determinar el límite de detección de los distintos métodos de detección de S. thermophilus se procedió del mismo modo que en el apartado 5.1.1. Se llevó a cabo un ensayo, por duplicado, con muestras de heces inoculadas artificialmente con distintas concentraciones de esta bacteria.

Se hicieron diluciones de $1 \mathrm{~g}$ de heces en diferentes diluciones de $9 \mathrm{ml}$ de PBS estéril. EI PBS había sido previamente inoculado con diluciones seriadas de un cultivo de 48 horas de $S$. thermophilus STY7, desde $10^{8}$ hasta $10^{2} \mathrm{cel} / \mathrm{ml}$. La cantidad de células contenidas en cada dilución se calculó mediante recuento en placa en $\mathrm{M} 17$, incubado a $37^{\circ} \mathrm{C}$ en condiciones de anaerobiosis durante 48 horas.

Se extrajo $1 \mathrm{ml}$ de la muestra extracción de ADN para la detección por PCR, $100 \mu$ que se sembraron en Agar M-17 y Agar LS diferencial para la detección mediante cultivo y $1 \mathrm{ml}$ para realizar el DVC-FISH cuyo estudio del límite de detección en heces se describe en el apartado 6.1.3. 


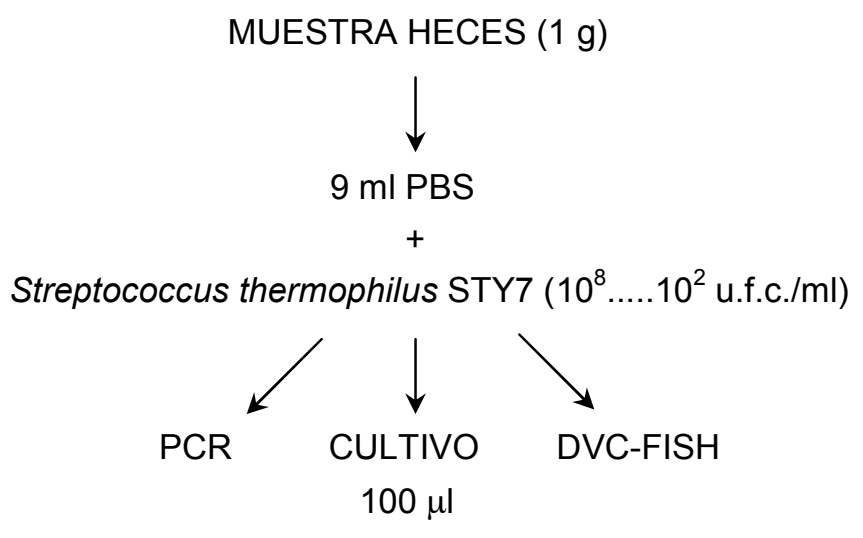

Figura 16. Detección de Streptococcus thermophilus en heces inoculadas con concentraciones crecientes de la bacteria

\subsubsection{Aplicación del DVC-FISH para la detección de células viables en heces y determinación del límite de detección del método.}

En los apartados 4.1. y 4.2. se desarrolló el método del DVC-FISH para la determinación de células viables de las cepas de $L$. delbrueckii subsp. bulgaricus y de $S$. thermophilus del producto $Y 7$. Se ensayaron diferentes concentraciones y tipos de inhibidores de la ADN girasa a tiempos de incubación.

Una vez seleccionado el antibiótico, su concentración y el tiempo de incubación óptimos (10 $\mu \mathrm{g} / \mathrm{ml}$ de novobiocina durante 7 horas), se quiso comprobar la eficacia del método en una matriz compleja como son las heces y determinar su límite de detección para su aplicación en estudios in vivo.

Se realizaron diluciones de $1 \mathrm{~g}$ de heces en $9 \mathrm{ml}$ de caldo PBS a las cuales se les inoculó cultivos de Lactobacillus delbrueckii subsp. bulgaricus y de Streptococcus thermophilus hasta alcanzar concentraciones desde $10^{2}$ hasta $10^{8}$ células/ml. Para ello, se partió de dos cultivos de 48 horas delas cepas de Lactobacillus delbrueckii subsp. bulgaricus y de Streptococcus thermophilus del producto Y7 en caldo MRS y caldo M17 respectivamente. Se determinaron sus concentraciones mediante la realización de recuentos en placa en agar MRS y agar M17, respectivamente. Finalmente, se realizaron las diluciones correspondientes 
para obtener las concentraciones deseadas de ambas bacterias en las diluciones de heces.

Se inoculó $1 \mathrm{ml}$ de cada una de las diluciones con concentraciones conocidas de L. delbrueckii subsp. bulgaricus y de $S$. thermophilus (ver apartados 6.1.1. y 6.1.2.) en diversos matraces que contenían $25 \mathrm{ml}$ de MRS, con una concentración de novobiocina de $10 \mu \mathrm{g} / \mathrm{ml}$. También se inocularon dos matraces más con este caldo que no contenían antibiótico como control negativo.

Todos los matraces se incubaron a $37^{\circ} \mathrm{C}$ en anaerobiosis durante 7 horas. Tras ese tiempo se tomó $1 \mathrm{ml}$ de cada matraz para su análisis por FISH. Se centrifugó y el precipitado se resuspendió en $250 \mu \mathrm{l}$ de PBS y $750 \mu \mathrm{l}$ de paraformaldehído. Tras las 3 horas de fijación se lavaron las muestras con $1 \mathrm{ml}$ de PBS dos veces consecutivas y se resuspendió en igual volumen de etanol frío y PBS. Se almacenaron todas estas muestras a $-20^{\circ} \mathrm{C}$ hasta su análisis por $\mathrm{FISH}$. 
$1 \mathrm{~g}$ heces en $9 \mathrm{ml}$ PBS
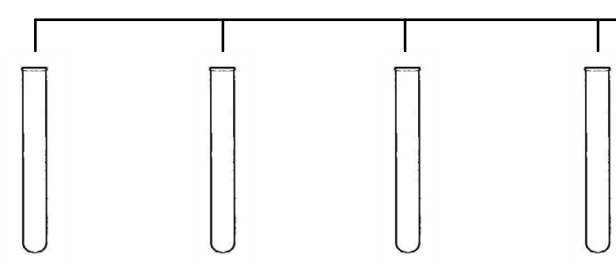

Con $10^{2}$ ufc/ml de

Con $10^{3}$

Con $10^{4}$ ufc/ml de Con $10^{5}$
ufc $/ \mathrm{ml} \mathrm{de}$ ufc $/ \mathrm{ml} \mathrm{de}$
L. delb.
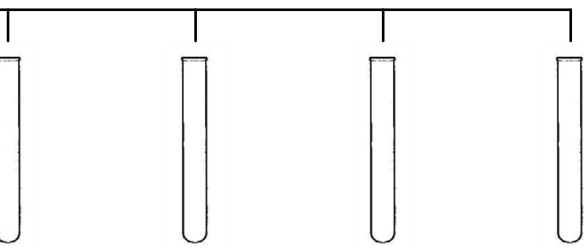

L. delb.

L. delb.

L. delb.

Con $10^{6}$
ufc $/ \mathrm{ml}$ de

Con $10^{7}$ ufc/ml de

L. delb.

L. delb.

Con $10^{8}$

ufc/ml de

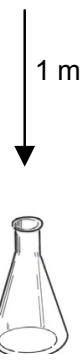

$25 \mathrm{ml}$ MRS

$+$

Novobiocina

$10 \mu \mathrm{g} / \mathrm{ml}$
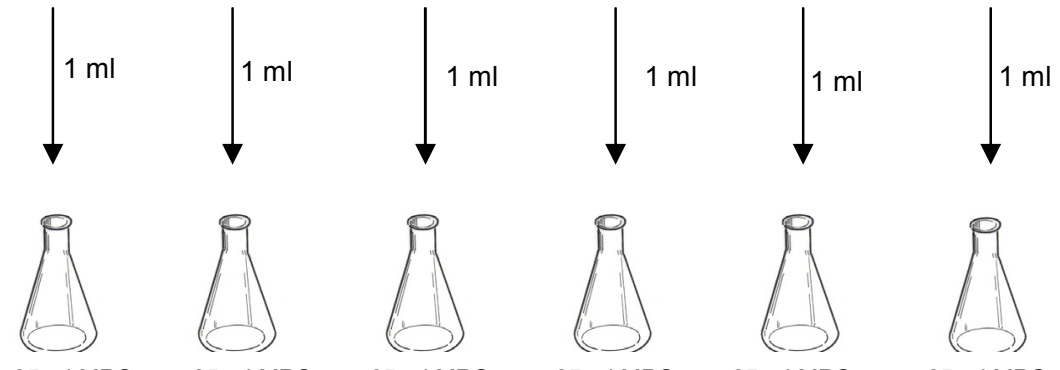

$25 \mathrm{ml}$ MRS $\stackrel{+}{+}$ $10 \mu \mathrm{g} / \mathrm{ml}$

$25 \mathrm{ml}$ MRS

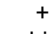

$\stackrel{+}{\text { Novobiocina }}$

$10 \mu \mathrm{g} / \mathrm{ml}$

$25 \mathrm{ml}$ MRS

$+$

$25 \mathrm{ml}$ MRS

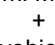

$\stackrel{+}{\text { Novobiocina }}$

$10 \mathrm{\mu g} / \mathrm{ml}$

$25 \mathrm{ml}$ MRS

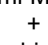

$10 \mu \mathrm{g} / \mathrm{ml}$

Novobiocina

$10 \mu \mathrm{g} / \mathrm{ml}$

$25 \mathrm{ml}$ MRS

$\stackrel{+}{\stackrel{+}{+}}$

$10 \mu \mathrm{g} / \mathrm{ml}$

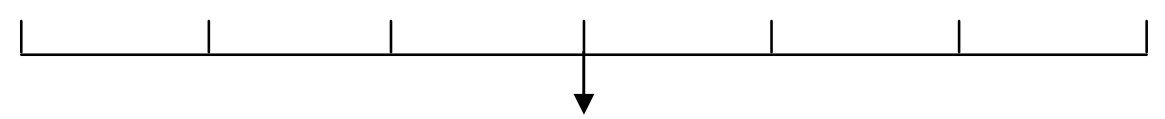

Incubar en anaerobiosis a $37^{\circ} \mathrm{C}$ durante 7 horas

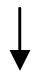

Se toma $1 \mathrm{ml}$ de cada tubo para FISH

Figura 17. Estudio del límite de detección del método DVC-FISH para Lactobacillus delbrueckii subsp. bulgaricus en heces inoculadas con concentraciones crecientes de la bacteria 
$1 \mathrm{~g}$ heces en $9 \mathrm{ml}$ PBS

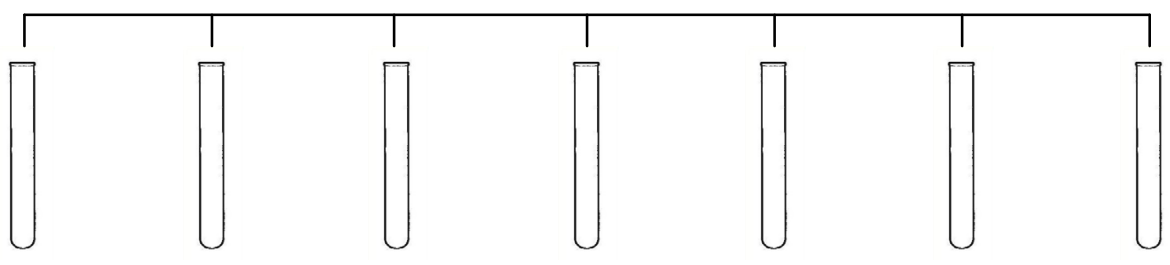

$\begin{array}{lllllll}\text { Con } 10^{2} & \text { Con } 10^{3} & \text { Con } 10^{4} & \text { Con } 10^{5} & \text { Con } 10^{6} & \text { Con } 10^{7} & \text { Con } 10^{8} \\ \text { ufc } / \mathrm{ml} \mathrm{de} & \text { ufc } / \mathrm{ml} \mathrm{de} & \text { ufc } / \mathrm{ml} \mathrm{de} & \text { ufc } / \mathrm{ml} \mathrm{de} & \text { ufc } / \mathrm{ml} \mathrm{de} & \text { ufc } / \mathrm{ml} \mathrm{de} & \text { ufc } / \mathrm{ml} \mathrm{de} \\ \text { S. therm. } & \text { S. therm. } & \text { S. therm. } & \text { S. therm. } & \text { S. therm. } & \text { S. therm. } & \text { S. therm. }\end{array}$
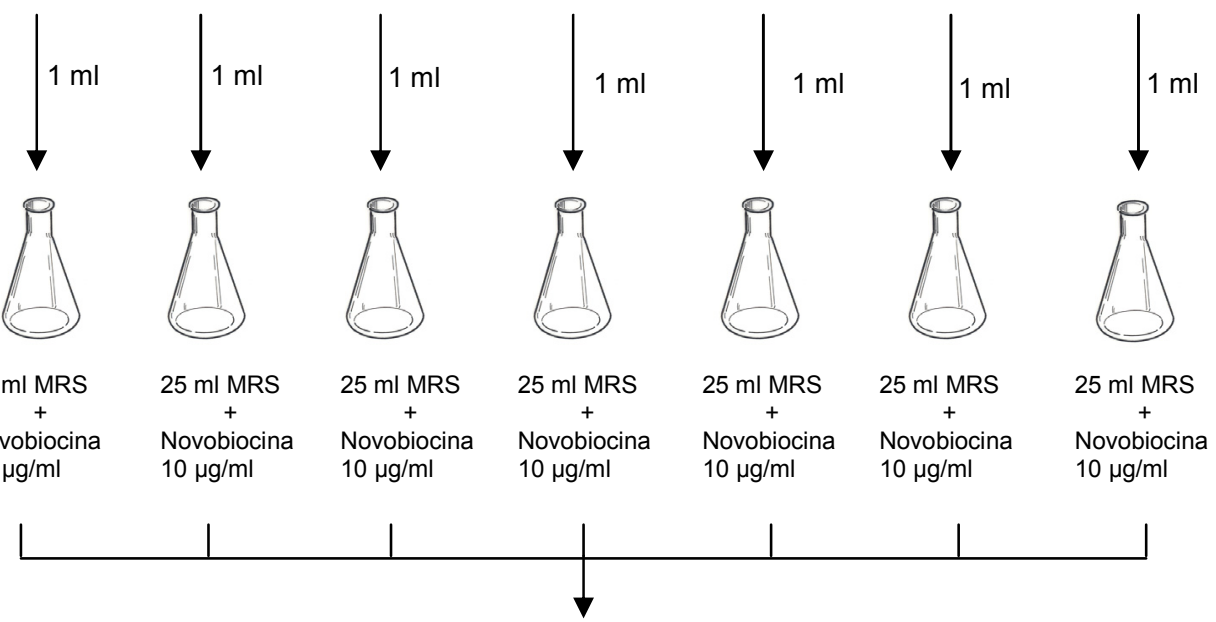

Incubar en anaerobiosis a $37^{\circ} \mathrm{C}$ durante 7 horas

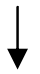

Se toma $1 \mathrm{ml}$ de cada tubo para FISH

Figura 18. Estudio del límite de detección del método DVC-FISH para Streptococcus thermophilus en heces inoculadas con concentraciones crecientes de la bacteria 
Materiales y métodos

\subsection{Estudio in vivo para determinar la supervivencia al tracto gastrointestinal de las cepas de BAL de un producto fermentado (yogur)}

\subsubsection{Diseño del estudio}

Se seleccionaron 30 voluntarios sanos de edades comprendidas entre los 25 y 65 años que seguían una dieta habitual carente de leches fermentadas. Además, no tomaron ningún tipo de antibiótico durante la duración del experimento (un total de 11 semanas).

La duración del estudio fue de 11 semanas con tres periodos diferenciados:

- Periodo control: tres semanas sin ingestión de ninguna leche fermentada con lactobacilos y estreptococos, ni ningún otro producto lácteo.

- Periodo de administración: cuatro semanas en las que se administró $250 \mathrm{~g}$ diarios del yogur natural $Y 7$, el mismo producto que se utilizó para la puesta a punto de los métodos de detección en apartados anteriores.

- Periodo de post-administración: cuatro semanas sin ingestión de ninguna leche fermentada con lactobacilos y estreptococos, ni ningún otro producto lácteo.

También participó un voluntario más que no ingirió el producto durante todo el ensayo (control negativo).

Durante el periodo de ingesta se les administró $250 \mathrm{~g}$ diarios de producto (Y7) y, por tanto, una cantidad conocida de Lactobacillus delbrueckii subsp. bulgaricus y de Streptococcus thermophilus. En todo caso, se realizó un recuento previo de estas dos bacterias presentes en el yogur antes del periodo de administración para comprobar que se encontraban en las cantidades habituales.

Durante el estudio, los voluntarios no consumieron ningún otro producto lácteo fermentado que contuviera bacterias lácticas (BAL). 


\subsubsection{Análisis de las muestras fecales}

Se realizaron un total de seis tomas de muestras fecales durante las 11 semanas que duró el ensayo tal y como se refleja en la figura 19. Todas las muestras de heces fueron recogidas en fresco y almacenadas en recipientes estériles de plástico, refrigeradas y transportadas inmediatamente al laboratorio para procesarlas ese mismo día.

\section{Ingesta YOGUR NATURAL Y7}

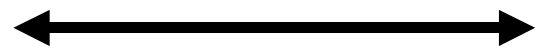

Semanas

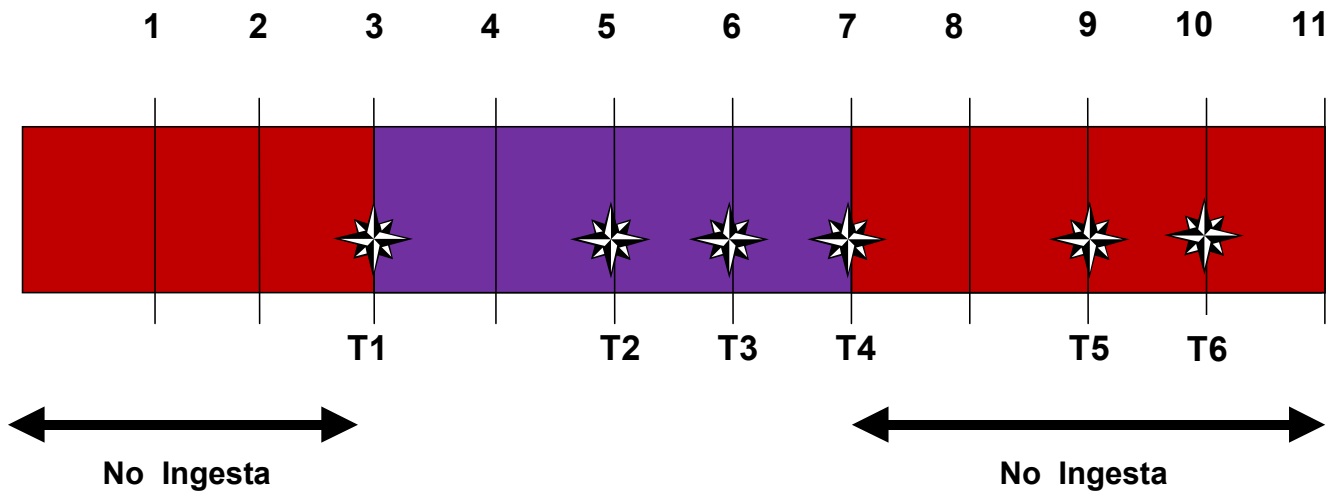

Toma de muestras

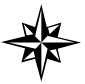

Figura 19. Esquema de las tomas de muestras durantes el estudio in vivo

El plan de trabajo fue el mismo durante las seis tomas de muestra del ensayo que fueron denominadas desde T1 hasta T6. Los individuos fueron denominados desde N1 hasta N30. Así pues, por ejemplo, la muestra del individuo 23 en la toma 4 se denominaría como N23T4, y así para todas las muestras de todos los individuos.

Como paso previo y en todos los casos, las muestras de heces se atemperaron y se tomó 1 gramo de cada una que se homogeinizó en tampón fosfato (PBS1x). Esta dilución fue denominada $10^{-1}$. 
Materiales y métodos

A partir de ahí, se analizaron las muestras para aplicar los distintos métodos de detección puestos a punto.

\section{Recuentos en placa}

A partir de la primera dilución realizada en PBS1x, se realizaron diluciones decimales seriadas hasta $10^{-7}$ de los homogeneizados de las muestras fecales de cada individuo y se realizaron recuentos en placa en diferentes medios de cultivo tal como se describe posteriormente en el apartado 6.3 en el estudio de la evolución de la microbiota bacteriana en las heces.

\section{Extracción de ADN}

Se tomó un $\mathrm{ml}$ de la dilución $10^{-1}$ para la extracción de $\mathrm{ADN}$ de todas las muestras. Todas las extracciones se realizaron de acuerdo con el método del CTAB, descrito en el apartado 1.5.1. El ADN se almacenó para el posterior estudio de detección por PCR de las BAL.

\section{DVC-FISH}

Se tomó $1 \mathrm{ml}$ de la primera dilución para la realización del DVC-FISH para Lactobacillus delbrueckii subsp. bulgaricus y otro para el DVC-FISH de Streptococcus thermophilus, tal y como se describe en los siguientes apartados.

6.2.3 Estudio de la viabilidad por DVC-FISH y detección por PCR seminested de Lactobacillus delbrueckii subsp. bulgaricus en muestras de heces

\section{Detección por PCR seminested}

Se empleó el protocolo de PCR descrito en el apartado 2.4, aplicando los mismos iniciadores y las mismas condiciones para la posible detección de esta bacteria en las heces.

En todos los casos, $10 \mu \mathrm{l}$ del producto de PCR se analizó por gel de elctroforesis en gel de agarosa al $1 \%$ en tampón TAE 1x, sometido a $100 \mathrm{~V}$ durante 60 minutos. Los fragmentos se visualizaron bajo luz UV tras teñirlos con bromuro de etidio con una concentración del $1 \%$. 
Se consideró la reacción de PCR como positiva y, por tanto, como presencia de ADN genómico de esta bacteria en las heces la aparición de la banda correspondiente de $678 \mathrm{pb}$.

\section{Detección de células viables por DVC-FISH}

Se utilizaron las mismas condiciones consideradas como óptimas en la puesta a punto del método (apartado 4.1). Además, fueron las mismas condiciones utilizadas en el estudio de resistencia de esta bacteria a los jugos gastrointestinales.

Se inocularon alícuotas de $1 \mathrm{ml}$ de las diluciones $10^{-1}$ de las heces de cada individuo en diferentes matraces, todos ellos conteniendo $25 \mathrm{ml}$ de caldo MRS con $10 \mu \mathrm{g} / \mathrm{ml}$ de novobiocina. Se incubaron a $37^{\circ} \mathrm{C}$ durante 7 horas y se tomó $1 \mathrm{ml}$ para fijar la muestra con paraformaldehído (4\%). Tras 3 horas de fijación, se procedió al lavado de cada muestra con $1 \mathrm{ml}$ de PBS. Se decidió hacerlo por triplicado debido a la complejidad de la matriz de la que se partía. Las muestras se almacenaron después a $-20^{\circ} \mathrm{C}$.

La hibridación se realizó a continuación según el método Amann et al. (1995) ya descrito en el apartado 1.4.2. Se realizó la hibridación in situ de cada muestra utilizando las mismas condiciones, es decir, misma concentración de formamida y misma sonda de hibridación LDE23R diseñada (cuya especificidad se comprobó en apartados anteriores). La observación también se realizó en las condiciones anteriormente descritas.

Se consideraron como positivas las muestras en las cuales se observaron células viables de la bacteria. Se utilizaron los mismos criterios descritos anteriormente para considerar una célula de Lactobacillus delbrueckii subsp. bulgaricus como viable. Si había detección, se realizaban recuentos de células viables de Lactobacillus delbrueckii subsp. bulgaricus. Para ello, se contaban 20 campos de la muestra positiva, se realizaba una media y se multiplicaba por el factor del microscopio para obtener el número de células viables por gramo de heces del individuo. 
Materiales y métodos

Para aumentar el nivel de sensibilidad y, en caso de no haber detección, descartar que el resultado se debiera a la sensibilidad de la técnica, se utilizó un medio más selectivo según bibliografia para lactobacilos en muestras complejas.

El medio de enriquecimiento fue el siguiente:

Medio MRS + 0,05\% cistina, $\mathrm{pH} 5,2$

Se inocularon las muestras de heces de la toma T4 (en principio la toma que debería presentar una cantidad superior puesto que es tras las 4 semanas de ingesta) a $42^{\circ} \mathrm{C}$ durante 72 horas en anaerobiosis. Para ello, se tomaron $10 \mathrm{ml}$ de heces diluídas en PBS y se introdujeron en $90 \mathrm{~m}$ del medio descrito.

Tras este tiempo se tomó $1 \mathrm{ml}$ del caldo y se siguió el mismo procedimiento para la detección mediante DVC-FISH descrito anteriormente.

\subsubsection{Estudio de la viabilidad por DVC-FISH y detección por PCR de Streptococcus thermophilus en muestras de heces \\ Detección por PCR}

Se realizó previamente la puesta a punto de la reacción de PCR (apartado 2.5). Se emplearon por lo tanto esas mismas condiciones e inciadores para su posible detección en las heces.

En todos los casos, $10 \mu \mathrm{l}$ del producto de PCR se analizaron por gel de elctroforesis en gel de agarosa al $1 \%$ en tampón TAE 1x, sometido a $100 \mathrm{~V}$ durante 60 minutos. Los fragmentos se visualizaron bajo luz UV tras teñirlos con bromuro de etidio con una concentración del $1 \%$.

Se consideró la reacción de PCR como positiva y, por tanto, como presencia de ADN genómico de esta bacteria en las heces la aparición de la banda correspondiente de $259 \mathrm{pb}$.

\section{Detección de células viables por DVC-FISH}

Se utilizaron las mismas condiciones consideradas como óptimas en la puesta a punto del método (apartado 4.2). Además, fueron las mismas usadas en el estudio de resistencia de esta bacteria a los jugos gastrointestinales. 
Se inocularon alícuotas de $1 \mathrm{ml}$ de las diluciones $10^{-1}$ de cada individuo en diferentes matraces, todos ellos conteniendo $25 \mathrm{ml}$ de caldo MRS con $10 \mu \mathrm{g} / \mathrm{ml}$ de novobiocina (antibiótico seleccionado tras el ensayo descrito en el apartado 4.2). Se incubaron a $37^{\circ} \mathrm{C}$ durante 7 horas y se tomó $1 \mathrm{ml}$ para fijar la muestra con paraformaldehído (4\%). Tras 3 horas de fijación se procedió al lavado de cada muestra con $1 \mathrm{ml}$ de PBS. Se decidió hacerlo por triplicado debido a la matriz de la cual se partía. Las muestras se almacenan después a $-20^{\circ} \mathrm{C}$.

Se realizaron las hibridaciones de todas las muestras utilizando las mismas condiciones y la misma sonda de hibridación STH23 diseñada y descrita en el apartado 1.4.1.

Se consideraron como positivas las muestras en las cuales se observaron células viables de la bacteria. Se utilizaron los mismos criterios descritos anteriormente para considerar una célula de Streptococcus thermophilus como viable.

En las muestras que hubo detección positiva mediante DVC-FISH, se realizaron recuentos de células viables. Se contaron un total de 20 campos en cada una de las muestras positivas, realizándose la media de los recuentos en cada campo. Se multiplicó por el factor de microscopio para obtener el número de Streptococcus thermophilus vivos en cada una de las muestras en las que hubo detección positiva.

\subsection{Estudio de la evolución de la microbiota de las heces de las personas sometidas al ensayo in vivo}

\subsubsection{Recuentos de la población bacteriana presente en las heces a lo largo del ensayo}

Se realizó un estudio de la evolución de la microbiota fecal de todas las personas sometidas al ensayo in vivo durante todas las tomas de muestras realizadas en el mismo.

El estudio consistió en medir el impacto del consumo del yogur tradicional en la microbiota fecal mediante la utilización de técnicas de cultivo selectivas y no selectivas. La composición de la microbiota fecal de los 30 individuos se controló antes (toma 1), durante (periodo de ingesta de 4 semanas en las cuales se 
Materiales y métodos

realizaron 3 tomas de muestras) y después (2 tomas durante las 3 semanas posteriores) de la administración del producto lácteo conteniendo Lactobacillus delbrueckii subsp. bulgaricus y Streptococcus thermophilus tal y como se describe anteriormente.

$1 \mathrm{~g}$ de heces fue añadido a un tubo estéril con $9 \mathrm{ml}$ de tampón salino (PBS1x). Después de homegeinizar el contenido, se realizaron diluciones seriadas $\left(10^{-2}\right.$ a $\left.10^{-8}\right)$ en agua estéril. $100 \mu \mathrm{l}$ de cada dilución fueron sembrados en una placa en superficie por triplicado en medios selectivos (agar MRS, agar MacConkey y agar BFM) y en medios no selectivos (agar Columbia para aerobios y agar WilkinsChalgren para anaerobios). El medio de cultivo, los microorganismos investigados, la composición de la fase gaseosa y el tiempo de incubación se detallan en la tabla 19.

Tabla 19. Medios de cultivo, condiciones y tiempos de incubación para cada grupo de microorganismos estudiado

\begin{tabular}{cccc}
\hline Microorganismos & Medios de cultivo & Atmósfera & Tiempo (h) \\
\hline Aerobios totales & Base de agar Columbia sangre & $\mathrm{O} 2$ & 24 \\
\hline Anaerobios totales & Agar Wilkins-Calgren & $\mathrm{CO}_{2}+\mathrm{H}_{2}$ & 48 \\
\hline $\begin{array}{c}\text { Coliformes y otras } \\
\text { enterobacterias }\end{array}$ & Agar MacConkey n $\mathrm{n}^{\circ}$ & $\mathrm{O}_{2}$ & 24 \\
\hline Lactobacilos & Agar MRS & $\mathrm{CO}_{2}+\mathrm{H}_{2}$ & 48 \\
\hline Bifidobacterias & Agar BFM & $\mathrm{CO}_{2}+\mathrm{H}_{2}$ & 72 \\
\hline
\end{tabular}

El medio base de agar Columbia sangre (Oxoid) se emplea para el cultivo de microorganismos en general y en particular aquellos que son especialmente exigentes a partir de una amplia variedad de muestras. Se utilizó el medio de la casa Oxoid.

El medio agar Wilkins-Chalgren (Oxoid) se utiliza para el cultivo y para las pruebas de susceptibilidad antimicrobiana de las bacterias anaerobias. El extracto de levadura asegura el buen crecimiento de Peptostreptococcus anaerobius y Bacteroides melaninogenicus. La arginina asegura suficientes aminoácidos, necesarios para el crecimiento de Eubacterium lentum. El piruvato está presente como fuente de energía para cocos como Veilonella. La hemina es esencial para el 
crecimiento de especies de Bacteroides y la menadiona para Bacteroides melaninogenicus.

El medio agar MacConkey $n^{\circ} 3$ (Oxoid) es un medio selectivo que da una excelente diferenciación entre coliformes y no fermentadores de la lactosa, con inhibición de cocos gram positivos. Todas las especies de la familia Enterobacteriaceae se desarrollan en el mismo. En el medio de cultivo, las peptonas, aportan los nutrientes necesarios para el desarrollo bacteriano, la lactosa es el hidrato de carbono fermentable, y la mezcla de sales biliares y el cristal violeta son los agentes selectivos que inhiben el desarrollo de gran parte de la microbiota Gram positiva. Por fermentación de la lactosa, disminuye el $\mathrm{pH}$ alrededor de la colonia. Esto produce un viraje del color del indicador de $\mathrm{pH}$ (rojo neutro), la absorción en las colonias, y la precipitación de las sales biliares. Los microorganismos no fermentadores de lactosa producen colonias incoloras.

Para el cultivo selectivo de lactobacilos se utilizó el agar MRS (Oxoid). Este medio de cultivo fue desarrollado por Man, Rogosa y Sharpe para proveer un medio que pudiera evidenciar un buen crecimiento de lactobacilos y otras bacterias ácido lácticas. El medio de cultivo permite un abundante desarrollo de todas las especies de lactobacilos. La peptona y glucosa constituyen la fuente de nitrógeno, carbono y de otros elementos necesarios para el crecimiento bacteriano. El citrato de amonio actúa como agente inhibitorio del crecimiento de bacterias Gram negativas. Las colonias de lactobacilos son generalmente pequeñas, blanco-grisáceo, lisas o rugosas.

Para la enumeración de las bifidobacterias se utilizó el agar BFM (Nebra y Blanch, 1999), donde forman pequeñas colonias de color blanquecino o semitransparente, claramente diferenciables gracias al color azul del medio. El crecimiento de otros géneros fue estudiado por Lynch et al. 2002, comprobando que únicamente crecían bifidobacterias.

La composición de los diferentes medios de cultivo y sus preparaciones aparecen en los anexos.

Para conseguir las condiciones de anaerobiosis en los medios que lo requieren, las placas se introdujeron en jarras junto a sobre generadores de esta atmósfera (Anaerogen de Oxoid). La microaerofilia se logró con sobres de la casa Oxoid. Las placas se incubaron a $37^{\circ} \mathrm{C}$. 
Materiales y métodos

Todos los recuentos se realizaron por triplicado. Los resultados se calcularon como la media de los tres recuentos y fueron expresados como logaritmo de las unidades formadoras de colonias (u.f.c.) por gramo de heces.

\subsubsection{Análisis estadísticos}

Los resultados de la evolución de los diferentes grupos de microorganismos en el tiempo fueron expresados como la media y la mediana de los valores de los 30 individuos en cada una de las tomas de muestras. Se realizó un análisis de varianza simple (ANOVA) para cada uno de los grupos bacterianos estudiados (anexo VIII). Este análisis realiza varios tests y gráficos para comparar los valores medios de cada uno de los grupos durante las seis tomas de muestras. El F-test en la tabla de ANOVA comprueba si hay alguna diferencia significativa entre las medias. Si las hay, los Tests de Rangos Múltiples indicarán las medias que son significativamente diferentes unas de otras. Si hay valores atípicos se elige el test Kruskal-Wallis que compara las medianas en lugar de las medias. Las diferencias entre las medias a los diferentes tiempos fueron consideradas significativas cuando $p<0,05$. Todos los análisis estadísticos fueron realizados con el programa Statgraphics Plus 5.1. 
RESULTADOS 
Resultados

\section{AISLAMIENTO, IDENTIFICACIÓN Y CARACTERIZACIÓN MOLECULAR DE LAS BACTERIAS LÁCTICAS (Lactobacillus delbrueckii subsp. bulgaricus $Y$ Streptococcus thermophilus) PRESENTES EN 11 YOGURES COMERCIALES}

\subsection{Aislamiento y recuento en placa de BAL de las muestras de yogur analizadas}

Ya que la temperatura recomendada para el crecimiento de las BAL oscila entre $37^{\circ} \mathrm{C}$ y $42^{\circ} \mathrm{C}$, se realizó una prueba inicial de crecimiento por duplicado con las cepas de referencia a $37^{\circ} \mathrm{C}$ y $42^{\circ} \mathrm{C}$ optando finalmente por la temperatura de $37^{\circ} \mathrm{C}$ al observarse un crecimiento ligeramente mayor.

En el análisis de todos los yogures naturales, los recuentos y aislamientos de Lactobacillus delbrueckii subsp. bulgaricus y Streptococcus thermophilus se realizaron en el medio LS Diferencial (Scharlau Chemie), siendo necesario un tiempo de 72 horas para realizar los recuentos. En la Figura 20 puede observarse el crecimiento de estas dos bacterias en este medio de cultivo, claramente diferente.

Se picaron las colonias típicas de L. delbrueckii subsp. bulgaricus y $S$. thermophilus de cada producto y se sembraron en triple estría en MRS y M17, respectivamente (figuras 21 y 22), reduciéndose el tiempo de incubación a 48 horas para ambas bacterias. Los microorganismos fueron simultáneamente identificados morfológicamente mediante tinciones. Finalmente, se realizó un cultivo en masa de los mismos empleando también los medios MRS y M17 y se congelaron las cepas para posteriores experimentos como las identificaciones bioquímicas mediante tira API. Todos los medios se incubaron a $37^{\circ} \mathrm{C}$, en anaerobiosis durante 48 horas.

Se realizaron, por tanto, recuentos por duplicado de estos dos microorganismos para cada uno de los yogures estudiados. El número de $L$. delbrueckii subsp. bulgaricus y $S$. thermophilus contenidos en los productos lácteos analizados se muestra en la Tabla 20. Los datos que aparecen son el resultado de la media de ambos recuentos.

Todos los productos lácteos analizados cumplieron la normativa legal vigente, pues contenían más de $10^{7}$ microorganismos cultivables por gramo de producto y fueron capaces de mantener estas características durante la vigencia legal del producto (24 días). En lo que se refiere al recuento total, todas las muestras oscilaron entre $10^{8}-10^{9}$ células $/ \mathrm{ml}$. 
TABLA 20. Recuentos de la microbiota de los productos lácteos analizados

\begin{tabular}{cccc}
\hline Producto & $\begin{array}{c}\text { Lactobacilos } \\
\text { (u.f.c./ml) }\end{array}$ & $\begin{array}{c}\text { Estreptococos } \\
\text { (u.f.c./ml) }\end{array}$ & $\begin{array}{c}\text { Recuento Total } \\
\text { (u.f.c./ml) }\end{array}$ \\
\hline Y1 & $3,0 \times 10^{7}$ & $4,2 \times 10^{8}$ & $4,5 \times 10^{8}$ \\
\hline Y2 & $1,0 \times 10^{6}$ & $4,0 \times 10^{8}$ & $4,0 \times 10^{8}$ \\
\hline Y3 & $4,0 \times 10^{6}$ & $8,8 \times 10^{8}$ & $8,8 \times 10^{8}$ \\
\hline Y4 & $3,5 \times 10^{7}$ & $4,7 \times 10^{8}$ & $5,0 \times 10^{8}$ \\
\hline Y5 & $4,5 \times 10^{7}$ & $1,1 \times 10^{9}$ & $1,1 \times 10^{9}$ \\
\hline Y6 & $4,0 \times 10^{7}$ & $5,5 \times 10^{8}$ & $5,9 \times 10^{8}$ \\
\hline Y7 & $4,0 \times 10^{7}$ & $8,3 \times 10^{8}$ & $8,7 \times 10^{8}$ \\
\hline Y8 & $2,1 \times 10^{8}$ & $7,9 \times 10^{8}$ & $1,0 \times 10^{9}$ \\
\hline Y9 & $5,6 \times 10^{8}$ & $5,5 \times 10^{8}$ & $1,1 \times 10^{9}$ \\
\hline Y10 & $3,0 \times 10^{7}$ & $4,2 \times 10^{8}$ & $4,5 \times 10^{8}$ \\
\hline Y11 & $3,0 \times 10^{7}$ & $8,0 \times 10^{8}$ & $8,3 \times 10^{8}$ \\
\hline
\end{tabular}
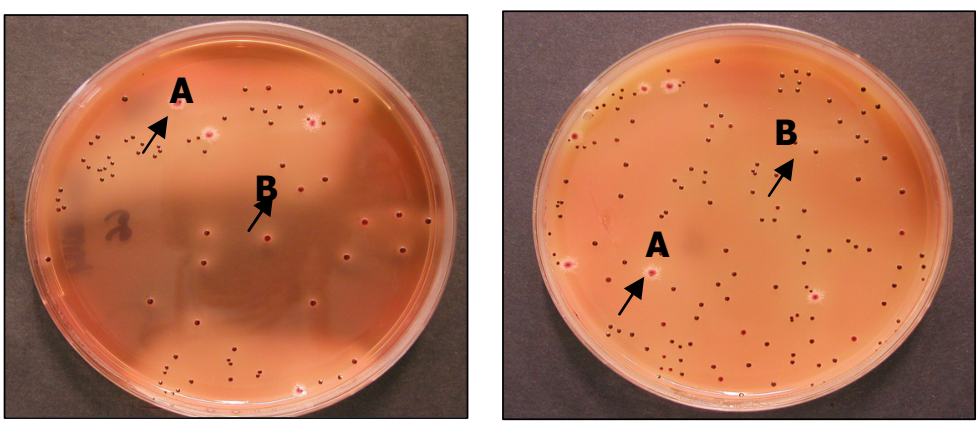

Figura 20. Medio de Cultivo LS Diferencial. Colonia A: lactobacilo y Colonia B: estreptococo 


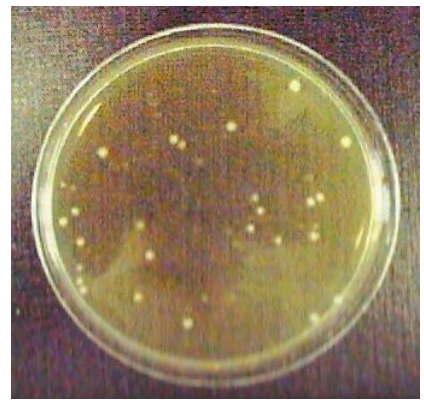

Figura 21. Estreptococos en agar M17

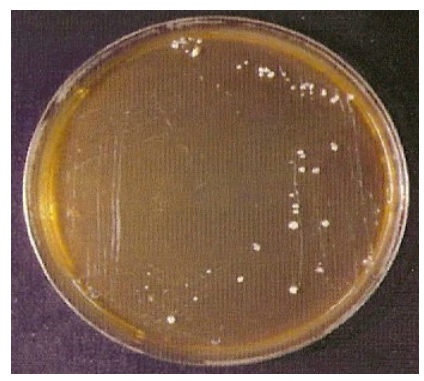

Figura 22. Lactobacilos en agar MRS

Se realizaron los recuentos anteriormente descritos en tres productos pasteurizados después de la fermentación para comprobar que este proceso produce la muerte de las bacterias fermentadoras. No se observó ningún crecimiento después del periodo de incubación de las placas. Se puede afirmar, por tanto, que en este tipo de productos no hay bacterias ácido lácticas viables. Existiría la posibilidad de que algún microorganismo viable pudiera reproducirse en la matriz del producto por contaminación externa o por problemas en el proceso tecnológico.

Generalmente, se observó en todos los productos que los estreptococos (recuentos del orden de $10^{8}$ u.f.c./ml) predominaron en la matriz frente a los lactobacilos (recuentos del orden de $10^{7}$ u.f.c./ml), salvo en el caso de dos marcas (yogures $\mathrm{Y} 8$ e $\mathrm{Y} 9$ ) donde ambas bacterias se hallaron prácticamente en la misma proporción $\left(10^{8}\right.$ u.f.c. $\left./ \mathrm{ml}\right)$. 
1.2. Identificación de los microorganismos mediante pruebas bioquímicas (sistema comercial API-50CHL)

Las presuntas colonias típicas de cada microorganismo estudiado se sembraron en su medio selectivo (MRS para lactobacilos y $\mathrm{M}-17$ para estreptococos) por el método de triple estría para la obtención de colonias aisladas, a partir de las cuales se realizaron las identificaciones bioquímicas mediante el sistema API-50CHL y posteriores pruebas moleculares.

Se sembraron las tiras API por duplicado para cada una de las cepas aisladas de las 11 muestras obteniendo perfiles correspondientes a $L$. delbrueckii subsp. bulgaricus o $S$. thermophilus, en función de la colonia sembrada.

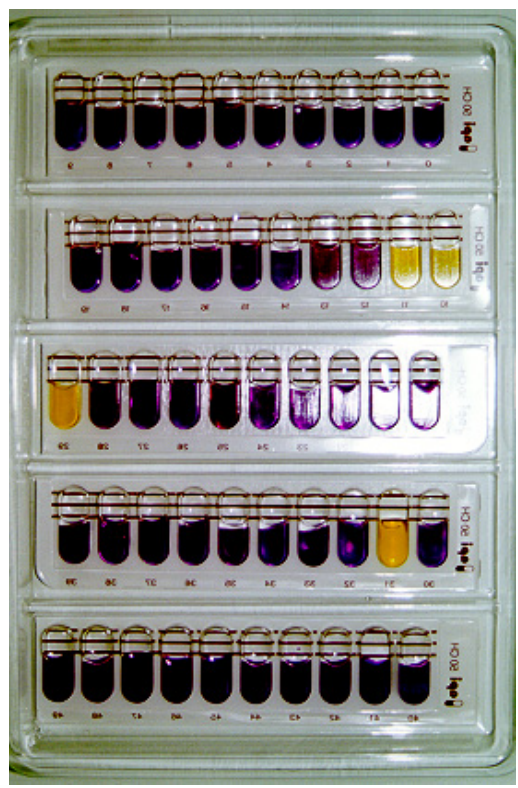

Figura 23. Perfil de L. delbrueckii subsp. bulgaricus en Tira API-50 CHL.

En el caso del género Streptococcus, la tira API-50 CHL sólo puede identificar Streptococcus thermophilus. En cuanto a los lactobacilos, se encontró más variabilidad en la identificación.

Todos los estreptococos aislados de los once yogures de las once marcas diferentes fueron identificados correctamente como Streptococcus thermophilus 
mediante este sistema, presentando en todos los casos el mismo perfil de fermentación de azúcares.

Por su parte, todos los lactobacilos fueron identificados a nivel de especie como Lactobacillus delbrueckii, mientras que al nivel de subespecie se encontraron diferencias. En algunos casos, la muestra analizada se identificó como L. delbrueckii subsp. bulgaricus, mientras que la misma muestra en otros casos apareció como $L$. delbrueckii subsp. delbrueckii. Estas diferencias en cuanto a subespecie son debidas en su mayoría a la falta de reproducibilidad de las tiras API, ya que el considerar una prueba como negativa y/o positiva (puesto que en ciertas ocasiones algunas pruebas resultan confusas) provoca variaciones en la identificación del microorganismo. Por tanto, para $L$. delbrueckii subsp. bulgaricus únicamente se puede llegar a una identificación fiable a nivel de especie.

Todas las identificaciones de microorganismos realizadas mediante pruebas bioquímicas fueron corroboradas mediante FISH con el uso de sondas específicas así como por PCR (ver apartado 1.3 de resultados). Igualmente, se realizaron recuentos mediante FISH para compararlos a los obtenidos por recuento en placa.

\subsection{Identificación y recuento de Lactobacillus delbrueckii subsp. bulgaricus y} Streptococcus thermophilus mediante hibridación in situ con sondas fluorescentes (FISH)

\subsubsection{Identificación de $L$. delbrueckii subsp. bulgaricus mediante sondas fluorescentes. Especificidad de las sondas y recuento en productos comerciales}

En primer lugar su utilizó la sonda LDE16S, complementaria a una región del gen $16 \mathrm{~S}$ y con la siguiente secuencia: (5'- GAC TCT TCG GGG TGA TTT -3').

El alineamiento de la secuencia de la sonda LDE16S con las secuencias contenidas en el GeneBank mostró su validez teórica para la hibridación con Lactobacillus delbrueckii subsp. bulgaricus (tabla 21). 
Tabla 21. Alineamiento de secuencias de la sonda LDE16S

\begin{tabular}{|c|c|c|c|c|c|c|c|c|c|c|c|c|c|c|c|c|c|c|c|c|c|}
\hline 1 & $\begin{array}{l}g \\
\text { l }\end{array}$ & $\begin{array}{l}\mathrm{a} \\
\mathrm{l}\end{array}$ & $\begin{array}{l}\mathrm{c} \\
\mathrm{l}\end{array}$ & $\begin{array}{l}\mathrm{t} \\
\mathrm{l}\end{array}$ & $\begin{array}{l}\mathrm{c} \\
\mathrm{I}\end{array}$ & $\begin{array}{l}\mathrm{t} \\
\mathrm{l}\end{array}$ & $\begin{array}{l}\mathrm{t} \\
\mathrm{l}\end{array}$ & $\begin{array}{l}\mathrm{c} \\
\mathrm{I}\end{array}$ & $\begin{array}{l}g \\
\text { g }\end{array}$ & $\begin{array}{l}g \\
\text { l }\end{array}$ & $\begin{array}{l}g \\
1\end{array}$ & $\begin{array}{l}g \\
\text { I }\end{array}$ & $\begin{array}{l}\mathrm{t} \\
\mathrm{l}\end{array}$ & $\begin{array}{l}\mathrm{g} \\
\mathrm{l}\end{array}$ & $\begin{array}{l}a \\
\text { l }\end{array}$ & $\begin{array}{l}\mathrm{t} \\
\mathrm{l}\end{array}$ & $\begin{array}{l}\mathrm{t} \\
\mathrm{l}\end{array}$ & & & 18 & Sonda LDE16S \\
\hline 83 & $\begin{array}{l}g \\
l\end{array}$ & $\begin{array}{l}c \\
\text { l }\end{array}$ & $\begin{array}{l}g \\
l\end{array}$ & $\mathrm{t}$ & $g$ & $t$ & $\begin{array}{l}\mathrm{t} \\
\mathrm{l}\end{array}$ & $\begin{array}{l}c \\
\text { l }\end{array}$ & $\begin{array}{l}c \\
\text { l }\end{array}$ & $\begin{array}{l}c \\
\text { l }\end{array}$ & $\mathrm{t}$ & $\begin{array}{l}c \\
\text { l }\end{array}$ & $\begin{array}{l}c \\
\text { l }\end{array}$ & $\mathrm{t}$ & $\begin{array}{l}\mathrm{t} \\
\mathrm{l}\end{array}$ & $\begin{array}{l}a \\
1\end{array}$ & $\begin{array}{l}a \\
1\end{array}$ & $\begin{array}{l}g \\
l\end{array}$ & & 100 & $\begin{array}{l}\text { 16S ARNr L. delb. bulg. } \\
\text { ATCC BAA-365 }\end{array}$ \\
\hline 685466 & $g$ & $\mathrm{c}$ & $g$ & $\mathrm{t}$ & $g$ & $\mathrm{t}$ & $\mathrm{t}$ & c & c & c & $\mathrm{t}$ & $c$ & c & $t$ & $\mathrm{t}$ & a & a & $g$ & c & 685448 & $\begin{array}{l}\text { 16S ARNr L. delb. bulg. } \\
\text { ATCC } 11842\end{array}$ \\
\hline
\end{tabular}

\section{L.delbrueckii 16S rARN}

Length $=1488$

Score $=36.2$ bits $(18)$, Expect $=0.042$

Identities $=18 / 18(100 \%)$, Gaps $=0 / 18(0 \%)$

Strand=Plus/Plus

Query 1 GACTCTTCGGGGTGATTT 18

Sbjct 83 GACTCTTCGGGGTGATTT 100

La especificidad de esta sonda se comprobó experimentalmente por medio de la hibridación con la batería de cepas de BAL, las cepas aisladas de productos comerciales denominadas de LY1 a LY11 y otras de referencia (tabla 22). La sonda resultó específica para las cepas de L. delbrueckii subsp. bulgaricus aisladas del yogures naturales, así como para la cepa de referencia de la CECT. 
Tabla 22. Especificidad de la sonda LDE16S

\begin{tabular}{llc}
\hline \multicolumn{1}{c}{ Especies o subespecies } & \multicolumn{1}{c}{ Cepa } & $\begin{array}{c}\text { Resultado de } \\
\text { hibridación }\end{array}$ \\
\hline Lactobacillus delbrueckii subsp bulgaricus & LY1 a LY11 & + \\
\hline Lactobacillus delbrueckii subsp bulgaricus & CECT 4005T & + \\
\hline Lactobacillus delbrueckii subsp. delbrueckii & CECT 286 & - \\
\hline Lactobacillus delbrueckii subsp. lactis & CECT 282 & - \\
\hline Lactobacillus paracasei & CECT 4022 & - \\
\hline Lactobacillus brevis & CECT 4121 & - \\
\hline Lactobacillus acidophilus & CECT 903 & - \\
\hline Lactobacillus casei & CECT 475 & - \\
\hline Lactobacillus rhamnosus & CECT 278 & - \\
\hline Lactobacillus salivarius & CECT 4063 & - \\
\hline Lactobacillus reuteri & CECT 225T & - \\
\hline Lactobacillus fermentum & CECT 562 & - \\
\hline
\end{tabular}

Sin embargo, la intensidad de fluorescencia fue baja (figura 24) pese a la utilización de diferentes concentraciones de formamida en el tampón.

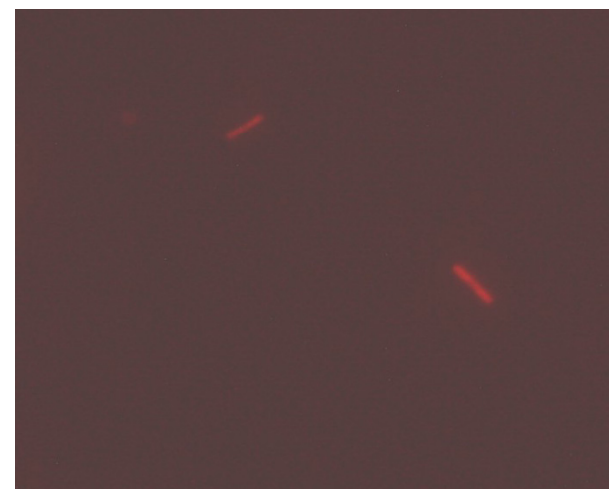

Figura 24. Cultivo puro de Lactobacillus delbrueckii subsp. bulgaricus hibridado con LDE16S marcada con CY3 (rojo)

En la figura 25 se observa una clasificación de las zonas del $A R N r$ en función de la accesibilidad de las sondas, de forma que las zonas de clase I, serían las más accesibles, entre un 81 y $100 \%$ y las zonas de clase VI serían las menos accesibles, entre un $0 \%$ y un $5 \%$. 
La sonda LDE16S hibridaría en una zona de clase $V$ con una accesibilidad entre el 6 y el $20 \%$ (se encuentra entre los pares de bases 83 y 100), por lo que no sería una buena sonda a pesar de ser totalmente específica para $L$. delbrueckii subsp. bulgaricus. Ésto justificaría la baja señal de fluorescencia emitida en las hibridaciones realizadas con esta sonda. 


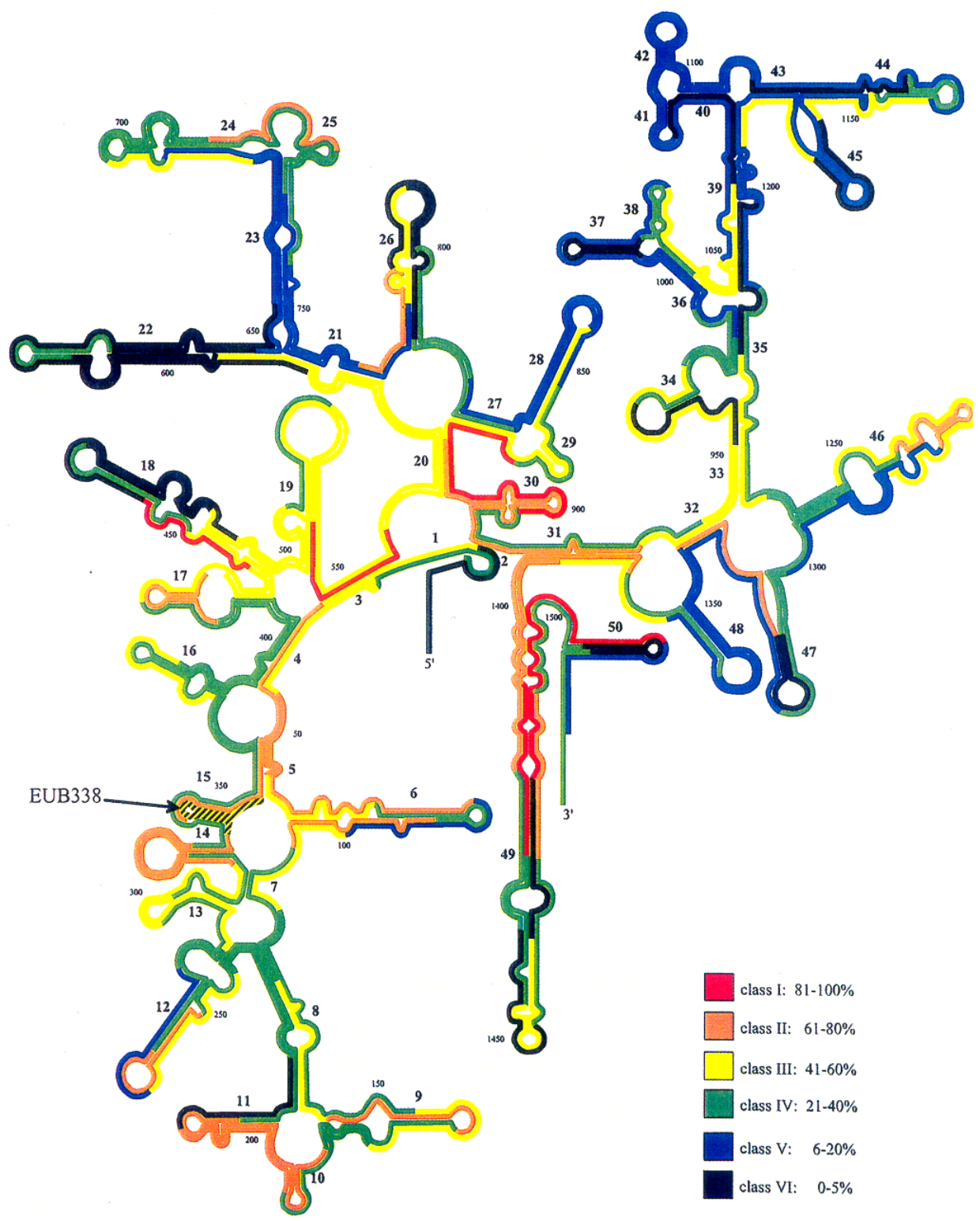

Figura 25. Acceso a la estructura secundaria del ARNr 16S 
Por lo tanto, se decidió diseñar otra sonda específica complementaria al $23 \mathrm{~S}$ (LDE23S) con la siguiente secuencia:

\section{LDE23S: 5'- GCG TGT TCC CTC CTT AAG C -3}

El alineamiento de las secuencias de la sonda LDE23S con las secuencias contenidas en el GeneBank mostró su validez teórica (tabla 23) para la detección de L. delbrueckii subsp. bulgaricus, no presentando homología con otras especies del género ni otros géneros próximos.

Tabla 23. Alineamiento de secuencias de la sonda LDE23S

\begin{tabular}{|c|c|c|c|c|c|c|c|c|c|c|c|c|c|c|c|c|c|c|c|c|c|c|}
\hline \multirow[t]{2}{*}{1} & $g$ & $\mathrm{c}$ & $g$ & $\mathrm{t}$ & $g$ & $\mathrm{t}$ & $\mathrm{t}$ & c & c & c & $\mathrm{t}$ & c & c & t & $t$ & $\mathrm{t}$ & a & $a$ & $\mathrm{~g}$ & c & 19 & Sonda LDE23S \\
\hline & 1 & I & I & | & | & | & | & | & । & 1 & | & I & I & & | & | & l & I & I & 1 & & \\
\hline \multirow[t]{2}{*}{47119} & g & $\mathrm{c}$ & $g$ & $t$ & $g$ & $\mathrm{t}$ & $\mathrm{t}$ & C & c & c & $\mathrm{t}$ & c & c & t & $t$ & $\mathrm{t}$ & a & a & $\mathrm{g}$ & C & 47101 & 23S ARNr L. delb. \\
\hline & I & I & I & | & I & I & | & | & I & | & | & । & । & & | & I & I & I & I & I & & 1842 \\
\hline \multirow[t]{2}{*}{691334} & $g$ & $\mathrm{c}$ & $g$ & $\mathrm{t}$ & g & $\mathrm{t}$ & $\mathrm{t}$ & c & c & c & $\mathrm{t}$ & c & c & $t$ & $\mathrm{t}$ & $\mathrm{t}$ & a & a & $g$ & c & 691316 & RNr L. delb. \\
\hline & I & I & I & | & | & I & | & | & । & | & । & । & । & & | & I & I & I & l & I & & 842 \\
\hline \multirow[t]{2}{*}{808352} & $g$ & $\mathrm{c}$ & $g$ & $\mathrm{t}$ & $g$ & $\mathrm{t}$ & $\mathrm{t}$ & c & c & c & $\mathrm{t}$ & c & c & 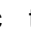 & $\mathrm{t}$ & $\mathrm{t}$ & a & a & $g$ & c & 808334 & 23S ARNr L. delb. bulg. \\
\hline & I & I & I & | & I & I & । & | & । & | & । & । & । & & | & I & I & I & I & I & & 1842 \\
\hline 1359296 & $\mathrm{~g}$ & $\mathrm{c}$ & $\mathrm{g}$ & $\mathrm{t}$ & $g$ & $\mathrm{t}$ & $\mathrm{t}$ & c & c & c & $t$ & c & c & 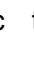 & $t$ & $\mathrm{t}$ & $a$ & $a$ & $g$ & c & 1359314 & $\begin{array}{l}\text { 23S ARNr L. delb. bulg. } \\
\text { ATCC } 11842\end{array}$ \\
\hline
\end{tabular}

Su especificidad real fue comprobada mediante la hibridación de la misma con una batería de cepas de BAL, tanto aisladas de productos como de colección (tabla 24). Resultó solamente específica para las cepas de Lactobacillus delbrueckii subsp. bulgaricus aisladas del yogur, así como para las cepas de colección de esta misma bacteria.

Tabla 24. Especificidad de la sonda LDE23S

\begin{tabular}{llc}
\hline \multicolumn{1}{c}{ Especies o subespecies } & Cepa & $\begin{array}{c}\text { Resultado de } \\
\text { hibridación }\end{array}$ \\
\hline Lactobacillus delbrueckii subsp bulgaricus & LY1 a LY11 & + \\
\hline Lactobacillus delbrueckii subsp bulgaricus & CECT 4005T & + \\
\hline Lactobacillus delbrueckii subsp. delbrueckii & CECT 286 & - \\
\hline Lactobacillus delbrueckii subsp. lactis & CECT 282 & - \\
\hline Lactobacillus paracasei & CECT 4022 & - \\
\hline Lactobacillus brevis & CECT 4121 & - \\
\hline Lactobacillus acidophilus & CECT 903 & - \\
\hline Lactobacillus casei & CECT 475 & - \\
\hline
\end{tabular}


Resultados

\begin{tabular}{lll}
\hline Lactobacillus rhamnosus & CECT 278 & - \\
\hline Lactobacillus salivarius & CECT 4063 & - \\
\hline Lactobacillus reuteri & CECT 225T & - \\
\hline Lactobacillus fermentum & CECT 562 & - \\
\hline
\end{tabular}

Utilizando una concentración de $20 \%$ de formamida se consiguió una elevada especificidad y una buena señal de fluorescencia para realizar los recuentos. Las figuras 26 y 27 muestran células de L. delbrueckii subsp bulgaricus hibridadas con la sonda específica LDE23S en un cultivo puro y en yogur natural respectivamente.

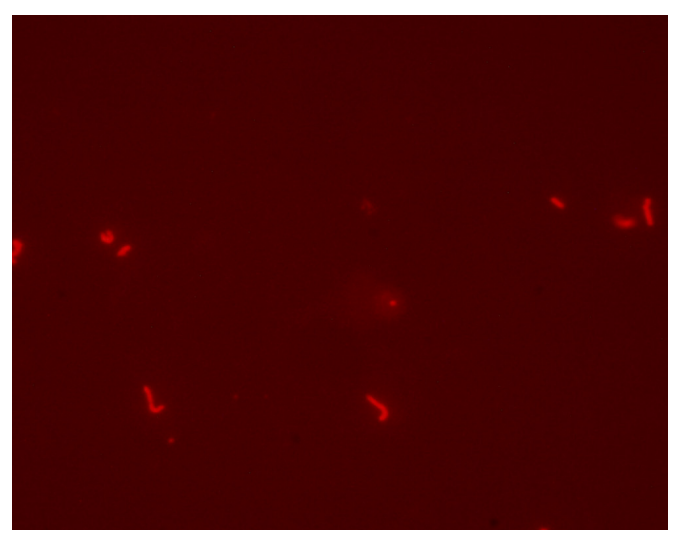

Figura 26. Cultivo puro de Lactobacillus delbrueckii subsp bulgaricus hibridada con LDE23S marcada con CY3 (rojo)

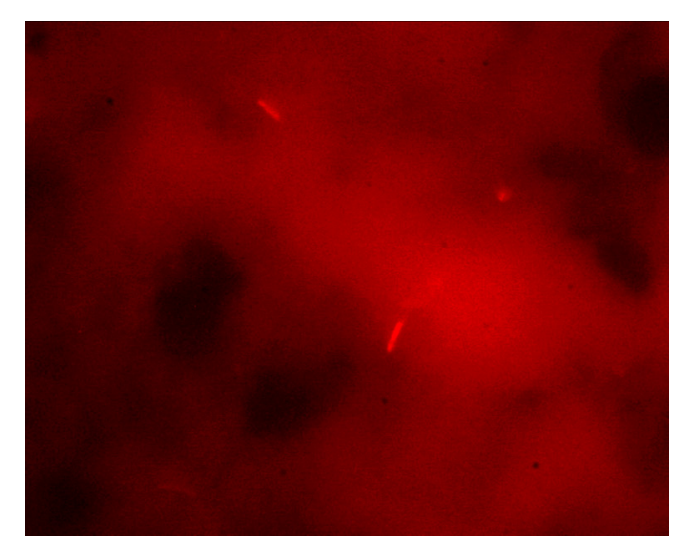

Figura 27. Lactobacillus delbrueckii subsp. bulgaricus en yogur natural, hibridado con LDE23S marcada CY3 (rojo) 
Se realizaron, por tanto, recuentos de L. delbrueckii subsp. bulgaricus de los diferentes yogures naturales comerciales estudiados anteriormente mediante FISH, utilizando la sonda de hibridación LDE23S. Para ello, se contaron las células hibridadas en veinte campos y se multiplicó por el factor de microscopio correspondiente al objetivo de 60x. Los resultados se recogen en la tabla 25.

TABLA 25. Recuentos de Lactobacillus delbrueckii subsp. bulgaricus en los diferentes yogures naturales mediante FISH

\begin{tabular}{cc}
\hline Producto & N $^{0}$ Lactobacilos/g yogur \\
\hline Y1 & $5 \times 10^{7}$ \\
\hline Y2 & $3,5 \times 10^{6}$ \\
\hline Y3 & $8,8 \times 10^{6}$ \\
\hline Y4 & $2 \times 10^{7}$ \\
\hline Y5 & $4,5 \times 10^{7}$ \\
\hline Y6 & $5 \times 10^{7}$ \\
\hline Y7 & $6,2 \times 10^{7}$ \\
\hline Y8 & $8,5 \times 10^{7}$ \\
\hline Y9 & $2 \times 10^{8}$ \\
\hline Y10 & $4,8 \times 10^{7}$ \\
\hline Y11 & $6 \times 10^{7}$ \\
\hline
\end{tabular}

Se observó que los recuentos mediante hibridación in situ fueron ligeramente superiores aunque del mismo orden a los obtenidos por recuento en placa para prácticamente todos los productos.

Pese a la correcta hibridación de la sonda con la cepa de Lactobacillus delbrueckii subsp. bulgaricus aislada del producto $Y 7$, se decidió secuenciar los genes $16 S$ y $23 S$ de ésta para intentar identificar únicamente el lactobacilo del producto que se utilizaría en el ensayo in vivo, diferenciándolo del resto. Se comprobó que había una base, justo en la zona de alineamiento, que variaba respecto a la sonda LDE23S. Se decidió, por tanto, diseñar una sonda específica para esta cepa que sirviera para la detección de esta cepa en los posteriores estudios in vitro e in vivo y que fuera totalmente complementaria. Las secuencias de estos genes pueden verse en el anexo VI.

La secuencia de esta sonda fue: 


\section{LDE23R: 5'- GCG TGT TCC (T/C)TC CTT AAG C -3'}

Esta sonda variaba sólo en una base respecto a la anterior, siendo complementaria en su totalidad al gen $23 \mathrm{~S}$ de la cepa aislada del producto Y7.

Se llevaron a cabo hibridaciones de la cepa del lactobacilo aislado de Y7 con esta sonda, comprobándose una mejoría en la intensidad de fluorescencia respecto a la hibridación realizada con la sonda LDE23S para esta cepa. Con la adición al tampón del $20 \%$ de formamida se consiguió discriminar entre L. delbrueckii subsp. bulgaricus y el resto de microorganismos. La sonda hibridó también con las cepas de $L$. delbrueckii subsp. bulgaricus aisladas del resto de productos comerciales. La figura 28 muestra células del producto $Y 7$ de L. delbrueckii subsp. bulgaricus hibridadas con la sonda específica LDE23R para esta cepa.

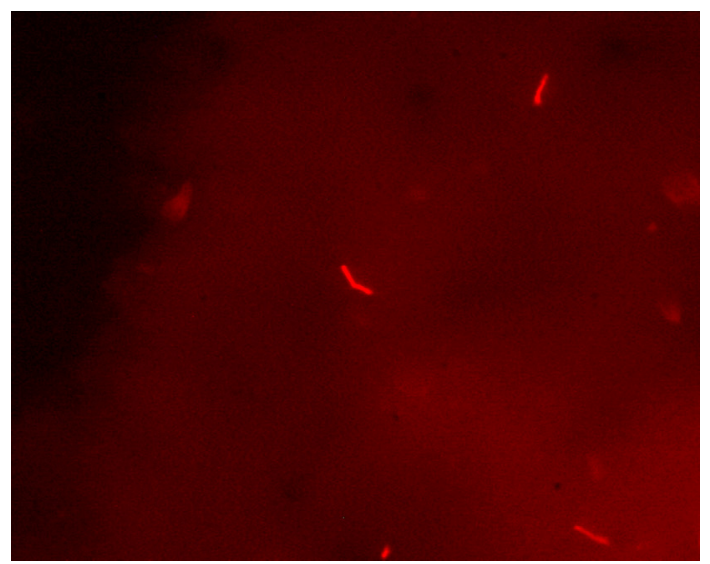

Figura 28. Lactobacillus delbrueckii subsp bulgaricus (Y7) hibridado con LDE23R marcada con $\mathrm{CY} 3$ (rojo)

En consecuencia, la sonda LDE23R será la usada en los posteriores estudios de resistencia a jugos gastrointestinales (in vitro) y el estudio in vivo de supervivencia que se realice en humanos, puesto que se ensayará con el yogur natural Y7.

1.3.2. Identificación de $S$. thermophilus mediante sondas fluorescentes. Especificidad de la sonda y recuento en productos comerciales 
Se utilizó la sonda diseñada (apartado de materiales y métodos 1.4.1.), complementaria del $23 \mathrm{~S}$ rARN de Streptococcus thermophilus.

El alineamiento de la secuencia de la sonda diseñada STH23S con las secuencias contenidas en el GeneBank mostró su validez teórica (tabla 26) para la detección de $S$. thermophilus, no presentando alineamiento con otras especies del género ni con otros géneros próximos.

Tabla 26. Alineamiento de secuencias de la sonda STH 235

\begin{tabular}{|c|c|c|c|c|c|c|c|c|c|c|c|c|c|c|c|c|}
\hline \multirow[t]{2}{*}{1} & C & $a \mathrm{t}$ & $g$ & C & & & $\mathrm{t}$ & $c$ & $\mathrm{t}$ & a & 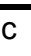 & g & & & 18 & STH23S \\
\hline & 1 & | | & | & | & d & | & 1 & & $\mid$ & & & & & & & \\
\hline \multirow[t]{2}{*}{21518} & c & a $\mathrm{t}$ & $g$ & c & c & $\mathrm{t}$ & $t$ & c & $\mathrm{t}$ & a & C & g & c & & 21501 & $23 \mathrm{~S} A R I$ \\
\hline & 1 & | | & 1 & | & 1 & 1 & & 1 & & 1 & 1 & 1 & | & & & $\mathrm{CN}$ \\
\hline \multirow[t]{2}{*}{69286} & c & a t & $g$ & c & c & $\mathrm{t}$ & t & c & $\mathrm{t}$ & a & c & g & $c$ & & 69269 & 23S ARNr S. therm. \\
\hline & | & | | & l & I & । & । & & | & । & 1 & | & $\mid$ & 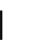 & & & CNRZ 1066 \\
\hline \multirow[t]{2}{*}{132774} & C & $a t$ & $g$ & C & c & $\mathrm{t}$ & $t$ & 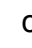 & $\mathrm{t}$ & a & $\mathrm{C}$ & $g$ & $c$ & & 132757 & 23S ARNr S. therm. \\
\hline & | & | | & | & | & | & | & & & I & | & | & 1 & & & & CNRZ 1066 \\
\hline 138581 & c & $a t$ & g & ; & C & $\mathrm{t}$ & $t$ & & $\mathrm{t}$ & a & C & $g$ & c & & 138564 & $\begin{array}{l}\text { 23S ARNr S. therm. } \\
\text { CNRZ } 1066\end{array}$ \\
\hline
\end{tabular}

S.thermophilus for $23 S$ rARN

Length $=2900$

Score $=40.1$ bits (20), Expect $=0.005$

Identities $=20 / 20(100 \%)$, Gaps $=0 / 20(0 \%)$

Strand=Plus/Minus

Query 1 CATGCCTTCGCTTACGCTAA 20

sbjet 1883 CATGCCTTCGCTTACGCTAA 1864

A nivel práctico, la especificidad de la misma se comprobó mediante la hibridación con una batería de cepas de BAL y otros estreptococos (endógenos), resultando específica únicamente para $S$. thermophilus. Con la adición al tampón del $10 \%$ de formamida se consiguió discriminar entre $S$. thermophilus y el resto de estreptococos testados. 
La figuras 29 y 30 muestran células de $S$. thermophilus hibridadas con la sonda específica STH23S, marcada con CY3, en cultivo puro y en un yogur natural.

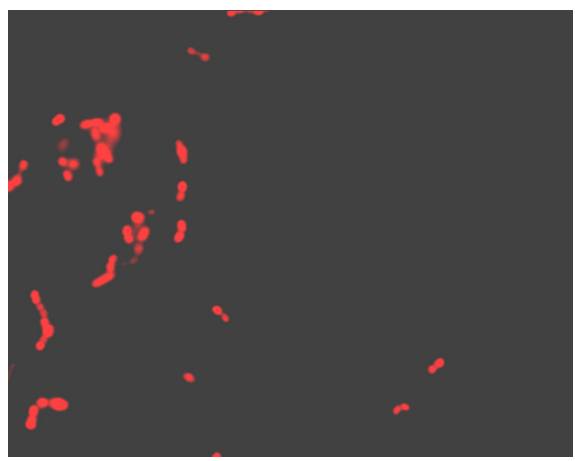

Figura 29. Cultivo puro Streptococcus thermophilus hibridado con STH23S marcada con CY3 (rojo)

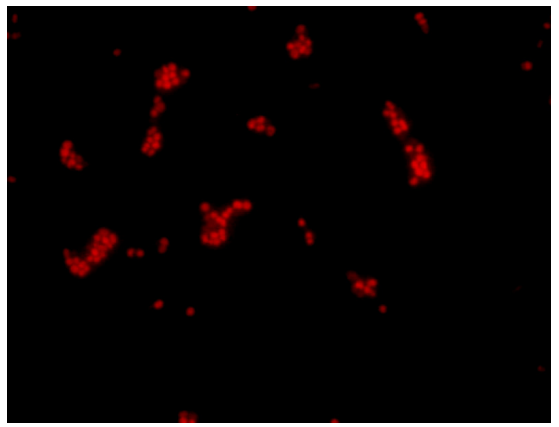

Figura 30. Streptococcus thermophilus en yogur Y7 hibridado con STH 23S marcada con CY3 (rojo)

Tabla 27. Hibridación de cepas de BAL con la sonda STH23S

\begin{tabular}{lcc}
\hline Especies o subespecies & Cepa & $\begin{array}{c}\text { Resultado de } \\
\text { hibridación }\end{array}$ \\
\hline $\begin{array}{l}\text { Streptococcus thermophilus } \\
\text { aislados de los yogures }\end{array}$ & STY1 a STY11 & + \\
\hline Streptococcus thermophilus & CECT 986 & + \\
\hline Streptococcus intermedius & CECT 803 & - \\
\hline Enterococcus faecalis & CECT 407 & - \\
\hline
\end{tabular}




\begin{tabular}{lll}
\hline Enterococcus faecium & CECT 4102 & - \\
\hline $\begin{array}{l}\text { Lactobacillus delbrueckii subsp } \\
\text { bulgaricus }\end{array}$ & DN 100182 & - \\
\hline $\begin{array}{l}\text { Lactobacillus delbrueckii subsp. } \\
\text { delbrueckii }\end{array}$ & CECT 286 & - \\
\hline Lactobacillus paracasei & CECT 4022 & - \\
\hline Lactobacillus brevis & CECT 4121 & - \\
\hline Lactobacillus acidophilus & CECT 903 & - \\
\hline Lactobacillus casei & CECT 475 & - \\
\hline Lactobacillus rhamnosus & CECT 278 & - \\
\hline Lactobacillus salivarius & CECT 4063 &
\end{tabular}

Una vez comprobada la especificad de la sonda, se realizaron recuentos de células de $S$. thermophilus mediante FISH de los diferentes productos comerciales, obteniendo los resultados que se recogen en la tabla 28. Para ello, se contaron las células hibridadas en veinte campos y se multiplicó por el factor de microscopio correspondiente.

Tabla 28. Recuentos de células de Streptococcus thermophilus hibridadas en los diferentes yogures.

\begin{tabular}{cc}
\hline Producto & $\begin{array}{c}\mathbf{N}^{\circ} \text { Streptococcus } \\
\text { thermophilus/g yogur }\end{array}$ \\
\hline Y1 & $2,5 \times 10^{8}$ \\
\hline Y2 & $2,8 \times 10^{8}$ \\
\hline Y3 & $7,4 \times 10^{8}$ \\
\hline Y4 & $5,2 \times 10^{8}$ \\
\hline Y5 & $9 \times 10^{8}$ \\
\hline Y6 & $6,5 \times 10^{8}$ \\
\hline Y7 & $7,7 \times 10^{8}$ \\
\hline Y8 & $8 \times 10^{8}$ \\
\hline Y9 & $3,5 \times 10^{8}$ \\
\hline 10 & $4 \times 10^{8}$ \\
\hline 11 & $8,5 \times 10^{8}$ \\
\hline
\end{tabular}


Los recuentos por este método fueron muy similares a los realizados por recuento en placa.

En los posteriores estudios de la cepa de $S$. thermophilus contenida en el producto $\mathrm{Y} 7$ de resistencia a los jugos gastrointestinales (estudio in vitro) y de supervivencia al tracto gastrointestinal (estudio in vivo en humanos) se utilizó, por tanto, esta sonda STH23S.

\subsection{Análisis de los perfiles de bandas generados por RAPDs}

Una vez aisladas las cepas de lactobacilos y estreptococos de los productos comerciales se realizaron RAPDs para obtener una diferenciación intraespecífica de éstos. Se caracterizaron por separado las dos especies en estudio: Streptococcus

thermophilus y Lactobacillus delbrueckii subsp. bulgaricus. Se utilizaron dos iniciadores diferentes, RAPD1y RAPD2, para ambas bacterias obteniendo más de un perfil por especie.

Los perfiles generados se estudiaron mediante el programa informático TDI Lane Manager, obteniéndose un dendrograma en el que se puede observar gráficamente las similitudes genéticas.

\subsubsection{Caracterización molecular mediante RAPD's de las cepas de $L$. delbrueckii subsp. bulgaricus aisladas de productos comerciales}

Con el iniciador RAPD1 (figura 31) se observaron entre 8 y 12 bandas con pesos moleculares entre 2800 y $300 \mathrm{pb}$. Todas las cepas compartieron 4 bandas con pesos moleculares de 2800, 2200, 1350 y $1250 \mathrm{pb}$. 


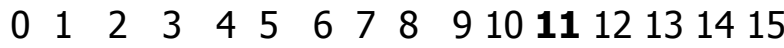

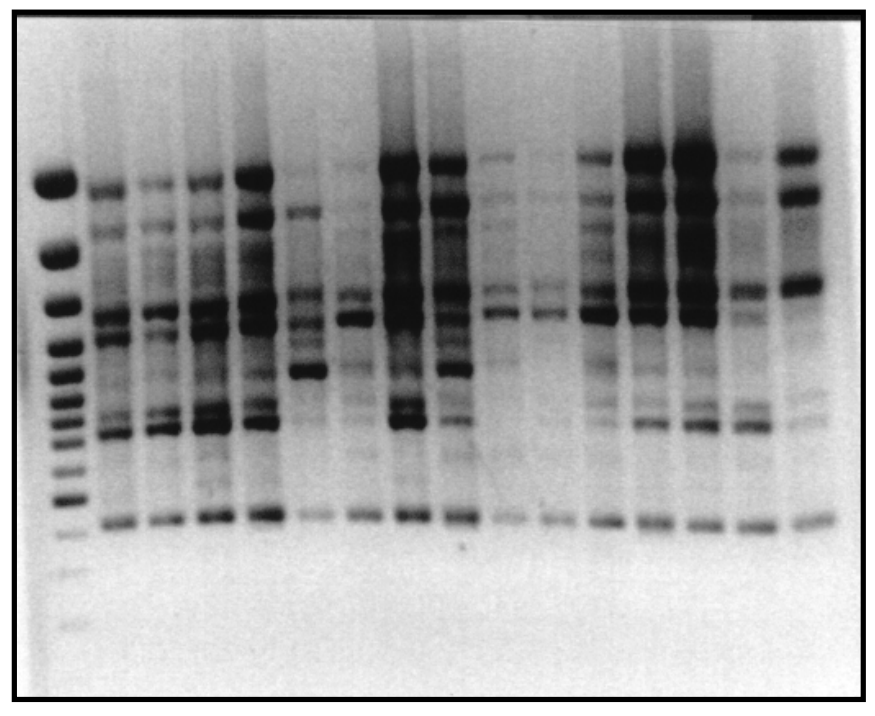

0.- Marcador de peso molecular 100 bp

1.- Y9

2. $-\mathrm{Y} 10$

3.- Y6

4.- Y6

5.- Y11

6.- Y4

7.- Y6

8.- Y8

9.- Y4

10.- Y3

11.- Y7

12.- Y2

13.- Y1

14.- $Y 10$

Figura 31. Perfiles obtenidos mediante RAPDs de las diferentes cepas de Lactobacillus delbrueckii subsp. bulgaricus con el iniciador RAPD1

Seis cepas compartieron exactamente el mismo perfil de bandas $(100 \%$ homólogas) entre las que se encuentran Y7 e Y1. La figura 32 muestra los porcentajes de homología entre todas las cepas de Lactobacillus de los distintos productos usando el iniciador RAPD1 mientras que la tabla 29 muestra el porcentaje de homología únicamente frente a $\mathrm{Y} 7$, por ser la cepa que utilizaremos en lo ensayos in vitro e in vivo posteriores, mostrando por tanto un interés mayor para nosotros.

A continuación, se muestra el porcentaje de homología genética entre la cepa de Lactobacillus delbrueckii subsp. bulgaricus LDY7 (la cepa de la marca comercial que se utilizó para el resto de esta tesis doctoral) y el resto de lactobacilos de las otras marcas comerciales obtenido por RAPDs mediante el uso del iniciador RAPD1. 


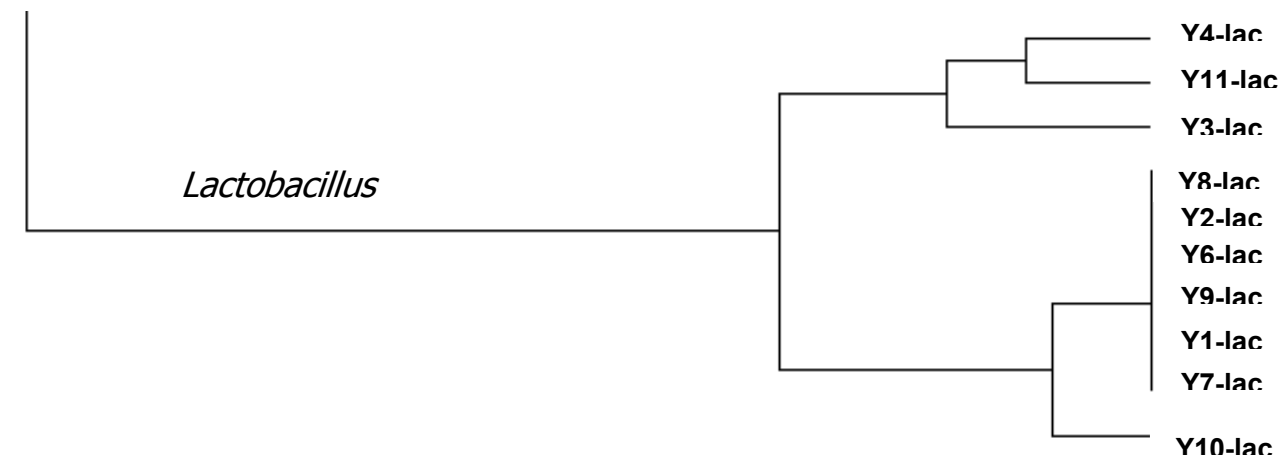

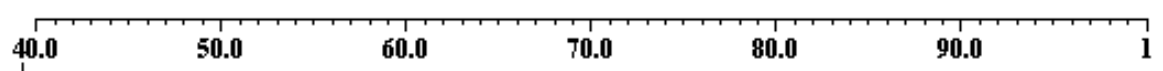

39.3

Figura 32. Dendrograma de las cepas de $L$. delbrueckii subsp. bulgaricus, empleando el iniciador RAPD1 y el coeficiente de similitud de DICE

Tabla 29. Porcentajes de homología genética entre la cepa de L. delbrueckii subsp. bulgaricus $Y 7$ y el resto de lactobacilos de otras marcas comerciales, obtenido por RAPD mediante el uso del iniciador RAPD1

\begin{tabular}{cccc}
\hline PRODUCTO & \% HOMOLOGIA & PRODUCTO & \% HOMOLOGÍA \\
\hline Y9 & 100 & Y10 & 95 \\
\hline Y8 & 100 & Y4 & 80 \\
\hline Y1 & 100 & Y3 & 80 \\
\hline Y2 & 100 & Y11 & 80 \\
\hline Y6 & 100 & & \\
\hline
\end{tabular}

Con el iniciador RAPD2 se consiguió una mayor discriminación entre cepas, con 7 perfiles de bandas distintos, con un número de bandas entre 7 y 14 y con pesos moleculares entre 2500 y 500 pb (figura 33). 


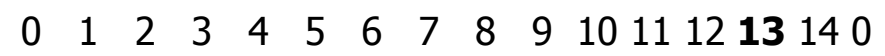

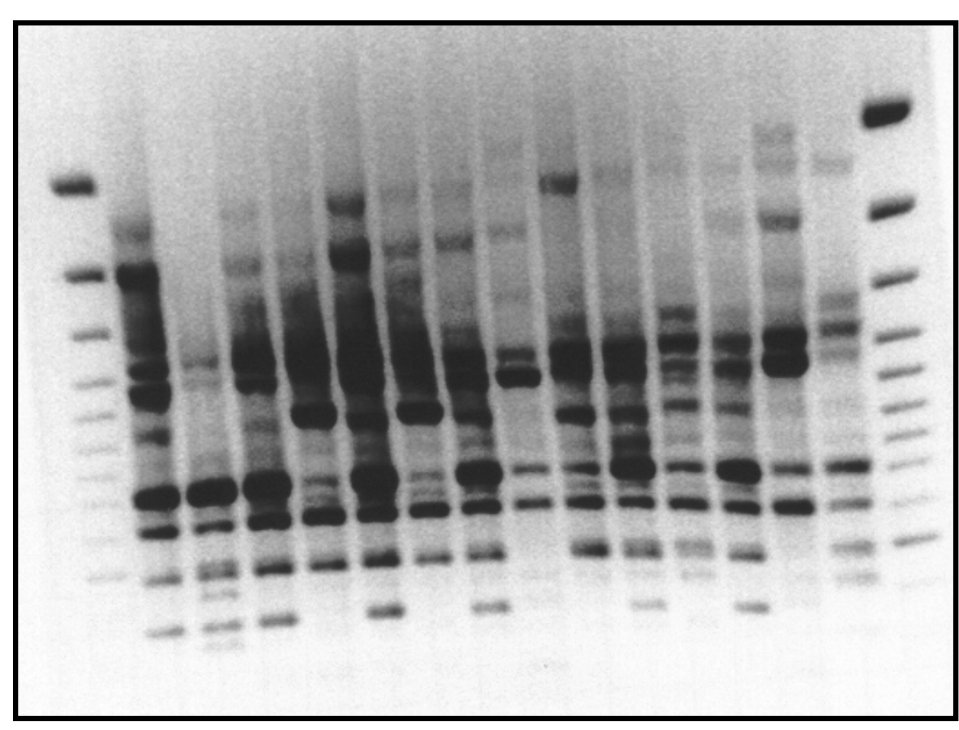

0.- Marcador de peso molecular 100 bp

1.- Y3

2.- Y5

3.- Y6

4.- Y1

5.- Y3

6.- Y10

7.- Y2

8.- Y4

9.- Y8

10.- Y8'

11.- Y9

12.- Y9

13.- Y7

14.- Y11

Figura 33. Perfiles obtenidos mediante RAPDs de bacterias del género Lactobacillus spp. con el iniciador RAPD2

Se obtuvieron perfiles de bandas muy heterogéneos. Aunque la cepa de Y7 presentó un perfil único, se observó una homología entre esta cepa y la cepa de Y9 del $89 \%$ frente al $100 \%$ de homología que se consigue con el primer RAPD1. Sin embargo, existe una homología del 95\% entre Y1, Y10 e Y7. La figura 34 representa los porcentajes de homología entre las cepas de Lactobacillus de los distintos yogures mientras que la tabla 30 muestra la homología solamente con respecto a la cepa LY7, que es la que será utilizada en estudios posteriores. Todas las cepas se agrupan en un $80 \%$ de similitud, diferenciándose tres grupos unidos en más del $90 \%$ de similitud. 


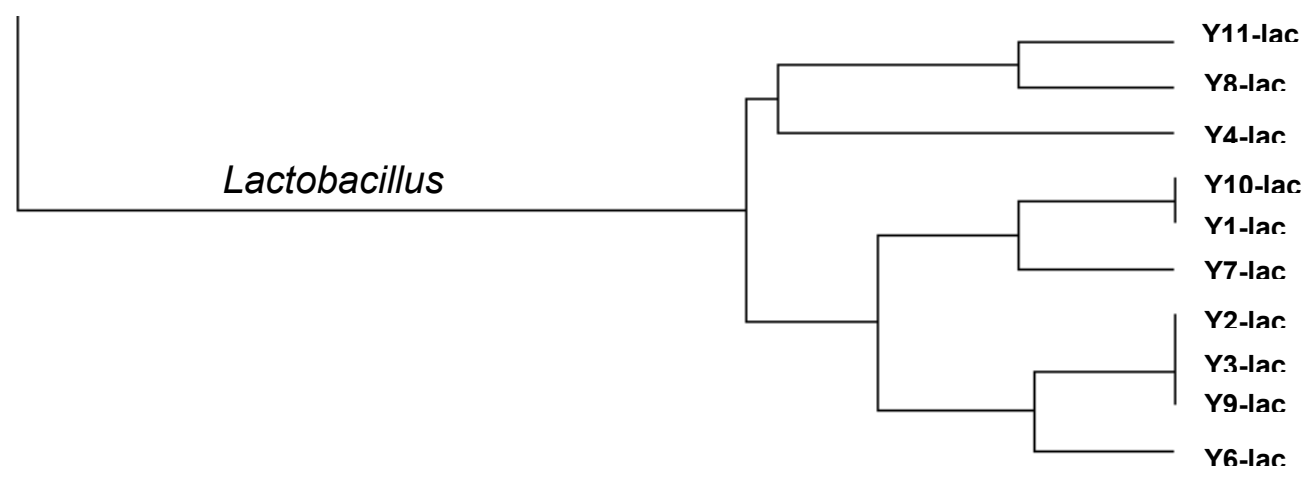

60.0

TO.0

80.0

90.0

56.0

Figura 34. Dendrograma de las cepas de L. delbrueckii subsp. bulgaricus, empleando el iniciador RAPD2 y el coeficiente de similitud de DICE

TABLA 30. Porcentajes de homología genética entre la cepa de $L$. delbrueckii subsp. bulgaricus $Y 7$ y el resto de lactobacilos de otras marcas comerciales, obtenido por RAPD mediante el uso del iniciador RAPD2

\begin{tabular}{cccc}
\hline PRODUCTO & \% HOMOLOGÍA & PRODUCTO & \% HOMOLOGÍA \\
\hline Y1 & 95 & Y3 & 89 \\
\hline Y10 & 95 & Y8 & 84 \\
\hline Y9 & 89 & Y4 & 84 \\
\hline Y2 & 89 & Y11 & 84 \\
\hline Y6 & 89 & & \\
\hline
\end{tabular}


1.4.2. Caracterización molecular mediante RAPDs de las cepas de $S$. thermophilus aisladas de productos comerciales

Los perfiles obtenidos mediante RAPDs tras la amplificación con el iniciador RAPD1, descrito por Tynkkynen et al. (1999) para los estreptococos aislados de yogures naturales se muestran en la siguiente figura.

\section{$\begin{array}{llllllllllllll}M & 1 & 2 & 3 & 4 & 5 & 6 & 7 & 8 & 9 & 10 & 11 & M\end{array}$}

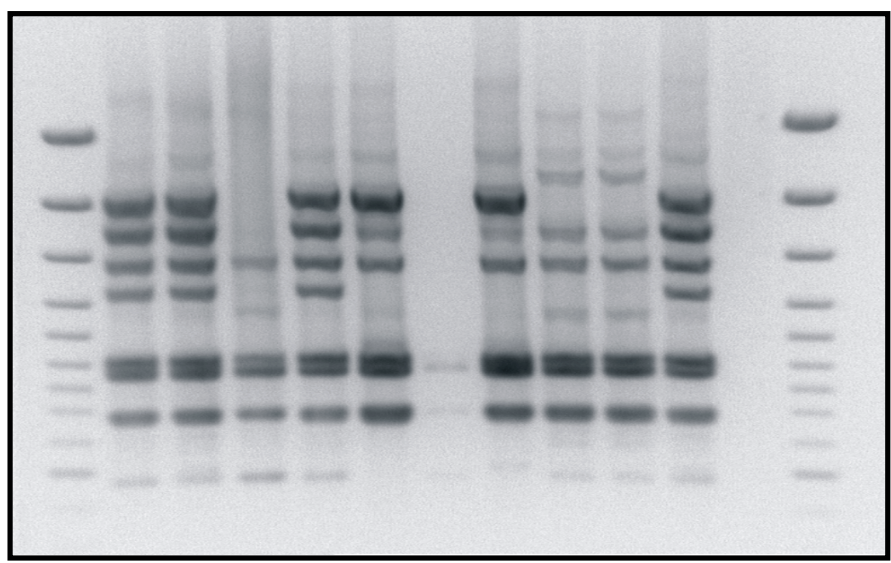

M: Marcador de peso molecular 100pb

1.- Y10

2.- $Y 1$

3.- Y11

4.- Y3

5.- Y7

6.- Y8

7.- Y9

8.- Y6

9.- Y5

10.- Y4

11.- Y2

M: Marcador de peso molecular 100pb

Figura 35. Perfiles obtenidos mediante RAPDs de bacterias del género Streptococcus con el iniciador RAPD1

Con el uso del iniciador RAPD1, los estreptococos aislados de los productos lácteos presentaron una gran homología en sus patrones de bandas. Los perfiles presentaron un número de bandas entre 6 y 10 con pesos moleculares que oscilaron entre 2000 y $500 \mathrm{pb}$. Todas las cepas tuvieron en común tres bandas de pesos moleculares: 900,850 y $570 \mathrm{pb}$.

Se compararon los perfiles obtenidos respecto a la cepa del producto $\mathrm{Y} 7$ puesto que es el que se usaría posteriormente en los estudios in vitro e in vivo de supervivencia. Se observó que las cepas de los productos Y9 e Y7 compartían el mismo patrón de bandas, siendo único y diferente al resto de cepas. La figura 36 muestran los porcentajes de homología entre todas las cepas de Streptococcus thermophilus de los distintos productos usando el iniciador RAPD1, mientras que la 
tabla 31 muestra el porcentaje de homología de las diferentes cepas respecto a la del producto $\mathrm{Y} 7$.

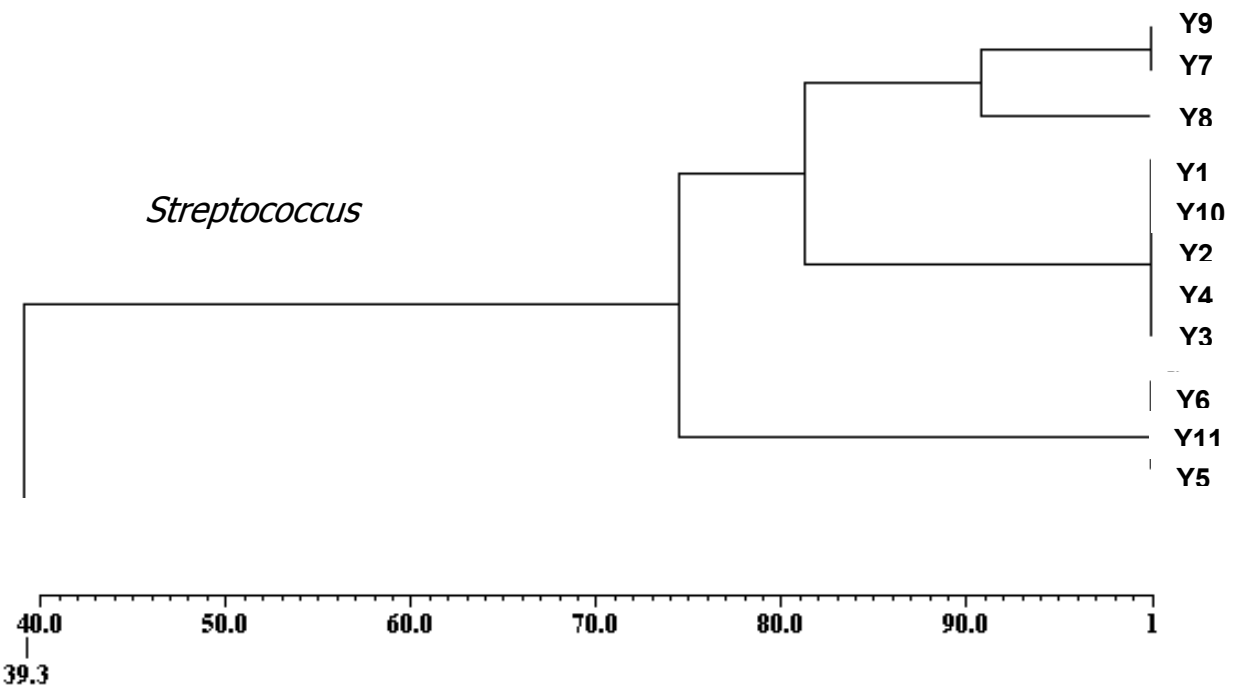

Figura 36. Dendrograma de las cepas de Streptococcus thermophilus empleando el iniciador RAPD1 y el coeficiente de similitud de DICE

Se puede observar que las cepas utilizadas por las diferentes casas comerciales coinciden en algunas ocasiones, mientras que en otras no son las mismas. Con respecto a la cepa del producto $Y 7$, solamente se estaría utilizando también en el producto Y9.

Tabla 31. Porcentajes de homología genética entre la cepa del $S$. thermophilus $Y 7$ y el resto de estreptococos aislados de otras marcas comerciales obtenido por RAPD mediante el uso del iniciador RAPD1

\begin{tabular}{cccc} 
PRODUCTO & \% HOMOLOGÍA & PRODUCTO & \% HOMOLOGÍA \\
\hline Y9 & 100 & Y4 & 80 \\
\hline Y8 & 90 & Y3 & 80 \\
\hline Y1 & 80 & Y6 & 75 \\
\hline Y10 & 80 & Y11 & 75 \\
\hline Y2 & 80 & Y5 & 75 \\
\hline
\end{tabular}


Cuando se utilizó el iniciador RAPD2, los $S$. thermophilus aislados de los diferentes yogures presentaron una gran homología entre sí (Figura 37) aunque inferior que con el anterior iniciador utilizado, diferenciándose tres perfiles distintos que comparten dos bandas. Los perfiles presentaron un número de banda entre 2 y 10 con pesos moleculares oscilantes entre 2000 y 500 pb.

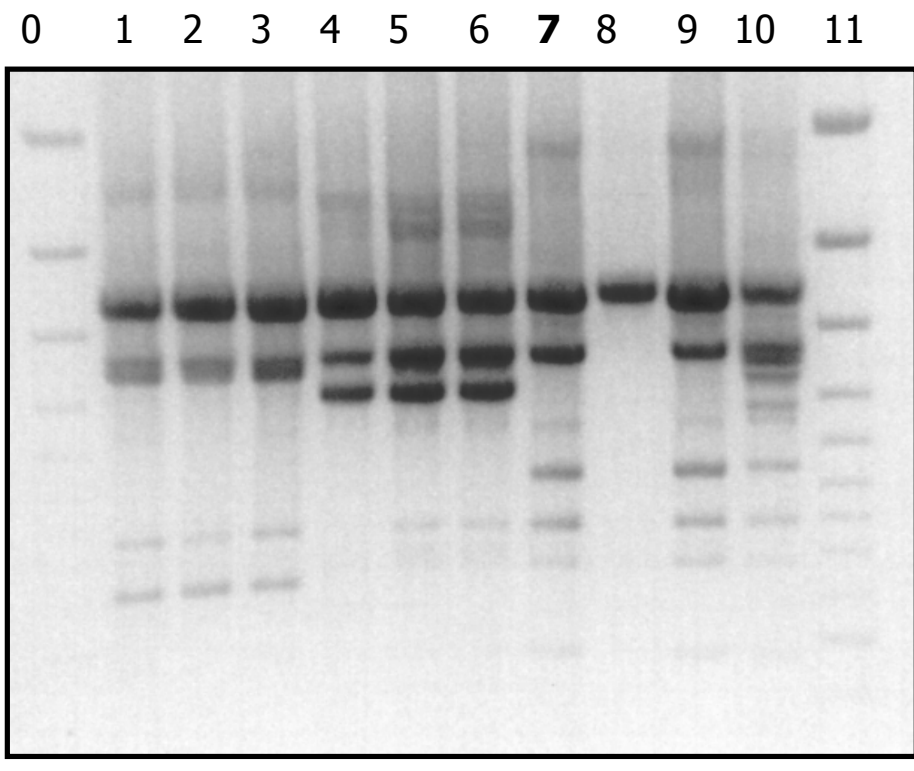
0.- Marcador de peso molecular 100pb
1.- Y10
2.- Y1
3.- Y3
4.- Y11
5.- Y5
6.- Y6
7.- Y7
8.- Y8
9.- Y9
10.- Y2
11.- Marcador de peso molecular 100pb

Figura 37. Perfiles obtenidos mediante RAPDs de bacterias del género Streptococcus con el iniciador RAPD2

Nuevamente, se observó que el perfil de bandas de las cepas de $S$. thermophilus de $\mathrm{Y} 7$ e $\mathrm{Y} 9$ es idéntico y distinto al resto de los perfiles obtenidos. La figura 38 muestra los porcentajes de homología entre todas las cepas de estreptococos de los distintos productos usando el iniciador o primer RAPD2 mientras que la tabla 32 muestra el porcentaje de homología únicamente frente a la cepa del producto $\mathrm{Y} 7$. 
Resultados

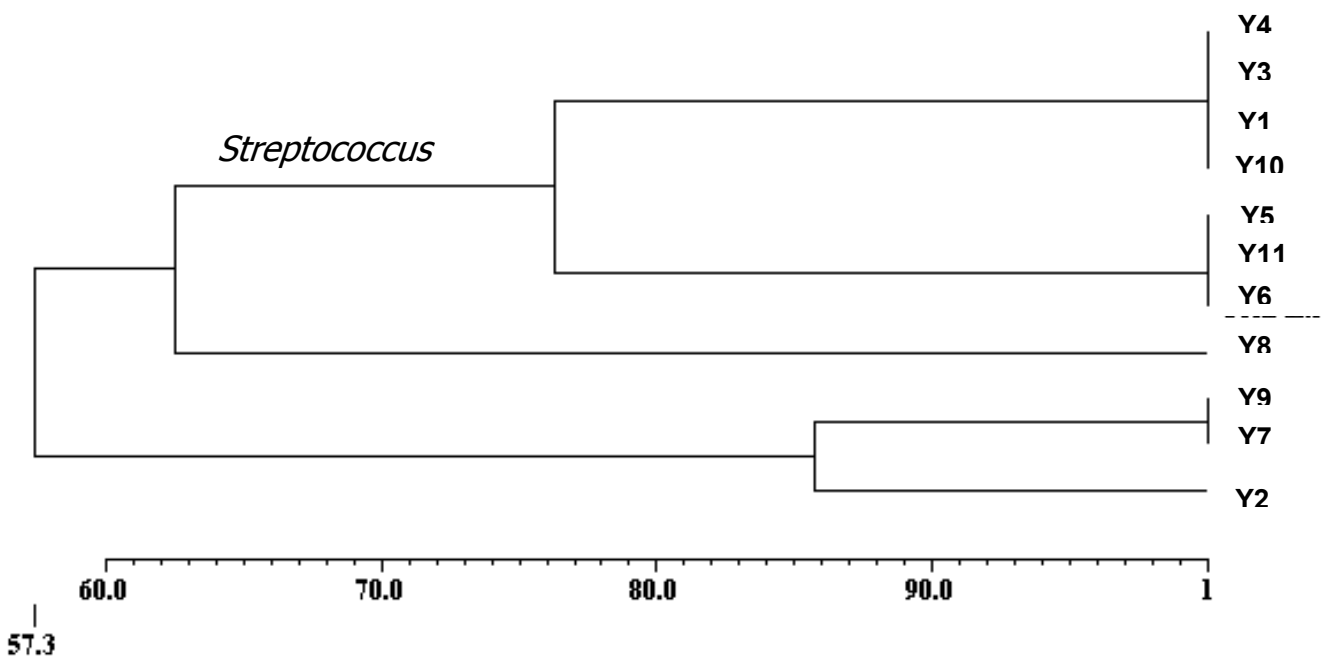

Figura 38. Dendrograma de las cepas de Streptococcus thermophilus empleando el iniciador RAPD2 y el coeficiente de similitud de DICE

TABLA 32. Porcentajes de homología genética entre la cepa de $S$. thermophilus que Y7 y el resto de estreptococos aislados de otras marcas comerciales, obtenido por RAPD mediante el uso del iniciador RAPD2

\begin{tabular}{cccc}
\hline PRODUCTO & \% HOMOLOGÍA & PRODUCTO & \% HOMOLOGÍA \\
\hline Y9 & 100 & Y4 & 65 \\
\hline Y2 & 85 & Y3 & 65 \\
\hline Y1 & 65 & Y6 & 65 \\
\hline Y10 & 65 & Y11 & 65 \\
\hline Y8 & 65 & Y5 & 65 \\
\hline
\end{tabular}

Por tanto, en los RAPDs de los estreptococos aislados de los once yogures naturales obtenidos por ambos iniciadores, se observó que la cepa de $S$. thermophilus empleada por las marcas 7 y 9 tiene probablemente el mismo origen, ya que presentan el mismo perfil entre ellos para los dos iniciadores empleados en el estudio. Del mismo modo, los estreptococos de las marcas 5, 6 y 11 presentaron el mismo perfil entre sí y, en consecuencia, pueden ser la misma cepa. Para los estreptococos de las marcas 1, 3, 4 y 10 se observó la misma situación descrita anteriormente. Sin embargo, los estreptococos de las marcas 2 y 8 se agruparían en diferente similitud dependiendo del iniciador usado. 
Con ambos iniciadores, los lactobacilos presentaron homologías más altas que los estreptococos, con perfiles de bandas mucho más complejos y con un mayor número de bandas.

Aunque existe una gran homología entre todas las cepas de lactobacilos, la cepa de Lactobacillus delbrueckii subsp. bulgaricus contenida en el yogur Y7 muestra un perfil distinto al resto de lactobacilos de los demás yogures aunque muy similar a los perfiles empleados por Y1 e Y10. 
Resultados

2. DETECCIÓN DE Lactobacillus delbrueckii subsp. bulgaricus Y Streptococcus thermophilus MEDIANTE PCR TRADICIONAL y PCR SEMINESTED

\subsection{Detección de $L$. delbrueckii mediante PCR}

Se utilizaron los iniciadores 1 y 2 propuestos por Lick et al. (2001):

$$
\begin{aligned}
& \text { 1: AAT TCC GTC AAC TCC TCA TC } \\
& \text { 2: TGA TCC GCT GCT TCA TTT CA }
\end{aligned}
$$

El alineamiento de estos iniciadores con las secuencias de $L$. delbrueckii subsp. bulgaricus publicadas en el GeneBank, mostraron que Ldelb1 y Ldelb2 resultaban adecuados para su detección (Tabla 1).

Tabla 33. Alineamiento de las secuencias de los iniciadores Ldelb1 y Ldelb2

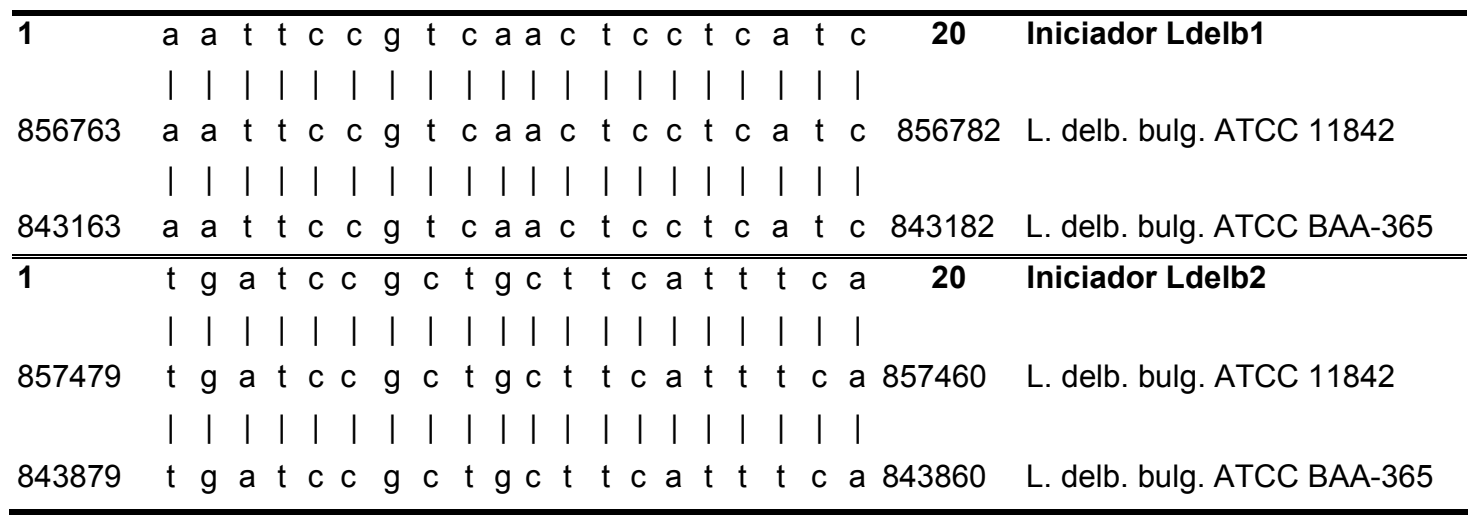

Se observaron las bandas esperadas de $717 \mathrm{pb}$ para todas las cepas $L$. delbrueckii subsp bulgaricus, aisladas de productos comerciales así como para la cepa de referencia (figura 39). 


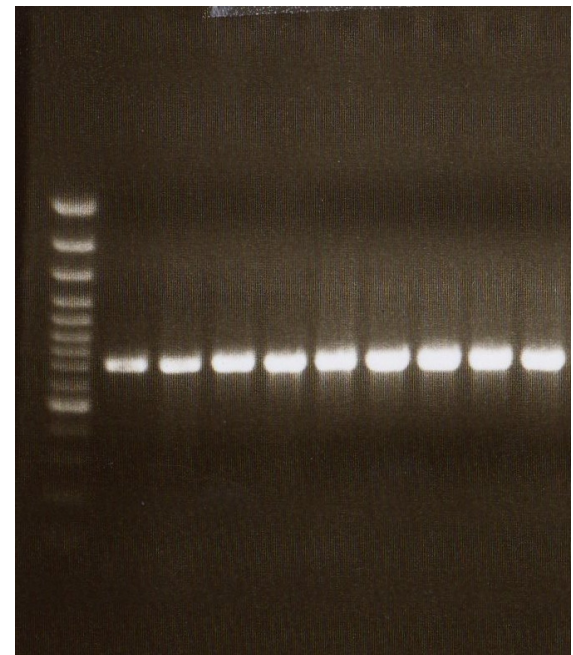

Figura 39. Detección de Lactobacillus delbrueckii subsp bulgaricus aisladas de productos comerciales

Sin embargo, estos iniciadores también alineaban con las secuencias de $L$. delbrueckii subsp. delbrueckii y L. delbrueckii subsp. lactis al $100 \%$ (tablas 34 y 35). En efecto, se observaron las bandas esperadas de 717 pb para estas cepas tras la realización de las reacciones de PCR. Por lo tanto esta reacción de PCR no es específica para $L$. delbrueckii subsp.bulgaricus.

Tabla 34. Alineamiento de las secuencias de los iniciadores Ldelb1 y Ldelb2 con $L$. delbrueckii subsp. delbrueckii

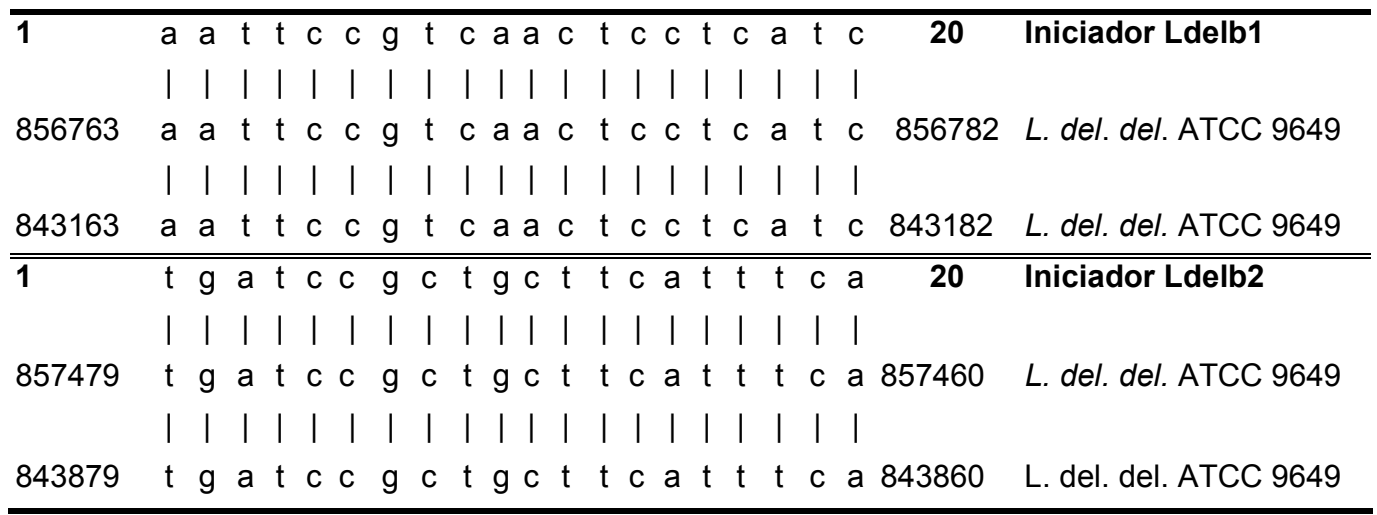


Resultados

Tabla 35. Alineamiento de las secuencias de los iniciadores Ldelb1 y Ldelb2 con $L$.

delbrueckii subsp. lactis

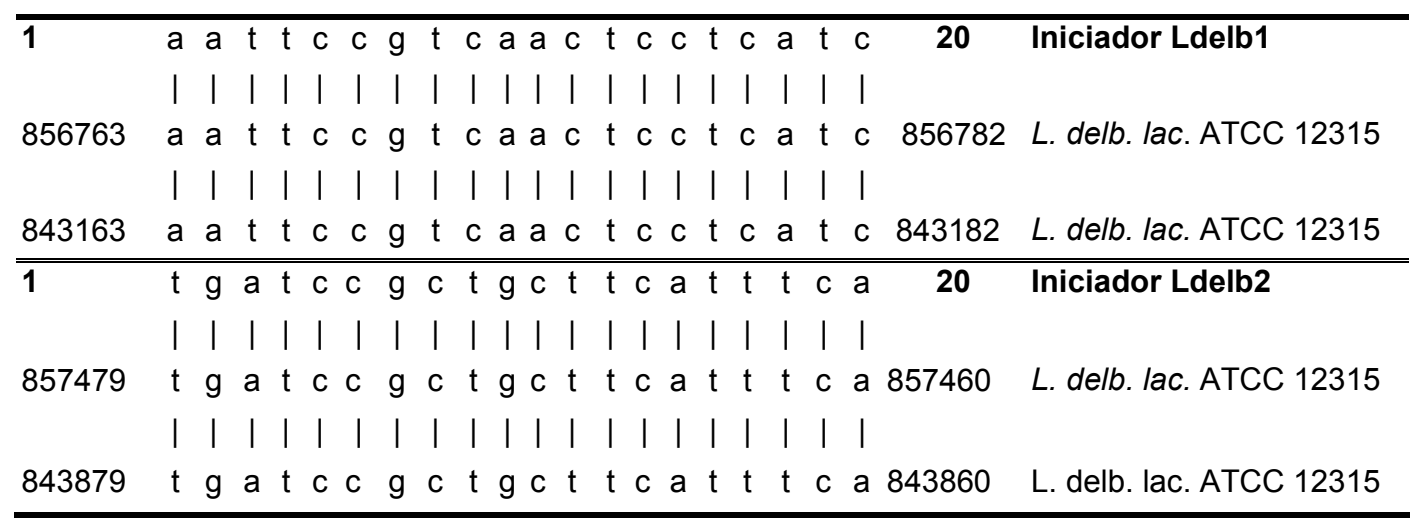

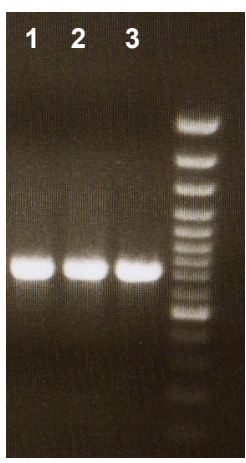

Figura 40. 1) Detección de Lactobacillus delbrueckii subsp bulgaricus, 2) Detección de Lactobacillus delbrueckii subsp lactis, 3) Detección de Lactobacillus delbrueckii subsp delbrueckii

Aunque para el resto de especies de lactobacilos ensayados (tabla 16), entre los cuales se incluyeron varios presentes en la microbiota endógena humana, la reacción de PCR fue negativa, se decidió no utilizar estos iniciadores para los ensayos in vivo ya que, las subespecies lactis y delbrueckii, pese a no ser endógenas, podrían formar parte de la microbiota intestinal por alguna circunstancia $y$, por lo tanto, inducir a error en un estudio in vivo si se utilizaran estos iniciadores. Se podrían obtener falsos positivos por la detección de esas dos cepas. 


\subsection{Detección de $L$. delbrueckii subsp bulgaricus mediante PCR seminested}

Se comprobó la validez del protocolo de PCR seminested (Lick et al., 2000) para detectar de forma específica $L$. delbrueckii subsp bulgaricus a nivel se subespecie.

El alineamiento de los iniciadores seleccionados con las secuencias de $L$. delbrueckii subsp. bulgaricus publicadas en el GeneBank mostraron que estos iniciadores utilizados en este estudio, LdelbF, LdelbR1 y LdelbR2 resultaban adecuados para la detección de la subespecie (Tabla 1). Además los iniciadores LdelbR2 y LdelbF resultaron solamente específicos para las subespcie bulgaricus, coincidiendo LdelbR1 con el iniciador 2 descrito anteriormente en la PCR simple.

LdelbF: CCTCATCAACCGGGGCT

LdelbR1: TGA TCC GCT GCT TCA TTT CA

LdelbR2: CGC CCG GGT GAA GGT G

Tabla 36. Alineamiento de las secuencias de los iniciadores LdelbF, LdelbR1 y LdelbR2

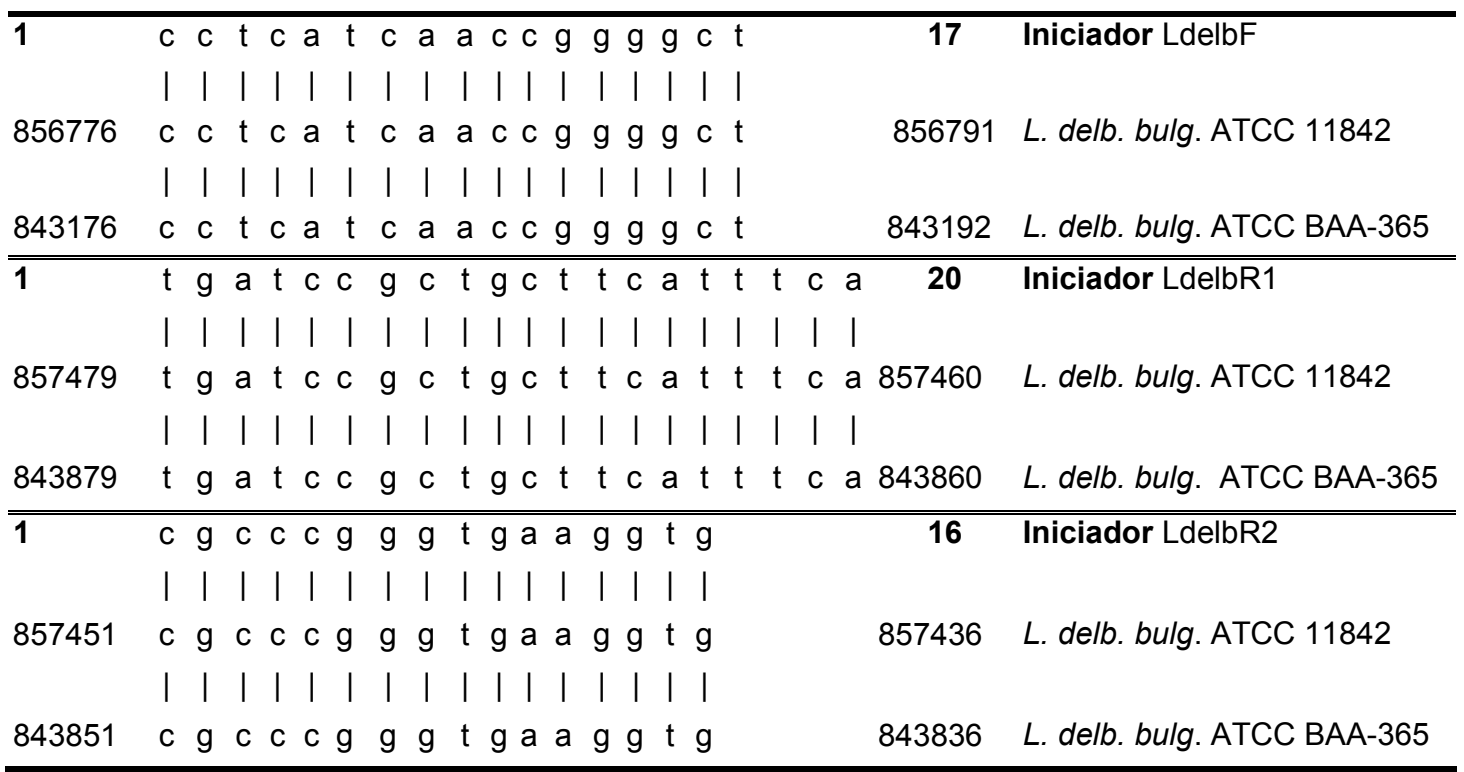


Los iniciadores LdelbR2 y LdelbF utilizados resultaron completamente específicos, corroborando el análisis teórico. Se obtuvo una la banda esperada de 678 pb para la detección de L. delbrueckii subsp. bulgaricus. Se comprobó la especificidad con el resto de cepas de lactobacilos indicadas en la tabla 16. Estas especies no mostraron banda cuando se sometieron a esta PCR empleando estos iniciadores y las condiciones de amplificación (Figura 41).

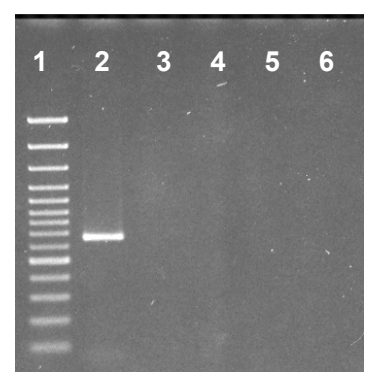

Figura 41. Detección de L. delbrueckii subsp. bulgaricus por PCR seminested 1) marcador pesos moleculares (100pb), 2) L. delbrueckii subsp. bulgaricus, 3-6) otros lactobacilos

\subsection{Detección de S. thermophilus mediante PCR}

El alineamiento de los iniciadores seleccionados $\mathrm{TH}_{1}$ y $\mathrm{TH} 2$ con las secuencias de $S$. thermophilus publicadas en el GeneBank mostró que los iniciadores resultaban específicos para la detección de esta bacteria (Tabla 37). 
Tabla 37. Alineamiento de las secuencias de los iniciadores TH1 y TH2

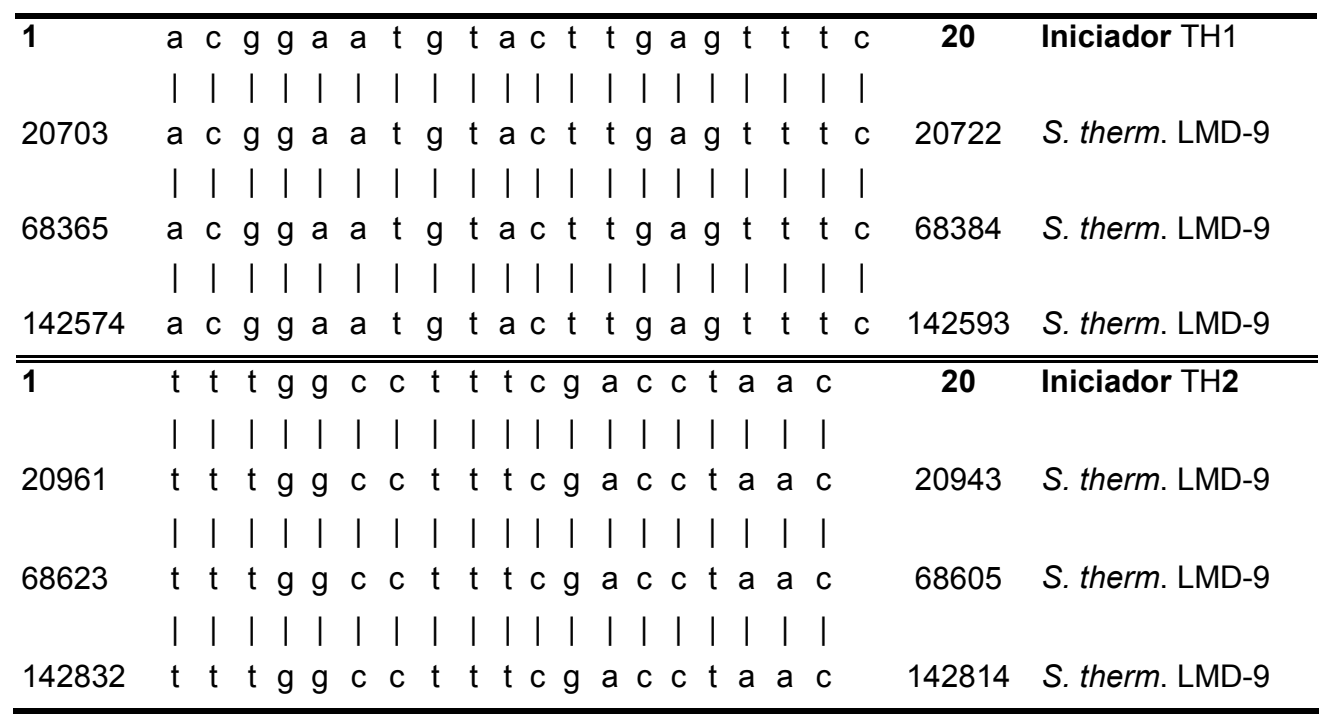

Los primeros ensayos se realizaron a una temperatura de $51^{\circ} \mathrm{C}$, que fue aumentándose de $1^{\circ} \mathrm{C}$ en $1^{\circ} \mathrm{C}$ hasta $56^{\circ} \mathrm{C}$, para obtener la temperatura óptima de unión de los iniciadores lo mas restrictiva posible. La temperatura de unión de $55^{\circ} \mathrm{C}$ resultó ser la óptima. Finalmente, las condiciones adoptadas fueron las siguientes:

\begin{tabular}{ccc}
\hline $\mathbf{N}^{\circ}$ ciclos & Temperaturas y tiempos & Proceso \\
\hline \multirow{2}{*}{1 ciclo } & $92^{\circ} \mathrm{C}$ durante $2 \mathrm{~min}$ & Desnaturalización \\
\cline { 2 - 3 } & $95^{\circ} \mathrm{C}$ durante $30 \mathrm{~s}$ & Desnaturalización \\
\hline 35 ciclos & $55^{\circ} \mathrm{C}$ durante $30 \mathrm{~s}$ & Unión al iniciador \\
\cline { 2 - 3 } & $72^{\circ} \mathrm{C}$ durante $30 \mathrm{~s}$ & Extensión del producto \\
\hline 1 ciclo & $72^{\circ} \mathrm{C}$ durante $2 \mathrm{~min}$ & Extensión del producto \\
\hline
\end{tabular}

La reacción de PCR resultó positiva para todas las cepas de $S$. thermophilus aisladas de productos comerciales así como para la cepa de referencia de esta bacteria (ver tabla 16). 


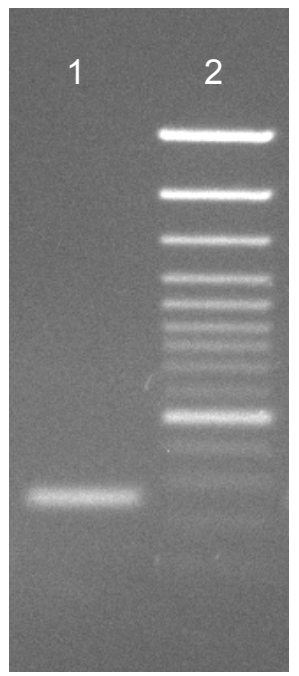

Figura 42. Detección de Streptococcus thermophilus por PCR 1) Streptococcus thermophilus aislado del producto $Y 7,2$ ) marcador pesos moleculares (100pb)

La especificidad de los iniciadores Th1 y TH2 para $S$. thermophilus se comprobó con las otras especies enumeradas en el apartado 2.1 (tabla 16). Se observó la banda esperada de 259 pares de bases solamente en el caso de esta especie. No hubo banda de amplificación ni para las especies más próximas genéticamente como $S$. intermedius ni para otras bacterias ensayadas como Enterococcus faecalis y Enterococcus faecium. 


\section{PUESTA A PUNTO DE MÉTODO COMBINADO DVC-FISH PARA LA DETECCIÓN DE CÉLULAS VIABLES DE Lactobacillus delbrueckii subsp. bulgaricus $\mathrm{Y}$ Streptococcus thermophilus}

\subsection{Detección de células viables de Lactobacillus delbrueckii subsp bulgaricus}

En el procedimiento del DVC (Direct Viable Count), las bacterias deben ser incubadas en un caldo rico en nutrientes y con una concentración óptima de antibióticos que inhiban la replicación celular pero que permita otras vías de síntesis para sobrevivir (Buchrieser and Kaspar, 1993). Por tanto, en estas condiciones las bacterias viables continúan metabolizando nutrientes y se elongan, pero no se replican. Se considerarán células viables aquellas que presenten una longitud igual o mayor de $18 \mu \mathrm{m}$, es decir el doble de la original.

La longitud de las células control de lactobacilos LDY7, aquellas a las que no se le había aplicado ningún antibiótico, varió entre 3 y $9 \mu \mathrm{m}$ de longitud.

La evaluación de los distintos antibióticos, concentraciones y tiempos de incubación mostró grandes diferencias entre los mismos como se puede ver en la tabla 38.

El Ácido Pipemídico resultó no ser apropiado para el ensayo de DVC, ya que a ninguna de las concentraciones ni a los tiempos analizados se observó un aumento destacado del tamaño celular.

El agente antimicrobiano Ciprofloxacino tampoco resultó demasiado efectivo en la elongación de las células a concentraciones bajas, aunque a una concentración de $100 \mu \mathrm{g} / \mathrm{ml}$ se observó que las células aumentaban su tamaño. Antes del tratamiento con el antibiótico, L. delbrueckii subsp. bulgaricus tenía una longitud celular de entre 3 y $9 \mu \mathrm{m}$ y, tras 7 horas de tratamiento con este antibiótico, la longitud de algunas células alcanzaba los $29 \mu \mathrm{m}$. Se observó, además, que tras el tratamiento con este antibiótico aparecían algunas células elongadas pero con morfología en forma helicoidal (figura 48). Tras 24 horas de incubación, también se detectaron algunas células elongadas de $15 \mu \mathrm{m}$ si bien esta longitud no es suficiente para considerar la célula viable de acuerdo al criterio establecido anteriormente. El resto de tiempos y concentraciones evaluadas no modificaron la longitud original. 
Resultados

El Ácido Nalidíxico no resultó efectivo a ninguna de las concentraciones ni tiempos ensayados, lo que coincide con los resultados de otros autores que indican que solamente resulta efectivo para las bacterias Gram- (figuras 52 y 53 ).

Fue la Novobiocina el que produjo la mayor elongación en las células de Lactobacillus delbrueckii subsp. bulgaricus (figuras 44, 45, 46 y 47), a una concentración de $10 \mu \mathrm{g} / \mathrm{ml}$ y tras 7 y 24 horas de incubación, alcanzándose tamaños celulares de hasta 56 y $59 \mu \mathrm{m}$ de longitud respectivamente, lo que quintuplicaría el tamaño de las células control (figura 43). A la concentración de $100 \mu \mathrm{g} / \mathrm{ml}$, pese a ser efectivo a la hora de elongar las células, el número total de bacterias presentes se reducía considerablemente, presentando cierto efecto bactericida. Este efecto no se produjo a la concentración de $10 \mu \mathrm{g} / \mathrm{ml}$.

Por todo ello, se decidió considerar la Novobiocina, a la concentración de 10 $\mu \mathrm{g} / \mathrm{ml}$ como el antibiótico más efectivo para la aplicación de la técnica DVC-FISH para esta bacteria.

Tabla 38. Antibióticos, concentraciones y tiempos de incubación evaluados en la puesta a punto de la técnica DVC-FISH para la detección de células viables de $L$. delbrueckii subsp bulgaricus LDY7 según longitud celular

\begin{tabular}{|c|c|c|c|c|c|}
\hline [conc.] & Tiempo & Ac. nalidíxico & Novobiocina & Ciprofloxacina & Ac. pipemídico \\
\hline & $0 \mathrm{~h}$ & $9 \mu \mathrm{m}$ & $9 \mu \mathrm{m}$ & $9 \mu \mathrm{m}$ & $9 \mu \mathrm{m}$ \\
\hline & $3 \mathrm{~h}$ & $9 \mu \mathrm{m}$ & $9 \mu \mathrm{m}$ & $9 \mu \mathrm{m}$ & $9 \mu \mathrm{m}$ \\
\hline \multirow[t]{4}{*}{$0,5 \mu \mathrm{g} / \mathrm{ml}$} & $7 \mathrm{~h}$ & $9 \mu \mathrm{m}$ & $3 \mu \mathrm{m}$ & $9 \mu \mathrm{m}$ & $9 \mu \mathrm{m}$ \\
\hline & $24 \mathrm{~h}$ & $9 \mu \mathrm{m}$ & $3 \mu \mathrm{m}$ & $9 \mu \mathrm{m}$ & $9 \mu \mathrm{m}$ \\
\hline & $0 \mathrm{~h}$ & $9 \mu \mathrm{m}$ & $9 \mu \mathrm{m}$ & $9 \mu \mathrm{m}$ & $9 \mu \mathrm{m}$ \\
\hline & $3 \mathrm{~h}$ & $9 \mu \mathrm{m}$ & $9 \mu \mathrm{m}$ & $9 \mu \mathrm{m}$ & $9 \mu \mathrm{m}$ \\
\hline \multirow[t]{4}{*}{$1 \mu \mathrm{g} / \mathrm{ml}$} & $7 \mathrm{~h}$ & $9 \mu \mathrm{m}$ & $10 \mu \mathrm{m}$ & $9 \mu \mathrm{m}$ & $9 \mu \mathrm{m}$ \\
\hline & $24 \mathrm{~h}$ & $9 \mu \mathrm{m}$ & $12 \mu \mathrm{m}$ & $9 \mu \mathrm{m}$ & $9 \mu \mathrm{m}$ \\
\hline & $\mathrm{Oh}$ & $9 \mu \mathrm{m}$ & $9 \mu \mathrm{m}$ & $9 \mu \mathrm{m}$ & $9 \mu \mathrm{m}$ \\
\hline & $3 \mathrm{~h}$ & $12 \mu \mathrm{m}$ & $15 \mu \mathrm{m}$ & $11 \mu \mathrm{m}$ & $9 \mu \mathrm{m}$ \\
\hline \multirow[t]{4}{*}{$10 \mu \mathrm{g} / \mathrm{ml}$} & $7 \mathrm{~h}$ & $12 \mu \mathrm{m}$ & $56 \mu \mathrm{m}$ & $12 \mu \mathrm{m}$ & $9 \mu \mathrm{m}$ \\
\hline & $24 \mathrm{~h}$ & $11 \mu \mathrm{m}$ & $59 \mu \mathrm{m}$ & $9 \mu \mathrm{m}$ & $9 \mu \mathrm{m}$ \\
\hline & $\mathrm{Oh}$ & $9 \mu \mathrm{m}$ & $9 \mu \mathrm{m}$ & $9 \mu \mathrm{m}$ & $9 \mu \mathrm{m}$ \\
\hline & $3 \mathrm{~h}$ & $12 \mu \mathrm{m}$ & $16 \mu \mathrm{m}$ & $9 \mu \mathrm{m}$ & $9 \mu \mathrm{m}$ \\
\hline \multirow[t]{2}{*}{$100 \mu \mathrm{g} / \mathrm{ml}$} & $7 \mathrm{~h}$ & $11 \mu \mathrm{m}$ & $50 \mu \mathrm{m}$ & $29 \mu \mathrm{m}$ & $9 \mu \mathrm{m}$ \\
\hline & $24 \mathrm{~h}$ & $12 \mu \mathrm{m}$ & $52 \mu \mathrm{m}$ & $15 \mu \mathrm{m}$ & $9 \mu \mathrm{m}$ \\
\hline
\end{tabular}




\begin{tabular}{llllll}
\hline & $0 \mathrm{~h}$ & $9 \mu \mathrm{m}$ & $9 \mu \mathrm{m}$ & $9 \mu \mathrm{m}$ & $9 \mu \mathrm{m}$ \\
\hline & $3 \mathrm{~h}$ & $9 \mu \mathrm{m}$ & $9 \mu \mathrm{m}$ & $9 \mu \mathrm{m}$ & $9 \mu \mathrm{m}$ \\
\hline $1000 \mu \mathrm{g} / \mathrm{ml}$ & $7 \mathrm{~h}$ & $9 \mu \mathrm{m}$ & $10 \mu \mathrm{m}$ & $9 \mu \mathrm{m}$ & $9 \mu \mathrm{m}$ \\
\hline & $24 \mathrm{~h}$ & $9 \mu \mathrm{m}$ & $9 \mu \mathrm{m}$ & $9 \mu \mathrm{m}$ & $9 \mu \mathrm{m}$ \\
\hline
\end{tabular}
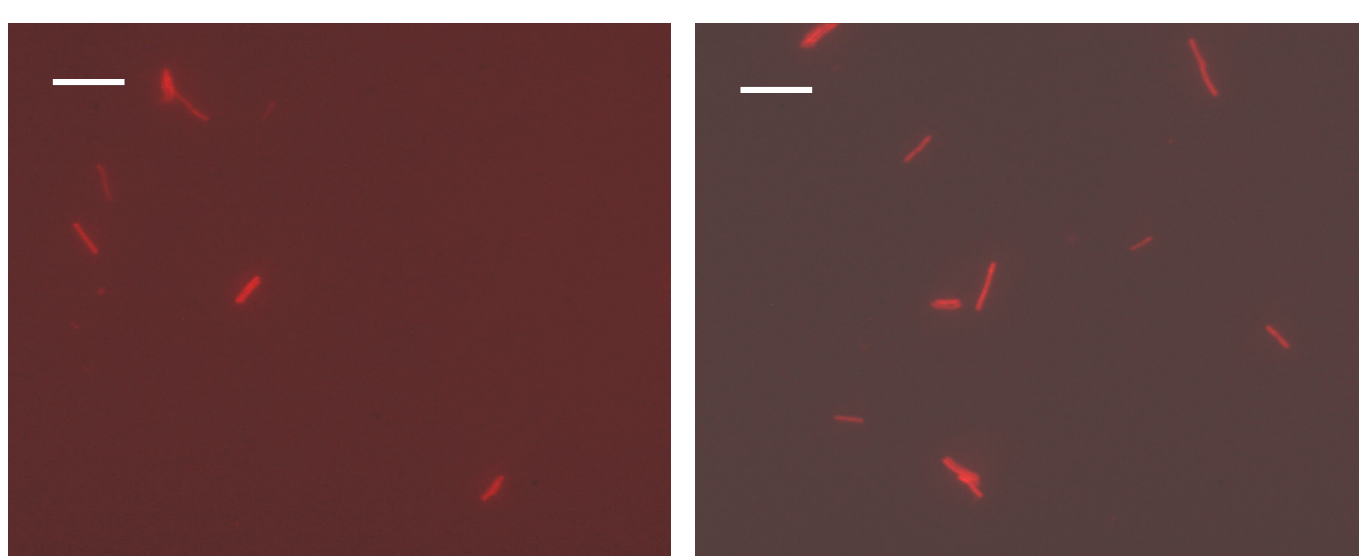

Figura 43. Control negativo del DVC-FISH para Lactobacillus delbrueckii subsp. bulgaricus LDY7 mostrando el tamaño normal de la célula (barra: $10 \mu \mathrm{m}$ )

Las fotografías siguientes muestran células de L. delbrueckii subsp bulgaricus tratadas con varias concentraciones de distintos antibióticos durante diferentes tiempos y observadas mediante hibridación in situ y SEM.
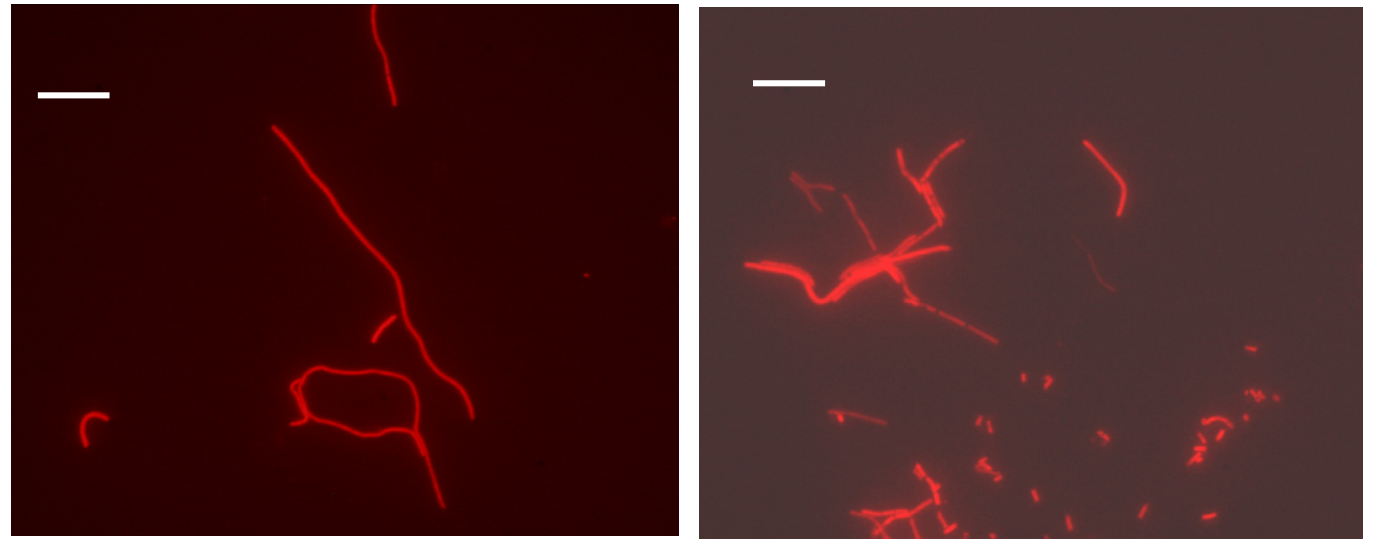

Figura 44. Lactobacillus delbrueckii subsp bulgaricus LDY7 incubado con una concentración de $10 \mu \mathrm{g} / \mathrm{ml}$ de novobiocina durante $7 \mathrm{~h}$ detectado mediante microscopía de fluorescencia con la sonda LDE marcada con CY3 (barra: $10 \mu \mathrm{m}$ ) 

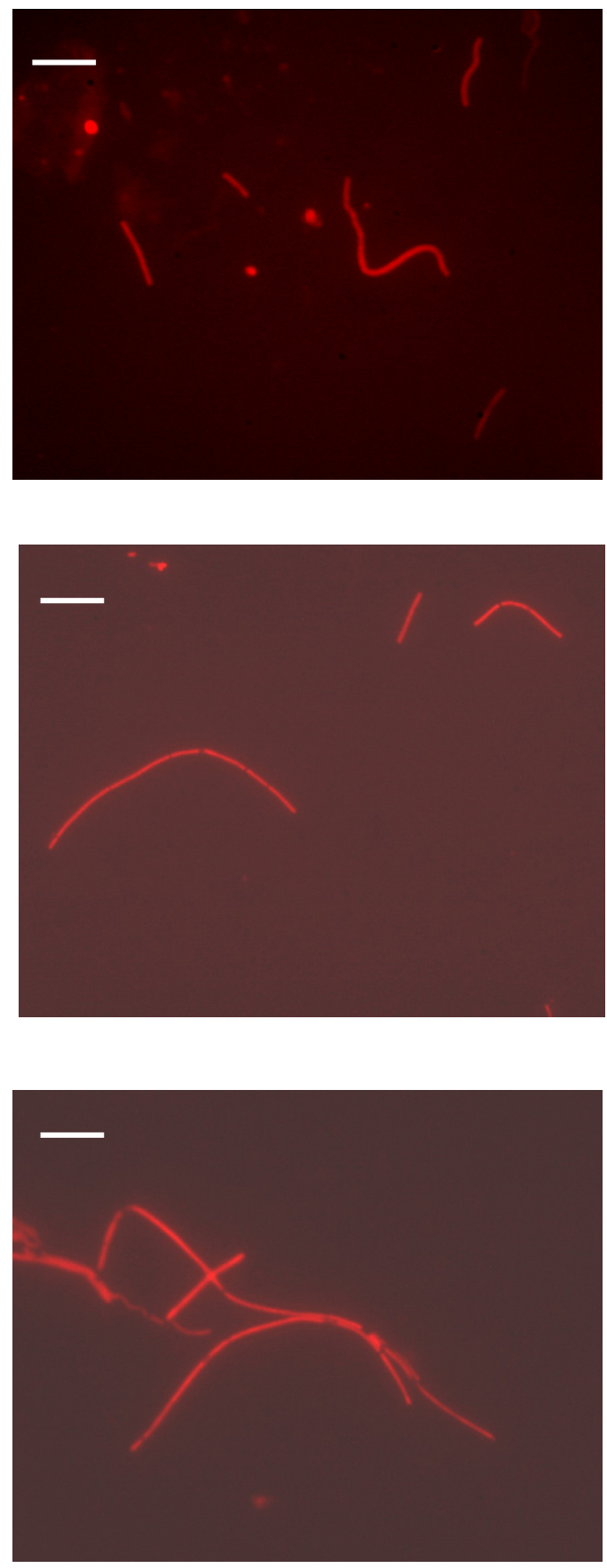

Figura 45. Lactobacillus delbrueckii subsp bulgaricus LDY7 incubado con una concentración de $10 \mu \mathrm{g} / \mathrm{ml}$ de novobiocina durante $24 \mathrm{~h}$ detectado mediante microscopía de fluorescencia con la sonda LDE marcada con CY3 (barra: $10 \mu \mathrm{m}$ )

Figura 46. Lactobacillus delbrueckii subsp bulgaricus LDY7 incubado con una concentración de $100 \mu \mathrm{g} / \mathrm{ml}$ de novobiocina durante $7 \mathrm{~h}$ detectado mediante microscopía de fluorescencia con la sonda LDE marcada con CY3 (barra: $10 \mu \mathrm{m}$ )

Figura 47. Lactobacillus delbrueckii subsp bulgaricus LDY7 incubado con una concentración de $100 \mu \mathrm{g} / \mathrm{ml}$ de novobiocina durante $24 \mathrm{~h}$ detectado mediante microscopía de fluorescencia con la sonda LDE marcada con CY3 (barra: $10 \mu \mathrm{m}$ ) 


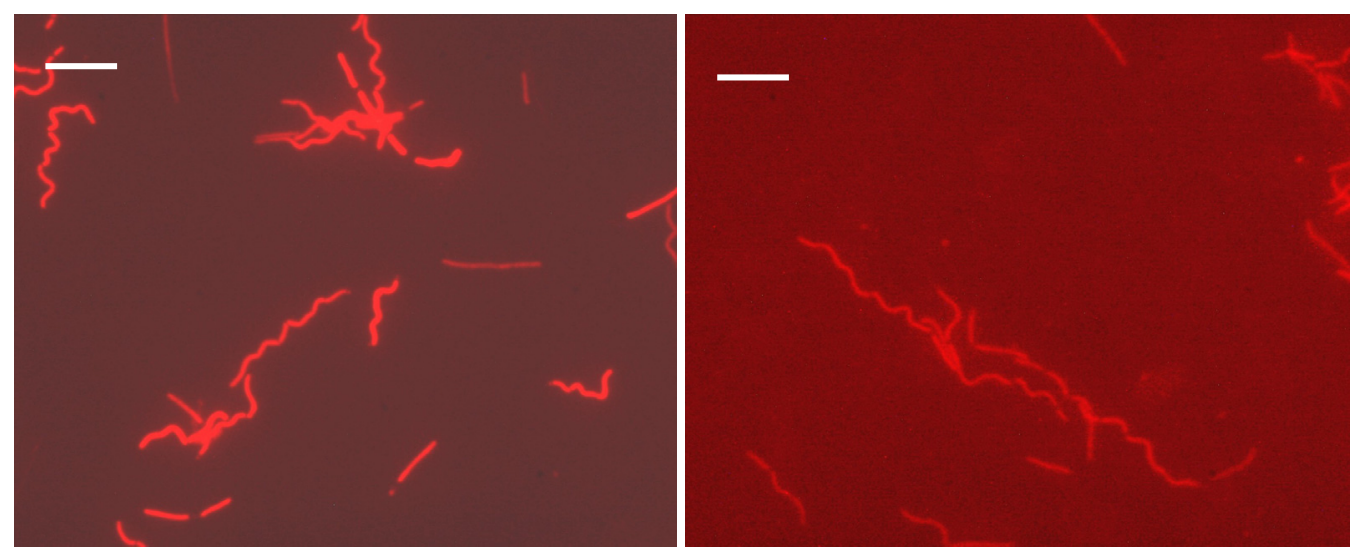

Figura 48. Lactobacillus delbrueckii subsp bulgaricus LDY7 incubado con una concentración de $100 \mu \mathrm{g} / \mathrm{ml}$ de ciprofloxacino durante $7 \mathrm{~h}$ detectado mediante microscopía de fluorescencia con la sonda LDE marcada con CY3 (barra: $10 \mu \mathrm{m}$ )

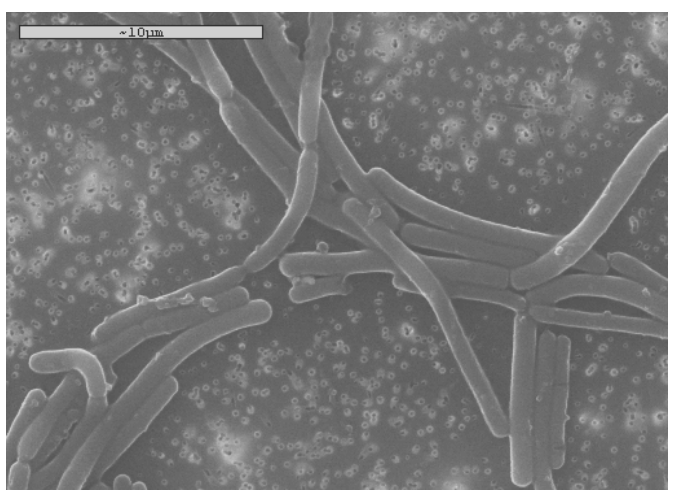

Figura 49. Control de Lactobacillus delbrueckii subsp bulgaricus LDY7 incubado en MRS (sin antibiótico) durante $24 \mathrm{~h}$ detectado mediante microscopía de barrido
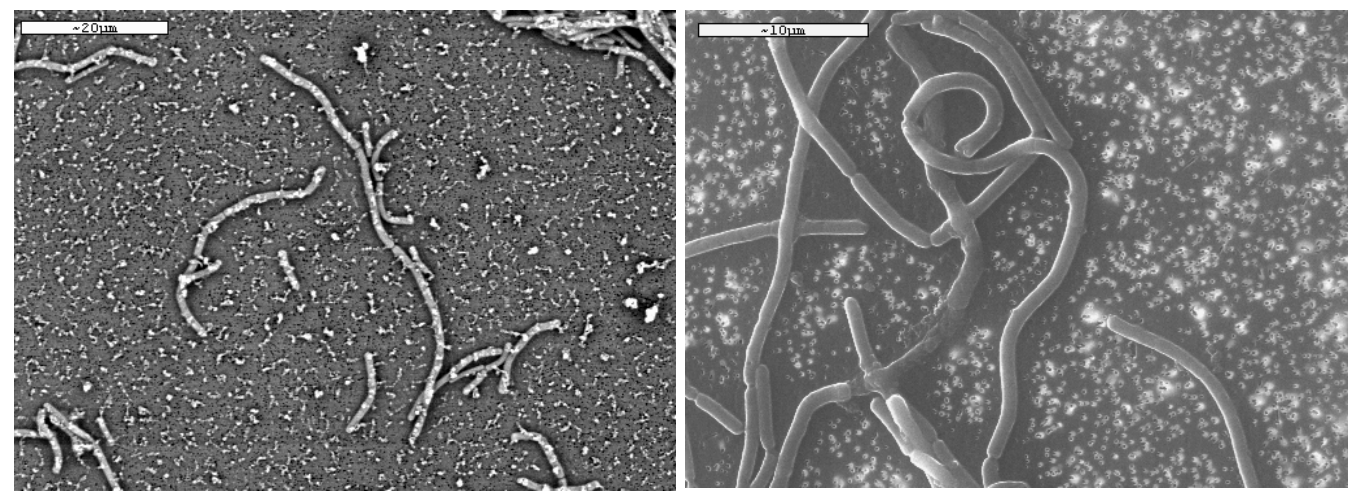

Figura 50. L. delbrueckii subsp bulgaricus LDY7 incubado con una concentración de 10 $\mu \mathrm{g} / \mathrm{ml}$ de novobiocina durante $7 \mathrm{~h}$ detectado mediante microscopía de barrido 
Resultados
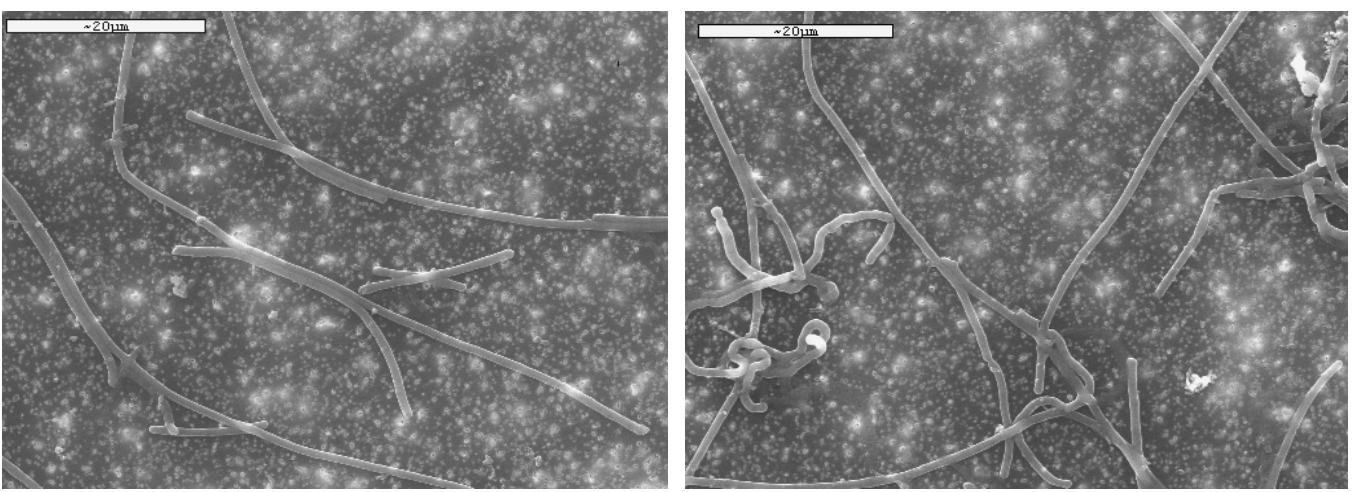

Figura 51. L. delbrueckii subsp bulgaricus LDY7 incubado con una concentración de 10 $\mu \mathrm{g} / \mathrm{ml}$ de novobiocina durante $24 \mathrm{~h}$ detectado mediante microscopía de barrido

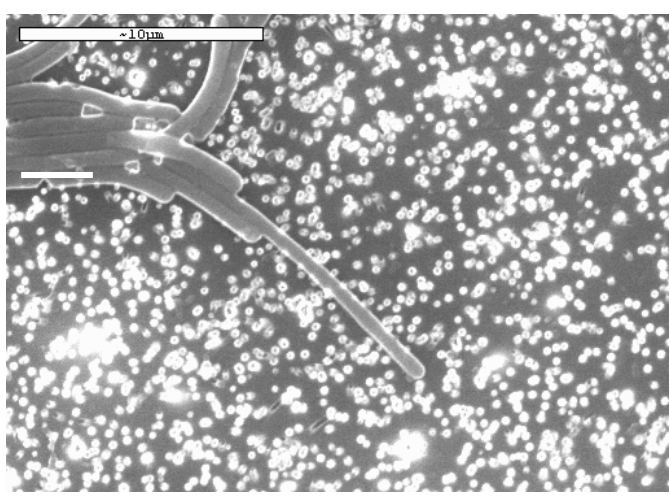

Figura 52. Lactobacillus delbrueckii subsp bulgaricus LDY7 incubado con una concentración de $100 \mu \mathrm{g} / \mathrm{ml}$ de ácido nalidíxico durante $7 \mathrm{~h}$ detectado mediante microscopía de barrido
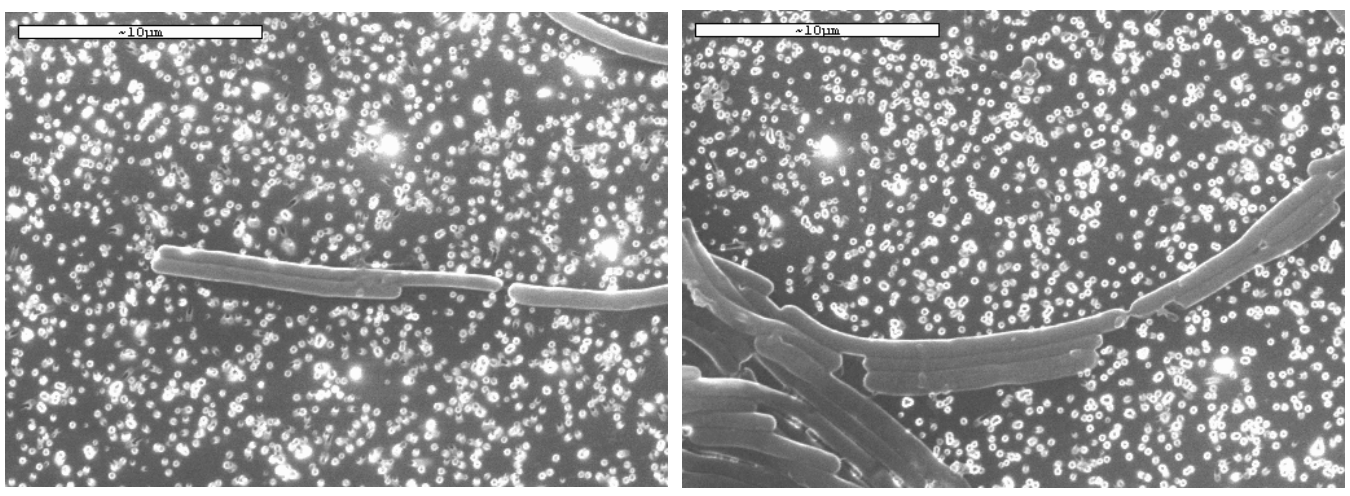

Figura 53. Lactobacillus delbrueckii subsp. bulgaricus LDY7 incubado con una concentración de $100 \mu \mathrm{g} / \mathrm{ml}$ de ácido nalidíxico durante $24 \mathrm{~h}$ detectado mediante microscopía de barrido 

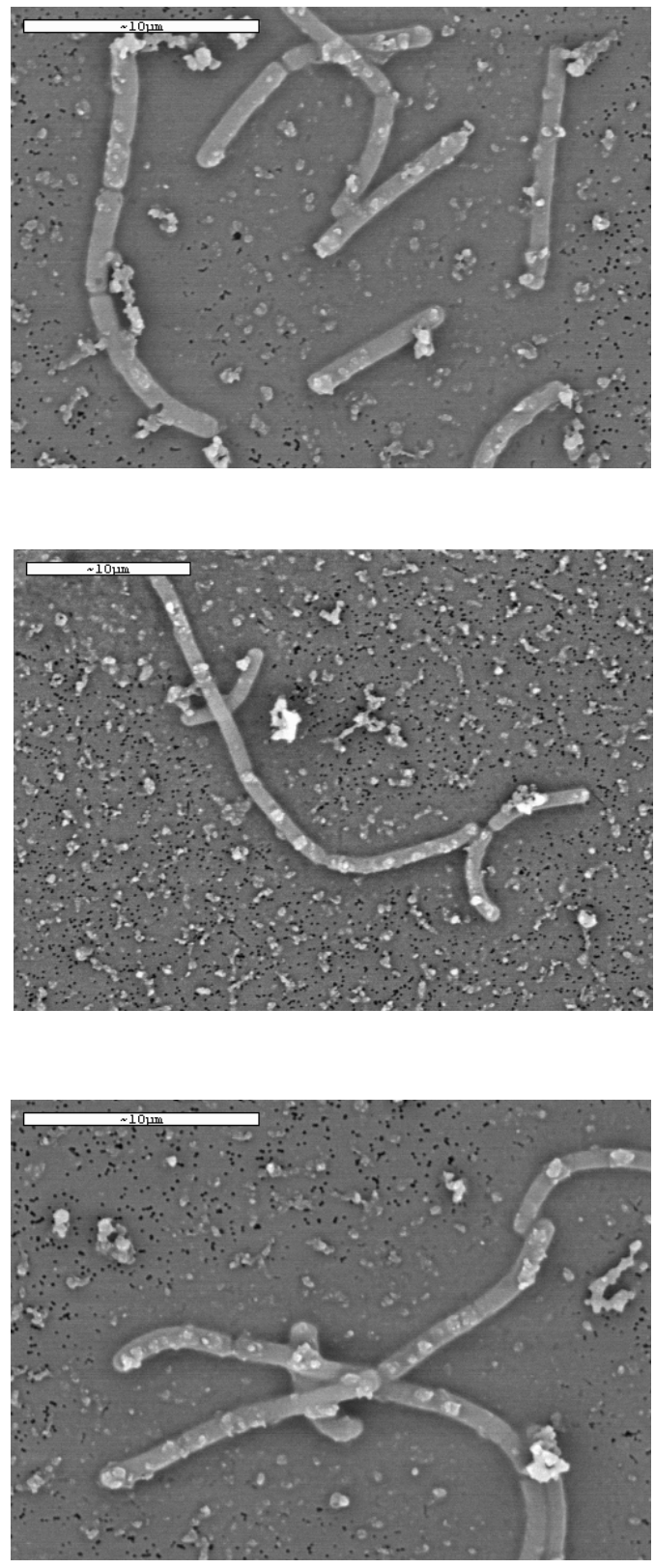

Figura 54. Lactobacillus delbrueckii subsp. bulgaricus LDY7 incubado con una concentración de $10 \mu \mathrm{g} / \mathrm{ml}$ de ciprofloxacino durante $7 \mathrm{~h}$ detectado mediante microscopía de barrido

Figura 55. Lactobacillus delbrueckii subsp. bulgaricus LDY7 incubado con una concentración de $100 \mu \mathrm{g} / \mathrm{ml}$ de ciprofloxacino durante $7 \mathrm{~h}$ detectado mediante microscopía de barrido

Figura 56. Lactobacillus delbrueckii subsp. bulgaricus LDY7 incubado con una concentración de $100 \mu \mathrm{g} / \mathrm{ml}$ de ciprofloxacino durante $24 \mathrm{~h}$ detectado mediante microscopía de barrido 
Resultados

\subsection{Detección de células viables de S. thermophilus}

En el caso de $S$. thermophilus, la aplicación del DVC inhibe la replicación celular pero en lugar de una elongación se produce un aumento del tamaño celular que se cuantificará por medición del diámetro. Se considerarán células viables aquellas que presenten un diámetro superior a 1,6 $\mu \mathrm{m}$, es decir el doble del habitual $(0,8 \mu \mathrm{m})$.

Para la puesta a punto de este método, se utilizó la cepa STY7, aislada del producto Y7. Todos los antibióticos, concentraciones y tiempos de incubación ensayados para S. thermophilus aparecen en la tabla 39.

El Ácido Pipemídico resultó no ser apropiado para el ensayo del DVC ya que a ninguna de las concentraciones ni a los tiempos analizados se observó un aumento destacado del tamaño celular.

El agente antimicrobiano Ciprofloxacino tampoco fue demasiado efectivo en el aumento del diámetro de las células a bajas concentraciones, aunque a una concentración de $100 \mu \mathrm{g} / \mathrm{ml}$ se observó un ligero incremento del tamaño, alcanzándose diámetros celulares de 1,2 $\mu \mathrm{m}$. estos valores no fueron por lo tanto suficientes para discriminar entre las células viables y las no viables.

El Ácido Nalidíxico produjo aumento del tamaño celular a concentraciones de 10 y $100 \mu \mathrm{g} / \mathrm{ml}$ y los tiempos 7 y 24 horas pero no de forma significativa para poder diferenciar entre los estreptococos vivos y muertos.

La Novobiocina resultó ser el antibiótico más efectivo como inhibidor de la ADN-girasa para el caso del $S$. thermophilus. La concentración y el tiempo de incubación óptimos de este antibiótico fue de $10 \mu \mathrm{g} / \mathrm{ml}$ y 7 horas respectivamente. Se observó un importante aumento del tamaño celular así como un incremento significativo en la fluorescencia de las células viables frente a las no viables como puede apreciarse en la figura 57.

Antes del tratamiento con novobiocina, $S$. thermophilus tenía un diámetro celular de hasta 0,8 $\mu \mathrm{m}$. Tras 7 horas de incubación con este antibiótico, a una concentración de $10 \mu \mathrm{g} / \mathrm{ml}$, la longitud de algunas células alcanzó los 2,3 $\mu \mathrm{m}$ de diámetro (figura 59). Del mismo modo, a las 24 horas también se detectaron células viables de 2,2 $\mu \mathrm{m}$ pero se eligió un tratamiento de 7 horas para minimizar el tiempo 
del proceso así como el contacto con el antibiótico. El resto de tiempos y concentraciones evaluadas no modificaron significativamente el diámetro original.

Tabla 39. Antibióticos, concentraciones y tiempos de incubación evaluados en la puesta a punto de la técnica DVC-FISH para la detección de células viables de Streptococcus thermophilus STY7 según diámetro celular

\begin{tabular}{|c|c|c|c|c|c|}
\hline [conc.] & Tiempo & Ac. nalidíxico & Novobiocina & Ciprofloxacino & Ac. pipemídico \\
\hline \multirow{4}{*}{$0,5 \mu \mathrm{g} / \mathrm{ml}$} & $\mathrm{Oh}$ & $0,8 \mu \mathrm{m}$ & $0,8 \mu \mathrm{m}$ & $0,8 \mu \mathrm{m}$ & $0,8 \mu \mathrm{m}$ \\
\hline & $3 \mathrm{~h}$ & $0,8 \mu \mathrm{m}$ & $0,8 \mu \mathrm{m}$ & $0,8 \mu \mathrm{m}$ & $0,8 \mu \mathrm{m}$ \\
\hline & $7 \mathrm{~h}$ & $0,8 \mu \mathrm{m}$ & $0,8 \mu \mathrm{m}$ & $0,8 \mu \mathrm{m}$ & $0,8 \mu \mathrm{m}$ \\
\hline & $24 \mathrm{~h}$ & $0,8 \mu \mathrm{m}$ & $0,8 \mu \mathrm{m}$ & $0,8 \mu \mathrm{m}$ & $0,8 \mu \mathrm{m}$ \\
\hline \multirow{4}{*}{$1 \mu \mathrm{g} / \mathrm{ml}$} & $\mathrm{Oh}$ & $0,8 \mu \mathrm{m}$ & $0,8 \mu \mathrm{m}$ & $0,8 \mu \mathrm{m}$ & $0,8 \mu \mathrm{m}$ \\
\hline & $3 \mathrm{~h}$ & $0,8 \mu \mathrm{m}$ & $0,8 \mu \mathrm{m}$ & $0,8 \mu \mathrm{m}$ & $0,8 \mu \mathrm{m}$ \\
\hline & $7 \mathrm{~h}$ & $0,8 \mu \mathrm{m}$ & $0,8 \mu \mathrm{m}$ & $0,8 \mu \mathrm{m}$ & $0,8 \mu \mathrm{m}$ \\
\hline & $24 \mathrm{~h}$ & $0,8 \mu \mathrm{m}$ & $0,8 \mu \mathrm{m}$ & $0,8 \mu \mathrm{m}$ & $0,8 \mu \mathrm{m}$ \\
\hline \multirow{4}{*}{$10 \mu \mathrm{g} / \mathrm{ml}$} & $\mathrm{Oh}$ & $0,8 \mu \mathrm{m}$ & $0,8 \mu \mathrm{m}$ & $0,8 \mu \mathrm{m}$ & $0,8 \mu \mathrm{m}$ \\
\hline & $3 \mathrm{~h}$ & $1 \mu \mathrm{m}$ & $1,2 \mu \mathrm{m}$ & $0,8 \mu \mathrm{m}$ & $0,8 \mu \mathrm{m}$ \\
\hline & $7 \mathrm{~h}$ & $1,2 \mu \mathrm{m}$ & $2,3 \mu \mathrm{m}$ & $0,8 \mu \mathrm{m}$ & $0,8 \mu \mathrm{m}$ \\
\hline & $24 \mathrm{~h}$ & $1,5 \mu \mathrm{m}$ & $2,2 \mu \mathrm{m}$ & $0,8 \mu \mathrm{m}$ & $0,8 \mu \mathrm{m}$ \\
\hline \multirow{4}{*}{$100 \mu \mathrm{g} / \mathrm{ml}$} & $\mathrm{Oh}$ & $0,8 \mu \mathrm{m}$ & $0,8 \mu \mathrm{m}$ & $0,8 \mu \mathrm{m}$ & $0,8 \mu \mathrm{m}$ \\
\hline & $3 \mathrm{~h}$ & $1,2 \mu \mathrm{m}$ & $2,2 \mu \mathrm{m}$ & $1,2 \mu \mathrm{m}$ & $0,8 \mu \mathrm{m}$ \\
\hline & $7 \mathrm{~h}$ & $1,2 \mu \mathrm{m}$ & $2,2 \mu \mathrm{m}$ & $1,2 \mu \mathrm{m}$ & $0,8 \mu \mathrm{m}$ \\
\hline & $24 \mathrm{~h}$ & $1,5 \mu \mathrm{m}$ & $2,2 \mu \mathrm{m}$ & $1,1 \mu \mathrm{m}$ & $0,8 \mu \mathrm{m}$ \\
\hline \multirow{4}{*}{$1000 \mu \mathrm{g} / \mathrm{ml}$} & $\mathrm{Oh}$ & $0,8 \mu \mathrm{m}$ & $0,8 \mu \mathrm{m}$ & $0,8 \mu \mathrm{m}$ & $0,8 \mu \mathrm{m}$ \\
\hline & $3 \mathrm{~h}$ & $1 \mu \mathrm{m}$ & $1 \mu \mathrm{m}$ & $0,8 \mu \mathrm{m}$ & $0,8 \mu \mathrm{m}$ \\
\hline & $7 \mathrm{~h}$ & $1 \mu \mathrm{m}$ & $1 \mu \mathrm{m}$ & $0,8 \mu \mathrm{m}$ & $0,8 \mu \mathrm{m}$ \\
\hline & $24 \mathrm{~h}$ & $1 \mu \mathrm{m}$ & $1 \mu \mathrm{m}$ & $0,8 \mu \mathrm{m}$ & $0,8 \mu \mathrm{m}$ \\
\hline
\end{tabular}

Las fotografías siguientes muestran células de $S$. thermophilus incubadas con varias concentraciones de antibióticos a diferentes tiempos y observadas mediante FISH y SEM. La barra blanca en cada una de ellas indica una longitud de $10 \mu \mathrm{m}$. 

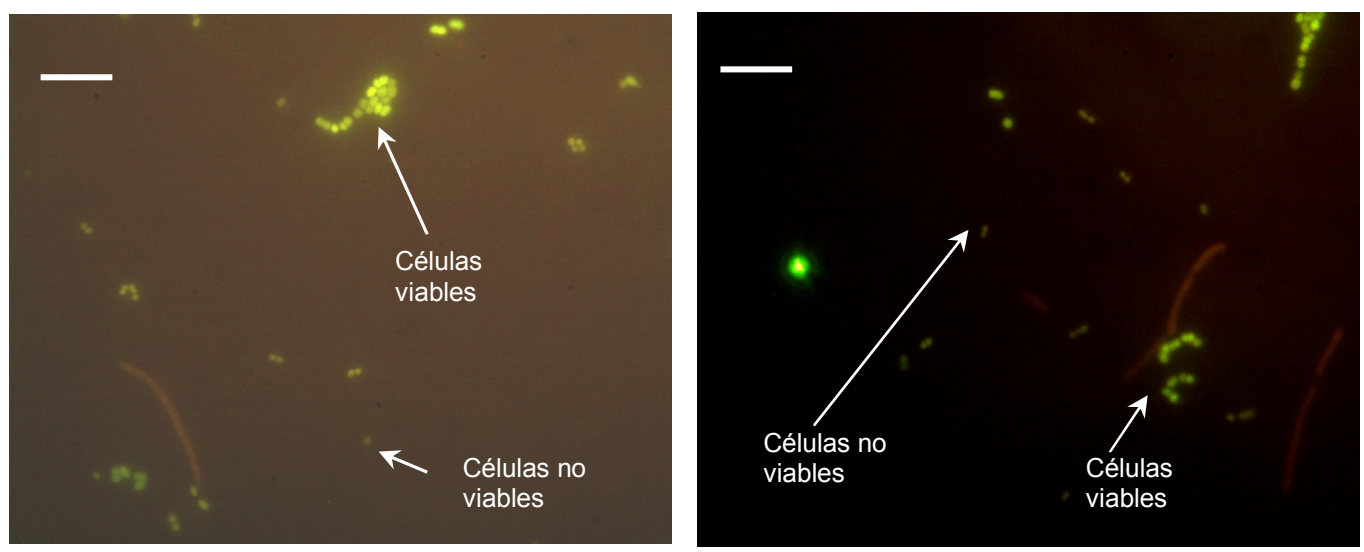

Figura 57. Streptococcus thermophilus STY7 incubado con una concentración de $10 \mu \mathrm{g} / \mathrm{ml}$ de novobiocina durante $7 \mathrm{~h}$ detectado mediante microscopía de fluorescencia con la sonda STH23S marcada con FLUOS (barra: $10 \mu \mathrm{m}$ )
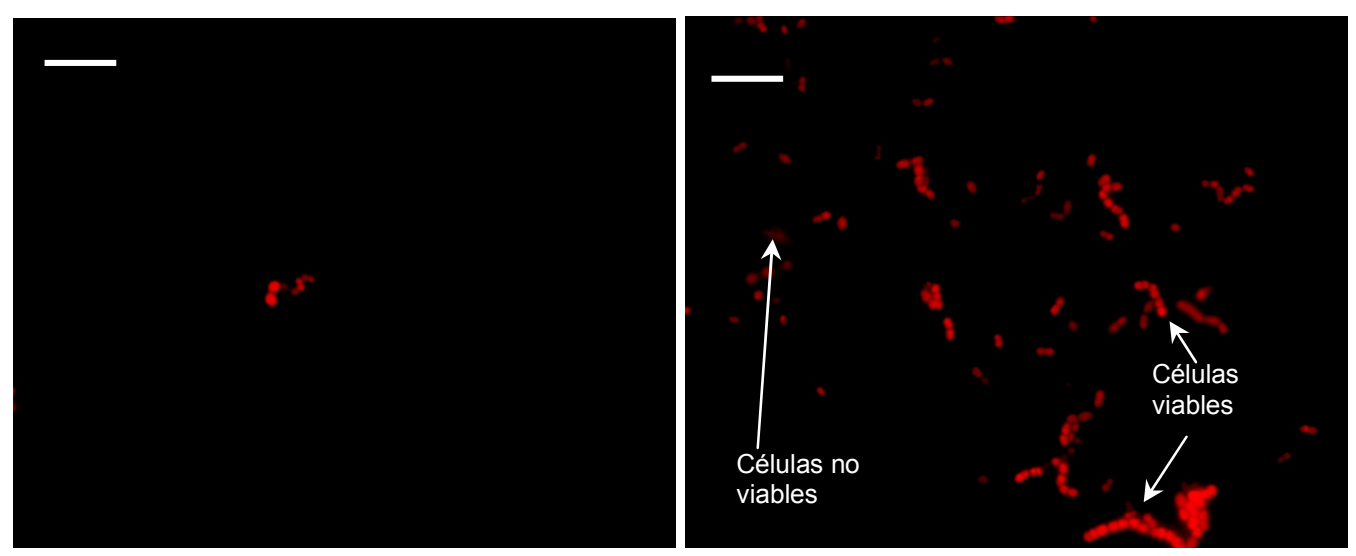

Figura 58. Streptococcus thermophilus STY7 incubado con una concentración de 10 $\mu \mathrm{g} / \mathrm{ml}$ de novobiocina durante $7 \mathrm{~h}$ detectado mediante microscopía de fluorescencia con la sonda STH23S marcada con CY3 (barra: $10 \mu \mathrm{m}$ ) 


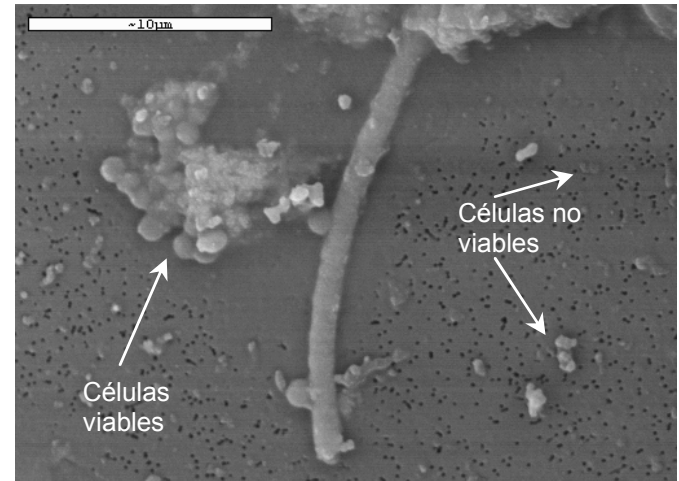

Figura 59. Streptococcus thermophilus STY7 viables y no viables tras su incubación con una concentración de $10 \mu \mathrm{g} / \mathrm{ml}$ de novobiocina durante $7 \mathrm{~h}$ detectado mediante microscopía de barrido (SEM).

La utilización de la novobiocina como antibiótico para la realización del DVCFISH a $10 \mu \mathrm{g} / \mathrm{ml}$ de concentración y durante 7 horas permite discriminar entre células vivas y muertas tanto para $L$. delbrueckii subsp bulgaricus como para $S$. thermophilus. 
Resultados

\section{ESTUDIO IN VITRO DE LA RESISTENCIA DE Lactobacillus delbrueckii subsp. bulgaricus $Y$ Streptococcus thermophilus A LOS JUGOS GASTROINTESTINALES MEDIANTE LA APLICACIÓN DEL MÉTODO DVC-FISH}

La metodología in vitro que simula el tránsito a través del tracto gastrointestinal ha sido empleada para la selección de cepas probióticas en diversas ocasiones. Este tipo de estudio de viabilidad es, por tanto, de gran interés para averiguar si éstas pueden sobrevivir a través del tránsito gastrointestinal.

Inicialmente, y antes de someter a las bacterias del yogur a los efectos de los jugos gastrointestinales, se realizaron recuentos en placa por duplicado del producto a ensayar (yogur natural Y7). Los recuentos de lactobacilos y estreptococos aparecen en la tabla 40.

Del mismo modo, se comprobó que la técnica DVC-FISH puesta a punto resultaba igual de efectiva cuando la matriz era más compleja como la del yogur, utilizando como antibiótico la novobiocina a concentración $10 \mu \mathrm{g} / \mathrm{ml}$ durante 7 horas de incubación.

Se pudo comprobar mediante SEM, midiendo la longitud de las células, que este método era efectivo para determinar la viabilidad de ambas cepas dentro de una leche fermentada.

Se quiso descartar igualmente que se hubiera cambiado de cepas en el producto comercial $Y 7$ y que se produjera un mal funcionamiento del antibiótico o las sondas de hibridación correspondientes a cada cepa en la matriz del producto fermentado.

Tanto para L. delbrueckii subsp bulgaricus como para S. thermophilus del producto $\mathrm{Y} 7$, el número de bacterias viables obtenido por recuento en placa fue ligeramente inferior al obtenido mediante el recuento por DVC-FISH, aunque los resultados fueron muy similares (tabla 40 ). 
TABLA 40. Media de los recuentos del producto Y7 realizados en placa y por DVC-FISH previos a la realización de las pruebas de resistencia a los jugos gastronintestinales

\begin{tabular}{ccc}
\hline Recuento & $\begin{array}{c}\text { Lactobacilos } \\
\text { (u.f.c./ml) }\end{array}$ & $\begin{array}{c}\text { Estreptococos } \\
\text { (u.f.c. } / \mathrm{ml} \text { ) }\end{array}$ \\
\hline En placa & $4,4 \times 10^{\prime}$ & $8,1 \times 10^{8}$ \\
\hline DVC-FISH & $4,6 \times 10^{\prime}$ & $8,9 \times 10^{8}$ \\
\hline
\end{tabular}

Fue posible enumerar las bacterias viables así como las no viables de Lactobacillus delbrueckii subsp bulgaricus y Streptococcus thermophilus después de la exposición a los jugos gastrointestinales gracias al método del DVC-FISH. EI estudio de resistencia al tránsito gástrico y el de resistencia al tránsito intestinal se hicieron por separado como se ha descrito anteriormente. Se realizaron recuentos en 20 campos de visión diferentes en el microscopio de epifluorescencia para cada uno de los tiempos de exposición en los cuales se tomaron muestras. Todas las hibridaciones se hicieron por duplicado para evitar posibles errores.

\subsection{Acción de los jugos gástricos}

Las células viables y no viables de Lactobacillus delbrueckii subsp. bulgaricus LDY7 y de Streptococcus thermophilus STY7 se diferenciaron perfectamente bajo la acción de la pepsina, tras la aplicación del DVC con la novobiocina y la posterior hibridación con las sondas correspondientes para cada bacteria.

Se pudo comprobar que los componentes del yogur no interfirieron en la correcta aplicación de la técnica DVC-FISH ya que, pese a haber cierto ruido de fondo en algunos casos, en ningún momento impidió la correcta visualización de las células y la realización de los recuentos (figuras 60,61 y 62). 


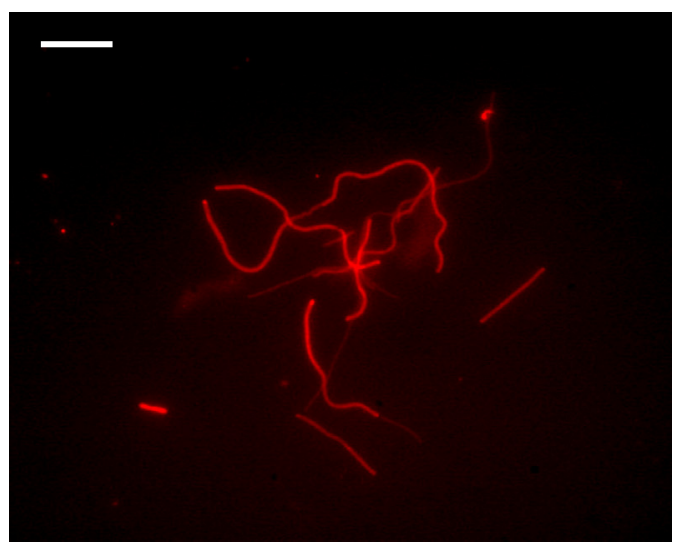

Figura 60. Células viables y no viables de $L$. delbrueckii subsp. bulgaricus LDY7 tras la acción de la pepsina (10 $\mathrm{min}$ ) y tras el DVC-FISH con la sonda LDE marcada con $\mathrm{CY} 3$ (barra: $10 \mu \mathrm{m}$ )

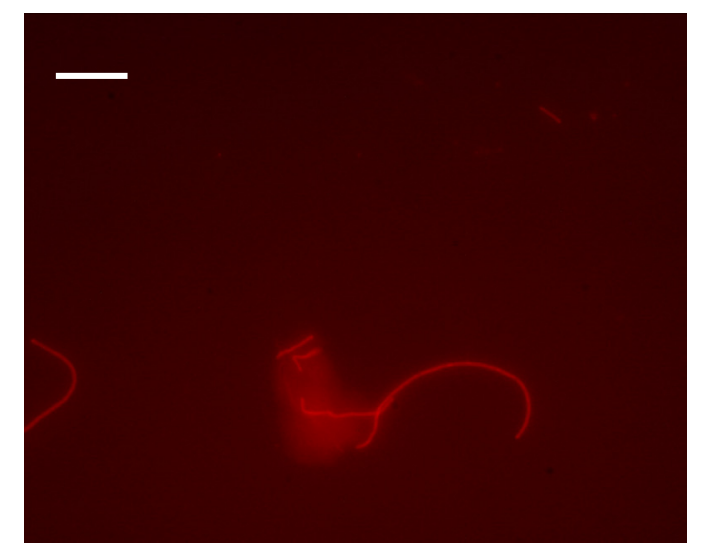

Figura 61. Células viables y no viables de Lactobacillus delbrueckii subsp. bulgaricus LDY7 tras la acción de la pepsina (60 min) y tras el DVC-FISH con la sonda LDE marcada con $\mathrm{CY} 3$ (barra: $10 \mu \mathrm{m}$ )

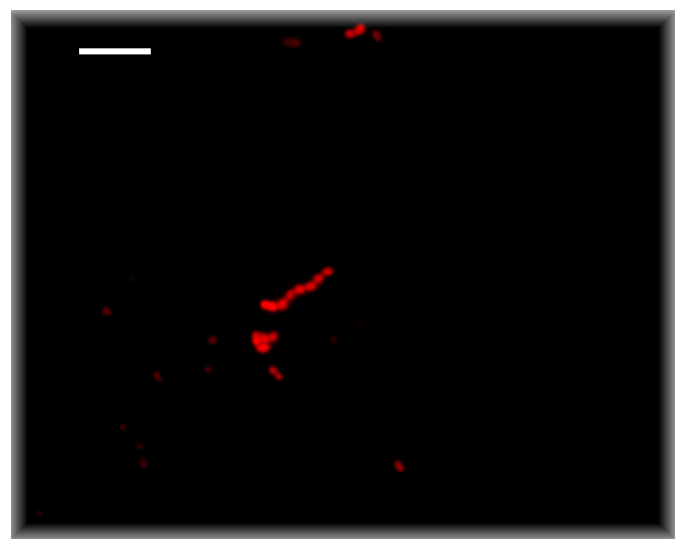

Figura 62. Células viables y no viables de Streptococcus thermophilus STY7 tras la acción de la pepsina (60 min) y tras el DVCFISH con la sonda STH23 marcada con $\mathrm{CY} 3$ 
Tanto la viabilidad de $L$. delbrueckii subsp. bulgaricus como la de $S$. thermophilus frente a los jugos gástricos (pepsina) se vio afectada con el tiempo de exposición. Tras el choque inicial (datos tomados en tiempo 0), la viabilidad frente al $\mathrm{pH}$ ácido de la pepsina se redujo hasta un $61,2 \%$ para Lactobacillus delbrueckii subsp. bulgaricus y hasta un $40,7 \%$ para Streptococcus thermophilus. Para ambas cepas este porcentaje fue decreciendo con el tiempo de exposición a este jugo. Tras 180 minutos de exposición, la supervivencia final fue del 29,6\% para los lactobacilos del $10,9 \%$ para los estreptococos (tabla 41 ). Por lo tanto se puede decir que la cepa aislada del producto $Y 7$ de L. delbrueckii subsp. bulgaricus tolera mejor la exposición a los jugos gástricos que la aislada de $S$. thermophilus. En ambos casos, se obtuvieron células viables en órdenes de $10^{7}$ tras 180 minutos de exposición a la pepsina. Todos los recuentos se hicieron por duplicado contando en cada preparación un mínimo de 20 campos.

Igualmente, se realizaron recuentos en placa a los diferentes tiempos de exposición y los resultados obtenidos muestran que el número de células viables recuperadas en el medio de cultivo es inferior que el número de células obtenidas mediante DVC-FISH, llegando a ser de un orden menor en algunos casos.

TABLA 41. Efecto in vitro del tránsito gástrico (pepsina) sobre la viabilidad de las cepas de Lactobacillus delbrueckii subsp. bulgaricus y de Streptococcus thermophilus de un yogur natural comercial

\begin{tabular}{cccccc}
\hline & \multicolumn{5}{c}{ Tiempo de exposición a la pepsina } \\
\hline & $0 \mathrm{~min}$ & $5 \mathrm{~min}$ & $10 \mathrm{~min}$ & $60 \mathrm{~min}$ & $180 \mathrm{~min}$ \\
\hline $\begin{array}{c}\mathrm{N}^{\circ} \text { lactobacilos viables } \\
\text { por gramo de yogur } \\
\text { (DVC-FISH) }\end{array}$ & $2,82 \times 10^{7}$ & $1,86 \times 10^{7}$ & $1,74 \times 10^{7}$ & $1,49 \times 10^{7}$ & $1,36 \times 10^{7}$ \\
\hline $\begin{array}{c}\% \text { lactobacilos viables } \\
\text { tras tránsito gástrico }\end{array}$ & 61,2 & 40,5 & 37,9 & 32,4 & 29,6 \\
\hline $\begin{array}{c}\mathrm{N}^{\circ} \text { lactobacilos por } \\
\text { gramo de yogur } \\
\text { (recuento en placa) }\end{array}$ & $2,1 \times 10^{7}$ & $1,2 \times 10^{7}$ & $9,8 \times 10^{6}$ & $9,5 \times 10^{6}$ & $9,1 \times 10^{6}$ \\
\hline $\begin{array}{c}\mathrm{N}^{\circ} \text { estreptococos viables } \\
\text { por gramo de yogur } \\
\text { (DVC- FISH) }\end{array}$ & $3,62 \times 10^{8}$ & $2,01 \times 10^{8}$ & $1,34 \times 10^{8}$ & $1,09 \times 10^{8}$ & $9,7 \times 10^{7}$ \\
\hline $\begin{array}{c}\% \text { estreptococos viables } \\
\text { tras tránsito gástrico }\end{array}$ & 40,7 & 22,6 & 15,1 & 12,2 & 10,9 \\
\hline $\begin{array}{c}\mathrm{N}^{\circ} \text { estreptococos por } \\
\text { gramo de yogur } \\
\text { (recuento en placa) }\end{array}$ & $3,1 \times 10^{8}$ & $1,5 \times 10^{8}$ & $9,7 \times 10^{7}$ & $8,8 \times 10^{7}$ & $7,5 \times 10^{7}$ \\
\hline & & & & &
\end{tabular}




\subsection{Acción de los jugos intestinales}

Las células viables y no viables de Lactobacillus delbrueckii subsp. bulgaricus y de Streptococcus thermophilus se diferenciaron perfectamente bajo la acción de la pancreatina y tras la aplicación del DVC-FISH (figuras 63, 64, 65 y 66)

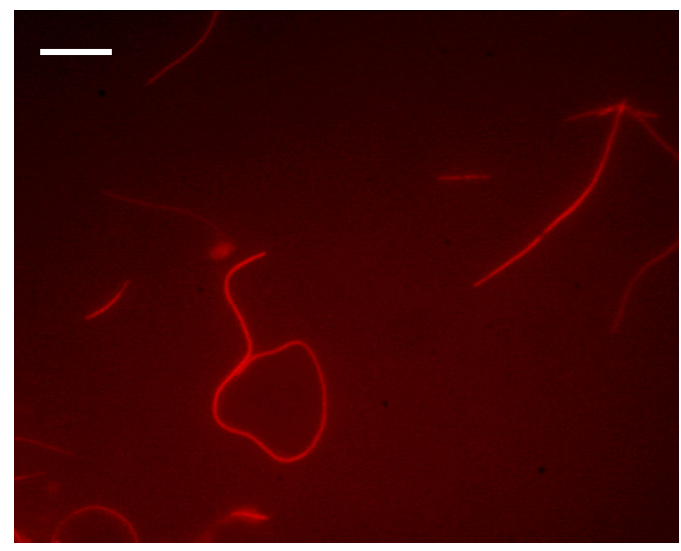

Figura 63. Células viables y no viables de Lactobacillus delbrueckii subsp. bulgaricus LDY7 tras la acción de la pancreatina (10 $\mathrm{min})$ y tras el DVC-FISH con la sonda STH23 marcada con CY3

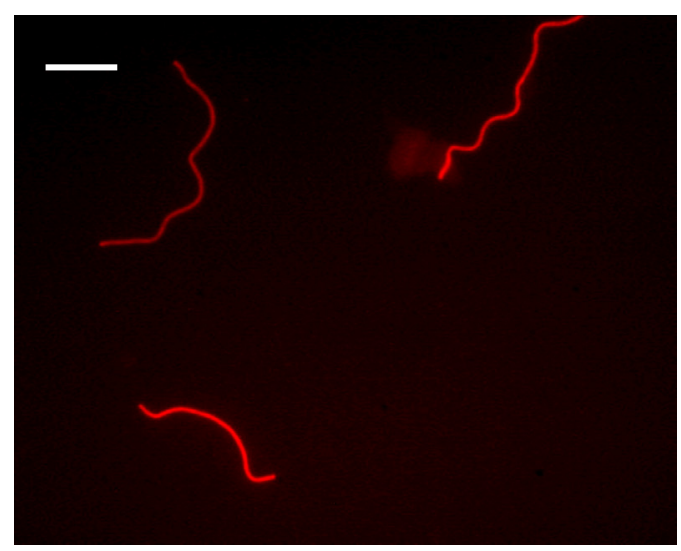

Figura 64. Células viables de Lactobacillus delbrueckii subsp. bulgaricus LDY7 tras la acción de la pancreatina (240 $\mathrm{min}$ ) y tras el DVC-FISH con la sonda STH23 marcada con CY3 

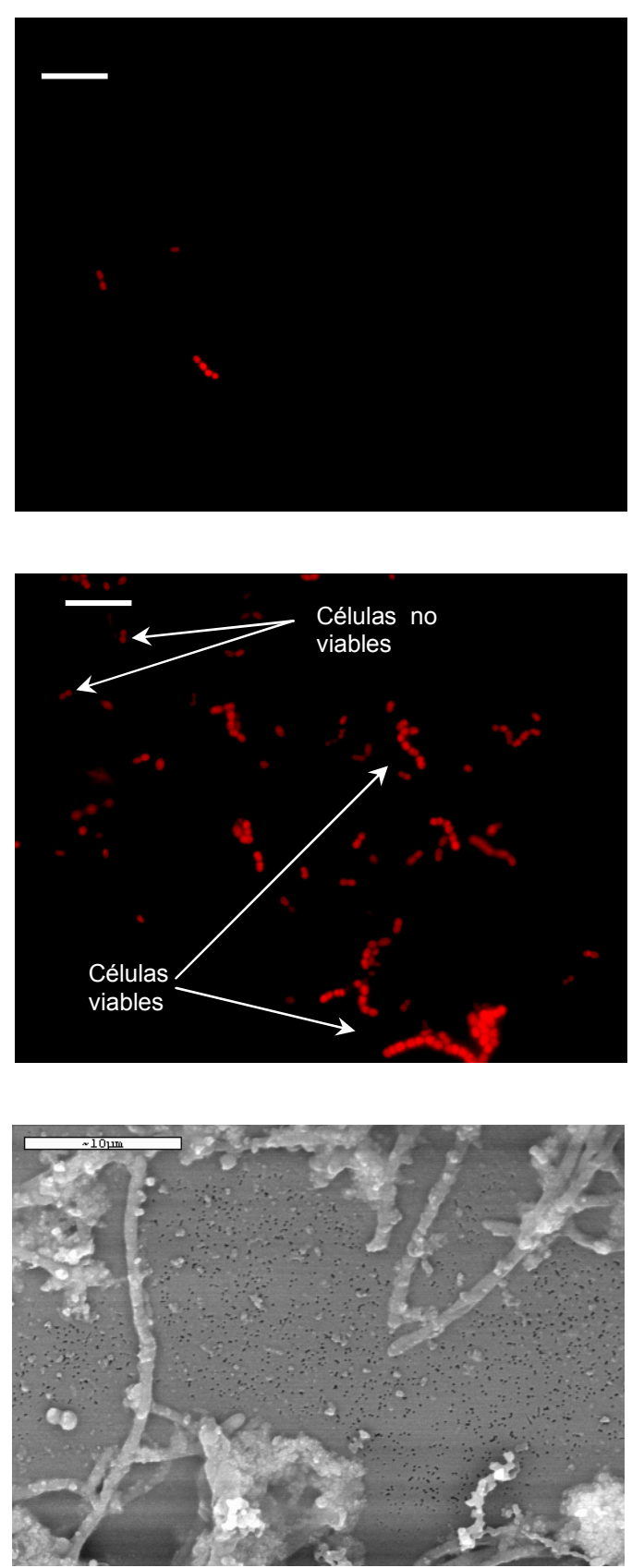

Figura 67. Lactobacilos y estreptococos LDY7 y STY7 tras la acción de la pancreatina y la aplicación del DVC detectados mediante microscopía electrónica de barrido

Frente a los jugos intestinales (pancreatina), tanto la viabilidad de $L$. delbrueckii subsp. bulgaricus como la de $S$. thermophilus disminuyó ligeramente (tabla 42). En el caso de los lactobacilos disminuyó en un $10 \%$ aproximadamente (viabilidad del $90 \%$ ) al inicio y se mantuvo prácticamente constante al cabo de las 
seis horas de exposición mientras que la viabilidad de $S$. thermophilus se redujo hasta un $84,6 \%$, es decir que el porcentaje de estreptococs viables descendió un $15 \%$ aproximadamente (tabla 42). Los recuentos por FISH se hicieron por duplicado, contando en cada preparación un mínimo de veinte campos. Los porcentajes de viabilidad recogidos en la tabla 42 se calcularon como la relación entre el número de células viables obtenidas en el recuento mediante FISH a los distintos tiempos de exposición frente al número de bacterias viables del control inicial.

Se realizaron recuentos en placa en medio LS-diferencial a los diferentes tiempos de exposición y los resultados obtenidos indicaron que el número de células viables recuperadas en el medio de cultivo fue menor que el número de células viables detectadas mediante DVC-FISH tanto para L. delbrueckii subsp. bulgaricus como para S. thermophilus.

TABLA 42. Efecto in vitro del tránsito intestinal (pancreatina) sobre la viabilidad de las cepas de Lactobacillus delbrueckii subsp. bulgaricus y de Streptococcus thermophilus del yogur natural Y7 empleando la técnica del DVC-FISH para realizar los recuentos

\begin{tabular}{|c|c|c|c|c|c|}
\hline & \multicolumn{5}{|c|}{ Tiempo de exposición a la pancreatina } \\
\hline & 0 min & $5 \mathrm{~min}$ & $10 \mathrm{~min}$ & $240 \mathrm{~min}$ & $360 \mathrm{~min}$ \\
\hline $\begin{array}{c}\mathrm{N}^{\circ} \text { lactobacilos } \\
\text { viables por gramo de } \\
\text { yogur (DVC-FISH) }\end{array}$ & $4,27 \times 10^{7}$ & $4,24 \times 10^{7}$ & $4,23 \times 10^{7}$ & $4,19 \times 10^{7}$ & $4,09 \times 10^{7}$ \\
\hline $\begin{array}{c}\text { \% viabilidad } \\
\text { lactobacilos tras } \\
\text { tránsito gástrico }\end{array}$ & 92,8 & 92,2 & 92,0 & 91,1 & 88,7 \\
\hline $\begin{array}{l}\mathrm{N}^{\circ} \text { lactobacilos por } \\
\text { gramo de yogur } \\
\text { (recuento en placa) }\end{array}$ & $4,1 \times 10^{7}$ & $2,9 \times 10^{7}$ & $2,2 \times 10^{7}$ & $1,5 \times 10^{7}$ & $1,4 \times 10^{7}$ \\
\hline $\begin{array}{l}\mathrm{N}^{\circ} \text { estreptococos } \\
\text { viables por gramo de } \\
\text { yogur (DVC-FISH) }\end{array}$ & $7,95 \times 10^{8}$ & $7,84 \times 10^{8}$ & $7,7 \times 10^{8}$ & $7,65 \times 10^{8}$ & $7,53 \times 10^{8}$ \\
\hline $\begin{array}{l}\text { \% viabilidad } \\
\text { estreptococos tras } \\
\text { tránsito gástrico }\end{array}$ & 89,3 & 88,1 & 86,5 & 86 & 84,6 \\
\hline $\begin{array}{l}\mathrm{N}^{\circ} \text { estreptococos por } \\
\text { gramo de yogur } \\
\text { (recuento en placa) }\end{array}$ & $6,9 \times 10^{8}$ & $6,5 \times 10^{8}$ & $6,3 \times 10^{8}$ & $5,8 \times 10^{8}$ & $5,3 \times 10^{8}$ \\
\hline
\end{tabular}


El método del DVC-FISH se presentó como un método rápido y apropiado para la enumeración total de las bacterias viables, si bien es cierto que resultó bastante más sencillo discriminar entre células viables y no viables por longitud en el caso de los lactobacilos, ya que medir el diámetro de los estreptococos resultó más complicado.

Tanto L. delbrueckii subsp. bulgaricus como S. thermophilus resultaron más sensibles a la acción de los jugos gástricos que a los intestinales, como puede observarse en los resultados de la tabla 43.

Se observó que $L$. delbrueckii subsp. bulgaricus resiste ligeramente mejor las condiciones del tránsito intestinal, presentando un porcentaje de viabilidad del $88,7 \%$ frente al $84,6 \%$ de $S$. thermophilus.

Ambas cepas perdieron viabilidad justo en el mismo instante de su exposición a los dos jugos gastrointestinales debido al shock ácido y básico causado por la acción inmediata de los mismos (figuras 68 y 69). Esta respuesta es mucho más acusada frente a la acción de la pepsina $(\mathrm{pH} 2,0)$ de $\mathrm{pH}$ ácido (figura 70).

Los resultados de la viabilidad teórica acumulada (número de células viables al final del tracto gastrointestinal) se muestran en la tabla 43. Los resultados se calcularon de forma teórica multiplicando el número inicial de cada bacteria por sus porcentajes de supervivencia frente a cada jugo gastrointestinal.

TABLA 43. Viabilidad acumulada de Lactobacillus delbrueckii subsp. bulgaricus y de Streptococcus thermophilus del producto $\mathrm{Y} 7$ tras superar tránsito gastrointestinal por recuento mediante DVC-FISH

\begin{tabular}{cccccc}
\hline Cepa & $\begin{array}{c}\mathrm{N}^{0} \text { inicial } \\
\text { células } \\
\text { viables }\end{array}$ & $\begin{array}{c}\mathbf{N}^{0} \text { células } \\
\text { viables tras } \\
\text { tránsito } \\
\text { gastrointestinal }\end{array}$ & $\begin{array}{c}\% \\
\text { viabilidad } \\
\text { frente a la } \\
\text { pepsina }\end{array}$ & $\begin{array}{c}\% \\
\text { viabilidad } \\
\text { frente a la } \\
\text { pancreatina }\end{array}$ & $\begin{array}{c}\% \text { viabilidad } \\
\text { acumulada tras } \\
\text { tránsito } \\
\text { gastrointestinal }\end{array}$ \\
\hline $\begin{array}{c}\text { L. delbrueckii } \\
\text { subsp. } \\
\text { bulgaricus }\end{array}$ & $4,6 \times 10^{7}$ & $1,2 \times 10^{7}$ & 29,6 & 88,7 & 26,2 \\
\hline S.thermophilus & $8,9 \times 10^{8}$ & $8,2 \times 10^{\prime}$ & 10,9 & 84,6 & 9,2 \\
\hline
\end{tabular}

L. delbrueckii subsp. bulgaricus y $S$. thermophilus presentaron una resistencia in vitro a ambos jugos gastrointestinales del $26,2 \%$ y $9,2 \%$ 
respectivamente. Esto quiere decir que, partiendo de un producto con un número de células viables conocido, el $26,2 \%$ de lactobacilos y el $9,2 \%$ de estreptococos podrían ser capaces de llegar vivos al final del intestino (figura 70). Esta cantidad sería por lo tanto el porcentaje de células que podrían ejercer efectos beneficiosos para la salud. Según bibliografía, únicamente las células resistentes podrían sobrevivir al tránsito gastrointestinal y llegar vivas al final del intestino para ejercer su efecto beneficioso.

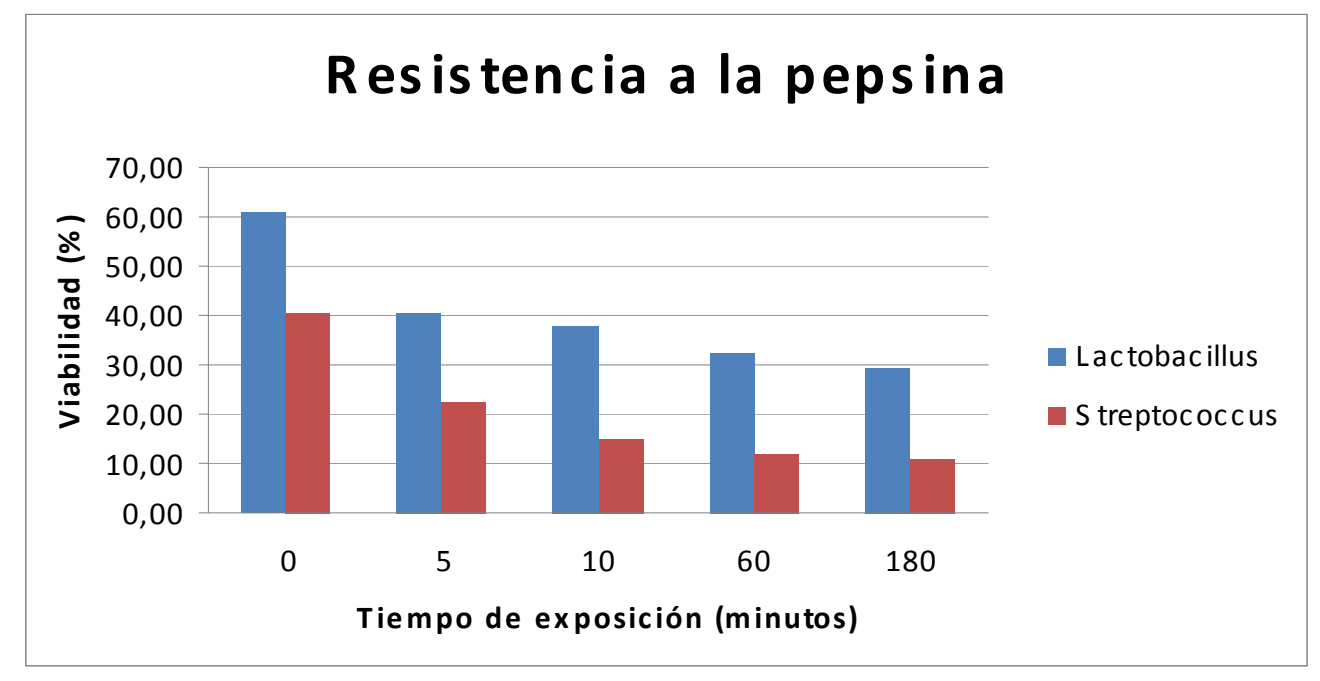

Figura 68. Resistencia a la pepsina (evolución de su viabilidad) de las cepas de lactobacilos y de estreptococos aisladas del producto Y7 


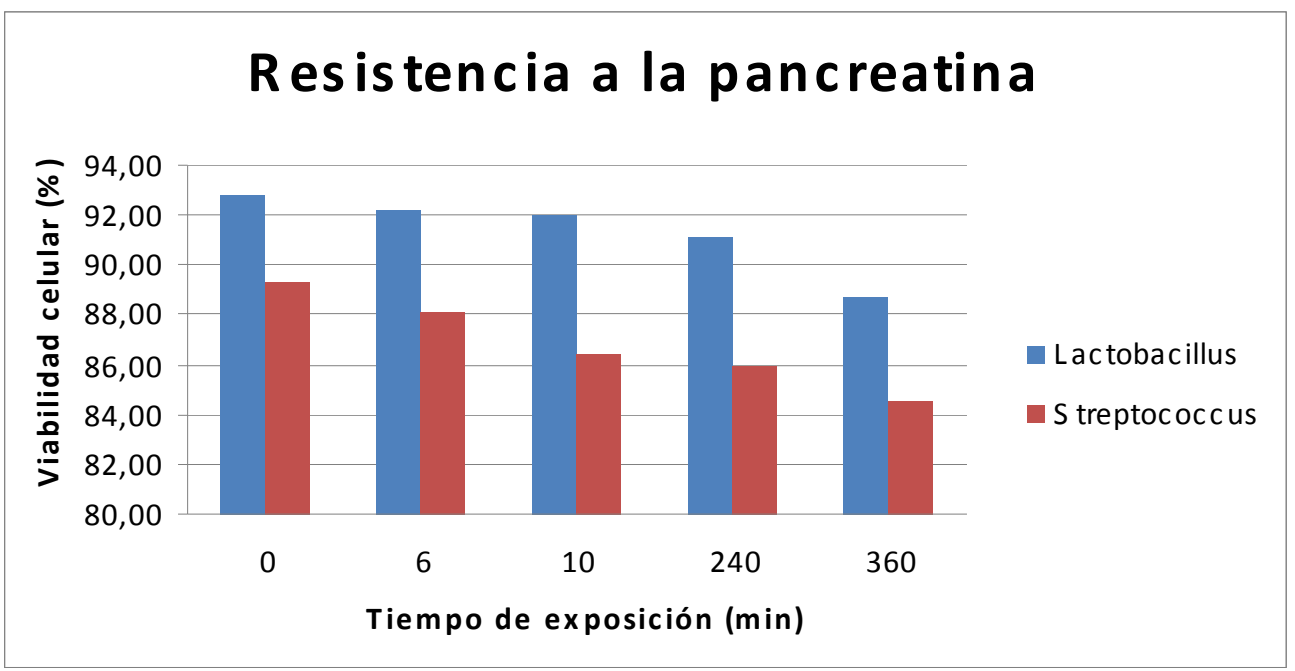

Figura 69. Resistencia a la pancreatina (evolución de su viabilidad) de las cepas de lactobacilos y de estreptococos aisladas del producto Y7

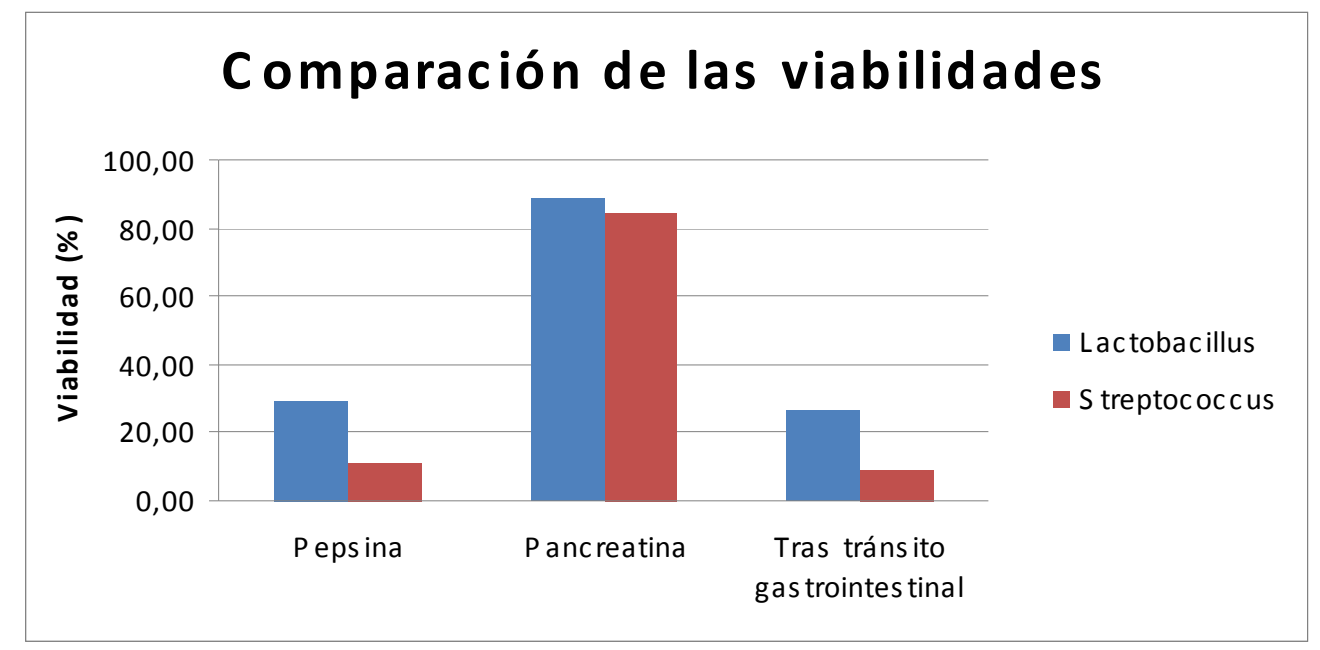

Figura 70. Viabilidad acumulada de las cepas de lactobacilos y de estreptococos aisladas del producto $\mathrm{Y} 7$ tras el tránsito gastrointestinal 
Resultados

5. ESTUDIO IN VIVO PARA DETERMINAR LA SUPERVIVENCIA AL TRACTO GASTROINTESTINAL DE LAS CEPAS DE Lactobacillus delbrueckii subsp. bulgaricus Y Streptococcus thermophilus

\subsection{Estudio del límite de detección de los métodos ensayados en heces humanas inoculadas artificialmente}

\subsubsection{Límites de detección de los métodos de cultivo en placa, PCR y DVC- FISH para la detección de Lactobacillus delbrueckii subsp. bulgaricus en heces inoculadas artificialmente}

Se llevó a cabo un estudio del límite de detección de las distintas técnicas de detección de L. delbrueckii subsp. bulgaricus LDY7 desarrolladas anteriormente, como cultivo en placa, PCR y DVC-FISH. Se emplearon heces que se inocularon artificialmente. Los ensayos se repitieron en cinco ocasiones utilizando cinco tipos de heces diferentes, todas ellas procedentes de personas que no habían ingerido ningún producto lácteo fermentado durante las dos semanas anteriores a la recogida de muestra.

El cultivo en placa con los medios utilizados resultó no ser un método eficaz para la detección de L. delbrueckii subsp. bulgaricus en heces debido al enorme crecimiento de microbiota acompañante, que enmascara el posible crecimiento de esta bacteria en caso de que se produjera. Ninguno de los medios de cultivo utilizados resultó ser suficientemente selectivo para su detección y cuantificación.

El límite de detección de la PCR seminested para la detección de $L$. delbrueckii subsp. bulgaricus en heces inoculadas artificialmente fue de $1 \times 10^{4}$ u.f.c./g de heces en cuatro ocasiones y de $1 \times 10^{5}$ u.f.c./g de heces en el quinto ensayo realizado (figura 71).

También se evaluó el límite de detección del método DVC-FISH para los cinco ensayos de heces inoculadas artificialmente. En las cinco repeticiones la sensibilidad en esta matriz fue de $10^{4}$ u.f.c./g de material evaluado. El ensayo, a la vez sirvió para comprobar que la sonda no hibridaba inespecíficamente. Para ello se realizaron hibridaciones en heces sin inocular lactobacilos y se comprobó que no se producía hibridación alguna con la microbiota propia de las heces.

Por último, se comprobó que el método DVC-FISH para la detección de células viables de $L$. delbrueckii subsp. bulgaricus era válido para emplearlo en esta 
matriz mucho más compleja, y que el ruido de fondo no interfería en su detección. También se comprobó que se producía la elongación celular, pudiendo diferenciar entre bacterias viables y no viables (figuras 74 ).

En la siguiente tabla se recogen las sensibilidades de las diferentes técnicas desarrolladas.

Tabla 44. Comparación de los límites de detección de las distintas técnicas para la detección de $L$. delbrueckii subsp. bulgaricus en muestras de heces inoculadas en u.f.c./g de heces

\begin{tabular}{cccccc}
\hline & $\begin{array}{c}\text { Muestra } \\
\text { heces 1 }\end{array}$ & $\begin{array}{c}\text { Muestra } \\
\text { heces 2 }\end{array}$ & $\begin{array}{c}\text { Muestra } \\
\text { heces 3 }\end{array}$ & $\begin{array}{c}\text { Muestra } \\
\text { heces 4 }\end{array}$ & $\begin{array}{c}\text { Muestra } \\
\text { heces 5 }\end{array}$ \\
\hline Cultivo & - & - & - & - & - \\
\hline PCR & $1 \times 10^{4}$ & $1 \times 10^{5}$ & $1 \times 10^{4}$ & $1 \times 10^{4}$ & $1 \times 10^{4}$ \\
\hline DVC-FISH & $1 \times 10^{4}$ & $1 \times 10^{4}$ & $1 \times 10^{4}$ & $1 \times 10^{4}$ & $1 \times 10^{4}$ \\
\hline
\end{tabular}

La figura 71 muestra el límite de detección de $1 \times 10^{4}$ u.f.c./g de heces de la técnica de PCR para muestras de heces inoculadas artificialmente con Lactobacillus delbrueckii subsp. bulgaricus LDY7.

Las figuras 72,73 y 74 muestran la capacidad de la técnica DVC-FISH para discriminar entre células viables y no viables de Lactobacillus delbrueckii subsp. bulgaricus en heces siempre y cuando haya una presencia mínima de $10^{4}$ u.f.c./g en esas heces.

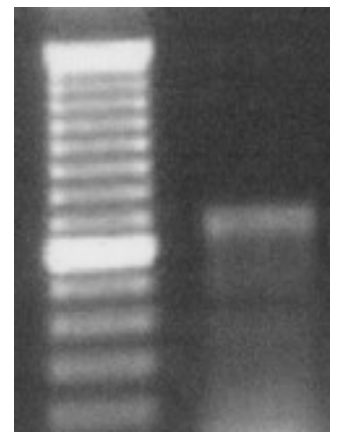

Figura 71. Detección de Lactobacillus delbrueckii subsp bulgaricus LDY7 mediante PCR en heces inoculadas artificialmente en cantidad de $10^{4}$ células $/ g$ de heces. 


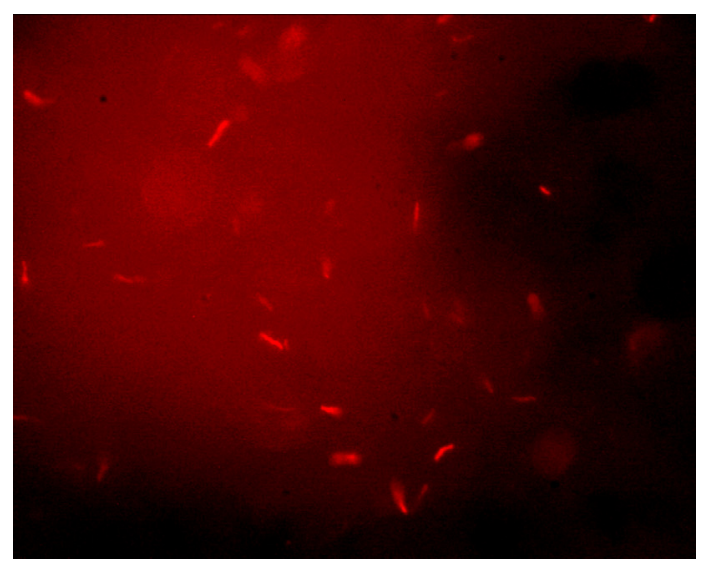

Figura 72. Detección de Lactobacillus delbrueckii subsp. bulgaricus LDY7 mediante FISH en heces inoculadas artificialmente en cantidad de $10^{6}$ células $/ g$ de heces empleando la sonda LDE23S (CY3)

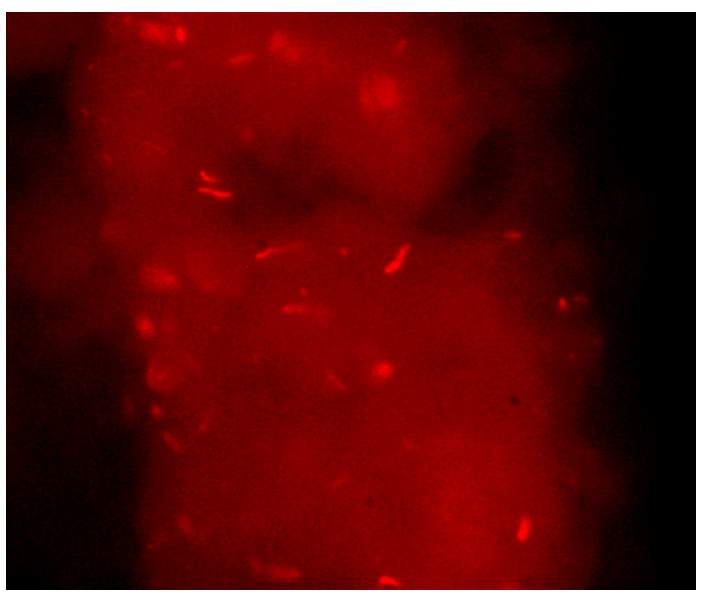

Figura 73. Detección de Lactobacillus delbrueckii subsp. bulgaricus LDY7 mediante FISH en heces inoculadas artificialmente en cantidad de $10^{5}$ células $/ g$ de heces empleando la sonda LDE23S (CY3) 


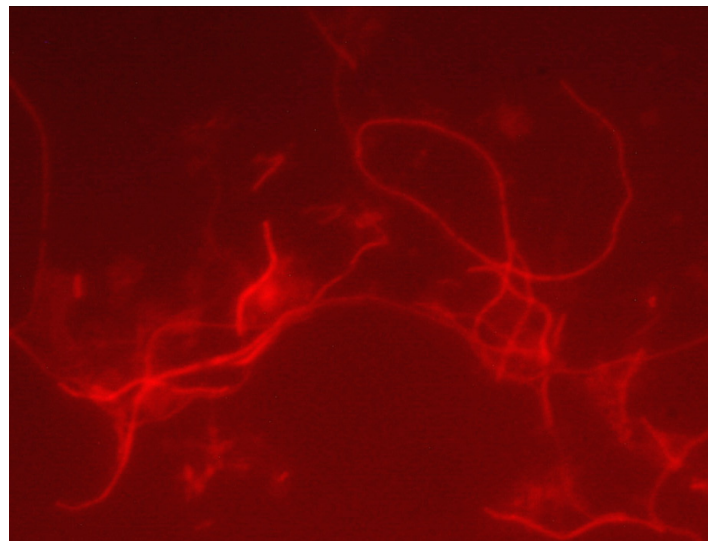

Figura 74. Detección de células viables y no viables de $L$. delbrueckii subsp. bulgaricus LDY7 mediante DVC-FISH en heces inoculadas artificialmente en cantidad de $10^{6}$ células $/ \mathrm{g}$ de heces, empleando la sonda LDE23S (CY3)

\subsubsection{Límite de detección de los métodos de cultivo en placa, PCR y DVC-FISH} para la detección de Streptococcus thermophilus en heces inoculadas artificialmente

Se inocularon artificialmente heces para determinar el límite de detección de las distintas técnicas de detección de S. thermophilus STY7: cultivo en placa, PCR y DVC-FISH. Se realizaron ensayos utilizando cinco heces de diferentes individuos, todos ellos sin haber ingerido ningún producto lácteo fermentado durante las dos semanas anteriores a la recogida de muestra.

El cultivo en placa en todos los medios utilizados resultó no ser un método eficaz para la detección de $S$. thermophilus en heces debido a la falta de selectividad de los medios.

El límite de detección del método de PCR para la detección de $S$. thermophilus en heces inoculadas artificialmente fue de $1 \times 10^{4}$ u.f.c./g de heces en las cinco ocasiones que se realizó el ensayo. La figura 75 muestra el límite de detección de esta técnica. En un ensayo in vivo debería haber al menos $10^{4}$ lactobacilos por gramo de heces para poder ser detectado mediante esta técnica aunque su detección no garantice su viabilidad. 


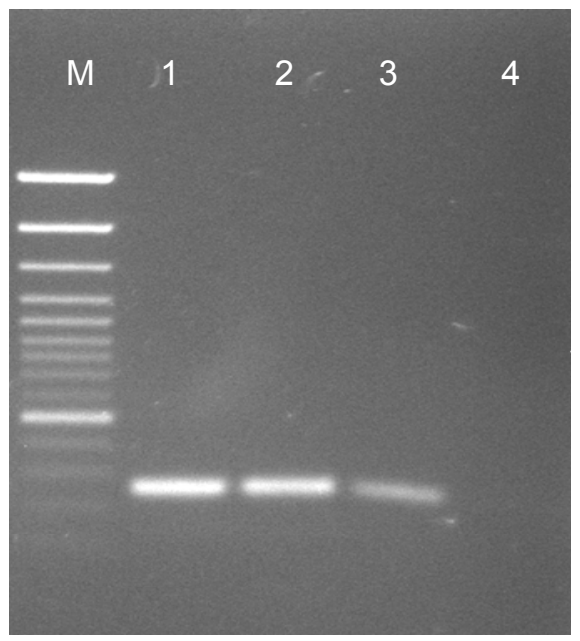

Figura 75. Límite de detección de la PCR de S. thermophilus STY7 en heces inoculadas artificialmente (1: $10^{6}$ u.f.c/g; 2: $10^{5}$ u.f.c./g; 3: $10^{4}$ u.f.c./g; 4: $10^{3}$ u.f.c./ M: marcador de pesos moleculares)

Se comprobó la especificidad del método FISH ya que se realizaron hibridaciones en heces sin inocular y se comprobó que no se producía hibridación alguna con la microbiota propia de las heces.

También se verificó que el método DVC-FISH para la detección de células viables de $S$. thermophilus desarrollado anteriormente era válido para emplearlo en esta matriz. En las cinco muestras del ensayo se comprobó que el límite de detección de esta técnica era de $10^{4}$, ya que se detectó hasta una concentración de $10^{4}$ estreptococos inoculados por gramo de heces. Se diferenció entre bacterias viables y no viables por diferencia del diámetro celular como puede verse en las siguientes figuras.

En la siguiente tabla se recogen los límites de detección de las diferentes técnicas ensayadas. 
Tabla 45. Comparación de los límites de detección de las distintas técnicas para la detección de Streptococcus thermophilus en muestras de heces inoculadas en u.f.c./g de heces.

\begin{tabular}{cccccc} 
& $\begin{array}{c}\text { Muestra } \\
\text { heces 1 }\end{array}$ & $\begin{array}{c}\text { Muestra } \\
\text { heces 2 }\end{array}$ & $\begin{array}{c}\text { Muestra } \\
\text { heces 3 }\end{array}$ & $\begin{array}{c}\text { Muestra } \\
\text { heces 4 }\end{array}$ & $\begin{array}{c}\text { Muestra } \\
\text { heces 5 }\end{array}$ \\
\hline Cultivo & - & - & - & - & - \\
\hline PCR & $1 \times 10^{4}$ & $1 \times 10^{4}$ & $1 \times 10^{4}$ & $1 \times 10^{4}$ & $1 \times 10^{4}$ \\
\hline DVC-FISH & $1 \times 10^{4}$ & $1 \times 10^{4}$ & $1 \times 10^{4}$ & $1 \times 10^{4}$ & $1 \times 10^{4}$ \\
\hline
\end{tabular}

La figura 76 muestra la presencia de $10^{4}$ u.f.c./g de heces, mediante la técnica FISH, mientras que la figura 77 muestra la capacidad de la técnica DVCFISH para discriminar entre células viables y no viables de Streptococcus thermophilus en heces siempre y cuando haya una presencia mínima de $10^{4}$ u.f.c./g en esas heces.

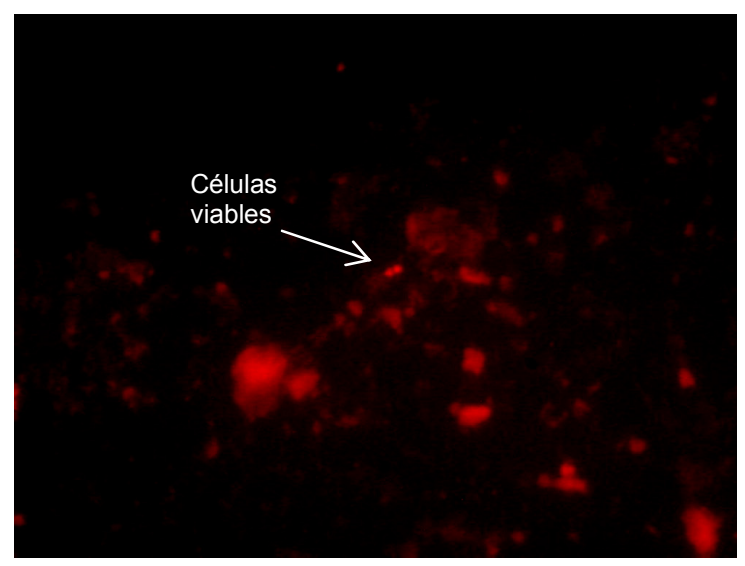

Figura 76. Detección de Streptococcus thermophilus STY7 mediante FISH en la dilución $10^{4}$ empleando la sonda LDE23S (CY3) 


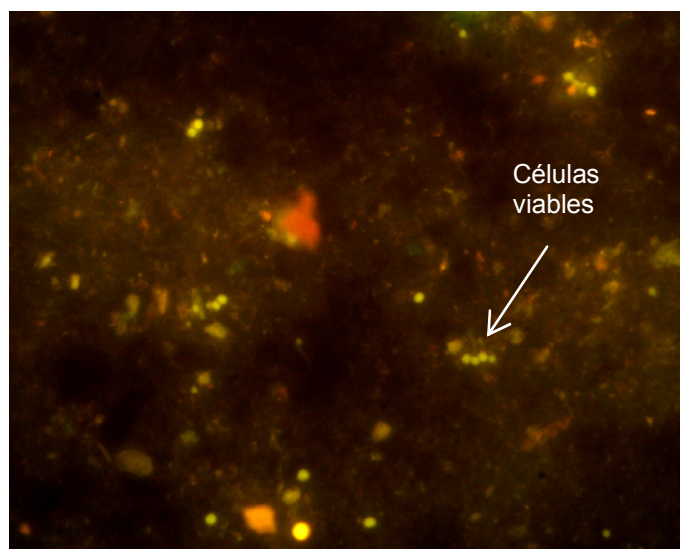

Figura 77. Detección y determinación de viabilidad de Streptococcus thermophilus STY7 mediante DVC-FISH en heces inoculadas artificialmente en cantidad de $10^{5}$ células $/ g$ de heces, empleando la sonda LDE23S (FLUOS)

\subsection{Estudio in vivo para determinar la supervivencia al tracto gastrointestinal de las cepas de L. delbrueckii subsp. bulgaricus y $S$. thermophilus de un producto fermentado}

Se analizaron un total de 30 muestras de heces de 30 individuos incluidos en el ensayo en cada una de las seis tomas de muestras según la forma descrita anteriormente en material y métodos.

Se emplearon las técnicas PCR seminested y DVC-FISH para la detección y recuento de L. delbrueckii subsp. bulgaricus LDY7 y las técnicas PCR y DVC-FISH para la detección y recuento de S. thermophilus STY7.

\subsubsection{Detección y recuento de $L$. delbrueckii subsp. bulgaricus en heces}

Ninguna de las 180 muestras analizadas dieron reacción positiva tras su análisis mediante PCR seminested y DVC-FISH. No se detectaron ni células viables de L. delbrueckii subsp. bulgaricus ni presencia de ADN. Podemos concluir por lo tanto que, o bien se encuentran en una cantidad inferior a nuestro límite de detección $\left(10^{4}\right.$ u.f.c./g) o bien no son capaces de resistir el tránsito intestinal.

El análisis mediante DVC-FISH de las muestras de heces de la toma T4 tras introducir un paso previo de enriquecimiento no mejoró los resultados obtenidos ya 
que, al no disponer de un medio lo suficientemente selectivo para esta bacteria, se incrementó toda la microbiota acompañante, enmascarando la visualización de las posibles células hibridadas mediante la sonda específica.

En el caso de la PCR no se realizó el paso previo de enriquecimiento puesto que la posible detección no nos garantizaría la viabilidad celular.

\subsubsection{Análisis de las muestras de heces mediante PCR y DVC-FISH para la detección de $S$. thermophilus en heces}

Se analizaron un total de 180 muestras, es decir 30 muestras de otros tantos individuos a lo largo del experimento en el que se recogieron seis tomas.

En la toma T1 no hubo detección alguna de S. thermophilus. En T2 hubo detección en el $6,7 \%$ y el $10 \%$ de las muestras mediante PCR y DVC-FISH respectivamente. El número de muestras positivas fue en aumento durante todo el periodo de ingesta. Así en T3 se detectó en un 13,3\% por PCR y en un 23,3\% por DVC-FISH. En T4 un 16,7\% y en un $30 \%$ de las muestras fueron positivas, mediante PCR y DVC-FISH respectivamente. Ya en el periodo de post-administración hubo un descenso acusado en el número de muestras positivas. Así, en T5 únicamente hubo detección en un $6,7 \%$ mediante PCR y en un $10 \%$ mediante DVC-FISH. En T6 no se produjo detección positiva en ninguna de las muestras analizadas.

Las tablas 46,47 y 48 muestran los resultados de los análisis de las muestras fecales para la detección de S. thermophilus mediante PCR y DVC-FISH. 
Tabla 46. Análisis de muestras fecales de las tomas T1 y T2 para la detección de Streptococcus thermophilus mediante PCR seminested y DVC-FISH

\begin{tabular}{|c|c|c|c|c|}
\hline \multirow[b]{2}{*}{ MUESTRA } & \multicolumn{2}{|c|}{$\mathrm{T1}$} & \multicolumn{2}{|c|}{$\mathrm{T} 2$} \\
\hline & $\begin{array}{c}\text { PCR } \\
\text { SEMINESTED }\end{array}$ & DVC-FISH & $\begin{array}{c}\text { PCR } \\
\text { SEMINESTED }\end{array}$ & DVC-FISH \\
\hline N.1 & - & - & - & - \\
\hline N.2 & - & - & - & - \\
\hline N.3 & - & - & - & + \\
\hline N.4 & - & - & - & - \\
\hline N.5 & - & - & + & + \\
\hline N.6 & - & - & - & - \\
\hline N.7 & - & - & - & - \\
\hline N.8 & - & - & - & - \\
\hline N.9 & - & - & - & - \\
\hline N.10 & - & - & - & - \\
\hline N.11 & - & - & - & - \\
\hline N.12 & - & - & - & - \\
\hline N.13 & - & - & - & - \\
\hline N.14 & - & - & - & - \\
\hline N.15 & - & - & - & - \\
\hline N.16 & - & - & - & - \\
\hline N.17 & - & - & + & + \\
\hline N.18 & - & - & - & - \\
\hline N.19 & - & - & - & - \\
\hline N.20 & - & - & - & - \\
\hline N.21 & - & - & - & - \\
\hline N.22 & - & - & - & - \\
\hline N.23 & - & - & - & - \\
\hline N.24 & - & - & - & - \\
\hline N.25 & - & - & - & - \\
\hline
\end{tabular}




\begin{tabular}{c|c|c|cc}
\hline N.26 & - & - & - & - \\
\hline N.27 & - & - & - & - \\
\hline N.28 & - & - & - & - \\
\hline N.29 & - & - & - & - \\
\hline N.30 & - & - & - & \\
\hline
\end{tabular}

Tabla 47. Análisis de muestras fecales de las tomas T3 y T4 para la detección de Streptococcus thermophilus mediante PCR seminested y DVC-FISH

\begin{tabular}{|c|c|c|c|c|}
\hline \multirow[b]{2}{*}{ MUESTRA } & \multicolumn{2}{|c|}{ T3 } & \multicolumn{2}{|c|}{$\mathrm{T} 4$} \\
\hline & $\begin{array}{c}\text { PCR } \\
\text { SEMINESTED }\end{array}$ & DVC-FISH & $\begin{array}{c}\text { PCR } \\
\text { SEMINESTED }\end{array}$ & DVC-FISH \\
\hline N.1 & - & - & - & - \\
\hline N.2 & - & - & - & - \\
\hline N.3 & + & + & - & + \\
\hline N.4 & - & - & - & - \\
\hline N.5 & + & + & + & + \\
\hline N.6 & - & - & - & - \\
\hline N.7 & - & - & - & - \\
\hline N.8 & - & - & - & - \\
\hline N.9 & - & - & - & - \\
\hline N.10 & - & - & - & + \\
\hline N.11 & - & - & - & - \\
\hline N.12 & - & - & - & - \\
\hline N.13 & - & + & + & + \\
\hline N.14 & - & - & - & - \\
\hline N.15 & - & - & - & - \\
\hline N.16 & - & + & + & + \\
\hline N.17 & + & + & + & + \\
\hline N.18 & - & - & - & - \\
\hline N.19 & - & - & - & - \\
\hline N.20 & - & - & - & - \\
\hline
\end{tabular}


Resultados

\begin{tabular}{c|cc|cc}
\hline N.21 & - & - & - & - \\
\hline N.22 & - & - & - & - \\
\hline N.23 & - & - & - & - \\
\hline N.24 & + & + & - & + \\
\hline N.25 & - & - & - & - \\
\hline N.26 & - & - & - & - \\
\hline N.27 & - & - & - & + \\
\hline N.28 & - & - & + & + \\
\hline N.29 & - & + & - & - \\
\hline N.30 & - & - & - & \\
\hline
\end{tabular}

Tabla 48. Análisis de muestras fecales de las tomas T5 y T6 para la detección de Streptococcus thermophilus mediante PCR seminested y DVC-FISH

\begin{tabular}{|c|c|c|c|c|}
\hline \multirow[b]{2}{*}{ MUESTRA } & \multicolumn{2}{|c|}{$\mathrm{T5}$} & \multicolumn{2}{|c|}{ T6 } \\
\hline & $\begin{array}{c}\text { PCR } \\
\text { SEMINESTED }\end{array}$ & DVC-FISH & $\begin{array}{c}\text { PCR } \\
\text { SEMINESTED }\end{array}$ & DVC-FISH \\
\hline N.1 & - & - & - & - \\
\hline N.2 & - & - & - & - \\
\hline N.3 & - & - & - & - \\
\hline N.4 & - & - & - & - \\
\hline N.5 & + & + & - & - \\
\hline N.6 & - & - & - & - \\
\hline N.7 & - & - & - & - \\
\hline N.8 & - & - & - & - \\
\hline N.9 & - & - & - & - \\
\hline N.10 & - & - & - & - \\
\hline N.11 & - & - & - & - \\
\hline N.12 & - & - & - & - \\
\hline N.13 & - & - & - & - \\
\hline N.14 & - & - & - & - \\
\hline N.15 & - & - & - & - \\
\hline N.16 & + & + & - & - \\
\hline N.17 & - & + & - & - \\
\hline
\end{tabular}




\begin{tabular}{|c|c|c|c|c|}
\hline N.18 & - & - & - & - \\
\hline N.19 & - & - & - & - \\
\hline N.20 & - & - & - & - \\
\hline N.21 & - & - & - & - \\
\hline N.22 & - & - & - & - \\
\hline N.23 & - & - & - & - \\
\hline N.24 & - & - & - & - \\
\hline N.25 & - & - & - & - \\
\hline N.26 & - & - & - & . \\
\hline N.27 & - & - & - & . \\
\hline N.28 & - & - & $=$ & . \\
\hline N.29 & - & - & - & . \\
\hline N.30 & - & - & - & . \\
\hline
\end{tabular}

La figura 78 muestra varias PCRs con la banda de 259 pares de bases indicando la presencia de Streptococcus thermophilus en las muestras de heces.

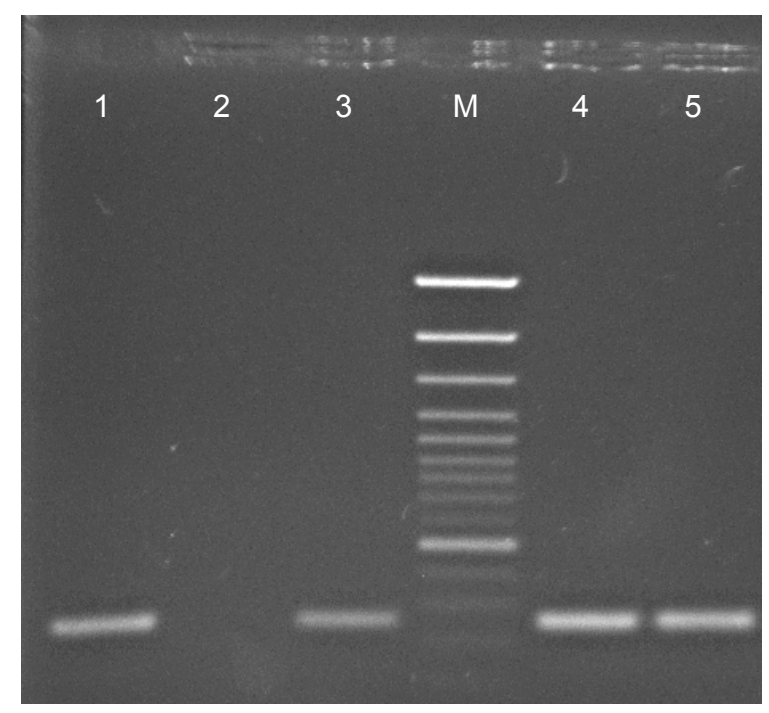

Figura 78. Detección de $S$. thermophilus STY7 en muestras de heces en T4 mediante PCR (1: N5T4; 2: N6T4; 3: N13T4; 4: N16T4; 5: N17T4; M: marcador de pesos moleculares)

Las figuras 79 y 80 muestran la detección de células viables y no viables de Streptococcus thermophilus mediante DVC-FISH en diferentes muestras de heces. 


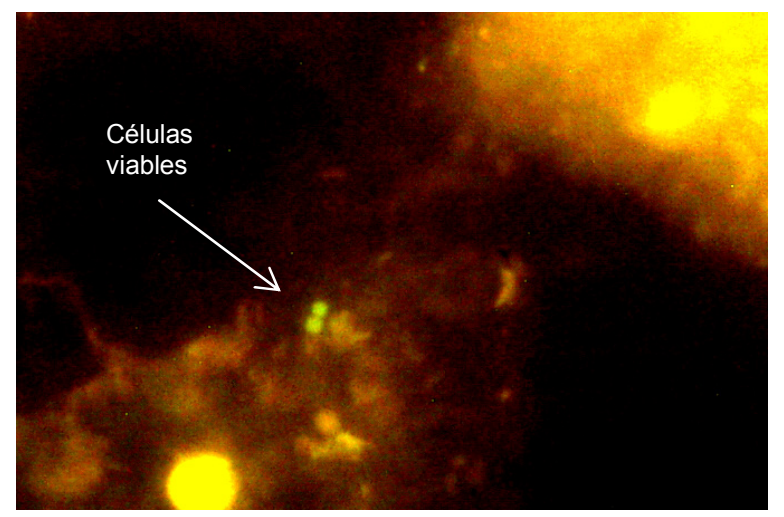

Figura 79. DVC-FISH mostrando células viables de S. thermophilus STY7 en muestras N5T4
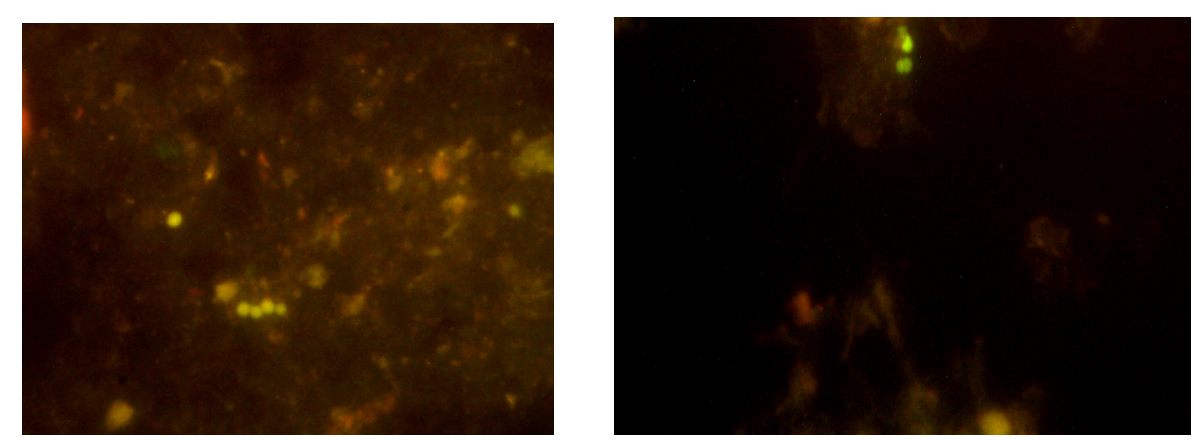

Figura 80. DVC-FISH mostrando células viables (derecha) y no viables (izquierda) de $S$. thermophilus STY7 en muestras N13T4

Los resultados del número $S$. thermophilus viables en las muestras en las que hubo detección vienen recogidos en las siguientes tablas, expresados como la media del recuento de 20 campos multiplicado por el factor de microscopio. 
Tabla 49. Recuentos de células viables de Streptococcus thermophilus STY7 mediante DVC-FISH en diferentes individuos durante la toma de muestras

\begin{tabular}{c|c|c|c|c}
\hline \multirow{2}{*}{ MUESTRA } & \multicolumn{3}{|c}{$\mathbf{N}^{\circ}$ Streptococcus thermophilus viables por gramo de heces } \\
\cline { 2 - 5 } & T2 & T3 & T4 & T5 \\
\hline 3 & $4,2 \times 10^{4}$ & $4,2 \times 10^{4}$ & $4,6 \times 10^{4}$ & - \\
$\mathbf{5}$ & $1,3 \times 10^{4}$ & $1,3 \times 10^{4}$ & $3,3 \times 10^{4}$ & $2,8 \times 10^{4}$ \\
10 & - & - & $1,7 \times 10^{4}$ & - \\
13 & $2,6 \times 10^{4}$ & $2,5 \times 10^{4}$ & $4,4 \times 10^{4}$ & - \\
16 & - & $6,6 \times 10^{4}$ & $3,5 \times 10^{4}$ & $1,2 \times 10^{4}$ \\
17 & - & $1,9 \times 10^{4}$ & $3,7 \times 10^{4}$ & $1,6 \times 10^{4}$ \\
$\mathbf{2 4}$ & - & $2,6 \times 10^{4}$ & $2,1 \times 10^{4}$ & - \\
$\mathbf{2 8}$ & - & - & $5,5 \times 10^{4}$ & - \\
$\mathbf{2 9}$ & - & $3 \times 10^{4}$ & $3,7 \times 10^{4}$ & - \\
\hline
\end{tabular}

El límite de detección de las técnica es de $10^{4}$ células por gramo de heces, por lo que en el resto de las muestras donde no se produjo detección, no podemos asegurar que no hayan células viables de Streptococcus thermophilus en las heces sino que hay menos de $10^{4}$ células por gramo de muestra. 
Resultados

\section{ESTUDIO DE LA EVOLUCIÓN DE LA MICROBIOTA DE LAS HECES DE LAS PERSONAS SOMETIDAS AL ENSAYO IN VIVO}

Se realizaron recuentos en placa en diferentes medios de cultivo para cada uno de los grupos de bacterias estudiados.

\subsection{Recuentos de la población bacteriana presente en las heces a lo largo del ensayo}

\subsubsection{Recuentos de lactobacilos}

En el anexo VII se muestra una tabla con los resultados obtenidos de los recuentos de lactobacilos en heces para los 30 individuos durante cada una de las tomas de muestras del ensayo.

El número de lactobacilos tras el periodo de no ingesta de productos lácteos fue de $5,15 \log _{10}$ u.f.c./g, expresado como el valor medio de los 30 individuos sometidos a ensayo. Se observó que desde la segunda semana de ingesta del producto lácteo (toma 2), los recuentos de lactobacilos aumentaban. De hecho, el porcentaje de individuos con una concentración de lactobacilos mayor de $6 \log _{10}$ u.f.c./g aumentó durante todo el periodo de ingesta (desde el $6,7 \%$ en T1 hasta el $33,3 \%$ en T2 tras 15 días de ingesta y el $60 \%$ en T4 tras las 4 semanas de ingesta).

El análisis ANOVA muestra que existen diferencias significativas $(F=$ $7,96, g l=5,174, p<0,05)$ entre las medias de los recuentos de lactobacilos durante las diferentes tomas de muestras para un nivel de confianza del $95 \%$.

Tabla 50: análisis de varianza simple (ANOVA) para Lactobacilos según Tiempo (días)

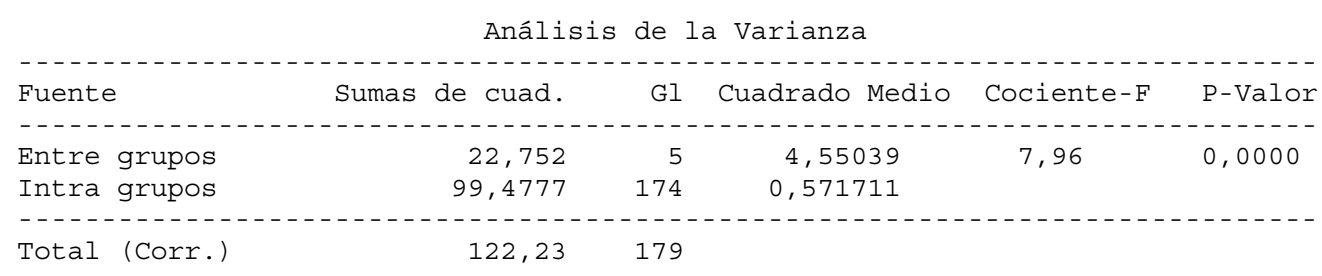


Así pues, se observa que existe un aumento significativo de lactobacilos desde la segunda semana de ingesta del producto lácteo (T2). Este aumento podría sugerir la supervivencia de $L$. delbrueckii subsp. bulgaricus al tracto digestivo o bien un aumento de lactobacilos endógenos tras el consumo de yogur. Igualmente, se produce un descenso significativo tras la interrupción de la administración, entre las tomas de muestras T4 y T5. Los recuentos realizados durante el periodo postadministración ( $T 5$ y T6) muestran valores del número de lactobacilos en las heces (5,87 $\log _{10}$ u.f.c./g y $5,49 \log _{10}$ u.f.c./g respectivamente) muy similares a los obtenidos tras dos semanas de ingesta, pero inferiores a los obtenidos tras la última semana de ingesta. Tras 3 semanas de no ingesta (T5), los recuentos de estos microorganismos descienden de forma significativa alcanzando valores similares a los iniciales.

Durante el periodo de consumo de yogur se detectó por lo tanto un importante aumento en el número de lactobacilos así como una lenta disminución de éstos tras la interrupción del consumo.

\subsubsection{Recuentos de microorganismos anaerobios estrictos y facultativos}

En el anexo VII aparecen los resultados obtenidos de los recuentos de microorganismos anaerobios en heces, realizados en agar Wilkins-Chalgren a los 30 individuos durante cada una de las tomas de muestras del ensayo.

Tras el periodo control (T1), se encontraron valores medios oscilantes entre 7,87 y $10,11 \log _{10}$ u.f.c./g (media 9,36). Durante el periodo de ingesta, se obtuvieron valores entre 7,89 y $9,98 \log _{10}$ u.f.c./g (media 9,25 ), entre 7,64 y $10,32 \log _{10}$ u.f.c./g (media 9,14) y entre 7,81 y $10,15 \log _{10}$ u.f.c./g (media 9,22) en las tomas T2, T3 y T4 respectivamente.

El análisis estadístico de los resultados revela que no existen diferencias significativas entre las medias de los recuentos de microorganismos anaerobios totales obtenido en el periodo control, periodo de administración y postadministración $(F=0,57, g l=5,174, p>0,05)$. 
Tabla 51: ANOVA para Anaerobios según Tiempo (días)

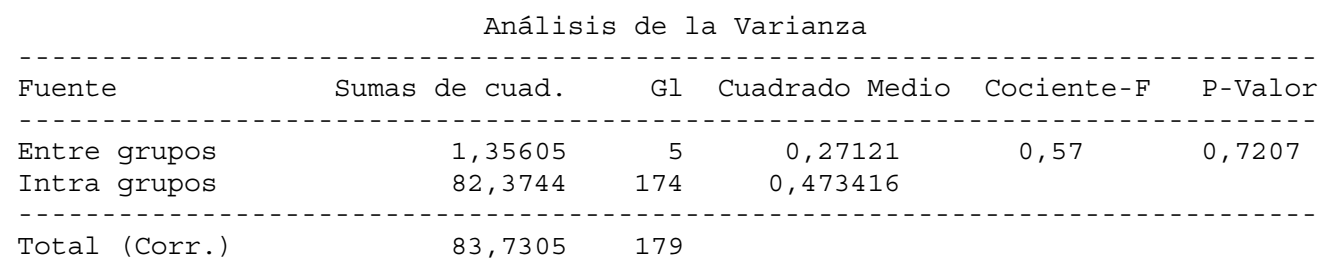

Por lo tanto, las comparaciones entre el número medio de anaerobios totales no revelan diferencias significativas entre los datos obtenidos en las diferentes tomas de muestras.

\subsubsection{Recuentos de microorganismos aerobios}

En la el anexo VII aparecen los resultados obtenidos de los recuentos de microorganismos aerobios en las heces de los 30 individuos durante cada una de las tomas de muestras del ensayo así como las medias y medianas de éstos.

Los valores medios obtenidos fueron $6,82 \log _{10}$ u.f.c./g, $6,85 \log _{10}$ u.f.c./g, $6,92 \log _{10}$ u.f.c./g, $6,98 \log _{10}$ u.f.c./g, $6,88 \log _{10}$ u.f.c./g y $6,87 \log _{10}$ u.f.c./g a T1, T2, T3, T4, T5 y $\mathrm{T} 6$ respectivamente.

El análisis estadístico de los resultados revela que no existen diferencias significativas entre las medias de los recuentos de microorganismos aerobios totales obtenido en el periodo control, periodo de administración y postadministración $(F=0,75, g l=5,174, p>0,05)$.

Tabla 52: ANOVA para Aerobios según Tiempo (días)

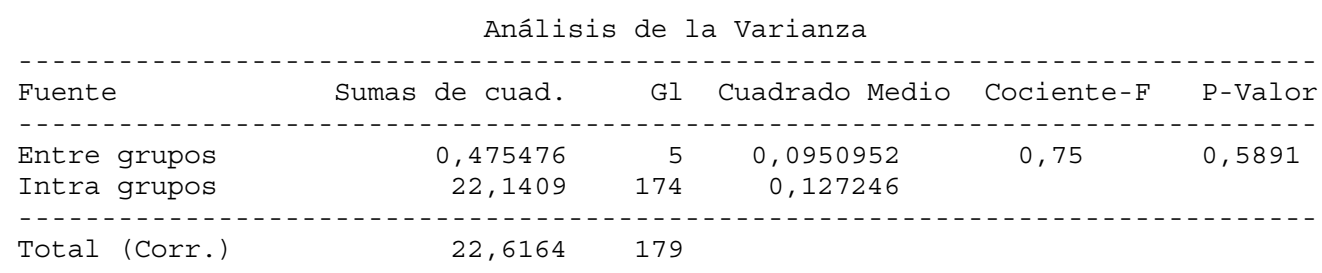




\subsubsection{Recuentos de bifidobacterias}

En la el anexo VII aparecen los resultados obtenidos de los recuentos de bifidobacterias en heces de los individuos sometidos al ensayo a cada una de las tomas de muestras así como las medias y medianas de éstos.

Así, en el control T1, se encontraron valores medios oscilantes entre 7,95 y 9,58 $\log _{10}$ u.f.c./g (media de 8.76), durante tomas T2, T3 y T4 valores medios de $8,84,8,67$ y $8,63 \log _{10}$ u.f.c./g respectivamente y durante T5 y T6, valores medios de 8,74 y $8,67 \log _{10}$ u.f.c./g. Los recuentos de bifidobacterias presentaron por lo tanto valores medios muy parecidos durante todas las tomas de muestras.

El análisis estadístico de los resultados revela que no existen diferencias significativas entre las medias de los recuentos de bifidobacterias en las diferentes tomas de muestras durante el periodo control, periodo de administración y post-administración $(F=0,84, g l=5,174, p>0,05)$.

Tabla 53: ANOVA para Bifidobacterias según Tiempo (días)

\begin{tabular}{|c|c|c|c|c|c|}
\hline Fuente & Sumas de cuad. & G1 & Cuadrado Medio & Cociente-F & P-Valor \\
\hline \multicolumn{6}{|c|}{ - - - - - - - - - - - - - - - - - - - - - - - - - - - - - - - - - - - - - - - - - - - - - - - - - - - - - - - - - - } \\
\hline Entre grupos & 0,835718 & 5 & 0,167144 & 0,84 & 0,5246 \\
\hline Intra grupos & 34,7164 & 174 & 0,19952 & & \\
\hline \multicolumn{6}{|c|}{ - - - - - - - - - - - - - - - - - - - - - - - - - - - - - - - - - - - - - - - - - - - - - - - - - - - - - - - - - - - - - - - - - - - - - - } \\
\hline Total (Corr.) & 35,5521 & & & & \\
\hline
\end{tabular}

\subsubsection{Recuentos de enterobacterias}

En la el anexo VII aparecen los resultados obtenidos de los recuentos de enterobacterias de las heces de los individuos sometidos al ensayo a cada una de las tomas de muestras así como las medias y medianas de éstos.

Así, la población media de enterobacterias descendió de $6.85 \log _{10}$ u.f.c./g en el periodo control a $6,40,6,26$ y $6,24 \log _{10}$ u.f.c./g en las tomas T2, T3. y T4 del periodo de ingesta. 
El análisis ANOVA muestra que existen diferencias significativas ( $F=$ 22,26, $g l=5,174, p<0,05$ ) entre las medias de los recuentos de enterobacterias durante las diferentes tomas de muestras para un nivel de confianza del $95 \%$.

Tabla 54: ANOVA para Enterobacterias según Tiempo (días)

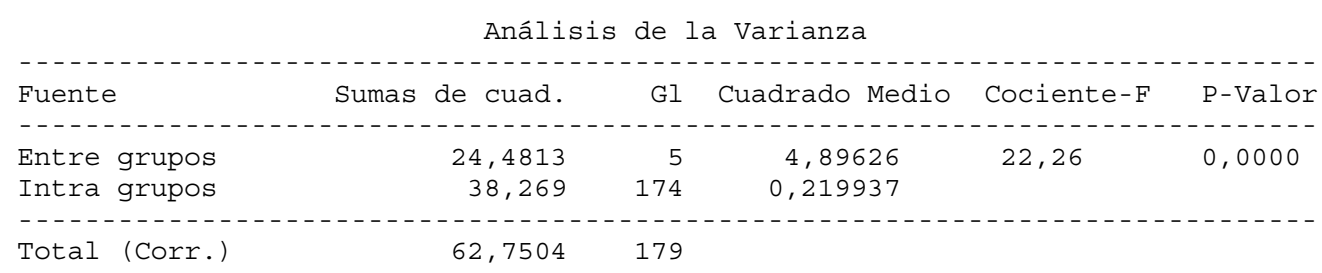

Los datos obtenidos demuestran que el número de enterobacterias disminuye de forma significativa durante las cuatro semanas que duró el periodo de ingesta. Igualmente, se produce un aumento estadísticamente significativo de esta población bacteriana cuando la ingesta de yogur natural cesa, alcanzándose valores medios de 6,84 y $6,96 \log _{10}$ u.f.c./g en T5 y T6 respectivamente. 
DISCUSIÓN 
Durante los últimos años el interés mostrado por la sociedad hacia los productos fermentados con cepas probióticas ha aumentado considerablemente. Se ha producido una cierta discrepancia entre diferentes líneas de investigación a la hora de afirmar los efectos beneficiosos del yogur tradicional. Algunas de ellas aseguran que sus bacterias no son capaces de sobrevivir al tracto gastrointestinal mientras que otras afirman lo contrario.

En la actualidad se discuten los efectos beneficiosos que puede tener el yogur tradicional sobre la salud. Durante la última década, se han llevado a cabo numerosos estudios de investigación realizados por todo el mundo con el objeto de evaluar las propiedades de las leches fermentadas sobre el organismo. Lo que sí está claro es que las bacterias probióticas deben sobrevivir al tracto gastrointestinal en cantidad suficiente para poder ejercer sus efectos. En este contexto se planteó un estudio para evaluar los efectos beneficiosos de las bacterias del yogur tradicional.

Este trabajo se estructuró en varias partes. En la primera se realizó una caracterización de cepas pertenecientes a los géneros Lactobacillus y Streptococcus presentes en yogures naturales comerciales mediante su aislamiento, identificación y caracterización molecular. Se observó mediante recuento en placa que todos los productos analizados contenían alrededor $10^{8}-10^{9}$ u.f.c. por gramo, cumpliendo la normativa legal vigente (R.D. 179/2003, de 14 de febrero, por el que se aprueba la Norma de Calidad para el yogur), que señala que un producto lácteo para denominarse yogur, debe contener, al menos $10^{7}$ microorganismos vivos por gramo para poder ejercer su posible acción beneficiosa sobre la salud así como ser capaces de mantener todas sus características durante la vigencia legal del producto (28 días). En general se observó que los estreptococos predominan en la matriz del producto, encontrándose los lactobacilos en menor medida.

El análisis de productos fermentados se realiza habitualmente mediante técnicas de recuento en placa, pero en realidad no existe un medio sintético lo suficientemente eficaz y selectivo para el aislamiento de BAL en matrices más complejas como por ejemplo las heces. Las técnicas moleculares permiten la detección y caracterización de bacterias en este tipo de matrices y, por ello, se decidió poner a punto diferentes metodologías.

En primer lugar se pusieron a punto dos protocolos de detección de Lactobacillus delbrueckii subsp. bulgaricus y Streptococcus thermophilus mediante 
FISH. La técnica FISH permite la visualización, identificación, enumeración y localización simultánea de células microbianas (Amman et al., 1995). Además, esta técnica presenta la ventaja frente a la PCR (que no proporciona información sobre la morfología o la distribución espacial de los microorganismos) de ser capaz de discernir entre diferentes morfologías de la misma bacteria.

En la puesta a punto de la técnica FISH para la detección de $L$. delbrueckii subsp. bulgaricus se diseñó, en primer lugar, una sonda complementaria del gen $16 \mathrm{~S}$ de $\mathrm{ARNr}$, altamente conservado y clave para establecer relaciones filogenéticas entre distintos organismos (Ludwig \& Schleifer, 1994).

Los análisis de especificidad mostraron que la sonda era completamente específica para esta bacteria. Sin embargo, no se pudo obtener una buena señal de fluorescencia a ninguna de las concentraciones de formamida testadas (del $0 \%$ hasta el $40 \%$ ). Las formas bacilares de $L$. delbrueckii subsp. bulgaricus producían señal fluorescente al hibridar con la sonda LDE16S, aunque de intensidad muy baja. Se evaluó entonces la accesibilidad de la sonda LDE16S al ARN ribosómico. Su estructura secundaria (puede verse en la figura 25 del apartado 1.3.1 de resultados), muestra una clasificación de las zonas del ARNr en función de la accesibilidad de las sondas, de forma que las zonas de clase I, serían las más accesibles, entre un 81 y $100 \%$ y las zonas de clase VI serían las menos accesibles, entre un $0 \%$ y un $5 \%$. La sonda LDE16S hibridaría en una zona de clase $V$ con una accesibilidad entre el 6 y el $20 \%$ (se encuentra entre los pares de bases 83 y 100) por lo que no sería una buena sonda de hibridación, a pesar de ser totalmente específica para $L$. delbrueckii subsp. bulgaricus.

Se diseñó entonces una sonda complementaria del gen $23 S$ del ARNr de esta misma bacteria. Se comprobó su total especificidad frente a una batería de BAL. En este caso la señal fluorescente fue muy alta con una concentración de formamida del $20 \%$. Se evaluó también su accesibilidad al ARN ribosómico. Según la estructura secundaria del 235 (Fuchs et al., 2001), se comprobó que esta sonda hibridaba en una zona de clase I, con una accesibilidad entre el $81 \%$ y el $100 \%$, lo que explicaría la buena señal de fluorescencia emitida. Un tiempo de incubación de dos horas fue suficiente para obtener buena señal de fluorescencia. Pese a la correcta hibridación de la sonda con la cepa de L. delbrueckii subsp bulgaricus aislada del producto $\mathrm{Y} 7$ (que se utilizaría en los posteriores estudios de supervivencia), se decidió secuenciar el gen 23S de ésta (cuya secuencia parcial aparece en el anexo VI) para asegurar el alineamiento total de la secuencia. Se 
comprobó que había una base, justo en la zona de alineamiento, que variaba respecto a la sonda, diferenciándose de la secuencia del resto de cepas. Por ello, se decidió diseñar una sonda específica para esta cepa (LDE23R) que sirviera para su detección en los posteriores estudios in vivo, para intentar que hibridara completamente con esta cepa en condiciones altamente específicas a altas concentraciones de formamida.

Para la detección de S. thermophilus mediante FISH, se diseñó una sonda complementaria del gen 23S. Los análisis de especificidad frente a una batería de cepas mostraron que la sonda era completamente específica para esta bacteria. La señal de fluorescencia fue muy alta con una concentración de formamida del $20 \%$.

Al igual que el método de recuento en placa, el recuento de lactobacilos y estreptococos presentes en los diferentes productos comerciales analizados mediante hibridación con sondas específicas (FISH) también resultó apropiado. Los recuentos de BAL mediante FISH fueron del mismo orden aunque algo más elevados. Ésto podría deberse a la presencia de bacterias viables no cultivables que no son capaces de crecer en los medios sólidos (como señalan los estudios de Auty et al., 2001 y Moreno et al., 2005.), o a que necesitan un tiempo mayor para crecer. Se puede afirmar que el método FISH para realizar recuentos, además de ser más rápido, es ligeramente más efectivo que el método tradicional de recuento en placa (Moreno et al. 2005).

Una vez aisladas e identificadas las BAL, se decidió caracterizarlas con la finalidad de encontrar diferencias entre las distintas marcas. Se empleo la técnica RAPDs (Random amplified Polymorphic DNA) como técnica de genotipado para obtener una diferenciación intraespecífica a nivel de cepa de las BAL aisladas, puesto que se desconocían sus secuencias y se trata de una técnica que emplea iniciadores aleatorios.

Después del análisis numérico de los perfiles obtenidos se obtuvieron dendrogramas que mostraron importantes diferencias entre las cepas de algunos productos mientras que la homología entre las cepas de otros resultó del 100\%. La caracterización a este nivel es importante ya que muchos de los efectos beneficiosos que estas bacterias ejercen en la salud humana no pueden atribuirse de una forma extendida a un género y/o especie, siendo en ocasiones dependientes de cada cepa. Por esta razón, es muy importante encontrar una técnica óptima con el fin de asociar un efecto específico a una cepa concreta para poder llevar a cabo las investigaciones necesarias en diferentes estudios tecnológicos, clínicos y 
epidemiológicos. Por consiguiente, la técnica RAPDs es una técnica rápida y sencilla que nos proporciona una herramienta adecuada para la identificación y caracterización de estas bacterias lácticas.

Los RAPDs se realizaron aplicando dos iniciadores diferentes denominados RAPD1 y RAPD2, siendo RAPD2 el que aportó mayor nivel de diferenciación puesto que se obtuvieron siete perfiles diferentes de lactobacilos y cinco de estreptococos. En cuanto a las cepas del producto $\mathrm{Y} 7$, el lactobacilo presentó un perfil único, por lo que podemos decir que esta casa comercial tiene una cepa que presenta claras diferencias genéticas con el resto de las cepas estudiadas. En cambio el estreptococo compartió perfil con la cepa de la casa comercial Y9.

La detección e identificación bacteriana en matrices complejas mediante PCR depende en gran medida de la especificidad de los iniciadores utilizados en la reacción de amplificación. Es importante el empleo de una amplia batería de bacterias pertenecientes a diferentes géneros, cercanos y lejanos filogenéticamente, o que pudieran estar presentes en las muestras donde se pretende aplicar la metodología, para realizar los estudios de especificidad.

Para la puesta a punto del método por PCR para la detección de Lactobacillus delbrueckii subsp. bulgaricus se recurrió en primer lugar a los iniciadores diseñados por Lick et al. (2001). Se observó que la reacción de PCR no era específica para $L$. delbrueckii subsp. bulgaricus ya que también resultó ser positiva para Lactobacillus delbrueckii subsp lactis y Lactobacillus delbrueckii subsp delbrueckii. Esta reacción de PCR de detección a nivel de especie no sería del todo apropiada para una posible detección de Lactobacillus delbrueckii subsp bulgaricus en heces en un estudio in vivo ya que las subespecies lactis y delbrueckii, pese a no ser endógenas, podrían formar parte de la microbiota intestinal por alguna circunstancia y, por lo tanto, obtener falsos positivos debido a su detección.

Se decidió entonces utilizar los iniciadores diseñados también por Lick et al. (2001) para la detección de Lactobacillus delbrueckii subsp. bulgaricus mediante PCR seminested. Esta reacción resultó totalmente especifíca para esta bacteria cuando se ensayó frente a una batería de BAL.

En la puesta a punto de la PCR para la detección de Streptococcus thermophilus se utilizó el protocolo descrito por Timisjärvi y Alatossawa en 1996. Éste resultó específico para esta bacteria al ensayar esta reacción frente a otras bacterias que pudieran dar falsos positivos en el futuro estudio in vivo. 
Discusión

Se puso a punto posteriormente la técnica DVC-FISH ya que, para poder demostrar que las BAL del yogur ejercen sus efectos beneficiosos, no basta con la detección de las moléculas de ADN o ARN en las heces, sino que es necesario determinar la viabilidad celular. Por lo tanto, esta parte del trabajo consistió en el desarrollo de una nueva metodología que permitiera la detección de células viables, discriminándolas de las formas celulares muertas.

El estado viable pero no cultivable (VNC) es un mecanismo de supervivencia adoptado por muchas bacterias cuando se exponen a condiciones adversas medioambientales (como pudieran ser las heces humanas). En este estado las bacterias pierden la capacidad para crecer en medios de cultivo, se hacen más resistentes a condiciones ambientales hostiles (Wong y Wang, 2004), mantienen la viabilidad y algunas veces son capaces de revertir a su estado normal restableciendo sus condiciones normales de crecimiento (Kell et al., 1998). El desarrollo y aplicación de la técnica del Direct Viable Count (DVC) y los primeros ensayos para la utilización del ARNm como indicador de viabilidad abren nuevas puertas en la detección de este estado fisiológico.

En el procedimiento del DVC, las bacterias deben ser incubadas en un caldo con una concentración óptima de antibiótico que inhiba la replicación celular pero que permita otras vías de síntesis para sobrevivir (Buchrieser and Kaspar, 1993). Por tanto, en estas condiciones las bacterias viables continúan metabolizando nutrientes y se elongan en el caso de ser bacilos o aumentan su tamaño en el caso de los cocos, pero no se replican.

Además, la incubación de una bacteria con un antibiótico que inhiba la ADN girasa produciría un aumento de la cantidad de ARN ribosómico en la célula y, por lo tanto, un teórico aumento de la intensidad de la señal de fluorescencia.

El método DVC combinado con la técnica FISH se presentaría como un método eficaz para detectar las células viables de L. delbrueckii subsp. bulgaricus y S. thermophilus. Así pues, se decidió ponerlo a punto por primera vez para BAL.

En este estudio se emplearon 4 antibióticos para la evaluación del método DVC, de acuerdo con trabajos previos (Besnard et al., 2000; Guyard et al., 1999; Jous and LeBaron, 1997). Puesto que el tiempo óptimo de incubación para la elongación celular depende de la tasa de crecimiento, se evaluaron distintos tiempos de incubación para cada concentración de antibiótico. 
En la puesta a punto del DVC para L. delbrueckii subsp. bulgaricus, ni el ácido pipemídico ni el ácido nalidíxico fueron efectivos a ninguna de las concentraciones ni tiempos de incubación. El agente antimicrobiano ciprofloxacino tampoco resultó suficientemente efectivo a las concentraciones y tiempos ensayados.

El tratamiento con novobiocina generó una elongación significativa de las células viables en comparación con las células no tratadas. A las concentraciones de 10 y $100 \mu \mathrm{g} / \mathrm{ml}$ y tras 7 y 24 horas de incubación se observaron bacterias que alcanzaban hasta $59 \mu \mathrm{m}$ de largo, lo que quintuplicaría el tamaño de las células control. Fue a una concentración de $10 \mu \mathrm{g} / \mathrm{ml}$ y tras 7 y 24 horas de incubación cuando se produjo la mayor elongación, alcanzándose tamaños celulares de hasta 56 y $59 \mu \mathrm{m}$ de longitud respectivamente. Sin embargo, a la concentración de 100 $\mu \mathrm{g} / \mathrm{ml}$, pese a ser efectivo a la hora de elongar las células, se constató que el número total de bacterias presentes se reducía considerablemente, como si el efecto del antibiótico a esa concentración fuera capaz de lisar las células. Este efecto no se produjo a la concentración de $10 \mu \mathrm{g} / \mathrm{ml}$. Además, los recuentos en placa mostraron que el número de Lactobacillus en el matraz control, sin antibiótico, aumentaron tras la incubación, mientras que el recuento de células tras el tratamiento con novobiocina permaneció constante. De acuerdo con otros autores (Besnard et al., 2000; Buchrieser et al., 1993), consideraron como células viables aquellas que se elongaron al menos dos veces respecto al tamaño original, aunque en nuestro caso las células presentaban un mayor tamaño.

Por todo ello, se decidió considerar la novobiocina, a la concentración de 10 $\mu \mathrm{g} / \mathrm{ml}$ y durante 7 horas como el antibiótico adecuado para la realización del DVC puesto que además de producir una elongación considerable de las células viables no produjo ningún efecto de lisado en éstas.

En la puesta a punto del DVC para $S$. thermophilus, ni el ácido pipemídico ni el ácido nalidíxico ni el ciprofloxacino resultaron apropiados, ya que a ninguna de las concentraciones ensayadas se observó un aumento significativo del tamaño celular. El antibiótico novobiocina resultó ser el antibiótico más efectivo para $S$. thermophilus como inhibidor de la ADN-girasa. La concentración y el tiempo de incubación óptimos fueron de $10 \mu \mathrm{g} / \mathrm{ml}$ y 7 horas respectivamente. Antes del ensayo, $S$. thermophilus tenía un diámetro celular de hasta $0,8 \mu \mathrm{m}$. Tras 7 horas de tratamiento con novobiocina a una concentración de $10 \mu \mathrm{g} / \mathrm{ml}$, el diámetro de algunas células alcanzó los 2,3 $\mu \mathrm{m}$. Del mismo modo, a las 24 horas también se detectaron células 
viables de 2,2 $\mu \mathrm{m}$ pero se eligió un tratamiento de 7 horas para minimizar el tiempo del proceso así como el tiempo de contacto con el antibiótico. El resto de tiempos y concentraciones evaluadas no modificaron significativamente el diámetro original. Además de un importante aumento del tamaño celular se observó también un incremento significativo en la fluorescencia de las células viables frente a las no viables. Este aumento en la fluorescencia también puede considerarse como un factor de viabilidad puesto que las células vivas son capaces de sintetizar más ribosomas, aunque en nuestro caso no fuera posible cuantificarlo.

La utilización de la novobiocina a la concentración de $10 \mu \mathrm{g} / \mathrm{ml}$ y durante 7 horas de tratamiento como antibiótico para la realización del DVC-FISH permite discriminar entre células vivas y muertas tanto para L. delbrueckii subsp. bulgaricus como para $S$. thermophilus. Además este antibiótico no reduce el número de células totales por lo que podemos considerar los recuentos de células como reales.

Algunos estudios han utilizado el método DVC-FISH para la detección de células viables de Escherichia coli (Villarino et al., 2000), para la enumeración directa de células viables de la familia Enterobacteriaceae en agua dulce y agua potable tras una filtración por membrana (Baudart et al. 2002) y para la detección específica de las células viables de patógenos como Helicobacter pylori en matrices complejas (Piqueres et al., 2006) pero nunca se ha utilizado para el estudio de la viabilidad celular de bacterias lácticas.

La técnica DVC-FISH permitiría realizar los recuentos en matrices que no fueran aptas para recuentos en placa como, por ejemplo, en heces humanas donde el contenido de otras especies bacterianas es muy elevado, pudiendo conducir a errores importantes a la hora de cuantificar.

El método del DVC-FISH se presenta como un método novedoso, rápido y apropiado para la enumeración total de BAL, si bien es cierto que, en el caso de los lactobacilos, resulta más sencillo discriminar entre células viables y no viables por longitud, puesto que medir el diámetro de los estreptococos es más complicado.

Una vez puesta a punto la técnica, se decidió aplicar el método para el estudio de la viabilidad de estas BAL frente a los jugos gastrointestinales, ya que, un microorganismo probiótico efectivo debe (además de otras características) presentar un elevado porcentaje de células viables, ser capaz de sobrevivir a la microbiota intestinal y permanecer viables durante su almacenamiento en refrigeración. 
Diversos estudios científicos, han investigado la viabilidad de las bacterias lácticas en distintos productos usando las técnicas tradicionales de recuento en medios selectivos (Nighswonger et al., 1996; Shing et al., 2000). Las principales barreras e impedimentos para la supervivencia de las BAL durante el tránsito gastrointestinal son el ambiente ácido del estómago y los efectos inhibitorios de las sales biliares secretadas en el duodeno. La metodología in vitro que simula el tránsito a través del tracto gastrointestinal (según Charteris et al., 1998) ha sido empleada para la selección de cepas probióticas en diversas ocasiones (De Champs et al., 2003). En 1998, Charteris et al. desarrollaron y aplicaron una metodología in vitro para determinar la tolerancia al tránsito gastrointestinal de las especies probióticas Lactobacillus $y$ Bifidobacterium en la parte superior del tracto gastrointestinal humano. Se estudió también el efecto sobre la tolerancia al tránsito mediante la adición de proteínas lácteas, de mucina gástrica del cerdo y de inhibidores de tripsina-cimotripsina. La mayoría de las muestras perdieron más del $90 \%$ de viabilidad durante la simulación del tránsito gástrico. Sólo Lactobacillus fermentum se pudo considerar intrínsecamente resistente. La adición de proteínas lácteas solas o combinadas generalmente mejoró la tolerancia al tránsito gástrico. En general, la adición de mucina gástrica no influyó a la tolerancia gástrica de los lactobacilos, pero tendió a aumentar la de las bifidobacterias. Este tipo de estudio de supervivencia es, por tanto, de gran interés para averiguar si éstas pueden sobrevivir al tránsito gastrointestinal.

En la elaboración de productos probióticos, es necesaria la selección de cepas resistentes sobre todo al choque ácido. Por ello, y por las diferencias en la tolerancia a condiciones ácidas, la cantidad de inóculo inicial de las cepas en un producto debería variar en función de la cepa seleccionada ya que, aunque el contenido fuera el reglamentario, si la cepa es sensible no llegará a su lugar de acción en número adecuado.

Se realizó por tanto un estudio in vitro de supervivencia frente a los jugos gastrointestinales de las cepas de L. delbrueckii subsp. bulgaricus y $S$. thermophilus contenidas en un yogur natural de una importante marca comercial. En nuestro ensayo ambas cepas resultaron más sensibles a los jugos gástricos que a los intestinales. Los resultados mostraron que el paso de estas bacterias por la cavidad gástrica es crítico para que éstas puedan llegar al colon en número suficiente y ejercer sus efectos beneficiosos $y$, por tanto, deben de tratarse de cepas intrínsecamente tolerantes a estos ácidos. 
La técnica del DVC-FISH resultó adecuada para el estudio de supervivencia in vitro de BAL. Además, los resultados mediante esta técnica pueden obtenerse en menos de un día, mientras que las técnicas tradicionales de cultivo tardan entre dos y tres días. La utilización de la novobiocina como antibiótico para la realización del DVC-FISH a la concentración y el tiempo adecuados permitió discriminar entre células vivas y muertas tanto para $L$. delbrueckii subsp bulgaricus como para $S$. thermophilus así como realizar recuentos de éstas.

Los resultados obtenidos mostraron que las cepas de L. delbrueckii subsp. bulgaricus y $S$. thermophilus contenidas en el yogur comercial utilizado son tolerantes en una cantidad aceptable, tanto a la pepsina como a la pancreatina $y$, por tanto, podrían atravesar el tracto digestivo. Su tolerancia a los jugos intestinales, indica que podría colonizar el epitelio intestinal y ejercer sus efectos como probióticos. Además, según diversos autores (Charteris et al., 1997; Huang y Adams, 2004), la presencia de ingredientes alimenticios o los propios alimentos, podrían ejercer de protección de los microorganismos probióticos durante su tránsito gastrointestinal cuando son consumidos a través de productos alimenticios, aumentando de este modo la viabilidad de los mismos frente a condiciones gastrointestinales.

Ambas cepas mostraron una tolerancia moderada a la pepsina durante su tránsito simulado a través del estómago $(\mathrm{pH} 2.0)$ siendo el porcentaje de bacterias viables del $29,6 \%$ y del $10,9 \%$ para $L$. delbrueckii subsp. bulgaricus y $S$. thermophilus, respectivamente. El número de lactobacilos y de estreptococos capaz de llegar vivos al intestino es de 1,36 × $10^{7}$ y $9,7 \times 10^{7}$ células por gramo de yogur, respectivamente.

La tolerancia al tránsito intestinal es importante para que las cepas probióticas puedan colonizar el intestino. Las cepas utilizadas en este estudio demostraron su elevada capacidad de resistencia frente a las condiciones intestinales, ya que no presentaron pérdidas de viabilidad significativas tras exposición durante 360 minutos a la pancreatina. Un $88,7 \%$ de L. delbrueckii subsp. bulgaricus y un $84,6 \%$ de $S$. thermophilus fueron capaces de sobrevivir al tránsito intestinal. En consecuencia, la cantidad de bacterias capaces de sobrevivir a todo tracto gastrointestinal es de $1,2 \times 10^{7}$ lactobacilos/gramo de yogur y de $8,2 \times 10^{7}$ estreptococos/gramo de yogur.

En este estudio se ha demostrado que la viabilidad de las cepas de BAL contenidas en el yogur natural comercial objeto del posterior ensayo in vivo se ve 
afectada de forma importante aunque no definitiva por la acción de los jugos gastrointestinales, teniendo una supervivencia final del 26,25\% para Lactobacillus delbrueckii subsp. bulgaricus y del 9,22\% para Streptococcus thermophilus. Esta cantidad será, en consecuencia, el porcentaje de células resistentes que podría sobrevivir al tránsito gastrointestinal y llegar vivas al final del intestino para ejercer su efecto beneficioso. Según bibliografía sería suficiente para ejercer efectos beneficiosos para la salud.

El método DVC-FISH además de efectivo para la determinación de la viabilidad celular de los microorganismos del yogur, ha resultado eficaz para estudiar la resistencia de estas bacterias frente a los jugos gastrointestinales, puesto que ha permitido realizar recuentos de forma rápida y específica de las células viables y no viables en diferentes momentos del ensayo.

De acuerdo con los conceptos científicos actuales, los microorganismos se consideran probióticos si se puede obtener un efecto fisiológico beneficioso del consumo de cultivos vivos y si el beneficio ha sido apoyado de forma adecuada con estudios en humanos (Guarner et al., 2005). Por ello, la supervivencia a su paso a través del tracto gastrointestinal, está generalmente considerada como una característica clave para que los probióticos ejerzan los esperados efectos sobre la salud (Bezkorovainy, 2001).

Además, cada vez está más aceptado que la forma en que las bacterias son administradas es decisiva para su supervivencia y que, en función del sustrato que las acompaña, pueden verse más o menos protegidas de factores como por ejemplo la acidez (Bouhnik, 1993; Conway et al., 1987; Drouault, 1999; Klaenhammer, 1998; Pochart et al. 1989). Conway et al. (1987), estudiaron la viabilidad in vitro de algunas BAL al ser expuestas al jugo gástrico así como los efectos de un aditivo como la leche, tanto en la supervivencia como en la adhesión. Demostraron que, al incorporar la leche, ambas características (supervivencia y capacidad de adhesión) mejoraron para todas las cepas.

Dos años después, Pochart et al. (1989), se propusieron investigar la supervivencia de un cultivo iniciador, así como la actividad de la $\beta$-galactosidasa del yogur tras atravesar el estómago y detectar cualquier digestión de la lactosa por las enzimas bacterianas en el duodeno. Para ello, entubaron a diez personas con problemas de absorción de lactosa y se les suministró yogur fresco, a los que les añadieron polietilenglicol y esporas de Bacillus stearothermophilus, como patrones 
internos. Los datos obtenidos demostraron que, tras la ingesta de yogur fresco, el cultivo iniciador alcanza el duodeno en su forma viable y presenta actividad $\beta$ galactosidasa. Sin embargo, la capacidad tamponante del yogur que permite la protección de las bacterias lácticas de la secreción ácida del estómago, también reduce la hidrólisis de la lactosa en el duodeno por la $\beta$-galactosidasa.

En 1998, Charteris et al. concluyeron que las proteínas lácteas y la mucina podrían funcionar como agentes tamponantes e inhibidores de la actividad proteasa digestiva, protegiendo las cepas bacterianas ingeridas durante el tránsito gastrointestinal.

Los estudios de viabilidad han cobrado, por tanto, gran importancia, apareciendo entre ellos muchas discrepancias. Conway et al. (1987), estudiaron tanto in vitro como in vivo, la supervivencia de cuatro cepas de bacterias lácticas (dos de Lactobacillus acidophilus, una de Lactobacillus bulgaricus, y otra de Streptococcus thermophilus) al ser expuestas al jugo gástrico humano y su adhesión a células intestinales de humanos y de cerdos. La capacidad de sobrevivir al ácido gástrico y de adherirse a las células varió de forma significativa en función de las cepas. Así, L. acidophilus sobrevivió y se adhirió mejor que el resto, mientras que $S$. thermophilus sobrevivió y se adhirió muy poco. Tanto la supervivencia como la capacidad de adhesión mejoraron al incorporar estas bacterias junto a leche.

En lo relacionado con la recuperación de L. delbrueckii subsp. bulgaricus y S. thermophilus en muestras fecales tras la ingesta de yogur, se han llevado a cabo estudios contradictorios. Algunos de ellos afirman que estas BAL son capaces de sobrevivir en mayor o menor medida al tracto gastrointestinal.

Aunque algunos autores como Lick et al. (2001) han defendido que los recuentos en heces para estudiar la supervivencia de bacterias administradas no refleja verazmente la supervivencia durante el tránsito intestinal, por lo general, la mayoría de estudios, sobre todo en humanos se realiza mediante el análisis de éstas. En su estudio, Lick et al. (2001) alimentaron a cerdos con yogur que contenía $S$. thermophilus y L. delbrueckii subsp. bulgaricus vivos. Tras la ingesta se tomaron muestras detectándose ambos microorganismos con vida en números de entre $10^{6} \mathrm{y}$ $10^{7}$ por gramo de contenido intestinal en todos los animales de la investigación.

Drouault et al. (2002), investigaron si S. thermophilus era capaz de producir una $\beta$-galactosidasa activa durante el tránsito por el tracto digestivo que reducía el 
contenido de lactosa. Este hecho reforzaba la observación de que esta bacteria del yogur debía estar viva para ayudar a que se produjera la digestión de la lactosa (Marteau et al., 1990; Rizkalla et al., 2000). De hecho, estos datos sugieren que esta bacteria láctica del yogur no sólo no está muerta en el tracto digestivo, sino que además es capaz de responder a los estímulos de la dieta y mantener la síntesis de nuevas proteínas para adaptarse a las condiciones ambientales. En el yogur, Streptococcus thermophilus contiene una $\beta$-galactosidasa que es activa en el tracto digestivo de ratones libres de gérmenes (Drouault et al. 2002), mientras que $L$. delbrueckii ssp. bulgaricus no dispone de ella (Pochart et al., 1989). Esto sugiere que Streptococcus thermophilus sobrevive al tránsito gastrointestinal, resultado similar al obtenido en nuestro estudio, como se verá más adelante

Por su parte, Brigidi et al. (2003), llevaron a cabo un estudio para estudiar la supervivencia de Streptococcus thermophilus, Bifidobacterium infantis Y1 y Bifidobacterium breve $\mathrm{Y} 8$, al tracto gastrointestinal. La persistencia intestinal de $S$. thermophilus fue estudiada en las heces de diez individuos sanos que consumieron durante diez días una dieta sin yogur y durante los siguientes diez días recibieron una dieta con $250 \mathrm{~g}$ diarios de yogur. A partir del tercer día de consumo, se pudo identificar $S$. thermophilus en las muestras fecales de estos sujetos en una cantidad de $5 \times 10^{5}$ ufc/g. Cuando se dejó de administrar el yogur disminuyó la presencia de $S$. thermophilus en las muestras fecales.

Posteriormente, Mater et al. (2005) recogieron 39 muestras de 13 sujetos sanos a lo largo de un periodo de 12 días de ingesta de yogur y de ellas, 32 contenían $S$. thermophilus vivos (con un valor medio de 6,3 x 10 4 UFC por gramo de heces) y 37 contenían $L$. delbrueckii (con un valor medio de $7,2 \times 10^{4}$ UFC por gramo de heces), demostrando con ello que un número importante de bacterias del yogur es capaz de sobrevivir al tránsito gastrointestinal.

Recientemente, Elli et al., (2006) investigaron si Lactobacillus delbrueckii subsp. bulgaricus y Streptococcus thermophilus podían ser recuperadas tras su paso por el intestino humano, alimentando a 20 voluntarios sanos con yogur comercial durante una semana. Sólo se recuperó por cutivo Streptococcus thermophilus en uno de los voluntarios en el día 7, no pudiendo excluir la posibilidad de que una ingesta más prolongada o una mayor cantidad ingerida de yogur tal y como describieron Mater et al. 2005, pudiese afectar positivamente a la tasa de recuperación del microorganismo de muestras fecales. Sí pudieron, sin embargo, 
Discusión

confirmar la presencia de L. delbrueckii subsp. bulgaricus viables en las heces, apareciendo en las muestras de seis de los diez voluntarios desde el segundo día del experimento y aumentando el número hasta siete positivos el último día de ingesta. Como conclusión, los autores afirmaron que las bacterias del yogur pueden sobrevivir al tracto intestinal.

Alvaro et al. (2007), compararon la composición y el metabolismo de la microbiota fecal de personas que habitualmente consumían al menos 200 gramos de yogur al día y de otros que no consumían yogur. En un $73 \%$ de las muestras fecales de los consumidores de yogur se identificó $L$. delbrueckii subsp. bulgaricus. Además, durante el estudio, la actividad de la $\beta$-galactosidasa en las heces aumentó de forma significativa para los consumidores de yogur y exhibía una correlación positiva con la cantidad de yogur consumida dentro de este grupo.

En contraposición, los trabajos de Gilliland (1979 y 1989), Pedrosa et al. (1995), Marteau et al. (1997), García de los Ríos et al., (2003) Yuste et al. (2003) y Del campo et al. (2005) afirman que las bacterias lácticas del yogur no son capaces de sobrevivir al tracto gastrointestinal.

En nuestro trabajo se pusieron a punto diversos métodos de detección y de viabilidad de $L$. delbrueckii subsp. bulgaricus en heces y se estudiaron sus respectivos límites de detección. Así pues, el límite de detección de L. delbrueckii subsp. bulgaricus mediante PCR resultó de $10^{4}$ lactobacilos por gramo de heces. Aún así su detección no garantizaría su viabilidad puesto que las baterías podrían no ser viables y ser detectadas mediante esta técnica por presencia del ADN en la matriz. El límite de detección de la técnica DVC-FISH para la detección de esta bacteria en las heces también fue de $10^{4}$ lactobacilos por gramo de heces. Esta técnica proporciona una reducción en el tiempo de detección con respecto a la PCR ya se puede realizar en el mismo día de recogida, lo que supone un importante ahorro de tiempo. Hasta el momento no se había realizado ningún estudio de supervivencia de BAL aplicando el método DVC-FISH.

En nuestro estudio in vivo de detección y supervivencia de $L$. delbrueckii subsp. bulgaricus, tras el análisis de las muestras, no se consiguió detectar la presencia de esta bacteria en ninguna de las 180 muestras analizadas mediante las técnicas utilizadas. Siendo el límite de detección de $10^{4}$ lactobacilos por gramo de heces, tanto para la PCR como para el DVC-FISH, se puede concluir que, 
o bien esta bacteria se encuentra en una cantidad inferior al límite de detección de estas técnicas, o bien no son capaces de sobrevivir el tránsito gastrointestinal.

Similares resultados fueron obtenidos por diversos autores.

Gilliland (1979), tras comparar la resistencia a la acidez gástrica de muchas especies, llegó a la conclusión de que $L$. bulgaricus no podría sobrevivir a la primera hora de exposición. Posteriormente, en 1989, el mismo autor hizo una revisión acerca de los potenciales beneficios para los consumidores de los productos lácteos con Lactobacillus acidophilus concluyendo nuevamente que las bacterias del yogur no sobrevivirían ni crecerían en el tracto intestinal por su falta de resistencia a la bilis.

Pedrosa et al. (1995) diseñaron un estudio para investigar las supervivencia de Streptococcus thermophilus y Lactobacillus bulgaricus en el estómago y el intestino delgado de ancianos con gastritis atrófica y de ancianos con una función secretora gástrica normal, tras ingerir yogur en una pequeña cantidad de leche conteniendo exclusivamente Lactobacillus gasseri vivos diariamente. No se recuperaron ni $S$. thermophilus ni L. bulgaricus del estómago o el intestino delgado de sujetos alimentados con yogur o yogur pasteurizado, si bien se demostró que bacterias como Lactobacillus gasseri pueden sobrevivir al paso por el tracto gastrointestinal.

Poco después, Marteau et al. (1997), validaron un modelo predictivo del estómago y del intestino delgado que habían desarrollado en un estudio anterior para cuantificar la supervivencia de bacterias ácido lácticas y para evaluar la influencia de las secreciones gastrointestinales. Al aplicarlo, se encontró que incluso para las especies más sensibles a la acidez como Lactobacillus bulgaricus y Streptococcus thermophilus, una fracción relativamente elevada de bacterias ingeridas fue capaz de alcanzar el duodeno con vida (26 y $12 \%$, respectivamente). Esto sucedió principalmente durante los primeros 20 a 30 minutos tras la comida. Sin embargo, tras un tiempo de digestión entre 70 y 110 minutos, este porcentaje se reducía al $1 \%$ aproximadamente. Tras el paso a través del intestino delgado, la supervivencia se redujo drásticamente.

Por su parte, García de los Ríos et al., (2003) iniciaron un trabajo con el objetivo de analizar la composición de la microbiota y la supervivencia de los microorganismos del yogur en animales alimentados con una dosis normal de yogur 
Discusión

fresco y de yogur termizado. El análisis estadístico de los resultados no mostró diferencias significativas en la microbiota intestinal de los diferentes grupos de animales.

Ese mismo año, Yuste et al. analizaron el comportamiento de las bacterias del yogur en el tracto gastrointestinal. Para ello, estudiaron a 114 sujetos sanos que recibieron alternativamente yogur tradicional y yogur pasteurizado durante 15 días continuados, mas un tercer grupo, que se utilizó como control de calidad y para el contraste de resultados, no consumió ningún tipo de yogur. Los autores concluyeron que no se produce una colonización del intestino por los gérmenes ingeridos vivos y que, en consecuencia, los iniciadores del yogur no se comportan como probióticos.

Del campo et al. (2005) valoraron la presencia de los microorganismos del yogur en las heces de voluntarios sanos en condiciones basales, así como tras consumo reiterado de yogur y de yogur pasteurizado mediante el uso de medios de cultivo y por PCR. Obtuvieron resultados consistentemente negativos por ambos métodos. Mediante PCR se detectó únicamente ADN compatible con las bacterias del yogur en 10 de 96 individuos que habían consumido yogur fresco $(10,52 \%)$ y en 2 individuos que habían consumido yogur pasteurizado $(2,10 \%)(p=0.01)$. Se obtuvo una proporción significativamente mayor de resultados positivos en los voluntarios que consumieron yogur fresco que entre los voluntarios que consumieron yogur pasteurizado, pero aún con todo en el primer grupo, el $90 \%$ de las muestras no se detectó ningún resto de $A D N$. Sin embargo, los autores no asociaron esta observación a una mayor colonización entre los voluntarios que consumieron yogur fresco, sino a una mayor degradación del ADN en los productos pasteurizados por el propio proceso de pasteurización, que mata a las bacterias y se empieza a degradar el ADN antes del consumo del producto.

En cambio, en nuestro estudio in vivo de detección y supervivencia de S. thermophilus, desde la toma de muestras T2 se hallaron muestras positivas tanto por PCR como por DVC-FISH. En T4, momento de máxima ingesta, en un $16,7 \%$ de las muestras se detectó esta bacteria por PCR. Además, en un $30 \%$ del número de muestras analizadas en esta toma (todas ellas coincidentes con las detectadas por PCR) se detectaron células viables de $S$. thermophilus por DVCFISH. Se puede concluir que, tras 4 semanas de ingesta, S. thermophilus fue capaz de sobrevivir al tránsito gastrointestinal en un $30 \%$ de la población estudiada. En todas las muestras que hubo detección mediante DVC-FISH se realizaron 
recuentos, obteniendo un número de estreptococos viables de $4,5 \times 10^{4}$ de media, lo que supone un orden por debajo de los resultados obtenidos por Brigidi et al. (2003) y coinciden con los obtenidos por Mater et al. (2005), ya comentados anteriormente. Los resultados de supervivencia de esta bacteria al tracto gastrointestinal también coinciden con los obtenidos por Lick et al. (2001) y por Drouault et al. (2002).

Pese a que el límite de detección de la técnica DVC-FISH era del mismo orden que el obtenido para la PCR, se obtuvo un mayor número de muestras positivas de $S$. thermophilus, mediante DVC-FISH que mediante PCR. Este resultado podría explicarse debido a la presencia de productos de inhibición de la PCR en este tipo de muestras (Radström et al., 2004). Otra posible explicación podría encontrarse en los ensayos realizados. Es posible que el límite de detección real de FISH sea mayor que el teórico. La cepa empleada en los ensayos era una cepa de referencia, con lo que podría no adaptarse bien al ambiente fecal en el que fue introducida, y por lo tanto sufrir daños celulares y disminución del contenido ribosómico, emitiendo menor señal de fluorescencia.

Ya que las técnicas DVC-FISH y PCR puestas a punto en este trabajo resultan altamente especificas y suponen una reducción importante de tiempo, no se incluyeron en el trabajo las técnicas culturales, ya que, aunque algunos autores las utilizan, no existe ningún medio de cultivo lo suficientemente selectivo para el aislamiento de estas BAL en muestras fecales y que distinga las BAL ingerdias con el yogur de las endógenas.

Finalmente se hizo un estudio de la evolución de la microbiota de las heces de las 30 personas sometidas al ensayo in vivo con la intención de estudiar el efecto de la ingesta de las BAL del yogur sobre los otros grupos de poblaciones bacterianas.

En los recuentos de lactobacilos en heces, se observó que, desde la segunda semana de ingesta del producto lácteo (T2), existieron diferencias estadísticamente significativas respecto a los recuentos en las tomas iniciales. Éstos aumentaron de forma significativa durante todo el periodo de ingesta. Este aumento podría sugerir la supervivencia de $L$. delbrueckii subsp. bulgaricus al tracto digestivo o bien un aumento de lactobacilos endógenos tras el consumo de la lactobacilos exógenos, lo que demostraría el efecto prebiótico . Los recuentos realizados durante el periodo post-administración mostraron valores del número de lactobacilos en las 
heces muy similares a los obtenidos durante el periodo de ingesta, si bien es cierto que tras 3 semanas de no ingesta los recuentos de estos microorganismos comienzan a descender.

Estos resultados concuerdan con los de Tannock et al. (2000), quienes describieron los resultados de un estudio a largo plazo en el cual sujetos sanos consumieron un producto probiótico con células viables de Lactobacillus rhamnosus DR20. Para ello, midieron el impacto del consumo de este probiótico en la microbiota fecal mediante la utilización de una gran variedad de métodos. La microbiota fecal de 10 individuos se controló antes, durante y después de la administración de un producto lácteo conteniendo esa BAL. Según sus resultados el consumo de la leche fermentada dio como resultado una frecuencia mayor de detección $(100 \%)$ de lactobacilos en muestras fecales en comparación con el periodo inicial de control $(76 \%)$ y el periodo posterior al ensayo (84\%). Las frecuencias de detección en los periodos de control y post-ensayo no difirieron. El número de u.f.c. de lactobacilos por gramo fue más elevado durante el periodo de ensayo (mediana: 5,8 $\log _{10}$ UFC/g; intervalo: 4,1 a 9,3 $\log _{10}$ u.f.c./g) que durante el periodo de control. El periodo de control y el periodo tras el ensayo (mediana, 5,3 $\log _{10}$ u.f.c./g; intervalo, 2,0 a $8,4 \log _{10}$ u.f.c./g) no presentaron diferencias significativas.

Igualmente, Guerin-Danan et al. (1998) evaluaron la influencia de dos leches fermentadas sobre varios géneros de la microbiota intestinal en 39 niños sanos de entre 10 y 18 meses. Un $0 \%$ del grupo consumidor de yogur presentó concentraciones iniciales de lactobacilos superiores a $6 \log _{10} \mathrm{UFC} / \mathrm{g}$ de heces. Este porcentaje aumentó hasta el $10 \%$ tras 15 días de suplementación o $30 \%$ tras 30 días de ingesta. Estos resultados concuerdan plenamente con los obtenidos en nuestro estudio.

Por su parte, García-Albiach et al., 2008 analizaron los cambios ocurridos en la microbiota fecal normal de 63 individuos sanos tras un consumo sostenido de yogur fresco y yogur termizado, mediante el empleo de las técnicas de PCR-DGGE cuantitativa y de PCR en tiempo real. Los autores no detectaron diferencias significativas entre ninguna muestra fecal. Sin embargo, tras el consumo de ambos tipos de yogur, se observó una densidad mayor de BAL y de Clostridium perfringens y un descenso significativo de Bacteroides. La densidad de la microbiota no 
presentó diferencias significativas entre ambos grupos, excepto para las BAL, que fue significativamente superior para el grupo de yogur fresco.

Gotteland et al. 2006, evaluaron cómo el consumo de distintas cantidades del probiótico Lactobacillus johnsonii contribuye a la modulación de las principales poblaciones de la microbiota fecal. Se obtuvieron muestras de deposición en diferentes períodos del experimento, determinándose las cantidades de lactobacilos excretados por cultivo en agar MRS. Se observaron cambios leves en la excreción de Lactobacillus a lo largo del estudio, que afectaron principalmente a los niveles post-ingestión. La excreción fecal de Lactobacillus johnsonii aumentó durante el período de consumo, pero desapareció después de 14 días de haber terminado el período de ingestión. El consumo de Lactobacillus johnsonii aumentó las poblaciones de Lactobacillus y Bifidobacterium que son consideradas como beneficiosas para el huésped. Las poblaciones bacterianas afectadas volvieron a sus niveles basales durante el periodo post-ingestión.

Otros autores han demostrado también que el recuento total de lactobacilos endógenos en adultos aumenta tras el consumo de lactobacilos exógenos permaneciendo altas durante dos semanas (Patel et al., 1992; Sepp et al., 1993) y durante 4 semanas (Ayebo et al. 1980). Igualmente, se recuperó Lactobacillus GG en niños tras 2 semanas (Sheen et al., 1995) y tras 3 semanas (Millar et al., 1993). Estos resultados positivos contrastan con los de Gilliland et al. 1978 y Pedrosa et al., 1995, quienes detectaron un descenso de lactobacilos fecales tras la ingesta de lactobacilos exógenos.

Las comparaciones de las medias de los recuentos de microorganismos anaerobios totales durante el periodo de control, el periodo de ensayo y el periodo posterior al ensayo no presentaron diferencias significativas. Los datos durante el periodo post-administración tampoco mostraron diferencias estadísticamente significativas. Estos resultados concuerdan con los de Tannock et al. 2000, para quienes los recuentos totales de anaerobios no difirieron a lo largo su estudio.

Se encontraron algunas variaciones en cuanto a la evolución en algunos sujetos pero las diferencias resultaron ser puntuales y se cree que no fueron debidas al consumo del alimento fermentado.

También coinciden con los resultados obtenidos por Guerin-Danan et al. 1998. En su estudio, ocho días antes de iniciar la ingestión con los lácteos y a 
tiempo 0, la concentración media inicial de anaerobios totales fue $9,7 \log _{10}$ u.f.c./g. Tras 15 y 30 días de ingesta, estos valores se mantuvieron en torno a $9,8 \log _{10}$ UFC/g para los tres grupos, no presentando modificaciones estadísticamente significativas.

En nuestro estudio, no se encontraron diferencias estadísticamente significativas entre las medias de los recuentos de microorganismos aerobios en heces, durante el periodo de ingesta de yogur respecto a los periodos de control y de post administración.

Estos resultados coinciden con los obtenidos por Tannock et al. 2000, quienes encontraron valores medios que oscilaron entre 6,4 y $7,8 \log _{10}$ u.f.c./g (media 7,2) en el ensayo, mientras que en el periodo de control oscilaron entre $6.6 \mathrm{y}$ $7,7 \log _{10}$ u.f.c./g (media 7,2 ) y en el posterior al ensayo entre 6,2 y $7,7 \log _{10}$ u.f.c./g (media 7,3 ), no siendo diferencias estadísticamente significativas.

Los recuentos de bifidobacterias en los periodos de control, ensayo y postadministración no revelaron diferencias significativas.

Estos resultados concuerdan con los obtenidos por Tannock et al. 2000, quienes, para el caso de las bifidobacterias, encontraron valores medios en el control que variaron entre 9,4 y $10,2 \log _{10}$ u.f.c./g, en el ensayo entre 9,1 y $10,3 \log _{10}$ u.f.c./g y en el periodo posterior al ensayo, entre 9,1 y $9,8 \log _{10}$ u.f.c./g. En ningún caso, se apreciaron diferencias estadísticamente significativas entre los distintos periodos.

También hay coincidencia con los resultados de Guerin-Danan et al. 1998, que ocho días antes de iniciar la suplementación con los lácteos y a tiempo 0 determinaron un valor medio de $9,1 \log _{10}$ u.f.c./g de este género. Tras 15 y 30 días de ingesta, esta media se mantuvo en valores de $9,3 \log _{10}$ u.f.c./g y a los 38 días (tras una semana sin administración), este valor medio volvió a ser de $9,1 \log _{10}$ u.f.c./g. En ningún caso, las diferencias entre periodos fueron estadísticamente significativas.

Sin embargo, nuestros resultados discrepan con los de Alvaro et al. 2007, quienes, con la técnica FISH adaptada para la detección por citometría de flujo detectaron, para el grupo de consumidores de yogur tradicional, que la proporción de bifidobacterias era directamente proporcional a su consumo. La técnica PCR 
combinada con electroforesis en gel mostraron los mismos resultados. Los autores, en su interpretación de los resultados, afirmaron que, un consumo regular de yogur en una dieta cualquiera, puede inducir modificaciones en la microbiota endógena.

El número de enterobacterias disminuyó de forma significativa durante las cuatro semanas que duró el periodo de ingesta. Igualmente, se produjo un rápido aumento de esta población bacteriana cuando la ingesta de yogur natural cesó, volviéndose a niveles anteriores a la ingesta.

En la investigación de Tannock et al. 2000, los valores medios de las enterobacterias fermentadoras de lactosa oscilaron, en el caso del control, entre 5,3 y $7,2 \log _{10}$ u.f.c./g, en el ensayo entre 5,6 y $7,5 \log _{10}$ u.f.c./g y en periodo posterior al ensayo entre 3,8 y $7,7 \log _{10}$ u.f.c./g. En ningún caso estas diferencias fueron estadísticamente significativas, lo que contrastaría con los resultados del presente estudio.

Tampoco concuerdan los resultados de Guerin-Danan et al. 1998, para quienes ocho días antes de iniciar la suplementación con los lácteos y a tiempo 0 las enterobacterias fueron, de los microorganismos estudiados, los menos abundantes con $8,0 \log _{10}$ u.f.c./g. A los 15 días de ingesta, el valor medio fue de $7,7 \log _{10}$ u.f.c./g y a los 30 , éste fue de $8 \log _{10}$ u.f.c./g. Tras una semana sin administración (día 38), el valor fue de $7,6 \log _{10}$ u.f.c./g, no resultando las diferencias entre los periodos estadísticamente significativas.

Sin embargo, los resultados de Alvaro et al. 2007, apoyan los obtenidos en el presente estudio. Observaron una diferencia significativa en la evolución de la población de Enterobacteriaceae, que incluye bacterias patógenas, al encontrarse niveles significativamente inferiores en el grupo de consumidores, lo que podría sugerir que el consumo regular de yogur induce modificaciones de la microbiota endógena. 
CONCLUSIONES 
1. Todos los yogures naturales analizados cumplen la normativa legal vigente en cuanto al número de microorganismos viables. La cantidad de lactobacilos y estreptococos es muy variable aunque éstos últimos predominan en todos ellos.

2. Todas las sondas diseñadas, específicas del ARNr, permitieron identificar a nivel de especie todas las cepas de Streptococcus thermophilus y a nivel de subespecie todas las cepas de Lactobacillus delbrueckii subsp. bulgaricus contenidas en los diferentes productos lácteos. Esto permitió realizar recuentos de las BAL de los productos comerciales mediante $\mathrm{FISH}$, con resultados ligeramente superiores a los obtenidos mediante las técnicas tradicionales de recuento en placa y de forma más rápida y específica.

3. La técnica de caracterización molecular de RAPDs resulta adecuada para la caracterización y diferenciación de las distintas BAL contenidas en los productos comerciales estudiados, presentando diferencias en los perfiles obtenidos en función de su origen. Los perfiles obtenidos para las cepas del género Lactobacillus presentaron mayor heterogeneidad que los obtenidos para las cepas del género Streptococcus.

4. La técnica DVC-FISH se muestra como un método novedoso, rápido y eficaz para el recuento de células viables de $L$. delbrueckii subsp. bulgaricus y $S$. thermophilus en las distintas matrices estudiadas (yogur natural y heces humanas). El antibiótico novobiocina, a la concentración de $10 \mu \mathrm{g} / \mathrm{ml}$ y tiempo de incubación de 7 horas, ha resultado ser el más efectivo para la aplicación de la técnica DVC-FISH para las BAL del yogur natural.

5. Tras estudiar in vitro la resistencia de las BAL del yogur frente a los jugos gastrointestinales mediante la aplicación del método DVC-FISH, L. delbrueckii subsp. bulgaricus mostró una supervivencia del $26,2 \%$ mientras $S$. thermophilus sobrevivió en un $9,2 \%$. Podemos decir que las cepas del producto estudiado son tolerantes a los jugos in vitro y, por tanto, potencialmente a los jugos generados por el tránsito gastrointestinal humano.

6. La técnica DVC-FISH es eficaz para la detección de L. delbrueckii subsp. bulgaricus y $S$. thermophilus en heces y la determinación de su viabilidad. 
permitiendo una detección visual de las células y evitando los falsos positivos, al proporcionar información acerca del número, morfología y distribución de las bacterias dentro de matrices complejas.

7. La técnica DVC-FISH no requiere de extracción de ADN, por lo que resulta más rápida que la PCR. Aunque en los ensayos previos ambas técnicas presentan el mismo límite de detección, la mayor eficiencia de detección de las BAL en heces mediante DVC-FISH la hace más apropiada para su aplicación en este tipo de matrices.

8. El cultivo no resulta adecuado para la detección de L. delbrueckii subsp. bulgaricus y $S$. thermophilus en heces, debido al gran crecimiento de microbiota acompañante que enmascara el crecimiento de estas bacterias en los medios de cultivo utilizados para su aislamiento habitualmente.

9. En el estudio in vivo de supervivencia de las $B A L$ de $Y 7$ al tracto gastrointestinal, la detección en heces de L. delbrueckii subsp. bulgaricus mediante las técnicas de detección por PCR y DVC-FISH ha demostrado que esta bacteria no se detecta en cantidad superior a $1 \times 10^{4}$ células $/ g$.

10. En el ensayo in vivo de supervivencia de BAL de $Y 7$, S. thermophilus ha sido detectada (en cantidad superior a $1 \times 10^{4}$ células $/ g$ ) en las heces del $30 \%$ de personas que ingirieron 250 gramos de yogur natural durante 4 semanas consecutivas. Por tanto esta bacteria cumple uno de los requisitos para considerarla como probiótica.

11. Tras el consumo continuado de yogur $Y 7$ se observa un incremento significativo en la población de lactobacilos endógenos que vuelve a niveles basales en el periodo de post-ingesta. Esta acción se considera como efecto prebiótico ya que las múltiples propiedades de este género proporcionarían un efecto saludable en el organismo.

12. La población de enterobacterias, que incluye bacterias patógenas, se ve reducida de forma estadísticamente significativa desde la segunda semana de ingesta de yogur, proporcionando un posible beneficio sobre la salud intestinal. 
13. El estudio in vivo muestra que las poblaciones de bifidobacterias, aerobios totales y anaerobios totales no se ven afectadas significativamente por la ingesta de yogur natural. 
BIBLIOGRAFÍA 
Adlerberth, I; Cerquetti, M; Poilane, I; Wold, A; Collignon, A (2000). Mechanisms of colonisation and colonisation resistance of the digestive tract. Microbial Ecology in Health and Disease; 11: 223-239.

Agence Française de securite sanitaire des aliments: AFSSA (2005). Effects of probiotics and prebiotics on flora and immunity in adults.

Alifano, P., Bruni, B., and Carlomagno, S. (1994). Control of mRNA processing and decay in prokaryotes. Genetica, 94: 157-172.

Alvaro, E.; Andrieux, C.; Rochet, V.; Rigottier-Gois, L.; Lepercq, P.; Sutren, M.; Galan, P.; Duval, Y.; Juste, C.; Doré, J. (2007). Composition and metabolism of the intestinal microbiota in consumers and non-consumers of yogurt. British Journal of Nutrition, 97: 126-133.

Amman R. I., Krumholz, L. and Stahl, D. A. (1990). Fluorescent oligonucleotide probing of whole cells for determinative phylogenetic and environmental studies of microbiology. Journal of Bacteriology, 172: 762-770.

Amman, R.I., Ludwig, W and Schleifer, K. H. (1995). Phylogenetic identification and in situ detection of individual microbial cells without cultivation. Microbiological Reviews, 59: 143-169.

Ampe, F. (2000). Design and evaluation of a Lactobacillus manihotivorans speciesspecific rRNA-targeted hybridization probe and its application to the study of sour cassava fermentation. Applied Environmental Microbiology, 66: 2224-2226.

Andrighetto, C.; De Dea, P.; Lombardi, A.; Neviani, E.; Rossetti, L.; Giraffa, G. (1998). Molecular identification and cluster analysis of homofermentative thermophilic lactobacilli isolated from dairy products. Research in Microbiology, 149: 631-643.

Anónimo (2006). Derivados lácteos; crecimiento sostenido y alta rentabilidad. Tecnifood, mayo-junio, pp. 40-47. 
Antonsson, M.; Ardo, Y.; Molin, G. (2001). A comparison between the microflora of Herrgard cheese from three different dairies. International Dairy Journal, 11: 285291.

Anukam KC, Osazuwa E, Osemene GI, Ehigiagbe F, Bruce AW, Reid G. (2006). Clinical study comparing probiotic Lactobacillus GR-1 and RC-14 with metronidazole vaginal gel to treat symptomatic bacterial vaginosis. Microbes and infection / Institut Pasteur, Oct; 8 (12-13): 2772-6.

Ashwell, M. (2001). Functional foods: a simple scheme for establishing the scientific validity for all claims. Public Health Nutrition. 4(3): 859-862.

Aso Y, Akaza H, Kotake T, Tsukamoto T, Imai K, Naito S. (1995). Preventive effect of a Lactobacillus casei preparation on the recurrence of superficial bladder cancer in a double-blind trial. The BLP Study Group. European Urology; 27 (2): 104-9.

Back, W.; BohaK, I.; Ehrmann, M.; Ludwig, W.; Pot, B.; Kersters, K.; Schleifer, K.H. (1999). Lactobacillus perolens sp. nov., a soft drink spoilage bacterium. Systematic Applied Microbiology, 22: 354-359.

Bañares Vilella, S. (2006). Los alimentos funcionales y las alegaciones alimentarias en la Unión Europea: una somera aproximación jurídica. Alimentación, nutrición y salud, Vol. 13, N. ${ }^{\circ} 3$, pp. 81-90.

Barcina, I.; Arana, I.; Santorum, P.; Iriberri, J.; Egea, L. (1995). Direct viable count of Gram-positive and Gram-negative bacteria using ciprofloxacin as inhibitor of cellular division. Journal of Microbiological Methods, 22 (2): 139-150.

Baruzzi, F.; Morea, M.; Matarante, A.; Cocconcelli, P.S. (2000). Changes in the Lactobacillus community during Ricotta forte cheese natural fermentation. Journal of Applied Microbiology, 89: 807-814.

Baudart, J.; Coallier, J.; Laurent, P.; Prévost, M. (2002). Rapid and sensitive enumeration of viable diluted cells of members of the family Enterobacteriaceae in freshwater and drinking water. Applied and Environmental Microbiology, 68 (10): 5057-5063. 
Beijjerinck, MW (1901). Sur les ferments lactiques de l'industrie. Archives Néerlandaises des sciences Exactes et Naturelles (Section 2), 6, 212-243.

Beimfohr, C.; Krause, A.; Amann, R.; Ludwig, W.; Schleifer, KH. (1993). In situ identification of Lactococci, enterococci and streptococci. Systematic applied microbiology, 16: 450-453.

Bej, A. K., Morgan, W., Jones, D. and Mahbubani, M. (1996). Detection of viable Vibrio choleae by reverse-transcriptase polymerase chain reaction. Molecular Biotechnology, 5: 1-10.

Belasco, J. (1993). mRNA degradation in prokaryotic cells: an overview. En: J. Belasco and G. Brawerman (eds.). Control of messenger RNA stability. Academic Press, San Diego.

Beltrán-Orozco, María del Carmen (2006). Ingredientes Funcionales; definición, ubicación y usos. Industria alimentaria-Alfa editores técnicos, julio-agosto, pp. 36-42.

Benno, Y; Mitsuoka, T (1986). Development of intestinal microflora in humans and animals. Bifidobacteria and Microflora; 5: 13-25.

Bentley, R. W.; Leigh, J. A. (1995). Development of PCR-Based Hybridization Protocol for Identification of Streptococcal Species. Journal of Clinical microbiology, Mayo, Vol. 33, No. 5, p. 1296-1301.

Berg, RD (1996). The indigenous gastrointestinal microflora. Trends in Microbiology, 4: 430-435.

Berthier, F.; Beuvier, E.; Dasen, A.; Grappin, R. (2001). Origin and diversity of mesophilic lactobacilli in Comté cheese, as revealed by PCR with repetitive and species-specific primers. International Dairy Journal, 11: 293-305.

Berthier, F.; Ehrlich, S.D. (1998). Rapid species identification within two groups of closely related lactobacilli using PCR primers that target the 16S/23S rRNA spacer region, FEMS Microbiology Letters, 161: 97-106. 
Berthier, F.; Ehrlich, S.D. (1999). Genetic diversity within Lactobacillus sakei and Lactobacillus curvatus and design of PCR primers for its detection using randomly amplified polymorphic DNA. International Journal of Systematic Bacteriology, 49: 997-1007.

Berthier, F.; Ehrlich, S.D. (1999). Genetic diversity within Lactobacillus sakei and Lactobacillus curvatus and design of PCR primers for its detection using randomly amplified polymorphic DNA. International Journal of Systematic Bacteriology, 49: 997-1007.

Bezkorovainy, A. (2001). Probiotics: determinants of survival and growth in the gut. American Journal of Clinical Nutrition, 73(Suppl. 2): 399S-405S.

Bianchi-Salvadori, B; Camaschella, P; Bazzigaluppi, E. (1984). Distribution and adherence of Lactobacillus bulgaricus in the gastroenteric tract of germ-free animals. Milk Science International, 39: 387-391.

Bouton, Y.; Guyot, P.; Beuvier, E.; Tailliez, P.; Grappin, R. (2002). Use of PCRbased methods and PFGE for typing and monitoring homofermentativo lactobacilli during Comté cheese ripening. International Journal of Food Microbiology, 76: 27-38.

Bouhnik, Y. (1993). Survie et effets chez l'homme des bactéries ingérées dans les laits fermentés. Lait, 73: 241-247.

Brigidi, P.; Swennen, E.; Vitali, B.; Rossi, M.; Matteuzzi, D. (2003). PCR detection of Bifidobacterium strains and Streptococcus thermophilus in feces of human subjects after oral bacteriotherapy and yogurt consumption. International Journal of Food Microbiology, 81: 203-209.

Brouns, F; Kettlitz, B; Arrioni, E. (2002). Resistant starch and the butyrate revolution. Trends in Food Science Technology; 13: 251-261.

Buchrieser, C; Kaspar, CW. (1993). An improved direct viable count for the enumeration of bacteria in milk. International Journal of Food Microbiology. Dec; 20 (4): 227-37. 
Bunte C.; Hertel, C.; Hammes, W.P. (2000). Monitoring and survival of Lactobacillus paracasei LTH 2579 in food and the human intestinal tract. Systematic Applied Microbiology, 23: 260-266.

Castro Rodrígez, Rubén (2007). El sector lácteo español: Una actividad estratégica y necesaria para los consumidores. Distribución y Consumo, Noviembre-Diciembre 2007, páginas 68-76.

Cebra, JJ. (1999). Influences of microbiota on intestinal immune system development. American Journal of Clinical Nutrition; 69: 1046-1051.

Cellini, L., Del Vecchio, A., Di Candia, M., Di Campli, E., Favaro, M. and Donelli, G. (2005). Detection of free and plankton-associated Helicobacter pylori in seawater Journal of Applied Microbiology, 97: 285-292.

Chagnaud, P.; Machinis, K.; Coutte, L.A.; Marecat, A.; Mercenier, A. (2001). Rapid PCR based procedure to identify lactic acid bacteria: application to six common Lactobacillus species. Journal of Microbiological Methods, 44: 139-148.

Charteris, WP.; Kelly, PM.; Morelli, L; Collins, JK. (1997). Selective detection, enumeration and identification of potentially probiotic Lactobacillus and Bifidobacterium species in mixed bacterial populations. International Journal of Food Microbiology, 35: 1-27.

Chervaux, C.; Ehrlich, SD.; Maguin, E. (2000). Physiological Study of Lactobacillus delbrueckii subsp. bulgaricus Strains in a Novel Chemically Defined Medium. Applied and Environmental Microbiology, 66 (2): 5306-5311.

Chisholm, S. A., Owen, R. J., Teare, E. L. and Saverymuttu, S. (2001). PCR-based diagnosis of Helicobacter pylori infection and real-time determination of clarithromycin resistance directly from human gastric biopsy samples. Journal of Clinical Microbiology, 39: 1217-1220.

Cocconcelli ,P.S.; Porro, D.; Galandini, S.; Senini, L. (1995). Development of RAPD protocolfor typing of strains of lactic acid bacteria and enterococci, Letters in Applied Microbiology, 21: 376-379. 
Cocconcelli, P.S.; Parisi, M.G.; Senini, L.; Bottazzi, V. (1997). Use of RAPD and $16 S$ rDNA sequencing for the study of Lactobacillus population dynamics in natural whey culture. Letters in Applied Microbiology, 25: 8-12.

Coeuret, V.; Ségolène Dubernet, S.; Bernardeau, M; Gueguen, M.: Vernoux, JP. (2003). Isolation, characterisation and identification of lactobacilli focusing mainly on cheeses and other dairy products. Lait, 83: 269-306.

Collins, MD and Gibson, GR (1999). Probiotics, prebiotics and synbiotics: approaches for modulating the microbial ecology of the gut. American Journal of Nutrition, 69 (suppl.):1052S-7S.

Collins, MD; Rodríguez, U; Aguirre, M; Farrow, JAE; Martínez-Murcia, A; Phillips, BA; Williams, AM; Wallbanks, S (1991). Phylogenetic analysis of genus Lactobacillus and related lactic acid bacteria as determined by reverse transcriptase sequencing of $16 \mathrm{~S}$ rRNA. FEMS microbiology Letters, 77: 5-12.

Colman, G. (1976). The viridans streptococci. In Selected Topics in Clinical Bacteriology, pp. 179-198. Edited by J. de Louvois. London: Bailliere Tindal.

Conway, P. L.; Gorbach, S. L.; Goldin. B. R. (1987). Survival of lactic acid bacteria in the human stomach and adhesion to intestinal cells. Journal of Dairy Science, 70 : $1-12$.

Corthésy B, Gaskins HR, Mercenier A. (2007). Cross-talk between probiotic bacteria and the host immune system. The Journal of Nutrition; 137 (3 Suppl 2): 781S-90S.

Coullier, J., Prevots, M. and Rompre, A. (1994). The optimiztion and application of two direct viable count methods for bacteria in distributed drinking water. Canadian Journal of Microbiology, 40: 830-836.

Couret, V., Dubernet, S., Bernardeau, M., Gueguen, M., Vernoux, J. P. (2003). Isolation, characterisation and identification of lactobacilli focusing mainly on cheeses and other daily products. Lait, 83: 269-306.

Cremonini F, Di Caro S, Nista EC, Bartolozzi F, Capelli G, Gasbarrini G, Gasbarrini A. (2002). Meta-analysis: the effect of probiotic administration on antibioticassociated diarrhoea. Alimentary pharmacology \& therapeutics; 16(8):1461-7. 
Crittenden, R. G., Morris, L. F., Harvey, M. L., Tran, L. T., Mitchell, H. L. and Playne, M. J. (2001). Selection of a Bifidobacterium strain to complement resistant starch in a synbiotic yoghurt. Journal of Applied Microbiology, 90: 268-278.

Cusick, SM.; O'Sullivan, DJ. (2000). Use of a Single, Triplicate Arbitrarily PrimedPCR Procedure for Molecular Fingerprinting of Lactic Acid Bacteria. Applied and Environmental Microbiology, 66 (5): 2227-2231.

Daud Khaled, A.K.; Neilan, B.A.; Henriksson, A.; Conway, P.L. (1997). Identification and phylogenetic analysis of Lactobacillus using multiplex RAPD-PCR. FEMS Microbiology Letters, 153: 191-197.

De Champs, C.; Maroncle, N.; Balestrino, D.; Rich, C.; Forestier, C. (2003). Persistence of Colonization of Intestinal Mucosa by a Probiotic Strain, Lactobacillus casei subsp. rhamnosus Lcr35, after Oral Consumption. Journal of Clinical Microbiology, 41 (3), p. 1270-1273.

de Vrese M, Marteau PR. (2007). Probiotics and prebiotics: effects on diarrhea. Journal of Nutrition; 137(3 Supplement 2): 803S-11S.

de Vrese M, Stegelmann A, Richter B, Fenselau S, Laue C, Schrezenmeir J. (2001). Probiotics-compensation for lactase insufficiency. The American journal of clinical nutrition; 73 (2 Suppl): 421S-429S.

Del Campo, Rosa; Bravo, Daniel; Cantón, Rafael; Ruiz-Garbajosa, Patricia; GarcíaAlbiach, Raimundo; Montesi-Libois, Alejandra; Yuste, Francisco-Javier; Abraira, Victor; Baquero, Fernando (2005). Scarce Evidence of Yogurt Lactic Acid Bacteria in Human Feces after Daily Yogurt Consumption by Healthy Volunteers. Applied and Environmental Microbiology, Vol. 71, No. 1, p. 547-549.

Dickson, E. M.; Riggio, M. P.; Macpherson, L. (2005). A novel species-specific PCR assay for identifying Lactobacillus fermentum. Journal of Medical Microbiology, 54: 299-303.

Diplock A, Aggett P, Ashwell M, et al (1999). Scientific concepts of functional foods in Europe: Consensus Document. British Journal of Nutrition. 81(4): S1-27. 
Dong, X.; Cheng, G. Jian, W. (2000). Simultaneous identification of five Bifidobacterium species isolated from human beings using multiple PCR primers. Systematic and applied microbiology , vol. 23, no3, pp. 386-39

Drake, M.; Small, C.L.; Spence, K.D.; Swanson, B.G. (1996). Rapid detection and identification of Lactobacillus spp. in dairy products by using the polymerase chain reaction. Journal of Food Protection, 59: 1031-1036.

Drouault, S.; Anba, J.; Corthier, G. (2002). Streptococcus thermophilus is able to produce a beta-galactosidase active during its transit in the digestive tract of germfree mice. Applied Environmental Microbiology, 68: 938-941.

Du Plessis EM, Dicks LM. (1995). Evaluation of random amplified polymorphic DNA (RAPD)-PCR as a method to differentiate Lactobacillus acidophilus, Lactobacillus crispatus, Lactobacillus amylovorus, Lactobacillus gallinarum, Lactobacillus gasseri, and Lactobacillus johnsonii. Current Microbiology, 31 (2): 114-118.

Dubernet, S.; Desmasures, N.; Guéguen, M. (2002). A PCR-based method for identification of lactobacilli at genus level. FEMS Microbiology Letters, 214: 271.

Ehrmann, M.; Ludwig, W.; Schleifer, K.H. (1992). Species specific oligonucleotide probe for the identification of Streptococcus thermophilus. Systematic applied microbiology, 15: 453-455.

Ehrmann, M.; Ludwig, W.; Schleifer, K.H. (1994). Reverse dot blot hybridization: a useful method for the direct identification of lactic acid bacteria in fermented food. FEMS microbiological letters, 117: 143-149.

Elli, M.; Callegari, M. L.; Ferrari, S.; Bessi, E.; Cattivelli, D.; Soldi, S.; Morelli, L.; Goupil Feuillerat, N.; Antoine, J.-M. (2006). Survival of yogurt bacteria in the human gut. Applied and Environmental Microbiology, 72: 5113-5117.

Engelbrektson AL, Korzenik JR, Sanders ME, Clement BG, Leyer G, Klaenhammer TR, Kitts CL (2006). Analysis of treatment effects on the microbial ecology of the human intestine. FEMS microbiology ecology ; 57(2): 239-50. 
Eriksson K, Carlsson B, Forsum U, Larsson PG. (2005). A double-blind treatment study of bacterial vaginosis with normal vaginal lactobacilli after an open treatment with vaginal clindamycin ovules. Acta dermato-venereologica; 85 (1): 42-6.

Falk, P. G.; Hooper, L. V.; Midtvedt, T.; Gordon, J. I. (1998). Creating and maintaining the gastrointestinal ecosystem: what we know and need to know from gnotobiology. Microbiology and Molecular Biology Reviews, 62: 1157-1170.

Fanedl, L.; Nekrep, F.V.; Avguštin, G. (1998). Random amplified polymorphic DNA analysis and demonstration of genetic variability among bifidobacteria isolated from rats fed with raw kidney beans. Canadian Journal of Microbiology, 44: 1094-1101.

Farjas Abadía, P. (2003). Sobre los alimentos funcionales. Revista Española de Salud Pública. 77: 313-316.

Figueroa, I., Gómez-Ruiz, L., García Garibay, M., Cruz-Guerrero, A. (2006). EL beneficio de los probióticos. Industria alimentaria, julio-agosto 2006: 22-27.

Fooks, LJ and Gibson, GR (2002). Probiotics as modulators of the gut flora. British Journal of Nutrition, 88: S39S49.

Franks, A H.; Harmsen, H J M.; Raangs, GC.; Jansen, GJ.; Schut, F.; Welling GW. (1998). Variations of Bacterial Populations in Human Feces Measured by Fluorescent In Situ Hybridization with Group-Specific 16S rRNA-Targeted Oligonucleotide Probes. Applied and Environmental Microbiology, 64 (9): 33363345.

Fuchs, B.M., Syutsubo, K., Ludwing, W. and Amann, R. (2001). In situ accesibility of Escherichia coli $23 S$ ribosomal RNA for fluorescently labeled oligonucleotide probes. Applied Environmental Microbiology, 67: 961-968.

Fujimura, S., Kawamura, T., Kato, S., Tateno, H. and Wanatabe, A. (2002). Detection of Helicobacter pylori in cow's milk. Letters in Applied Microbiology, 35: 504-507.

Fuller R. (1989). Probiotics Lactobacillus acidophilus in man and animals. Journal of Applied Bacteriology; 66: 365-378. Comentado en: The American journal of clinical nutrition 2001; 73: 430S-436s 
Furrie, E. (2005). Probiotics and allergy. Proceedings of the Nutrition Society, Nov: 64(4):465-9. Review.

Gancheva, A.; Pot, B.; Vanhonacker, K; Hoste, B.; Kersters, K. (1999). A polyphasic approach towards the identification of strains belonging to and related species. Systematic Applied Microbiology, 22: 573-585.

García de los Ríos, JE; Santos Jiménez Gómez, J; Jiménez Gómez, PA; Reche Sainz, Ma P; Álvarez Dávila, F; Rojas Mendoza, A Mª (2003). Estudio microbiológico comparativo de yogur fresco y termizado en un modelo animal in vivo. Nutrición hospitalaria, 18 (4): 207-214.

Garcia-Albiach, R.; Pozuelo de Felipe, MJ; Angulo, S.; Morosini, M. I.; Bravo, D.; Baquero, F.; del Campo, R. (2008). Molecular analysis of yogurt containing Lactobacillus delbrueckii subsp. bulgaricus and Streptococcus thermophilus in human intestinal microbiota. American Journal of Clinical Nutrition, 87: 91-96.

Germond, J-E.; Mamin, O.; Mollet, B. (2002). Species Specific Identification of Nine Human Bifidobacterium spp. in Feces. Systematic and Applied Microbiology, 25: 536-543.

Gibson, GR; Roberfroid, MB (1995): Dietary modulation of the human colonic microbiota: Introducing the concept of prebiotics. Journal of Nutrution, 125: 14011412.

Gilliland, SE. (1979). Beneficial interreleationships between certain microorganisms and humans: candidate microorganisms for use as dietary adjuncts. Journal of Food Protection, 42: 146- 167.

Gilliland, S.E.; Kim, H.S. (1984). Effect of viable starter culture bacteria in yogurt on lactose utilization in humans. Journal of Dairy Science, 67: 1.

Gilliland, SE. (1989). Acidophilus milk products: A review of potential benefits to consumers. Journal of Dairy Science, 72: 2483-2494.

Giraffa, G.; De Vecchi, P.; Rossetti, L. (1998). Note: identification of Lactobacillus delbrueckii subspecies bulgaricus and subspecies lactis dairy isolates by amplified rDNA restriction analysis. Journal of Applied Microbiology, 85: 918-924. 
Gotteland R., M; Garrido C., D; Cruchet M., S. (2006). Regulación de la microbiota intestinal en voluntarios sanos mediante el consumo de un producto con el probiótico Lactobacillus johnsonii La1. Revista Chilena de Nutrición, 33 (2): 198-203.

Greene, J. D.; Klaenhammer, T. R. (1994). Factors involved in adherence of lactobacilli to human Caco-2 cells. Applied and Environmental Microbiology, 60: 4487-4494.

Grimont, PA. (1988). Use of DNA reassociation in bacterial classification. Canadian Journal of Microbiology, 34: 541-546.

Grönlund, MM; Arvilommi, H; Kero, P; Lehtonen, OP; Isolauri, E. (2000). Importance of intestinal colonisation in the maturation of humoral immunity in early infancy: a prospective follow up study of healthy infants aged 0-6 months. Archives of Disease in Childhood; 83: F186-F192.

Grönlund, MM; Lehtonen, OP; Eerola, E; Kero, P (1999). Fecal microflora in healthy infants born by different methods of delivery: permanent changes in intestinal flora after Cesarean delivery. Journal of Pediatric Gastroenterology and Nutrition; 28: 19-25.

Guarner, F.; Malagelada, JR. (2003). Gut flora in health and disease. Lancet; 361: 512-519.

Guarner, F. (2002). El colon como órgano: hábitat de la flora bacteriana. Nutrición Hospitalaria XVII (Sup. 2) 7-10.

Guarner, F. (2006). Funciones de la microflora intestinal. Alimentación, nutrición y salud- Instituto Danone, 13 (2): 41-47.

Guarner, F.; Perdigon, G.; Corthier, G.; Salminen, S.; Koletzko, B.; Morelli, L. (2005). Should yoghurt cultures be considered probiotic? British Journal of Nutrition, 93: 783-786.

Guarner, F. and Schaafna, GJ. (1998). Probiotics. International Journal of Food Microbiology, 39, 237-238. 
Guerin-Danan, C.; Chabanet, C.; Pedone, C.; Popot, F.; Vaissade, P.; Bouley, C.; Szylit, O.; Andrieux, C. (1998). Milk fermented with yogurt cultures and Lactobacillus casei compared with yogurt and gelled milk: influence on intestinal microflora in healthy infants. The American Journal of Clinical Nutrition, 67: 111-7.

Guyard, S.; Mary, P.; Defives, C.; Hornez, J.P. (1999). Enumeration and characterization of bacteria in mineral water by improved direct viable count method. Journal of Applied Microbiology, 86: 841-850.

Hammes, WP; Vogel (1995). The genus Lactobacillus. The genera of Lactic acid bacteria (B. J. B Wood and W. H. Holzapfel, eds). Blackie Academic and Professional. Glasgow, NZ, pp 19-54.

Haq, A. and Colwell, R. R. (1996). A microbiological paradox-viable but nonculturable bacteria with special reference to Vibrio cholerae. Journal of Food Protection, 59: 96-101.

Hardie, JM and Whiley, RA (1995). The genus Streptococcus, in The genera of Lactic Acid Bacteria (B. J. B Wood and W. H. Holzapfel, eds), Chapman and Hall, London, pp. 55-124.

Harmsen, HJM; Gibson, GR; ; Elfferich, P.; Raangs, GC; Wildeboer-Veloo, ACM; Argaiz, A.; Roberfroid, MB; Welling, GW (1999). Comparison of viable cell counts and fluorescence in situ hybridization using specific rRNA-based probes for the quantification of human fecal bacteria. FEMS Microbiology Letters; 183: 125-129.

Harmsen, HJM; Raangs, GC; He, T.; Degener, JE.; Welling, GW. (2002). Extensive Set of 16S rRNA-Based Probes for Detection of Bacteria in Human Feces. Applied and Environmental Microbiology, 68 (6): 2982-2990.

Harmsen, HJM; Wildeboer-Veloo, ACM; Raangs, GC; Wagendorp, AA; Klijn, N; Bindels, JG; Welling, GW (2000). Analysis of intestinal flora development in breastfed and formula-fed infants by using molecular identification and detection methods. Journal of Pediatric Gastroenterology and Nutrition; 30: 61-67.

Hartemink, R.; Domenech, V.R.; Rombouts, F.M. (1997). LAMVAB - A new selective medium for the isolation of lactobacilli from faeces. Journal of Microbiological Methods, 29: 77-84. 
Heilig, HGHJ; Zoetendal, EG.; Vaughan, EE.; Marteau, P.; Akkermans, ADL.; de Vos, WM. (2002). Molecular Diversity of Lactobacillus spp. and Other Lactic Acid Bacteria in the Human Intestine as Determined by Specific Amplification of $16 \mathrm{~S}$ Ribosomal DNA. Applied and Environmental Microbiology, 68 (1): 114-123.

Hensiek, R.; Krupp, G.; Stackebrandt, E. (1992). Development of diagnostic oligonucleotide probes for four Lactobacillus species occurring in the intestinal tract. Systematic applied microbiology, 15: 123-128.

Hernández, J., Fayos, A., Ferrús, M. A. and Owen, R. J. (1995). Random amplified polymorphic DNA fingerprinting of Campylobacter jejuni and C. coli isolated from human faeces, seawater and poultry products. Research in Microbiology, 146: 685-696.

Hertel, C.; Ludwig, W.; Obst, M.; Vogel, RF.; Hammes, WR.; Schleifer, K.H. (1991). 23S rRNA-targeted oligonucleotide probes for the rapid identification of meat lactobacilli. Systematic and Applied Microbiology, 14: 173-177.

Hertel, C.; Ludwig, W.; Pot, B.; Kersters, K.; Schleifer, K.H. (1993). Differentiation of lactobacilli occuring in fermented milk products by using oligonucleotides probes and electrophoretic protein profiles. Systematic and Applied Microbiology, 16: 463467.

Hod, Y. (1992). A simplified ribonuclease protection assay. Biotechniques, 13: 852854.

Hooper, L. V.; Wong, M. H.; Thelin, A.; Hansson, L.; Falk, P. G.; Gordon, J. I. (2001). Molecular analysis of commensal host-microbial relationships in the intestine. Science 291: 881-884.

Hooper, LV; Midtvedt, T; Gordon, JI (2002). How host-microbial interactions shape the nutrient environment of the mammalian intestine. Annual Review of Nutrition; 22: 283-307.

Horie, M.; Kajikawa, H.S.; Toba, T. (2002). Identification of Lactobacillus crispatus by polymerase chain reaction targeting S-layer protein gene. Letters in Applied Microbiology, 35: 57-61. 
Ishikawa H, Akedo I, Otani T, Suzuki T, Nakamura T, Takeyama I, Ishiguro S, Miyaoka E, Sobue T, Kakizoe T. (2005). Randomized trial of dietary fiber and Lactobacillus casei administration for prevention of colorectal tumors. International Journal of Cancer, 20;116(5):762-7.

Islam, M. S., Hasan, M. K., Miah, M. A., Sur, G. C., Felsesnstein, A., Venkatesan, M., Sack, R. B. and Albert, M. J. (1993). Use of the polymerase chain reaction and fluorescence-antibody methods for detecting viable but nonculturable Shigella dysenteriae Type I in laboratory microcosms. Applied and Environmental Microbiology, 59: 53-540.

Isolauri, E.; Salminen, S.; Ouwehand, A. C. (2004). Probiotics. Best Practice \& Research Clinical Gastroenterology, Vol. 18, No. 2, pp. 299-313.

Isolauri, E; Kirjavainen, PV; Salminen, S (2002). Probiotics-a role in the treatment of intestinal infection and inflammation. Gut; 50 (supplement III): iii54-iii59.

Johansson, M.L.; Molin, G; Pettersson, B.; Uhlén, M.; Ahrné, S. (1995). Characterization and species recognition of Lactobacillus plantarum strains by restriction fragment length polymorphism (RFLP) of the 16S rRNA gene, Journal of Applied Bacteriology, 79: 536-541.

Johansson, ML.; Quednau, M.; Ahrné, S.; Molin, G. (1995). Randomly amplified polymorphic DNA (RAPD) for rapid typing of Lactobacillus plantarum strains. Letters in Applied Microbiology, 21: 155-159.

Joux, Fabien and LeBaron, Philippe (1997). Ecological implications of an improved direct viable count method for aquatic bacteria. Applied and environmental microbiology, Vol. 63, No. 9, p. 3643-3647.

Juárez, M. (2007). Alimentos funcionales y publicidad. Alimentación, nutrición y salud, Vol. $14, \mathrm{~N}^{\circ} 2$, pp. 31-32.

Kalliomäki , S . Salminen , H . Arvilommi , P . Kero , P . Koskinen , E . Isolauri (2001). Probiotics in primary prevention of atopic disease: a randomised placebocontrolled trial. The Lancet, Volumen 357, Issue 9262 , Páginas 1076 - 1079 M. 
Kalmbach, S.; Manz, W.; Szewzyk, U. (1997). Dynamics of biofilm formation in drinking water: phylogenetic affiliation and metabolic potential of single cells assessed by formazan reduction and in situ hybridization. FEMS Microbiology Ecology, 22: 265-279.

Karner, M., Fuhrman, J. A. (1997). Detemination of active marine bacterioplankton: a comparison of universal 16S rRNA probes, autoradiography and nucleoid staining. Applied and Environmental Microbiology, 63: 1208-1213.

Kaufmann, P.; Pfefferkorn, A.; Teuber, M.; Meile, L. (1997). Identification and Quantification of Bifidobacterium Species Isolated from Food with Genus-Specific 16S rRNA-Targeted Probes by Colony Hybridization and PCR. Applied and Environmental Microbiology; 63 (4): p. 1268-1273.

Kimura, K; McCartney, AL; McConnell, MA; Tannock, GW (1997). Analysis of fecal populations of bifidobacteria and lactobacilli and investigations of the immunological responses to their human hosts to the predominant strains. Applied and Environmental Microbiology; 63: 3394-8.

Klein, P. G. and Juneja, V. K. (1997). Sensitive detection of viable Listeria monocytogenes by reverse-transcriptase PCR. Applied and Environmental Microbiology, 63: 4441-4448.

Kogure, K., Simidu, U., and Taga, H. (1979). A tentative direct microscopic method for counting living marine bacteria. Canadian Journal of Microbiology, 25: 415420.

Kullen, MJ; Brady, LJ; O'Sullivan, DJ. (1997). Evaluation of using a short region of the recA gene for the rapid and sensitive speciation of dominant bifidobacteria in the human large intestine. FEMS Microbiology Letters ; 154: 377-383.

Lane, DL; Field, KG; Olsen, GJ; Pace, NR (1998). Reverse transcriptase sequencing of ribosomal RNA for phylogenetic analysis. Methods of Enzymology, 167: 138-144.

Lankaputhra, W.E.V.; Shah, N.P. (1995). Survival of Lactobacillus and Bifidobacterium spp. in the presence of acid and bile salts. Cultured Dairy Produce Journal, 30: 2-7. 
Larsen, B; Monif, GRG (2001). Understanding the bacterial flora of the female genital tract. Clinical Infectious Diseases; 32: e69-e77.

Lepeuple, S; Delabre, K; Gilouppe, S; Intertaglia, L; de Roubin, MR. (2003). Laser scanning detection of FISH-labelled Escherichia coli from water samples. Water science and technology : a journal of the International Association on Water Pollution Research, 47(3):123-129.

Lesbros-Pantoflickova D, Corthésy-Theulaz I, Blum AL. (2007). Helicobacter pylori and probiotics. The Journal of nutrition; 137 (3 Supplement 2): 812S-8S.

Lick, S., K. Drescher, and K. J. Heller (2001). Survival of Lactobacillus delbrueckii subsp. bulgaricus and Streptococcus thermophilus in the terminal ileum of fistulated Göttingen minipigs. Applied Environmental Microbiology, 67: 4137-4143.

Lick, S.; Brockmann, E.; Heller, K.J. (2000). Identification of Lactobacillus delbrueckii and subspecies by hybridization probes and PCR. Systematic Applied Microbiology, 23: 251-259.

Lilly, D; Stillwell, R. (1965). Probiotcis: Growth promoting factors produced by Microorganisms. Science; 47: 747-8.

Lionetti E, Miniello VL, Castellaneta SP, Magistá AM, de Canio A, Maurogiovanni G, lerardi E, Cavallo L, Francavilla R. (2006). Lactobacillus reuteri therapy to reduce side-effects during anti-Helicobacter pylori treatment in children: a randomized placebo controlled trial. Alimentary pharmacology \& therapeutics 15;24(10):14618. Epub 2006 Oct 10.

Lucchini, F.; Kmet, V.; Cesena, C.; Coppi, L.; Bottazzi, V.; Morelli, L. (1998). Specific detection of a probiotic Lactobacillus strain in faecal samples by using multiplex PCR. FEMS Microbiology Letters, 158: 273-278.

Lynch, PA.; Gilpin, BJ.; Sinton, LW.; Savill, MG. (2002). The detection of Bifidobacterium adolescentis by colony hybridization as an indicator of human fecal pollution. Journal of Applied Microbiology, 92: 526-533. 
Mannu, L.; Comunian, R.; Scintu, M.F. (2000). Mesophilic lactobacilli in Fiore Sardo cheese: PCR-identification and evolution during cheese ripening. International Dairy Journal, 10: 383-389.

Marteau, P.; Minekus, M.; Havenaar, R.; Huis in-t Veld, JHJ. (1997). Survival of Lactic Acid Bacteria in a Dynamic Model of the Stomach and Small Intestine: Validation and the Effects of Bile. Journal of Dairy Science, 80: 1031-1037.

Masters, C. I.; Shallcross, J. A.; Mackey, B. M. (1994). Effect of stress treatments on the detection of Listeria monocytogenes and enterotoxigenic Escherichia coli by the polymerase chain reation. Journal of Applied Bacteriology, 77: 73-79.

Mater, D. D. G.; Bretigny, L.; Firmesse, O.; Flores, M.-J.; Mogenet, A.; Bresson, J.-L.; Corthier, G. (2005). Streptococcus thermophilus and Lactobacillus delbrueckii subsp. bulgaricus survive gastrointestinal transit of healthy volunteers consuming yoghurt. FEMS Microbiology Letters, 250: 185-187.

Mayo, B. y Delgado, S. (2003). Alimentación, nutrición y salud- Instituto Danone, Vol. $10,{ }^{\circ}{ }^{\circ} 3$, páginas, 61-70.

McCartney, A. L. (2002). Application of molecular biological methods for studying probiotics and the gut flora. British Journal of Nutrition, 88, Suppl. 1, S29-S37.

McCartney, AL; Wang, W; Tannock, GW (1996). Molecular analysis of the composition of the bifido bacterial and lactobacilli microflora of humans. Applied Environmental Microbiology; 62: 4608-13.

McCarty, S. C. and Atlas, R. M. (1993). Effect of amplicon size on PCR detection of bacteria exposed to chlorine. PCR methods and applications, 3:181-185.

McPherson, JM; Eckstein, PE.; Scoles, GJ.; Gajaonar, AA. (1993). Variability of the random amplified polymorphic DNA assay among thermal cyclers and effects of primer and DNA concentration. Molecular and cellular probes, 7: 293-299.

Melton, D. A., Krieg, P. A., Rebagliati, M. R., Maniatis, T. Zinn, K and Green, M. R. (1984). Efficient in vitro synthesis of biologycally active RNA and RNA hybridization probes from plasmids containing a bacteriophage SP6 promotor. Nucleic Acids Research, 12: 70-35-7056. 
Metchnikoff, E. (1907). The prolongation of life: optimistic studies, GP. Putram and sons, The Kniclerbocker Press, 161-183, New York.

Mitsuoka, Tomotari (1992). Intestinal Flora and Aging. Nutrition Reviews; 50 (12): 438-46.

Moreno Espinosa, S. (2001). Características generales de la flora intestinal. Revista de Enfermedades Infecciosas en Pediatría, 15 (59): 75-78.

Moschetti, G.; Blaiotta, G.; Aponte, M.; Catzeddu, P.; Villani, F.; Deiana, P.; Coppola, S. (1998). Random amplified polymorphic DNA and amplified ribosomal DNA spacer polymorphism: powerful methods to differentiate Streptococcus thermophilus strains. Journal of Applied Microbiology, 85 (1): $25-36$.

Moter, A. and Göbel, U.B. (2000). Fluorescent in situ hybridization (FISH) for direct visualization of microorganisms. Journal of Microbiological Methods. 41: 85-112.

Muller, M.R.; Ehrmann, M.A.; Vogel, R.F. (2000). Multiplex PCR for the detection of Lactobacillus pontis and two related species in a sourdough fermentation. Applied Environmental Microbiology, 66: 2113-2116.

Mullié, C.; Odou, M.F.; Singer, E.; Romond, M.B.; Izard, D. (2003). Multiplex PCR using 16S rRNA gene-targeted primers for the identification of bifidobacteria from human origin. FEMS Microbiology Letters, 222: 129-136.

Mullis, K.B. (1990). The unusual origin of the polymerase chain reaction. Science of America, 262: 56-61, 64-65.

Mykkänen, H; Laiho, K; Salminen, S (1998). Variations in faecal bacterial enzyme activities and associations with bowel function and diet in elderly subjects. Journal of Applied Microbiology; 85: 37-41.

Näse L, Hatakka K, Savilahti E, Saxelin M, Pönkä A, Poussa T, Korpela R, Meurman $\mathrm{JH}$. (2001). Effect of long-term consumption of a probiotic bacterium, Lactobacillus rhamnosus GG, in milk on dental caries and caries risk in children. Caries research, Nov-Dec; 35 (6): 412-20. 
Nebra, Y.; Blanch, A.R. (1999). A new selective medium for Bifidobacterium spp. Applied Environmental Microbiology, 65: 5173-5176.

Nilsson, H., Blom, J., Al-Soud, W., Ljungh A., Andersen, L. and Eadström, T. (2002). Effect of cold starvation, acid stress and nutrients on metabolic activity of Helicobacter pylori. Applied Environmental Microbiology, 68: 11-19.

Nova Rebato, E.; Gómez Martínez, S.; Marcos Sánchez, A. (2006). La actuación de las leches fermentadas sobre el sistema immune. Alimentación, nutrición y salud, Vol. 13, N. ${ }^{\circ} 1$, pp. 15-22.

O'Sullivan, DJ (1999). Methods for analysis of the intestinal microflora. In Probiotics. A Critical Review, pp. 23-44 [GW Tannock, editor]. Norfolk, UK: Horizon Scientific Press.

O'Sullivan, DJ; Kullen, MJ (1998). Tracking of probiotic bifidobacteria in the intestine. International Dairy Journal 8, 513-525.

Ouwehand, C. A.; Kirjavainen, V. P.; Shortt, C.; Salminen, S. (1999). Probiotics: mechanisms and established effects. International Dairy Journal. 9: 42-52.

Ouwehand, C. A.; Kurvinen, T; Rissanen, P. (2004). Use of a probiotic Bifidobacterium in a dry food matrix, an in vivo study. International Journal of Food Microbiology, 95: 103-106.

Parker, R. M., Barnes, N. M., (1990). mRNA: detection by in situ and norhern hybridization. Methods in Molecular Biology, 106: 247-283.

Parra, D.; Martínez de Morentín, B. E.; Cobo, J. M.; Lenoir-Wijnkoop, I.; Martínez, J. A. (2006). La carga probiótica del yogur interviene en la asimilación aguda de nutrientes. Alimentación, nutrición y salud - Instituto Danone, 13 (1): 9-14.

Patel, B. K., Banjerjee, R. D. and Butcher, P.D. (1993). Determination of Mycobacterium leprae viability by polymerase chain reaction amplification of $71 \mathrm{Kda}$ heat shock protein mRNA. The Journal of Infectious Diseases, 168: 799-800.

Pedrosa, M. C.; Golner, B. B.; Goldin, B. R.; Barakat, S.; Dallal, G. E.; Russell, R. M. (1995). Survival of yogurt-containing organisms and Lactobacillus gasseri (ADH) and 
their effect on bacterial enzyme activity in the gastrointestinal tract of healthy and hypochlorhydric elderly subjects. American Journal of Clinical Nutrition, 61: 353359.

Pereira DI, Gibson GR (2002). Effects of consumption of probiotics and prebiotics on serum lipid levels in humans. Critical reviews in biochemistry and molecular biology, 37(4): 259-81.

Pinkel, D., Segraves, R., Sudar, D., Clark, S., Poole, I., Kowbel, D., Collins, C., Kuo, w. L., Chen, C., Zhai, Y., Dairkee, S. H., Ljung, B. M., Gray, J. W. and Albertson, D. G. (1998). High resolution analysis of DNA copy number variation using comparative genomic hybridization to microarrays. Nature Genetics, 20: 207-211.

Piqueres, P.; Moreno, Y; Alonso, JL.; Ferrús, MA. (2006). A combination of direct viable count and fluorescent in situ hybridization for estimating Helicobacter pylori cell viability. Research in Microbiology,157(4): 345-349.

Pochart, P.; Dewit, O.; Desjeux, J. F.; Bourlioux, P. (1989). Viable starter culture, pgalactosidase activity, and lactose in duodenum after yogurt ingestion in lactasedeficient humans. American Journal of Clinical Nutrition, 49: 828-831.

Pochart, P., Marteau, P., Bouhnik, Y., Goderel, I., Bourliou, P. \& Rambaud, J. C. (1992). Survival of Bifidobacteria ingested in a fermented milk during their passage in the human small intestine: an in vivo study using intestinal perfusion. American Journal of Clinical Nutrition, 55: 78- 80.

Pot, B.; Hertel, C.; Ludwig, W.; Descheemaeker, P.; Kersters, K.; Schleifer, KH. (1993). Identification and classification of Lactobacillus acidophilus, $L$. gasseri and $L$. johnsonii strains by SDS-PAGE and rRNA targeted oligonucleotide probe hybridization. Journal of general microbiology, vol. 139 (3), pp. 513-517.

Quere, F.; Deschamps, A.; Urdaci, M.C. (1997). DNA probe and PCR-specific reaction for Lactobacillus plantarum. Journal of Applied Microbiology, 82: 783790.

Quiberoni, A.; Tailliez ,P.; Quénée, P.; Suarez, V.; Reinheimer, J. (1998). Genetic (RAPDPCR) and technological diversities among wild Lactobacillus helveticus strains, Journal of Applied Microbiology, 85: 591-596. 
Rådström, P.; Knutsson R.; Wolffs P. and Löfström C. (2004). Pre-PCR processing: strategies to generate PCR-compatible samples. Molecular Biotechnology, 26: $133-146$

Rahman, I., Shahamat, M., Kirchman, P. A., Russek-Cohen, E. and Colwell, R. R. (1994). Methionine uptake and cytopathogenicity of viable but nonculturable Shigella dysenteriae Type I. Applied Environmental Microbiology, 60: 3573-3578.

Rappolee, D. A., Mark, D., Banda, M. J. and Werb, Z. (1988). Wound macrophages express TGF-alpha and other growth factors in vivo: analysis by mRNA phenotyping. Science. 241: 708-712.

Rebecchi, A.; Crivori, S.; Sarra, PG.; Cocconcelli, PS. (1998) Physiological and molecular techniques for the study of bacterial community development in sausage fermentation. Journal of Applied Microbiology, 84: 1043-1049.

Recio, I.; López-Fandiño, R. (2005). Efectos en la salud de los ingredientes lácteos funcionales. Alimentación, nutrición y salud- Instituto Danone, Vol. 12, № 4, pp. 121-131.

Regnault, B.; Martin-Delautre, S.; Grimont, PAD. (2000). Problems associated with the direct viable count procedure applied to gram-positive bacteria. International Journal of Food Microbiology, 55 (1-3): 281-284.

Reid G, Bruce AW, Fraser N, Heinemann C, Owen J, Henning B. (2001). Oral probiotics can resolve urogenital infections. FEMS immunology and medical microbiology, Feb; 30 (1): 49-52.

Reynolds, D. T. and Fricker, C. R. (1999). Application of laser scanning for the rapid and automated detection of bacteria in water samples. Journal of Applied Microbiology 86: 785-795.

Rizkalla, S. W.; Luo, J.; Kabir, M.; Chevalier, A.; Pacher N.; Slama, G. (2000). Chronic consumption of fresh but not heated yogurt improves breath hydrogen status and short-chain fatty acid profiles: a controlled study in healthy men with or without lactose maldigestion. American Journal of Clinical Nutrition, 72: 1474-1479. 
Roberfroid, M B (2000). Prebiotics and probiotics: are they functional foods? American Journal of Clinical Nutrition; 71(suppl): 1682S-7S.

Robins-Browne, R. M.; Levine, M. M. (1981). The fate of ingested lactobacilli in the proximal small intestine. American Journal of Clinical Nutrition, 34: 514-519.

Rodriguez., G. G., Phipps, D., Ishiguro, K. and Ridgwaty, H. F. (1992). Use of fluorescent redox probe for direct visualization of an actively respiring bacteria. Applied Environmental Microbiology, 58: 1801-1808.

Rolfe, RD (2000). The role of probiotic cultures in the control of gastrointestinal health. Journal of Nutrition, 130: 396S-402S.

Roller M, Clune Y, Collins K, Rechkemmer G, Watzl B. (2007). Consumption of prebiotic inulin enriched with oligofructose in combination with the probiotics Lactobacillus rhamnosus and Bifidobacterium lactis has minor effects on selected immune parameters in polypectomised and colon cancer patients. British Journal Nutrition; 97(4): 676-84.

Roselló-Mora, R; Amann, R (2001).The species concept for prokaryotes. FEMS Microbiology Reviews, 25:39-67.

Roy, D.; Sirois, S. (2000). Molecular differentiation of Bifidobacterium species with amplified ribosomal DNA restriction analysis and alignment of short regions of the Idh gene. FEMS Microbiology Letters, 191: 17-24.

Savadogo, A.; Ouattara, CAT.; W. Savadogo, PW.; Barro, N.; Ouattara, AS.; Traoré, AS. (2004). Identification of exopolysaccharides-producing lactic acid bacteria from Burkina Faso fermented milk samples. African Journal of Biotechnology, 3 (3): 189-194.

Saccomanno, C. F., Bordonara, M., Chen, J. S. and Nordstrom, J. L. (1992). A faster ribonuclease protection assay. Biotechniques. 13: 846-850.

Sakai, K.; Mori, M.; Fujii, A.; Iwami, Y.; Chukeatirote, E.; Shirai, Y. (2004). Fluorescent in situ hybridization analysis of open lactic acid fermentation of kitchen refuse using rRNA-targeted oligonucleotide probes. Journal of Bioscience and Bioengineering, 98(1): 48-56. 
Salminen, S; Bouley, C.; Boutron-Ruault, M. C. (1998a). Gastrointestinal physiology and function-targets for functional food development. British Journal of Nutrition; 80 (supplement): 147-171.

Salminen, S.; von Wright, A.; Morellic, L.; Marteaud, P.; Brassarte, D.; de Vosf, WM.; Fondéng, R.; Saxelinh, M.; Collinsi, K.; Mogensenj, G.; Birkelandk, SE.; MattilaSandholm, T. (1998b). Demonstration of safety of probiotics - a review. International Journal of Food Microbiology, 44 (1-2): 93-106.

Sanders, ME (2003). Probiotics: considerations for human health. Nutrition Review; 61: 91-99.

Sanders, ME; Klaenhammer, TR (2001). Invited review: The scientific basis of Lactobacillus acidophilus NCFM functionality as a probiotic. Journal of Dairy Science, 84: 319-331.

Saran S, Gopalan S, Krishna TP. (2002). Use of fermented foods to combat stunting and failure to thrive. Nutrition, May; 18 (5): 393-6.

Savaiano, D. A.; AbouElAnouar, A.; Smith, D. E.; Levitt, M. D. (1984). Lactose malabsorption from yogurt, pasteurized yogurt, sweet acidophilus milk, and cultured milk in lactase-deficient individuals. American Journal of Clinical Nutrition, 40: 1219-1223.

Schleifer, K H; Kandler, O (1972). Peptidoglycan types of bacterial cell walls and their

Selvaratnam, S., Schoedel, B. L., McFarland and Kulpa, C. F. (1995). Application of reverse transcriptase PCR for monitoring expression of the catabolic dmpN gene in a phenol-degrading sequencing reactor. Applied and Environmental Microbiology, 61: 3981-3985.

Servis, N.A.; Nichols, S.; Adams, JC. (1995). Development of a direct viable count procedure for some Gram-positive bacteria. Letters in Applied Microbiology, 20 (4): $237-239$. 
Settanni, L.; van Sinderen, D.; Suzzi, G.; Rossi, J.; Corsetti, A. (2005). Rapid Differentiation and In Situ Detection of 16 Sourdough Lactobacillus Species by Multiplex PCR. Applied and Environmental Microbiology, 71 (6): 3049-3059.

Sghir, A.; Gramet, G.; Suau, A.; Rochet, V.; Pochart, P.; Dore, J. (2000). Quantification of Bacterial Groups within Human Fecal Flora by Oligonucleotide Probe Hybridization. Applied and Environmental Microbiology, Vol. 66, No. 5, p. 2263-2266.

Shah N.P. (2000). Probiotic bacteria: selective enumeration and survival in dairy foods. Journal of Dairy Science, 83: 894-907.

Sheil B, Shanahan F, O'Mahony L. (2007). Probiotic effects on inflammatory bowel disease. The Journal of Nutrition; 137 (3 Suppl 2): 819S-24S.

Sheridan, G. E., Masters, C. I., Shallcross, J. A., MacKey B. M. (1998). Detection of mRNA by reverse transcription-PCR as an indicator of viability in Escherichia coli cells. Applied and Environmental Microbiology, 64:1313-8.

Singh, A.; Pyle, BH.; McFeter, GA. (1989). Rapid enumeration of viable bacteria by image analysis. Journal of Microbiological Methods, 10 (2): 91-101.

Singh, A.; Yu, F P.; McFeters, GA. (1990). Rapid detection of chlorine-induced bacterial injury by the direct viable count method using image analysis. Applied and Environmental Microbiology, 56 (2): 389-394.

Smiley, K. L.; Niven, C. F.; Sherman, J. M. (1943). The Nutrition of Streptococcus salivarius. Journal of Bacteriology, 45(5): 445-454.

Sohier, D.; Coulon, J.; Lonvaud-Funel, A. (1999). Molecular identification of Lactobacillus hilgardii and genetic relatedness with Lactobacillus brevis. International Journal of Systematic Bacteriology, 49: 1075-1081.

Song, Y.; Kato, N.; Liu, C.; Matsumiya, Y.; Kato, H.; Watanabe, K. (2000). Rapid identification of 11 human intestinal Lactobacillus species by multiplex PCR assays using group and species-specific primers derived from the 16S-23S rRNA intergenic spacer region and its flanking 23S rRNA. FEMS Microbiology Letters, 187: 167173. 
Stackebrandt, E; Teuber, M (1988).Molecular taxonomy and phylogenetic position of lactic acid bacteria. Biochimie, 70: 317-324. Review.

Stackebrandt, E; Fowler, VJ; Woese, RA (1983). A phylogenetic analysis of lactobacilli, Pediococcus pentosaceus and Leuconostoc mesenteroides. Systematic and Applied Microbiology, Vol. 4, no. 3, pp. 326-337.

Stackebrandt, E; Liesack, W; Witt, D (1992). Ribosomal RNA and rDNA sequence analyses. Genetica, 15: 115, 255-260. Review.

Sullivan, A; Edlund, C; Nord, CE (2001). Effect of antimicrobial agents on the ecological balance of human microflora. Lancet Infectious Diseases; 1: 101-114.

Swaminathan, B.; Barrett, TJ (1995). Amplification methods for epidemiologic investigations of infectious diseases. Journal of Microbiological Methods, 23 (1): 129-139.

Swaminathan, B.; Matar, GM. (1993). Molecular typing methods. In: Diagnostic Molecular Microbiology: principles and applications”, pp: 26-50. De: DH. Persing, TF Smith, FC Tenover and TJ White. American Society for Microbiology. Washington DC.

Takayama, K. and Kjlleberg, S. (2000). The role of RNA stability during bacterial stress responses and starvation. Environmental Microbiology, 2: 355-65.

Tannock, GW (2001). Molecular assessment of intestinal microflora. American Journal of Clinical Nutrition, 73:410S-414S.

Tannock, GW; Tilsala-Timisjarvi, A.; Rodtong, S.; NG, J; Munro, K.; Alatossava, T. (1999). Identification of Lactobacillus isolates from the gastrointestinal tract, silage and yoghurt by 16S-23S rRNA gene intergenic spacer region sequence comparisons. Applied and Environmental Microbiology, 65 (9): 4264-4267.

Tannock, G. W.; Munro, K.; Harmsen, H. J. M. ; Welling, G. W. ; Smart, J.; Gopal, P. K. (2000). Analysis of the Fecal Microflora of Human Subjects Consuming a Probiotic Product Containing Lactobacillus rhamnosus DR20. Applied and environmental microbiology, 66 (6): 2578-2588. 
Tejeda Rojas, Antonio; Hernández Medel, $M^{a}$ del Rosario; Solís Fuentes, Julio A. (2003). El microcosmos biológico: ¿aliado o adversario de la salud humana?. La Ciencia y el hombre, volumen XVI, número 3.

Tharmaraj, N.; Shah, NP. (2003). Selective Enumeration of Lactobacillus delbrueckii ssp. bulgaricus, Streptococcus thermophilus, Lactobacillus acidophilus, Bifidobacteria, Lactobacillus casei, Lactobacillus rhamnosus, and Propionibacteria. Journal of Dairy Science, 86: 2288-2296.

Thomas MR, Litin SC, Osmon DR, Corr AP, Weaver AL, Lohse CM. (2001). Lack of effect of Lactobacillus GG on antibiotic-associated diarrhea: a randomized, placebocontrolled trial. Mayo Clinic proceedings; 76(9): 883-9.

Tilsala-Timisjarvi, A.; Alatossava, T. (1997). Development of oligonucleotide primers from the 16S-23S rRNA intergenic sequences for identifying different dairy and probiotic lactic acid bacteria by PCR. International journal of food microbiology, 35 (1): 49-56.

Tilsala-Timisjarvi, A.; Alatossava, T. (1998). Strain-Specific Identification of Probiotic Lactobacillus rhamnosus with Randomly Amplified Polymorphic DNA-Derived PCR Primers. Applied and Environmental Microbiology, 64 (12): 4816-4819.

Torriani, S.; Zapparoli, G.; Dellaglio, F. (1999). Use of PCR-Based Methods for Rapid Differentiation of Lactobacillus delbrueckii subsp. bulgaricus and L. delbrueckii subsp. lactis. Applied and Environmental Microbiology, 65 (10): 4351-4356.

Tubelius P, Stan V, Zachrisson A. (2005). Increasing work-place healthiness with the probiotic Lactobacillus reuteri: a randomised, double-blind placebo-controlled study. Environmental health: a global access science source, 7; 4: 25.

Turchet P, Laurenzano M, Auboiron S, Antoine JM. (2003). Effect of fermented milk containing the probiotic Lactobacillus casei DN-114001 on winter infections in freeliving elderly subjects: a randomised, controlled pilot study. The journal of nutrition, health \& aging; 7 (2): 75-7.

Tynkkynen, S.; Satokari, R.; Saarela, M.; Mattila-Sandholm, T.; Saxelin, M. (1999) Comparison of ribotyping, randomly amplified polymorphic DNA analysis and pulsed- 
Bibliografía

field gel electrophoresis in typing of Lactobacillus rhamnosus and L. casei strains. Applied and Environmental Microbiology, 65: 3908-3914.

Valmorri, S.; van Sinderen, D.; Suzzi, G.; Paparella, A.; Corsetti, A. (2006). Combination of Multiplex PCR and PCR-Denaturing Gradient Gel Electrophoresis for Monitoring Common Sourdough-Associated Lactobacillus Species. Applied and Environmental Microbiology, 72 (5): 3793-3796.

Van Niel CW, Feudtner C, Garrison MM, Christakis DA (2007). Lactobacillus therapy for acute infectious diarrhea in children: a meta-analysis. Pediatrics; 109(4):678-84.

Van Reenen, C.A.; Dicks, L.M. (1996). Evaluation of numerical analysis of random amplified polymorphic DNA (RAPD)-PCR as a method to differentiate Lactobacillus plantarum and Lactobacillus pentosus. Current Microbiology, 32:183-187.

Vandamme, P; Pot, B; Gillis, M; de Vos, P; Kersters, K; Swings, J (1996). Polyphasic taxonomy, a consensus approach to bacterial systematic. Microbiology and Molecular Biology Reviews, 60: 407-438.

Ventura, M.; Reniero, R.; Zink, R. (2001). Specific Identification and Targeted Characterization of Bifidobacterium lactis from Different Environmental Isolates by a Combined Multiplex-PCR Approach. Applied and Environmental Microbiology; 67 (6): 2760-2765.

Vidal, R. (2006). Probióticos: aspectos microbiológicos y tecnológicos. Alimentación, nutrición y salud- Instituto Danone, Vol. 13, № 2, pp. 48-52.

Villarino, A., Bouvet, O. M. M., Regnault, B., Martin-Delautre, S., and Grimont, A. D. (2000). Exploring the frontier between life and death in Escherichia coli: evaluation of different viability markers in live and heat-or UV-killed cells. Research in Microbiology, 151: 755-760.

Vincent, D.; Roy, D.; Mondou, F.; Déry, C. (1998). Characterization of bifidobacteria by random DNA amplification. International journal of food microbiology, 43 (3): 185-193. 
Virta, M., Lineri, S., Kankaanpää, P., Karp, M., Peltonen, K., Nuutila, J., Lilius, E. M., D. (1998). Determination of complement-mediated killing of bacteria by viability staining and bioluminiscence. Applied Environmental Microbiology, 64: 515-519.

Vlková, E.; Rada, V.; Trojanová, I. (2004). Enumeration, isolation, and identification of bifidobacteria from dairy products. Acta agriculturae slovenica, 84 (1): 31-36.

Vogel, R.; Böcker, G.; Stolz, P.; Ehrmann, M.; Fanta, D.; Ludwig, W.; Pot, B.; Kersters, K.; Schleifer, K.H.; Hammes, W. (1994). Identification of lactobacilli from sourdough and description of Lactobacillus pontis sp. nov.. International Journal of Systematic Bacteriology, 44: 223-239.

Waage, A. S., Vardund, T., Lund, V. and Kapperud, G. (1999). Detection of small numbers of Campylobacter jejuni and Campylobacter coli cells in environmental water, sewage, and food samples by a seminested PCR assay. Applied Environmental Microbiology 65: 1636-1643.

Walter, J.; Tannock, G.W.; Tilsala-Timisjarvi, A.; Rodtong; S., Loach, D.M.; Munro, K.; Alatossava, T. (2000). Detection and identification of gastrointestinal Lactobacillus species by using denaturing gradient gel electrophoresis and speciesspecific PCR primers. Applied Environmental Microbiology, 66: 297-303.

Wang, RF; Cao, WW; Cerniglia, CE (1996). PCR detection and quantification of predominant anaerobic bacteria in human and animal fecal samples. Applied and Environmental Microbiology; 62: 1242-7.

Ward, L.J.; Timmins, M.J. (1999). Differentiation of Lactobacillus casei, Lactobacillus paracasei and Lactobacillus rhamnosus by polymerase chain reaction. Letters in Applied Microbiology, 29 90-92.

Ward, P.; Roy, D. (2005). Review of molecular methods for identification, characterization and detection of bifidobacterias. Lait, 85: 23-32.

Weinsier, R L and Krumdieck, C L (2000). Dairy foods and bone health: examination of the evidence. American Journal of Clinical Nutrition, 72: 681-9. 
Weizman, Z; Asli, G; Alsheikh, A. (2005). Effect of a probiotic infant formula on infections in child care centers: comparison of two probiotic agents. Pediatrics. Jan; 115 (1):5-9.

Welling, GW; Elfferich, P; Raangs, GC; Wildeboer-Veloo, AC; Jansen, GJ; Degener, JE. (1997). 16S ribosomal RNA-targeted oligonucleotide probes for monitoring of intestinal tract bacteria. Scandinavian journal of gastroenterology. Supplement. 222: 17-9.

Welsh, J.; McClelland, M. (1990). Fingerprinting genomes using PCR with arbitrary primers. Nucleic Acids Research, 18:7213-7218.

Williams, JGK; Kubelik, AR; Livak, KJ; Refalski, JA; Tingey, SV. (1990). DNA polymorphisms amplified by arbitrary primers are useful as genetic markers. Nucleic acids research, 18: 6531-6535.

Wilson, KH and Blitchington, RB (1996). Human colonic biota studied by ribosomal DNA sequence analysis. Applied and Environmental Microbiology; 62: 2273-8.

Winter, D. K. and Slavik, M. F. (2000). Multiplex PCR detection of Campylobacter jejuni and Arcobacter butzleri in food products. Mol Cell. Probes. 14: 95-99.

Woese, CR (1987). Bacterial Evolution. Microbiological Reviews, June, p. 221-271.

Wood, BJB and Holzapfel, WH (1995). The genera of lactic acid bacteria. Volume 2, blackie academic and professional, Glasgow.

Yost, C.K.; Nattress, F.M. (2000). The use of multiplex PCR reactions to characterize populations of lactic acid bacteria associated with meat spoilage. Letters in Applied Microbiology, 31: 129-133.

Yokomaku, D.; Yamaguchi, N.; Nasu, M. (2000). Improved Direct Viable Count Procedure for Quantitative Estimation of Bacterial Viability in Freshwater Environments. Applied and Environmental Microbiology, 66 (12): 5544-5548.

Yuki, N.; Watanabe, K.; Mike, A.; Tagami, Y.; Tanaka, R.; Ohwaki, M.; Morotomi, M. (1999). Survival of a probiotic, Lactobacillus casei strain Shirota, in the 
gastrointestinal tract: Selective isolation from faeces and identification using monoclonal antibodies. International Journal of Food Microbiology, 48 (1): 51-57.

Yuste, F. J.; Vázquez, C.; Köning, M. Alfredo; Bootello, A.; Coll, J.; González, P.; Baquero, F.; del Campo, R.; Bravo, D.; Abraira, V. (2003). Efectos de dos presentaciones comerciales de yogur sobre la salud de algunos colectivos de población sana. Medicina Preventiva, Vol. IX, N. ${ }^{\circ} 4,4^{\circ}$ Trimestre. $^{\circ}$

Zoetendal EG, Akkermans AD \& de Vos WM (1998). Temperature gradient gel electrophoresis analysis of 16S rRNA from human faecal samples reveals stable and host-specific communities of active bacteria. Applied and Environmental Microbiology; 64: 3854-3859.

\section{LEGISLACIÓN}

REAL DECRETO 179/2003, de 14 de febrero, por el que se aprueba la Norma de Calidad para el yogur o yoghourt.

Norma del CODEX para leches fermentadas. CODEX STAN 243-2003.

\section{LIBROS Y PUBLICACIONES}

Albalat, Concha; Mataix, José; Núñez, Manuel; Hernández, Enrique; Samartín, Sonia; Gómez, Sonia; Nova, Esther; Marcos, Ascensión; Pujol, P; Drobnic, F.; Ruiz, O.; Huguet, J.; Bixquert, Miguel; María, Rosa; Guarner, Franciso; Sastre, Ana. (1998). El hombre y las bacterias saludables. Fundación Valenciana de Estudios Avanzados (FVEA). Valencia.

Aleixandre Benavent, J. L. y García Esparza, M. J. (1999). Industrias agroalimentarias. Universidad Politécnica de Valencia. Valencia.

Ashwell, M. (2004). Conceptos sobre los alimentos funcionales. International Life Science Institute (Instituto Internacional de Ciencias de la Vida, ILSI). ILSI Europe Concise Monograph Series. Bélgica. 
Bergey's Manual

Collado Amores, M. C. (2004). Caracterización de cepas del género Bifidobacterium con carácter probiótico. Tesis doctoral. Universidad Politécnica de Valencia. Valencia.

Comité FAO-OMS (2002). Guidelines for the Evaluation of Probiotics in Food. London Ontario, Canadá, 2002.

Comité FAO-OMS. ESTUDIO FAO Y OMS, ALIMENTACIÓN Y NUTRICIÓN, 85 (2006). Probióticos en los alimentos. Propiedades saludables y nutricionales y directrices para la evaluación. Roma.

European Comission (1998). Functional Food Science in Europe. British Journal of Nutrition, 80 (1): S1-S193.

Instituto Omega 3, Confederación de Consumidores y Usuarios (CECU) y Sociedad Española de Nutrición Comunitaria (SENC) (2003). Guía de alimentos funcionales.

Kandler, O.; N. Weiss. 1986. Regular, non-sporing Gram-positive rods, p. 12081234. In: P. H. A. Sneath, N. Mair, M. E. Sharpe, and J. G. Holt (ed.), Bergey's manual of systematic bacteriology, vol. 2. William and Wilkins, Baltimore.

Paulus M. Verschuren (2002). Functional foods- Scientific and global perspectives. ILSI Europe Report Series

Piqueres Alfonso, Patricia (2005). Desarrollo de técnicas moleculares de alta precisión para la detección y cuantificación de especies patógenas de Helicobacter en muestras ambientales: evidencia del potencial de transmisión de aguas y alimentos. Tesis doctoral. Universidad Politécnica de Valencia. Valencia.

Salminen, S., and Von Wright, A. (1998). Lactic acid bacteria: microbiology and functional aspects. Marcel Deker, Inc. New York.

Sarmiento Rubiano, Luz Adriana (2008). Influencia del consumo de sorbitol en la microbiota intestinal de un modelo animal. Tesis doctoral. Universidad Politécnica de Valencia y Consejo Superior de Investigaciones Científicas. Valencia. 
Saxelin, M. (2002). LGG Summatim. El Lactobacilo GG y sus efectos en la salud. Valio Ltd, R\&D. Helsinki, Finlandia.

Tannock, Gerald W. (1999). Probiotics: a critical review. Horizon scientific press. England.

Yogures pasteurizados después de la fermentación. Educa marketing, 2005

\section{RECURSOS ELECTRÓNICOS}

Asociación para la Autorregulación de la Comunicación Comercial: www.autocontrol.es

Cinco días, 4/12/2004

Federación nacional de Industrias Lácteas: www.fenil.org

Grupo Leche Pascual: www.lechepascual.com

Ministerio de Agricultura, Pesca y Alimentació: www.mapya.es

Organización Interprofesional Láctea: www.inlac.com

\section{http://www.usprobiotics.org}

Página web del Consejo Europeo de Información sobre la Alimentación (EUFIC): www.eufic.org

http://www.elpais.com

- 3 de junio de 2001. El MAPA reserva la denominación 'yogur' para los yogures tradicionales

- VIDAL MATÉ 22/01/2002 Recta final en la guerra por la denominación del yogur Pascual 
- 4 de julio de 2003. El Codex Alimentarius rechaza el nombre de yogur para el postre lácteo pasteurizado.

- VIDAL MATÉ 18/02/2007. El yogur se queda en el frío.

Página web del Instituto Tomás Pascual: www.institutotomaspascual.es

Página web del Instituto Danone: $\underline{w w w . i n s t i t u t o d a n o n e . e s}$

Página web de LA Empresa Nacional MERCASA: www.mercasa.es

Página web de Puleva Salud: www.puleva salud.com

http://salud.medicinatv.com

Página web de la Universidad de Wichita, Estados Unidos: www.wichita.edu

www.pediatraldia.cl

www.saludlandia.com

www.consumer.es

www.juliantrubin.com/encyclopedia/biochemistry/pcr.html

http://www.international.inra.fr/ 


\section{ANEXO I. Abreviaturas empleadas}

\begin{tabular}{|c|c|}
\hline ADN & Ácido desoxirribonucleico \\
\hline AGCC & Ácidos grasos de cadena corta \\
\hline $\mathrm{ARNr}$ & Ácido ribonucleico ribosómico \\
\hline ATCC & American Type CUltures Collection \\
\hline $\mathrm{BAL}$ & Bacterias acidolácticas \\
\hline CDR & Cantidad diaria recomendada \\
\hline CeNAN & Centro Nacional de Alimentación y Nutrición \\
\hline CTAB & Bromuro de cetil-trimetil-amonio \\
\hline dNTPs & Desoxinucleótidos trifosfato \\
\hline EDTA & Ácido etilendiaminotetracético \\
\hline$\overline{F A}$ & Formamida \\
\hline FAO & $\begin{array}{l}\text { Food and Agriculture Organization - Organización de las Naciones Unidas } \\
\text { para la agricultura y la alimentación }\end{array}$ \\
\hline FISH & Hibridación in situ con sondas fluorescentes (Fluorescent in situ Hybridization) \\
\hline FLUOS & 5(6)-carboxy-fluorescein-N-hidroxisuccinimida éster \\
\hline FOSHU & Foods for Specific Health Use \\
\hline FUFOSE & $\begin{array}{l}\text { The European Commission Concerted Action on Functional Food Science in } \\
\text { Europe }\end{array}$ \\
\hline $\mathrm{g}$ & Gramo \\
\hline $\mathrm{G}+\mathrm{C}$ & Guanina+Citosina \\
\hline ILSI & International Life Sciences Institute \\
\hline IMS & Separación inmunomagnética \\
\hline $\mathrm{Kb}$ & Kilobases (1000 pb) \\
\hline $\mathrm{kDa}$ & KiloDaltons \\
\hline $\mathrm{M}$ & Molar \\
\hline $\min$ & Minuto \\
\hline $\mathrm{ml}$ & Mililitro \\
\hline $\mathrm{mM}$ & Milimolar \\
\hline MRS & Man Rogosa y Sharp, medio de cultivo \\
\hline NCTC & National Collection of Type Cultures, England \\
\hline
\end{tabular}




\begin{tabular}{|c|c|}
\hline $\mathrm{ng}$ & Nanogramo \\
\hline${ }^{\circ} \mathrm{C}$ & Grados centígrados \\
\hline OMS & Organización Mundial de la Salud \\
\hline $\mathrm{pb}$ & Pares de bases \\
\hline PBS & Tampón salino fosfato \\
\hline PCR & Reacción en cadena de la polimerasa (Polymerase Chain Reaction) \\
\hline PFA & Paraformaldehído \\
\hline $\mathrm{Pl}$ & Yoduro de propidio \\
\hline RAPDs & $\begin{array}{l}\text { Amplificación aleatoria con iniciadores inespecíficos (Randomly Amplified } \\
\text { Polymorphic DNA) }\end{array}$ \\
\hline RNA & Ácido ribonucleico \\
\hline rpm & Revoluciones por minuto \\
\hline rRNA & Ácido ribonucleico ribosómico \\
\hline SDS & Dodecil sulfato sódico \\
\hline SOD & Superóxido dismutasa \\
\hline $\mathrm{t}$ & Tiempo \\
\hline $\mathrm{T}^{\mathrm{a}}$ & Temperatura \\
\hline TAE & Tris-acético-EDTA \\
\hline TE & Tris-EDTA \\
\hline$U$ & unidades \\
\hline u.f.c. & Unidades formadoras de colonia \\
\hline UPV & Universidad Politécnica de Valencia \\
\hline UV & Ultravioleta \\
\hline $\mathrm{V}$ & Voltios \\
\hline $\mathrm{VNC}$ & Viable No Cultivable \\
\hline$\mu l$ & Microlitro \\
\hline$\mu \mathrm{M}$ & Micromolar \\
\hline
\end{tabular}


Anexos

\section{ANEXO II. \\ Lista actual de especies incluidas en el género Lactobacillus (datos obtenidos de List of Prokaryotic names with Sanding in Nomenclatura, septiembre 2010, www.bacterio.cict.fr)}

\begin{tabular}{|c|c|c|}
\hline Especie & Subespecie & Referencia \\
\hline Lactobacillus & & Beijerinck 1901 (Approved Lists 1980), genus. \\
\hline L. acetotolerans & & Entani et al. 1986, sp. nov. \\
\hline L. acidifarinae & & Vancanneyt et al. 2005, sp. nov. \\
\hline L. acidipiscis & & Tanasupawat et al. 2000 , sp. nov. \\
\hline L. acidophilus & & $\begin{array}{l}\text { (Moro 1900) Hansen and Mocquot } 1970 \\
\text { (Approved Lists 1980), species. }\end{array}$ \\
\hline L. acidophilus & & Johnson et al. 1980, sp. nov. \\
\hline L. agilis & & Weiss et al. 1982, sp. nov. \\
\hline L. algidus & & Kato et al. 2000, sp. nov. \\
\hline L. alimentarius & & $\begin{array}{l}\text { (ex Reuter 1970) Reuter 1983, sp. nov., nom. } \\
\text { rev. }\end{array}$ \\
\hline L. amylolyticus & & Bohak et al. 1999, sp. nov. \\
\hline L. amylophilus & & Nakamura and Crowell 1981, sp. nov. \\
\hline L. amylotrophicus & & Naser et al. 2006, sp. nov. \\
\hline L. amylovorus & & Nakamura 1981, sp. nov. \\
\hline L. animalis & & Dent and Williams 1983, sp. nov. \\
\hline L. antri & & Roos et al. 2005, sp. nov. \\
\hline L. apodemi & & Osawa et al. 2006, sp. nov. \\
\hline L. aquaticus & & Mañes-Lázaro et al. 2009, sp. nov. \\
\hline L. arizonensis & & Swezey et al. 2000, sp. nov. \\
\hline L. aviarius & & Fujisawa et al. 1985, sp. nov. \\
\hline \multirow[t]{2}{*}{ L. aviarius } & subsp. araffinosus & Fujisawa et al. 1986, subsp. nov. \\
\hline & subsp. aviarius & Fujisawa et al. 1985, subsp. nov. \\
\hline L. bavaricus & & Stetter and Stetter 1980, sp. nov. \\
\hline L. bifermentans & & $\begin{array}{l}\text { (ex Pette and van Beynum 1943) Kandler et al. } \\
1983 \text {, sp. nov., nom. rev. }\end{array}$ \\
\hline L. bobalius & & Mañes-Lázaro et al. 2008, sp. nov. \\
\hline L. brevis & & $\begin{array}{l}\text { (Orla-Jensen 1919) Bergey et al. } 1934 \\
\text { (Approved Lists 1980), species. }\end{array}$ \\
\hline L. buchneri & & $\begin{array}{l}\text { (Henneberg 1903) Bergey et al. } 1923 \\
\text { (Approved Lists 1980), species. }\end{array}$ \\
\hline L. bulgaricus & & $\begin{array}{l}\text { (Orla-Jensen 1919) Rogosa and Hansen } 1971 \\
\text { (Approved Lists 1980), species. }\end{array}$ \\
\hline L. cacaonum & & De Bruyne et al. 2009, sp. nov. \\
\hline L. camelliae & & Tanasupawat et al. 2007, sp. nov. \\
\hline L. capillatus & & Chao et al. 2008, sp. nov. \\
\hline L. carnis & & Shaw and Harding 1986, sp. nov. \\
\hline \multirow[t]{3}{*}{ L. casei } & & $\begin{array}{l}\text { (Orla-Jensen 1916) Hansen and Lessel } 1971 \\
\text { (Approved Lists 1980), species. }\end{array}$ \\
\hline & subsp. alactosus & $\begin{array}{l}\text { Mills and Lessel } 1973 \text { (Approved Lists 1980), } \\
\text { subspecies. }\end{array}$ \\
\hline & subsp. casei & $\begin{array}{l}\text { (Orla-Jensen 1916) Hansen and Lessel } 1971 \\
\text { (Approved Lists 1980), subspecies. }\end{array}$ \\
\hline
\end{tabular}




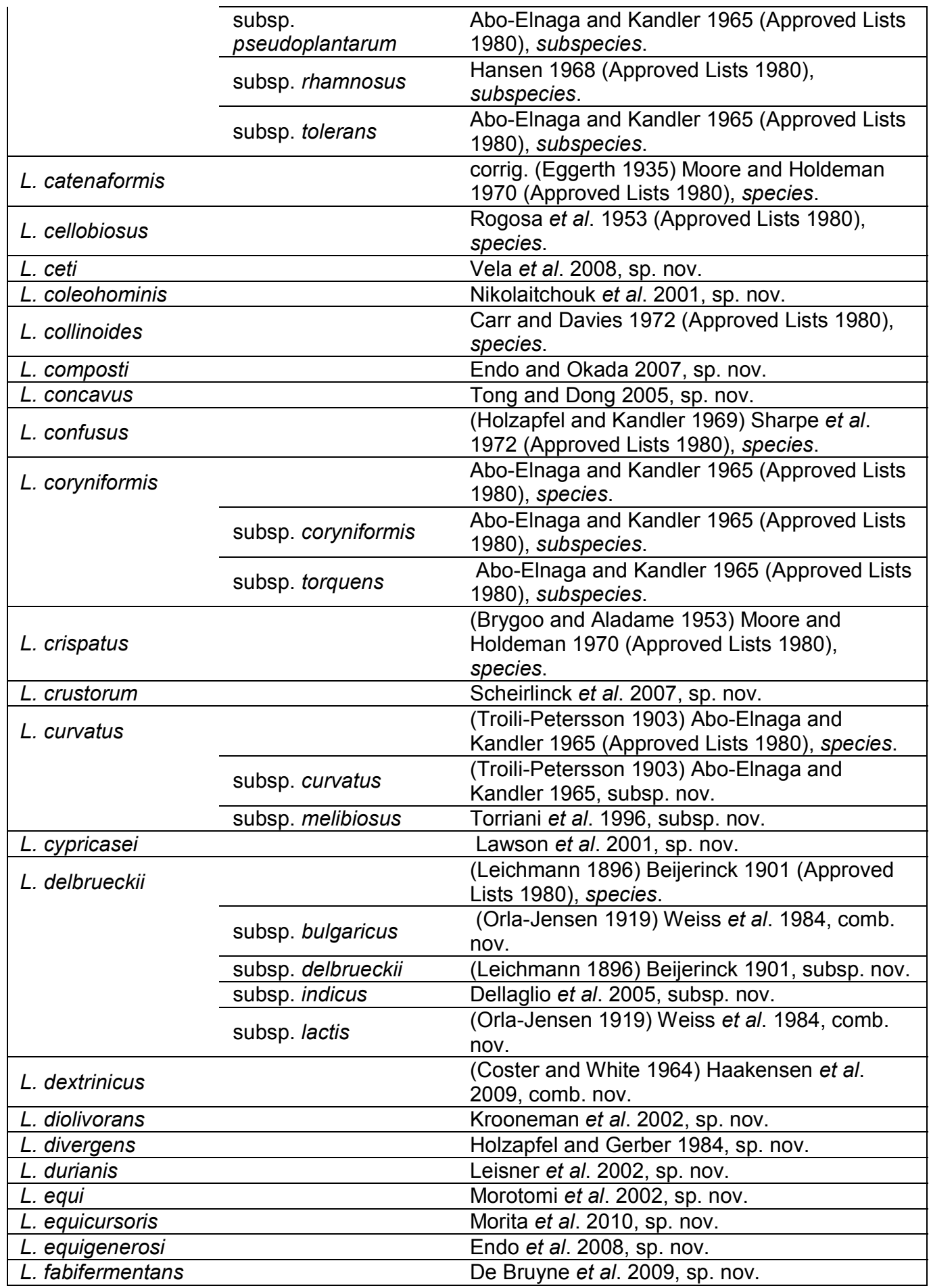




\begin{tabular}{|c|c|c|}
\hline L. farciminis & & $\begin{array}{l}\text { (ex Reuter 1970) Reuter 1983, sp. nov., nom. } \\
\text { rev. }\end{array}$ \\
\hline L. farraginis & & Endo and Okada 2007, sp. nov. \\
\hline L. ferintoshensis & & Simpson et al. 2002, sp. nov. \\
\hline L. fermentum & & $\begin{array}{l}\text { Beijerinck } 1901 \text { (Approved Lists 1980), } \\
\text { species. }\end{array}$ \\
\hline L. florum & & Endo et al. 2010, sp. nov. \\
\hline L. fornicalis & & Dicks et al. 2000, sp. nov. \\
\hline L. fructivorans & & $\begin{array}{l}\text { Charlton et al. } 1934 \text { (Approved Lists 1980), } \\
\text { species. }\end{array}$ \\
\hline L. fructosus & & Kodama 1956 (Approved Lists 1980), species. \\
\hline L. frumenti & & Müller et al. 2000, sp. nov. \\
\hline L. fuchuensis & & Sakala et al. 2002, sp. nov. \\
\hline L. gallinarum & & Fujisawa et al. 1992, sp. nov. \\
\hline L. gasseri & & Lauer and Kandler 1980, sp. nov. \\
\hline L. gastricus & & Roos et al. 2005, sp. nov. \\
\hline L. ghanensis & & Nielsen et al. 2007, sp. nov. \\
\hline L. graminis & & Beck et al. 1989, sp. nov. \\
\hline L. halotolerans & & $\begin{array}{l}\text { (ex Reuter 1970) Kandler et al. 1983, nom. } \\
\text { rev., comb. nov. }\end{array}$ \\
\hline L. hammesii & & Valcheva et al. 2005, sp. nov. \\
\hline L. hamsteri & & Mitsuoka and Fujisawa 1988, sp. nov. \\
\hline L. harbinensis & & Miyamoto et al. 2006, sp. nov. \\
\hline L. hayakitensis & & Morita et al. 2007, sp. nov. \\
\hline L. helveticus & & $\begin{array}{l}\text { (Orla-Jensen 1919) Bergey et al. } 1925 \\
\text { (Approved Lists 1980), species. }\end{array}$ \\
\hline L. heterohiochii & & $\begin{array}{l}\text { Kitahara et al. } 1957 \text { (Approved Lists 1980), } \\
\text { species. }\end{array}$ \\
\hline L. hilgardii & & $\begin{array}{l}\text { Douglas and Cruess } 1936 \text { (Approved Lists } \\
\text { 1980), species. }\end{array}$ \\
\hline L. homohiochii & & $\begin{array}{l}\text { Kitahara et al. } 1957 \text { (Approved Lists 1980), } \\
\text { species. }\end{array}$ \\
\hline L. hordei & & Rouse et al. 2008, sp. nov. \\
\hline L. iners & & Falsen et al. 1999, sp. nov. \\
\hline L. ingluviei & & Baele et al. 2003, sp. nov. \\
\hline L. intestinalis & & $\begin{array}{l}\text { (ex Hemme 1974) Fujisawa et al. 1990, sp. } \\
\text { nov., nom. rev. }\end{array}$ \\
\hline L. jensenii & & $\begin{array}{l}\text { Gasser et al. } 1970 \text { (Approved Lists 1980), } \\
\text { species. }\end{array}$ \\
\hline L. johnsonii & & Fujisawa et al. 1992, sp. nov. \\
\hline L. kalixensis & & Roos et al. 2005, sp. nov. \\
\hline L. kandleri & & Holzapfel and van Wyk 1983, sp. nov. \\
\hline L. kefiranofaciens & & Fujisawa et al. 1988, sp. nov. \\
\hline \multirow[t]{2}{*}{ L. kefiranofaciens } & subsp. kefiranofaciens & Fujisawa et al. 1988, subsp. nov. \\
\hline & subsp. kefirgranum & $\begin{array}{l}\text { (Takizawa et al. 1994) Vancanneyt et al. 2004, } \\
\text { comb. nov. }\end{array}$ \\
\hline L. kefirgranum & & Takizawa et al. 1994, sp. nov. \\
\hline L. kefiri & & corrig. Kandler and Kunath 1983, sp. nov. \\
\hline L. kimchii & & Yoon et al. 2000, sp. nov. \\
\hline L. kisonensis & & Watanabe et al. 2009, sp. nov. \\
\hline L. kitasatonis & & Mukai et al. 2003, sp. nov. \\
\hline
\end{tabular}


Anexos

\begin{tabular}{|c|c|c|}
\hline L. kunkeei & & Edwards et al. 1998, sp. nov. \\
\hline L. lactis & & $\begin{array}{l}\text { (Orla-Jensen 1919) Bergey et al. } 1934 \\
\text { (Approved Lists 1980), species. }\end{array}$ \\
\hline L. leichmannii & & $\begin{array}{l}\text { (Henneberg 1903) Bergey et al. } 1923 \\
\text { (Approved Lists 1980), species. }\end{array}$ \\
\hline L. lindneri & & $\begin{array}{l}\text { (ex Henneberg 1901) Back et al. 1997, sp. } \\
\text { nov., nom. rev. }\end{array}$ \\
\hline L. malefermentans & & $\begin{array}{l}\text { (ex Russell and Walker 1953) Farrow et al. } \\
1989, \text { sp. nov., nom. rev. }\end{array}$ \\
\hline L. mali & & $\begin{array}{l}\text { Carr and Davies } 1970 \text { (Approved Lists 1980), } \\
\text { species. }\end{array}$ \\
\hline L. maltaromicus & & $\begin{array}{l}\text { Miller et al. } 1974 \text { (Approved Lists 1980), } \\
\text { species. }\end{array}$ \\
\hline L. manihotivorans & & Morlon-Guyot et al. 1998, sp. nov. \\
\hline L. mindensis & & Ehrmann et al. 2003, sp. nov. \\
\hline L. minor & & $\begin{array}{l}\text { (ex Abo-Elnaga and Kandler 1965) Kandler et } \\
\text { al. } 1983 \text {, nom. rev., comb. nov. }\end{array}$ \\
\hline L. minutus & & $\begin{array}{l}\text { (Hauduroy et al. 1937) Moore and Holdeman } \\
1972 \text { (Approved Lists 1980), species. }\end{array}$ \\
\hline L. mucosae & & Roos et al. 2000, sp. nov. \\
\hline L. murinus & & Hemme et al. 1982, sp. nov. \\
\hline L. nagelii & & Edwards et al. 2000, sp. nov. \\
\hline L. namurensis & & Scheirlinck et al. 2007, sp. nov. \\
\hline L. nantensis & & Valcheva et al. 2006, sp. nov. \\
\hline L. nodensis & & Kashiwagi et al. 2009, sp. nov. \\
\hline L. oeni & & Mañes-Lázaro et al. 2009, sp. nov. \\
\hline L. oligofermentans & & Koort et al. 2005, sp. nov. \\
\hline L. oris & & Farrow and Collins 1988, sp. nov. \\
\hline L. otakiensis & & Watanabe et al. 2009, sp. nov. \\
\hline L. panis & & Wiese et al. 1996, sp. nov. \\
\hline L. pantheris & & Liu and Dong 2002, sp. nov. \\
\hline L. parabrevis & & Vancanneyt et al. 2006, sp. nov. \\
\hline L. parabuchneri & & Farrow et al. 1989, sp. nov. \\
\hline L. paracasei & & Collins et al. 1989, sp. nov. \\
\hline \multirow[t]{2}{*}{ L. paracasei } & subsp. paracasei & Collins et al. 1989, subsp. nov. \\
\hline & subsp. tolerans & $\begin{array}{l}\text { (Abo-Elnaga and Kandler 1965) Collins et al. } \\
\text { 1989, comb. nov. }\end{array}$ \\
\hline L. paracollinoides & & Suzuki et al. 2004, sp. nov. \\
\hline L. parafarraginis & & Endo and Okada 2007, sp. nov. \\
\hline L. parakefiri & & corrig. Takizawa et al. 1994, sp. nov. \\
\hline L. paralimentarius & & Cai et al. 1999, sp. nov. \\
\hline L. paraplantarum & & Curk et al. 1996, sp. nov. \\
\hline L. paucivorans & & Ehrmann et al. 2010, sp. nov. \\
\hline L. pentosus & & $\begin{array}{l}\text { (ex Fred et al. 1921) Zanoni et al. 1987, sp. } \\
\text { nov., nom. rev. }\end{array}$ \\
\hline L. perolens & & Back et al. 2000, sp. nov. \\
\hline L. piscicola & & Hiu et al. 1984, sp. nov. \\
\hline L. plantarum & & $\begin{array}{l}\text { (Orla-Jensen 1919) Bergey et al. } 1923 \\
\text { (Approved Lists 1980), species. }\end{array}$ \\
\hline L. plantarum & $\begin{array}{l}\text { subsp. } \\
\text { argentoratensis }\end{array}$ & Bringel et al. 2005, subsp. nov. \\
\hline
\end{tabular}


Anexos

\begin{tabular}{|c|c|c|}
\hline & subsp. plantarum & $\begin{array}{l}\text { (Orla-Jensen 1919) Bergey et al. 1923, subsp. } \\
\text { nov. }\end{array}$ \\
\hline L. pobuzihii & & Chen et al. 2010, sp. nov. \\
\hline L. pontis & & Vogel et al. 1994, sp. nov. \\
\hline L. psittaci & & Lawson et al. 2001, sp. nov. \\
\hline L. rapi & & Watanabe et al. 2009, sp. nov. \\
\hline L. rennini & & Chenoll et al. 2006, sp. nov. \\
\hline L. reuteri & & Kandler et al. 1982, sp. nov. \\
\hline L. rhamnosus & & (Hansen 1968) Collins et al. 1989, comb. nov. \\
\hline L. rimae & & Olsen et al. 1991, sp. nov. \\
\hline L. rogosae & & $\begin{array}{l}\text { Holdeman and Moore } 1974 \text { (Approved Lists } \\
\text { 1980), species. }\end{array}$ \\
\hline L. rossiae & & corrig. Corsetti et al. 2005, sp. nov. \\
\hline L. ruminis & & $\begin{array}{l}\text { Sharpe et al. } 1973 \text { (Approved Lists 1980), } \\
\text { species. }\end{array}$ \\
\hline L. saerimneri & & Pedersen and Roos 2004, sp. nov. \\
\hline L. sakei & & $\begin{array}{l}\text { corrig. Katagiri et al. } 1934 \text { (Approved Lists } \\
\text { 1980), species. }\end{array}$ \\
\hline L. sakei & subsp. carnosus & corrig. Torriani et al. 1996, subsp. nov. \\
\hline L. sakei & subsp. sakei & corrig. Katagiri et al. 1934, subsp. nov. \\
\hline \multirow[t]{3}{*}{ L. salivarius } & & $\begin{array}{l}\text { Rogosa et al. } 1953 \text { (Approved Lists 1980), } \\
\text { species. }\end{array}$ \\
\hline & subsp. salicinius & $\begin{array}{l}\text { Rogosa et al. } 1953 \text { (Approved Lists 1980), } \\
\text { subspecies. }\end{array}$ \\
\hline & subsp. salivarius & $\begin{array}{l}\text { Rogosa et al. } 1953 \text { (Approved Lists 1980), } \\
\text { subspecies. }\end{array}$ \\
\hline L. sanfranciscensis & & $\begin{array}{l}\text { corrig. (ex Kline and Sugihara 1971) Weiss and } \\
\text { Schillinger 1984, sp. nov., nom. rev. }\end{array}$ \\
\hline L. satsumensis & & Endo and Okada 2005, sp. nov. \\
\hline L. secaliphilus & & Ehrmann et al. 2007, sp. nov. \\
\hline L. senmaizukei & & Hiraga et al. 2008, sp. nov. \\
\hline L. sharpeae & & Weiss et al. 1982, sp. nov. \\
\hline L. siliginis & & Aslam et al. 2006, sp. nov. \\
\hline L. similis & & Kitahara et al. 2010, sp. nov. \\
\hline L. sobrius & & Konstantinov et al. 2006, sp. nov. \\
\hline L. spicheri & & Meroth et al. 2004, sp. nov. \\
\hline L. suebicus & & Kleynmans et al. 1989, sp. nov. \\
\hline L. sucicola & & Irisawa and Okada 2009, sp. nov. \\
\hline L. sunkii & & Watanabe et al. 2009, sp. nov. \\
\hline L. suntoryeus & & Cachat and Priest 2005, sp. nov. \\
\hline L. taiwanensis & & Wang et al. 2009, sp. nov. \\
\hline L. thailandensis & & Tanasupawat et al. 2007, sp. nov. \\
\hline L. thermotolerans & & Niamsup et al. 2003, sp. nov. \\
\hline L. trichodes & & $\begin{array}{l}\text { Fornachon et al. } 1949 \text { (Approved Lists 1980), } \\
\text { species. }\end{array}$ \\
\hline L. tucceti & & Chenoll et al. 2009, sp. nov. \\
\hline L. uli & & Olsen et al. 1991, sp. nov. \\
\hline L. ultunensis & & Roos et al. 2005, sp. nov. \\
\hline L. uvarum & & Mañes-Lázaro et al. 2009, sp. nov. \\
\hline L. vaccinostercus & & Kozaki and Okada 1983, sp. nov. \\
\hline L. vaginalis & & Embley et al. 1989, sp. nov. \\
\hline
\end{tabular}


Anexos

\begin{tabular}{|c|c|c|}
\hline \multicolumn{2}{|l|}{ L. versmoldensis } & Kröckel et al. 2003, sp. nov. \\
\hline \multicolumn{2}{|l|}{ L. vini } & Rodas et al. 2006, sp. nov. \\
\hline \multicolumn{2}{|l|}{ L. viridescens } & $\begin{array}{l}\text { Niven and Evans } 1957 \text { (Approved Lists 1980), } \\
\text { species. }\end{array}$ \\
\hline \multicolumn{2}{|l|}{ L. vitulinus } & $\begin{array}{l}\text { Sharpe et al. } 1973 \text { (Approved Lists 1980), } \\
\text { species. }\end{array}$ \\
\hline \multicolumn{2}{|l|}{ L. xylosus } & Kitahara 1938 (Approved Lists 1980), species. \\
\hline \multirow[t]{3}{*}{ L. yamanashiensis } & & $\begin{array}{l}\text { (ex Nonomura et al. 1965) Nonomura 1983, sp. } \\
\text { nov., nom. rev. }\end{array}$ \\
\hline & subsp. mali & $\begin{array}{l}\text { (Carr and Davies 1970) Nonomura 1983, } \\
\text { comb. nov. }\end{array}$ \\
\hline & $\begin{array}{l}\text { subsp. } \\
\text { yamanashiensis }\end{array}$ & $\begin{array}{l}\text { (ex Nonomura et al. 1965) Nonomura 1983, } \\
\text { subsp. nov., nom. rev. }\end{array}$ \\
\hline \multicolumn{2}{|l|}{ L. zeae } & $\begin{array}{l}\text { (ex Kuznetsov 1959) Dicks et al. 1996, nom. } \\
\text { rev., comb. nov. }\end{array}$ \\
\hline \multicolumn{2}{|l|}{ L. zymae } & Vancanneyt et al. 2005, sp. nov. \\
\hline
\end{tabular}




\section{ANEXO III. \\ Lista actual de especies incluidas en el género Streptococcus (datos obtenidos de List of Prokaryotic names with Sanding in Nomenclatura, septiembre 2010, www.bacterio.cict.fr)}

\begin{tabular}{|c|c|c|}
\hline Especie & Subespecie & Referencias \\
\hline Streptococcus & & $\begin{array}{l}\text { Rosenbach } 1884 \text { (Approved Lists } \\
\text { 1980), genus. }\end{array}$ \\
\hline S. acidominimus & & $\begin{array}{l}\text { Ayers and Mudge } 1922 \text { (Approved Lists } \\
\text { 1980), species. }\end{array}$ \\
\hline S. adjacens & & Bouvet et al. 1989, sp. nov. \\
\hline S. agalactiae & & $\begin{array}{l}\text { Lehmann and Neumann } 1896 \\
\text { (Approved Lists 1980), species. }\end{array}$ \\
\hline S. alactolyticus & & Farrow et al. 1985, sp. nov. \\
\hline S. anginosus & & $\begin{array}{l}\text { (Andrewes and Horder 1906) Smith and } \\
\text { Sherman } 1938 \text { (Approved Lists 1980), } \\
\text { species. }\end{array}$ \\
\hline S. australis & & Willcox et al. 2001, sp. nov. \\
\hline S. bovis & & $\begin{array}{l}\text { Orla-Jensen } 1919 \text { (Approved Lists } \\
\text { 1980), species. }\end{array}$ \\
\hline S. caballi & & Milinovich et al. 2008, sp. nov. \\
\hline S. canis & & Devriese et al. 1986, sp. nov. \\
\hline S. caprinus & & Brooker et al. 1996, sp. nov. \\
\hline S. castoreus & & Lawson et al. 2005, sp. nov. \\
\hline S. cecorum & & Devriese et al. 1983, sp. nov. \\
\hline \multirow[t]{3}{*}{ S. constellatus } & & $\begin{array}{l}\text { (Prévot 1924) Holdeman and Moore } \\
1974 \text { (Approved Lists 1980), species. }\end{array}$ \\
\hline & subsp. constellatus & $\begin{array}{l}\text { (Prévot 1924) Holdeman and Moore } \\
\text { 1974, subsp. nov. }\end{array}$ \\
\hline & subsp. pharyngis & Whiley et al. 1999, subsp. nov. \\
\hline S. cremoris & & $\begin{array}{l}\text { Orla-Jensen } 1919 \text { (Approved Lists } \\
\text { 1980), species. }\end{array}$ \\
\hline S. criceti & & $\begin{array}{l}\text { corrig. Coykendall } 1977 \text { (Approved Lists } \\
\text { 1980), species. }\end{array}$ \\
\hline S. cristatus & & corrig. Handley et al. 1991, sp. nov. \\
\hline S. defectives & & Bouvet et al. 1989, sp. nov. \\
\hline S. dentapri & & Takada et al. 2010, sp. nov. \\
\hline S. dentirousetti & & Takada and Hirasawa 2008, sp. nov. \\
\hline S. devriesei & & Collins et al. 2004, sp. nov. \\
\hline S. didelphis & & Rurangirwa et al. 2000, sp. nov. \\
\hline S. difficilis & & corrig. Eldar et al. 1995, sp. nov. \\
\hline S. downei & & Whiley et al. 1988, sp. nov. \\
\hline S. durans & & $\begin{array}{l}\text { (ex Sherman and Wing 1937) Knight et } \\
\text { al. 1984, sp. nov., nom. rev. }\end{array}$ \\
\hline \multirow[t]{3}{*}{ S. dysgalactiae } & & $\begin{array}{l}\text { (ex Diernhofer 1932) Garvie et al. 1983, } \\
\text { sp. nov., nom. rev. }\end{array}$ \\
\hline & subsp. dysgalactiae & $\begin{array}{l}\text { (ex Diernhofer 1932) Garvie et al. 1983, } \\
\text { subsp. nov. }\end{array}$ \\
\hline & subsp. equisimilis & Vandamme et al. 1996, subsp. nov. \\
\hline S. entericus & & Vela et al. 2002, sp. nov. \\
\hline
\end{tabular}




\begin{tabular}{|c|c|c|}
\hline \multicolumn{2}{|l|}{ S. equi } & $\begin{array}{l}\text { Sand and Jensen } 1888 \text { (Approved Lists } \\
\text { 1980), species. }\end{array}$ \\
\hline \multicolumn{2}{|l|}{ S. equi subsp. equi } & Sand and Jensen 1888, subsp. nov. \\
\hline \multicolumn{2}{|l|}{$\begin{array}{l}\text { S. equi subsp. } \\
\text { ruminatorum }\end{array}$} & Fernández et al. 2004, subsp. nov. \\
\hline \multicolumn{2}{|l|}{$\begin{array}{l}\text { S. equi subsp. } \\
\text { zooepidemicus }\end{array}$} & $\begin{array}{l}\text { (ex Frost and Englebrecht 1936) Farrow } \\
\text { and Collins 1985, nom. rev., comb. nov. }\end{array}$ \\
\hline \multicolumn{2}{|l|}{ S. equinus } & $\begin{array}{l}\text { Andrewes and Horder } 1906 \text { (Approved } \\
\text { Lists 1980), species. }\end{array}$ \\
\hline \multicolumn{2}{|l|}{ S. faecalis } & $\begin{array}{l}\text { Andrewes and Horder } 1906 \text { (Approved } \\
\text { Lists 1980), species. }\end{array}$ \\
\hline \multicolumn{2}{|l|}{ S. faecium } & $\begin{array}{l}\text { Orla-Jensen } 1919 \text { (Approved Lists } \\
\text { 1980), species. }\end{array}$ \\
\hline \multicolumn{2}{|l|}{ S. ferus } & $\begin{array}{l}\text { (ex Coykendall 1977) Coykendall 1983, } \\
\text { sp. nov., nom. rev. }\end{array}$ \\
\hline \multicolumn{2}{|l|}{ S. gallinaceus } & Collins et al. 2002, sp. nov. \\
\hline \multicolumn{2}{|l|}{ S. gallinarum } & Bridge and Sneath 1982, sp. nov. \\
\hline \multirow[t]{4}{*}{ S. gallolyticus } & & Osawa et al. 1996, sp. nov. \\
\hline & subsp. gallolyticus & Osawa et al. 1996, subsp. nov. \\
\hline & subsp. macedonicus & $\begin{array}{l}\text { (Tsakalidou et al. 1998) Schlegel et al. } \\
\text { 2003, comb. nov. }\end{array}$ \\
\hline & subsp. pasteurianus & $\begin{array}{l}\text { (Poyart et al. 2002) Schlegel et al. } \\
\text { 2003, comb. nov. }\end{array}$ \\
\hline \multicolumn{2}{|l|}{ S. garvieae } & Collins et al. 1984, sp. nov. \\
\hline \multicolumn{2}{|l|}{ S. gordonii } & Kilian et al. 1989, sp. nov. \\
\hline \multicolumn{2}{|l|}{ S. halichoeri } & Lawson et al. 2004, sp. nov. \\
\hline \multicolumn{2}{|l|}{ S. hansenii } & $\begin{array}{l}\text { Holdeman and Moore } 1974 \text { (Approved } \\
\text { Lists 1980), species. }\end{array}$ \\
\hline \multicolumn{2}{|l|}{ S. henryi } & Milinovich et al. 2008, sp. nov. \\
\hline \multicolumn{2}{|l|}{ S. hyointestinalis } & Devriese et al. 1988, sp. nov. \\
\hline \multicolumn{2}{|l|}{ S. hyovaginalis } & Devriese et al. 1997, sp. nov. \\
\hline \multicolumn{2}{|l|}{ S. ictaluri } & Shewmaker et al. 2007, sp. nov. \\
\hline \multirow[t]{3}{*}{ S. infantarius } & & Schlegel et al. 2000, sp. nov. \\
\hline & subsp. coli & Schlegel et al. 2003, subsp. nov. \\
\hline & subsp. infantarius & Schlegel et al. 2003, subsp. nov. \\
\hline \multicolumn{3}{|l|}{$\begin{array}{l}\text { S. infantis Kawamura } \\
\text { et al. } 1998, \text { sp. nov. }\end{array}$} \\
\hline \multicolumn{2}{|l|}{ S. iniae } & $\begin{array}{l}\text { Pier and Madin } 1976 \text { (Approved Lists } \\
\text { 1980), species. }\end{array}$ \\
\hline \multicolumn{2}{|l|}{ S. intermedius } & $\begin{array}{l}\text { Prévot } 1925 \text { (Approved Lists 1980), } \\
\text { species. }\end{array}$ \\
\hline \multicolumn{2}{|l|}{ S. intestinalis } & Robinson et al. 1988, sp. nov. \\
\hline \multirow[t]{4}{*}{ S. lactis } & & $\begin{array}{l}\text { (Lister 1873) Löhnis } 1909 \text { (Approved } \\
\text { Lists 1980), species. }\end{array}$ \\
\hline & subsp. cremoris & $\begin{array}{l}\text { (Orla-Jensen 1919) Garvie and Farrow } \\
\text { 1982, comb. nov. }\end{array}$ \\
\hline & subsp. diacetilactis & $\begin{array}{l}\text { (ex Matuszewski et al. 1936) Garvie } \\
\text { and Farrow 1982, nom. rev., comb. nov. }\end{array}$ \\
\hline & subsp. lactis & (Lister 1873) Löhnis 1909, subsp. nov. \\
\hline \multicolumn{2}{|l|}{ S. Iutetiensis } & Poyart et al. 2002, sp. nov. \\
\hline \multicolumn{2}{|l|}{ S. macacae } & Beighton et al. 1984, sp. nov. \\
\hline
\end{tabular}




\begin{tabular}{|c|c|}
\hline S. macedonicus & Tsakalidou et al. 1998, sp. nov. \\
\hline S. marimammalium & Lawson et al. 2005, sp. nov. \\
\hline S. massiliensis & Glazunova et al. 2006, sp. nov. \\
\hline S. merionis & Tappe et al. 2009, sp. nov. \\
\hline S. minor & Vancanneyt et al. 2004, sp. nov. \\
\hline S. mitis & $\begin{array}{l}\text { Andrewes and Horder } 1906 \text { (Approved } \\
\text { Lists 1980), species. }\end{array}$ \\
\hline S. morbillorum & $\begin{array}{l}\text { (Prévot 1933) Holdeman and Moore } \\
1974 \text { (Approved Lists 1980), species. }\end{array}$ \\
\hline S. mutans & $\begin{array}{l}\text { Clarke } 1924 \text { (Approved Lists 1980), } \\
\text { species. }\end{array}$ \\
\hline S. oligofermentans & Tong et al. 2003, sp. nov. \\
\hline S. oralis & Bridge and Sneath 1982, sp. nov. \\
\hline S. orisratti & Zhu et al. 2000, sp. nov. \\
\hline S. orisuis & Takada and Hirasawa 2007, sp. nov. \\
\hline S. ovis & Collins et al. 2001, sp. nov. \\
\hline S. parasanguinis & corrig. Whiley et al. 1990, sp. nov. \\
\hline S. parauberis & Williams and Collins 1990, sp. nov. \\
\hline S. parvulus & $\begin{array}{l}\text { (Weinberg et al. 1937) Cato 1983, } \\
\text { comb. nov. }\end{array}$ \\
\hline S. pasteurianus & Poyart et al. 2002, sp. nov. \\
\hline S. peroris & Kawamura et al. 1998, sp. nov. \\
\hline S. phocae & Skaar et al. 1994, sp. nov. \\
\hline S. plantarum & Collins et al. 1984, sp. nov. \\
\hline S. pleomorphus & $\begin{array}{l}\text { Barnes et al. } 1979 \text { (Approved Lists } \\
\text { 1980), species. }\end{array}$ \\
\hline S. pluranimalium & Devriese et al. 1999, sp. nov. \\
\hline S. plurextorum & Vela et al. 2009, sp. nov. \\
\hline S. pneumoniae & $\begin{array}{l}\text { (Klein 1884) Chester } 1901 \text { (Approved } \\
\text { Lists 1980), species. }\end{array}$ \\
\hline S. porci & Vela et al. 2010, sp. nov. \\
\hline S. porcinus & Collins et al. 1985, sp. nov. \\
\hline S. pseudopneumoniae & Arbique et al. 2005, sp. nov. \\
\hline S. pseudoporcinus & Bekal et al. 2007, sp. nov. \\
\hline S. pyogenes & $\begin{array}{l}\text { Rosenbach } 1884 \text { (Approved Lists } \\
\text { 1980), species. }\end{array}$ \\
\hline S. raffinolactis & $\begin{array}{l}\text { Orla-Jensen and Hansen } 1932 \\
\text { (Approved Lists 1980), species. }\end{array}$ \\
\hline S. ratti & $\begin{array}{l}\text { corrig. Coykendall } 1977 \text { (Approved Lists } \\
\text { 1980), species. }\end{array}$ \\
\hline S. saccharolyticus & Farrow et al. 1985, sp. nov. \\
\hline S. salivarius & $\begin{array}{l}\text { Andrewes and Horder } 1906 \text { (Approved } \\
\text { Lists 1980), species. }\end{array}$ \\
\hline $\begin{array}{l}\text { S. salivarius subsp. } \\
\text { salivarius }\end{array}$ & $\begin{array}{l}\text { Andrewes and Horder 1906, subsp. } \\
\text { nov. }\end{array}$ \\
\hline $\begin{array}{l}\text { S. salivarius subsp. } \\
\text { thermophilus }\end{array}$ & $\begin{array}{l}\text { (Orla-Jensen 1919) Farrow and Collins } \\
\text { 1984, comb. nov. }\end{array}$ \\
\hline S. sanguinis & $\begin{array}{l}\text { corrig. White and Niven } 1946 \text { (Approved } \\
\text { Lists 1980), species. }\end{array}$ \\
\hline S. shiloi & Eldar et al. 1995, sp. nov. \\
\hline S. sinensis & Woo et al. 2002, sp. nov. \\
\hline
\end{tabular}




\begin{tabular}{|ll|}
\hline S. sobrinus & $\begin{array}{l}\text { (ex Coykendall 1974) Coykendall 1983, } \\
\text { nom. rev., comb. nov. }\end{array}$ \\
\hline S. suis & $\begin{array}{l}\text { (ex Elliot 1966) Kilpper-Bälz and } \\
\text { Schleifer 1987, sp. nov., nom. rev. }\end{array}$ \\
\hline S. thermophilus & $\begin{array}{l}\text { Orla-Jensen } 1919 \text { (Approved Lists } \\
\text { 1980), species. }\end{array}$ \\
\hline S. thoraltensis & Devriese et al. 1997, sp. nov. \\
\hline S. uberis & Diernhofer 1932 (Approved Lists 1980), \\
S. urinalis & species. \\
\hline S. vestibularis & Collins et al. 2000, sp. nov. \\
\hline S. waius & Whiley and Hardie 1988, sp. nov. \\
\hline
\end{tabular}




\section{ANEXO IV. \\ Medios de cultivo}

A continuación, se describe la composición de cada uno de los medios de cultivos empleados, referida a un litro de agua destilada.

\section{AGAR MRS O MAN, ROGOSA AND SHARPE AGAR (SCHARLAU)}

\begin{tabular}{lc}
\hline Composición $(\mathrm{g} / \mathrm{l}):$ \\
\hline Peptona proteosa & $10,0 \mathrm{~g}$ \\
\hline Extracto de Carne & $8,0 \mathrm{~g}$ \\
\hline Extracto de Levadura & $4,0 \mathrm{~g}$ \\
\hline $\mathrm{D}(+)$ Glucosa & $20,0 \mathrm{~g}$ \\
\hline Acetato de Sodio & $5,0 \mathrm{~g}$ \\
\hline Citrato triamónico & $2,0 \mathrm{~g}$ \\
\hline Sulfato Magnésico & $0,2 \mathrm{~g}$ \\
\hline Sulfato manganoso & $0,05 \mathrm{~g}$ \\
\hline Fosfato dipotásico & $2,0 \mathrm{~g}$ \\
\hline Polisorbato 80 & $1 \mathrm{ml}$ \\
\hline Agar & $14,0 \mathrm{~g}$ \\
\hline pH final aproximado & $6,2 \pm 0,2$ \\
\hline
\end{tabular}

Preparación:

Suspender $66 \mathrm{~g}$ de medio en 1 litro de agua destilada. Calentar y agitar hasta ebullición y disolución total. Distribuir en recipientes adecuados y esteriilzar durante 15 mintuos a $121^{\circ} \mathrm{C}$ en autoclave.

\section{MRS CALDO (MERCK):}

\begin{tabular}{lc}
\hline Composición $(\mathrm{g} / \mathrm{l})$ : \\
\hline Citrato triamónico & $2,0 \mathrm{~g}$ \\
\hline Extracto de Carne & $8,0 \mathrm{~g}$ \\
\hline Extracto de Levadura & $4,0 \mathrm{~g}$ \\
\hline $\mathrm{D}(+)$-Glucosa & $20,0 \mathrm{~g}$ \\
\hline Sulfato Magnésico & $0,2 \mathrm{~g}$ \\
\hline Sulfato manganoso & $0,05 \mathrm{~g}$ \\
\hline Peptona & $10,0 \mathrm{~g}$ \\
\hline Acetato de Sodio & $5,0 \mathrm{~g}$ \\
\hline Polisorbato 80 & $1 \mathrm{ml}$ \\
\hline pH final aproximado & 6,3 \\
\hline
\end{tabular}


Medio esterilizado a $121^{\circ} \mathrm{C}$ durante un período de tiempo que oscila entre 15 y 20 minutos.

\section{AGAR M17 (MERCK):}

\begin{tabular}{lc}
\hline Composición $(\mathrm{g} / \mathrm{l}):$ & \\
\hline Glicerofosfato sódico & $19,0 \mathrm{~g}$ \\
\hline Peptona de soja & $5,0 \mathrm{~g}$ \\
\hline Extracto de carne & $5,0 \mathrm{~g}$ \\
\hline Lactosa & $5,0 \mathrm{~g}$ \\
\hline Triptona & $2,5 \mathrm{~g}$ \\
\hline Peptona de carne & $2,5 \mathrm{~g}$ \\
\hline Extracto de levadura & $2,5 \mathrm{~g}$ \\
\hline Ácido ascórbico & $0,5 \mathrm{~g}$ \\
\hline Sulfato magnésico & $0,25 \mathrm{~g}$ \\
\hline Agar & $18,0 \mathrm{~g}$ \\
\hline $\mathrm{pH}$ final aproximado & 7 \\
\hline
\end{tabular}

Medio esterilizado a $121^{\circ} \mathrm{C}$ durante un período de tiempo que oscila entre 15 y 20 minutos.

\section{M-17 CALDO (MERCK):}

\begin{tabular}{lc}
\hline Composición $(\mathrm{g} / \mathrm{l}):$ \\
\hline Glicerofosfato sódico & $19,0 \mathrm{~g}$ \\
\hline Peptona de soja & $5,0 \mathrm{~g}$ \\
\hline Extracto de carne & $5,0 \mathrm{~g}$ \\
\hline Lactosa & $5,0 \mathrm{~g}$ \\
\hline Triptona & $2,5 \mathrm{~g}$ \\
\hline Peptona de carne & $2,5 \mathrm{~g}$ \\
\hline Extracto de levadura & $2,5 \mathrm{~g}$ \\
\hline Ácido ascórbico & $0,5 \mathrm{~g}$ \\
\hline Sulfato magnésico & $0,25 \mathrm{~g}$ \\
\hline pH final aproximado & 7 \\
\hline
\end{tabular}


Medio esterilizado a $121^{\circ} \mathrm{C}$ durante un período de tiempo que oscila entre 15 y 20 minutos.

\section{MEDIO LS DIFFERENTIAL}

\begin{tabular}{lc}
\hline Composición $(\mathrm{g} / \mathrm{l}):$ & \\
\hline Triptona & $10,0 \mathrm{~g}$ \\
\hline Peptona de soja & $5,0 \mathrm{~g}$ \\
\hline Extracto de levadura & $5,0 \mathrm{~g}$ \\
\hline Extracto de carne & $5,0 \mathrm{~g}$ \\
\hline Dextrosa & $20,0 \mathrm{~g}$ \\
\hline Cloruro sódico & $5,0 \mathrm{~g}$ \\
\hline Cisteína & $0,3 \mathrm{~g}$ \\
\hline Agar & $18,0 \mathrm{~g}$ \\
\hline pH final aproximado & 6,7 \\
\hline
\end{tabular}

En frasco aparte y se añade una vez atemperado al medio:

\begin{tabular}{ll}
\hline Composición $(\mathrm{g} / \mathrm{l}):$ \\
\hline Leche descremada & $10,0 \mathrm{~g}$ \\
\hline Solución estéril de TTC al $1 \%$ & $10 \mathrm{ml}$ \\
\hline
\end{tabular}

\section{CALDO GLICERINADO $20 \%$}

\section{Composición (g/l):}

Polvo "Lab-Lemco"

Peptona

$10,0 \mathrm{~g}$

Cloruro sódico

$10,0 \mathrm{~g}$

Glicero

$5,0 \mathrm{~g}$




\section{AGAR ROGOSA (OXOID):}

\begin{tabular}{lc}
\hline Composición $(\mathrm{g} / \mathrm{I}):$ & \\
\hline Acetato sódico & $25,0 \mathrm{~g}$ \\
\hline Glucosa & $20,0 \mathrm{~g}$ \\
\hline Triptona & $10,0 \mathrm{~g}$ \\
\hline Fosfato monopotásico & $6,0 \mathrm{~g}$ \\
\hline Extracto de levadura & $5,0 \mathrm{~g}$ \\
\hline Citrato amónico & $2,0 \mathrm{~g}$ \\
\hline Mono-oleato de sorbitan & $1,0 \mathrm{~g}$ \\
\hline Sulfato de magnesio & $0,575 \mathrm{~g}$ \\
\hline Sulfato de manganeso & $0,12 \mathrm{~g}$ \\
\hline Sulfato férrico & $0,034 \mathrm{~g}$ \\
\hline Agar-agar & $20,0 \mathrm{~g}$ \\
\hline Agua destilada & $1 \mathrm{~L}$ \\
\hline pH final aproximado & $\mathbf{5 , 4 \pm 0 , 2}$ \\
\hline
\end{tabular}

\section{Preparación:}

Suspender $75 \mathrm{~g}$ de medio en 1 litro de agua destilada. Calentar y agitar hasta ebullición y disolución total. Añadir $1,32 \mathrm{ml}$ de ácido acético al $96 \%$ y mezclar bien. Calentar hasta $90-100^{\circ} \mathrm{C}$ durante 2 minutos. NO ESTERILIZAR EN AUTOCLAVE. Distribuir asépticamente.

\section{AGUA DE PEPTONA TAMPONADA (MERCK):}

\begin{tabular}{lc}
\hline Composición $(\mathrm{g} / \mathrm{l}):$ & \\
\hline Peptona & $10,0 \mathrm{~g}$ \\
\hline Cloruro sódico & $5,0 \mathrm{~g}$ \\
\hline Tampón fosfato & $10,5 \mathrm{~g}$ \\
\hline Agua destilada & $1 \mathrm{~L}$ \\
\hline
\end{tabular}

\section{Preparación:}

Disolver $25.5 \mathrm{~g}$ en 1 litro de agua desmineralizada; eventualmente introducir en recipientes pequeños; tratar en autoclave $\left(15\right.$ minutos a $\left.121^{\circ} \mathrm{C}\right)$. 


\section{MEDIO BASE DE AGAR SANGRE COLUMBIA (SCHARLAU)}

\begin{tabular}{lc}
\hline Composición $(\mathrm{g} / \mathrm{l}):$ \\
\hline Peptona caseína & $12,0 \mathrm{~g}$ \\
\hline Peptona de carne & $11,0 \mathrm{~g}$ \\
\hline Almidón & $1,5 \mathrm{~g}$ \\
\hline Cloruro sódico & $5,0 \mathrm{~g}$ \\
\hline Agar & $15,0 \mathrm{~g}$ \\
\hline Agua destilada & $1 \mathrm{~L}$ \\
\hline pH & $\mathbf{7 , 3 \pm 0 , 2}$ \\
\hline
\end{tabular}

\section{Preparación:}

Suspender 44,5 g de polvo en $950 \mathrm{ml}$ de agua destilada. Llevar a ebullición y y distribuir en recipientes adecuados. Esterilizar a $121^{\circ} \mathrm{C}$ durante 15 minutos. Dejar enfriar a $45-50{ }^{\circ} \mathrm{C}$ y añadir asépticamente sangre estéril desfibrinada en una proporción del $5 \%$.

\section{MEDIO AGAR MACCONKEY $N^{\circ} 3$ (OXOID)}

\begin{tabular}{lc}
\hline Composición $(\mathrm{g} / \mathrm{l}):$ \\
\hline Peptona & $23,0 \mathrm{~g}$ \\
\hline Lactosa & $10,0 \mathrm{~g}$ \\
\hline Sal biliar $\mathrm{n}^{\circ} 3$ & $1,5 \mathrm{~g}$ \\
\hline Cloruro sódico & $5,0 \mathrm{~g}$ \\
\hline Rojo neutro & $0,03 \mathrm{~g}$ \\
\hline Cristal violeta & $0,001 \mathrm{~g}$ \\
\hline Agar & $15,0 \mathrm{~g}$ \\
\hline Agua destilada & $1 \mathrm{~L}$ \\
\hline pH & $\mathbf{7 , 1 \pm 0 , 2}$ \\
\hline
\end{tabular}

\section{Preparación:}

Suspender 51,5 g de medio en 1 litro de agua destilada. Calentar y agitar hasta ebullición y hervir hasta disolución total. Esterilizar a $121^{\circ} \mathrm{C}$ durante 15 minutos y distribuir en placas.Conservar el medio preparado a temperaturas de entre 2 y $8^{\circ} \mathrm{C}$. 


\section{MEDIO WILKINS-CHALGREN PARA ANAEROBIOS (WILKINS-CHALGREN ANAEROBE) (OXOID)}

\begin{tabular}{lc}
\hline Composición $(\mathrm{g} / \mathrm{l}):$ & \\
\hline Triptona & $10,0 \mathrm{~g}$ \\
\hline Peptona de gelatina & $10,0 \mathrm{~g}$ \\
\hline Extracto de levadura & $5,0 \mathrm{~g}$ \\
\hline Glucosa & $1,0 \mathrm{~g}$ \\
\hline Cloruro sódico & $5,0 \mathrm{~g}$ \\
\hline L-arginina & $1,0 \mathrm{~g}$ \\
\hline Piruvato sódico & $1,0 \mathrm{~g}$ \\
\hline Menadiona & $0,0005 \mathrm{~g}$ \\
\hline Haemina & $0,005 \mathrm{~g}$ \\
\hline Agua destilada & $1 \mathrm{~L}$ \\
\hline pH & $\mathbf{7 , 1 \pm 0 , 2}$ \\
\hline
\end{tabular}

\section{Preparación:}

Suspender $33 \mathrm{~g}$ de medio en 1 litro de agua destilada. Calentar y agitar hasta ebullición y hervir durante un minuto. Esterilizar a $121^{\circ} \mathrm{C}$ durante 15 minutos. Dejar enfriar hasta $50-55^{\circ} \mathrm{C}$ y distribuir en placas de Petri estériles.

\section{MEDIO AGAR PLATE COUNT(SCHARLAU)}

\begin{tabular}{lc}
\hline Composición $(\mathrm{g} / \mathrm{l}):$ & \\
\hline Peptona caseína & $5,0 \mathrm{~g}$ \\
\hline Extracto de levadura & $2,5 \mathrm{~g}$ \\
\hline Dextrosa & $1,0 \mathrm{~g}$ \\
\hline Agar & $15,0 \mathrm{~g}$ \\
\hline Agua destilada & $1 \mathrm{~L}$ \\
\hline $\mathbf{p H}$ & $\mathbf{7 , 0 \pm 0 , 2}$ \\
\hline
\end{tabular}

\section{Preparación:}

Suspender 23,5 g de polvo en 1 litro de agua destilada. Calentar y agitar hasta ebullición y hervir hasta disolución total. Distribuir en recipientes adecuados y esterilizar a $121^{\circ} \mathrm{C}$ durante 15 minutos. 
Anexos

\section{MEDIO BFM}

\begin{tabular}{lc}
\hline Composición $(\mathrm{g} / \mathrm{l})$ : & \\
\hline Extracto de levadura & $7 \mathrm{~g}$ \\
\hline Cloruro sódico & $5 \mathrm{~g}$ \\
\hline Peptona & $5 \mathrm{~g}$ \\
\hline Lactulosa & $5 \mathrm{~g}$ \\
\hline Cloruro de litio & $2 \mathrm{~g}$ \\
\hline Extracto de carne & $2 \mathrm{~g}$ \\
\hline Ácido propiónico & $5 \mathrm{ml}$ \\
\hline Triptona & $2 \mathrm{~g}$ \\
\hline Almidón & $2 \mathrm{~g}$ \\
\hline Cisterna & $0,5 \mathrm{~g}$ \\
\hline Tiamina & $1 \mathrm{mg}$ \\
\hline Riboflavina & $1 \mathrm{mg}$ \\
\hline Azul de metileno & $16 \mathrm{mg}$ \\
\hline Agar & $18 \mathrm{~g}$ \\
\hline pH & $\mathbf{5 , 5}$ \\
\hline
\end{tabular}

\section{Preparación:}

Todos los componentes excepto el ácido propiónico se disuelven en agua destilada y son esterilizados en el autoclave a $121^{\circ} \mathrm{C}$ durante 20 minutos. Posteriormente, se deja atemperar el medio hasta $55^{\circ} \mathrm{C}$ aproximadamente, momento en que se añade el ácido propiónico y se ajusta el pH con hidróxido sódico $10 \mathrm{M}$ hasta $\mathrm{pH}$ igual a 5,5 . 


\section{ANEXO IV}

Soluciones, reactivos y material para identificación con PCR

\section{Solución CTAB/CINa}

CTAB $10 \%$ en CINa $0,7 \mathrm{M}$

\section{Proteinasa K}

$20 \mathrm{mg} / \mathrm{ml}$ de agua estéril e incubar a $37^{\circ} \mathrm{C}$ durante 1 hora aproximadamente.

\section{Cloroformo/alcohol isoamílico}

Solución de proporción 24:1 (v/v) de cloroformo y alcohol isoamílico.

\section{Fenol/Cloroformo/alcohol isoamílico}

Solución de proporción 25:24:1 (v/v/v) de fenol, coroformo y alcohol isoamílico.

\section{Lisozima (Sigma)}

Concentración $5 \mathrm{mg} / \mathrm{ml}$, introducir en un baño a $37^{\circ} \mathrm{C}$ durante 10 minutos antes de su uso.

\section{Espermidina}

Solución de espermidina (SIGMA) 0,1 M en TRIS-HCI 0,1 M, pH 7.

\section{Tampón TE}

Tris-CHI 10 mM, EDTA 1 mM

\section{Solución RNAsa}

\begin{tabular}{ll}
\hline Composición & \\
\hline RNAsa A (Boehringer) & $5 \mathrm{mg}$ \\
\hline EDTA 0,5 M & $15 \mathrm{ml}$ \\
\hline $\mathrm{NaCl} 0,1 \mathrm{M}$ & $6 \mathrm{ml}$ \\
\hline Tris 1 M (pH 8,3) & $1,5 \mathrm{ml}$ \\
\hline Agua MilliQ & $77 \mathrm{ml}$ \\
\hline
\end{tabular}


Calentar a $100^{\circ} \mathrm{C}$ durante 5 min para inactivar las DNAsas y enfriar. Conservar a $20^{\circ} \mathrm{C}$.

Tampón TAE 1X

\begin{tabular}{lc}
\hline Composición & \\
\hline Tris-CHI & $0,04 \mathrm{M}$ \\
\hline EDTA & $0,002 \mathrm{M}$ \\
\hline Ácido acético glacial & $0,02 \mathrm{M}$ \\
\hline
\end{tabular}

\section{Tampón de carga}

\begin{tabular}{lc}
\hline Composición & \\
\hline Azul bromofenol 1\% & $2,5 \mathrm{ml}$ \\
\hline Ficoll & $2,5 \mathrm{~g}$ \\
\hline EDTA 0,5M & $1 \mathrm{ml}$ \\
\hline Agua MilliQ & $4 \mathrm{ml}$ \\
\hline
\end{tabular}

\section{Gel de Agarosa}

Agarosa SEAKEM LE (FMC Products) 1\% y Agarosa NuSieve 3\%.

Solución de bromuro de etidio, $10 \mathrm{mg} / \mathrm{ml}$ (IBERLABO)

Pesar la agarosa y transferir a un matraz. Añadir el tampón TAE 1X, calentar hasta que rompa a hervir, agitar y atemperar hasta $50^{\circ} \mathrm{C}$. Añadir $5 \mu \mathrm{l}$ de solución de bromuro de etidio por cada $50 \mathrm{ml}$ de tampón TAE $1 \mathrm{X}$ y verter en el molde.

\section{Marcadores de pesos moleculares}

100 pb DNA Ladder (BioLabs L-101): de 100 a 4000 pb

Marcador L-101

$50 \mu \mathrm{l}$

Tampón TE

$750 \mu \mathrm{l}$

Tampón de carga

$200 \mu \mathrm{l}$ 


\section{ANEXO IV. \\ Soluciones y reactivos para FISH}

\section{PBS 3X}

\begin{tabular}{lc}
\hline Compuesto & Cantidad \\
\hline $\mathrm{NaCl}$ & $22,8 \mathrm{~g}$ \\
\hline $\mathrm{NaH}_{2} \mathrm{PO}_{4}$ & $3 \mathrm{~g}$ \\
\hline $\mathrm{Na}_{2} \mathrm{HPO}_{4}$ & $2,88 \mathrm{~g}$ \\
\hline Agua destilada & $1 \mathrm{~L}$ \\
\hline $\mathrm{pH} 7.5$ & \\
\hline
\end{tabular}

Disolver los fosfatos y el cloruro sódico por separado. Esterilizar a $115^{\circ} \mathrm{C}, 20 \mathrm{~min}$.

\section{Paraformaldehido (Panreac)}

Calentar $30 \mathrm{ml}$ de agua destilada a $60^{\circ} \mathrm{C}$.

Añadir $2 \mathrm{~g}$ de PFA al agua precalentada y agitar. Se adiciona unas gotas de $\mathrm{NaOH}$ $5 \mathrm{M}$ para disolver el polvo.

Completar hasta $50 \mathrm{ml}$ con PBS 3X. Ajustar el pH hasta 7,5. Eliminar los posibles cristales mediante filtración.

Guardar a $4^{\circ} \mathrm{C}$ durante un máximo de $48 \mathrm{~h}$, o a $-20^{\circ} \mathrm{C}$ varias semanas.

\section{Solución de gelatina}

\begin{tabular}{lc}
\hline Compuesto & Cantidad \\
\hline Gelatina bacteriológica (Cultimed 170-180) & $0,1 \%$ \\
\hline Sulfato potásico cromato (Sigma C-5926) & $0,01 \%$ \\
\hline
\end{tabular}

Calentar previamente $40 \mathrm{ml}$ de agua destilada en agitación, añadir $50 \mathrm{mg}$ de gelatina y $5 \mathrm{mg}$ de sal de cromato. Una vez disuelta dejar atemperar a $45^{\circ} \mathrm{C}$. 
Anexos

\section{Portaobjetos cubiertos con teflón (Marienfeld 9782100)}

Lavar los portaobjetos con desengrasante, enjuagar con agua destilada y secar al aire.

Sumergir los portaobjetos en gelatina al $0.1 \%$ y dejar escurrir.

Secar al aire.

\section{Tampón de hibridación}

$\begin{array}{lc}\mathrm{NaCl} 5 \mathrm{M} & 360 \mu \mathrm{l}(0.9 \mathrm{M}) \\ \mathrm{HCl}-\mathrm{Tris} 1 \mathrm{M} & 40 \mu \mathrm{l}(20 \mathrm{mM}) \\ \text { SDS } 10 \% & 2 \mu \mathrm{l}(0.01 \%) \\ \text { Formamida (SIGMA F-7503) } & \mathrm{X} \mu \mathrm{l}(0-50 \%) \\ \text { Agua milliQ } & \text { completar hasta } 2 \mathrm{ml}\end{array}$

Mezclar todos los componentes y añadir en último lugar el SDS 10\%. Completar hasta $2 \mathrm{ml}$ y agitar.

\section{Tampón de lavado}

$\begin{array}{lc}\text { NaCl } 5 M^{*} & (9000-100 \mu \mathrm{l}) \\ \text { HCl-Tris } 1 \mathrm{M} & 1000 \mu \mathrm{l} \\ \text { SDS } 10 \% & 50 \mu \mathrm{l} \\ \text { EDTA } 0,5 \mathrm{M}^{* *} & 500 \mu \mathrm{l} \\ \text { Agua milliQ } & \text { completar hasta } 50 \mathrm{ml}\end{array}$

* La concentración de $\mathrm{NaCl}$ depende de la concentración de formamida en el tampón de hibridación.

$\begin{array}{lll}0 \% & \text { formamida } & 9000 \mu \mathrm{l} \mathrm{NaCl} \\ 20 \% & \text { formamida } & 2150 \mu \mathrm{l} \mathrm{NaCl} \\ 30 \% & \text { formamida } & 1020 \mu \mathrm{l} \mathrm{NaCl} \\ 35 \% & \text { formamida } & 700 \mu \mathrm{l} \mathrm{NaCl}\end{array}$

** Solo se añade en caso de que el tampón de hibridación contenga un 20\% de formamida o más. 


\section{Sondas}

Diluir en agua MilliQ la solución madre de sondas marcadas con fluorocromos (MWG Biotech, Germany) hasta una concentración $50 \mathrm{ng} / \mu \mathrm{l}$. Tanto la solución madre como la de trabajo se almacenan $a-20^{\circ} \mathrm{C}$ en oscuridad. 


\section{ANEXO V.}

Otros reactivos

\section{PARA DVC}

Antibióticos:

Ácido nalidíxico, ciprofloxacino, novobiocina, moxifloxacino y amoxicilina (Sigma Chemical Co., St. Louis,)

\section{PARA MICROSCOPÍA ELECTRÓNICA DE BARRIDO}

Glutaraldehydo (Sigma-Aldrich, Madrid, España) En PBS $0.1 \mathrm{M}(\mathrm{pH} 7,2)$

Tetroxido de Osmio (Sigma-Aldrich, Madrid, España)

Membranas de policarbonato de $25 \mathrm{~mm}$ de diámetro y $0,2 \mu \mathrm{m}$ de tamaño de poro (Sigma-Aldrich, Madrid, España) 


\section{ANEXO VI. \\ Secuenciación parcial de los genes 165 y 235 de Lactobacillus delbrueckii subsp bulgaricus $\mathrm{Y} 7$}

\section{S CEPA Y7 - DN100 182 (about 1500 bp)}

gagtttgatcctggctcaggacgaacgctggcggcgtgcctaatacatgcaagtcgagcgagctgaattcaaagatc ccttcggggtgatttgttggacgctagcggcggatgggtgagtaacacgtgggcaatctgccctaaagactgggatac cacttggaaacaggtgctaataccggataacaacatgaatcgcatgattcaagtttgaaaggcggcgyaagctgtca ctttaggatgagcccgcggcgcattagctagttggtggggtaaaggcctaccaaggcaatgatgcgtagccgagttg agagactgatcggccacattgggactgagacacggcccaaactcctacgggaggcagcagtagggaatcttccac aatggacgcaagtctgatggagcaacgccgcgtgagtgaagaaggtttcggatcgtaaagctctgttgttggtgaag aaggatagaggcagtaactggtctttatttgacggtaatcaaccagaaagtcacggctaactacgtgccagcagccg cggtaatacgtaggtggcaagcgttgtccggatttattgggcgtaaagcgagcgcaggcggaatgataagtctgatgt gaaagcccacggctcaaccgtggaactgcatcggaaactgtcattcttgagtgcagaagaggagagtggaattccat gtgtagcggtggaatgcgtagatatatggaagaacaccagtggcgaaggcggctctctggtctgcaactgacgctga ggctcgaaagcatgggtagcgaacaggattagataccctggtagtccatgccgtaaacgatgagcgctaggtgttgg ggactttccggtcctcagtgccgcagcaaacgcattaagcgctccgcctggggagtacgaccgcaaggttgaaactc aaaggaattgacggggggcccgcacaagcggtggagcatgtggtttaattcgaagcaacgcgaagaaccttaccag gtcttgacatcctgygctacacctagagataggtggttcccttcggggacgcagagacaggtggtgcatggctgtcgtc agctcgtgtcgtgagatgttgggttaagtcccgcaacgagcgcaaccttgtctttagttgccatcattaagttgggcact ctaaagagactgccggtgacaaaccggaggaaggtggggatgacgtcaagtcatcatgcccttatgacctgggct acacacgtgctacaatgggcagtacaacgagaagcgaacccgcgagggtaagcggatctcttaaagctgttctcag ttcggactgcaggctgcaactcgcctgcacgaagctggaatcgctagtaatcgcggatcagcacgccgcggtgaata cgttcccgggccttgtacacaccgcccgtcacaccatggaagtctgcaatgcccaaagtcggtgggataacctttata ggagtcagccgcctaaggcagggcagatgactggggtgaagtcgtaacaaggtagccgta

\section{S CEPA Y7 - DN100 182 (first 500 bp on the left)}

cgaaagaacaaacttgcaaggtcaagtgaagaagggcgcacggtgaatgccttggcactggaagccgatgaagg acgcgactaaccgcgaaagtcttcggggagccgtaagtaggctttgatccggaggtctccgaatgggggaacccag catgtgcagacatgctatccttaagtgaatacatagcttaaggarggaacacgcagtgaactgaaacatctaagtagc tgcaggaagagaaagaaatatcgatttcccaagtagcggcgagcgaacaggaaagagcccaaaccggcagattt atctgccggggttgtaggactgagacatggcacttcagaggatagcagaagcgtttgggaaagcgcgccagagag ggtgagagccccgtaagcgaaatccaaagaaggcctatcagtatcctgagtagggcgggacacgtgaaatcccgtt tgaatccgcgaggaccatctcgcaaggctaaatactaaccagtgaccgatagtgaaccagtaccgtgagggaaag gtgaaaagaaccccgggaggggagtgaa 
Anexos

ANEXO VII.

Recuentos de la microbiota en las heces de los individuos sometidos al ensayo in vivo

\section{Lactobacilos}

\begin{tabular}{|c|c|c|c|c|c|c|}
\hline & \multicolumn{2}{|c|}{ T1 } & \multicolumn{2}{|c|}{ T2 } & \multicolumn{2}{|c|}{ T3 } \\
\hline INDIVIDUO & ufc/g & $\log _{10} \mathrm{ufc} / \mathrm{g}$ & ufc/g & $\log _{10} \mathrm{ufc} / \mathrm{g}$ & ufc/g & $\log _{10} \mathrm{ufc} / \mathrm{g}$ \\
\hline Control & $6,10 E+05$ & 5,79 & $5,30 \mathrm{E}+05$ & 5,72 & $8,70 E+05$ & 5,94 \\
\hline 1 & $3,00 E+05$ & 5,48 & $1,10 \mathrm{E}+07$ & 7,04 & $9,40 \mathrm{E}+06$ & 6,97 \\
\hline 2 & $2,20 E+04$ & 4,34 & $3,00 \mathrm{E}+05$ & 5,48 & $5,50 \mathrm{E}+05$ & 5,74 \\
\hline 3 & $6,50 \mathrm{E}+04$ & 4,81 & $1,00 \mathrm{E}+05$ & 5,00 & $2,00 \mathrm{E}+04$ & 4,30 \\
\hline 4 & $2,50 E+05$ & 5,40 & $2,00 \mathrm{E}+05$ & 5,30 & $1,70 E+06$ & 6,23 \\
\hline 5 & $2,10 E+06$ & 6,32 & $2,50 \mathrm{E}+06$ & 6,40 & $3,50 E+06$ & 6,54 \\
\hline 6 & $5,30 \mathrm{E}+05$ & 5,72 & $5,00 \mathrm{E}+05$ & 5,70 & $2,90 E+05$ & 5,46 \\
\hline 7 & $2,60 E+04$ & 4,41 & $4,00 \mathrm{E}+05$ & 5,60 & $2,40 \mathrm{E}+07$ & 7,38 \\
\hline 8 & $7,00 \mathrm{E}+05$ & 5,85 & $5,20 \mathrm{E}+06$ & 6,72 & $2,00 \mathrm{E}+04$ & 4,30 \\
\hline 9 & $2,20 E+04$ & 4,34 & $1,90 \mathrm{E}+05$ & 5,28 & $2,40 E+05$ & 5,38 \\
\hline 10 & $2,50 \mathrm{E}+04$ & 4,40 & $8,00 \mathrm{E}+05$ & 5,90 & $1,70 \mathrm{E}+06$ & 6,23 \\
\hline 11 & $8,50 E+05$ & 5,93 & $2,50 \mathrm{E}+06$ & 6,40 & $3,80 \mathrm{E}+06$ & 6,58 \\
\hline 12 & $1,00 \mathrm{E}+05$ & 5,00 & $4,70 \mathrm{E}+06$ & 6,67 & $2,10 E+05$ & 5,32 \\
\hline 13 & $9,30 E+04$ & 4,97 & $5,80 \mathrm{E}+05$ & 5,76 & $1,40 \mathrm{E}+07$ & 7,15 \\
\hline 14 & $9,00 \mathrm{E}+03$ & 3,95 & $7,00 \mathrm{E}+04$ & 4,85 & $2,00 E+04$ & 4,30 \\
\hline 15 & $3,00 E+05$ & 5,48 & $7,00 \mathrm{E}+05$ & 5,85 & $2,00 E+04$ & 4,30 \\
\hline 16 & $2,20 E+04$ & 4,34 & $2,00 \mathrm{E}+05$ & 5,30 & $1,70 E+06$ & 6,23 \\
\hline 17 & $2,10 E+04$ & 4,32 & $2,90 \mathrm{E}+04$ & 4,46 & $3,30 E+06$ & 6,52 \\
\hline 18 & $2,50 \mathrm{E}+05$ & 5,40 & $7,00 \mathrm{E}+05$ & 5,85 & $2,50 E+05$ & 5,40 \\
\hline 19 & $1,10 E+06$ & 6,04 & $1,30 \mathrm{E}+07$ & 7,11 & $2,40 E+07$ & 7,38 \\
\hline 20 & $7,60 \mathrm{E}+03$ & 3,88 & $8,00 \mathrm{E}+04$ & 4,90 & $2,00 E+04$ & 4,30 \\
\hline 21 & $6,50 \mathrm{E}+05$ & 5,81 & $9,10 \mathrm{E}+05$ & 5,96 & $4,50 E+06$ & 6,65 \\
\hline 22 & $3,10 E+05$ & 5,49 & $2,00 \mathrm{E}+06$ & 6,30 & $1,70 \mathrm{E}+06$ & 6,23 \\
\hline 23 & $4,20 E+05$ & 5,62 & $6,00 \mathrm{E}+05$ & 5,78 & $9,40 \mathrm{E}+05$ & 5,97 \\
\hline 24 & $5,70 \mathrm{E}+04$ & 4,76 & $5,00 \mathrm{E}+05$ & 5,70 & $2,50 E+05$ & 5,40 \\
\hline 25 & $8,10 \mathrm{E}+05$ & 5,91 & $1,90 \mathrm{E}+07$ & 7,28 & $1,40 \mathrm{E}+07$ & 7,15 \\
\hline 26 & $3,00 E+05$ & 5,48 & $7,00 \mathrm{E}+05$ & 5,85 & $2,00 E+04$ & 4,30 \\
\hline 27 & $2,80 \mathrm{E}+05$ & 5,45 & $3,30 \mathrm{E}+06$ & 6,52 & $2,70 E+06$ & 6,43 \\
\hline 28 & $2,00 \mathrm{E}+05$ & 5,30 & $6,00 \mathrm{E}+05$ & 5,78 & $7,30 E+05$ & 5,86 \\
\hline 29 & $4,90 \mathrm{E}+05$ & 5,69 & $1,50 \mathrm{E}+06$ & 6,18 & $3,50 E+06$ & 6,54 \\
\hline 30 & $2,90 \mathrm{E}+04$ & 4,46 & $5,80 \mathrm{E}+05$ & 5,76 & $2,50 \mathrm{E}+05$ & 5,40 \\
\hline promedio & $3,45 \mathrm{E}+05$ & 5,15 & $2,45 \mathrm{E}+06$ & 5,89 & $3,91 \mathrm{E}+06$ & 5,87 \\
\hline mediana & $2,50 \mathrm{E}+05$ & 5,40 & $6,50 \mathrm{E}+05$ & 5,81 & $1,32 E+06$ & 6,10 \\
\hline
\end{tabular}


Anexos

\section{Lactobacilos (continuación)}

\begin{tabular}{|c|c|c|c|c|c|c|}
\hline & \multicolumn{2}{|c|}{$\mathrm{T4}$} & \multicolumn{2}{|c|}{ T5 } & \multicolumn{2}{|c|}{ T6 } \\
\hline INDIVIDUO & ufc/g & $\log _{10} \mathrm{ufc} / \mathrm{g}$ & ufc/g & $\log _{10} \mathrm{ufc} / \mathrm{g}$ & ufc/g & $\log _{10} \mathrm{ufc} / \mathrm{g}$ \\
\hline Control & $8,20 \mathrm{E}+05$ & 5,91 & $7,90 \mathrm{E}+05$ & 5,90 & $6,50 \mathrm{E}+05$ & 5,81 \\
\hline 1 & $1,70 \mathrm{E}+07$ & 7,23 & $1,40 \mathrm{E}+07$ & 7,15 & $5,30 \mathrm{E}+06$ & 6,72 \\
\hline 2 & $3,20 \mathrm{E}+06$ & 6,51 & $1,80 \mathrm{E}+06$ & 6,26 & $2,20 \mathrm{E}+05$ & 5,34 \\
\hline 3 & $7,00 \mathrm{E}+05$ & 5,85 & $8,30 \mathrm{E}+05$ & 5,92 & $9,50 \mathrm{E}+04$ & 4,98 \\
\hline 4 & $1,10 E+06$ & 6,04 & $9,60 \mathrm{E}+06$ & 6,98 & $2,50 \mathrm{E}+05$ & 5,40 \\
\hline 5 & $6,40 \mathrm{E}+06$ & 6,81 & $3,30 \mathrm{E}+06$ & 6,52 & $2,10 \mathrm{E}+06$ & 6,32 \\
\hline 6 & $8,80 \mathrm{E}+05$ & 5,94 & $1,70 \mathrm{E}+06$ & 6,23 & $5,30 \mathrm{E}+05$ & 5,72 \\
\hline 7 & $3,50 \mathrm{E}+07$ & 7,54 & $7,70 \mathrm{E}+04$ & 4,89 & $2,60 \mathrm{E}+04$ & 4,41 \\
\hline 8 & $4,10 \mathrm{E}+06$ & 6,61 & $1,50 \mathrm{E}+06$ & 6,18 & $7,00 \mathrm{E}+05$ & 5,85 \\
\hline 9 & $1,20 \mathrm{E}+05$ & 5,08 & $8,70 \mathrm{E}+05$ & 5,94 & $2,20 \mathrm{E}+05$ & 5,34 \\
\hline 10 & $8,20 \mathrm{E}+05$ & 5,91 & $7,20 \mathrm{E}+05$ & 5,86 & $2,50 \mathrm{E}+05$ & 5,40 \\
\hline 11 & $9,10 \mathrm{E}+05$ & 5,96 & $1,10 \mathrm{E}+06$ & 6,04 & $8,50 \mathrm{E}+05$ & 5,93 \\
\hline 12 & $7,70 \mathrm{E}+05$ & 5,89 & $9,30 \mathrm{E}+05$ & 5,97 & $4,70 \mathrm{E}+06$ & 6,67 \\
\hline 13 & $9,60 \mathrm{E}+06$ & 6,98 & $7,60 \mathrm{E}+05$ & 5,88 & $9,30 \mathrm{E}+04$ & 4,97 \\
\hline 14 & $1,20 \mathrm{E}+06$ & 6,08 & $1,30 \mathrm{E}+06$ & 6,11 & $1,40 \mathrm{E}+05$ & 5,15 \\
\hline 15 & $7,80 \mathrm{E}+04$ & 4,89 & $4,10 \mathrm{E}+05$ & 5,61 & $3,30 \mathrm{E}+05$ & 5,52 \\
\hline 16 & $4,40 \mathrm{E}+06$ & 6,64 & $9,20 \mathrm{E}+06$ & 6,96 & $2,20 \mathrm{E}+04$ & 4,34 \\
\hline 17 & $1,80 \mathrm{E}+07$ & 7,26 & $8,40 \mathrm{E}+04$ & 4,92 & $8,60 \mathrm{E}+04$ & 4,93 \\
\hline 18 & $9,00 E+04$ & 4,95 & $1,70 \mathrm{E}+05$ & 5,23 & $2,50 \mathrm{E}+05$ & 5,40 \\
\hline 19 & $1,50 \mathrm{E}+07$ & 7,18 & $5,80 \mathrm{E}+06$ & 6,76 & $1,10 \mathrm{E}+06$ & 6,04 \\
\hline 20 & $4,20 \mathrm{E}+05$ & 5,62 & $4,20 \mathrm{E}+05$ & 5,62 & $1,80 \mathrm{E}+04$ & 4,26 \\
\hline 21 & $1,10 \mathrm{E}+07$ & 7,04 & $4,10 \mathrm{E}+04$ & 4,61 & $6,50 \mathrm{E}+05$ & 5,81 \\
\hline 22 & $6,60 \mathrm{E}+06$ & 6,82 & $6,60 \mathrm{E}+05$ & 5,82 & $3,10 \mathrm{E}+05$ & 5,49 \\
\hline 23 & $4,30 \mathrm{E}+04$ & 4,63 & $4,30 \mathrm{E}+04$ & 4,63 & $8,90 \mathrm{E}+05$ & 5,95 \\
\hline 24 & $9,00 \mathrm{E}+05$ & 5,95 & $3,00 E+05$ & 5,48 & $5,40 \mathrm{E}+04$ & 4,73 \\
\hline 25 & $2,20 \mathrm{E}+07$ & 7,34 & $9,40 E+05$ & 5,97 & $8,10 \mathrm{E}+05$ & 5,91 \\
\hline 26 & $7,50 \mathrm{E}+06$ & 6,88 & $6,60 \mathrm{E}+05$ & 5,82 & $3,00 \mathrm{E}+05$ & 5,48 \\
\hline 27 & $4,10 \mathrm{E}+06$ & 6,61 & $5,40 \mathrm{E}+05$ & 5,73 & $1,80 \mathrm{E}+05$ & 5,26 \\
\hline 28 & $1,70 \mathrm{E}+06$ & 6,23 & $3,50 E+05$ & 5,54 & $7,50 \mathrm{E}+05$ & 5,88 \\
\hline 29 & $1,40 \mathrm{E}+07$ & 7,15 & $4,70 \mathrm{E}+06$ & 6,67 & $6,90 \mathrm{E}+06$ & 6,84 \\
\hline 30 & $8,20 \mathrm{E}+04$ & 4,91 & $8,20 \mathrm{E}+04$ & 4,91 & $4,90 \mathrm{E}+04$ & 4,69 \\
\hline promedio & $6,26 \mathrm{E}+06$ & 6,28 & $2,10 \mathrm{E}+06$ & 5,87 & $9,39 \mathrm{E}+05$ & 5,49 \\
\hline mediana & $2,45 \mathrm{E}+06$ & 6,37 & $7,95 \mathrm{E}+05$ & 5,90 & $2,75 \mathrm{E}+05$ & 5,44 \\
\hline
\end{tabular}


Anexos

\section{Anaerobios}

\begin{tabular}{|c|c|c|c|c|c|c|}
\hline \multirow[b]{2}{*}{ INDIVIDUO } & \multicolumn{2}{|c|}{$\mathrm{T} 1$} & \multicolumn{2}{|c|}{$\mathbf{T} 2$} & \multicolumn{2}{|c|}{ T3 } \\
\hline & ufc/g & $\log _{10} u f c / g$ & ufc/g & $\log _{10} \mathrm{ufc} / \mathrm{g}$ & ufc/g & $\log _{10} \mathrm{ufc} / \mathrm{g}$ \\
\hline Control & $1,60 E+09$ & 9,20 & $9,80 \mathrm{E}+08$ & 8,99 & $1,40 E+09$ & 9,15 \\
\hline 1 & $8,30 E+09$ & 9,92 & $7,50 \mathrm{E}+09$ & 9,88 & $1,90 \mathrm{E}+08$ & 8,28 \\
\hline 2 & $7,20 E+08$ & 8,86 & $4,20 E+09$ & 9,62 & $4,40 E+09$ & 9,64 \\
\hline 3 & $1,40 E+09$ & 9,15 & $6,60 \mathrm{E}+09$ & 9,82 & $5,10 \mathrm{E}+09$ & 9,71 \\
\hline 4 & $2,50 E+09$ & 9,40 & $5,40 E+09$ & 9,73 & $4,40 \mathrm{E}+07$ & 7,64 \\
\hline 5 & $4,20 E+09$ & 9,62 & $6,40 E+09$ & 9,81 & $1,30 \mathrm{E}+08$ & 8,11 \\
\hline 6 & $2,40 E+08$ & 8,38 & $7,20 \mathrm{E}+08$ & 8,86 & $2,80 \mathrm{E}+08$ & 8,45 \\
\hline 7 & $7,40 E+07$ & 7,87 & $9,90 E+08$ & 9,00 & $1,90 \mathrm{E}+08$ & 8,28 \\
\hline 8 & $6,40 E+09$ & 9,81 & $2,50 E+09$ & 9,40 & $4,20 \mathrm{E}+09$ & 9,62 \\
\hline 9 & $2,50 E+09$ & 9,40 & $4,20 E+09$ & 9,62 & $2,40 \mathrm{E}+08$ & 8,38 \\
\hline 10 & $8,30 E+09$ & 9,92 & $6,60 \mathrm{E}+09$ & 9,82 & $5,40 \mathrm{E}+09$ & 9,73 \\
\hline 11 & $7,20 E+08$ & 8,86 & $2,50 \mathrm{E}+09$ & 9,40 & $1,90 \mathrm{E}+08$ & 8,28 \\
\hline 12 & $9,90 E+08$ & 9,00 & $1,30 E+08$ & 8,11 & $4,20 E+09$ & 9,62 \\
\hline 13 & $2,50 E+09$ & 9,40 & $2,80 E+08$ & 8,45 & $1,20 \mathrm{E}+10$ & 10,08 \\
\hline 14 & $4,20 E+09$ & 9,62 & $1,90 E+08$ & 8,28 & $6,40 \mathrm{E}+09$ & 9,81 \\
\hline 15 & $6,60 E+09$ & 9,82 & $4,20 E+09$ & 9,62 & $2,40 \mathrm{E}+09$ & 9,38 \\
\hline 16 & $1,20 E+10$ & 10,08 & $2,40 E+08$ & 8,38 & $7,20 \mathrm{E}+08$ & 8,86 \\
\hline 17 & $6,40 E+09$ & 9,81 & $7,70 \mathrm{E}+07$ & 7,89 & $9,90 \mathrm{E}+08$ & 9,00 \\
\hline 18 & $2,50 E+09$ & 9,40 & $6,40 \mathrm{E}+09$ & 9,81 & $2,50 \mathrm{E}+09$ & 9,40 \\
\hline 19 & $1,30 E+10$ & 10,11 & $9,50 \mathrm{E}+09$ & 9,98 & $8,30 E+09$ & 9,92 \\
\hline 20 & $6,20 E+08$ & 8,79 & $8,30 E+09$ & 9,92 & $6,60 \mathrm{E}+09$ & 9,82 \\
\hline 21 & $8,00 E+08$ & 8,90 & $6,60 \mathrm{E}+09$ & 9,82 & $2,50 \mathrm{E}+09$ & 9,40 \\
\hline 22 & $1,90 E+08$ & 8,28 & $2,50 E+09$ & 9,40 & $3,70 \mathrm{E}+09$ & 9,57 \\
\hline 23 & $4,20 E+09$ & 9,62 & $3,70 \mathrm{E}+09$ & 9,57 & $2,80 E+08$ & 8,45 \\
\hline 24 & $1,10 E+09$ & 9,04 & $2,80 E+08$ & 8,45 & $2,10 \mathrm{E}+10$ & 10,32 \\
\hline 25 & $6,20 E+09$ & 9,79 & $4,20 E+09$ & 9,62 & $7,20 \mathrm{E}+08$ & 8,86 \\
\hline 26 & $6,40 E+09$ & 9,81 & $1,90 \mathrm{E}+08$ & 8,28 & $2,80 E+08$ & 8,45 \\
\hline 27 & $2,50 E+09$ & 9,40 & $4,20 E+09$ & 9,62 & $2,50 \mathrm{E}+09$ & 9,40 \\
\hline 28 & $3,70 E+09$ & 9,57 & $5,10 \mathrm{E}+09$ & 9,71 & $4,20 \mathrm{E}+09$ & 9,62 \\
\hline 29 & $6,40 E+09$ & 9,81 & $7,90 \mathrm{E}+07$ & 7,90 & $2,80 \mathrm{E}+08$ & 8,45 \\
\hline 30 & $2,50 E+09$ & 9,40 & $6,40 E+09$ & 9,81 & $4,20 \mathrm{E}+09$ & 9,62 \\
\hline promedio & $3,94 E+09$ & 9,36 & $3,67 E+09$ & 9,25 & $3,47 E+09$ & 9,14 \\
\hline mediana & $2,50 E+09$ & 9,40 & $4,20 E+09$ & 9,62 & $2,50 \mathrm{E}+09$ & 9,40 \\
\hline
\end{tabular}


Anaerobios (continuación)

\begin{tabular}{|c|c|c|c|c|c|c|}
\hline & \multicolumn{2}{|c|}{ T4 } & \multicolumn{2}{|c|}{ T5 } & \multicolumn{2}{|c|}{ T6 } \\
\hline INDIVIDUO & ufc/g & $\log _{10}$ ufc/g & ufc/g & $\log _{10}$ ufc/g & ufc/g & $\log _{10} \mathrm{ufc} / \mathrm{g}$ \\
\hline Control & 4,40E+09 & 9,64 & $3,80 \mathrm{E}+09$ & 9,58 & $3,70 E+09$ & 9,57 \\
\hline 1 & $6,40 \mathrm{E}+09$ & 9,81 & $2,00 \mathrm{E}+08$ & 8,30 & $1,40 \mathrm{E}+10$ & 10,15 \\
\hline 2 & $7,20 \mathrm{E}+08$ & 8,86 & $1,00 \mathrm{E}+08$ & 8,00 & $2,50 E+09$ & 9,40 \\
\hline 3 & $9,90 \mathrm{E}+08$ & 9,00 & $2,50 \mathrm{E}+09$ & 9,40 & $4,20 \mathrm{E}+09$ & 9,62 \\
\hline 4 & $2,50 \mathrm{E}+09$ & 9,40 & $1,40 \mathrm{E}+09$ & 9,15 & $2,40 \mathrm{E}+08$ & 8,38 \\
\hline 5 & $4,20 \mathrm{E}+09$ & 9,62 & $4,00 \mathrm{E}+08$ & 8,60 & $9,20 \mathrm{E}+07$ & 7,96 \\
\hline 6 & $2,40 \mathrm{E}+08$ & 8,38 & $1,10 \mathrm{E}+09$ & 9,04 & $2,40 \mathrm{E}+09$ & 9,38 \\
\hline 7 & $5,10 \mathrm{E}+09$ & 9,71 & $2,40 \mathrm{E}+07$ & 7,38 & $2,40 \mathrm{E}+08$ & 8,38 \\
\hline 8 & $8,10 \mathrm{E}+07$ & 7,91 & $2,20 \mathrm{E}+08$ & 8,34 & $2,00 \mathrm{E}+08$ & 8,30 \\
\hline 9 & 1,30E+09 & 9,11 & $1,10 \mathrm{E}+09$ & 9,04 & $1,00 \mathrm{E}+08$ & 8,00 \\
\hline 10 & $2,80 \mathrm{E}+08$ & 8,45 & $2,40 \mathrm{E}+09$ & 9,38 & $2,50 \mathrm{E}+10$ & 10,40 \\
\hline 11 & $1,90 \mathrm{E}+08$ & 8,28 & $2,40 \mathrm{E}+09$ & 9,38 & $2,80 \mathrm{E}+08$ & 8,45 \\
\hline 12 & $7,20 \mathrm{E}+08$ & 8,86 & $2,00 \mathrm{E}+08$ & 8,30 & $1,90 \mathrm{E}+08$ & 8,28 \\
\hline 13 & $2,80 \mathrm{E}+09$ & 9,45 & $1,00 \mathrm{E}+08$ & 8,00 & $1,20 \mathrm{E}+10$ & 10,08 \\
\hline 14 & $1,90 \mathrm{E}+08$ & 8,28 & $2,50 \mathrm{E}+09$ & 9,40 & $2,40 \mathrm{E}+08$ & 8,38 \\
\hline 15 & $4,20 \mathrm{E}+09$ & 9,62 & $1,40 \mathrm{E}+09$ & 9,15 & $5,40 \mathrm{E}+09$ & 9,73 \\
\hline 16 & $1,40 \mathrm{E}+10$ & 10,15 & $4,00 \mathrm{E}+09$ & 9,60 & $1,40 \mathrm{E}+10$ & 10,15 \\
\hline 17 & $8,30 \mathrm{E}+09$ & 9,92 & $1,10 \mathrm{E}+09$ & 9,04 & $4,00 \mathrm{E}+08$ & 8,60 \\
\hline 18 & $6,60 \mathrm{E}+09$ & 9,82 & $2,40 \mathrm{E}+09$ & 9,38 & $1,10 \mathrm{E}+09$ & 9,04 \\
\hline 19 & $1,00 \mathrm{E}+10$ & 10,00 & $2,20 \mathrm{E}+08$ & 8,34 & $2,40 \mathrm{E}+09$ & 9,38 \\
\hline 20 & $3,70 \mathrm{E}+09$ & 9,57 & $1,10 \mathrm{E}+09$ & 9,04 & $2,20 \mathrm{E}+10$ & 10,34 \\
\hline 21 & $2,80 \mathrm{E}+08$ & 8,45 & $2,40 \mathrm{E}+09$ & 9,38 & $7,70 \mathrm{E}+07$ & 7,89 \\
\hline 22 & $1,20 \mathrm{E}+10$ & 10,08 & $2,40 \mathrm{E}+08$ & 8,38 & $6,40 \mathrm{E}+09$ & 9,81 \\
\hline 23 & $6,60 \mathrm{E}+09$ & 9,82 & $4,20 \mathrm{E}+09$ & 9,62 & $9,50 \mathrm{E}+09$ & 9,98 \\
\hline 24 & $2,50 \mathrm{E}+09$ & 9,40 & $6,60 \mathrm{E}+09$ & 9,82 & $8,30 \mathrm{E}+09$ & 9,92 \\
\hline 25 & $3,70 \mathrm{E}+09$ & 9,57 & $4,20 \mathrm{E}+09$ & 9,62 & $6,60 \mathrm{E}+09$ & 9,82 \\
\hline 26 & $7,20 \mathrm{E}+08$ & 8,86 & $6,60 \mathrm{E}+09$ & 9,82 & $6,30 \mathrm{E}+09$ & 9,80 \\
\hline 27 & $2,80 \mathrm{E}+08$ & 8,45 & $1,20 \mathrm{E}+10$ & 10,08 & $2,20 \mathrm{E}+09$ & 9,34 \\
\hline 28 & $8,50 \mathrm{E}+09$ & 9,93 & $6,40 \mathrm{E}+09$ & 9,81 & $7,10 \mathrm{E}+08$ & 8,85 \\
\hline 29 & $1,90 \mathrm{E}+08$ & 8,28 & $2,50 \mathrm{E}+09$ & 9,40 & $2,00 \mathrm{E}+09$ & 9,30 \\
\hline 30 & $4,20 \mathrm{E}+09$ & 9,62 & $3,30 \mathrm{E}+10$ & 10,52 & $1,90 \mathrm{E}+08$ & 8,28 \\
\hline promedio & $3,72 \mathrm{E}+09$ & 9,22 & $3,43 \mathrm{E}+09$ & 9,09 & 4,98E+09 & 9,18 \\
\hline mediana & $2,65 \mathrm{E}+09$ & 9,42 & $1,90 \mathrm{E}+09$ & 9,26 & $2,30 \mathrm{E}+09$ & 9,36 \\
\hline
\end{tabular}


Anexos

\section{Aerobios}

\begin{tabular}{|c|c|c|c|c|c|c|}
\hline \multirow[b]{2}{*}{ INDIVIDUO } & \multicolumn{2}{|c|}{$\mathrm{T} 1$} & \multicolumn{2}{|c|}{$\mathrm{T} 2$} & \multicolumn{2}{|c|}{ T3 } \\
\hline & ufc/g & $\log _{10}$ ufc/g & ufc/g & $\log _{10} u f c / g$ & ufc/g & $\log _{10} u f c / g$ \\
\hline Control & $7,10 E+06$ & 6,85 & $6,30 \mathrm{E}+06$ & 6,80 & $8,10 E+06$ & 6,91 \\
\hline 1 & $5,30 E+06$ & 6,72 & $8,80 E+06$ & 6,94 & $5,80 E+06$ & 6,76 \\
\hline 2 & $2,20 E+06$ & 6,34 & $3,50 \mathrm{E}+06$ & 6,54 & $7,00 \mathrm{E}+06$ & 6,85 \\
\hline 3 & $6,50 \mathrm{E}+06$ & 6,81 & $4,10 \mathrm{E}+06$ & 6,61 & $7,50 \mathrm{E}+06$ & 6,88 \\
\hline 4 & $2,50 E+07$ & 7,40 & $1,20 E+07$ & 7,08 & $2,00 E+07$ & 7,30 \\
\hline 5 & $7,00 E+06$ & 6,85 & $8,20 E+06$ & 6,91 & $2,90 \mathrm{E}+06$ & 6,46 \\
\hline 6 & $1,10 E+07$ & 7,04 & $7,20 \mathrm{E}+06$ & 6,86 & $7,80 \mathrm{E}+06$ & 6,89 \\
\hline 7 & $6,40 E+06$ & 6,81 & $1,10 \mathrm{E}+07$ & 7,04 & $4,40 \mathrm{E}+06$ & 6,64 \\
\hline 8 & $8,80 E+06$ & 6,94 & $9,30 \mathrm{E}+06$ & 6,97 & $1,80 \mathrm{E}+07$ & 7,26 \\
\hline 9 & $3,50 E+06$ & 6,54 & $7,60 \mathrm{E}+06$ & 6,88 & $9,00 E+06$ & 6,95 \\
\hline 10 & $1,70 \mathrm{E}+07$ & 7,23 & $1,30 \mathrm{E}+07$ & 7,11 & $1,50 \mathrm{E}+07$ & 7,18 \\
\hline 11 & $3,80 E+06$ & 6,58 & $7,80 \mathrm{E}+06$ & 6,89 & $2,50 \mathrm{E}+07$ & 7,40 \\
\hline 12 & $2,10 E+06$ & 6,32 & $4,40 \mathrm{E}+06$ & 6,64 & $7,00 \mathrm{E}+06$ & 6,85 \\
\hline 13 & $1,40 E+06$ & 6,15 & $1,80 \mathrm{E}+07$ & 7,26 & $1,10 \mathrm{E}+07$ & 7,04 \\
\hline 14 & $2,00 E+07$ & 7,30 & $9,00 E+06$ & 6,95 & $6,40 E+06$ & 6,81 \\
\hline 15 & $4,10 \mathrm{E}+06$ & 6,61 & $1,50 \mathrm{E}+07$ & 7,18 & $8,80 \mathrm{E}+06$ & 6,94 \\
\hline 16 & $9,20 E+06$ & 6,96 & $2,00 E+06$ & 6,30 & $3,80 E+06$ & 6,58 \\
\hline 17 & $8,40 E+06$ & 6,92 & $2,40 \mathrm{E}+06$ & 6,38 & $2,10 \mathrm{E}+06$ & 6,32 \\
\hline 18 & $1,70 \mathrm{E}+07$ & 7,23 & $1,70 \mathrm{E}+07$ & 7,23 & $8,20 \mathrm{E}+06$ & 6,91 \\
\hline 19 & $5,80 E+06$ & 6,76 & $3,80 E+06$ & 6,58 & $9,10 E+06$ & 6,96 \\
\hline 20 & $4,20 \mathrm{E}+06$ & 6,62 & $2,10 \mathrm{E}+06$ & 6,32 & $7,70 \mathrm{E}+06$ & 6,89 \\
\hline 21 & $1,10 \mathrm{E}+07$ & 7,04 & $8,20 E+06$ & 6,91 & $7,60 \mathrm{E}+06$ & 6,88 \\
\hline 22 & $6,60 E+06$ & 6,82 & $9,10 E+06$ & 6,96 & $1,30 E+07$ & 7,11 \\
\hline 23 & $4,30 E+06$ & 6,63 & $7,70 \mathrm{E}+06$ & 6,89 & $7,80 \mathrm{E}+06$ & 6,89 \\
\hline 24 & $9,00 E+06$ & 6,95 & $9,60 \mathrm{E}+06$ & 6,98 & $4,40 E+06$ & 6,64 \\
\hline 25 & $4,70 \mathrm{E}+06$ & 6,67 & $1,20 \mathrm{E}+07$ & 7,08 & $1,80 \mathrm{E}+07$ & 7,26 \\
\hline 26 & $5,80 E+06$ & 6,76 & $2,40 \mathrm{E}+06$ & 6,38 & $1,20 \mathrm{E}+07$ & 7,08 \\
\hline 27 & $7,00 E+06$ & 6,85 & $2,00 E+07$ & 7,30 & $8,20 E+06$ & 6,91 \\
\hline 28 & $7,50 \mathrm{E}+06$ & 6,88 & $2,40 \mathrm{E}+06$ & 6,38 & $7,20 \mathrm{E}+06$ & 6,86 \\
\hline 29 & $2,00 \mathrm{E}+07$ & 7,30 & $1,70 \mathrm{E}+07$ & 7,23 & $1,10 \mathrm{E}+07$ & 7,04 \\
\hline 30 & $2,90 \mathrm{E}+06$ & 6,46 & $3,80 \mathrm{E}+06$ & 6,58 & $9,30 \mathrm{E}+06$ & 6,97 \\
\hline promedio & $8,25 E+06$ & 6,82 & $8,61 \mathrm{E}+06$ & 6,85 & $9,50 \mathrm{E}+06$ & 6,92 \\
\hline mediana & $6,55 E+06$ & 6,82 & $8,20 E+06$ & 6,91 & $8,00 E+06$ & 6,90 \\
\hline
\end{tabular}


Anexos

\section{Aerobios (continuación)}

\begin{tabular}{|c|c|c|c|c|c|c|}
\hline & \multicolumn{2}{|c|}{$\mathrm{T} 4$} & \multicolumn{2}{|c|}{ T5 } & \multicolumn{2}{|c|}{ T6 } \\
\hline INDIVIDUO & ufc/g & $\log _{10}$ ufc/g & ufc/g & $\log _{10}$ ufc/g & ufc/g & $\log _{10} \mathrm{ufc} / \mathrm{g}$ \\
\hline Control & $1,40 \mathrm{E}+07$ & 7,15 & $9,50 \mathrm{E}+06$ & 6,98 & $5,50 \mathrm{E}+06$ & 6,74 \\
\hline 1 & $2,50 \mathrm{E}+07$ & 7,40 & $7,80 \mathrm{E}+06$ & 6,89 & $9,10 \mathrm{E}+06$ & 6,96 \\
\hline 2 & $7,00 \mathrm{E}+06$ & 6,85 & $6,50 \mathrm{E}+06$ & 6,81 & $7,70 \mathrm{E}+06$ & 6,89 \\
\hline 3 & $1,10 \mathrm{E}+07$ & 7,04 & $2,50 \mathrm{E}+07$ & 7,40 & $7,60 \mathrm{E}+06$ & 6,88 \\
\hline 4 & $6,40 \mathrm{E}+06$ & 6,81 & $7,00 \mathrm{E}+06$ & 6,85 & $1,30 \mathrm{E}+07$ & 7,11 \\
\hline 5 & $8,80 \mathrm{E}+06$ & 6,94 & $1,10 \mathrm{E}+07$ & 7,04 & $7,80 \mathrm{E}+06$ & 6,89 \\
\hline 6 & $1,10 \mathrm{E}+07$ & 7,04 & $4,10 \mathrm{E}+06$ & 6,61 & $4,40 \mathrm{E}+06$ & 6,64 \\
\hline 7 & $9,30 \mathrm{E}+06$ & 6,97 & $1,20 \mathrm{E}+07$ & 7,08 & $1,80 \mathrm{E}+07$ & 7,26 \\
\hline 8 & $7,60 \mathrm{E}+06$ & 6,88 & $8,20 \mathrm{E}+06$ & 6,91 & $1,20 \mathrm{E}+07$ & 7,08 \\
\hline 9 & $1,30 \mathrm{E}+07$ & 7,11 & $7,20 \mathrm{E}+06$ & 6,86 & $8,20 \mathrm{E}+06$ & 6,91 \\
\hline 10 & $7,80 \mathrm{E}+06$ & 6,89 & $1,10 \mathrm{E}+07$ & 7,04 & $7,20 \mathrm{E}+06$ & 6,86 \\
\hline 11 & $6,50 \mathrm{E}+06$ & 6,81 & $7,70 \mathrm{E}+06$ & 6,89 & $1,10 \mathrm{E}+07$ & 7,04 \\
\hline 12 & $2,50 \mathrm{E}+07$ & 7,40 & $9,60 \mathrm{E}+06$ & 6,98 & $4,70 \mathrm{E}+06$ & 6,67 \\
\hline 13 & $7,00 \mathrm{E}+06$ & 6,85 & $1,20 \mathrm{E}+07$ & 7,08 & $9,30 \mathrm{E}+06$ & 6,97 \\
\hline 14 & $1,10 \mathrm{E}+07$ & 7,04 & $2,40 \mathrm{E}+06$ & 6,38 & $1,40 \mathrm{E}+07$ & 7,15 \\
\hline 15 & $6,40 \mathrm{E}+06$ & 6,81 & $2,00 \mathrm{E}+07$ & 7,30 & $3,30 \mathrm{E}+07$ & 7,52 \\
\hline 16 & $2,00 \mathrm{E}+07$ & 7,30 & $8,80 \mathrm{E}+06$ & 6,94 & $2,20 \mathrm{E}+06$ & 6,34 \\
\hline 17 & $2,90 \mathrm{E}+06$ & 6,46 & $1,10 \mathrm{E}+07$ & 7,04 & $7,00 \mathrm{E}+06$ & 6,85 \\
\hline 18 & $7,80 \mathrm{E}+06$ & 6,89 & $9,30 \mathrm{E}+06$ & 6,97 & $1,10 \mathrm{E}+07$ & 7,04 \\
\hline 19 & $4,40 \mathrm{E}+06$ & 6,64 & $7,60 \mathrm{E}+06$ & 6,88 & $6,40 \mathrm{E}+06$ & 6,81 \\
\hline 20 & $1,80 \mathrm{E}+07$ & 7,26 & $1,30 \mathrm{E}+07$ & 7,11 & $8,80 \mathrm{E}+06$ & 6,94 \\
\hline 21 & $5,80 \mathrm{E}+06$ & 6,76 & $4,10 \mathrm{E}+07$ & 7,61 & $3,80 \mathrm{E}+06$ & 6,58 \\
\hline 22 & $7,00 \mathrm{E}+06$ & 6,85 & $6,60 \mathrm{E}+06$ & 6,82 & $2,10 \mathrm{E}+06$ & 6,32 \\
\hline 23 & $7,50 \mathrm{E}+06$ & 6,88 & $4,30 \mathrm{E}+06$ & 6,63 & $8,20 \mathrm{E}+06$ & 6,91 \\
\hline 24 & $2,00 \mathrm{E}+07$ & 7,30 & $3,00 \mathrm{E}+07$ & 7,48 & $2,90 \mathrm{E}+06$ & 6,46 \\
\hline 25 & $2,90 \mathrm{E}+06$ & 6,46 & $9,40 \mathrm{E}+06$ & 6,97 & $7,80 \mathrm{E}+06$ & 6,89 \\
\hline 26 & $1,80 \mathrm{E}+07$ & 7,26 & $6,60 \mathrm{E}+06$ & 6,82 & $4,40 \mathrm{E}+06$ & 6,64 \\
\hline 27 & $9,00 \mathrm{E}+06$ & 6,95 & $5,40 \mathrm{E}+06$ & 6,73 & $1,80 \mathrm{E}+07$ & 7,26 \\
\hline 28 & $1,50 \mathrm{E}+07$ & 7,18 & $3,50 \mathrm{E}+07$ & 7,54 & $5,80 \mathrm{E}+06$ & 6,76 \\
\hline 29 & $2,50 \mathrm{E}+07$ & 7,40 & $4,70 \mathrm{E}+06$ & 6,67 & $7,00 \mathrm{E}+06$ & 6,85 \\
\hline 30 & $7,00 \mathrm{E}+06$ & 6,85 & $8,20 \mathrm{E}+03$ & 3,91 & $4,90 \mathrm{E}+06$ & 6,69 \\
\hline promedio & $1,11 \mathrm{E}+07$ & 6,98 & $1,15 \mathrm{E}+07$ & 6,88 & $8,91 \mathrm{E}+06$ & 6,87 \\
\hline mediana & $8,30 \mathrm{E}+06$ & 6,92 & $8,50 \mathrm{E}+06$ & 6,93 & $7,75 E+06$ & 6,89 \\
\hline
\end{tabular}




\section{Bifidobacterias}

\begin{tabular}{|c|c|c|c|c|c|c|}
\hline & \multicolumn{2}{|c|}{$\mathrm{T} 1$} & \multicolumn{2}{|c|}{$\mathrm{T} 2$} & \multicolumn{2}{|c|}{ T3 } \\
\hline INDIVIDUO & ufc/g & $\log _{10}$ ufc/g & ufc/g & $\log _{10}$ ufc/g & ufc/g & $\log _{10} \mathrm{ufc} / \mathrm{g}$ \\
\hline Control & $8,50 E+08$ & 8,93 & $8,30 E+08$ & 8,92 & $8,70 \mathrm{E}+08$ & 8,94 \\
\hline 1 & $3,50 \mathrm{E}+09$ & 9,54 & $3,30 \mathrm{E}+09$ & 9,52 & $9,40 \mathrm{E}+08$ & 8,97 \\
\hline 2 & $2,90 \mathrm{E}+08$ & 8,46 & $3,30 \mathrm{E}+08$ & 8,52 & $6,60 \mathrm{E}+08$ & 8,82 \\
\hline 3 & $2,40 \mathrm{E}+09$ & 9,38 & $1,70 \mathrm{E}+08$ & 8,23 & $5,40 \mathrm{E}+08$ & 8,73 \\
\hline 4 & $2,00 E+08$ & 8,30 & $7,70 E+08$ & 8,89 & $3,50 E+08$ & 8,54 \\
\hline 5 & $2,40 \mathrm{E}+08$ & 8,38 & $1,50 \mathrm{E}+08$ & 8,18 & $4,70 \mathrm{E}+08$ & 8,67 \\
\hline 6 & $1,70 \mathrm{E}+08$ & 8,23 & $8,70 \mathrm{E}+08$ & 8,94 & $8,20 \mathrm{E}+07$ & 7,91 \\
\hline 7 & $3,80 E+09$ & 9,58 & $7,20 \mathrm{E}+08$ & 8,86 & $9,40 \mathrm{E}+07$ & 7,97 \\
\hline 8 & $2,10 \mathrm{E}+08$ & 8,32 & $1,10 \mathrm{E}+09$ & 9,04 & $6,60 \mathrm{E}+08$ & 8,82 \\
\hline 9 & $1,40 \mathrm{E}+09$ & 9,15 & $9,30 \mathrm{E}+08$ & 8,97 & $5,40 \mathrm{E}+08$ & 8,73 \\
\hline 10 & $2,00 \mathrm{E}+09$ & 9,30 & $7,60 \mathrm{E}+08$ & 8,88 & $3,50 \mathrm{E}+08$ & 8,54 \\
\hline 11 & $2,00 \mathrm{E}+08$ & 8,30 & $1,30 \mathrm{E}+09$ & 9,11 & $4,70 \mathrm{E}+08$ & 8,67 \\
\hline 12 & $4,40 \mathrm{E}+08$ & 8,64 & $1,40 \mathrm{E}+08$ & 8,15 & $8,20 \mathrm{E}+07$ & 7,91 \\
\hline 13 & $1,80 E+09$ & 9,26 & $3,30 \mathrm{E}+08$ & 8,52 & $1,40 \mathrm{E}+09$ & 9,15 \\
\hline 14 & $9,00 \mathrm{E}+07$ & 7,95 & $2,20 \mathrm{E}+08$ & 8,34 & $7,70 \mathrm{E}+08$ & 8,89 \\
\hline 15 & $1,50 \mathrm{E}+09$ & 9,18 & $8,60 \mathrm{E}+08$ & 8,93 & $1,50 \mathrm{E}+09$ & 9,18 \\
\hline 16 & $4,20 \mathrm{E}+08$ & 8,62 & $2,50 \mathrm{E}+09$ & 9,40 & $8,70 \mathrm{E}+08$ & 8,94 \\
\hline 17 & $1,10 \mathrm{E}+09$ & 9,04 & $1,20 \mathrm{E}+09$ & 9,08 & $7,20 \mathrm{E}+07$ & 7,86 \\
\hline 18 & $6,60 \mathrm{E}+08$ & 8,82 & $1,80 \mathrm{E}+09$ & 9,26 & $1,10 \mathrm{E}+09$ & 9,04 \\
\hline 19 & $4,30 \mathrm{E}+08$ & 8,63 & $6,50 \mathrm{E}+08$ & 8,81 & $9,30 \mathrm{E}+07$ & 7,97 \\
\hline 20 & $7,60 \mathrm{E}+08$ & 8,88 & $3,10 E+08$ & 8,49 & $7,60 \mathrm{E}+08$ & 8,88 \\
\hline 21 & $6,50 \mathrm{E}+08$ & 8,81 & $8,90 \mathrm{E}+08$ & 8,95 & $1,30 \mathrm{E}+08$ & 8,11 \\
\hline 22 & $3,10 \mathrm{E}+09$ & 9,49 & $5,40 \mathrm{E}+09$ & 9,73 & $4,10 \mathrm{E}+08$ & 8,61 \\
\hline 23 & $4,20 \mathrm{E}+08$ & 8,62 & $8,10 \mathrm{E}+08$ & 8,91 & $9,20 \mathrm{E}+08$ & 8,96 \\
\hline 24 & $5,70 \mathrm{E}+08$ & 8,76 & $5,00 \mathrm{E}+08$ & 8,70 & $8,40 \mathrm{E}+07$ & 7,92 \\
\hline 25 & $8,10 \mathrm{E}+08$ & 8,91 & $9,40 \mathrm{E}+08$ & 8,97 & $1,70 \mathrm{E}+09$ & 9,23 \\
\hline 26 & $3,00 \mathrm{E}+08$ & 8,48 & $6,60 \mathrm{E}+08$ & 8,82 & $5,80 \mathrm{E}+08$ & 8,76 \\
\hline 27 & $2,80 \mathrm{E}+08$ & 8,45 & $5,40 \mathrm{E}+08$ & 8,73 & $4,20 \mathrm{E}+08$ & 8,62 \\
\hline 28 & $2,00 \mathrm{E}+08$ & 8,30 & $3,50 \mathrm{E}+08$ & 8,54 & $2,10 \mathrm{E}+09$ & 9,32 \\
\hline 29 & $4,90 \mathrm{E}+08$ & 8,69 & $4,70 \mathrm{E}+09$ & 9,67 & $1,40 \mathrm{E}+09$ & 9,15 \\
\hline 30 & $2,90 \mathrm{E}+08$ & 8,46 & $8,20 \mathrm{E}+07$ & 7,91 & $2,00 \mathrm{E}+09$ & 9,30 \\
\hline promedio & $9,57 \mathrm{E}+08$ & 8,76 & 1,11E+09 & 8,84 & $7,18 \mathrm{E}+08$ & 8,67 \\
\hline mediana & $4,65 E+08$ & 8,67 & $7,65 E+08$ & 8,88 & $5,60 \mathrm{E}+08$ & 8,75 \\
\hline
\end{tabular}


Bifidobacterias (continuación)

\begin{tabular}{|c|c|c|c|c|c|c|}
\hline & \multicolumn{2}{|c|}{$\mathrm{T4}$} & \multicolumn{2}{|c|}{ T5 } & \multicolumn{2}{|c|}{ T6 } \\
\hline INDIVIDUO & ufc/g & $\log _{10} \mathrm{ufc} / \mathrm{g}$ & ufc/g & $\log _{10} \mathrm{ufc} / \mathrm{g}$ & ufc/g & $\log _{10} \mathrm{ufc} / \mathrm{g}$ \\
\hline Control & $1,20 \mathrm{E}+09$ & 9,08 & $9,90 \mathrm{E}+08$ & 9,00 & $6,50 \mathrm{E}+08$ & 8,81 \\
\hline 1 & $1,40 \mathrm{E}+08$ & 8,15 & $7,70 \mathrm{E}+08$ & 8,89 & $7,20 E+08$ & 8,86 \\
\hline 2 & $1,80 \mathrm{E}+09$ & 9,26 & $1,50 \mathrm{E}+09$ & 9,18 & $1,10 E+09$ & 9,04 \\
\hline 3 & $8,30 \mathrm{E}+07$ & 7,92 & $8,70 \mathrm{E}+08$ & 8,94 & $9,30 E+08$ & 8,97 \\
\hline 4 & $9,60 \mathrm{E}+08$ & 8,98 & $7,20 \mathrm{E}+08$ & 8,86 & $7,60 \mathrm{E}+08$ & 8,88 \\
\hline 5 & $3,30 \mathrm{E}+08$ & 8,52 & $1,10 \mathrm{E}+09$ & 9,04 & $1,30 \mathrm{E}+09$ & 9,11 \\
\hline 6 & $1,70 \mathrm{E}+08$ & 8,23 & $9,30 \mathrm{E}+08$ & 8,97 & $1,40 E+08$ & 8,15 \\
\hline 7 & $7,70 \mathrm{E}+07$ & 7,89 & $7,60 \mathrm{E}+08$ & 8,88 & $3,30 E+08$ & 8,52 \\
\hline 8 & $1,50 \mathrm{E}+09$ & 9,18 & $1,30 \mathrm{E}+08$ & 8,11 & $2,20 \mathrm{E}+08$ & 8,34 \\
\hline 9 & $8,70 \mathrm{E}+08$ & 8,94 & $4,10 \mathrm{E}+08$ & 8,61 & $8,60 \mathrm{E}+08$ & 8,93 \\
\hline 10 & $7,20 \mathrm{E}+08$ & 8,86 & $9,20 \mathrm{E}+08$ & 8,96 & $2,50 E+09$ & 9,40 \\
\hline 11 & $1,10 \mathrm{E}+09$ & 9,04 & $3,50 \mathrm{E}+08$ & 8,54 & $1,20 E+09$ & 9,08 \\
\hline 12 & $9,30 \mathrm{E}+07$ & 7,97 & $4,70 \mathrm{E}+08$ & 8,67 & $4,40 E+08$ & 8,64 \\
\hline 13 & $7,60 \mathrm{E}+08$ & 8,88 & $8,20 \mathrm{E}+07$ & 7,91 & $1,80 E+08$ & 8,26 \\
\hline 14 & $1,30 \mathrm{E}+08$ & 8,11 & $9,40 \mathrm{E}+08$ & 8,97 & $9,00 \mathrm{E}+07$ & 7,95 \\
\hline 15 & $7,80 \mathrm{E}+08$ & 8,89 & $6,60 \mathrm{E}+08$ & 8,82 & $1,50 E+08$ & 8,18 \\
\hline 16 & $4,40 \mathrm{E}+08$ & 8,64 & $5,40 \mathrm{E}+08$ & 8,73 & $4,20 E+08$ & 8,62 \\
\hline 17 & $1,80 \mathrm{E}+09$ & 9,26 & $3,50 \mathrm{E}+08$ & 8,54 & $1,10 \mathrm{E}+08$ & 8,04 \\
\hline 18 & $9,00 \mathrm{E}+07$ & 7,95 & $4,70 \mathrm{E}+08$ & 8,67 & $6,60 \mathrm{E}+08$ & 8,82 \\
\hline 19 & $1,50 \mathrm{E}+09$ & 9,18 & $8,20 \mathrm{E}+07$ & 7,91 & $4,30 E+08$ & 8,63 \\
\hline 20 & $4,20 \mathrm{E}+08$ & 8,62 & $1,40 \mathrm{E}+09$ & 9,15 & $9,00 E+07$ & 7,95 \\
\hline 21 & $1,10 \mathrm{E}+09$ & 9,04 & $1,80 \mathrm{E}+09$ & 9,26 & $2,20 \mathrm{E}+08$ & 8,34 \\
\hline 22 & $6,60 \mathrm{E}+08$ & 8,82 & $6,50 \mathrm{E}+09$ & 9,81 & $5,40 \mathrm{E}+08$ & 8,73 \\
\hline 23 & $4,30 \mathrm{E}+08$ & 8,63 & $3,10 \mathrm{E}+08$ & 8,49 & $3,50 E+08$ & 8,54 \\
\hline 24 & $9,00 \mathrm{E}+07$ & 7,95 & $3,00 \mathrm{E}+08$ & 8,48 & $4,70 \mathrm{E}+08$ & 8,67 \\
\hline 25 & $2,20 \mathrm{E}+09$ & 9,34 & $9,40 \mathrm{E}+08$ & 8,97 & $8,20 E+08$ & 8,91 \\
\hline 26 & $7,50 \mathrm{E}+08$ & 8,88 & $6,60 \mathrm{E}+08$ & 8,82 & $7,80 \mathrm{E}+07$ & 7,89 \\
\hline 27 & $4,10 \mathrm{E}+08$ & 8,61 & $5,40 \mathrm{E}+08$ & 8,73 & $4,40 E+09$ & 9,64 \\
\hline 28 & $1,70 \mathrm{E}+09$ & 9,23 & $3,50 \mathrm{E}+08$ & 8,54 & $1,80 E+09$ & 9,26 \\
\hline 29 & $1,40 \mathrm{E}+08$ & 8,15 & $4,70 \mathrm{E}+08$ & 8,67 & $9,00 E+08$ & 8,95 \\
\hline 30 & $8,20 \mathrm{E}+07$ & 7,91 & $8,20 \mathrm{E}+07$ & 7,91 & $4,90 \mathrm{E}+08$ & 8,69 \\
\hline promedio & $7,11 \mathrm{E}+08$ & 8,63 & $8,47 \mathrm{E}+08$ & 8,74 & $7,57 \mathrm{E}+08$ & 8,67 \\
\hline mediana & $5,50 \mathrm{E}+08$ & 8,73 & $6,00 \mathrm{E}+08$ & 8,78 & $4,80 \mathrm{E}+08$ & 8,68 \\
\hline
\end{tabular}


Anexos

\section{Enterobacterias}

\begin{tabular}{|c|c|c|c|c|c|c|}
\hline \multirow[b]{2}{*}{ INDIVIDUO } & \multicolumn{2}{|c|}{$\mathrm{T} 1$} & \multicolumn{2}{|c|}{$\mathrm{T} 2$} & \multicolumn{2}{|c|}{ T3 } \\
\hline & ufc/g & $\log _{10} \mathrm{ufc} / \mathrm{g}$ & ufc/g & $\log _{10} \mathrm{ufc} / \mathrm{g}$ & ufc/g & $\log _{10}$ ufc/g \\
\hline Control & $8,50 \mathrm{E}+06$ & 6,93 & $1,80 \mathrm{E}+07$ & 7,26 & $1,30 \mathrm{E}+07$ & 7,11 \\
\hline 1 & $9,20 \mathrm{E}+05$ & 5,96 & $1,70 E+06$ & 6,23 & $9,40 \mathrm{E}+05$ & 5,97 \\
\hline 2 & $8,40 \mathrm{E}+05$ & 5,92 & $3,30 E+05$ & 5,52 & $5,50 \mathrm{E}+05$ & 5,74 \\
\hline 3 & $1,70 \mathrm{E}+07$ & 7,23 & $2,50 \mathrm{E}+07$ & 7,40 & $2,00 \mathrm{E}+06$ & 6,30 \\
\hline 4 & $5,80 \mathrm{E}+06$ & 6,76 & $2,40 E+06$ & 6,38 & $1,70 \mathrm{E}+06$ & 6,23 \\
\hline 5 & $4,20 E+06$ & 6,62 & $2,00 E+06$ & 6,30 & $6,60 \mathrm{E}+05$ & 5,82 \\
\hline 6 & $4,10 \mathrm{E}+06$ & 6,61 & $4,50 \mathrm{E}+06$ & 6,65 & $2,90 \mathrm{E}+06$ & 6,46 \\
\hline 7 & $6,60 \mathrm{E}+06$ & 6,82 & $1,70 \mathrm{E}+05$ & 5,23 & $9,90 \mathrm{E}+05$ & 6,00 \\
\hline 8 & $4,30 \mathrm{E}+07$ & 7,63 & $9,40 \mathrm{E}+06$ & 6,97 & $2,00 \mathrm{E}+06$ & 6,30 \\
\hline 9 & $3,00 \mathrm{E}+07$ & 7,48 & $2,50 E+06$ & 6,40 & $2,40 \mathrm{E}+06$ & 6,38 \\
\hline 10 & $9,40 \mathrm{E}+06$ & 6,97 & $1,40 \mathrm{E}+07$ & 7,15 & $1,70 \mathrm{E}+07$ & 7,23 \\
\hline 11 & $6,60 \mathrm{E}+06$ & 6,82 & $2,00 \mathrm{E}+06$ & 6,30 & $3,80 \mathrm{E}+06$ & 6,58 \\
\hline 12 & $5,40 \mathrm{E}+06$ & 6,73 & $2,70 \mathrm{E}+06$ & 6,43 & $2,10 \mathrm{E}+06$ & 6,32 \\
\hline 13 & $3,50 \mathrm{E}+06$ & 6,54 & $7,30 \mathrm{E}+05$ & 5,86 & $1,40 \mathrm{E}+06$ & 6,15 \\
\hline 14 & $4,70 \mathrm{E}+07$ & 7,67 & $3,50 \mathrm{E}+07$ & 7,54 & $2,00 \mathrm{E}+07$ & 7,30 \\
\hline 15 & $8,20 \mathrm{E}+05$ & 5,91 & $2,50 \mathrm{E}+05$ & 5,40 & $2,00 \mathrm{E}+06$ & 6,30 \\
\hline 16 & $1,10 \mathrm{E}+07$ & 7,04 & $9,40 \mathrm{E}+06$ & 6,97 & $1,70 \mathrm{E}+07$ & 7,23 \\
\hline 17 & $3,00 \mathrm{E}+06$ & 6,48 & $5,50 \mathrm{E}+05$ & 5,74 & $3,30 \mathrm{E}+05$ & 5,52 \\
\hline 18 & $1,00 \mathrm{E}+07$ & 7,00 & $2,00 E+06$ & 6,30 & $9,50 \mathrm{E}+05$ & 5,98 \\
\hline 19 & $2,00 \mathrm{E}+06$ & 6,30 & $1,70 \mathrm{E}+06$ & 6,23 & $6,80 \mathrm{E}+05$ & 5,83 \\
\hline 20 & $2,50 \mathrm{E}+07$ & 7,40 & $3,50 E+06$ & 6,54 & $1,20 E+06$ & 6,08 \\
\hline 21 & $5,00 \mathrm{E}+06$ & 6,70 & $2,90 \mathrm{E}+06$ & 6,46 & $4,50 \mathrm{E}+06$ & 6,65 \\
\hline 22 & $4,00 \mathrm{E}+06$ & 6,60 & $2,40 E+06$ & 6,38 & $1,70 \mathrm{E}+06$ & 6,23 \\
\hline 23 & $5,20 \mathrm{E}+06$ & 6,72 & $2,00 E+06$ & 6,30 & $9,40 \mathrm{E}+05$ & 5,97 \\
\hline 24 & $1,90 \mathrm{E}+07$ & 7,28 & $2,40 \mathrm{E}+06$ & 6,38 & $9,30 \mathrm{E}+05$ & 5,97 \\
\hline 25 & $8,00 \mathrm{E}+06$ & 6,90 & $1,70 \mathrm{E}+06$ & 6,23 & $1,40 \mathrm{E}+06$ & 6,15 \\
\hline 26 & $2,50 \mathrm{E}+07$ & 7,40 & $3,80 E+06$ & 6,58 & $2,00 E+06$ & 6,30 \\
\hline 27 & $4,70 \mathrm{E}+07$ & 7,67 & $2,10 \mathrm{E}+06$ & 6,32 & $2,70 \mathrm{E}+06$ & 6,43 \\
\hline 28 & $5,80 \mathrm{E}+06$ & 6,76 & $1,40 E+07$ & 7,15 & $2,70 \mathrm{E}+05$ & 5,43 \\
\hline 29 & $7,00 \mathrm{E}+06$ & 6,85 & $2,00 E+06$ & 6,30 & $3,50 \mathrm{E}+06$ & 6,54 \\
\hline 30 & $7,00 \mathrm{E}+06$ & 6,85 & $2,00 \mathrm{E}+06$ & 6,30 & $2,50 \mathrm{E}+06$ & 6,40 \\
\hline promedio & $1,23 \mathrm{E}+07$ & 6,85 & $5,17 \mathrm{E}+06$ & 6,40 & $3,37 \mathrm{E}+06$ & 6,26 \\
\hline mediana & $6,60 \mathrm{E}+06$ & 6,82 & $2,25 E+06$ & 6,35 & $1,85 E+06$ & 6,27 \\
\hline
\end{tabular}


Anexos

Enterobacterias (continuación)

\begin{tabular}{|c|c|c|c|c|c|c|}
\hline \multirow[b]{2}{*}{ INDIVIDUO } & \multicolumn{2}{|c|}{$\mathrm{T} 4$} & \multicolumn{2}{|c|}{ T5 } & \multicolumn{2}{|c|}{ T6 } \\
\hline & ufc/g & $\log _{10} \mathrm{ufc} / \mathrm{g}$ & ufc/g & $\log _{10}$ ufc/g & ufc/g & $\log _{10}$ ufc/g \\
\hline Control & $6,60 \mathrm{E}+06$ & 6,82 & $4,10 \mathrm{E}+06$ & 6,61 & $1,40 E+07$ & 7,15 \\
\hline 1 & $1,50 \mathrm{E}+06$ & 6,18 & $2,40 \mathrm{E}+06$ & 6,38 & $4,50 E+06$ & 6,65 \\
\hline 2 & $8,70 \mathrm{E}+05$ & 5,94 & $1,70 \mathrm{E}+07$ & 7,23 & $1,70 \mathrm{E}+07$ & 7,23 \\
\hline 3 & $7,20 \mathrm{E}+05$ & 5,86 & $3,80 \mathrm{E}+06$ & 6,58 & $9,40 E+06$ & 6,97 \\
\hline 4 & $1,10 \mathrm{E}+06$ & 6,04 & $2,10 \mathrm{E}+06$ & 6,32 & $2,50 E+06$ & 6,40 \\
\hline 5 & $9,30 E+05$ & 5,97 & $1,40 \mathrm{E}+07$ & 7,15 & $1,50 \mathrm{E}+07$ & 7,18 \\
\hline 6 & $7,60 \mathrm{E}+05$ & 5,88 & $2,00 \mathrm{E}+06$ & 6,30 & $2,00 \mathrm{E}+07$ & 7,30 \\
\hline 7 & $1,30 \mathrm{E}+05$ & 5,11 & $2,00 \mathrm{E}+06$ & 6,30 & $2,70 \mathrm{E}+06$ & 6,43 \\
\hline 8 & $4,10 E+05$ & 5,61 & $1,70 \mathrm{E}+07$ & 7,23 & $7,30 \mathrm{E}+06$ & 6,86 \\
\hline 9 & $1,20 \mathrm{E}+06$ & 6,08 & $3,30 \mathrm{E}+06$ & 6,52 & $3,50 E+07$ & 7,54 \\
\hline 10 & $8,40 \mathrm{E}+05$ & 5,92 & $2,50 \mathrm{E}+07$ & 7,40 & $2,50 \mathrm{E}+06$ & 6,40 \\
\hline 11 & $1,70 \mathrm{E}+06$ & 6,23 & $2,40 \mathrm{E}+07$ & 7,38 & $9,40 \mathrm{E}+06$ & 6,97 \\
\hline 12 & $5,80 \mathrm{E}+05$ & 5,76 & $2,00 \mathrm{E}+06$ & 6,30 & $5,50 \mathrm{E}+06$ & 6,74 \\
\hline 13 & $4,20 E+05$ & 5,62 & $4,50 \mathrm{E}+07$ & 7,65 & $2,00 E+07$ & 7,30 \\
\hline 14 & $1,20 \mathrm{E}+06$ & 6,08 & $8,70 \mathrm{E}+06$ & 6,94 & $7,20 E+06$ & 6,86 \\
\hline 15 & $1,40 \mathrm{E}+06$ & 6,15 & $7,20 \mathrm{E}+07$ & 7,86 & $1,10 \mathrm{E}+07$ & 7,04 \\
\hline 16 & $2,00 \mathrm{E}+07$ & 7,30 & $1,10 \mathrm{E}+07$ & 7,04 & $9,30 \mathrm{E}+06$ & 6,97 \\
\hline 17 & $1,70 \mathrm{E}+06$ & 6,23 & $9,30 \mathrm{E}+05$ & 5,97 & $7,60 \mathrm{E}+06$ & 6,88 \\
\hline 18 & $3,30 \mathrm{E}+05$ & 5,52 & $7,60 \mathrm{E}+06$ & 6,88 & $1,30 E+07$ & 7,11 \\
\hline 19 & $2,50 \mathrm{E}+05$ & 5,40 & $1,30 \mathrm{E}+06$ & 6,11 & $4,10 E+06$ & 6,61 \\
\hline 20 & $2,40 E+06$ & 6,38 & $4,10 \mathrm{E}+06$ & 6,61 & $9,20 E+06$ & 6,96 \\
\hline 21 & $2,00 \mathrm{E}+06$ & 6,30 & $9,20 \mathrm{E}+06$ & 6,96 & $8,40 \mathrm{E}+06$ & 6,92 \\
\hline 22 & $7,00 \mathrm{E}+06$ & 6,85 & $8,40 \mathrm{E}+06$ & 6,92 & $1,70 E+06$ & 6,23 \\
\hline 23 & $2,20 \mathrm{E}+05$ & 5,34 & $1,70 \mathrm{E}+07$ & 7,23 & $5,80 \mathrm{E}+07$ & 7,76 \\
\hline 24 & $2,50 \mathrm{E}+05$ & 5,40 & $5,80 \mathrm{E}+07$ & 7,76 & $4,20 E+06$ & 6,62 \\
\hline 25 & $8,50 \mathrm{E}+05$ & 5,93 & $4,20 \mathrm{E}+06$ & 6,62 & $1,20 E+07$ & 7,08 \\
\hline 26 & $4,70 \mathrm{E}+05$ & 5,67 & $1,20 \mathrm{E}+07$ & 7,08 & $2,00 \mathrm{E}+07$ & 7,30 \\
\hline 27 & $9,30 \mathrm{E}+05$ & 5,97 & $2,00 \mathrm{E}+06$ & 6,30 & $2,00 E+06$ & 6,30 \\
\hline 28 & $1,40 \mathrm{E}+06$ & 6,15 & $2,00 \mathrm{E}+06$ & 6,30 & $1,70 \mathrm{E}+07$ & 7,23 \\
\hline 29 & $3,30 \mathrm{E}+05$ & 5,52 & $1,70 \mathrm{E}+07$ & 7,23 & $3,30 \mathrm{E}+07$ & 7,52 \\
\hline 30 & $8,20 \mathrm{E}+05$ & 5,91 & $3,30 \mathrm{E}+06$ & 6,52 & $2,50 \mathrm{E}+07$ & 7,40 \\
\hline promedio & $1,76 \mathrm{E}+06$ & 6,24 & $1,33 \mathrm{E}+07$ & 6,84 & $1,31 \mathrm{E}+07$ & 6,96 \\
\hline mediana & $8,60 \mathrm{E}+05$ & 5,93 & $8,00 \mathrm{E}+06$ & 6,90 & $9,35 E+06$ & 6,97 \\
\hline
\end{tabular}




\section{ANEXO VIII. \\ Direcciones de interés en Internet}

Direcciones de grupos especializados consultadas en este trabajo:

\section{Dirección Portal}

National Center for Biotechnology www.ncbi.nlm.nih.gov/ Information (USA)

European Molecular Biology Laboratory www.embl.org/

(Europe)

Buscadores de publicaciones periódicas utilizados en este trabajo:

\begin{tabular}{|c|c|}
\hline Dirección & Portal \\
\hline Buscador investigación genómica & www.ncbi.nlm.nih.gov/PubMed \\
\hline BioMedNet Journal Collection & http://journals.bmn.com/journals \\
\hline Science Direct & www.sciencedirect.com/ \\
\hline Ingenta & www.ingenta.com \\
\hline Journal search & www.blackwell-science.com/ \\
\hline Journal of Nutrition & www.nutrition.org/ \\
\hline Biblioteca UPV & www.upv.es/revistas/ \\
\hline
\end{tabular}

Herramientas de análisis:

\begin{tabular}{cc}
\hline Dirección & Portal \\
\hline 1. ARB & $\underline{\text { www.mikro.biologie.tu-muenchen.de }}$ \\
\hline 2. BLAST & $\underline{\text { www.ncbi.nlm.nih.gov/BLAST }}$ \\
\hline 3. RNA world & $\underline{w w w . i m b-j e n a . d e / R N A . h t / m}$ \\
\hline 4. PCR electrónica & $\underline{w w w . n c b i . n l m . n i h . g o v / S T S /}$ \\
\hline
\end{tabular}

